$+2$

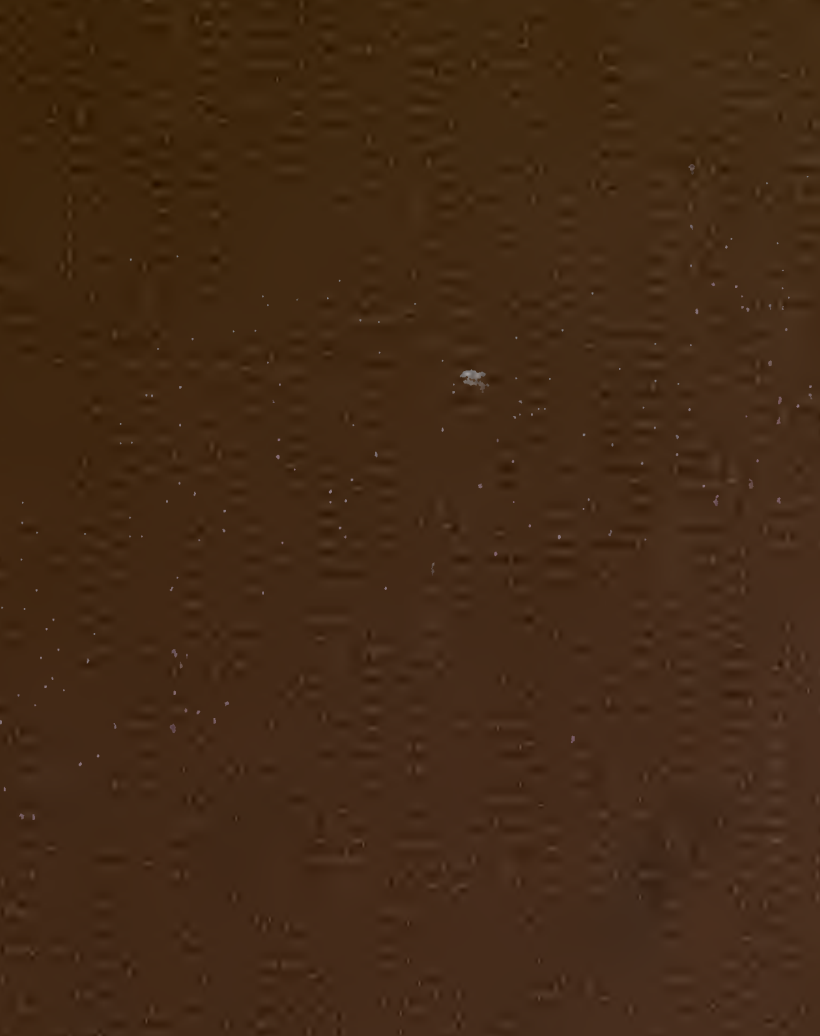

ing

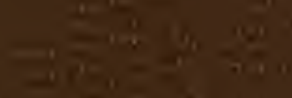

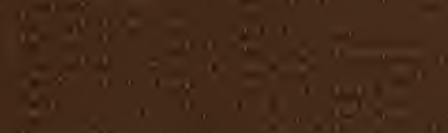

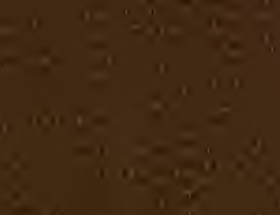

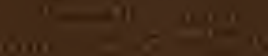

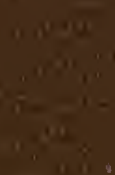

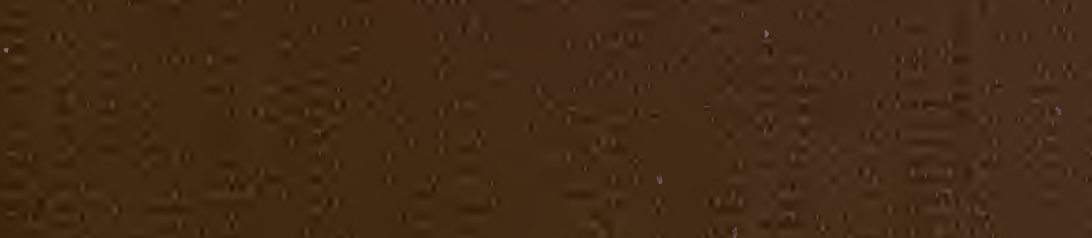

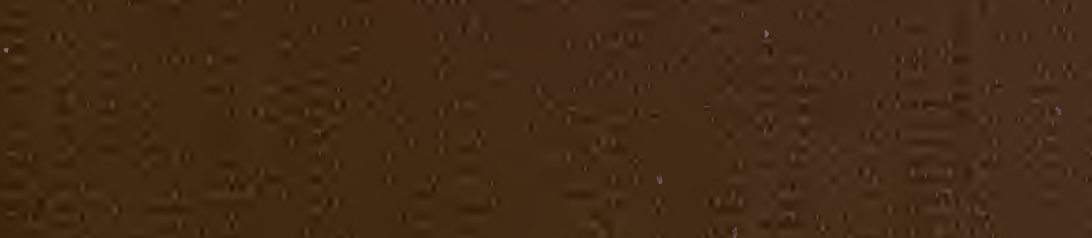

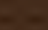

$\frac{1+2 x}{2 y}$

n.

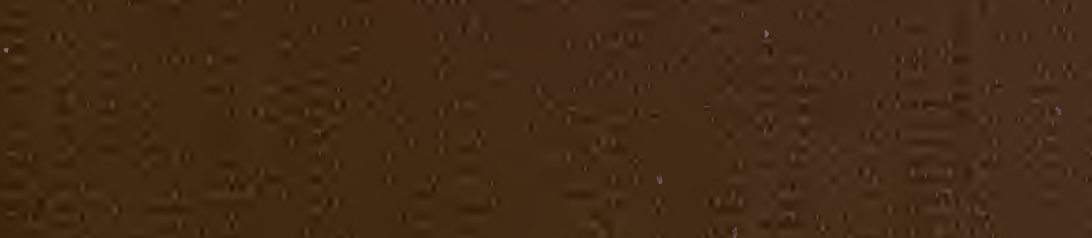

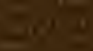

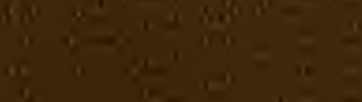

$\frac{-3}{3 x}=-21$

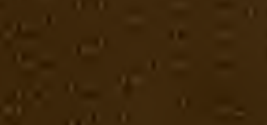

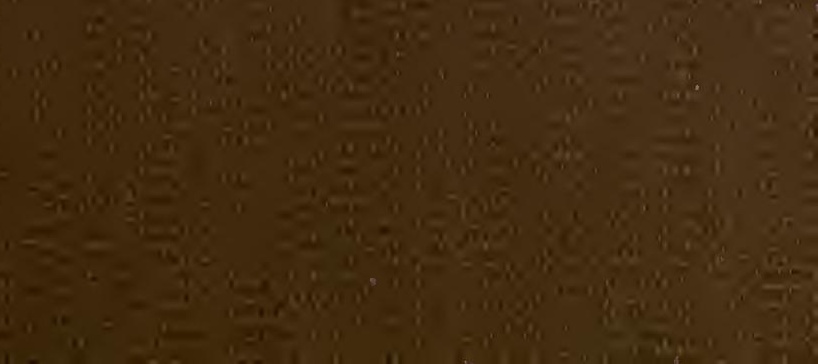




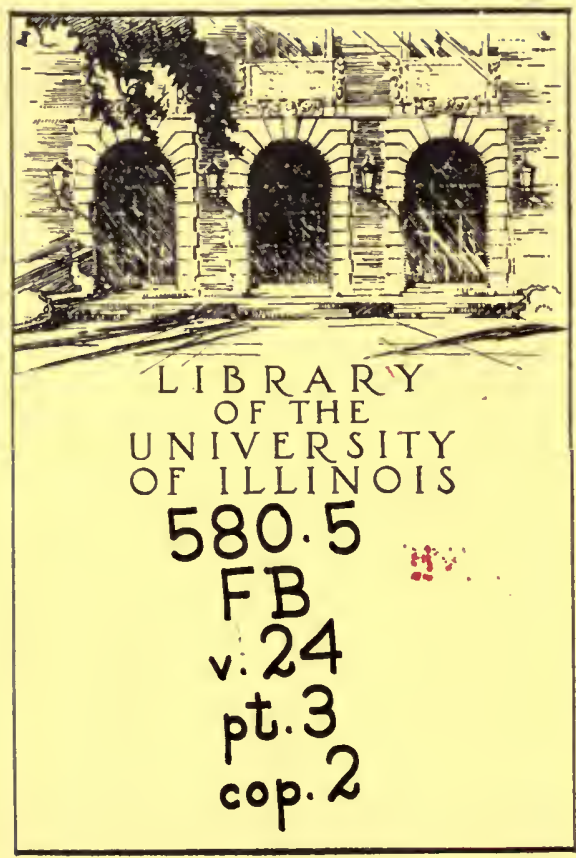




\section{CENTRAL CIRCULATION BOOKSTACKS}

The person charging this material is responsible for its return to the library from which it was borrowed on or before the Latest Date stamped below.

Thoft, mutlletien, and underlining of books are reasons for disciplinery action and may resuit in dismissal from the Unlverstiy.

TO RENEW CALL TELEPHONE CENTER, 333-8400

UNIVERSITY OF ILLINOIS LIBRARY AT URBANA-CHAMPAIGN

MAR 181994

MAY O g 1994

MAR 291995

When renewing by phone, write new due date below previous due date. 





FLORA OF GUATEMALA

PART III 



\title{
FLORA OF GUATEMALA
}

\author{
PAUL C. STANDLEY
}

Curalor Emeritus of the Herbarium

AND

JULIAN A. STEYERMARK

Curator of the Herbarium

\author{
FIELDIANA: BOTANY \\ VOLUME 24, PART III \\ Published by \\ CHICAGO NATURAL HISTORY MUSEUM \\ APRIL 25, 1952
}

TYE CIBRARY OF THE

MAY $5-1925$ 
PRINTED IN THE UNITED STATES OF AMERICA BY CHICAGO NATURAL HISTORY MUSEUM PRESS 


\section{CONTENTS}

\section{Families Included in Part III}

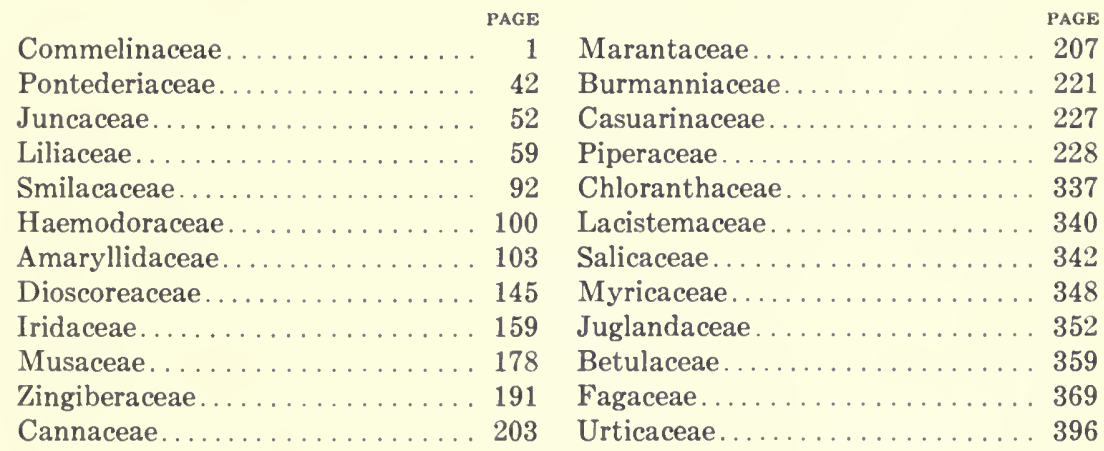





\section{COMMELINACEAE. Spiderwort Family}

References: C. B. Clarke, Commelinaceae, in DC. Monogr. Phan. 3: 113-324. 1881. Robert E. Woodson, Jr., Commentary on the North American genera of Commelinaceae, Ann. Mo. Bot. Gard. 29: 141-154. 1942.

Annual or perennial, mostly succulent herbs, erect to procumbent or repent, often rooting at the nodes; leaves alternate, entire, the petiole dilated into a basal sheath; flowers perfect, mostly small, umbellate, cymose, racemose or capitate, the bracts small or large, often spathaceous; perianth usually differentiated into a distinct calyx and corolla; sepals 3 , free or connate, imbricate, usually herbaceous, the 2 inner ones generally subfalcate or asymmetric; petals usually 3 , free or connate, equal or unequal, marcescent, blue, purple, pink, or white; stamens normally 6 but sometimes fewer, all or partly fertile, usually free, the anthers 2-celled; ovary superior, sessile, 3-2-celled, ovules orthotropous, few; stigma entire or obscurely lobate; fruit capsular, or crustaceous and indehiscent.

An essentially tropical family, with about 25 genera, the plants widely distributed in both hemispheres. Other genera represented in southern Central America are Floscopa and Cochliostema. The treatment used here is that proposed by Woodson in the paper listed above. His treatment is radical in some respects, although not startlingly so. Most of the groups are left undisturbed in their traditional sense, while discordant elements have been removed from some of the larger genera and united with minor groups to form more easily recognized and consistent units.

Ultimate branches of the inflorescence composed of individual scorpioid cymes, these appearing 1-sided superficially, solitary or variously clustered, very rarely reduced to a single terminal flower; corolla regular or irregular.

Commelineae.

Cymes solitary, enclosed by a conspicuous compressed spathe-like bract.

Fruit dehiscent, capsular; sterile stamens, when present, with cordate anthers. Commelina.

Fruit indehiscent, pergamentaceous; sterile stamens with hastate-triangular anthers............................... Phaeosphaerion.

Cymes variously clustered or compounded, rarely solitary but never enclosed by a compressed spathaceous bract.

Anthers large, with an inconspicuous connective, dehiscent by apical pores; seeds with a fleshy aril...................... Dichorisandra.

Anthers small but with a conspicuous sterile connective, dehiscent longitudinally; seeds dry, not arillate.

Flowers regular or essentially so . ................... Aneilema.

Flowers very strongly irregular.................... Tinantia. 
Ultimate branches of the inflorescence composed of paired sessile scorpioid cymes, appearing as a 2 -sided unit superficially, rarely reduced to a single flower;

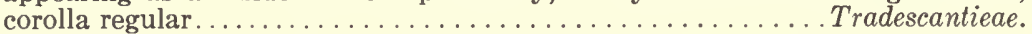

Corolla gamopetalous, the petals united at the base.

Plants acaulescent or nearly so; flowers solitary and sessile in the axils of the congested upper leaves; corolla tube $4-6.5 \mathrm{~cm}$. long........Weldenia.

Plants with elongate leafy stems; flowers in leafy-bracted cymes; corolla

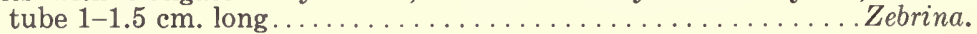

Corolla polypetalous, the petals free to the base.

Paired cymes distinctly pedunculate, never sessile or subtended by leafy bracts; stamens 6 , usually in 2 very dissimilar series, the outer ones occasionally sterile, rarely all the stamens fertile and essentially similar; sepals foliaceous or petaloid................... Tripogandra.

Paired cymes sessile and subtended by conspicuous bracts similar to the leaves (coriaceous spathes in Rhoeo), rarely appearing pedunculate and the bracts greatly reduced but the stamens then usually $1-3$, and the sepals paleaceous.

Paired cymes sessile and subtended by more or less conspicuous, leafy bracts, rarely appearing pedunculate and the bracts greatly reduced, but the stamens usually $1-3$, rarely 6 , all fertile, and the sepals pale-

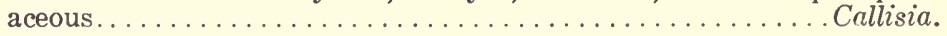

Paired cymes sessile and subtended by conspicuous bracts essentially similar to the leaves (coriaceous spathes in Rhoeo); stamens 6, all fertile and essentially similar; sepals foliaceous or petaloid.

Cymes terminal on the main stem, occasionally also lateral in the upper leaf axils; lateral cymes very rarely reduced to a single flower.

Cymes on slender peduncles lateral to the main stem.

Tradescantia.

Flowering peduncles elongate, usually branched; bracts foliaceous; sepals becoming fleshy in fruit.............. Campelia.

Flowering peduncles very short, simple; bracts appearing as coriaceous spathes; sepals drying in fruit................ Rhoeo.

\section{ANEILEMA R. Brown}

Herbs with branched stems, the leaves narrow or rather broad; peduncles axillary or terminal, many-flowered, paniculate, thyrsoid, or corymbose, or fewflowered, rarely 1-flowered; lowest bracts resembling reduced leaves, never spathaceous or complicate, the upper ones small, often amplexicaul, generally persistent; sepals 3 , free, the outer one cucullate, oblong-elliptic, the 2 inner ones obovate or oblong, falcate, green, scarious, or petaloid, persistent; petals 3 , free, all alike or slightly unequal, blue or white, deciduous or marcescent; stamens 3-6, only 2 or 3 of them perfect, the filaments slender, barbate or glabrous; ovary sessile, glabrous or pubescent, 2-3-celled, the dorsal cell smaller or wanting; ovules 1-20 in each cell; capsule dry, 2-3-celled, loculicidally 2-3-celled; seeds 1-20 in each cell; seeds rugose or foveolate, often puberulent.

Species about sixty, in the tropics of both hemispheres, most of them in the Old World. All the known Central American species are listed below.

Plants erect; leaves glabrous or nearly so; bracts at the base of the ultimate peduncles opposite, large and leaf-like................ aguensis.

Plants prostrate or procumbent; leaves densely long-pilose beneath; bracts at the base of the ultimate peduncles small and inconspicuous......... geniculata. 


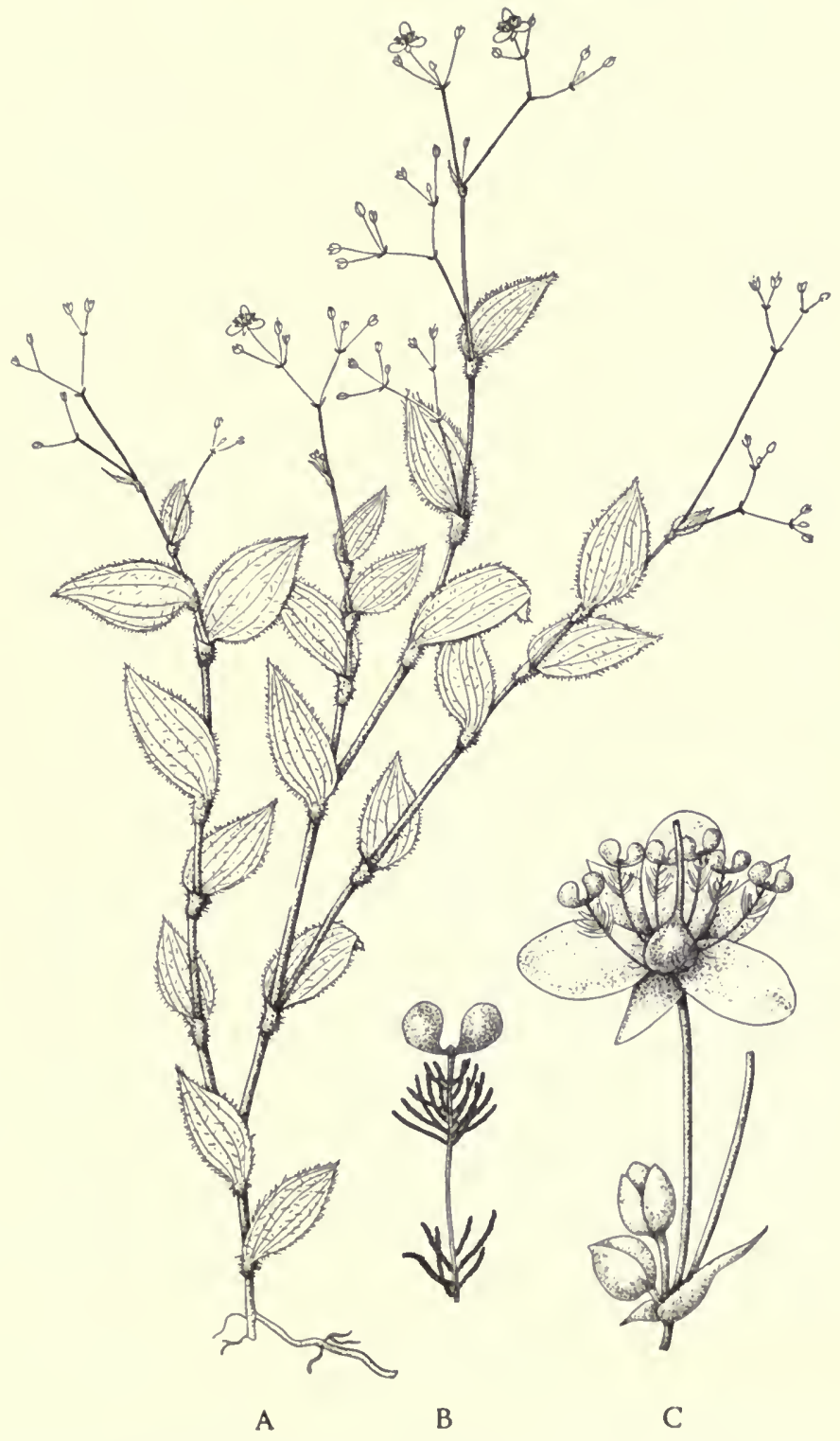

Fig. 1. Aneilema geniculata. A. Habit; $\times 3 / 5$. B. Stamen; $\times 11$. C. Portion of inflorescence with flower in anthesis; $X 4$. 
Aneilema aguensis Standl. \& Steyerm., comb. nov. Tradescantia aguensis Standl. \& Steyerm. Field Mus. Bot. 23: 36. 1944.

Moist shaded banks and brushy slopes, 1,800-2,900 meters; endemic; Huehuetenango; Sacatepequez (type collected on slopes of Volcán de Agua above Santa María de Jesús, Standley 59358).

Plants slender, erect, about $50 \mathrm{~cm}$. high, apparently with fibrous roots, simple or branched, the stems densely or lightly villous; leaves thin, lanceolate or oblonglanceolate, $2-6.5 \mathrm{~cm}$. long, $1-1.5 \mathrm{~cm}$. wide, acuminate, subequally cuneate at the base, sparsely pilose above, glabrous beneath or sparsely pilose along the costa, ciliate; sheaths thin, $4-5 \mathrm{~mm}$. long, $2-5 \mathrm{~mm}$. broad, villous, the orifice and margins ciliate; bracts at the base of the ultimate umbels 2 and opposite, lanceolate, $2-4 \mathrm{~cm}$. long; umbels on long slender glabrous peduncles, 3-4-flowered, the pedicels spreading to deflexed, filiform, glabrous or glabrate, 4-11 mm. long; sepals thin, greenish, scarious-marginate, $2-3 \mathrm{~mm}$. long, lance-oblong, acute, glabrous; petals pale blue, $2.5 \mathrm{~mm}$. long; filaments barbate at the middle; capsule $3-3.5 \mathrm{~mm}$. long; seeds 5 , dark grayish brown, irregularly sulcate, about $1.2 \mathrm{~mm}$. long and $1 \mathrm{~mm}$. broad.

Aneilema geniculata (Jacq.) Woodson, Ann. Mo. Bot. Gard. 29: 147. 1942. Tradescantia geniculata Jacq. Sel. Stirp. Amer. 94. pl. 64.1763.

Moist or wet thickets or forest, 300 meters or lower; Petén; Alta Verapaz; Izabal; Huehuetenango. Central and southern Mexico; British Honduras to Panama; West Indies; South America.

Plants perennial, apparently with fibrous roots, the stems simple or branched, prostrate or decumbent, rooting at the lower nodes, usually puberulent in a line along one side, 20-60 cm. long; leaves thin when dried, oblong-lanceolate to ovate, 3-7 cm. long, 1-3 cm. wide, somewhat paler beneath, acute or acuminate, rounded at the base or contracted at the somewhat unequal base, sparsely pilose or glabrate above, usually long-pilose beneath, sometimes ciliate; sheaths thin, scarious, 5-7 $\mathrm{mm}$. long, 2-4 $\mathrm{mm}$. broad, long-pilose, pilose-ciliate; peduncles terminal or in the upper leaf axils, filiform, $2.5-5 \mathrm{~cm}$. long, glabrous or sparsely pilose; ultimate umbels few-flowered, the pedicels filiform, 4-12 $\mathrm{mm}$. long, glabrous to glandularpilose; bracts at the base of the peduncles greatly reduced, 1-2 $\mathrm{mm}$. long; sepals green, often tinged with purple, acute or acuminate, 2-3 $\mathrm{mm}$. long, glabrous except for the sparsely barbate tip; petals white, 3-5 mm. long; filaments barbate; capsule 2-3 mm. long; seeds gray, finely and minutely reticulate, $1-1.5 \mathrm{~mm}$. in diameter. (Fig. 1.)

\section{CALLISIA L.}

Plants usually small, perennial, procumbent or prostrate, often with erect branches; leaves generally pale green, ovate to elliptic-lanceolate, acute, the upper ones subsessile, vaginate; flowers small, white, aggregate within the sheaths or axillary, sometimes in axillary umbels and forming terminal panicles; bracts uniform with the leaves, or the uppermost reduced almost to sheaths, the bractlets small or very narrow; sepals $2-3$, subequal or one of them smaller, free, elliptic to oblong-linear, green or hyaline, erect and persistent in fruit; petals $2-3$, sub- 
equal or one of them smaller, free, elliptic or lanceolate, marcescent; stamens 1-3, fertile, subequal, free, the filaments filiform, naked; anther cells rounded and separated by the connective, or oblong and contiguous; ovary sessile, oblong, 2-3-celled, compressed or subtrigonous; style long, the stigma penicillate or short and 3-lobate; ovules 2 in each cell; capsule small, thin, ellipsoid, 2-3-celled, loculicidally 2-3-valvate; seeds 2 in each cell or rarely by abortion 1 , superposed, cylindric-trigonous or subtrapezoid, the testa fuscous or stramineous, smooth, rugulose, or radiately striate.

Four species, in tropical America. The fourth one is native in central Mexico.

Flowers scarcely exserted from the sheaths, in dense sessile clusters; style filiform

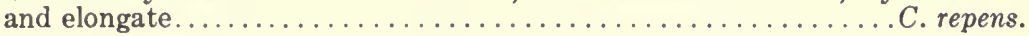

Flowers long-exserted from the sheaths, paniculate or umbellate, on obvious pedicels; style short.

Leaves usually glabrous beneath, thin; leaf sheaths $4-5 \mathrm{~mm}$. long; inflorescences

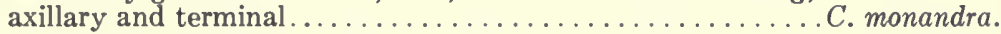

Leaves usually densely tomentulose beneath, firm-membranaceous; leaf sheaths 7-12 mm. long; inflorescences terminal, on a long peduncle. C. multiflora.

Callisia monandra (Swartz) Schult. in Roem. \& Schult. Syst. Veg. 7: 1179. 1830. Tradescantia monandra Swartz, Prodr. Veg. Ind. Occ. 57. 1788. C. umbellulata Lam. Ill. 1: 130. pl. 35, f. 2. 1791. Matajalin (Jutiapa); Lochoch (fide Aguilar).

Moist or wet thickets or forest, sometimes in oak forest or in roadside hedges, 1,700 meters or lower; Chiquimula; Jalapa; Jutiapa; Retalhuleu. Southern Mexico; British Honduras to Costa Rica; West Indies; South America.

Stems slender, pale green, simple or branched, $30-50 \mathrm{~cm}$. long, rooting at the nodes and often forming dense mats, glabrous below, glandular-pilose above; leaves ovate or ovate-lanceolate, $2-5 \mathrm{~cm}$. long, 1-1.5 cm. wide, acute or acuminate, rounded to subcordate or obliquely cuneate at the base, ciliolate, glabrous or sparsely pilose on both surfaces, sessile or the lower leaves subpetiolate; sheaths small, 4-5 mm. long, villous-ciliate; peduncles axillary, bearing laterally 3-10-flowered umbels, these sometimes forming lax terminal panicles, glandular-pilose; pedicels filiform, $15 \mathrm{~mm}$. long or shorter, glandular-pilose, the bractlets lanceolate, pilose; flowers minute, 2-3-parted, white; sepals 1-2 mm. long, elliptic-oblong, sparsely pilose, barbellate at the apex, green, scarious-marginate; petals smaller than the sepals, lanceolate, hyaline; stamens 1-2, the filaments glabrous, the anther cells rounded; capsule 1-1.3 $\mathrm{mm}$. long, apiculate, $2-3$-celled.

Callisia multiflora (Mart. \& Gal.) Standl. Journ. Wash. Acad. Sci. 15: 457. 1925. Commelina multiflora Mart. \& Gal. Bull. Acad. Brux. 9, pt. 2: 374. 1842. Tradescantia Martensiana Kunth, Enum. Pl. 4: 697. 1843. Callisia Martensiana C. B. Clarke in DC. Monogr. Phan. 3: 312. 1881. Tzimaac (Cobán, Quecchí). 

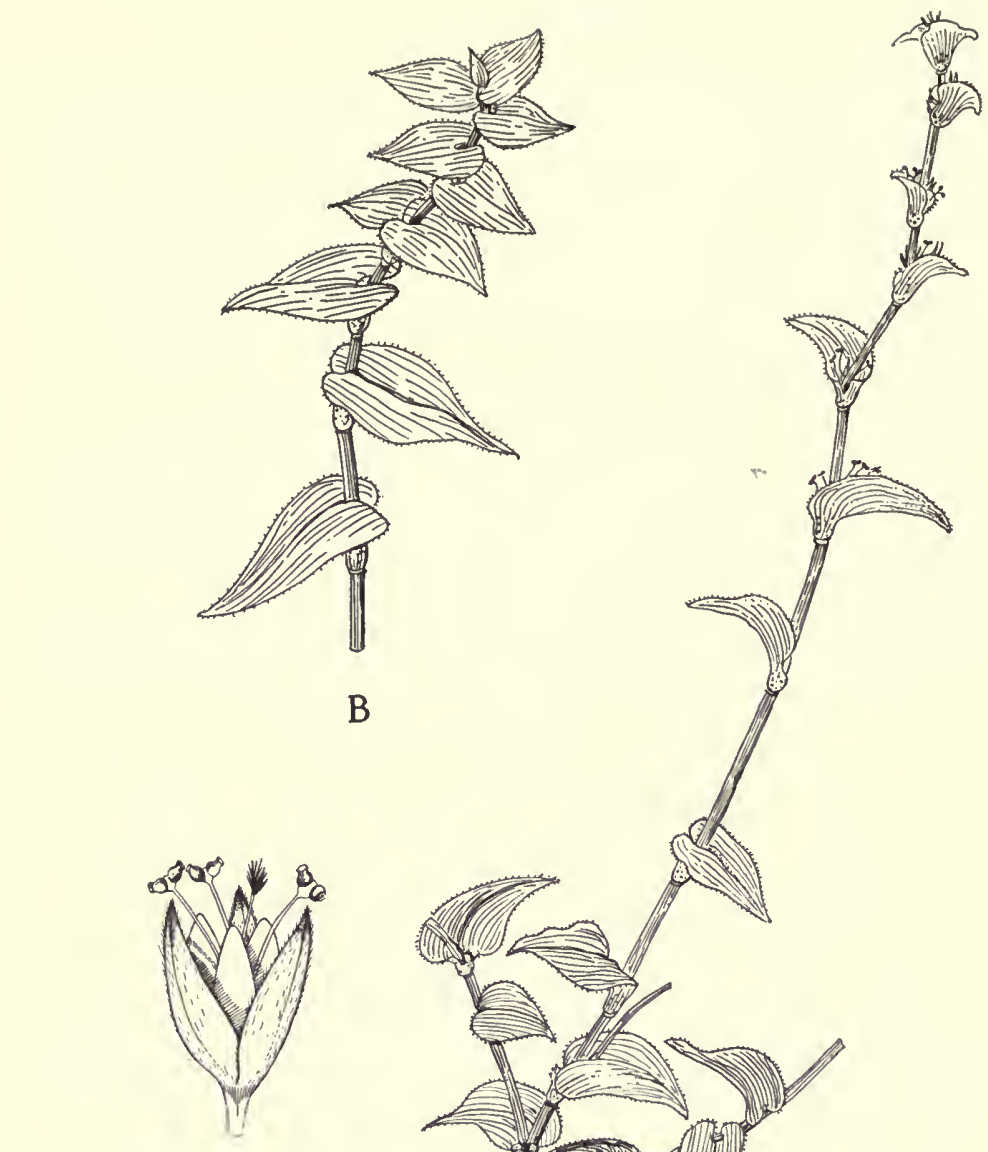

B

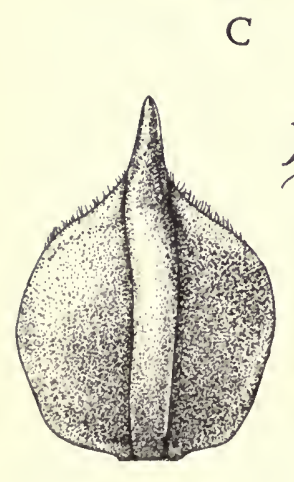

D

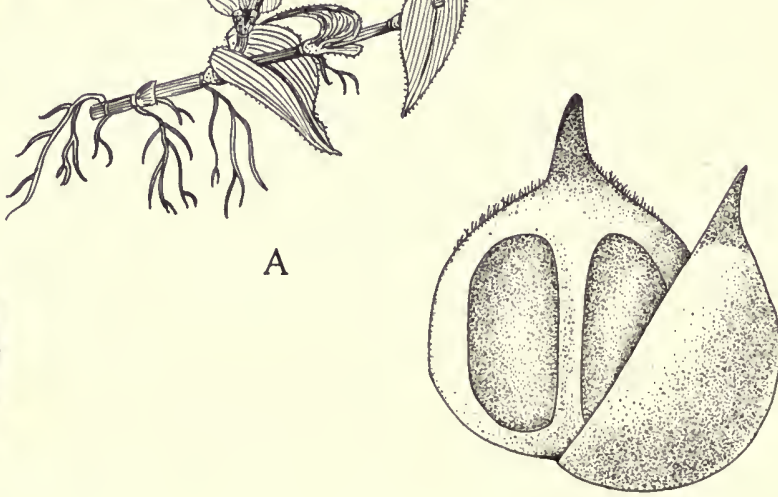

E

FIG. 2. Callisia repens. A. Habit; $\times 1 / 2$. B. Characteristic crowded leaves of sterile branch; $\times 1 / 2$. C. Flower; $\times 6$. D. Capsule; $\times 22$. E. Capsule dehiscing; $\times 22$. 
Moist or wet thickets or forest, often in wet places along streams, sometimes a weed in cultivated ground, 350-2,500 meters; Alta Verapaz; Baja Verapaz; Guatemala; Sacatepéquez; Chimaltenango; Huehuetenango. Southern Mexico; Honduras.

Stems rather stout, 3-4 mm. in diameter, pale green, procumbent, sometimes with erect branches, $30-80 \mathrm{~cm}$. long, somewhat branched above or simple, glabrous or pilose; leaves lance-oblong or elliptic-lanceolate, 3-9 cm. long, 1-2.5 cm. wide, acute or acuminate, sometimes abruptly so, rounded or subcordate at the sessile base, pale green, usually densely tomentulose beneath, glabrate or tomentulose on the upper surface; sheath usually very villous, sometimes glabrate, villous-ciliate, 7-12 mm. long, 3-6 mm. broad; peduncles elongate and branched, forming dichotomous panicles, large and many-flowered, the branches glandular-pilose or glabrate, the pedicels glandular-pilose, the bracts ovate-lanceolate; flowers 3-parted, in clusters of 3-6; sepals $2-3 \mathrm{~mm}$. long, green and scarious-marginate, glandularpubescent or glabrate; petals white, 3-4 mm. long, elliptic; stamens 3 , the filaments glabrous; capsule ellipsoid, $2 \mathrm{~mm}$. long; seeds 6 .

\section{Called "carricillo" in Veracruz.}

Callisia repens L. Sp. Pl. ed. 2. 62. 1762. Lochoch (fide Aguilar).

Moist or wet thickets or forest, or on shaded banks or rocks, sometimes on wet stream banks, frequently a weed in cultivated ground in the lowlands, 2,300 meters or lower; El Progreso; Izabal; Zacapa; Jalapa; Jutiapa; Santa Rosa; Guatemala; Sacatepéquez; Chimaltenango; Huehuetenango; Quezaltenango; San Marcos. Southern Mexico; British Honduras to Costa Rica; West Indies; South America.

Stems slender, prostrate, rooting at the nodes, often forming large mats, simple or branched, short or often much elongate, glabrous; leaves ovate, pale green, somewhat succulent when fresh, membranaceous when dried, mostly $1-4 \mathrm{~cm}$. (rarely $7 \mathrm{~cm}$.) long, 1-1.5 or rarely $2 \mathrm{~cm}$. wide, acute or acuminate, rounded or subcordate at the sessile base, or the lower leaves sometimes subcuneate and petiolate, glabrous, ciliolate; sheaths usually glabrous, villous-ciliate; uppermost leaves of sterile branches much crowded and imbricate, successively smaller; flowering branches erect or ascending, the flowers 3-parted, in dense sessile clusters of 3-9 on an elongate terminal axis, the flowers scarcely exserted beyond the sheaths; sepals 2-3 mm. long, linear-oblong, green, pubescent, scarious-marginate; petals 3 , shorter than the sepals, white, oblong, hyaline; stamens 3 , the filaments glabrous, the anther cells rounded; capsule $1.5 \mathrm{~mm}$. long, 6-seeded. (Fig. 2.)

This is an abundant weedy plant in wet places of the lowlands and lower mountains in many parts of Central America, frequently invading cultivated ground, especially cafetales. The plants often form large mats, and cover large areas of ground in moist places. As in other species, they usually are of a very pale shade of green, thus being conspicuous in contrast to neighboring vegetation. 


\section{GAMPELIA L. Richard}

Stout, usually erect, perennial herbs, glabrous or pubescent, the stems simple or sparsely branched; leaves mostly lanceolate, succulent when fresh, sheathing at the base; peduncles axillary, elongate, almost leafless, 1-2-dichotomous above or simple, the branches bearing at the apex 2 subopposite, lanceolate, sometimes complicate or cymbiform bracts; flowers fasciculate, short-pedicellate, subtended by 2 bracts, usually little or not at all exceeding the bracts, the bractlets numerous, small, ovate; flowers almost regular, the sepals 3, almost free, ovate-oblong, herbaceous, somewhat accrescent in age, the outer one somewhat cucullate, all the sepals succulent, persistent in fruit; petals 3 , free, white; stamens 6 , subequal, the filaments barbate; anther cells oblong, separated by an oblong-triangular connective; ovary sessile, 3-celled; capsule 3-celled or by abortion 2-celled, ellipsoid, trigonous, loculicidally 3 -valvate, the cells 1-2-seeded; seeds osseous, compressedellipsoid, punctate.

\section{About three species, in tropical America.}

Sheaths of the leaves densely hirsute with spreading golden-brown hairs. C. hirsuta. Sheaths of the leaves glabrous or sericeous with appressed, pale or dull hairs.

Stems, peduncles, and lower surface of the leaves glabrous; inflorescence subtended by 2 reduced bracts, the larger one $1.5-6.5 \mathrm{~cm}$. long and $1-2 \mathrm{~cm}$. wide; bractlets $1-3 \mathrm{~mm}$. long . . ................... Zanonia.

Stems, peduncles, and lower leaf surface more or less densely sericeous; inflorescence subtended by 2 reduced bracts and a large leaf $8-11 \mathrm{~cm}$. long and $3-4.5 \mathrm{~cm}$. wide; bractlets $7-10 \mathrm{~mm}$. long............. Standleyi.

Campelia hirsuta Standl. Field Mus. Bot. 8: 135. 1930.

Dense wet mixed forest, 1,600 meters or lower; Alta Verapaz (near Tactic); Izabal (Cerro San Gil). Atlantic lowlands of Honduras, the type collected in the Lancetilla Valley, near Tela.

A stout erect herb a meter high or less, the stems simple, sparsely hirsute or glabrate, sometimes purplish red; leaves oblong-oblanceolate or lanceolate, 14-20 $\mathrm{cm}$. long, 4-5.5 cm. wide, abruptly long-acuminate, gradually attenuate to the base into a petioliform portion; sheaths somewhat inflated, about $1 \mathrm{~cm}$. long; peduncles mostly longer than the leaves, sparsely or densely fulvous-hirsute; flowers few, white; bracts unequal, the larger one oval-ovate, 4.5-6 cm. long, 2-3.5 $\mathrm{cm}$. wide, abruptly acute, truncate or subcordate at the base, densely hirsute on both surfaces, the smaller bract $1.5-3 \mathrm{~cm}$. long, acute, complicate, densely hirsute at the apex; sepals oblong, 4-5 mm. long, sparsely hirsute-ciliate, more densely hirsute about the apex; petals white. (Fig. 3.)

Campelia Standleyi Steyermark in Standl. \& Steyerm. Field Mus. Bot. 23: 32. 1944.

Moist or wet forest, 200-1,500 meters; endemic; Alta Verapaz; San Marcos (type from Volcán de Tajumulco, above Finca El Porvenir, Steyermark 37187).

Plants stout, decumbent or erect, the stems purple or dull green mottled with purple, 4-6 mm. thick, 60-100 cm. tall or more, sparsely or densely sericeous, 


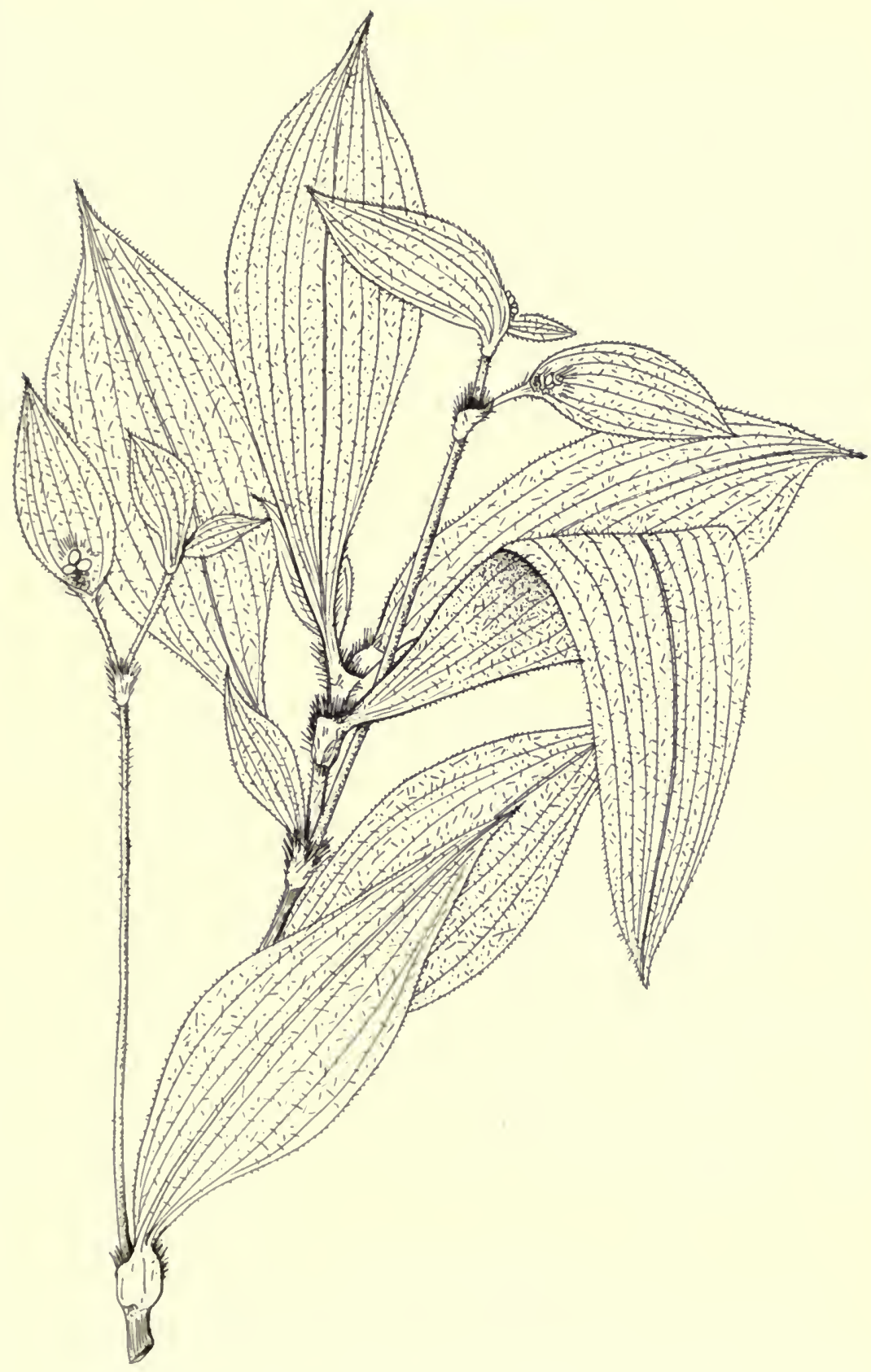

FIG. 3. Campelia hirsuta. Habit of upper portion of plant; $\times 1 / 2$. 
especially in the upper half; leaves deep green above and lustrous, pale or dull green beneath, the main cauline ones broadly oblanceolate or oblong-elliptic, 9-25 $\mathrm{cm}$. long, 2.5-6 $\mathrm{cm}$. wide, acuminate or caudate-acuminate, gradually attenuate below into a petioliform portion 1-2 $\mathrm{cm}$. long, glabrous above, densely and shortly sericeous beneath with dull hairs, the young leaves often with 2 silver stripes on the upper surface; sheaths lax, membranaceous, $1.3-2.5 \mathrm{~cm}$. long, 3-12 mm. broad, sparsely or densely sericeous, the margins and orifice finely ciliate; peduncles terminal and axillary, short or elongate, erect-ascending, 1-15 cm. long, densely sericeous, naked below, leafy or subtended by well-developed leaves, especially above; bracts at the base of the inflorescence 2 , reduced and somewhat spathelike, ovate, caudate-acuminate, rounded or subcordate at the broad base, densely short-sericeous beneath, 1-2 cm. long; pedicels short, the bractlets conspicuous, brown-scarious, 7-10 $\mathrm{mm}$. long; sepals $4.5-5 \mathrm{~mm}$. long, firm-membranaceous; petals rose-purple or white; seeds pale brownish, $2.3-3 \mathrm{~mm}$. long, $1.5-2 \mathrm{~mm}$. broad, shallowly rugose.

Campelia Zanonia (L.) HBK. Nov. Gen. \& Sp. 1: 264. 1816. Commelina Zanonia L. Sp. Pl. 41. 1753. Campelia glabrata Kunth, Enum. Pl. 4: 109. 1843. Campelia mexicana Kunth, loc. cit. $C$. Zanonia var. glabrata C. B. Clarke in DC. Monogr. Phan. 3: 315. 1881. Coyontura; Lochoc amargo; Oreja de burro.

Moist or wet, usually mixed forest, or in thickets, 2,400 meters or lower; Petén; Alta Verapaz; Izabal; Zacapa; Chiquimula; Jalapa; Santa Rosa; Guatemala; Sacatepéquez; Quiché; Huehuetenango; Suchitepequez; Quezaltenango; San Marcos. Southern Mexico; British Honduras to Panama; West Indies; South America.

A stout herb, the stems erect or decumbent, a meter high or less, usually simple, glabrous, $8-10 \mathrm{~mm}$. thick, dull green or mottled or streaked with dull purple; leaves mostly crowded near the top of the stem, widely ascending, lanceolate to oblanceolate, $10-35 \mathrm{~cm}$. long, $3.5-8 \mathrm{~cm}$. wide, succulent, firm-membranaceous to subcoriaceous when dried, dark green above, pale dull green or silvery purplish beneath, the young leaves sometimes striped with cream-color and green, glabrous on both surfaces or appressed-pubescent beneath near the margins, longacuminate, gradually narrowed below into a petiolar portion 5-20 mm. long, or subsessile; sheaths $1.5-2.5 \mathrm{~cm}$. long, 1-2 cm. broad; pedicels $6 \mathrm{~mm}$. long or shorter, the bractlets 1-3 mm. long; sepals 3-5 mm. long, glabrous, firm-membranaceous; petals white, lilac, or pinkish, 9-10 mm. long, obovate; capsule 3-5 mm. long, black or dark purple.

\section{COMMELINA L.}

Perennial herbs, simple or branched, glabrous or pubescent; leaves mostly broad, sheathing at the base, more or less succulent; peduncles subtended by spathiform bracts, solitary or aggregate, scattered or crowded at the ends of the branches, the peduncles bifid above, the 2 branches racemiform, the lower branches 1-3-flowered, with usually sterile flowers, the upper branches flowering later, with 2-12 more or less secund flowers; sepals 3, the outer one cucullate, oblong- 
elliptic, the 2 inner ones obovate or oblong and falcate, green or petaloid, persistent, sometimes accrescent in age; petals 3 , free, the outer one cucullate, ovate, very shortly unguiculate, usually small, sometimes absent, the 2 inner petals usually long-unguiculate, ovate or cordate, generally blue, marcescent; perfect stamens 3 , 2 or 3 others usually present but with sterile cruciate-quadrifid anthers, the filaments long, slender, glabrous; anthers of the fertile stamens oblong; ovary sessile, glabrous, 2-3-celled, the dorsal cell 1-ovulate, sometimes abortive, the 2 ventral cells 1-2-ovulate; capsule dry, chartaceous, loculicidally 2-3-valvate; seeds small, pyramidal or ellipsoid, more or less compressed, the testa smooth or variously roughened.

About ninety species, widely distributed in both hemispheres, most numerous in tropical regions. Probably all the Central American ones are included in this treatment.

Sheaths conspicuously ferruginous-ciliate at the orifice and along the margins.

Sheaths white-ciliate, or at least not as above.

C. robusta f. vestita.

Margins of the spathe united below.

Spathes and leaves scabrous-ciliate on the margins; sheaths not auriculate at the summit, the lower and middle ones $3.5-4 \mathrm{~cm}$. long; leaves scabrous on both surfaces........................ Standleyi.

Spathes and leaves not scabrous-ciliate on the margins; sheaths prominently auriculate at the summit, the lower and middle ones $1-3 \mathrm{~cm}$. long; leaves not scabrous.

Larger leaves of the main branches lanceolate to lance-ovate, $1-4 \mathrm{~cm}$. wide; mature spathes $2-5 \mathrm{~cm}$. long.

Petals deep or pale blue.

Spathes glabrous or minutely hirtellous.............. erecta.

Spathes white-villous with long hairs at the base.C. erecta f. intercursa.

Petals white....................... erecta f. candida .

Larger leaves of the main branches narrowly linear to linear-lanceolate, $3-20 \mathrm{~mm}$. wide; mature spathes $1-3 \mathrm{~cm}$. long.

Sheaths usually glabrous or slightly pubescent; leaves glabrous to sparsely pubescent.

Spathes densely short-villous.

Petals blue................... erecta var. angustifolia.

Petals white.............. erecta var. angustifolia f. albina.

Spathe white-villous with long hairs.

Petals blue.............. erecta var. angustifolia f. crispa.

Petals white.............. erecta var. angustifolia f. cana.

Sheaths and both surfaces of the leaves densely pubescent.

Margins of the spathe free.

C. erecta var. angustifolia f. villosa.

Spathes not transversely striate, not with dark purple edges; plants glabrous or glabrate; petals usually small, less than $5 \mathrm{~mm}$. long....... diffusa.

Spathes conspicuously transverse-striate between the nerves, usually with dark purple edges; leaves, stems, peduncles, and spathes scabrous or finely pubescent; petals about $15 \mathrm{~mm}$. long.

Plants acaulescent when young, in age branched only from the base, the stem-like peduncles very stout and mostly 6-20 cm. long; spathes $2-3 \mathrm{~cm}$. wide (when folded) and $3-4 \mathrm{~cm}$. long.......... alpestris.

Plants with well-developed and much elongate stems from the beginning of anthesis, the stem bearing several or numerous spathes on slender, 
relatively short peduncles; folded spathes mostly $1-1.5 \mathrm{~cm}$. wide and 2-3 cm. long.

Leaves oblong-lanceolate to ovate-lanceolate, $2.5-4 \mathrm{~cm}$. wide.

Leaves narrowly lanceolate to linear, 5-12 mm. wide.

C. coelestis.

C. coelestis var. Bourgeaui.

Commelina alpestris Standl. \& Steyerm. Field Mus. Bot. 23: 213. 1947.

Moist meadows in the high mountains, usually in alpine regions, often on limestone, 2,500-3,700 meters; endemic; Chimaltenango (Cerro de Tecpám); Huehuetenango (Sierra de los Cuchumatanes; type from vicinity of Chémal, Steyermark 50265).

Plants perennial from a dense cluster of slender but fleshy roots, acaulescent at the beginning of anthesis, in age branched from the base or shortly above the base and becoming as much as $30 \mathrm{~cm}$. high, or perhaps even taller, the height consisting mostly of the length of the peduncles; leaves all basal or a few present on the lower part of the stem, lanceolate, $11 \mathrm{~cm}$. long and $2.5 \mathrm{~cm}$. wide or smaller, attenuate-acuminate, dilated and sheathing at the base, the sheaths membranous, pale, about $2.5 \mathrm{~cm}$. long and $1 \mathrm{~cm}$. broad, eciliate, the blades glabrous, eciliate, green above, slightly paler beneath, the margins slightly cartilaginous-thickened; peduncles mostly appearing simple and scapiform, but actually arising from a short stem bearing 1 or more large leaves near the base, the early and perhaps sometimes all the peduncles very short and concealed by the leaf sheaths, the fruiting peduncles much elongate, sometimes $22 \mathrm{~cm}$. long but mostly shorter, very stout, as much as $5 \mathrm{~mm}$. thick, smooth and glabrous; spathe at anthesis green, about $3-3.5 \mathrm{~cm}$. long and when folded $2-2.5 \mathrm{~cm}$. wide, obtuse or acute, in age as much as $3 \mathrm{~cm}$. broad (when folded) and $4 \mathrm{~cm}$. long, thinly hirsutulous, very strongly transverse-veined between the nerves; flowers numerous, borne on short stout pedicels; sepals glabrous, pale green, $5 \mathrm{~mm}$. long, subacute; petals large, about $15 \mathrm{~mm}$. long, deep blue.

This species is closely related to $C$. coelestis, of which it might be considered an extreme form, but apparently it is fully distinct and better marked than many other members of the genus. In general appearance it is quite distinct from C. coelestis in being acaulescent or bearing greatly elongate, scapiform peduncles, which are much stouter than in that species and at first glance appear to be stems rather than peduncles. The spathes also are much larger than in Guatemalan plants of $C$. coelestis, being both relatively and absolutely broader. The plants grow and flower only when there is abundant moisture, drying when the rains cease but remaining in place for a long time afterward, when the dry stems are conspicuous in the alpine meadows.

Commelina coelestis Willd. Enum. Hort. Berol. 1: 69. 1809. C. pallida Willd. Hort. Berol. 2: 87. pl.87. 1816. C. acuminata HBK. 
Nov. Gen. \& Sp. 1: 258. 1815. China cucharita (Guatemala); Lochoch (fide Aguilar).

Moist fields or meadows or open forest, often in pine-oak forest or with Juniperus, 900-3,500 meters; Jalapa; Jutiapa; Guatemala; Sacatepéquez; Chimaltenango; Quiché; Huehuetenango; Quezaltenango. Mexico.

Plants perennial from a dense cluster of elongate fleshy-thickened roots, erect, stout or slender, usually $40-70 \mathrm{~cm}$. high, generally branched above, the stems scabrous, especially above, the peduncles also scabrous; leaves oblong-lanceolate to ovate-lanceolate, $8-20 \mathrm{~cm}$. long, $2.5-4 \mathrm{~cm}$. wide, acute or acuminate, somewhat rounded or narrowed at the base, scaberulous above, villosulous or glabrate beneath; sheaths thin, scarious, often purplish or striped with purple, rather lax, $1.5-2.5 \mathrm{~cm}$. long, 5-7 mm. broad, white-ciliate, usually glabrous; peduncles slender, often numerous, erect, 1-6.5 $\mathrm{cm}$. long; spathes usually mottled or veined with purple in the upper half, shortly and abruptly acute or acuminate, subcordate or rounded at the base, short-villous throughout or villous at the base, mostly 2-3 cm. long and when folded 1-1.5 cm. wide, with conspicuous transverse veins between the nerves; upper raceme of the inflorescence 4-10-flowered, the lower raceme 1-2-flowered; petals deep blue, about $15 \mathrm{~mm}$. long; seeds blackish brown, foveolate.

This plant, like the preceding species, is found in fresh state only when there is abundant moisture, but the dry stems and foliage often persist long into the dry season.

Commelina coelestis var. Bourgeaui C. B. Clarke in DC. Monogr. Phan. 3: 153. 1881. Coyontura; Lochoch (fide Aguilar).

Moist meadows or pine-oak forest, 1,000-2,100 meters; Zacapa; Chimaltenango; Quiché; Huehuetenango. Southern Mexico.

Similar to the species except for the narrowly lanceolate to linear leaves, these only $5-12 \mathrm{~mm}$. wide.

This form is not sharply distinguished from the typical one.

Commelina diffusa Burm. f. Fl. Ind. 18. pl. 7, f. 2. 1768. C. nudiflora sensu Burm. f. op. cit. 17, and of many other later and recent authors, not L. C. longicaulis Jacq. Coll. Bot. 3: 234. 1789. Hierba de pollo; Lochoch, Lochoch de sapo (fide Aguilar).

Moist or wet, open places, thickets, or forest, often a weed in waste or cultivated ground, 1,600 meters or lower, most common in the lowlands; Petén; Alta Verapaz; El Progreso; Izabal; Zacapa; Chiquimula; Jalapa; Santa Rosa; Escuintla; Guatemala; Sacatepéquez; Sololá; Suchitepequez; Retalhuleu; Quezaltenango; San Marcos; Huehuetenango. Florida; Mexico; British Honduras to 
Salvador and Panama; West Indies; South America; Old World tropics.

Plants perennial, prostrate to ascending, green, the stems branched, rooting at the nodes, usually glabrous or nearly so, the roots fibrous; leaves somewhat paler beneath, lanceolate or ovate-lanceolate, $2.5-6 \mathrm{~cm}$. long, 1-2 cm. wide, acute

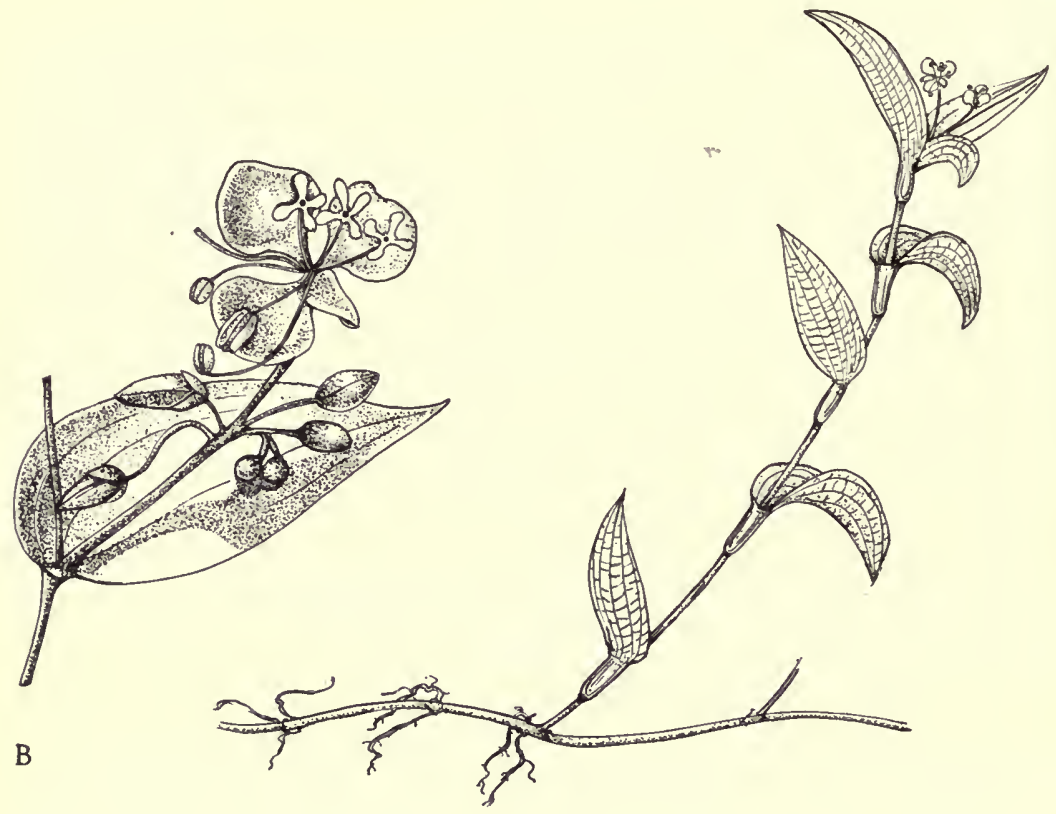

A

FIg. 4. Commelina diffusa. A. Habit of plant; $\times 1 / 2$. B. Portion of inflorescence; $\times 2$.

to acuminate, rounded at the base, glabrous or nearly so; sheaths thin, scarious, 1-1.5 cm. long, 3-4 mm. broad, white-ciliate, glabrous; peduncles sometimes almost obsolete, commonly 1-5 $\mathrm{cm}$. long, spreading or ascending, glabrous or sparsely puberulent above; spathes ovate-lanceolate, acute or acuminate, green, 8-20 mm. long, 5-10 mm. wide, glabrous, sometimes ciliate below; lower raceme of the inflorescence 1-3-flowered; sepals delicate, green, scarious-marginate, 3-4 $\mathrm{mm}$. long; petals blue, the upper 2 larger, $4-5 \mathrm{~mm}$. long; capsule normally 5-seeded; seeds black, reticulate. (Fig. 4.)

The Maya name of Yucatan is recorded as "bachaxiu." This species has been reported from Guatemala as C. nudiflora $\mathrm{L}$. and C. longicaulis Jacq. For a discussion of the nomenclature of the species see Merrill, Journ. Arnold Arb. 18: 64. 1937. This plant and others of the genus are said to be much eaten by cattle. It is one of the common dooryard weeds of Central America. 
Commelina erecta L. Sp. Pl. 41. 1753. C. erecta var. typica Fernald, Rhodora 42: 438. 1940. C. virginica of many authors, not L. Hierba de pollo; Lochoch; Ticuquito; Canutillo.

Moist or wet thickets or forest, often a weed in cultivated ground, especially in cafetales, 1,300 meters or lower, most common at the lower elevations; Petén; Izabal; Zacapa; Chiquimula; Jutiapa; Santa Rosa; Escuintla; Suchitepequez; Retalhuleu; Quezaltenango; Huehuetenango. Eastern and southern United States; Mexico; British Honduras to Salvador and Panama; West Indies; South America.

Stems slender, erect or decumbent, arising from a cluster of fleshy-fibrous roots, simple or branched, $40-120 \mathrm{~cm}$. long, glabrous; leaves lanceolate to ovatelanceolate, acute or acuminate, rounded at the base, abruptly contracted into the sheath, usually glabrous; sheaths thin, membranous, glabrous or sparsely pubescent, $22-35 \mathrm{~mm}$. long, 4-6 $\mathrm{mm}$. broad, the orifice sparsely ciliate; peduncles usually less than $1 \mathrm{~cm}$. long; mature spathes firm-membranaceous, ovate, green, shortly and abruptly acuminate, $2-3.5 \mathrm{~cm}$. long, glabrous or hirtellous; sepals $4-5 \mathrm{~mm}$. long; petals blue to very pale blue, 1-2.5 $\mathrm{cm}$. long; seeds grayish brown, smooth, puberulent, about $4 \mathrm{~mm}$. long and $3 \mathrm{~mm}$. broad.

Called "matalín" in Veracruz. This species, with its wide range in both tropical and temperate regions, is variable in size, shape, and pubescence of the leaves. Most of the Guatemalan material has spathes $2-2.5 \mathrm{~cm}$. long, and averaging smaller than the dimensions given by Fernald $(2.5-3.6 \mathrm{~cm}$. long). The following varieties and forms may be recognized in the Guatemalan material.

Commelina erecta f. intercursa Fernald, Rhodora 42: 439. 1940 .

Moist or wet thickets, 200-500 meters; Zacapa. Of occasional occurrence through much of the range of the species.

Like the typical form of the species, but more abundantly pubescent, the spathes densely villous near the base with long white hairs; petals usually blue.

Commelina erecta f. candida Standl. \& Steyerm. Field Mus. Bot. 23: 33. 1944.

Known in Guatemala only from the type, shaded slopes, Zacapa, between Zacapa and Santa María, 200 meters, Steyermark 29267. Chihuahua.

Spathes usually villous at the base with long white hairs, as in f. intercursa; petals white.

Commelina erecta var. angustifolia (Michx.) Fernald, Rhodora 42: 439. 1940. C. angustifolia Michx. Fl. Bor. Amer. 1: 
24. 1803. C. virginica var. angustifolia C. B. Clarke in DC. Monogr. Phan. 3: 183. 1881. Matalin de monte.

Usually on rather dry, brushy slopes or plains, in thickets or thin forest, or in open places, 850 meters or lower; Izabal; Jutiapa; Suchitepequez; Retalhuleu. Southern United States; Mexico; British Honduras, and probably farther southward.

Stems glabrous or sparsely pubescent; leaves and sheaths glabrous to somewhat villous; similar to the typical variety and differing chiefly in the narrower and often much smaller leaves; petals pale to deep blue.

Commelina erecta var. angustifolia f. albina Fernald, Rhodora 42: 439. 1940.

Not yet known definitely in Guatemala, but to be expected there; occurring in the Atlantic lowlands of Honduras, and scattered through the general range of the variety.

Spathes glabrous to short-pubescent, as in C. erecta var. angustifolia, but the petals white.

Commelina erecta var. angustifolia f. crispa (Wooton) Fernald, Rhodora 42: 440. 1940. C. crispa Wooton, Bull. Torrey Club 25: 451. 1898. C. erecta var. crispa Palmer \& Steyerm. Ann. Mo. Bot. Gard. 22: 417. 1935. Hierba de pollo.

At 1,100 meters or lower; Izabal (between Los Amates and Quiriguá); Guatemala (Lago de Amatitlán). Scattered throughout the range of the variety.

Sheaths, stems, and leaves often pubescent; leaves narrowly lanceolate or elliptic-lanceolate, $3-20 \mathrm{~mm}$. wide; spathes sparsely or densely villous, with longer white hairs at the base.

Commelina erecta var. angustifolia f. cana Standl. \& Steyerm. Field Mus. Bot. 23: 32. 1944.

Known definitely only from the type, Zacapa, along the railroad between La Fragua and Estanzuela, 200 meters, Steyermark 29136.

Similar to f. crispa in the pubescence of the sheaths, and differing only in the white petals.

Commelina erecta var. angustifolia f. villosa (C. B. Clarke) Standl. \& Steyerm. Field Mus. Bot. 23: 33. 1944. C. virginica var. villosa C. B. Clarke in DC. Monogr. Phan. 3: 183. 1881. C. elegans var. hirsuta Standl. Field Mus. Bot. 8: 136. 1930. 
Rocky slopes or open forest or plains, sometimes in pine forest, 2,000 meters or lower; Alta Verapaz; Zacapa; Chiquimula; Huehuetenango. British Honduras; Honduras; South America.

Stems glabrous or villosulous; leaves lanceolate to ovate-lanceolate, $5-18 \mathrm{~mm}$. wide, usually villosulous on both surfaces, or the lower surface less pubescent; sheaths villosulous; spathes usually rather densely pubescent; petals blue or white.

Commelina robusta Kunth, Enum. Pl. 4:52. 1843.

In forest, at or little above sea level; British Honduras (Sittee River, W. A. Schipp 746); Costa Rica; South America.

Plants rather stout, erect or decumbent, the stems $60-80 \mathrm{~cm}$. long, glabrous; leaves large, rather thin, broadly lanceolate, long-acuminate, rounded at the narrow, somewhat unequal base, mostly $8-12 \mathrm{~cm}$. long and $2.5-3.5 \mathrm{~cm}$. wide, transverse-veined between the nerves, glabrous or nearly so; sheaths $15-17 \mathrm{~mm}$. long, 3-4 mm. broad, ciliate, glabrate; peduncles less than $1 \mathrm{~cm}$. long; spathes several and crowded, usually terminal or nearly so, cordate-ovate, short-acute, firm-membranaceous, transverse-veined between the nerves, glabrous, $20-27 \mathrm{~mm}$. long, about $20 \mathrm{~mm}$. wide; petals blue or white; capsule normally with 5 seeds; seeds of the ventral cell grayish, foveolate, $2-2.5 \mathrm{~mm}$. long.

Commelina robusta f. vestita (C. B. Clarke) Standl. \& Steyerm. Field Mus. Bot. 23: 33. 1944. C. monticola Seub. in Mart. Fl. Bras. 3, pt. 1: 264. 1855. C. monticola var. vestita C. B. Clarke in DC. Monogr. Phan. 3: 162. 1882.

In forest, 400 meters; Quiché (Finca Chaila, Zona Reina, A. F. Skutch 1802). South America.

Like the typical form of the species but the leaves sparsely villosulous on the upper surface, more densely villosulous on the lower surface; petals white in the Guatemalan plant.

Commelina Standleyi Steyermark in Standl. \& Steyerm. Field Mus. Bot. 23: 33. 1944.

On rather dry slopes in pine forest, 1,000-2,000 meters; endemic; Zacapa (Sierra de las Minas; type collected along trail between Río Hondo and summit of mountain at Finca Alejandría, Steyermark 29644).

Plants erect, slender, sparsely leafy, the stems simple or sparsely branched, $50 \mathrm{~cm}$. high or more, glabrate below, scaberulous above; leaves rather thick and firm, linear, 7-13 $\mathrm{cm}$. long, 2.5-4.5 mm. wide, attenuate, little narrowed at the base, passing directly into the sheath, densely scaberulous on both surfaces, scabrous-ciliate; lower and middle sheaths $22-40 \mathrm{~mm}$. long, $2.5-3 \mathrm{~mm}$. broad, hirsutulous to glabrate, the orifice and margin white-ciliate; peduncles terminal, 1-2.5 cm. long, scabrous-hirtellous; spathe falcate-ovate, long-acuminate, less than half as wide as long, $2-2.5 \mathrm{~cm}$. long, $1-1.3 \mathrm{~cm}$. wide, scabrous-hirtellous, not 
evidently transverse-veined, the margins thickened and scabrous-hirtellous, the closed basal portion about $5 \mathrm{~mm}$. long.

\section{DICHORISANDRA Mikan}

Perennial herbs, usually large and coarse, the stems simple or branched, erect or often scandent leaves mostly rather broad, vaginate at the base; inflores-

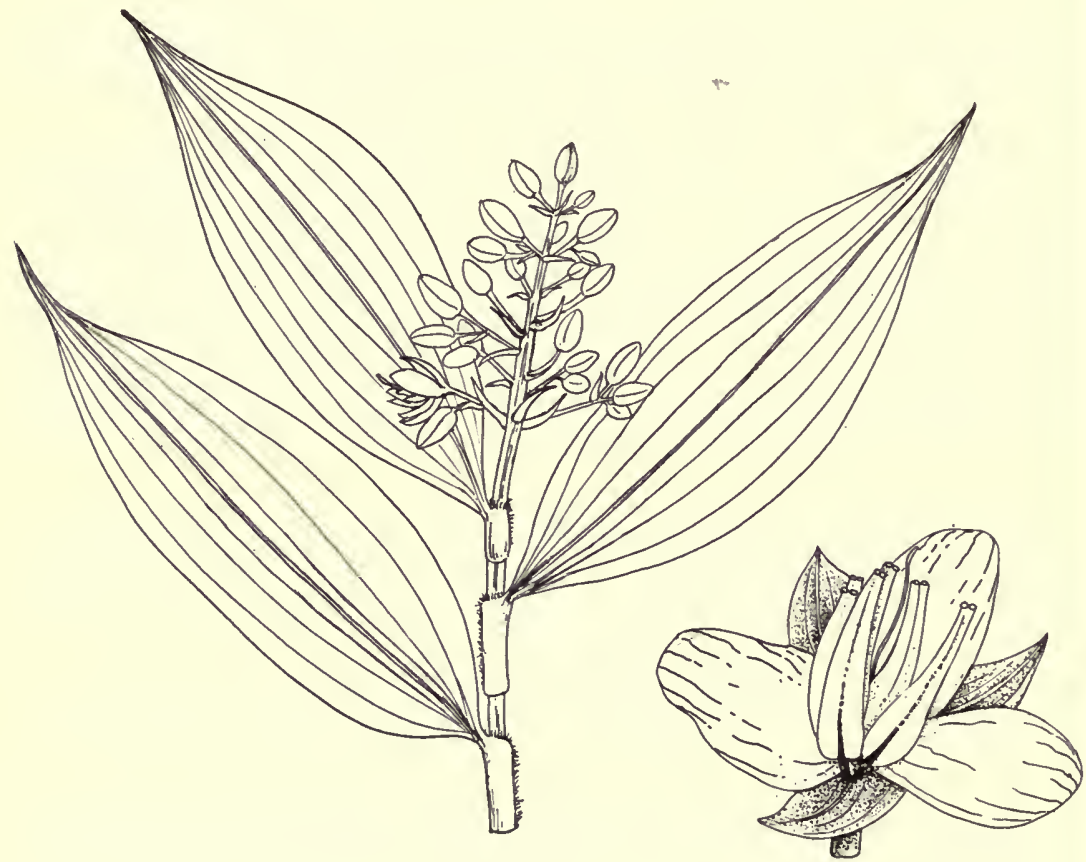

A

B

FIG. 5. Dichorisandra hexandra. A. Habit of upper portion of flowering stem; $\times 1 / 2$. B. Flower; $\times 2$.

cences usually terminal, racemose-paniculate, the racemes solitary, the branches short, bracteate at the base; bracts linear or narrow, flat; pedicels short, often subtended by ovate bractlets; flowers almost regular, the sepals 3 , free, the outer one cucullate, oblong-elliptic, the 2 inner ones oblong-falcate, green, sometimes scarious-marginate, or often petaloid, persistent in fruit and erect; petals 3 , free, the 2 inner ones subfalcate, short-unguiculate, blue or purple, marcescent; stamens usually 6 , equal or those of the outer series slightly shorter, those of the inner series subadnate to the petals, the filaments rather short, not barbate; anthers elongate, 2-celled, the cells narrow, parallel, contiguous, dehiscent by apical pores; ovary sessile, 3-celled, the cells generally 4-5-ovulate; capsule ovoid-trigonous, 3-celled, loculicidally 3-valvate; seeds several in each cell, covered with a pulpy 
aril, subpeltate, rounded or angulate, the testa crustaceous, rugose or almost smooth.

Species about thirty, in the American tropies, mostly in South America. Only one is known from continental North America. The South American ones are closely related, and their true number probably is less than thirty.

Dichorisandra hexandra (Aubl.) Standl. in Standl. \& Calderón, Lista Pl. Salvad. 48. 1925. Commelina hexandra Aubl. Pl. Guian. 35. pl. 12. 1775. D. Aubletiana Roem. \& Schult. Syst. Veg. 7: 1181. 1830. Hierba de pollo.

Moist or wet forests or thickets, 900 meters or lower; Alta Verapaz; Izabal; Jutiapa; Santa Rosa; Suchitepequez; Huehuetenango. Southern Mexico; British Honduras to Salvador and Panama; South America.

Plants usually scandent or subscandent, 1-5 meters long, the stems generally branched, glabrous; leaves thick-membranaceous, oblong-elliptic to elliptic-lanceolate, 6-18 cm. long, 2-7 cm. wide, long-acuminate, often abruptly so, unequally and broadly cuneate or somewhat rounded at the base, somewhat paler beneath, finely many-nerved, scarcely or not at all transverse-striate, glabrous, shortciliate at the base, subsessile or narrowed into a petioliform portion 1-2 mm. long; sheaths narrowly cylindric, close, glabrous to short-villosulous, especially near the margins, the orifice sparsely short-ciliate, 1-2 cm. long, 3-5 mm. broad; inflorescence racemose-paniculate, usually dense and many-flowered, sessile or pedunculate, 4-8 cm. long; bracts at the base of the branches linear, often shorter than the upper branches; axis of the panicle glabrous to densely hirsutulous; sepals 6-8 mm. long, usually glabrous; petals oblong, obtuse, blue or purplish blue, the margins and base edged with white, 10-13 mm. long; capsule 10-12 mm. long, 9-10 mm. broad; seeds 4-5 in each cell, the aril bright orange. (Fig. 5.)

\section{PHAEOSPHAERION Hasskarl}

Plants branched, with elongate, ascending or scandent, herbaceous stems, the leaves broad; peduncles solitary or aggregate toward the tips of the branches, arising from conspicuous spathaceous bracts, bifid; sepals 3, almost free; petals 3, free, the exterior one short-unguiculate, the 2 inner ones long-unguiculate, blue, marcescent; perfect stamens 3, the filaments elongate, glabrous, the anthers hastate-triangular; sterile stamens 2, opposite the inner petals; ovary 3-celled, the dorsal cell 1-ovulate, the 2 ventral cells 2-ovulate; capsule globose or ellipsoid, indehiscent, pergamentaceous, smooth and lustrous, blue, black, or white, containing normally 5 seeds.

About five species, in tropical America. No others are known from Central America. The name Athyrocarpus has been used by most authors of recent years for this group but, as pointed out by Woodson, that name, appearing first in 1853, was not formally published. 


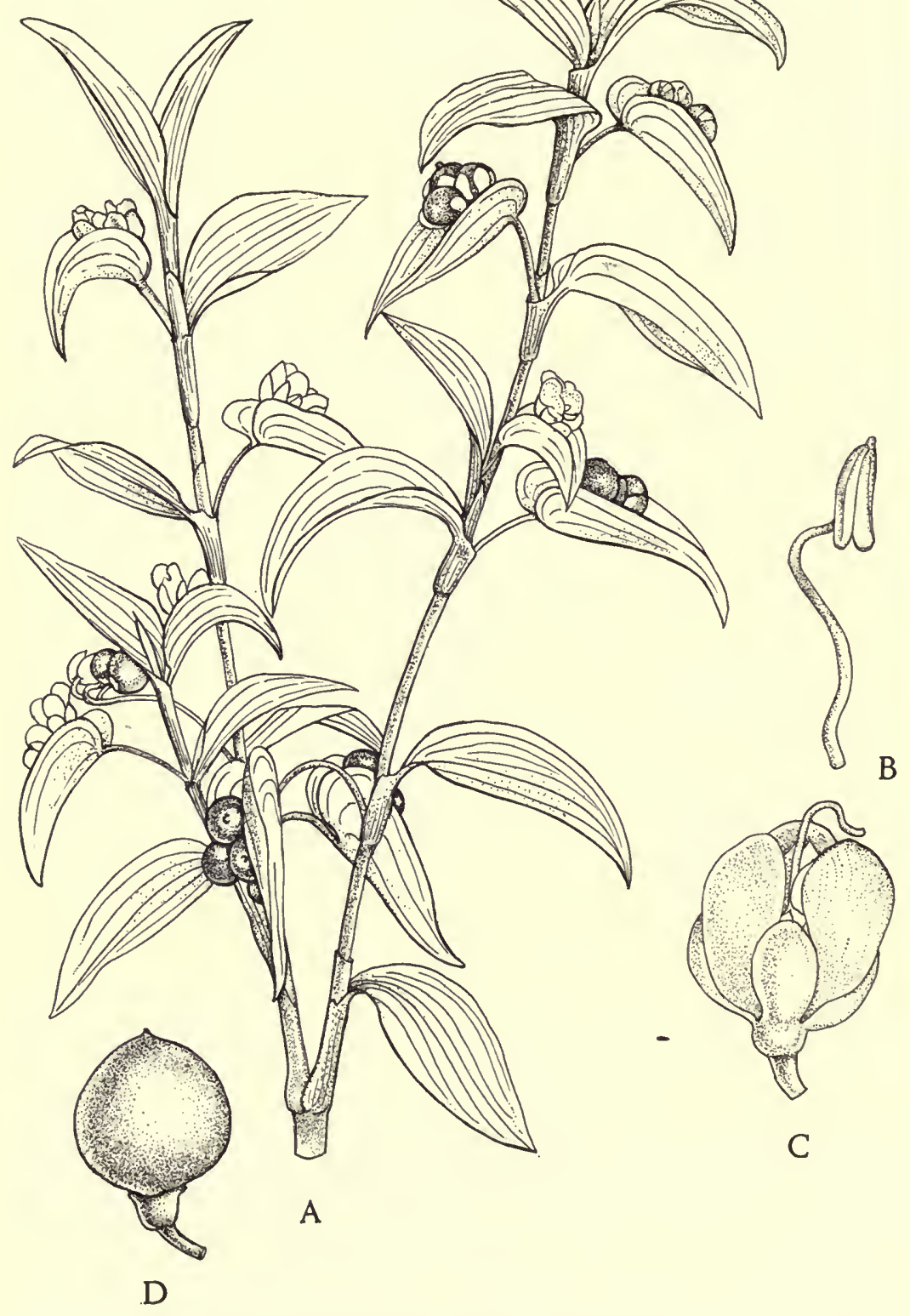

FIG. 6. Phaeosphaerion leiocarpum. A. Habit of upper portion of plant; $\times 1 / 2$. B. Stamen; $\times 5$. C. Flower; $\times 5$. D. Fruit; $\times 3$. 
Spathes long-pedunculate, axillary; fruit dark blue........... leiocarpum. Spathes short-pedunculate, chiefly terminal; fruit whitish.

Spathes glabrous or nearly so................ persicariaefolium.

Spathes densely rufous-hirsute................... rufipes.

Phaeosphaerion leiocarpum (Benth.) Hassk. Flora 49: 212. 1866. Commelina leiocarpa Benth. Bot. Voy. Sulph. 176. 1844 (type from Tigre Island, Golfo de Fonseca, Honduras). Athyrocarpus leiocarpus Benth. \& Hook. ex Hemsl. Biol. Centr. Amer. Bot. 3: 386. 1885. Lochoch, Lochoch amargo (fide Aguilar); Jicuquita.

Moist or wet thickets or mixed forest, often in rocky places, 1,900 meters or lower, most frequent at low elevations; Alta Verapaz; Zacapa; Chiquimula; Jalapa; Jutiapa; Santa Rosa; Escuintla; Guatemala; Sacatepéquez; Chimaltenango; Retalhuleu; Huehuetenango. Southern Mexico; Salvador to Panama; northern South America.

Plants large and diffuse, of ten much branched, frequently scandent over shrubs, the stems scabrous or villosulous to glabrate, often purplish; leaves thin, ovate to oblong-lanceolate, $2.5-10 \mathrm{~cm}$. long, 2-3 cm. wide, long-acuminate, rounded or subcordate at the base, sparsely pilose or glabrate, subsessile or abruptly contracted into a petiole 3-7 $\mathrm{mm}$. long, narrowed below into a purple-spotted, cylindric, scarcely inflated, sparsely or densely pubescent, ciliate sheath 9-17 mm. long and 2-4 mm. broad; peduncles 1-3.5 cm. long, pubescent or glabrate; spathes 2-5.5 $\mathrm{cm}$. long, ovate or lanceolate, long-acuminate, cordate at the base, finely pubescent or glabrate; racemes 3-5-flowered; petals blue or pale blue; fruit globose, dark blue or black, 6-7 mm. in diameter. (Fig. 6.)

Called "hierba de pollo" in Salvador.

Phaeosphaerion persicariaefolium (DC.) C. B. Clarke in DC. Monogr. Phan. 3: 137. 1881. Commelina persicariaefolia DC. in Red. Liliac. 8: pl. 472. 1816. Athyrocarpus persicariaefolius Hemsl. Biol. Centr. Amer. Bot. 3: 386. 1885. A. persicariaefolius f. tetraspermus Donn. Smith, Enum. Pl. Guat. 6: 54. 1903, nomen nudum.

Moist or wet thickets and mixed forest, 200-900 meters; Alta Verapaz; Jutiapa; Huehuetenango. Southern Mexico; Costa Rica; Panama; West Indies; South America.

Stems elongate, sometimes a meter long or more, erect or reclining on other plants, more or less branched, often rooting at the lower nodes, glabrous or nearly so; leaves lanceolate, $8-16 \mathrm{~cm}$. long, $2.5-4 \mathrm{~cm}$. wide, long-acuminate, gradually narrowed to the base, sparsely pubescent or glabrous, subsessile or narrowed into a petiole $3-4 \mathrm{~mm}$. long, the sheath sparsely pubescent or glabrate, rufous-ciliate; peduncles less than $1 \mathrm{~cm}$. long, terminal; spathes $2-3 \mathrm{~cm}$. long, acute, rounded 
at the base, densely and finely pubescent or glabrate; racemes densely flowered; fruit about $5 \mathrm{~mm}$. in diameter, white.

Phaeosphaerion rufipes (Seub.) Standl. \& Steyerm., comb. nov. Commelina rufipes Seub. in Mart. Fl. Bras. 3, pt. 1:265. 1855. P. persicariaefolium var. rufipes C. B. Clarke in DC. Monogr. Phan. 3: 137. 1881. Athyrocarpus rufipes Standl. in Standl. \& Cald. Lista Pl. Salv. 47. 1925.

Moist or wet forest and thickets, 1,200 meters or lower; Petén; Alta Verapaz; Santa Rosa; Escuintla; Chimaltenango. Salvador; Costa Rica; Panama; South America.

Plants suberect to procumbent, the stems slender, rooting at the nodes, glabrous or sparsely puberulent; leaves ovate-lanceolate or lanceolate, $7-10 \mathrm{~cm}$. long, 2-3 cm. wide, long-acuminate, obtuse or rounded at the base, villous to glabrate beneath, usually glabrate above, the sheaths rufous-hirsute near and along the margins or over the whole surface; peduncles about $5 \mathrm{~mm}$. long; spathes 1.5-2 cm. long, acuminate, densely rufous-hirsute, especially near the margins, or over the whole surface; racemes densely flowered; fruit $6 \mathrm{~mm}$. in diameter, white.

Called "zapupa" in Salvador.

\section{RHOEO Hance}

Perennial herbs with short stems, or sometimes acaulescent, glabrous; leaves large and rather broad, imbricate at the base; peduncles axillary, sometimes divided, terminated at the apex by 2 large boat-shaped bracts, the flowers numerous, included within the bracts, umbellately congested, the pedicels subtended at the base by sheathing ovate bractlets; sepals 3 , free, ovate-lanceolate, somewhat petaloid, marcescent; petals 3 , free, ovate, marcescent; stamens 6 , hypogynous, subequal, all fertile, the filaments barbate; anther cells oblong, separated by a subquadrate connective; ovary sessile, ovoid, subtrigonous, 3-celled, the cells 1-ovulate; capsule 3-celled, or by abortion 2-celled, loculicidally 3 -valvate; seeds solitary, oblong-ellipsoid, rugose, the hilum ventral.

The genus consists of a single species.

Rhoeo discolor (L'Hér.) Hance ex Walp. Ann. Bot. 3: 660 . 1852-53. Tradescantia discolor L'Hér. Sert. Angl. 8. pl. 12. 1788.

Moist or wet forest or thickets, often on rocky bluffs, said to be common on old Maya ruins, at or little above sea level; Petén; often grown for ornament in Guatemalan gardens, chiefly in the tierra caliente. Yucatan Peninsula of Mexico; British Honduras; West Indies.

Plants usually erect, somewhat fleshy, the stem glabrous, 10-20 cm. long or almost none; leaves densely imbricate, few or numerous, linear-lanceolate, 20-35 $\mathrm{cm}$. long, 3-5.5 cm. wide, acuminate, slightly narrowed to the sessile base, glabrous, 
green on both surfaces or often dark purple beneath; sheaths large, glabrous, or sparsely pilose at the orifice, as much as $4 \mathrm{~cm}$. broad; peduncles often branched above, $2-4.5 \mathrm{~cm}$. long, the bracts cymbiform, broadly ovate, opposite, glabrous, acute, $3-4.5 \mathrm{~cm}$. long; flowers numerous, the inflorescence shorter than the bracts and included in them; sepals ovate-lanceolate, $3-4 \mathrm{~mm}$. long; petals white, ovate, longer than the sepals, 5-8 mm. long; seeds rugose, $3 \mathrm{~mm}$. long, 1-1.5 mm. broad.

In Honduras, and probably elsewhere, this plant is known by the picturesque and appropriate name "señoritas embarcadas." From the form of the plant with bright purple leaves there may be obtained a colored decoction that is used by the Yucatecan Mayas as a cosmetic. It is probable that the plant is or has been used also for coloring various articles.

\section{TINANTIA Scheidweiler}

Erect herbs, usually annual, simple or branched; leaves large, mostly elliptic, usually pubescent, vaginate at the base; peduncles solitary and terminal on the branches, the peduncles subumbellate, 1-4-fid, the pedicels densely racemose or subumbellate, bracteolate or naked at the base; sepals 3 , free, elliptic, green, erect and persistent in fruit; petals 3 , free, subequal, short-unguiculate, elliptic, blue or purple, marcescent; stamens 6 , free, all fertile, 3 of the filaments longer, naked above, the anthers oblong, the 3 shorter filaments barbate at the middle, the anthers smaller and rounded; anther cells parallel or curved, slightly separated; ovary sessile, 3-celled, the cells mostly 3-5-ovulate, sometimes 2-ovulate; fruit capsular, dry, 3-celled, loculicidally 3-valvate; seeds $2-4$ in each cell, 1-seriate and superposed, the testa rugose-roughened.

About seven species, in tropical America. Only the following have been found in Central America but one other is known from Mexico.

Sepals glabrous.

Stems usually conspicuously retrorse-pubescent; leaves densely and finely puberulent, especially on the upper surface........... leiocalyx.

Stems glabrous or sparsely puberulent; upper leaf surface glabrous except for scattered slender hairs near the apex............ leiocalyx f. glabra.

Sepals pubescent.

Petiolar sheath ciliate; middle and upper part of the stem with a vertical line of puberulence; petals all blue, purple, or rose-colored; sepals 5-11 mm. long; common peduncle $2.5-8 \mathrm{~cm}$. long; leaves broadly ovate to elliptic, broadest at or below the middle, $3-11 \mathrm{~cm}$. long, $2-5 \mathrm{~cm}$. wide...T. erecta.

Petiolar sheath not ciliate; middle and upper part of the stem without a vertical line of puberulence; 2 or all the petals white; sepals $9-15 \mathrm{~mm}$. long; common peduncle 7-18 cm. long; leaves elliptic-obovate, broadest above the middle, 15-22 cm. long, $5-10 \mathrm{~cm}$. wide.................. Standleyi.

Tinantia erecta (Jacq.) Schlecht. Linnaea 25: 185. 1852. Tradescantia erecta Jacq. Coll. Bot. 4: 113. 1790. Tinantia fugax Scheidw. Allgem. Gartenzeit. 7: 365. 1839. Canutillo; Caña de Cristo; Plateado. 


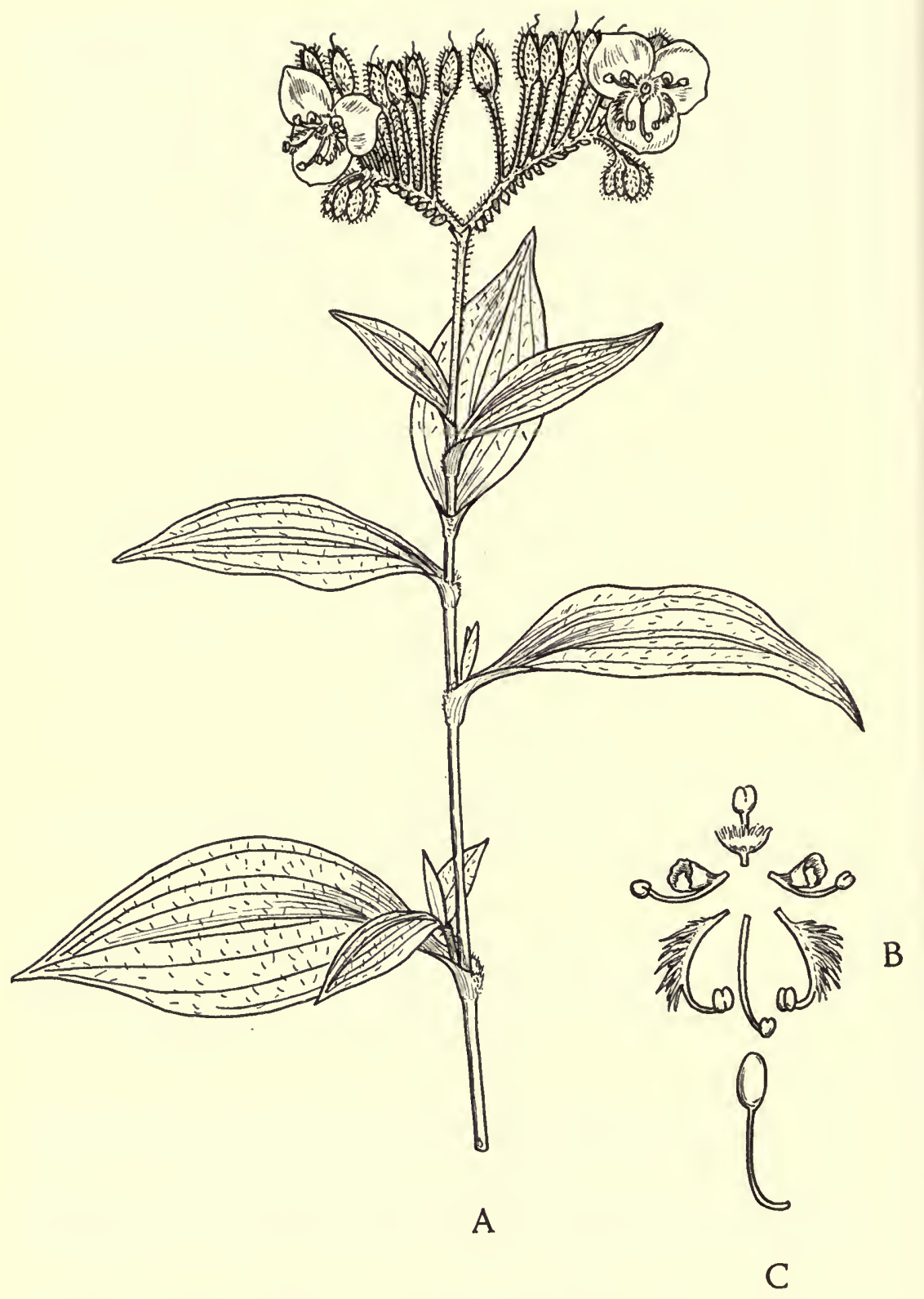

FIG. 7. Tinantia erecta. A. Habit of upper portion of plant; $\times 3 / 4$. B. Stamens, showing diverse forms within same flower; $\times 2$. C. Pistil; $\times 1 \frac{1}{2}$. 
Damp thickets or forest, river banks, or often a weed in cultivated fields, 1,200-2,600 meters; Alta Verapaz; Chiquimula; Jalapa; Santa Rosa; Escuintla; Guatemala; Sacatepéquez; Chimaltenango; Quiché; Huehuetenango; Quezaltenango; San Marcos. Mexico; Salvador and Honduras to Panama; South America.

Plants annual, erect, a meter high or lower, simple or often much branched, the stems succulent, often purplish, usually glabrous except for a line of puberulence on one side; leaves thin, mostly 4-12 cm. long, acuminate, acute to rounded at the base, with scattered hairs on both surfaces, deep green above, paler beneath, ciliate, usually finely pubescent beneath along the costa, the petioliform base 5-15 mm. long; sheaths membranaceous, ciliate, glabrous or sparsely pubescent, 5-10 mm. long, 3-7 mm. broad; peduncles conspicuously glandular-villous, subumbellate or 2-fid at the apex, 3-20-flowered, the inflorescence $1.5-5 \mathrm{~cm}$. long and 3-7 cm. broad, the bracts conspicuous or absent; pedicels 7-22 $\mathrm{mm}$. long, ascending in anthesis, spreading or recurved in fruit; sepals subacute, sparsely or usually densely glandular-villous; petals mostly blue to rose-purple, $1-1.5 \mathrm{~cm}$. long; capsule 7-11 mm. long, 4-5 mm. broad, rounded at the apex; seeds 2-3 in each cell, pale gray-brown, coarsely rugose, $3-3.5 \mathrm{~mm}$. long, $2-2.5 \mathrm{~mm}$. broad. (Fig. 7.)

During the rainy season this plant often springs up abundantly in gardens and grain fields, forming dense stands, but the leaves and stems wither as soon as there is a scarcity of moisture.

Tinantia leiocalyx C. B. Clarke in Donn. Smith, Bot. Gaz. 18: 211. 1893. Pogomesia leiocalyx Standl. Journ. Wash. Acad. Sci. 17: 161.1927.

Moist or wet thickets or forest, $500-1,700$ meters; Chiquimula; Retalhuleu (type from Río Samalá, W. C. Shannon 695); Quiché; Huehuetenango. Southern and western Mexico; Honduras; Costa Rica.

An erect annual 50-100 cm. high, the stems usually simple, sparsely or densely villous in the upper half, puberulent below; leaves thin, bright green on both surfaces, ovate or elliptic, $6-15 \mathrm{~cm}$. long, $2.5-8 \mathrm{~cm}$. wide, broadest at or below the middle, abruptly acuminate, rounded at the base and abruptly contracted into a petiole $1.5-5 \mathrm{~cm}$. long, ciliate, finely pubescent on both surfaces; sheaths membranous, ciliate, sparsely or densely villous, 6-8 $\mathrm{mm}$. long, 5-7 mm. broad; peduncles glabrous, about $3.5 \mathrm{~cm}$. long, subumbellate or corymbiform, sparsely 5-7-flowered, the inflorescence 1.5-4 cm. long and about as broad, the bracts oblong-lanceolate, acute, glabrous, $2-3 \mathrm{~mm}$. long; pedicels $6-10 \mathrm{~mm}$. long, ascending to reflexed; sepals subherbaceous, scarious-marginate, $9-13 \mathrm{~mm}$. long, rounded and broadly obtuse to narrowed at the apex, pale green, often petaloid and purplish tinged; capsule $8-13 \mathrm{~mm}$. long, 4-5 mm. broad; seeds coarsely rugose, $3 \mathrm{~mm}$. long, 2-2.5 mm. broad.

Tinantia leiocalyx f. glabra Standl. \& Steyerm. Field Mus. Bot. 23: 34. 1944. 
At about 1,500 meters; Guatemala (without special locality, Ignacio Aguilar 118). Mexico.

Stems glabrous or sparsely puberulent; leaves glabrous above except for scattered hairs near the apex, usually glabrous beneath, finely puberulent above close to the margins, ciliate, narrowed below into a petiole as much as $4 \mathrm{~cm}$. long; sheaths long-ciliate, glabrous or sparsely puberulent; peduncles glabrous or puberulent; sepals glabrous, 8-11 $\mathrm{mm}$. long, somewhat narrowed at the apex.

Tinantia longipedunculata Standl. \& Steyerm. Field Mus. Bot. 23: 35. 1944.

Moist thickets or forest, 300 meters or lower; Escuintla (type from Santa Lucía, Heyde \& Lux 6392); Suchitepequez. Central and southern Mexico; Costa Rica.

An erect herb 30-50 $\mathrm{cm}$. high or taller, the stems $3-4 \mathrm{~mm}$. thick, glabrous to sparsely antrorse-puberulent; leaves thin, 7-12 cm. long, $3-4.5 \mathrm{~cm}$. wide, acuminate, narrowed below into a petiole 1-3 $\mathrm{cm}$. long, sparsely or densely appressed-pilose above, glabrate or sparsely appressed-puberulent beneath, densely ciliate; sheaths loosely ciliate, glabrate to sparsely appressed-pubescent, 4-8 $\mathrm{mm}$. long, 3-8 $\mathrm{mm}$. broad; peduncles slender, 5-10 $\mathrm{cm}$. long, finely and antrorsely appressed-pubescent, simply racemose to 2 -fid at the apex, 4-14-flowered, the inflorescence $2-5 \mathrm{~cm}$. long, $3-4 \mathrm{~cm}$. broad, the bracts very small, poorly developed, about $1 \mathrm{~mm}$. long; pedicels spreading to ascending, 7-10 mm. long, finely puberulent or glabrate; sepals glabrous, 8-9 mm. long, narrowed and subobtuse at the apex; capsule about $9 \mathrm{~mm}$. long and $5 \mathrm{~mm}$. broad.

Tinantia Standleyi Steyermark in Standl. \& Steyerm. Field Mus. Bot. 23: 35. 1944. Caña de Cristo.

Moist or wet thickets and forest, 900-2,100 meters; Chiquimula; Sacatepéquez; Sololá; Quezaltenango (type from lower slopes of Volcán de Santa María, between Finca Pirineos and San Juan Patzulín, Steyermark 33605); San Marcos. Costa Rica.

A stout erect herb about a meter high, the stems simple or sparsely branched, usually much stouter than in other species, as much as $1 \mathrm{~cm}$. thick, glabrous or glabrate, often dark red below, purplish above; leaves thin, deep green above, paler beneath, mostly $12-21 \mathrm{~cm}$. long, abruptly acuminate, subsessile or gradually narrowed at the base into a petiolar portion 1-2.5 cm. long, sparsely or densely and finely pubescent above, glabrate to densely pubescent beneath; sheaths membranous, glabrous or sparsely villosulous, $1.5-2.5 \mathrm{~cm}$. long, 1-2 cm. broad; peduncles conspicuously and densely glandular-villous, $2-6$-fid at the apex, 16-100-flowered, the inflorescence $6-13 \mathrm{~cm}$. long, 5-14 cm. broad, the bracts conspicuously developed, spreading, lanceolate to ovate, acute or acuminate, densely glandular-villous, 3-10 $\mathrm{mm}$. long, 3-4 mm. wide; pedicels often purple, ascending in anthesis, reflexed in fruit, 10-23 mm. long, densely glandular-villous; sepals dull green, subobtuse, densely glandular-villous; petals $1 \mathrm{~cm}$. long, all white or the lower one blue or pale pink; anthers lilac; style yellow, barbate; capsule 10-13 $\mathrm{mm}$. long, $4 \mathrm{~mm}$. 
broad; seeds dull brown or gray-brown, coarsely rugose, $2.5-3 \mathrm{~mm}$. long, $2.5 \mathrm{~mm}$. broad.

This showy plant sometimes forms a ground cover on forested slopes of the volcanoes. From the common T. erecta it is distinguished by its stouter and more luxuriant habit, non-ciliate sheaths, differently colored flowers, long peduncles, and larger and differently shaped leaves.

\section{TRADESCANTIA L.}

Perennial herbs, erect to prostrate, glabrous or pubescent; flowers umbellate, the umbels several-many-flowered, sessile or nearly so, variously arranged, subtended at the base by large leaf-like bracts; sepals 3, free, elliptic or oblong, green or petaloid, persistent; petals 3 , free, equal, broad, short-unguiculate, generally blue or purple, sometimes white, marcescent; stamens 6 , free, all fertile, subequal or the 3 opposite the petals shorter, the filaments barbate or naked; anther cells ellipsoid or oblong, dehiscent by a longitudinal slit, approximate and almost parallel or separated by a rather broad connective; ovary sessile, 3-celled, the cells 2-ovulate; capsule dry, 3-celled, loculicidally 3 -valvate; seeds generally 2 in each cell, subpyramidal, usually rugose-reticulate.

Species perhaps forty, all American, in both tropical and temperate regions. Probably all the Central American species appear in the following list.

Umbels sessile along the branches, each umbel borne in the axis of a leaf-like bract.

Leaves $12-16 \mathrm{~cm}$. long, flat, not complicate, the margins not obviously thickened; sepals $3.5-5 \mathrm{~mm}$. long.................................

Leaves $3-11 \mathrm{~cm}$. long, usually complicate, the margins conspicuously thickened and brown; sepals $6.5-8 \mathrm{~mm}$. long. ................ crassifolia.

Umbels subtended at the base by 2 leaf-like bracts, pedunculate.

Stems covered throughout with long spreading hairs 1-3 mm. long. T. Standleyi. Stems glabrous or the hairs appressed or, if spreading, less than $1 \mathrm{~mm}$. long.

Peduncles and upper portion of the stem densely sericeous with appressed hairs; uppermost leaves densely soft-sericeous on both surfaces.

T. belizensis.

Peduncles and upper portion of the stem glabrous or villosulous with spreading hairs; uppermost leaves glabrous or sparsely villous.

Bracts 2-5.5 cm. long, leaf-like; pedicels $10-20 \mathrm{~mm}$. long; petals usually blue, sometimes white; leaves not unequal at the base; sepals 5-6 $\mathrm{mm}$. long.

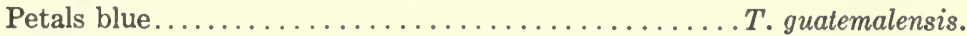

Petals white....................... guatemalensis f. alba.

Bracts 1-2 cm. long, spathe-like; pedicels 4-9 mm. long; petals usually pink or lilac, sometimes white; leaves very unequal at the base; sepals 3-4 mm. long.

Leaves glabrous or glabrate on both surfaces; spathes glabrous or glabrate.

T. commelinoides var. glabrata.

Leaves pubescent on one or both surfaces; spathes more or less puberulent. 
Petals usually pink or lilac; bracts ovate; upper leaves mostly oblong or ovate-oblong, usually $5-9 \mathrm{~cm}$. long and $2-3.5 \mathrm{~cm}$. wide.

T. commelinoides.

Petals white; bracts almost orbicular or orbicular-ovate; upper leaves mostly ovate, usually $3-5 \mathrm{~cm}$. long and $1.5-2 \mathrm{~cm}$. wide.

T. commelinoides var. rotundifolia.

Tradescantia belizensis Standl. Field Mus. Bot. 22: 5. 1940.

Moist forest, 1,000-2,000 meters; Chiquimula; Huehuetenango. Veracruz; Chiapas; British Honduras, the type from Vaca, El Cayo District, P. H. Gentle 2228.

A branched perennial herb, the stems procumbent or creeping, rooting at the nodes, covered with very long, soft, spreading or appressed hairs, rarely glabrate; leaves thin when dried, lance-oblong to ovate-lanceolate, $3-8 \mathrm{~cm}$. long, $1.5-3 \mathrm{~cm}$. wide, acute or acuminate, unequally narrowed at the base, usually densely pilose on both surfaces with long soft hairs, the older leaves sometimes glabrate or only sparsely pilose; sheaths thin, scarious, 9-13 $\mathrm{mm}$. long, 4-5 $\mathrm{mm}$. broad, more or less densely pilose with long soft hairs, the orifice and margins pilose-ciliate; inflorescences terminal, on a long or rather short peduncle; bracts similar to the leaves, unequal, dilated at the base, usually densely soft-pilose; flowers densely crowded, on slender pubescent pedicels; petals pink, pinkish lilac, or white, $8 \mathrm{~mm}$. long; stamens unequal, 3 of them shorter, the filaments long-pilose.

Tradescantia commelinoides Roem. \& Schult. Syst. Veg. 7: 1176. 1830. Lochoch (fide Aguilar).

Moist or wet thickets or forest, 900-3,000 meters; Alta Verapaz; El Progreso; Santa Rosa; Escuintla; Sacatepéquez; Chimaltenango; Sololá; Huehuetenango; Quezaltenango; San Marcos. Central and southern Mexico; Honduras and Salvador to Panama.

Plants perennial, apparently with fibrous roots, branched, the stems prostrate to procumbent and rooting at the nodes, sometimes ascending, generally pubescent in a line along one side, or more densely pilose above, often purplish; leaves very thin when dried, paler beneath and sometimes blotched with lilac, oblong-lanceolate to ovate, 5-9 cm. long, 2-3.5 cm. wide, acute or acuminate, somewhat oblique at the base, the petioliform portion $2-5 \mathrm{~mm}$. long, the uppermost leaves sessile, sparsely pilose on both surfaces or glabrate; sheaths scarious, long-pilose or glabrous, the margins ciliate, 5-11 mm. long, 2-6 mm. broad; umbels terminal, 2-bracteate, usually long-pedunculate, the peduncle slender, $1.5-5 \mathrm{~cm}$. long, more or less shortpilose; bracts spathe-like, ovate to rounded-ovate, acute or acuminate, rounded to subcordate at the base, 1-2 cm. long, usually long-pilose at the base, sparsely pilose or glabrous above, ciliate; umbels few-flowered, the pedicels villous; sepals pale green, scarious-marginate, $3-4 \mathrm{~mm}$. long, 2 of them usually glabrous, the third asymmetric and pilose-ciliate on one margin; petals rose-purple to pink or lilac, 5-7 mm. long; stamens subequal, the filaments barbate below. (Fig. 8.)

Tradescantia commelinoides var. glabrata Brueckner, Notizbl. Bot. Gart. Berlin 10: 59. 1928. T. macropoda Greenm. Proc. Amer. Acad. 32: 395. 1897. 


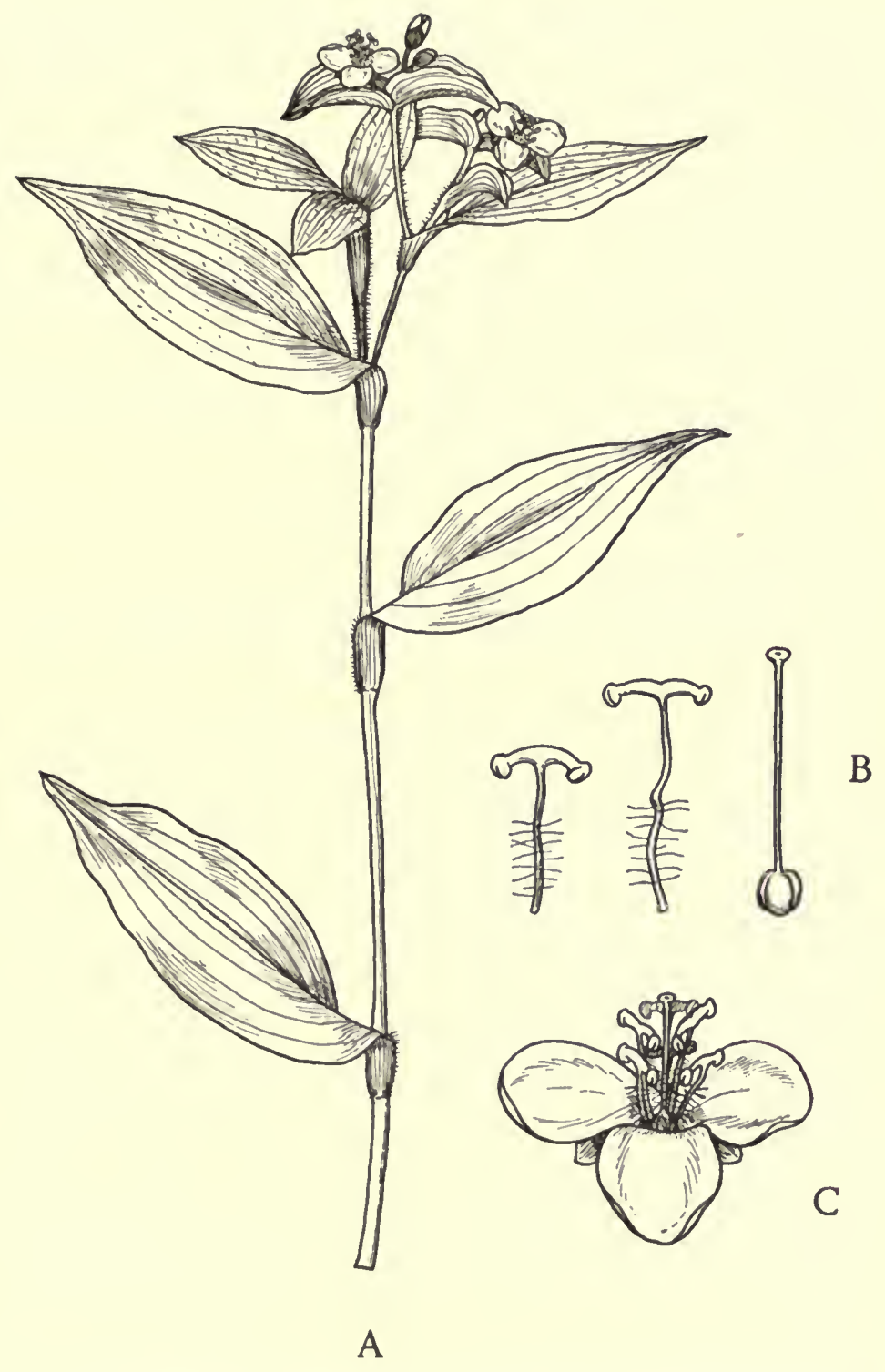

FIG. 8. Tradescantia commelinoides. A. Habit of upper portion of plant; $\times 3 / 4$. B. Two sizes of fertile stamens, and single pistil; $\times 4 \frac{1}{2}$. C. Flower; $\times 2$. 
Moist forest, 1,200-2,900 meters, or perhaps also at lower elevations; Escuintla; Suchitepequez; Huehuetenango. Southern Mexico.

A variety distinguished by its glabrous leaves, usually white flowers, and sometimes larger leaves.

Tradescantia commelinoides var. rotundifolia C. B. Clarke in DC. Monogr. Phan. 3: 296. 1881. T. gracillima Standl. Field Mus. Bot. 8: 135. 1930 (type from Tela, Honduras).

Moist or wet thickets or forest, 1,200-1,700 meters; Chiquimula; Guatemala. Honduras; Costa Rica; Panama.

Distinguished from the species by its proportionately broader and generally smaller leaves, the upper leaves, especially, ovate, the bracts generally broader and more rounded, the petals usually white.

Tradescantia crassifolia Cav. Icon. Pl. 1: 54. pl. 75. 1791. Zonji (Huehuetenango).

Open grassy slopes or fields, sometimes in pine forest, $1,600-2,500$ meters; Chimaltenango; Sololá; Huehuetenango. Widely distributed in Mexico.

Plants erect or ascending, from tuberous-thickened roots, the stems simple or sparsely branched, 12-60 $\mathrm{cm}$. high, lanate or densely pilose; leaves thick and fleshy when fresh, rather thick when dried, 2-ranked, linear-lanceolate to lanceoblong, 3-11 cm. long, 1-3 cm. wide, acute, at the base slightly broader than at the middle, the margins thickened, brownish, often undulate, sparsely pilose or glabrate above, more or less lanate-villous beneath; sheaths passing directly into the blade, sometimes almost obsolete, 4-8 $\mathrm{mm}$. long, 4-10 mm. broad, lanatevillous to glabrate; bracts 2, leaf-like, unequal, 1.5-6 cm. long, lanate-pilose or pubescent beneath, complicate; umbels terminal or axillary, sessile, usually dense, 1-8 umbels present on a stem or branch; pedicels 6-14 $\mathrm{mm}$. long, usually densely sericeous-lanate or white-pilose; sepals oblong-elliptic, subacute or acute, 6.5-8 $\mathrm{mm}$. long, membranaceous, scarious-marginate, white-lanate or white-pilose; petals purplish rose or bluish, 1-1.5 $\mathrm{cm}$. long; filaments equal, villosulous; ovary hirsute.

T. crassifolia var. glabrata C. B. Clarke (in DC. Monogr. Phan. $3: 293.1881$ ) is a form with glabrous leaves, only the margins lanate. It is known at present only in Mexico but may be expected in Guatemala.

Tradescantia guatemalensis C. B. Clarke in Donn. Smith, Bot. Gaz. 18: 210. 1893. T. anisophylla Standl. Field Mus. Bot. 22: 4.1940 (type from Volcán de Tacaná, Chiapas). T. tacanana Standl. op. cit. 6. 1940 (type from Volcán de Tacaná, Chiapas). Coholóm (Cobán, Quecchí); Hierba de pollo; Lochoch (fide Aguilar). 
Moist banks or moist or wet forest and thickets, sometimes in rocky places or along stream banks, 200-2,600 meters; Alta Verapaz; El Progreso; Zacapa; Jalapa; Jutiapa; Santa Rosa (type from Santa Rosa, Heyde \& Lux 3515); Guatemala; Sacatepéquez; Chimaltenango; Sololá; Huehuetenango; Quezaltenango; San Marcos. Chiapas; Salvador.

Plants perennial, apparently with fibrous roots, the stems procumbent or ascending, rooting at the lower nodes, $30-100 \mathrm{~cm}$. long, simple or branched, appearing glabrous or usually pubescent in a line along one side, the lower internodes rarely sparsely pubescent; leaves thin when dried, lance-oblong to ovate-oblong, 3-9 $\mathrm{cm}$. long, 1-2.5 cm. wide, acuminate, rounded or narrowed at the subequal base, densely short-pilose or glabrous on both surfaces; sheaths scarious, 8-15 mm. long, 5-6 mm. broad, glabrous or sparsely villous, pilose-ciliate; bracts leaf-like, unequal, deltoidovate to lanceolate, rounded at the base and contracted directly into the sheath, $2-5.5 \mathrm{~cm}$. long, 1-2 cm. wide; peduncles terminal, usually solitary or sometimes 2 , commonly 1-8 cm. long; umbels several-many-flowered, the pedicels flexuous, recurved after anthesis, $8-20 \mathrm{~mm}$. long, more or less villous with spreading hairs; sepals narrowly lanceolate or linear-oblong, 5-7 $\mathrm{mm}$. long, 1-2 $\mathrm{mm}$. wide, usually glabrous except for the barbate apex, rarely pilose on the surface or margins: petals blue or pale blue, venose, $7-9 \mathrm{~mm}$. long; filaments pilose below; seeds 6 , dark gray, rugulose-tuberculate, about $1.5 \mathrm{~mm}$. in diameter.

Tradescantia guatemalensis f. alba Standl. \& Steyerm. Field Mus. Bot. 23: 37. 1944.

Moist thickets or a weed in cafetales, 1,500-1,800 meters; Sacatepéquez (type collected at Antigua, Standley 58025; also collected in a barranco above Dueñas).

Differing from the typical form of the species only in having white petals.

Tradescantia Standleyi Steyermark in Standl. \& Steyerm. Field Mus. Bot. 23: 37. 1944.

Moist or wet forest, often on exposed rocks, 1,000-2,100 meters; endemic; Zacapa (Sierra de las Minas); Chiquimula (type from Montaña Nonojá, northeast of Camotán, Steyermark 31696); Huehuetenango (region of La Libertad).

A large coarse perennial, the stems erect or ascending, $120 \mathrm{~cm}$. high or less, simple or usually branched above, stout, 4-6 $\mathrm{mm}$. in diameter, densely hirsute throughout with lax spreading brownish hairs as much as $3 \mathrm{~mm}$. long; radical leaves often numerous and forming a large rosette; principal cauline leaves few or numerous, pale green, oblong-elliptic or ovate-elliptic, mostly $12-18 \mathrm{~cm}$. long and 5-6 $\mathrm{cm}$. wide, acute, narrowed to the base and gradually passing into the sheath, the uppermost leaves ovate and broadly rounded to subcordate at the base, densely hirsutulous on both surfaces with long or short hairs; sheaths $10-15 \mathrm{~mm}$. long, 7-12 mm. broad, brownish-hirsute, the margins and orifice hirsute-ciliate; 
peduncles terminal, $2.5-6 \mathrm{~cm}$. long, forming a very large and open, dichotomous inflorescence, densely hirsute with spreading brownish hairs; umbels few-flowered, subtended by 2 spathe-like or leaf-like, ovate or rounded-ovate, subequal bracts $2-3 \mathrm{~cm}$. long; pedicels about $9 \mathrm{~mm}$. long, recurved after anthesis, densely villosulous; sepals ovate, subobtuse, $3.5-5 \mathrm{~mm}$. long, $2.5-3 \mathrm{~mm}$. wide, 2 of them glabrous or sparsely pilose near the base, the third densely brown-villosulous; petals lilac; capsule $4 \mathrm{~mm}$. high; seeds usually 6 , gray-brown, $1.5-2 \mathrm{~mm}$. long, finely rugulose.

Tradescantia velutina Kunth \& Bouché, Ind. Sem. Hort. Berol. 12.1848 (described from plants cultivated in Europe, "serre de Rivage"; the type specimen formerly in the Berlin Herbarium is labeled as having been collected in Guatemala by Warscewicz).

Moist or dry, brushy, rocky slopes, sometimes on steep rocky banks along streams, 250-850 meters; Zacapa; Chiquimula; so far as known, endemic.

A rather stout, usually simple herb $40-100 \mathrm{~cm}$. high, erect or ascending, the stems 5-7 mm. in diameter, softly and sparsely or densely villosulous; leaves 2-ranked, dull green and lustrous above (in the fresh state), somewhat paler beneath, lanceolate or oblong-lanceolate, $12-16 \mathrm{~cm}$. long, $1.5-3.5 \mathrm{~cm}$. wide, acute to long-acuminate, gradually narrowed or rounded or subcordate at the sessile base, sparsely or densely short-pilose above, more densely villosulous beneath, the margins not obviously thickened; sheath loose, 7-10 $\mathrm{mm}$. long, 6-10 $\mathrm{mm}$. broad, sparsely or densely villosulous; umbels several to many along the upper part of the stem, sessile, solitary, each subtended by a large leaf-like bract, the bracts gradually reduced in size upward; pedicels $8-20 \mathrm{~mm}$. long, densely villosulous; sepals 3-5 mm. long, ovate-oblong, subacute, more or less densely villosulous; petals lilac to bright rose-purple; stamens subequal, the filaments deep rose-lilac, barbate below.

This plant is plentiful on the dry rocky hills about the divide on the road between Zacapa and Chiquimula, where so many other interesting and rare plants are found. It is a showy and handsome plant, well worthy of cultivation. It grows only during the invierno, for during the verano it would be impossible for any ordinary plant to continue growth in this sun-baked locality, one of the most arid in all Guatemala.

\section{TRIPOGANDRA Rafinesque}

Perennial herbs, succulent, the stems simple or branched, prostrate to erect, the plants small or sometimes large; leaves linear to ovate; flowers umbellate, or at least appearing so, the umbels long-pedunculate, never subtended by large leaf-like bracts, the bracts usually very small and narrow, the inflorescences borne in the axils of the upper leaves; sepals 3, free; petals 3, free, white or colored; stamens 6 , fertile, the 3 outer ones shorter, the anthers with a narrow connective and parallel cells; 3 inner stamens longer, the anther connective $4-3$-angulate, the 
cells thus separated; filaments pilose or glabrous; ovary 3-celled, the cells 1-2ovulate; capsule 3-celled, the seeds 1 or usually 2 in each cell.

Perhaps thirty species, in tropical America. By most recent authors the plants have been referred variously to Tradescantia, Leptorrhoeo, and Neodonnellia. For a discussion of the genus and its relationships see Woodson, Ann. Mo. Bot. Gard. 29: 150. 1942. Probably all the Central American species are included in the following account.

Stems naked, the leaves all in a basal rosette........... W. Warscewicziana. Stems leafy, the plants without basal rosettes of leaves.

Leaves linear, about $2 \mathrm{~mm}$. wide. T. angustifolia.

Leaves lanceolate or broader, 4-20 $\mathrm{mm}$. wide or wider.

Leaves small, mostly 4-6 mm. wide and $3 \mathrm{~cm}$. long or shorter. Flowers very

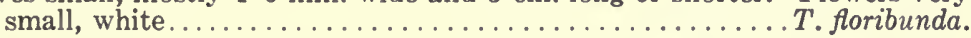

Leaves large, mostly 1-2 cm. wide and much more than $3 \mathrm{~cm}$. long.

Plants scandent. Petals white.................. grandiflora. Plants never scandent.

Petals normally white; peduncles shorter than the subtending leaves or scarcely exceeding them.

Sepals and pedicels more or less glandular-pilose......T. cumanensis.

Sepals and pedicels glabrous or nearly so....T. cumanensis f. glabrior. Petals lilac, pink, or purple; peduncles usually much exceeding the subtending leaves.

Leaves cordate at the base and amplexicaul.......T. amplexicaulis. Leaves not cordate at the base.

Peduncles generally in fascicles of $2-5$, rarely solitary; principal cauline leaves $5-13 \mathrm{~cm}$. long, $1.5-3.5 \mathrm{~cm}$. wide; roots at the nodes generally brown-villous; shorter filaments glabrous or with a few hairs; uppermost part of the peduncle usually densely hirtellous.

Leaves glabrous on both surfaces............T. elongata. Leaves pilose on the upper surface, softly villous beneath.

T. elongata f. diuretica.

Peduncles generally solitary; principal cauline leaves $3.5-5 \mathrm{~cm}$. long and 1-2 cm. wide; rootlets at the nodes usually not brownvillous; shorter filaments densely barbate at the apex; uppermost part of the peduncles glabrous, glandular, or sometimes villosulous.

Stems, sheaths, and lower leaf surfaces villous.

Stems, sheaths, and leaves glabrous.

T. disgrega f. pubescens.

Sepals more or less glandular-pilose, the hairs less than $1 \mathrm{~mm}$. long............................ disgrega.

Sepals glandular-pilose with hairs $2-3 \mathrm{~mm}$. long.

T. disgrega f. glandulosa.

Tripogandra amplexicaulis (Klotzsch) Woodson, Ann. Mo. Bot. Gard. 29: 152. 1942. Tradescantia amplexicaulis Klotzsch ex C. B. Clarke in DC. Monogr. Phan. 3: 304. 1881. Descantaria amplexicaulis Brueckner, Notizbl. Bot. Gart. Berlin 10: 56. 1927. Lochoch (fide Aguilar). 
Moist thickets or forest, $900-1,200$ meters, or perhaps higher; Jutiapa (near Jutiapa, Standley 75525); Guatemala; reported from Volcán de Fuego, Chimaltenango. Central and southern Mexico; reported from Costa Rica.

Plants perennial or perhaps annual, with fibrous roots, the stems erect, $20-50$ $\mathrm{cm}$. high, simple or branched, glabrous; leaves thin when dried, the middle and upper ones ovate, acuminate or long-acuminate, cordate and amplexicaul at the base, the lower cauline leaves ovate-elliptic to subovate, $2-8 \mathrm{~cm}$. long, $1.5-3 \mathrm{~cm}$. wide, glabrous; sheaths scarious, ciliolate or glandular-ciliolate, 7-9 $\mathrm{mm}$. long, 3-6 $\mathrm{mm}$. wide; leaves at the summit of the stem reduced to sheaths; peduncles terminal, slender, 3-7 cm. long, more or less glandular or glabrate, the pedicels umbellate, 4-8 mm. long, glandular-pilosulous; bractlets ovate, glandular-pilosulous; sepals 4-5 mm. long, ovate, acute or acuminate, glandular-pilosulous or glabrate; petals pale lavender to rose-purple, 6-7 $\mathrm{mm}$. long; stamens unequal, the 3 longer filaments dilated upward, sparsely barbate below; ovary sparsely pubescent at the apex; seeds $1.5 \mathrm{~mm}$. in diameter, brown, rugose.

Tripogandra angustifolia (Robinson) Woodson, Ann. Mo. Bot. Gard. 29: 152. 1942. Tradescantia angustifolia Robinson, Proc. Amer. Acad. 27: 185. 1892. Descantaria angustifolia Brueckner, Notizbl. Bot. Gart. Berlin 10: 56. 1927.

Moist or wet thickets or forest, sometimes on rocks, $800-1,600$ meters; Huehuetenango (between Santa Ana Huista and Nentón; between San Ildefonso Ixtahuacán and Cuilco). Southern Mexico.

Plants perennial or perhaps also annual, with fibrous roots, very slender, erect or ascending, simple or usually branched, glabrous; leaves linear, $2.5-5 \mathrm{~cm}$. long, about $2 \mathrm{~mm}$. wide, acute, glabrous, the sheaths small, ciliate; flowers small, about $6 \mathrm{~mm}$. broad, mostly in few-flowered umbels, sometimes solitary, the umbels on slender peduncles $5 \mathrm{~cm}$. long or shorter, the bracts very small; sepals ovate, acute; petals pale pink; outer filaments much longer than the inner ones, glabrous, geniculate, the connective dilated, horseshoe-shaped, the cells small, orange, transverse; inner stamens shorter, the anthers larger, pinkish, the connective much less developed, the cells parallel or nearly so; seeds triangular, brown, somewhat radiate-rugose.

Tripogandra cumanensis (Kunth) Woodson, Ann. Mo. Bot. Gard. 29: 152. 1942. Tradescantia cumanensis Kunth, Enum. Pl. 4: 96. 1843. Commelina floribunda HBK. Nov. Gen. 1: 260. 1816, not Tripogandra floribunda Woodson, 1942. Descantaria cumanensis Brueckner, Notizbl. Bot. Gart. Berlin 10: 56. 1927. Pie de pollo; Siempreviva; Canutillo; Rosana de llano (fide Aguilar).

Moist or wet thickets or forest, sometimes along streams or in open fields, occasionally a weed in cultivated ground, especially in cafetales, 1,500 meters or lower; Alta Verapaz; Izabal; Zacapa; Santa Rosa; Escuintla; Guatemala; Suchitepequez; Retalhuleu; 


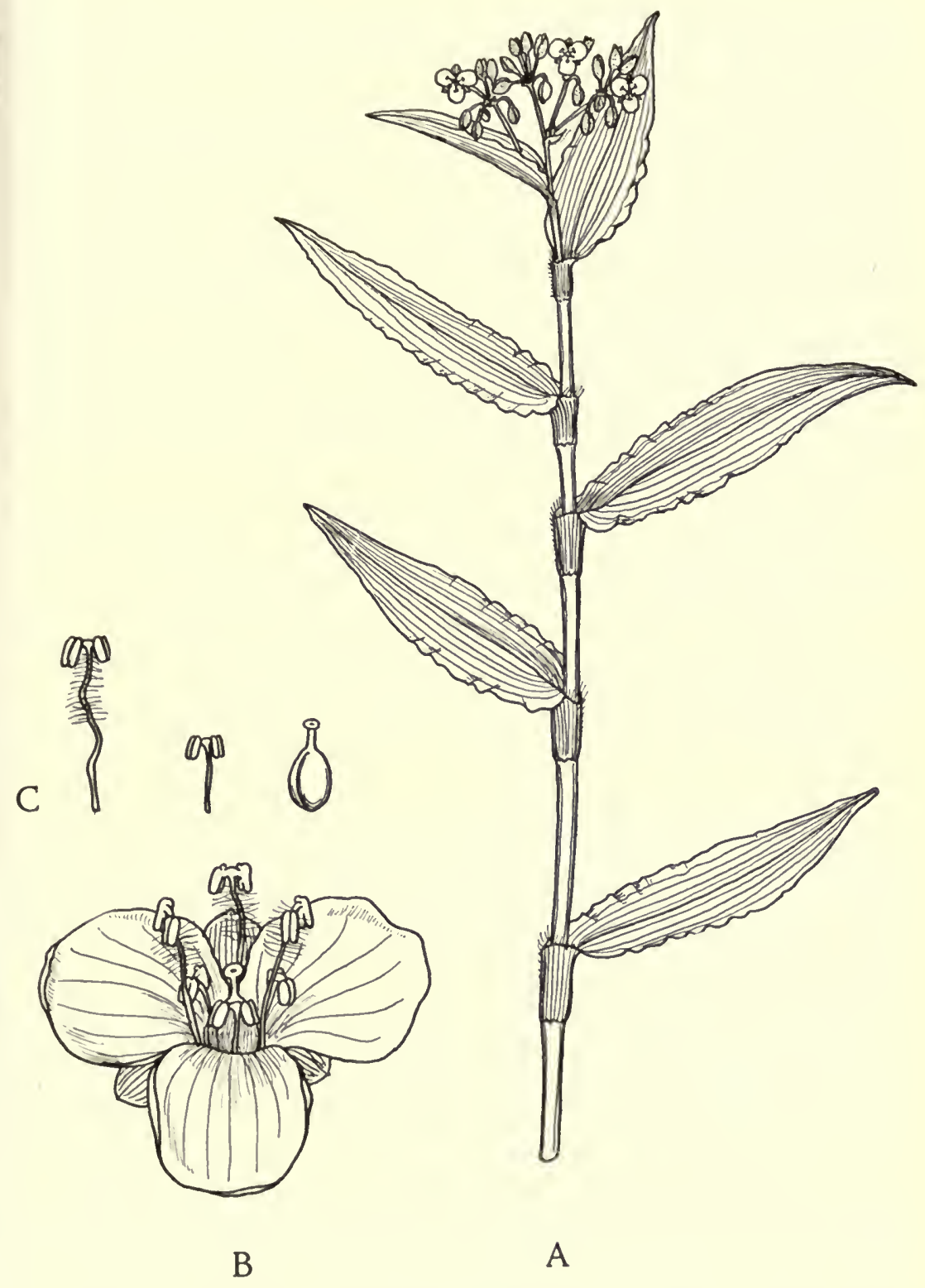

FIG. 9. Tripogandra cumanensis. A. Habit of upper portion of plant; $\times 3 / 4$. B. Flower; $\times 8$. C. One of the inner stamens at extreme left, one of outer stamens in center, and pistil at extreme right; $\times 8$. 
Quezaltenango; Huehuetenango. Southern Mexico; British Honduras to Salvador and Panama; South America.

Plants perennial, with fibrous roots, the stems procumbent to suberect, often rooting at the lower nodes, green or striped with purple or lavender, $15-50 \mathrm{~cm}$. tall, glabrous, very succulent; leaves fleshy when fresh, firm-membranaceous when dried, somewhat paler beneath, oblong-lanceolate or lanceolate, 5-13 cm. long, 1--2.5 cm. wide, acute to long-attenuate, rounded and abruptly contracted at the sessile base, glabrous except for the scaberulous margins; sheaths scarious, 7-16 mm. long, 4-9 mm. broad, glabrous, the margins ciliate; peduncles 1-5, terminal or from the uppermost leaf axils, $1.5-3 \mathrm{~cm}$. long, glabrous or puberulent in a line along one side; umbels several-many-flowered, the pedicels $2-5 \mathrm{~mm}$. long, more or less glandular-pilose; sepals pale green, often tinged with lavender, scarious-marginate, cucullate-obtuse, 3-4 $\mathrm{mm}$. long, sparsely or rather densely and shortly glandular-pilose; petals usually white, sometimes pale lilac at the base, 4.5-5 mm. long; shorter filaments glabrous; ovary glabrous; seeds 6, gray, areolatereticulate, about $1 \mathrm{~mm}$. in diameter. (Fig. 9.)

Tripogandra cumanensis f. glabrior (C. B. Clarke) Standl. \& Steyerm., comb. nov. Tradescantia cumanensis var. glabrior C. B. Clarke in DC. Monogr. Phan. 3: 306. 1881.

Moist or wet fields or thickets, 850-1,300 meters; Jutiapa; San Marcos. Honduras; Nicaragua; Panama; Ecuador.

Differing from the typical form of the species only in having glabrous sepals and pedicels.

Tripogandra disgrega (Kunth) Woodson, Ann. Mo. Bot. Gard. 29: 152. 1942. Tradescantia disgrega Kunth, Enum. Pl. 4: 97. 1843. Descantaria disgrega Brueckner, Notizbl. Bot. Gart. Berlin 10: 56. 1927. Tradescantia parvula Brandeg. Univ. Calif. Publ. Bot. 6: 51. 1914 (a depauperate form). Camotillo (Guatemala); Lochoch (fide Aguilar); Coyontura.

Moist or wet thickets or forest, often in pine-oak forest, sometimes on sandbars along streams, or a weed in cultivated ground, 600-2,400 meters; Chiquimula; Jalapa; Santa Rosa; Guatemala; Chimaltenango; Quiché; Huehuetenango; San Marcos. Mexico; Costa Rica.

Plants perennial, succulent, with fibrous roots, the stems procumbent to erect, 15-50 cm. long, simple or branched, often purplish at the nodes, glabrous; leaves lance-oblong to ovate-lanceolate, membranaceous when dried, $3-5.5 \mathrm{~cm}$. long, 1-2 cm. wide, acute or acuminate, rounded and contracted at the base, usually glabrous; sheaths scarious, $8-12 \mathrm{~mm}$. long, $3-5 \mathrm{~mm}$. broad, glabrous, ciliate; peduncles terminal or from the upper leaf axils, usually solitary or binate, 1-7.5 cm. long, glabrous below, usually sparsely and shortly glandular-pilosulous at the apex or throughout; umbels usually dense, the pedicels $3-8 \mathrm{~mm}$. long, glandular-pilose; sepals ovate, acute or subacute, somewhat scarious along the margins, $3.5-5.5 \mathrm{~mm}$. long, somewhat glandular-pilosulous; petals lilac to deep 
rose, 5-7 $\mathrm{mm}$. long; longer filaments naked, the 3 shorter ones densely barbate at the apex; ovary glabrous; seeds 6 , gray-brown, tuberculate, about $1.5 \mathrm{~mm}$. in diameter.

The specific name appeared originally as disgrega, but later writers sometimes have written it Disgrega.

Tripogandra disgrega f. glandulosa Standl. \& Steyerm., comb. nov. Tradescantia disgrega f. glandulosa Standl. \& Steyerm. Field Mus. Bot. 23: 36. 1944.

Moist or wet thickets or forest, 1,000-1,800 meters; known only from Guatemala; Zacapa (type from Sierra de las Minas, along trail between Río Hondo and summit of mountain at Finca Alejandría, Steyermark 29751); Chimaltenango (Finca Alameda).

Differing from the typical form in the much longer, gland-tipped hairs of the sepals, and in the slightly larger sepals, 5-6 mm. long.

Tripogandra disgrega f. pubescens Standl. \& Steyerm., comb. nov. Tradescantia disgrega f. pubescens Standl. \& Steyerm. Field Mus. Bot. 23: 37. 1944. Borraja.

Known only from the type, Guatemala, near Guatemala, 1,485 meters, Jesús Morales R. 1106.

Differing from the typical form and from f. glandulosa in the villous stems, sheaths, and lower leaf surfaces.

Tripogandra elongata (G. F. W. Mey.) Woodson, Ann. Mo. Bot. Gard. 29: 152. 1942. Tradescantia elongata G. F. W. Mey. Fl. Esseq. 146. 1818. Descantaria elongata Brueckner, Notizbl. Bot. Gart. Berlin 10: 56. 1927. Tzimá (Cobán, Quecchí).

Moist or wet thickets or mixed forest, sometimes in pine forest, often on shaded banks or along streams, 250-2,300 meters; Alta Verapaz; El Progreso; Zacapa; Chiquimula; Guatemala; Sacatepéquez; Sololá; Suchitepequez; Quezaltenango; San Marcos; Huehuetenango. Southern Mexico; Honduras; Costa Rica; South America.

Plants perennial, usually procumbent or decumbent and rooting at the lower nodes, the roots fibrous, the stems ascending to erect, sometimes pendent from banks, 3-6 mm. in diameter, simple or sparsely branched, 30-100 cm. long, glabrous or glabrate; leaves lanceolate or lance-oblong, thick and fleshy when fresh, thickmembranaceous when dried, paler beneath, the principal cauline leaves $5-13 \mathrm{~cm}$. long and 1.5-3.5 cm. wide, acute or acuminate, rounded and contracted at the base, glabrous, minutely scaberulous on the margins; sheaths scarious, $10-17 \mathrm{~mm}$. long, 5-9 mm. broad, glabrous, ciliate; peduncles 2-5, terminal, fasciculate, rarely solitary, 2-8 cm. long, usually pubescent in lines, densely hirtellous near the apex; umbels dense, the pedicels usually short, $3 \mathrm{~mm}$. long or less, glabrous to 
sparsely or densely glandular-villous; bractlets densely clustered at the apex of the peduncle; sepals $3-4 \mathrm{~mm}$. long, more or less glandular-pilose; petals rosepurple, lilac, or pink, 7-8 mm. long; longer filaments barbate above, the 3 shorter ones usually naked; ovary glabrous.

Tripogandra elongata f. diuretica (Mart.) Standl. \& Steyerm., comb. nov. Tradescantia diuretica Mart. in Spix \& Mart. Reise Bras. 1: 281. 1823. Tradescantia elongata var. diuretica C. B. Clarke in DC. Monogr. Phan. 3: 303. 1881.

Reported by Clarke as collected in Guatemala by Skinner. South America.

Distinguished from the typical forms of the species by having the leaves pilose above and softly villous beneath, and by the villous sheaths.

Tripogandra floribunda (Hook. \& Arn.) Woodson, Ann. Mo. Bot. Gard. 29: 152. 1942. Aneilema floribunda Hook. \& Arn. Bot. Beechey Voy. 311. 1840. Tradescantia filiformis Mart. \& Gal. Bull. Acad. Brux. 9, pt. 2: 276. 1842. Leptorrhoeo filiformis C. B. Clarke in Hemsl. Diag. Pl. Mex. 55. 1880. L. floribunda Baill. Hist. Pl. 13: 218. 1894 .

Moist or wet thickets or open fields, sometimes in moist rocky places, often on sandbars along streams, or a weed in cultivated ground, 200-1,600 meters; Zacapa; Chiquimula; Jalapa; Jutiapa; Santa Rosa; Escuintla; Retalhuleu; Huehuetenango. Mexico; Salvador; Honduras; Costa Rica; South America.

Plants low and very slender, perennial or probably in part annual, with fibrous roots, the stems simple or branched, ascending or diffusely spreading, rooting at the nodes, $10-20 \mathrm{~cm}$. long, pale green, glabrous or with a vertical line of pubescence along one side; leaves broadly linear to narrowly oblong-lanceolate, mostly 1-4 cm. long and 4-6 mm. wide, pale green, acute, slightly narrowed to the base, glabrous, ciliate; flowers white or pale bluish, small, the umbels 3-6flowered, pedunculate, terminal and axillary; peduncles very slender, $4 \mathrm{~cm}$. long or shorter, glabrous or sparsely puberulent, ascending or divaricate; pedicels obsolete or as much as $8 \mathrm{~mm}$. long, glabrous or sparsely puberulent, the bractlets minute, 1-2 mm. long, ovate, acute; sepals thin, green, scarious-marginate, 1.5-2 $\mathrm{mm}$. long, villosulous; petals ovate-elliptic, about equaling the sepals; stamens unequal, 3 of the filaments stouter and longer than the others, glabrous, the anther cells oblong; ovary ovoid, glabrous; capsule $1.5 \mathrm{~mm}$. long; seeds 3 , rugose, trapezoid.

Tripogandra grandiflora (Donn. Smith) Woodson, Ann. Mo. Bot. Gard. 29: 153. 1942. Callisia grandiflora Donn. Smith, Bot. Gaz. 31: 125. 1901. Donnellia grandiflora C. B. Clarke, in Donn. Smith, Bot. Gaz. 33: 261. pl. 11. 1902. Neodonnellia grandiflora Rose, Proc. Biol. Soc. Wash. 19: 96. 1906. Hoja de fluxión (Petén). 
Moist or wet thickets or forest, 1,000 meters or lower; Petén; Alta Verapaz (type from Cubilgüitz, Türckheim 7684). Campeche; British Honduras.

A large scandent herb, the stems glabrous, sometimes 3 meters long or more, branched, often geniculate, 4-8 $\mathrm{mm}$. in diameter; leaves divaricate, 2-ranked, elliptic to oblong-lanceolate, firm-membranaceous when dried, $5.5-12 \mathrm{~cm}$. long, $1.5-3 \mathrm{~cm}$. wide, acute or acuminate, rounded and sessile at the base, glabrous, ciliate at the base; sheath glabrous, long-ciliate; inflorescence often large and open, terminal, composed of few-flowered pedunculate umbels alternately arranged in an almost naked panicle 6-13 $\mathrm{cm}$. long, the rachis flexuous or zigzag, glabrous; lower bracts foliaceous, $1-5 \mathrm{~cm}$. long, the upper ones greatly reduced, small, subspathaceous; umbels 5-9-flowered, 7-13 mm. long, glabrous; sepals green, white-punctate, oblong-elliptic, subacute, 5-7 $\mathrm{mm}$. long, 2.5-3.5 mm. wide, glabrous; petals equal, white, elliptic-oblong, obtuse, 9-10 mm. long, 4-6 mm. wide; fertile stamens $3.5-7 \mathrm{~mm}$. long, the filaments densely barbate above with long yellow hairs, the anthers bright yellow, transverse-oval, $1.5 \mathrm{~mm}$. broad, bifid at the apex, the cells divergent, oblong; ovary oval, the stigma capitellate, papillose; capsule oval, 5-6 mm. long; seeds usually 2 , elongate-oblong, $4 \mathrm{~mm}$. long, rugulose.

The plant is said to be common in climax forest in Petén, and it is often planted in gardens there and elsewhere because of its handsome appearance, especially its panicles of rather large, pure white flowers. The flowers are highly fragrant. The species is the type of the genus Donnellia, later renamed Neodonnellia.

Tripogandra Warscewicziana (Kunth \& Bouché) Woodson, Ann. Mo. Bot. Gard. 29: 154. 1942. Tradescantia Warscewicziana Kunth \& Bouché, Ind. Sem. Hort. Berol. Add. 11. 1847 (described from plants grown in Berlin, said to have been collected somewhere in Guatemala by Warscewicz). Dichorisandra Warscewicziana Planch. Hort. Donat. 30. 1854-58. Tradescantia subscaposa C. B. Clarke in Donn. Smith, Bot. Gaz. 15: 29. 1890 (type from Santa Rosa, Baja Verapaz, Türckheim 1213). Spironema Warscewiczianum Brueckner, Nat. Pflanzenfam. ed. 2. 15a: 171. 1930.

On dry shaded rocks in oak or pine forest, 1,200-1,500 meters; Baja Verapaz (region of Santa Rosa); Zacapa (Sierra de las Minas, upper Río Sitio Nuevo).

Plants subscapose, stout, erect, with a very thick, elongate caudex covered by old leaf sheaths; stems erect, 10-40 cm. long, simple or furcate, glabrous, naked; leaves radical, forming a dense rosette, fleshy-coriaceous, green above and mottled with reddish purple, paler beneath and blotched or flushed with reddish or purplish, narrowly to broadly oblong, 8-30 cm. long, 3-4 cm. wide, cuspidate-acuminate, sessile and scarcely narrowed at the base, glabrous; inflorescence dense or rather lax, forming a small or large panicle; lowest bracts sheathing the peduncles, lilac, ovate-lanceolate, long-acuminate, $3 \mathrm{~cm}$. long or shorter; pedicels lilac, 3-7 mm. long, glabrous; bractlets ovate, scarious, 1-2 mm. long; sepals lilac, ovate, acute, 
4-5 mm. long, glabrous; petals lilac or rose-purple, venose, $5 \mathrm{~mm}$. long; filaments naked; ovary glabrous.

The plant is in cultivation in Salvador, where it is called "piña japonesa." Because of its handsome appearance it has been grown also in European greenhouses.

\section{WELDENIA Schultes}

Plants perennial, glabrous or nearly so, acaulescent or with very short stems, arising from a cluster of fleshy roots; leaves narrow, sheathing at the base, the lowest ones reduced to bladeless sheaths; flowers large, white, densely aggregate, axillary, sessile; calyx tubular, subspathaceous, cleft above on one side, the limb 3 -fid; corolla tube very long and slender, much exceeding the calyx, the 3 segments of the limb ovate, horizontally spreading; stamens 6 , equal, inserted in the upper part of the corolla tube, the filaments linear, naked; anther cells oblong, parallel, contiguous; ovary free, sessile, ovoid, 3-celled; style filiform, the stigma exserted, penicillate; ovules about 6 in each cell; fruit capsular.

The genus consists of a single species.

Weldenia candida Schult. f. Flora 12: 3. pl.1, A. 1829. Lampra volcanica Benth. Pl. Hartweg. 95. 1842 (type from crater of Volcán de Agua, Sacatepéquez, Hartweg, without number). Flor blanca, Loch (Huehuetenango).

Alpine meadows or hillsides, usually in moist places, often in rocky situations, 3,300-4,500 meters; Sacatepéquez (Volcán de Agua); Totonicapán (Desconsuelo); Huehuetenango (Sierra de los Cuchumatanes); San Marcos (Tajumulco, Tacaná). High mountains of central and southern Mexico.

Roots elongate, thick and fleshy; stems stout, erect, sometimes $30 \mathrm{~cm}$. long but usually short, and the plants often appearing acaulescent; leaves mostly flat on the ground, linear-lanceolate or liguliform, $5-35 \mathrm{~cm}$. long, 1-3 cm. wide, acute to attenuate-acuminate, rather thin when dried, green and glabrous above, somewhat paler and sparsely villosulous beneath, especially along the costa, sparsely ciliate near the base, the sheaths conspicuous, membranaceous, glabrous, 3-4.5 $\mathrm{cm}$. long, $1.5 \mathrm{~cm}$. broad; flowers 10-20, densely clustered at the apex of the stem, sessile, not bracteate; calyx tube $3 \mathrm{~cm}$. long, slightly ampliate above, sparsely puberulent; corolla tube 4-6.5 $\mathrm{cm}$. long, 1-1.5 $\mathrm{mm}$. in diameter, the lobes white, sometimes tinged with bluish, 1-2 cm. long, about $1 \mathrm{~cm}$. wide; anther cells $2 \mathrm{~mm}$. long.

This is one of the common, characteristic, and conspicuous plants of the alpine regions, abundant in some areas. The plants flower only during the rainy months. During the dry season the rosettes of leaves separate from the roots and become scattered over the rocky open terrain, resembling cushions of leaves. The Indians of 
the Sierra de los Cuchumatanes boil and eat the lower portions of the tender leaves as "greens." The junior author sampled this dish and found it fairly tasty.

\section{ZEBRINA Schnizlein. Wandering Jew}

Plants succulent, branched, more or less pubescent, the stems prostrate and creeping or sometimes pendent; leaves ovate or oblong, scattered along the stems, vaginate at the base; flowers small, aggregate between the 2 uppermost, somewhat bract-like leaves, subsessile; sepals 3 , connate below into a cylindric tube, petaloid, white or scarious; petals 3 , connate below into a slender tube longer than the calyx, the blade spreading, ovate or lanceolate, rose-purple, bluish purple, or white; stamens 6 , equal or slightly unequal, inserted in the throat of the corolla, the filaments barbate with moniliform hairs or glabrate; anther cells rotund, separated by a narrow oblong connective; ovary ovoid, trigonous, 3-celled, the cells 2-ovulate; capsule borne on a short recurved stipe, perforating the corolla tube, ovoid-oblong, smooth; seeds 1-2 in each cell, ovoid, obtuse, somewhat rugulose.

The genus consists of two species, one endemic to Guatemala.

Leaves purple beneath, bluish green with usually 2 longitudinal silvery stripes above; corolla rose-purple or bluish purple................. Leaves silvery green beneath, deep green above; corolla white....Z. huehueteca.

Zebrina huehueteca Standl. \& Steyerm. Field Mus. Bot. 23: 213. 1947.

Known only from the type, collected on barranco slopes, along Río Trapichillo, between Paso del Boquerón and below La Libertad and Democracia, Huehuetenango, 1,000-2,100 meters, Steyermark 51016.

A fibrous-rooted perennial, the stems sprawling or ascending, glaucous, $85 \mathrm{~cm}$. long, simple or slightly branched, $4-8 \mathrm{~mm}$. in diameter, glabrous; cauline leaves subsessile, firmly membranous, deep green above, silvery green beneath, lanceolate to elliptic-lanceolate, 9-15 $\mathrm{cm}$. long, 3-6 $\mathrm{cm}$. wide, long-acuminate, abruptly narrowed at the base into the sheath, glabrous; sheaths $1.5-2.2 \mathrm{~cm}$. long, 5-11 mm. broad, glabrous to sparsely ciliate at the orifice; inflorescences terminal and axillary, subtended by 2 bract-like leaves, the smaller included; bracts glabrous, unequal, sessile, cordate, long-acuminate, $3-8 \mathrm{~cm}$. long; flowers $10-12$, subsessile, the subtending bracts broadly ovate, asymmetric, $4 \mathrm{~mm}$. long, glabrous; sepals connate, the calyx tube $6 \mathrm{~mm}$. long, the lobes $3 \mathrm{~mm}$. long, oblong-lanceolate, acute, glabrous throughout; corolla white, the tube $1.5 \mathrm{~cm}$. long, 1-1.5 mm. broad, the lobes elliptic-oblong, obtuse, 6-7 $\mathrm{mm}$. long, $2.5 \mathrm{~mm}$. wide; stamens 6 , slightly unequal, three of them slightly longer than the others inserted at the base of the corolla lobes; filaments white, bearded in the lower half, 2-2.5 mm. long; anthers white, the cells rotund, separated by a narrow linear connective; ovary glabrous; capsule not seen.

Zebrina pendula Schnizl. Bot. Zeit. 7: 870. 1849. Z. pendula var. villosa C. B. Clarke, Bot. Gaz. 37: 213. 1904 (type from Cubil- 
güitz, Alta Verapaz, Türckheim 8326). Z. Purpusii Brueckner, Notizbl. Bot. Gart. Berlin 10: 57. 1928. Z. flocculosa Brueckner, op. cit. 58. Hierba de pollo; Adorno de Esquipulas (Huehuetenango); Barbija (Jutiapa).

Moist or wet forest or thickets, frequently growing on rocks in shaded or open places, or on banks, 2,000 meters or less, chiefly at lower elevations; Petén; Alta Verapaz; Jalapa; Santa Rosa; Guatemala; Sacatepéquez; Retalhuleu; Huehuetenango; doubtless in several other departments; often planted in gardens for ornament. Central and southern Mexico; British Honduras to Salvador and Panama; West Indies.

Plants prostrate, often forming dense mats or colonies, the stems glabrous or pilose; leaves rather thick and succulent, mostly ovate, $4-10 \mathrm{~cm}$. long, $1.5-3 \mathrm{~cm}$. wide, acute, rounded at the sessile base, glabrous or sparsely pilose on the upper surface, glabrous or pilose beneath, ciliate near the base, bluish green with usually two longitudinal stripes of silver on the upper surface, purple beneath; sheaths thin, membranaceous, $8-12 \mathrm{~mm}$. long, 5-8 mm. broad, long-ciliate at the orifice, otherwise glabrous or sparsely villous below; flowers clustered, subtended by two large leaf-like bracts, the bractlets narrow, ciliate; corolla lobes ovate, obtuse; seeds gray-brown. (Fig. 10.)

Called "matalí" and "sangría" in Salvador. This is much planted in gardens in Central America, and it is well known in the United States, especially as a house plant, under the name "Wandering Jew." Plants growing in exposed dry places, especially on rocks, often assume a vivid and intense, red-purple coloring throughout. They often become weeds in moist places about gardens and in patios.

\section{PONTEDERIAGEAE. Pickerel-Weed Family}

Reference: E. J. Alexander, Pontederiaceae, N. Amer. Flora 19: 51-60. 1937.

Perennial plants, aquatic or of wet soil, often floating; leaves vaginate, with broad or narrow blades; inflorescence axillary from the rootstock or stem, spathaceous, the 2 valves of the spathe similar or, when different, the lower leaf-like, the upper rarely with a small blade; flowers spicate, umbellate, or paniculate, rarely solitary, the bractlets minute or none; perianth marcescent, salverform or funnelform, 6-parted, or with a 6-parted limb, nearly regular or zygomorphic, the tube well developed; stamens 3 or 6 , commonly unequal and dissimilar, the anthers introrse, basifixed or versatile; ovary free, superior, the stigmas terminal, 3-6lobate or 3-6-dentate, the style slender or clavate; ovary 1- or 3-celled, the ovules numerous or by abortion 1; inflorescence usually decurved in fruit; fruit a 1- or 3-celled capsule, or 1-seeded and achene-like and enclosed in the fleshy, accrescent base of the perianth. 


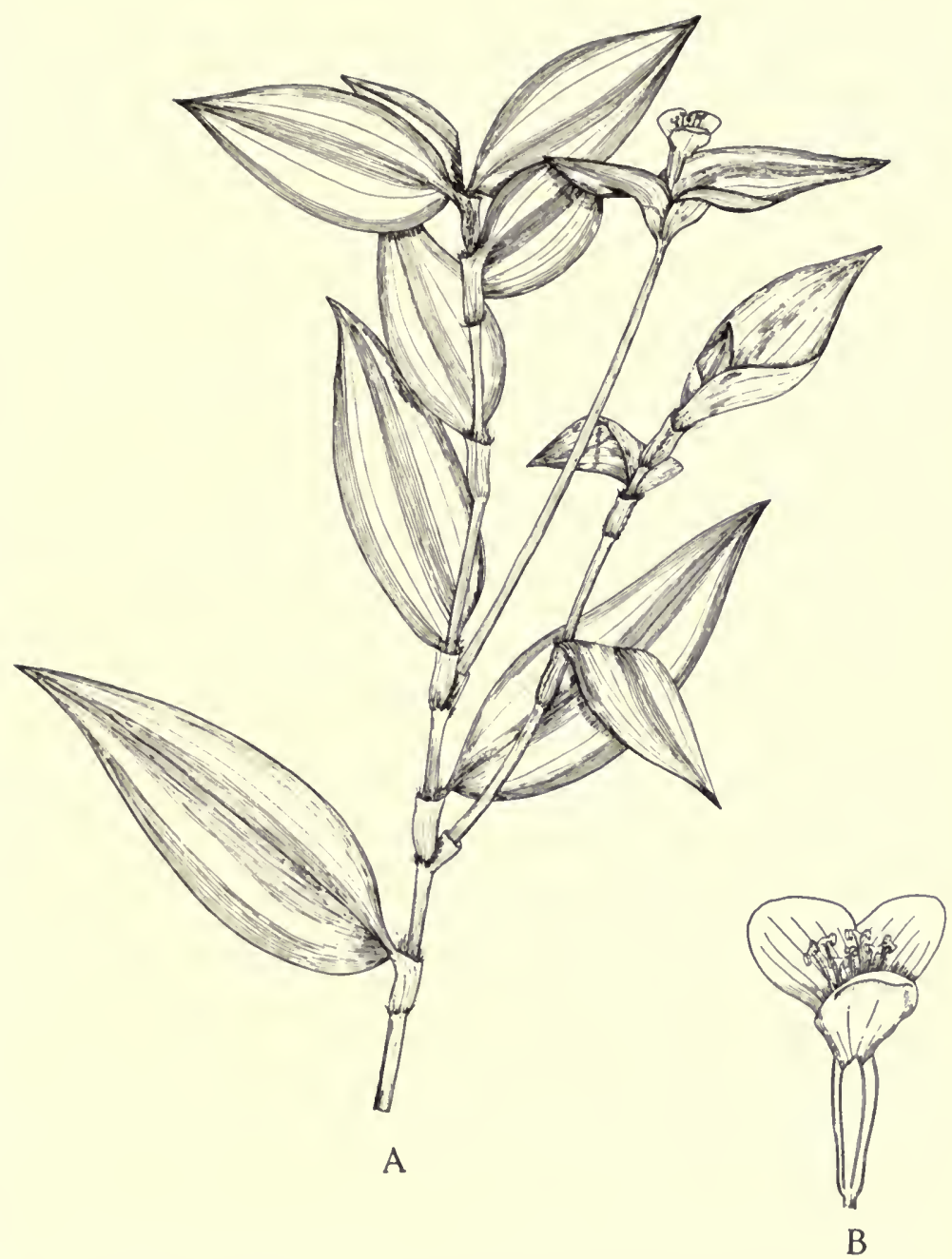

FIG. 10. Zebrina pendula. A. Upper portion of plant; $\times 1 / 2$. B. Flower; $\times 11 / 2$. 
Plants of the family are widely distributed in temperate and tropical regions of the earth. No other genera are known from Central America.

Stamens 3; fruit capsular............................. Hetanthera. Stamens 6; fruit capsular or achene-like.

Ovary with 3 fertile cells, the ovules numerous; fruit capsular; petioles often

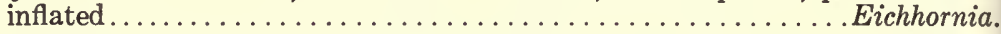

Ovary with 1 fertile cell, the fruit achene-like; petioles not inflated.Pontederia.

\section{EICHHORNIA Kunth. Water hyacinth}

Plants aquatic, usually floating, the leaves petiolate, the petioles often inflated, the blades broad or rarely wanting; inflorescence spike-like, rarely paniculate or umbellate, pedunculate or very short-pediceled, the 2 spathe valves unlike, the upper bractlike but frequently with a small dilated blade; perianth tubular, the limb 6-parted, somewhat bilabiate, the 3 outer segments narrower than the 3 inner ones; stamens 6 , the 3 anterior ones exserted, the 3 posterior ones included in the throat of the perianth, the filaments of the exserted ones pubescent or glabrous, those of the included ones glabrous, the anthers versatile; stigma subcapitate, shallowly 3- or 6-lobate, pilose; ovary 3-celled, many-ovulate; fruit capsular, 3-celled, dehiscent; seeds numerous, ovoid, multicostate, obtuse at each end; embryo cylindric, the endosperm farinaceous.

About a dozen species, in tropical America and Africa. One other is known from Panama.

Corolla small, less than $3 \mathrm{~cm}$. long; plants leafless; inflorescence surpassed by an ensiform prolongation of the spathe................... paradoxa.

Corolla large, $3.5-4.5 \mathrm{~cm}$. long; plants leafy; inflorescence not terminated by an ensiform spathe.

Petioles strongly inflated, often subglobose; plants with a short naked stem bearing new plants at the nodes; perianth lobes entire.......E. crassipes.

Petioles not or scarcely inflated, at most fusiform; plants with a continually growing stem bearing leaves for its whole length; perianth lobes erose.

E. azurea.

Eichhornia azurea (Swartz) Kunth, Enum. Pl. 4: 129. 1843. Pontederia azurea Swartz, Prodr. Veg. Ind. Occ. 57. 1788. Piaropus azureus Raf. Fl. Tell. 2: 81. 1831. Ninfa.

In marshes or shallow quiet water, often in slow streams; in the mountains at 1,500-1,900 meters, or more common at or near sea level; Petén; doubtless in Izabal; Escuintla; Quezaltenango; Huehuetenango. Southern Mexico; Honduras to Panama; West Indies; South America.

Plants usually rooting in mud and erect, often a meter high, generally forming large dense colonies, the petioles as much as $30 \mathrm{~cm}$. long, terete but often slightly thickened and fusiform; leaf blades obovate to orbicular, $15 \mathrm{~cm}$. long or less, broadly rounded to obtuse at the apex, abruptly short-cuneate at the base; flower 
spikes 5-15 cm. long, many-flowered, glandular-puberulent, the flowers violetblue; perianth tube $2 \mathrm{~cm}$. long, the lobes $1.5-3.5 \mathrm{~cm}$. long; capsule about $1 \mathrm{~cm}$. long; seeds columnar, with 10 narrow wings.

A characteristic plant in open swamps or marshes of the coastal regions, and doubtless abundant near the coasts of Guatemala, although we have few collections from the region. Often it occurs in other parts of Central America in great abundance, forming extensive and almost pure colonies. The plant grows typically in the tierra caliente, but we have two collections from the highlands, probably grown from seeds carried by birds.

Eichhornia crassipes (Mart.) Solms in DC. Monogr. Phan. 4: 527. 1883. Pontederia crassipes Mart. Nov. Gen. 1: 9. 1823. Piaropus crassipes Raf. Fl. Tell. 2: 81. 1837. Balsa; Ninfa; Lechuguilla.

Frequent in marshes and lagoons of the tierra caliente, found locally in lakes and ponds at much higher elevations, frequently planted in fountains of patios and gardens, 2,300 meters or lower, most plentiful at low elevations; Petén; Alta Verapaz; Baja Verapaz; Jutiapa; Santa Rosa; Escuintla; Sacatepéquez; Chimaltenango; Sololá; Huehuetenango. Florida; Mexico; British Honduras to Salvador and Panama; West Indies; South America.

Plants floating, the stems very short, the roots numerous, long, pendent, plumosely branched; petioles 2-30 cm. long, the shorter ones much inflated and globose, the longer ones less inflated; leaf blades rounded-reniform, often lacerate, variable in size; flower spikes $4-15 \mathrm{~cm}$. long, puberulent; flowers lilac or rarely white, the perianth tube $1.5-2 \mathrm{~cm}$. long, the lobes about $3 \mathrm{~cm}$. long; capsule 1.5 cm. long; seeds narrowly 10-winged. (Fig. 11.)

Sometimes known in Salvador as "lechuga" and "lechuga de concha." The common water hyacinth is frequent in many localities in Central America, but is far less common than the preceding species; there is, in fact, some possibility that it may be an introduced rather than a native plant. In some parts of its range, where it grows abundantly, it often obstructs navigation, as in the St. Johns River in Florida (where introduced) and in the Panama Canal, where constant dredging is necessary to keep it under control. All species of the genus are handsome and decorative plants because of their large spikes of beautifully colored flowers.

This species is widespread in small lakes and ponds of the mountains of Guatemala, sometimes almost filling them. For instance, in the Laguna de Ocubila near Huehuetenango the plants cover large areas to the exclusion of other vegetation. Near the shore, in shallow water, all the plants have spindle-shaped narrow petioles; farther 


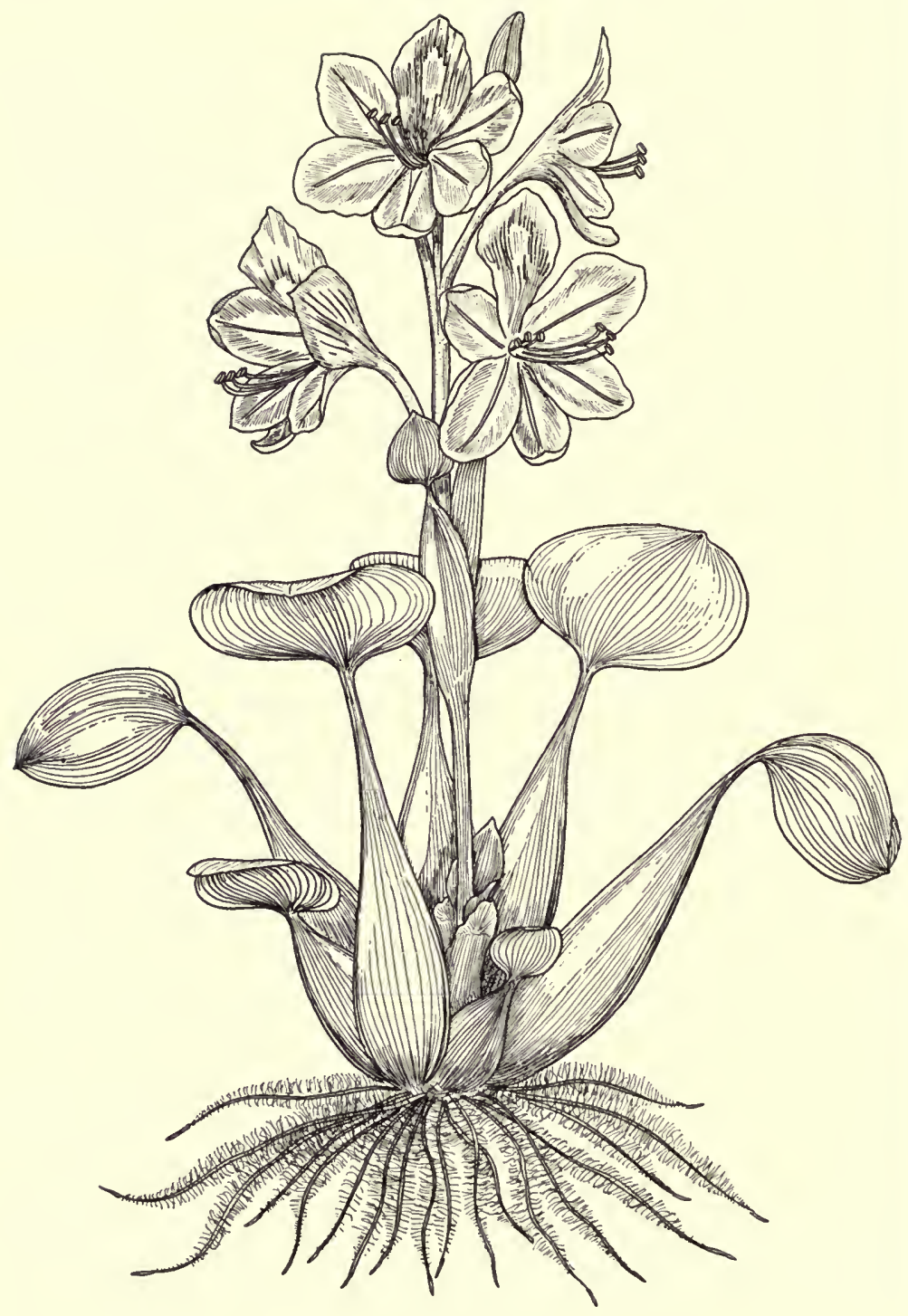

FIG. 11. Eichhornia crassipes. Habit of plant; $\times 1 / 2$. 
out, in deep water, they grade gradually into plants with globose petioles. The alteration is very gradual, as if all the plants were of the same species. In January, 1941, many of the leaves were brown, apparently having been frosted severely. There is considerable doubt that $E$. azurea and $E$. crassipes really are distinct species, at least as represented in Central America. Spruce states that along the Amazon when plants lodge and grow on the mur they no longer produce inflated petioles, having no need for them. Both the stems and the petioles, especially when inflated, contain large air spaces and are thus enabled to float on the water.

Eichhornia paradoxa (Kunth) Seub. in DC. Monogr. Phan. 4: 531. 1883. Pontederia paradoxa Kunth in Roem. \& Schult. Syst. Veg. 7: 1144. 1839. E. Schultesiana Seub. in Mart. Fl. Bras. 3, pt. 1: 94.1871.

Known in North America and Guatemala from a single locality, Chiquimula, near Finca San José, southeast of Concepción de las Minas, 1,500 meters, Steyermark 31167, in bogs in pine forest. Venezuela and Brazil.

Plants aquatic, rooting in mud, about $50 \mathrm{~cm}$. high, leafless; scapes all radical, 10-12 from each plant, erect, very spongy, pale green, 7-10 $\mathrm{mm}$. thick; leaf sheath ventricose, ovate-oblong, $2.5-3 \mathrm{~cm}$. long, opening longitudinally along the lateral margin, closed above the middle, prolonged above into a petioliform portion 18-23 $\mathrm{cm}$. long, the upper part of the petiole constricted into a green blade-like organ, this membranaceous and oblong-lanceolate, 6-7 cm. long, 1-1.2 cm. wide; flowers 5-7, subumbellate at the base of the sheath, 1.5-4 mm. long, 1.5-2 mm. thick, protruding from the open portion of the sheath; perianth lobes purple with yellow stripes on the upper lobe; perianth tube 1.5-2 cm. long, the lobes about $1 \mathrm{~cm}$. long; filaments glabrous; capsule elliptic-lanceolate, trigonous, 14-17 mm. long; seeds barrel-shaped or columnar, rufous-brown, about 10 -costate, $1 \mathrm{~mm}$. long, $0.5 \mathrm{~mm}$. broad, finely horizontally rugulose-striate.

This species, unknown elsewhere in Central America, reappears in parts of South America. The South American plant appears to have a scape half as thick as the Guatemalan specimen, and the spathe is terminated by a shorter prolongation with a narrower, linearinstead of oblong-lanceolate foliar portion at the tip. Whether these differences are real ones can be decided only when more collections are available for study.

\section{HETERANTHERA Ruiz \& Pavón}

Plants perennial, usually growing on mud, not in water; leaves with broad or narrow blades; inflorescence 1-flowered or spicate, pedunculate or sessile; 
spathe valves 2 , the lower leaf-like, the upper bract-like; perianth almost regular, salverform, the 3 outer lobes narrower than the inner ones; stamens 3 , the middle one with a larger anther and longer filament than the other 2 , the anthers basifixed, erect; ovary incompletely 3 -celled by intrusion of the placentae, many-ovulate; fruit a dehiscent capsule; seeds very numerous.

The genus is a small one, of tropical America and Africa. One other Central American species is reported from Panama.

Spathe 1-flowered; leaf blades ovate, rounded at the base............ limosa. Spathe 2-6-flowered; leaf blades reniform, cordate at the base.....H. reniformis.

Heteranthera limosa (Swartz) Willd. Ges. Nat. Freunde Berlin Neue Schrift. 3: 439. 1801. Pontederia limosa Swartz, Prodr. Veg. Ind. Occ. 57. 1788.

Usually in mud about pools or along small streams or in ditches, 200-3,000 meters; Zacapa; Jalapa; Jutiapa; Quiché; Huehuetenango; Totonicapán. United States; Mexico; El Salvador; Honduras; West Indies; South America.

Plants small, with succulent and spongy, usually creeping stems; petioles erect, $10 \mathrm{~cm}$. long or shorter, the leaf blades lanceolate to almost orbicular, 1-5 $\mathrm{cm}$. long, rounded or obtuse at the apex, cuneate to subcordate at the base; stipules $5 \mathrm{~cm}$. long or shorter, rounded or emarginate at the apex; lower bract of the spathe similar to the leaves, the upper bract oblong, 1.5-4 cm. long, caudate; spathes 1-flowered; perianth 2-6 cm. long, the tube 1-4 cm. long, whitish, the lobes violetblue or white, linear-lanceolate; capsule oblong or narrowly ellipsoid, 1-2.5 cm. long; seeds $0.6-0.8 \mathrm{~mm}$. long, gray-brown, 10-12-costate, coarsely striate horizontally.

The Maya name of Yucatan is recorded as "hacolel."

Heteranthera reniformis Ruiz \& Pavón, Fl. Peruv. 1: 43. pl. 2. 1798. Ninfa; Lechuguilla; Chispi (Retalhuleu).

Usually in mud, about ponds or lakes or along streams or ditches, 2,000 meters or lower; Alta Verapaz; Baja Verapaz; Izabal; Zacapa; Chiquimula; Jalapa; Jutiapa; Santa Rosa; Escuintla; Guatemala; Chimaltenango; Sololá; Suchitepequez; Retalhuleu; Huehuetenango. United States; Mexico; Honduras and Salvador to Panama; West Indies; South America.

Plants usually creeping on mud, rarely floating; leaves erect, the petioles 1-5 cm. long, the leaf blades $5 \mathrm{~cm}$. wide or smaller, reniform, rounded at the apex, cordate at the base; flower spikes $5 \mathrm{~cm}$. long or shorter; perianth tube slender, 6-9 $\mathrm{mm}$. long, the limb spreading, 8-12 mm. broad, white or pale blue, the lobes lanceolate; capsule narrowly conic, 8-12 mm. long; seeds pale yellow-brown, columnar, $0.5-0.8 \mathrm{~mm}$. long, narrowly 10-winged, the wings evanescent and leaving ridges at maturity. (Fig. 12.) 


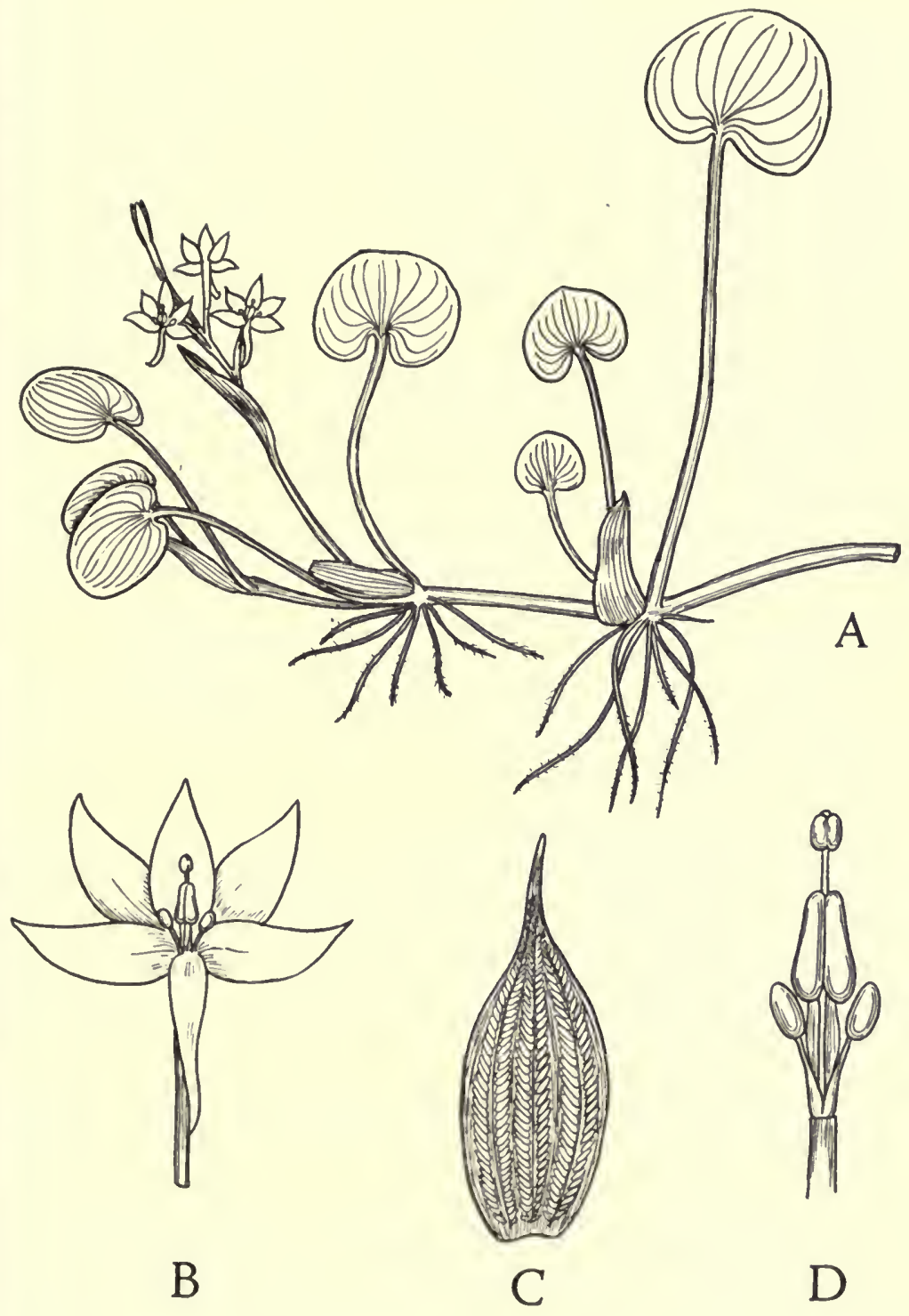

FIG. 12. Heteranthera reniformis. A. Habit of plant; $\times 3 / 4$. B. Flower; $\times 3$. C. Capsule; $\times 41 / 2$. D. Portion of flower, showing stamens and pistil; $\times 6$. 


\section{PONTEDERIA L. Pickerel-Weed}

Coarse and often tall herbs of marshes; leaves mostly erect, the blades narrow or broad, many-veined; inflorescence spike-like, pedunculate; spathe valves very unlike, the lower leaf-like, the upper bractlike; perianth pilose outside, funnelform, the limb bilabiate; stamens 6 , the 3 anterior ones exserted, the 3 posterior ones included in the throat, the anthers versatile; ovary 3-celled, 2 of the cells abortive and empty, the fertile one with a single ovule; fruit achene-like, enclosed in the accrescent base of the perianth tube, beaked by the persistent style base.

The few species are all American. One other species is reported from southern Central America (Panama).

Inflorescence as broad as long or nearly so; plants with elongate floating stems; perianth tube with elongate glands in the hairs............ rotundifolia.

Inflorescence much longer than broad; rootstock creeping under ground, the plants acaulescent; perianth tube with globose or ellipsoid glands (or none) in the hairs.

Basal auricles of the leaves spreading; perianth lobes lanceolate or lance-elliptic, $7-8 \mathrm{~mm}$. long, the resin streaks not prominent.......... lanceolata.

Basal auricles of the leaves directed downward; perianth lobes obovate or oblanceolate, $8-12 \mathrm{~mm}$. long, the resin streaks very prominent.P. sagittata.

\section{Pontederia lanceolata Nutt. Gen. Pl. 1: 216. 1818.}

In marshes, at or little above sea level; Petén; Izabal. Eastern and southern United States; Mexico; British Honduras; Honduras; Cuba; South America.

Plants stout, usually a meter high or less, with thick creeping rootstocks; leaves erect, the blades variable in shape and size, lanceolate to cordate or hastate, $18 \mathrm{~cm}$. long or usually smaller; stipules truncate, the costa produced into a mucro; lower spathe valve leaf-like, the upper one loosely vaginate, more or less recurved, 3-6 cm. long, caudate; inflorescence glabrate or hirtellous, the flowering portion 5-15 cm. long; perianth glabrate to densely glandular-pilose, violet-blue or white, the tube 5-7 mm. long; fruit 5-6 mm. long, broadly ovoid, the ridges of the crests with angular obtuse divisions.

Pontederia rotundifolia L. f. Suppl. Pl. 192. 1781. Lechuga de agua.

In marshes and borders of slow streams, 1,300 meters or lower; Alta Verapaz; Izabal. Honduras to Panama; South America.

Plants large and coarse, sometimes floating, usually creeping in mud, the stems branched, erect, a meter high or lower; leaf blades ovate to rounded-sagittate or reniform-cordate, as much as $12 \mathrm{~cm}$. long and $18 \mathrm{~cm}$. wide, obtuse or rounded at the apex, the basal lobes rounded; stipules truncate; lower spathe valve similar to the leaves, the upper one obovate, acute, erect-spreading; inflorescence shortspicate, the rachis pilose with long crispate hairs; perianth lilac, pilose outside, the tube 6-8 mm. long, the lobes 9-12 mm. long; fruit ovoid, rostrate, $7 \mathrm{~mm}$. long, with spinose-cristate ridges. (Fig. 13.) 
Called "balsa" in Salvador. Material of this species, as well as of the others known from Central America, has often been referred to $P$. cordata L., a plant of the United States and Canada. All the species are large and showy plants with handsome flowers, often forming large colonies in marshes or along the borders of slow streams. $P$. rotundifolia is especially plentiful in ditches and marshes about Cobán and in the North Coast.

Pontederia sagittata Presl, Rel. Haenk. 1: 116. 1827.

Swamps or marshes, usually in open places, sometimes about the borders of lakes, 500 meters or lower; Alta Verapaz; Izabal; Zacapa; San Marcos. Southern Mexico; Honduras.

Plants erect, frequently a meter high or more; leaf blades sagittate, often broadly so, as much as $24 \mathrm{~cm}$. long and $15 \mathrm{~cm}$. wide, mostly smaller, obtuse, the basal auricles usually long and narrow, directed downward; upper spathe valve laxly vaginate, the upper portion spreading, 5-9 $\mathrm{cm}$. long, abruptly caudate; inflorescence glabrous to pilose, the flowering portion $5-15 \mathrm{~cm}$. long; perianth lilac, sparsely glandular-pilose or glabrate, the tube 6-7 $\mathrm{mm}$. long, the lobes spreading, 8-10 $\mathrm{mm}$. long, broadly elliptic to ovate, with resinous streaks outside, the upper middle one with a large yellow blotch; filaments glabrous, the anthers ovate-sagittate; stigma 3-6-fid.

\section{JUNCACEAE. Rush Family}

Reference: Buchenau, Pflanzenreich IV. 36: 1-284. 1906.

Grass-like plants, herbaceous, annual or usually perennial; stems slender, simple, terete; leaves narrow and grass-like, flat or terete, with open or closed sheaths; inflorescence simple or compound, paniculate or corymbose; flowers small, perfect, with or without bractlets; perianth regular, the 6 segments glumaceous; stamens 6 or sometimes 3 , the filaments triangular to filiform, the anthers basifixed, 2-celled; ovary superior, 1- or 3-celled; ovules 3 to many, ascending, anatropous; stigmas 3; fruit a 1- or 3-celled, loculicidally dehiscent capsule.

This family is one of world-wide distribution, but is more abundant in the temperate and arctic regions than in the tropics. In Guatemala the species are most commonly found in wet meadows, along streams and margins of lakes, usually in regions of higher altitudes. The genus Luzula is most frequently found in moist coniferous mountain forests or on exposed alpine summits of volcanoes and mountain ranges. Of the three genera known from Central America, two of them are represented in Guatemala.

Plants glabrous; leaf sheaths open; capsule many-seeded............Juncus. Plants pubescent; leaf sheaths closed; capsule 3 -seeded.............. Luzula. 


\section{JUNCUS L.}

Mostly perennial plants, glabrous; stems pithy or hollow; leaves glabrous, the blades terete or flattened, the sheaths open and usually with 2 auricles at the summit; inflorescence cymose, paniculate, or glomerate, of ten unilateral; perianth segments glumaceous, usually greenish or brownish, the margins membranaceous; stamens 6 or rarely 3 ; ovary 1 - or 3 -celled; capsule 3 -celled with a central placenta, or 1-celled with parietal placentae, the seeds numerous, sometimes appendaged.

About 250 species, most abundant and widely dispersed in temperate and cold regions of both hemispheres. Besides the Central American species listed here, another is known in Costa Rica.

Lowest bract of the inflorescence terete, appearing like a continuation of the stem, the inflorescence apparently lateral; leaves all reduced to bladeless sheaths.

Stamens 6; perianth segments $5-6 \mathrm{~mm}$. long.............. andicola.

Stamens 3; perianth segments $2.5-4 \mathrm{~mm}$. long.

Perianth dark brown to castaneous............. effusus var. aemulans.

Perianth stramineous, greenish, or pale brown........J. effusus var. solutus.

Lowest bract of the inflorescence flat or channeled along the upper side, not appearing like a continuation of the stem, the inflorescence obviously terminal; leaves with well-developed blades.

Leaves terete, septate.

Style very short, inconspicuous.................. microcephalus.

Style elongate, usually very conspicuous.............. trinervis.

Leaves flat, not septate.

Leaves $2-4 \mathrm{~mm}$. wide; flowers in dense cymose-paniculate heads; stamens 3. $J$. marginatus var. setosus.

Leaves $0.8-1.5 \mathrm{~mm}$. wide; flowers inserted singly or clustered; stamens 6 .

Flowers mostly clustered at the tips of the branches of the inflorescence; perianth segments about equal, $3-4.5 \mathrm{~mm}$. long........... tenuis.

Flowers scattered or somewhat secund along the branches of the inflorescence; outer perianth segments attenuate-subulate, conspicuously longer than the inner ones, 5-6 mm. long...J. tenuis f. discretiflorus.

\section{Juncus andicola Hook. Icon. Pl. 8. pl. 714. 1848.}

\section{Huehuetenango, wet ground along streams, 2,450-3,500 meters} (Soloma; Tunimá). South America.

Plants coarse and stout, with thick creeping rhizomes, densely cespitose; stems 55-145 cm. tall, 5-8 mm. thick at the base and middle, $3.5-4 \mathrm{~mm}$. thick below the inflorescence, fleshy-subcoriaceous, terete, finely striate; leaves reduced to bladeless sheaths, the leaf scales (cataphylls) several at the base of the stem, large, black to yellow-brown, shining, obtuse; involucral bract erect, similar to and a continuation of the naked scape, 15-21 cm. long, gradually acuminate; inflorescence compound, dense, laterally spreading; flowers numerous, 5-6 mm. long, rigid and firm in texture; perianth segments narrowly lanceolate, acuminate, stiffly erect-ascending, the midrib buff to stramineous, conspicuous, the sides castaneous to dark brown; stamens 6 , the filaments about equaling or slightly 
shorter than the anthers; capsule slightly shorter than the perianth, 4-4.5 $\mathrm{mm}$. long, trigonous-ovate, mucronate, dark brown, almost 3-celled; seeds without tail-like appendages, $0.8-0.9 \mathrm{~mm}$. long, pale or rich brown.

Juncus effusus L. var. aemulans (Liebmann) Buchenau, Pflanzenreich IV. 36: 136. 1906. J. aemulans Liebmann, Vid. Medd. Nat. For. Kjoebenh. 38. 1850. Tule.

Swamps and bogs in open meadows, 2,100-3,400 meters; San Marcos; Totonicapán; Huehuetenango. Southern Mexico.

Plants forming large clumps, densely cespitose, the rootstocks short-creeping, with inconspicuous internodes; stems $60-80 \mathrm{~cm}$. tall, 2-4.5 $\mathrm{mm}$. thick at the base and middle, $1.5-3 \mathrm{~mm}$. thick below the inflorescence, firmly subcoriaceous, terete, inconspicuously many-striate; leaves reduced to bladeless sheaths, the leaf scales several at the base of the stem, firmly membranaceous, reddish brown at the base, obtuse, mucronate; involucral bract erect, $15-30 \mathrm{~cm}$. long, aciculate; inflorescence compound, loosely many-flowered, laterally spreading; flowers $3-3.5 \mathrm{~mm}$. long, membranous or becoming firmer in age; perianth segments linear-lanceolate, acuminate, erect-ascending, castaneous or reddish brown; capsule slightly shorter than the perianth, 2-2.5 $\mathrm{mm}$. long, dull brown, retuse, almost 3-celled; seeds with short points, without tail-like appendages, $0.6-0.7 \mathrm{~mm}$. long, pale brown.

Juncus effusus var. solutus Fern. \& Wieg. Rhodora 12: 90. 1910. Tule.

Borders of ponds, swamps, and wet meadows, or around dried pools on forested slopes, and infrequently along banks of large streams, 1,200-1,900 meters, or along the Motagua River descending to 250 meters; Alta Verapaz; Zacapa; Baja Verapaz; Jalapa; Quiché. Eastern, central, and southern United States; Mexico; Costa Rica.

Similar in most respects to the preceding variety; stems $60-130 \mathrm{~cm}$. tall, not sulcate; leaf scales dark brown to reddish brown at the base; involucral bract 10-40 cm. long; inflorescence mostly loosely flowered; flowers $2.5-3.5 \mathrm{~mm}$. long, firmly membranaceous; perianth segments erect-ascending, subequal, stramineous or greenish brown; capsule equaling or slightly shorter than the perianth, 2-2.5 $\mathrm{mm}$. long, dull brown; seeds without tail-like appendages, $0.5 \mathrm{~mm}$. long, pale brown.

Typical $J$. effusus with much smaller flowers, non-sulcate stems, and pale basal sheaths is a European species not known from the New World. The relative diffuseness of the inflorescence appears rather variable, and some of the Guatemalan collections examined seem to intergrade with forms of $J$. effusus var. compactus Lejeune and $J$. effusus var. prolifer Sonder. In the region about Cobán, the stems are used for weaving mats. The inside of the stems contains a white spongy pith. 


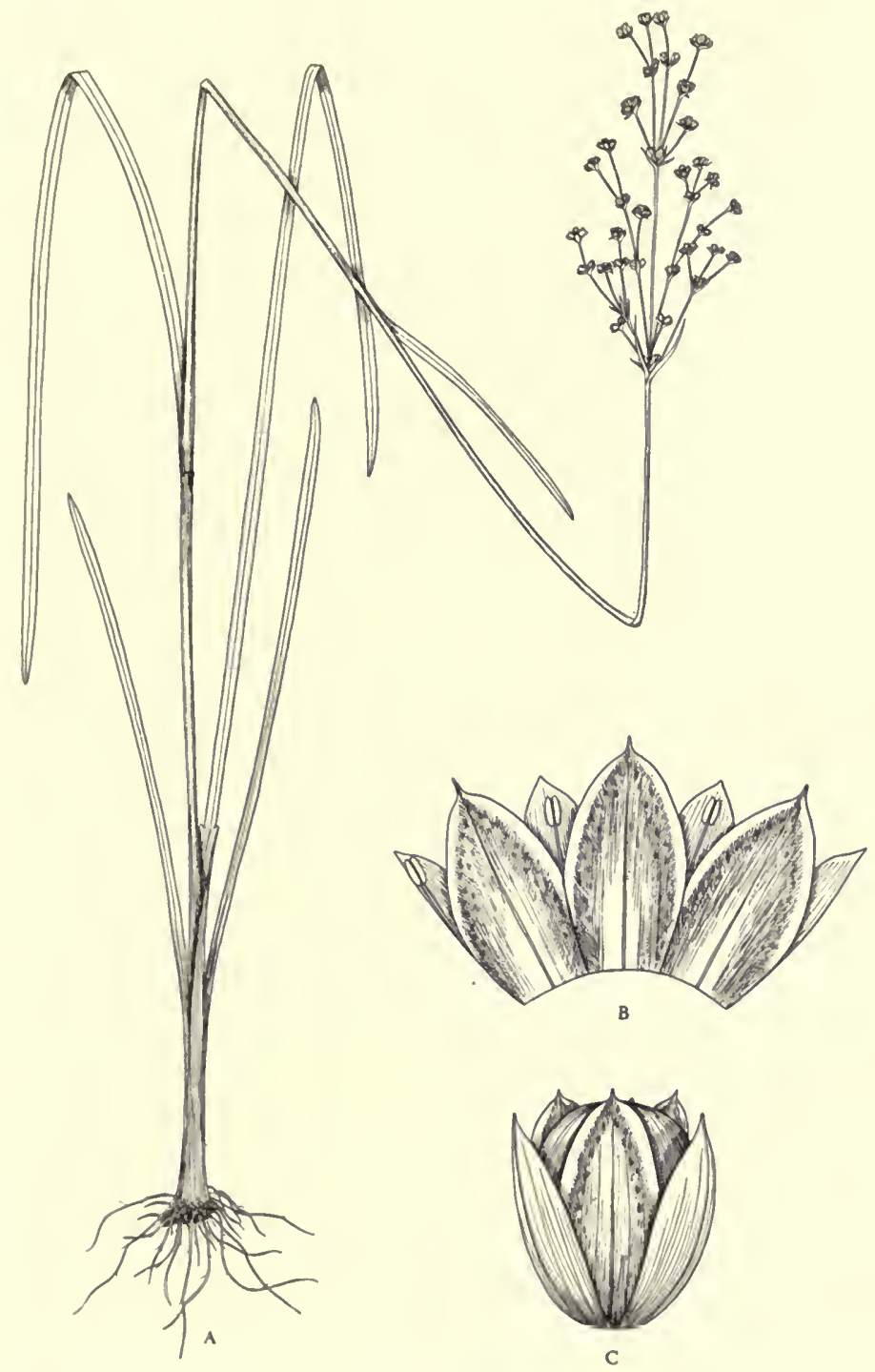

Fig. 14. Juncus marginatus. A. Habit of plant; $\times 1 / 2 . \quad$ B. Flower, opened, with sepals shown on outside; $\times 10$. C. Mature capsule in position with perianth segments; $\times 10$. 
Juncus marginatus Rostk. var. setosus Coville, Proc. Biol. Soc. Wash. 8: 124. 1893. J. setosus Small, Fl. Southeast. U. S. 258. 1903.

Borders of swamps, ponds, wet meadows, sometimes in wet open fields and on banks along small streams, 1,300-1,900 meters; Alta Verapaz; Zacapa; Quiché; Huehuetenango. United States and Mexico; Honduras.

Plants perennial from a bulbous thickened base; culms densely cespitose, erect, 20-65 cm. tall, 2-3 mm. thick below middle; leaves flat, shorter than the culms, $2-4 \mathrm{~mm}$. broad; bracts reduced and inconspicuous; inflorescence compound, with 20-35 heads, rather densely flowered, the heads 2-7-flowered; flowers 2.5$3.5 \mathrm{~mm}$. long; outer perianth segments broadly lanceolate, abruptly attenuatearistate, deep or rufous brown, the inner perianth segments slightly longer and broader than the outer ones, elliptic-ovate, subobtuse, abruptly aristate, similar in color to the outer ones but more scarious on margins; stamens 3, not exserted in fruit; capsule glossy, about equaling the perianth, subglobose-turbinate, deep brown to castaneous, imperfectly 3 -celled; seeds apiculate, $0.5-0.7 \mathrm{~mm}$. long, strongly ribbed, rufous brown. (Fig. 14.)

Typical $J$. marginatus Rostk., with the inner perianth segments obtuse and the capsule dull and lusterless, has not been found in Guatemala. Coville (Proc. Biol. Soc. Wash. 8: 123. 1893) referred Türckheim 431 from Cobán to J. marginatus var. aristulatus (Michx.) Coville. Fernald (Rhodora 37: 156. 1935) and Hermann have shown that Michaux's $J$. aristulatus (transferred by Coville as a variety under $J$. marginatus) is synonymous with $J$. biflorus Ell., a species with elongate nodulose rhizomes and stamens exserted in fruit. Since the specimens from Cobán and elsewhere in Guatemala have bulbous thickened bases and stamens included in fruit, they must be placed with $J$. marginatus.

Juncus microcephalus HBK. Nov. Gen. \& Sp. 1: 327. 1815.

Borders of swamps, ponds, and small streams, 1,300-3,100 meters; Alta Verapaz; Zacapa; Jalapa; Chimaltenango; Huehuetenango. Mexico; Honduras; Costa Rica; South America.

Plants perennial from a slightly thickened base; culms densely cespitose, erect, $20-90 \mathrm{~cm}$. tall, $2-3 \mathrm{~mm}$. thick below middle, compressed; leaves subterete, septate, rather soft, about two-thirds the height of the culms, $2-4 \mathrm{~mm}$. broad; bracts much reduced or inconspicuous; inflorescence compound, with 12-40 heads, the heads 2-8-flowered; flowers $3-3.5 \mathrm{~mm}$. long; perianth segments subequal, appressed-ascending, dull brown along the central portion, gray-buff and scarious on margins, lanceolate, acuminate; stamens 6; capsule slightly shorter than the perianth, obovate, obtuse, dull brown, 1-celled; seeds apiculate, without tail-like appendages, $0.4-0.5 \mathrm{~mm}$. long, pale brown. 
Juncus tenuis Willd. Sp. Pl. 2:214. 1800. J. macer S. F. Gray, Nat. Arr. Brit. Pl. 2: 164. 1821.

Wet banks, fields, and meadows, along roadside ditches or on sandbars along streams, sometimes along brooks in forest, 1,4003,500 meters; Zacapa; Baja Verapaz; Jalapa; Chimaltenango; Quezaltenango; Huehuetenango; San Marcos. Widely distributed in North America; Mexico; Costa Rica; also in the Old World.

A perennial with wiry roots, densely tufted; stems $5-45 \mathrm{~cm}$. tall, stiff and wiry, slender, $0.5-1 \mathrm{~mm}$. thick; leaves flat, $0.8-1.5 \mathrm{~mm}$. broad, shorter than the culms; auricles at the summit of the leaf sheath entire, white, scarious, conspicuously produced beyond the point of insertion, $0.5-1.5 \mathrm{~mm}$. long; bracts (at least the lowermost) exceeding the inflorescence; inflorescence erect, few- to manyflowered, open; flowers more or less clustered at the tips of the branches, 3-4.5 $\mathrm{mm}$. long; perianth segments lanceolate, acuminate, stramineous to greenish brown in the middle, scarious on the margins, slightly spreading in age; capsule slightly shorter than or almost equaling the perianth, ovoid to obovoid, retuse, dull greenish brown to stramineous (dull brown in age), falsely 1-celled; seeds short-pointed, without tail-like appendages, $0.5-0.6 \mathrm{~mm}$. long, pale brown.

In the United States this species of rush is exceedingly common, frequently being found along paths and in grassy places. The more common form found in Guatemala is the following:

Juncus tenuis $\mathrm{f}$. discretiflorus (Hermann) Fernald, Rhodora 47: 123. 1945. J. macer f. discretiflorus Hermann, Rhodora 40: 82 . 1938.

Distribution in Guatemala similar to that of the typical form, but more common. Eastern United States.

In most respects like typical $J$. tenuis, but the flowers scattered or secund along the branches, larger, $5-6 \mathrm{~mm}$. long, the outer perianth segments conspicuously longer than the inner ones.

For a discussion of the nomenclature of this species see Fernald, Rhodora 47: 117. 1945.

Juncus trinervis Liebm. Naturh. For. Kjoebenhavn Vid. Medd. 41. 1850.

Moist or wet meadows, often along brooks, 2,500-2,800 meters; Huehuetenango (Sierra de los Cuchumatanes: Cerro Cananá; near San Mateo Ixtatán). Central and southern Mexico.

Plants erect, with horizontal rhizomes, of ten producing stolons, the stems slender, $20-40 \mathrm{~cm}$. high; leaf blades terete or somewhat compressed, evidently septate; inflorescence compound or decompound, often umbelliform, the heads usually few, hemispheric or subglobose, chestnut-colored; flowers 4-5 $\mathrm{mm}$. long; sepals all about equal in length, lanceolate, broadly marginate; stamens 6 , some- 
what shorter than the sepals, the anthers linear, longer than the filaments; style long and slender, often projecting beyond the sepals, the stigmas elongate, conspicuously exserted; fruit usually conspicuously longer than the perianth, trigonous, gradually attenuate into the style; seeds obovate, apiculate, lineolate.

\section{LUZULA De Candolle}

Perennial plants, the stems more or less leafy; leaves sparsely or densely ciliate, the blades usually flat, the sheaths without auricles; inflorescence compound, dense or open, the flowers in heads, spikes, or loose cymes; perianth dark brown; stamens usually 6 , rarely 3 , shorter than the perianth; ovary 1-celled; capsule 1-celled, 3-valvate; seeds 3.

About sixty species, chiefly in temperate and arctic regions. All the known Central American species are listed here.

Inflorescence loose and open, corymbose, the flowers mostly solitary. . L. gigantea. Inflorescence very dense and crowded, spike-like.

Lowest branch of the inflorescence remote from the other branches; inflorescence erect...................................... caricina.

Lowest branch of the inflorescence close to the other branches, appearing to be part of the main spike-like inflorescence; inflorescence nodding.

J. racemosa.

Luzula caricina E. Mey. Linnaea 22: 418. 1849.

Alpine meadows, 2,500-3,700 meters; Huehuetenango (Sierra de los Cuchumatanes). Central and southern Mexico.

Plants cespitose, the stems strictly erect, $8-30 \mathrm{~cm}$. tall, 1-1.5 mm. thick, usually leafy to the inflorescence; leaves grass-like, conspicuously ciliate, 5-20 $\mathrm{cm}$. long, 2-5 mm. broad, callose-obtuse at the apex; inflorescence spike-like, erect, $1.5-4 \mathrm{~cm}$. long, 5-8 mm. thick, the few-flowered glomerules becoming looser in age, the lowest branch of the inflorescence more or less distant from the other branches and appearing to be removed from the main inflorescence, elongatestipitate; flowers about $3 \mathrm{~mm}$. long; perianth segments subequal, lanceolate, long-acuminate, castaneous with the upper half of the margins buff; capsule about equaling the perianth, trigonous-ovate, obtuse; seeds large, $1.5 \mathrm{~mm}$. long, castaneous, the basilar caruncle large, white-stramineous.

Luzula gigantea Desv. Journ. Bot. 1: 145. 1808.

Cool high coniferous mountain forests, sometimes in sphagnum bogs, 2,500-3,800 meters; El Progreso; Sacatepéquez; Chimaltenango; Quezaltenango; San Marcos. Mexico; Costa Rica; Panama; South America.

Plants densely cespitose and stoloniferous; stems copiously leafy at the base, ascending, 20-90 $\mathrm{cm}$. tall, $1.5-3.5 \mathrm{~mm}$. thick below the middle; leaves bright green, firmly membranaceous, ascending, mostly 5-25 cm. long, 5-14 mm. wide, densely ciliate or in age becoming glabrate; cauline leaves $2-4$, the basal ones numerous; lowest bract of the inflorescence leaf-like, shorter than the inflores- 
cence; inflorescence loosely corymbose, usually nodding, the branches filiform; flowers 2-2.5 mm. long; perianth segments subequal, lanceolate, long-acuminate, dull or dark brown; capsule equaling or slightly exceeding the perianth, trigonousovate, obtuse, deep brown to castaneous; seeds $1-1.3 \mathrm{~mm}$. long, rufous-brown to castaneous, obliquely obovate, shortly apiculate at the grayish apex.

Luzula racemosa Desv. Jour. Bot. 1: 162. pl. 6, f. 3. 1808. Sacatillo de peña.

Alpine meadows, exposed rocky summits of volcanoes, and open pine woods at high elevations, 3,500-4,500 meters; Quezaltenango; Huehuetenango; San Marcos; reported by Hemsley from Volcán de Fuego. Mexico. South America.

Plants densely cespitose; stems very leafy at the base, strictly erect, mostly 10-45 cm. tall, 0.5-1.5 mm. thick; leaves deep green, firmly membranaceous to subcoriaceous, much shorter than the stems, ascending to erect, densely ciliate or in age glabrate, $2-12 \mathrm{~cm}$. long, 2-5 mm. wide, flat or becoming convolute, curved, or more or less canaliculate; cauline leaves usually 2 , mostly smaller than the numerous basal leaves; lowest bract prolonged, more or less leaf-like; inflorescence conic to oblong-cylindric, nodding, 2-4 cm. long, 4-12 mm. thick, interrupted near the base, densely flowered, simple or somewhat lobate; flowers $2.5-3 \mathrm{~mm}$. long; bracts conspicuously exceeding the flowers, long-ciliate; perianth segments subequal or the outer slightly longer, lanceolate, caudate, the tips conspicuously hyaline as are the margins, dark brown to castaneous in the central portion and at the base; stamens mostly 3 ; capsule shorter than the perianth, broadly ovoid to trigonous-globose, very shortly mucronate, rufous-brown to castaneous; seeds 1-1.3 mm. long, castaneous to ferruginous, obliquely ovate, shortly apiculate at the gray apex.

Buchenau lists several varieties, but there does not appear to be any substantial basis for their segregation.

\section{LILIACEAE. Lily Family}

Perennial herbs or shrubs, rarely arborescent, often with rhizomes or bulbs, the root fibers often thick and fleshy or even tuber-like; stems herbaceous or woody, sometimes scandent, leafy or naked; inflorescence very variable in form, the flowers small or often large and showy, usually perfect and regular; perianth inferior and free from the ovary, or rarely adnate at its base, often marcescent and persistent, corolla-like, the segments free or more or less united, normally 6 , more or less definitely biseriate; stamens usually 6 , hypogynous or affixed to the perianth, opposite the segments, the filaments free or connate; anthers long or short, basifixed or dorsifixed, 2-celled, the cells dehiscent usually by longitudinal slits; ovary superior to partly inferior, usually 3-celled, rarely 1-celled, with axial placentae, the style filiform or columnar, with a small, terminal, capitate or 3-lobate stigma, or the styles sometimes 3 and apical; ovules 2-many in each cell; fruit baccate and indehiscent, more often dry and capsular and loculicidally or septicidally dehiscent; seeds many or few, sometimes by abortion only 1; endosperm copious. 
A large family, with many species in North America, chiefly in temperate regions, and well represented in all the continents. All the genera native in Central America are listed here.

Plants more or less woody, treelike or shrublike, not scandent, the stems bearing many long leaves.

Leaves mostly 6-12 cm. wide, often reddish or purplish; stems slender, simple;

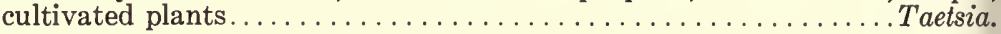

Leaves narrower; stems stout, often $10 \mathrm{~cm}$. or more in diameter, often branched. Flowers about $4 \mathrm{~cm}$. long; leaves stiff and hard............Yucca. Flowers less than $1 \mathrm{~cm}$. long; leaves flexible.

Fruit dry, winged.

Beaucarnea.

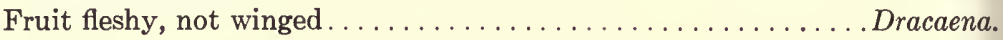

Plants herbaceous, low, sometimes woody but then with very slender, scandent stems.

Leaves cauline, no evident basal ones present.

Stems much branched, often scandent....................... Stems simple.

Flowers very large, $15 \mathrm{~cm}$. or more in length; cultivated plants. . . Lilium. Flowers relatively small, $2 \mathrm{~cm}$. long or shorter; native plants.

Leaves linear; stems with usually 2 flowers............ Calochortus.

Leaves mostly elliptic; flowers very numerous........... Smilacina.

Leaves all or chiefly basal, or the stems rarely bearing a few leaves.

Flowers in umbels.

Plants without bulbs or corms, cultivated. Flowers $3.5-5 \mathrm{~cm}$. long, blue

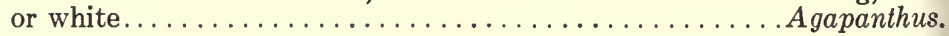

Plants with bulbs or bulb-like corms.

Perianth segments $2-3 \mathrm{~cm}$. long or larger; flowers usually $2-4 \ldots$ Milla.

Perianth segments less than $1 \mathrm{~cm}$. long; flowers usually numerous.

Perianth segments connate near the base; plants without an onion odor.

Nothoscordum.

Perianth segments distinct; plants with an onion-like odor.... Allium. Flowers not in umbels.

Plants with bulbs; perianth segments often with glands within.

Flowers solitary; perianth segments not glandular within........ Milla. Flowers numerous; perianth segments with glands within.

Flowers spicate; ovary superior.............. Schoenocaulon.

Flowers racemose; ovary partly inferior............Zygadenus.

Plants never with bulbs; perianth segments without glands.

Leaves thick and fleshy, with spinelike teeth; perianth cylindric... Aloe. Leaves not fleshy, unarmed.

Perianth tubular, the lobes much shorter than the tube....Kniphofia. Perianth not tubular, the lobes distinct or much longer than the tube.

Leaves stiff and hard, erect, dark green mottled with white or gray; flowers white or greenish white............. Sansevieria.

Leaves thin and soft, usually recurved, green.

Flowers $10-12 \mathrm{~cm}$. long................... Hemerocallis. Flowers less than $2 \mathrm{~cm}$. long, usually $1-1.5 \mathrm{~cm}$.

Anthers coherent into a tube about the style.......Echeandia.

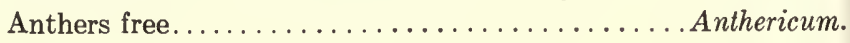


Several genera besides those listed here may be seen occasionally in cultivation in Guatemala, especially the Aspidistra (Aspidistra elatior Blume, native of Japan), grown as a pot plant. Tulips (Tulipa spp.; "Tulipán") and hyacinths (Hyacinthus; "Jacinto") probably have been grown in pots, but the spring-flowering bulbous plants as a rule do not succeed out of doors even in the mountains of Central America.

\section{AGAPANTHUS L'Héritier}

Large succulent plants with short rhizomes and thick fleshy root fibers; leaves radical, broadly linear or lorate; scape simple, naked, the flowers numerous in a terminal umbel, large and showy, usually blue, sometimes white; involucral bracts 2 , broad, caducous, the interior bracts numerous, linear-setaceous; perianth funnelform, the tube cylindric, usually short, the 6 segments subequal, longer than the tube, erect-spreading; stamens 6 , inserted in the throat, shorter than the perianth, the filaments filiform, the anthers oblong or oblong-linear, dorsifixed, bilobate at the base, the cells introrsely dehiscent; ovary sessile, 3-celled, the style filiform, the stigma small; ovules numerous; capsule oblong, obtuse, somewhat trilobate; seeds numerous, ascending, compressed, black, the testa produced as an oblong wing.

About three species in South Africa, one of them grown for ornament in most tropical regions.

Agapanthus africanus (L.) Hoffmannsegg, Verz. Pflanzenkult. 35. 1824. Crinum africanum L. Sp. Pl. 419. 1753. A. umbellatus L’Hér. Sert. Angl. 18. 1788. Agapanto.

Cultivated for ornament in the central highlands but not very common; also at lower elevations, and especially frequent about Cobán, where it perhaps is sometimes naturalized in hedges. Native of South Africa, but now cultivated in many tropical regions.

A large and rather robust plant, often forming dense clumps, the leaves about $60 \mathrm{~cm}$. long, rather broad, succulent; scape a meter high or less, bearing at the apex an umbel of 10-30 large, blue or sometimes white flowers; perianth $3.5-5$ cm. long.

The plant is a handsome and showy one, with a rather short blooming season, apparently. It is able to endure neglect and a cool climate, and was noted as high as the gardens of San Marcos (above 2,500 meters).

\section{ALLIUM L. Onion, Garlic, Leek}

Plants with bulbs, strong-scented, the bulbs tunicate, solitary or sometimes several and arising from a short rhizome; leaves basal, usually linear, sometimes 
terete or fistulose; scape simple, leafless, the flowers umbellate, few or numerous, on short or elongate pedicels, usually small, sometimes replaced by bulblets; involucral bracts 2 or very rarely 3 , often united below or throughout; perianth segments 6 , free, equal or the inner ones slightly larger, spreading or campanulateconnivent; stamens 6 , inserted at the base of the perianth segments, longer or shorter than the perianth segments, the filaments free or sometimes connate at the base, the anthers oblong, dorsifixed at the middle, the cells introrsely dehiscent; ovary sessile or short-stipitate, 3-celled, the style filiform, short or elongate, the stigma small, sometimes shortly trifid; ovules usually 2 in each cell; capsule membranaceous, surrounded by the persistent perianth, loculicidally dehiscent; seeds angulate-compressed or often disklike, the tèsta membranaceous, black.

A large genus of about 270 species, widely distributed in temperate and cold regions of both hemispheres, in America none of them strictly tropical. A single native species has been found in Central America. Several of the species are of great importance as food plants.

Native plants, the leaves about $2 \mathrm{~mm}$. wide.............. glandulosum. Cultivated plants, the leaves much broader.

Leaves terete, hollow........................... Cepa.

Leaves flat, not hollow.

Leaves broad, strongly conduplicate or carinate; flowers white or pinkish; bulb simple, scarcely more than an enlargement of the stalk. A. Porrum.

Leaves narrow, carinate; flowers purple, often replaced by bulblets; bulbs small, breaking up into numerous small ones that are covered with dry

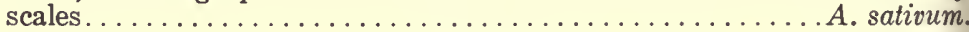

Allium Cepa L. Sp. Pl. 300. 1753. Ceboll (Quecchí); Sipoix (Quiché); Cebolla; Cucut (Maya). Onion.

Native of Persia and adjacent regions, now cultivated in almost all parts of the earth.

The onion is one of the commonest and most important vegetables of Guatemala and all Central America. There is, in fact, a common saying that sin cebollas no hay cocina. It is used either dry or fresh. No sight is more common on the roads and trails of Guatemala than the many Indians who carry heavy loads of onions from the producing regions to the various remote markets of the country. Onions are grown almost anywhere in Guatemala, and there are large fields, or fields of beds, of them about Almolonga and Zunil, to supply the densely populated region of Quezaltenango. The two principal centers of onion (and garlic) production, however, are Panajachel, on the shores of Lake Atitlán, and Aguacatán, in Huehuetenango. About the latter place the extensive irrigated valley is given over almost wholly to cultivation of onions and garlic, which are carried either fresh or dry, but especially fresh, to all parts of the country, and even to Chiapas. During the dry season when the surrounding 
hills are parched and brown, these great onion fields, vivid green, are a beautiful sight. The plants are watered by men, women, and children, who toss the water upon the beds from the ditches of clear water that are conducted through the fields, the same process used in watering most other vegetables where running water is available. Most of the onions grown in Guatemala are white, but red ones are seen occasionally.

Allium glandulosum Link \& Otto, Icon. Rar. 1: 33. pl. $1 \%$. 1841.

Meadows or open forest, 1,200-3,800 meters; El Progreso; Jalapa; Chimaltenango; Totonicapán; El Quiché; Huehuetenango; San Marcos. Southern Mexico.

Plants with small bulbs usually about $1.5 \mathrm{~cm}$. in diameter, producing long stolons; leaves often longer than the scapes, sometimes shorter, about $2 \mathrm{~mm}$. wide, flat; scapes slender, subterete, $20-40 \mathrm{~cm}$. tall, the flowers usually few, on slender pedicels $2.5 \mathrm{~cm}$. long or shorter; perianth segments deep purple-red, usually with white margins, sometimes white with lavender or purple stripes, 7-8 $\mathrm{mm}$. long, linear-oblong; stamens slightly shorter than the perianth; capsule subglobose, $3.5 \mathrm{~mm}$. high.

This is the southernmost representative of the genus in North America. Several additional species are native in Mexico, and in the western United States there are many other species.

\section{Allium Porrum L. Sp. Pl. 295. 1753. Puerro. Leek.}

Native of Europe, now grown in many temperate regions for its roots and leaves.

Leeks are seldom seen in markets of the United States, but they are plentiful in those of Guatemala, especially at Quezaltenango and Guatemala. They are planted to some extent about Cobán, and doubtless also in other regions. They probably are not used by the Indians, unless it be those who grow them for market. The center of production seems to be at Almolonga and Zunil, and leeks are plentiful in the Quezaltenango market, large and fine ones, fully equal in quality to any grown in the United States. They are used principally if not wholly for preparing a very good soup that is common on tables of the upper classes of society.

Allium sativum L. Sp. Pl. 296. 1753. Ajo; Cucut (Maya); Acuc (Jacaltenango); Axú (Quiché); Hanx, Anx (Quecchí). Garlic. 
Native of Europe, now grown in most temperate and tropical regions.

Garlic is planted extensively in many or most parts of Guatemala and consumed all too extensively, at least too generally for North American palates that are unaccustomed to it. It is found in almost all dishes, it would seem, except desserts, and often in too great amounts, even according to Central American standards. Excessive use of garlic is long established in the Iberian Peninsula, and those familiar with the dicta of Don Quixote will recall his admonitions on the subject to Sancho Panza. Garlic, like onions, is grown extensively about Aguacatán and Lake Atitlán. It is used only in the dry state, and for transportation usually the tops of the plants are braided together to form bunches, just as in the United States. In the markets the cloves often are separated, so that one may purchase a very small quantity if desired. The name "ajo" appears geographically as in the case of a caserio of Huehuetenango, called Ajal, i.e., a place where ajo is grown. The Indians of Alta Verapaz often carry an onion in their pockets or elsewhere about their clothing to avert misfortunes and disease.

Allium Schoenoprasum L., Chives, native of Europe, is grown rarely in Guatemala but commonly in the United States. The very slender and abundant, grass-like leaves are used in the latter country for flavoring soups and salads.

\section{ALOE L.}

Succulent plants, without bulbs, the caudex very short or tall and shrubby or arborescent, sometimes branched; leaves thick, rosulate or often distichous or scattered, sometimes spinose-dentate; scapes or peduncles axillary or pseudoterminal, usually elongate, simple or branched, the flowers mostly small, racemose, often nutant, solitary within the bracts; perianth cylindric or contracted above the ovary, the segments connivent or coherent or connate, erect or with spreading tips; stamens 6, hypogynous, equaling or longer than the perianth, the anthers oblong or oblong-linear, dorsifixed near the base, the filaments subulate, the cells introrsely dehiscent; ovary sessile, oblong or ovoid, 3-celled, the style filiform, the stigma small; ovules numerous; capsule coriaceous, ovoid or oblong, loculicidally dehiscent; seeds numerous, triquetrous or compressed, sometimes winged, the testa black.

About one hundred species, in Africa and western Asia, none native in America. Because of their often bizarre forms, some species are grown as pot plants, and some of these have found their way to Guatemala. The following species has become widely dispersed in tropical regions because of its medicinal properties. 


\section{Aloe vera L. Sp. Pl. 320. 1753. Sábila.}

Planted commonly in the Pacific bocacosta, and in some places thoroughly naturalized in hedges and thickets; seen also in the Oriente, and even as high as Antigua (1,500 meters); probably to be found in gardens in almost all parts of the country. Native of the Mediterranean region.

Plants acaulescent or nearly so, producing long stolons; leaves narrowly lanceolate, 30-60 cm. long, turgid, pale green, the margins with distant spinelike teeth; scape stout, a meter high or less, bearing a few distant scales; racemes 10-30 $\mathrm{cm}$. long, dense, the bracts lanceolate or ovate, longer than the short pedicels; flowers yellow, about $2.5 \mathrm{~cm}$. long.

The aloe plant probably was introduced into Central America soon after the conquest. It has long been used in medicine as a bitter purgative. The watery juice upon exposure to air soon hardens, and in this form is the aloes (acibar) of pharmacy. In recent years it has been found that the fresh sap is an effective agent in healing persistent sores or wounds, and the leaves are shipped for this purpose from Florida to the North. In Guatemala poultices of the crushed leaves are applied to heal sores, and the sap is applied to boils, to bring them to a head. Women sometimes wean nursing children by rubbing the bitter sap upon their nipples. The Maya name is reported from Yucatan as "hunpetskinci."

\section{ANTHERICUM L.}

Plants with short or no rhizomes, bearing a cluster of numerous thick fleshy fascicled roots, the base of the plant often covered with persistent sheaths of branched, withered leaves; leaves basal, linear, sometimes broadly so; scape simple or sometimes with a few leaflike bracts, the flowers slender-pedicellate, racemose, solitary or fasciculate in the axils of the bracts, these mostly scarious; perianth marcescent, usually persistent upon the fruit, the segments distinct, spreading, subequal, 3-5-nerved; stamens 6 , hypogynous, shorter than the perianth, the filaments filiform, the anthers linear, erect, the cells introrsely dehiscent; ovary 3-celled, sessile, the style filiform, the stigma small; ovules 4-8 in each cell; capsule oblong to globose or shallowly 3-lobate, loculicidally dehiscent; seeds often only 1-2 in the cell, angulate or angulate-compressed, the testa black.

A group of 50 or more species in Europe, Africa, and America. An additional Central American species occurs in Panama. The genus is in need of revision, and the species are not well known.

Anthericum Liliago L., sometimes known by the name St. Bernard's lily, native of southern Europe and northern Africa, is seen occasionally as a house plant in the patios of Guatemala, and is rather frequent in cultivation in the United States. It has slender 


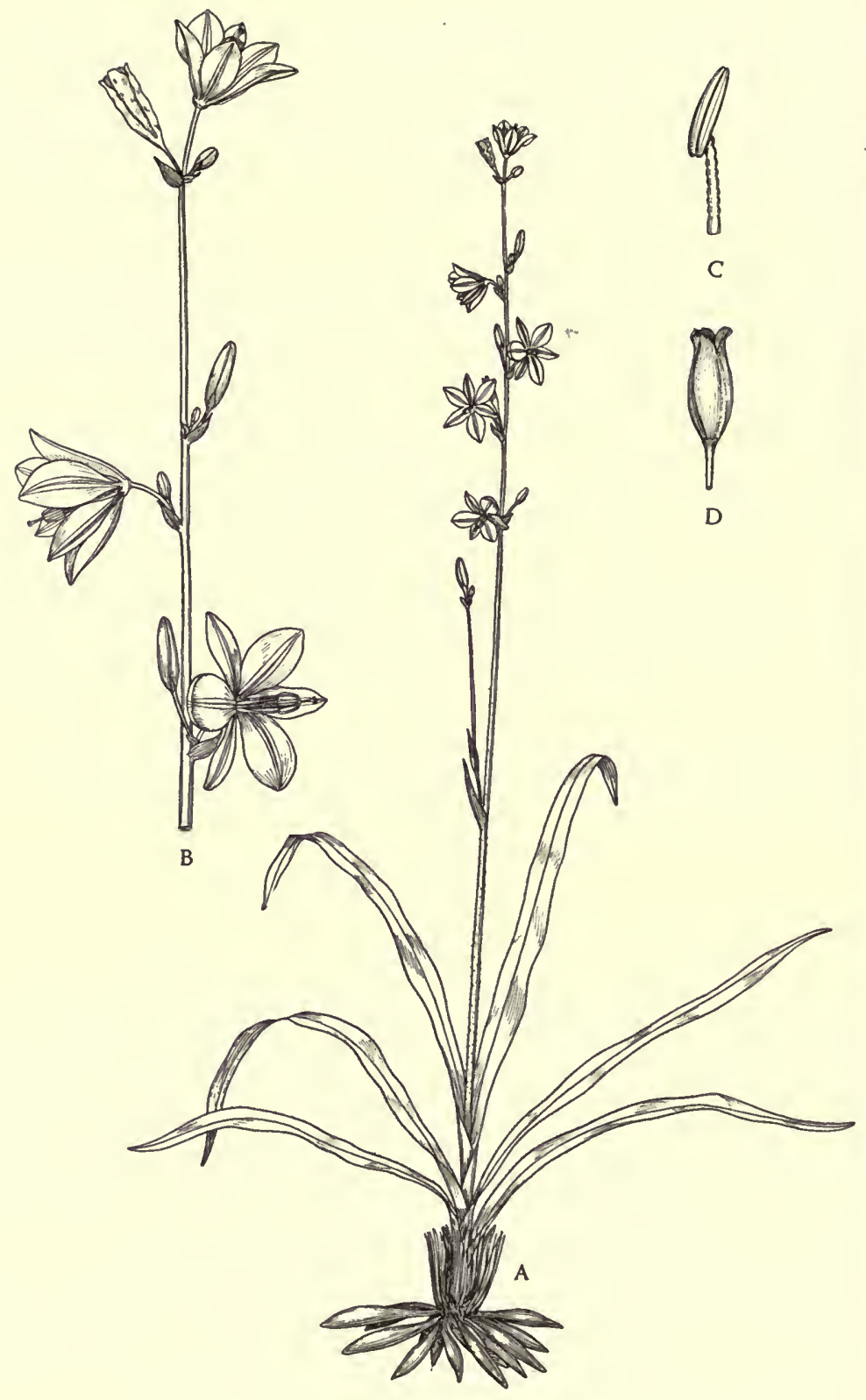

FIG. 15. Anthericum aurantiacum. A. Habit of plant; $\times 1 / 3$. B. Portion of inflorescence; $\times 1$. C. Stamen; $\times 3$. D. Capsule; $\times 1$. 
racemes of small white flowers and long narrow leaves. It is noteworthy for its habit of producing long stolons, usually above ground, which bear at the apex a tuft of small leaves. By using these for propagation, new plants are easily obtained. A variety with whitestriped leaves cultivated at Quezaltenango is known there by the name "listón."

Plants densely hirsute on the stems and leaves................. vestitum. Plants glabrous.

Anthers only $1 \mathrm{~mm}$. long; perianth $16-18 \mathrm{~mm}$. long........... Skinneri. Anthers 3-4 mm. long; perianth 10-14 $\mathrm{mm}$. long.

Leaves mostly $5-12 \mathrm{~mm}$. wide............................ Leaves mostly $15-25 \mathrm{~mm}$. wide.................. eleutherandrum.

Anthericum aurantiacum J. G. Baker ex Hemsl. Biol. Centr. Amer. Bot. 4:91. 1887; Bot. Jahrb. 8: 209. 1887. A. apodastanthum Donn. Smith, Bot. Gaz. 19: 265. 1894.

Moist thickets, open pine forest, rocky slopes, or open hillsides, 1,200-3,300 meters; Chiquimula; Jutiapa (type from Río Paz, Lehmann 1721); Sacatepéquez (type of $A$. apodastanthum from San Bartolo, 1,500 meters, Heyde \& Lux 4644); Chimaltenango; Huehuetenango. Honduras; Costa Rica; Panama.

Plants usually cespitose, the root fibers very numerous, thick and fleshy or sometimes rather slender; leaves thin, bright green, mostly 5-12 mm. wide; scapes usually simple, sometimes with a single branch, the flowers slender-pedicellate, orange-yellow; perianth segments 3-nerved, $10-14 \mathrm{~mm}$. long; anthers $3 \mathrm{~mm}$. long; capsule oblong-oval, about $13 \mathrm{~mm}$. long, the seeds 10 or fewer in each cell. (Fig. 15.)

We have seen no authentic material of $A$. aurantiacum, but the description indicates no characters by which it and $A$. apodastanthum may be separated, in spite of the fact that Captain Smith, in publishing the latter, states that the type had been seen by Baker, who reported it to be an undescribed species.

Anthericum eleutherandrum (Koch) H. E. Moore, Gent. Herb. 8, fasc. III: 246. 1951. Anthericum platyphyllum Greenm. Proc. Amer. Acad. 33: 472. 1898. Chuichuisa.

Brushy banks or hillsides, sometimes in damp pine forest, 1,3002,200 meters; Alta Verapaz; Jalapa; Huehuetenango. Mexico.

Plants with dense clusters of leaf fibers at the base; leaves basal, bright green and rather soft, $15-40 \mathrm{~cm}$. long, mostly $1.5-3 \mathrm{~cm}$. wide, long-attenuate to each end, glabrous, ciliolate; scapes $40-70 \mathrm{~cm}$. tall or more, usually sparsely branched above, the flowers numerous, orange-yellow, $2-4$ in the axils of each bract, the pedicels $3-12 \mathrm{~mm}$. long, articulate below the middle; perianth segments $10-12 \mathrm{~mm}$. long, 3-nerved, oblong, obtuse; filaments muricate, the anthers 3-4 $\mathrm{mm}$. long; capsule oblong, 10-15 mm. long, emarginate; seeds angulate, black. 
Anthericum Skinneri J. G. Baker, Journ. Linn. Soc. Bot. 15: 318. 1876.

Type from Guatemala, collected by Skinner, the locality not known.

Leaves 15-20 cm. long, 4-6 $\mathrm{mm}$. wide, ciliolate; scape glabrous, as much as $75 \mathrm{~cm}$. tall, bearing a single small bract; raceme lax, 10-12 $\mathrm{cm}$. long, the pedicels 12-16 $\mathrm{mm}$. long, articulate at the middle; perianth segments 3-5-nerved.

Known to the authors only from description. The very small anthers and unusually elongate pedicels should be distinctive, especially if the anther size is characteristic and not abnormal.

Anthericum vestitum Baker, in Journ. Linn. Soc. 15: 307. 1876. Anthericum crinitum Standl. Field Mus. Bot. 17: 228. 1937. Grassy slopes or plains, 1,600-2,000 meters; endemic; Chimaltenango (type from Finca Alameda, near Chimaltenango, J. R. Johnston 714); Huehuetenango.

Roots numerous, fleshy, much thickened; leaves all basal, linear, 5.5-18 cm. long, 6-7 mm. wide, long-attenuate to each end, hirsute with rather long, thick, spreading hairs; scape simple, stout, $18-35 \mathrm{~cm}$. tall, hirsute, the flowers few or numerous, forming an interrupted raceme as much as $17 \mathrm{~cm}$. long, the pedicels stout and stiff, scarcely $3 \mathrm{~mm}$. long; perianth glabrous, orange-yellow, the segments $12 \mathrm{~mm}$. long, 3-nerved; capsule sessile, glabrous, oblong, $1 \mathrm{~cm}$. long, $5 \mathrm{~mm}$. broad, emarginate at the apex.

\section{ASPARAGUS L. Asparagus}

Herbs or often more or less woody vines, or erect shrubs, the stems, at least in age, becoming much branched, the ultimate branchlets (cladodes) filiform and terete or angulate, or sometimes leaflike, solitary or fasciculate in the axils of small scales; flowers small, solitary or clustered at the bases of the cladodes, sometimes short-racemose; perianth marcescent and persistent, the segments subequal, distinct; stamens 6 , hypogynous or affixed to the bases of the perianth segments, the filaments filiform, the anthers ovate or oblong, dorsifixed, the cells introrsely dehiscent; ovary sessile, 3-celled, the style stout or slender, short or elongate, the 3 stigmas short, recurved; ovules 2-many in each cell; fruit baccate, globose, the seeds solitary or few, subglobose, usually black.

About 100 species, in temperate and warm regions of the Old World; none native in America.

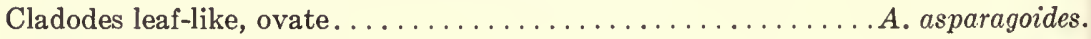

Cladodes linear or terete.

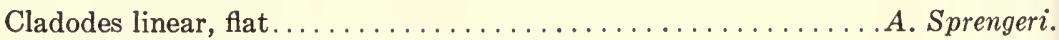

Cladodes terete.

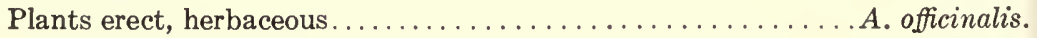

Plants scandent, woody......................... plumosus. 
Asparagus asparagoides (L.) W. F. Wight, Cent. Dict. 11: 845. 1913. Medeola asparagoides L. Sp. Pl. 339. 1753. Myrsiphyllum asparagoides Willd. Ges. Naturf. Freund. Berl. Mag. 2: 25. 1808.

Planted occasionally for ornament, chiefly in patios. Native of South Africa.

A very slender and usually interlaced, small vine with lustrous, pale green foliage; cladodes solitary (clustered in the other species), ovate, acute or acuminate, 1-2 cm. long; flowers greenish white; berries dark purple.

Known by the name "smilax" among florists of the United States, where formerly, at least, the plant was much used for making floral designs. The color and form of the foliage are well preserved for a long time after the branches are cut.

Asparagus officinalis L. Sp. Pl. 313. 1753. Espárrago. Asparagus.

Grown as a vegetable, and often planted in gardens for ornament. Native of Europe.

Plants herbaceous, erect, with much branched rootstocks, the young stems stout, simple, covered with large scales, later branching and often a meter tall or more; cladodes filiform, 6-15 mm. long, clustered in the axils of minute scales; flowers mostly solitary at the nodes of the branches, green, pendent on filiform articulate pedicels; perianth campanulate, about $5 \mathrm{~mm}$. long, with linear obtuse segments; stamens shorter than the perianth; berries red, about $8 \mathrm{~mm}$. in diameter.

Asparagus is not a common vegetable of Central America, but is seen more frequently in Guatemala than elsewhere, principally at rather high elevations. Most of that in the Guatemala City market is said to come from the vicinity of Amatitlán. It is moderately large and of good appearance, and is sometimes blanched before being cut. It is grown also about Cobán, but the stalks eaten there are all or mostly rather slender. Tinned asparagus from the United States is sold in small quantities in the more expensive food shops.

Asparagus plumosus J. G. Baker, Journ. Linn. Soc. 14: 613. 1875. Velo de novia.

Grown commonly in gardens for ornament in most regions of Guatemala. Native of South Africa.

Plants very slender and intricately branched and tangled, often climbing to a height of 3 meters or more, deep green, woody; stems green; cladodes numerous, 8-20 in a cluster, mostly 5-7 mm. long, terete; leaf scales on the main branches developing into short woody spines; flowers borne at the ends of the branchlets, white, the perianth lobes spreading, obovate; berry 1-3-seeded, purple-black. 
A rather common ornamental plant in gardens, in both hot and cool regions.

Asparagus Sprengeri Regel, Act. Hort. Petrop. 11: 302. 1890.

Planted commonly in gardens for ornament. Native of Natal.

A woody vine with tuberous roots; stems often 3 meters long or more, rather stout, the branchlets angled, pale; cladodes in clusters of $3-8$, linear, flat, 12-35 $\mathrm{mm}$. long, pointed; leaf scales on the main stems with a slender brown brittle spine; flowers in open racemes, pale pink, fragrant; berries 1-3-seeded, bright red, $1 \mathrm{~cm}$. or less in diameter.

The plant is especially handsome when covered with the showy bright-colored berries.

\section{BEAUCARNEA Lemaire}

Reference: Trelease, Proc. Amer. Phil. Soc. 50: 437-441. 1911.

Trees with clean trunks and few branches, the trunk usually enlarged at the base, the branches densely leafy at the ends; leaves elongate-linear, coriaceous, entire or minutely serrulate, dilated at the base; flowers small, dioecious, in large, much branched panicles, short-pedicellate and fasciculate in the axils of bracts, the pedicels articulate below the flowers; perianth campanulate, the segments distinct, acute, entire, subequal, spreading in anthesis; stamens 6, attached to the base of the segments, the filaments filiform, the anthers ovate or oblong, dorsifixed; ovary sessile, 1-celled; fruit dry, trigonous, 3-winged, neither lobate nor inflated, irregularly rupturing at maturity; seeds 3-sulcate or 3-lobate.

About nine species are known, in Guatemala and Mexico. By some authors the genus has been united with Nolina, in which the ovary is 3-celled and the fruit is not winged.

Nerves of the leaves minutely papillose, the leaves rough to the touch.

Nerves of the leaves not papillose, the leaves smooth to the touch.

B. guatemalensis.

Leaves up to $3 \mathrm{~cm}$. wide in the upper portion, about $1-1.5 \mathrm{~cm}$. wide above the

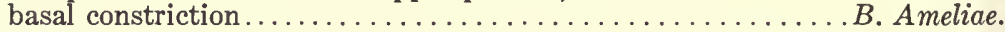

Leaves up to $2 \mathrm{~cm}$. wide in the upper portion, $7 \mathrm{~mm}$. wide above the basal

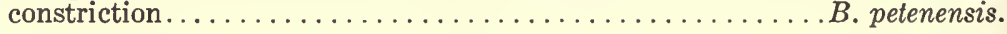

Beaucarnea Ameliae Lundell, Bull. Torrey Club 66: 585. f. 1. 1939. Corcho; Chicú (Huehuetenango).

Dry or wet, rocky, mountain slopes, 600-1,200 meters; Petén; Alta Verapaz (Lanquín); Huehuetenango. Yucatan; central British Honduras.

A shrub or tree 3-8 meters high, the trunk $20-45 \mathrm{~cm}$. in diameter, thickened at the base; branches few, erect; leaves clustered at the ends of the branches, usually spreading or pendent, flat, the enlarged base $2.5-5 \mathrm{~cm}$. wide, the blades 
mostly 85-105 $\mathrm{cm}$. long, tapering to a long setiform apex, the margins minutely serrulate with appressed teeth; staminate inflorescence as much as $75 \mathrm{~cm}$. long; flowers in fascicles of $2-3$, pale yellow or almost white; pedicels 5-7 mm. long; seeds shallowly lobate.

The Maya names are reported from Yucatan as "tsipil" and "chit." It is doubtful whether this species is distinct from $B$. petenensis.

Beaucarnea guatemalensis Rose, Contr. U. S. Nat. Herb. 10: 88. f. 1. 1906. Izote real; Izote de montaña (fide Aguilar).

Generally on dry rocky hillsides, 700-1,600 meters; Baja Verapaz (type from Sierra de las Minas opposite El Rancho, probably on the road to Cobán, W. A. Kellerman 4320); Jalapa (Volcán de Jumay); cultivated in the parks and gardens of Guatemala City; endemic.

A low tree with a tall trunk and few erect branches; leaves rather thin, a meter long or less, $2-3 \mathrm{~cm}$. wide, the edges smooth or roughened, the faces rough to the touch; inflorescence a large ovoid panicle, much branched, the branches $30 \mathrm{~cm}$. long or less; perianth segments about $3 \mathrm{~mm}$. long; fruit elliptic-obovate, 15-18 $\mathrm{mm}$. long and 13-15 mm. broad, emarginate at the base and apex; seeds $5 \mathrm{~mm}$. in diameter, irregularly trilobate, smooth.

The species is cultivated in Guatemala in the Jardín Botánico, Finca La Aurora, and elsewhere.

Beaucarnea petenensis Lundell, Bull. Torrey Club 66: 586. 1939. Dracaena petenensis Lundell, Journ. Wash. Acad. Sci. 25: 230. 1935. Izote (Chiquimula).

Petén (type from Monte Hiltún, a grove in limestone valley forest, Lundell 3271); Chiquimula (Montaña Nube, southeast of Concepción de las Minas, 1,500-1,700 meters, on open wind-swept slopes covered with small shrubs); endemic.

A tree 6-12 meters tall, the trunk 20-30 cm. in diameter, its base bulbousthickened, the branches few; leaves densely crowded at the ends of the branches, grass-green, soft and flexible, pendent, flat, the enlarged base $3.5 \mathrm{~cm}$. wide or less, the upper portion of the blade as much as $2 \mathrm{~cm}$. wide, tapering to a long setiform tip, as much as $140 \mathrm{~cm}$. long, the margins minutely serrulate with appressed teeth; inflorescence as much as $30 \mathrm{~cm}$. long and probably much larger, rather dense, the branches suberect or strongly ascending, the lowest subtended by long thin bracts.

Plants that probably belong to this species are occasional in cultivation in the city of Quezaltenango. The source of these cultivated plants is unknown, but they may well have been brought from northern Quiché or Alta Verapaz, by some of the Indians who bring live birds and mammals as well as cacti and orchids for sale. 


\section{GALOGHORTUS Pursh}

Reference: Marion Ownbey, A monograph of the genus Calochortus, Ann. Mo. Bot. Gard. 27: 371-561. 1940.

Plants glabrous, arising from tunicated bulbs with membranaceous or fibrousreticulate coats; stems scapiform or leafy, often branched; leaves mostly linear, the solitary basal ones often conspicuous, the cauline ones reduced upward; inflorescences monochasial or subumbellate, the bracts usually equaling the pedicels in number and opposite them; flowers small or rather large, erect or nutant, globose to broadly campanulate; outer perianth segments finally valvate in bud, more or less sepaloid, obtuse to attenuate, usually naked; inner perianth segments convolute in bud, usually more or less barbate on the inner face and with a glandular spot near the base; stamens 6 , in 2 series, the anthers oblong to linear, obtuse or apiculate, the base prolonged below the attachment of the filament as a tubular sheath; filaments subulate, dilated at the base; ovary triangular or 3-winged, abruptly contracted at the apex or attenuate to a persistent 3-fid stigma; ovules in 2 rows in each cell; capsule orbicular to linear, 3-angulate or 3-winged, erect or nutant, septicidally dehiscent; seeds irregular or compressed, the testa usually hexagonal-reticulate.

Species about 55, all in western North America. The genus reaches its southern limit of distribution in Guatemala. In California the plants are well known by the name "mariposa" (Spanish, "butterfly") or "mariposa lily," and some of them have been introduced into cultivation because of their handsome flowers.

Flowers erect; petals deep purple; sepals with a glandular spot near the base. C. Ghiesbreghtii.

Flowers nutant; petals white or whitish; sepals with a median glandular spot

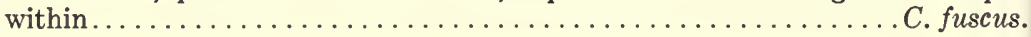

Calochortus fuscus Schult. f. Bijdr. Nat. Wet. 4: 131. 1829. Jekelén.

At 1,400-1,600 meters; Huehuetenango (Sierra de los Cuchumatanes, between Las Palmas and Chaculá, Steyermark 51760). Widely distributed in Mexico.

Bulb ovoid, with fibrous-reticulate coats; stems slender, erect, $60 \mathrm{~cm}$. high or less, sparsely branched, bulbiferous in the axils of the upper leaves and bracts; basal leaf linear-attenuate, not exceeding the stem; cauline leaves successively shorter upward, the lower ones linear, $5 \mathrm{~mm}$. wide, the upper ones linear-lanceolate and amplexicaul; flowers usually 2, campanulate, nutant; sepals shorter than the petals, obtuse or acute, with an oblong median spot bordered above by a laciniate membrane, dull lavender outside, creamy white within; petals narrowly elliptic to cuneate-obovate, about $15 \mathrm{~mm}$. long, acute or obtuse, ciliate distally, sparsely barbate above the gland, white outside and inside, the gland depressed, oblong, bordered above with a laciniate membrane; anthers yellow, about $5 \mathrm{~mm}$. long, shorter than the filaments; capsule linear-oblong, acute at each end, erect. 
Calochortus Ghiesbreghtii Wats. Proc. Amer. Acad. 14: 268. 1879.

Mountain slopes, usually on limestone, about 1,400-2,000 meters; Huehuetenango (Sierra de los Cuchumatanes: Trinidad; Cumbre Papal, between Cuilco and Ixmoquí). Southern Mexico.

Bulb small, ovoid, with thick fibrous-reticulate coats; stems slender, erect, often branched, rarely bulbiferous, about $60 \mathrm{~cm}$. high or lower; basal leaf linear, attenuate, almost equaling the stem, the cauline leaves linear-attenuate; flowers 2 or more, erect, broadly campanulate, the pedicels often greatly elongate; sepals about equaling the petals, elliptic, acute or obtuse, with a circular glandular spot near the base, dull purple outside, purple within; petals obovate, cuneate at the base, acute or obtuse, sparsely or densely barbate with short hairs about the gland, deep dull purple; gland not depressed, naked, bordered above by a deeply laciniate membrane; anthers apiculate, shorter than the filaments; capsule linear-oblong, 3-angulate, erect.

\section{DRACAENA L.}

Trees or shrubs with a thick woody caudex; leaves coriaceous, closely parallelveined, usually crowded at the ends of the branches; flowers usually densely fasciculate along the branches of a small or large panicle, the bracts scarious, large or small; perianth funnelform or narrowly campanulate, the tube short or somewhat elongate, the lobes narrow, subequal, longer or shorter than the tube; stamens 6 , affixed to the tube at the base of the lobes, the filaments filiform or somewhat complanate, the anthers oblong, dorsifixed at the middle, versatile, the cells introrsely dehiscent; ovary sessile or subsessile, 3-celled, the style filiform, the stigma capitate; ovules solitary in the cell, erect; fruit baccate, globose, smooth or shallowly sulcate; seeds usually solitary in the fruit, globose.

About 35 species, all except the following native of the warmer parts of the Old World.

Dracaena americana Donn. Smith, Trees \& Shrubs 1: 207. pl. 98. 1905. Izote de montaña; Caña de arco; Cukil (Kekchí); Cerbatana (Petén); Halal, Ilcaax (Petén, Maya).

In dense wet forest or in thickets of the Atlantic lowlands, ascending from sea level to about 1,350 meters; Petén (Cerro Ceibal); Alta Verapaz; Izabal. Tabasco to British Honduras and Costa Rica.

A tree, sometimes 12 meters high but usually lower and often only a shrub, the trunk often $30 \mathrm{~cm}$. in diameter, the bark grayish and somewhat exfoliating, the branches few, the branchlets marked by the oblique scars of fallen leaves; leaves linear-ensiform, 20-35 cm. long, 1-2.5 cm. wide, somewhat dilated and clasping at the base, attenuate to the apex, bright green, rather soft; panicles ovoid, dense and many-flowered, about 20-30 cm. long, the branches leafy-bracted; pedicels 3-6 $\mathrm{mm}$. long, articulate above the middle; perianth white or creamy white, about $7 \mathrm{~mm}$. long; berries oval or globose, yellowish green, $2 \mathrm{~cm}$. or less in diameter, containing 1-3 seeds; seeds subglobose, 10-12 mm. in diameter. (Fig. 16.) 


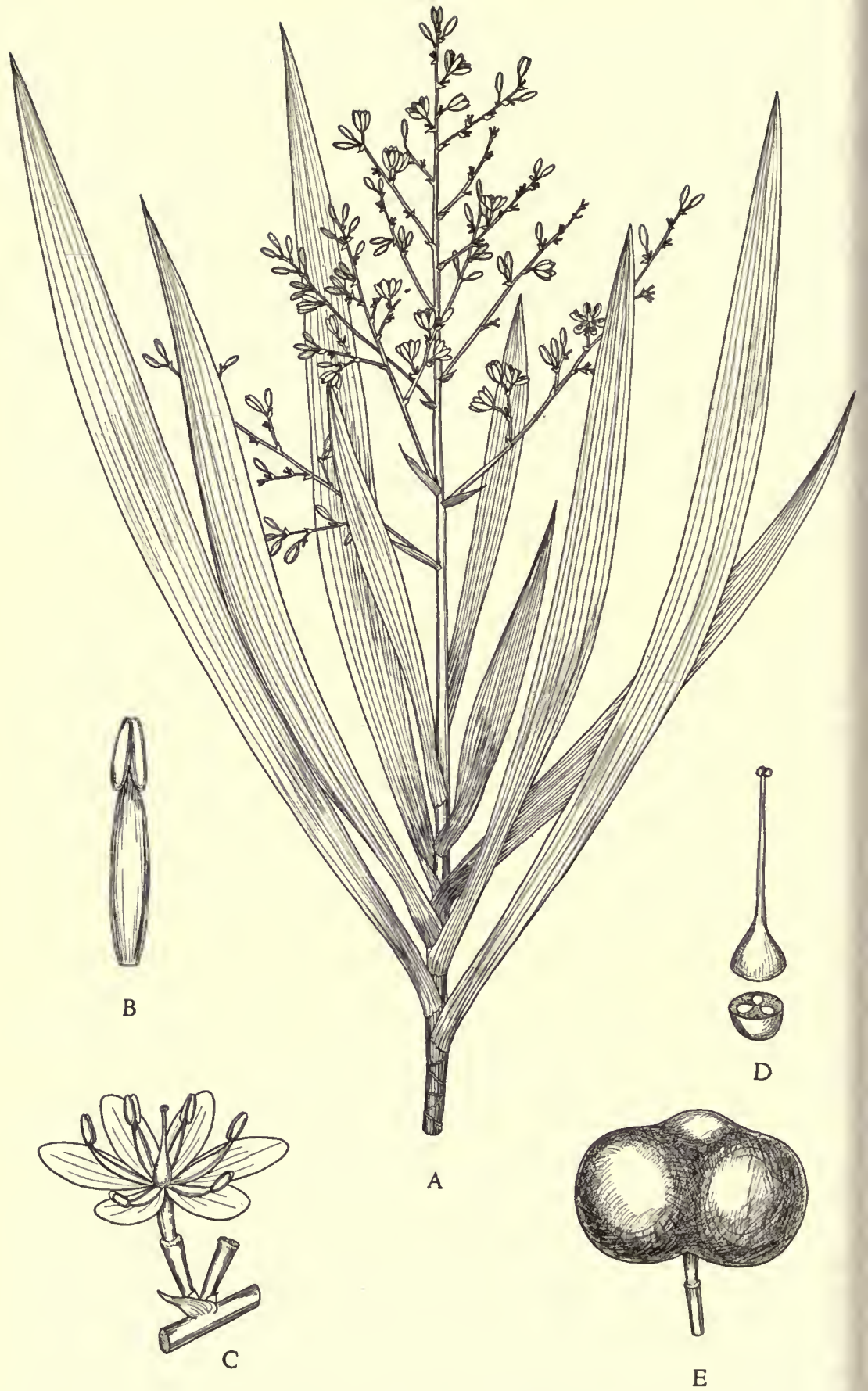

FIG. 16. Dracaena americana. A. Habit of uppermost portion of plant in anthesis; $\times 2 / 6$. B. Stamen; $\times 4$. C. Portion of inflorescence; $\times 2$. D. Pistil with ovary cut transversely; $\times 4$. E. Fruit; $\times 1$. 
Called "candlewood" in British Honduras, and "izote" in Honduras. We have not found the tree abundant in Guatemala, but it may well be plentiful in regions we have not visited. It is a handsome and ornamental plant, and has been introduced into cultivation, as at Quiriguá Hospital, and in Finca La Aurora, Guatemala.

\section{ECHEANDIA Ortega}

Reference: C. A. Weatherby, Synopsis of the genus Echeandia, Proc. Amer. Acad. 45: 387-394. 1910.

Plants with short rhizomes, the root fibers fasciculate, thick and fleshy, sometimes fusiform; leaves all or mostly radical, long and narrow, linear or linearlanceolate, membranaceous, distichous, narrowed at the base into long sheaths; scapes slender, simple or sparsely branched; flowers fasciculate along the scape or its branches, slender-pedicellate, white or yellow, the bracts small, scarious; perianth marcescent, the segments distinct, rotate-spreading, equal or the inner somewhat wider, 3-5-nerved; stamens 6 , hypogynous, shorter than the perianth, the filaments short, filiform, the anthers linear, basifixed, equaling or slightly longer than the filaments, coherent about the style to form a cylinder, the cells introrsely dehiscent; ovary sessile, 3-celled, the style filiform, slightly exserted beyond the anthers, the stigma small, capitate; ovules numerous in the cell; capsule ovoid or oblong, trigonous, loculicidally dehiscent; seeds numerous, angulatecompressed, black.

About ten species, ranging from Mexico to Venezuela, only two known from Central America. In general appearance as well as in most details the plants are exactly like species of Anthericum, and the genus can be determined only by examination of the anthers. Since many Guatemalan specimens are in fruit only, the determination in some instances is questionable.

Capsules 6-9 mm. long; filaments smooth................ parviflora. Capsules mostly $12-18 \mathrm{~mm}$. long; filaments roughened..........E. macrocarpa.

Echeandia macrocarpa Greenm. Proc. Amer. Acad. 39: 73. 1903.

Damp fields or oak forest in the mountains, sometimes in Juniperus forest, 1,400-1,800 meters; Jalapa; Guatemala; Sacatepéquez; Huehuetenango. Southern Mexico.

Leaves all or chiefly basal, much elongate, $6-15 \mathrm{~mm}$. wide, glabrous; scape glabrous, simple or with few branches, $40-60 \mathrm{~cm}$. tall, bearing 1-2 bracts; pedicels articulate below the middle, stout, in fruit becoming 1-1.5 cm. long; flowers yellow, the perianth segments $15-17 \mathrm{~mm}$. long, the inner ones ovate-lanceolate; filaments equaling or slightly longer than the anthers; capsule oblong, 4-6 $\mathrm{mm}$. broad. 
It is perhaps this species that was reported from Volcán de Fuego by Hemsley as $E$. terniflora Cav.

Echeandia parviflora J. G. Baker, Bot. Jahrb. 8: 209. 1887.

Open ground, 900-1,600 meters; Guatemala (type from Amatitlán, F. C. Lehmann 1647); Santa Rosa; material from Petén probably belongs here, and possibly a poor collection from Zacapa; Huehuetenango. Southern Mexico.

Leaves linear, thin, 4-8 $\mathrm{mm}$. wide, $20 \mathrm{~cm}$. long.or often longer, erect or somewhat spreading; scape scabrous or short-hirtellous below, simple or with a few slender branches, as much as $80 \mathrm{~cm}$. tall; pedicels rather short and stout, in fruit 6-8 $\mathrm{mm}$. long or longer, articulate below the middle or near the base; perianth creamy white, 5-6 $\mathrm{mm}$. long or somewhat longer; anthers about $5 \mathrm{~mm}$. long; capsule oval or broadly oblong, usually $6-8 \mathrm{~mm}$. long and $4-5 \mathrm{~mm}$. broad.

\section{HEMEROGALLIS L.}

Tall glabrous herbs with fibrous roots, the leaves basal, linear; flowers large and lily-like, orange or yellow, grouped at the ends of leafless scapes; perianth funnelform, the lobes oblong or spatulate, much longer than the cylindric tube; stamens 6 , inserted at the summit of the perianth tube, shorter than the lobes, declined, the filaments filiform, the anthers linear-oblong, the cells introrsely dehiscent; ovary oblong, 3-celled, the ovules numerous in each cell; style slender, declined, the stigma small, capitate; capsule oblong or ovoid, thick-walled, 3angulate, loculicidally 3-valvate.

About ten species, natives of Eurasia. Two of them are widely cultivated in temperate regions.

Hemerocallis fulva L. Sp. Pl. ed. 2. 462. 1762.

Occasionally cultivated for ornament at middle elevations; noted at Huehuetenango, Finca El Zapote in Escuintla, Cobán, Antigua, and elsewhere; tending to escape along hedges and roadsides in the mountains of Alta Verapaz. Native of Europe and Asia.

Leaves 8-12 mm. wide, tapering to an acute apex; scapes often a meter high or even taller, bearing several short bracts above, the flowers $6-15$, short-pedicellate, reddish orange, paniculate, $10-12 \mathrm{~cm}$. long, opening for one day only; perianth tube $2.5-3 \mathrm{~cm}$. long, the lobes oblong, somewhat spreading.

Usually called "orange day-lily" in the United States, where the plant has long been under cultivation in country gardens. Some of the plants grown in Guatemala have double flowers. In Salvador the plant is called "clavel de Italia." 


\section{KNIPHOFIA Moench}

Large coarse glabrous plants with short rhizomes, the root fibers numerous, thick and fleshy; leaves radical, long and linear, green; scape leafless, tall, simple, the flowers showy, very densely racemose or spicate, yellow or red, subsessile or short-pedicellate, deflexed; bracts small but rather conspicuous because of their great number, scarious; perianth tubular, the segments 1-nerved, connate for most of their length, the short free portion ovate or deltoid; stamens 6, hypogynous, slightly shorter than the perianth or often exserted, the filaments filiform, the anthers oblong or linear, dorsifixed, the cells introrsely dehiscent; ovary sessile, 3-celled, the style filiform, often exserted, the stigma small; ovules numerous in each cell; capsule globose or globose-ovoid, coriaceous, loculicidally dehiscent; seeds angulate, black.

About 25 species, in South Africa and Madagascar.

Kniphofia Uvaria (L.) Hook. Bot. Mag. pl. 4816. 1854. Aloe Uvaria L. Sp. Pl. 323. 1753. Espech (Quezaltenango); Candela (San Marcos); Pompón.

Abundantly naturalized in Quezaltenango and San Marcos, in fence-rows and along roadsides, very plentiful and conspicuous in many places, especially above Palestina and on the plains west and north of Quezaltenango; noted also in Totonicapán and at Huehuetenango; planted for ornament in many gardens of the highlands. Native of South Africa.

Leaves very numerous and usually forming dense clumps, recurved and often lying upon the ground, pale green, linear, usually $1-1.5 \mathrm{~cm}$. wide, $60-90 \mathrm{~cm}$. long, carinate, rough-margined, soft; racemes $15 \mathrm{~cm}$. long or less, spikelike, very dense and many-flowered; upper flowers bright red, the lower ones yellow, reflexed, the cylindric perianth $2.5-3.5 \mathrm{~cm}$. long; bracts scarious and pale, a third as long as the flowers or shorter.

Known in the United States, where sometimes cultivated, as "poker plant." When in flower, in the highlands of Guatemala in January, and probably also in most of the other months, the plant is a showy one because of its brilliant stalks of flowers. It was noted in abundance only in Quezaltenango and San Marcos, where it is conspicuous during the winter months because of its dense masses of green leaves, there being but little green at that season of the year at these high elevations. Evidently the foliage is not eaten by stock.

\section{LILIUM L. Lily}

Large or small plants with bulbs, the bulbs usually composed of thick fleshy scales; stems erect, leafy, simple or branched above; leaves various in shape, sessile or petiolate, verticillate or scattered; flowers large and showy, solitary 
at the apex of the stem or several or many and racemose or umbellate; perianth deciduous, funnelform or subcampanulate, the segments distinct, more or less unguiculate, the upper portion often recurved or revolute; stamens 6 , hypogynous, shorter than the perianth segments, the filaments filiform or somewhat complanate, the anthers linear or oblong-linear, dorsifixed, versatile, the cells introrsely dehiscent; ovary sessile, narrow, 3-celled, the style elongate, usually clavate at the apex; ovules numerous in the cell; capsule oblong, chartaceous or coriaceous, loculicidally dehiscent; seeds numerous, compressed, brown or pale, often marginate.

About 100 species, in temperate regions of the northern hemisphere. Numerous species are native in the United States, but no native ones are found as far south as Central America. Only one species is cultivated at all commonly in Central America, but a few others may be found in private gardens of Guatemala.

Lilium longiflorum Thunb. Trans. Linn. Soc. 2: 333. 1794. Azucena; Saquicotzij (Totonicapán, fide Tejada).

Grown generally for ornament, chiefly at middle and higher elevations, but sometimes even in the lowlands. Native of China and Japan.

Bulbs 5-10 cm. in diameter, subglobose or oblate, white or yellowish; stems stout, a meter high or less, smooth, green; leaves numerous, spreading or the upper suberect, linear-lanceolate, mostly $7-12 \mathrm{~cm}$. long and 9-15 mm. wide; flowers 1-10, pure white, fragrant, often tinged with green near the base, about $17 \mathrm{~cm}$. long; anthers yellow.

One of the favorite garden flowers of Guatemala and of the mountain regions generally of Central America, to be seen in gardens of rich and poor. Large quantities of the flowers are grown for market at Almolonga and Zunil (Quezaltenango), and presumably also not far from Guatemala, since they usually are plentiful in the Guatemala markets. The flowers are used everywhere for making funeral coronas or wreaths, and as decorations upon altars and in religious processions, where thousands of them sometimes may be seen. The lily does not thrive in the lowlands, but the flowers grown in the highlands are carried down commonly by cargadores to the tierra caliente for sale there.

Lilium tigrinum L. Lirio rojo. A native of Europe, rarely grown in Guatemalan gardens. The large flowers are orange-red; the leaves usually bear small dark-colored bulblets in their axils. Known in the United States as "tiger lily."

\section{MILLA Cavanilles}

Plants arising from a small corm, the root fibers fasciculate, sometimes fleshythickened; leaves few, radical, narrowly linear; scapes simple, naked, the flowers 
2-4 or rarely 1 , forming a terminal umbel, long-pedicellate, large, white; involucral bracts 2-3, small and inconspicuous; perianth salverform, the tube cylindric, equal, little constricted at the mouth, the lobes rotate-spreading, slightly unequal; stamens 6 , inserted in the mouth of the tube, exserted, the filaments very short; anthers oblong, erect, connivent about the style, the cells introrsely dehiscent; ovary sessile, elongate, 3-celled; style slightly longer than the anthers, the stigma little dilated, 3-lobate; ovules numerous in each cell; capsule oblong, obtuse, membranaceous, loculicidally dehiscent, the valves septicidally parted; seeds compressed, angulate, black.

The genus consists of a single species.

Milla biflora Cav. Icon. Pl. 2: 76. pl. 196. 1793. Jacinto de monte; Chumimi.

At 800-1,700 meters; Huehuetenango; Quiché. Mexico.

Corms about $1.5 \mathrm{~cm}$. in diameter, brown, with a loose outer coat; leaves few or numerous, often withering, $1 \mathrm{~mm}$. wide or sometimes wider, usually shorter than the scapes; scapes slender, generally $30 \mathrm{~cm}$. high or less, the pedicels rather stout, shorter than the scapes or frequently equaling them; perianth lobes $2-3 \mathrm{~cm}$. long, elliptic-oblong, obtuse-apiculate, white within, pale greenish outside, with a median several-nerved stripe; anthers narrowly oblong, about $6 \mathrm{~mm}$. long; capsule about $1.5 \mathrm{~cm}$. long.

A handsome and rather conspicuous plant, common at some places in the Sierra de los Cuchumatanes of Huehuetenango.

\section{NOTHOSCORDUM Kunth}

Low plants with tunicated bulbs, in general appearance exactly like some species of Allium, but without alliaceous odor; leaves radical, linear, flat; scape slender, naked, the flowers in a terminal umbel, not articulate with the pedicels; involucral bracts 2 , connate at the base; perianth marcescent, persistent, the 6 segments connate at the base or to the middle, spreading or campanulate-connivent, subequal, 1-nerved; stamens 6 , affixed to the bases of the perianth segments, shorter than the perianth, the filaments more or less dilated but subulate and entire at the apex; anthers oblong, dorsifixed, the cells introrsely dehiscent; ovary sessile, 3 -celled, the style filiform, the stigma small; ovules usually 6-12 in each cell; capsule membranaceous, 3-lobate, loculicidally dehiscent; seeds angulate-compressed or almost flat, black.

About 10 species, one Chinese, the others American. Only one is found in Central America.

Nothoscordum fragrans (Vent.) Kunth, Enum. Pl. 4: 461. 1843. Allium fragrans Vent. Descr. Pl. Nouv. Jard. Cels 26. 1800. Cebollin (fide Aguilar).

A weed in waste or cultivated ground, 1,250-1,500 meters; Alta Verapaz (Cobán and vicinity); Guatemala (Guatemala). Mexico and southeastern United States; Costa Rica; West Indies. 
Plants onion-like in appearance, with small white bulbs; leaves few or numerous, erect or weak and recurved, usually as long as the scape, mostly $2-8 \mathrm{~mm}$. wide, succulent and soft; scape slender, 30-60 cm. tall, glabrous, bearing at the apex an umbel of few or numerous greenish white flowers, the slender pedicels unequal, 2-3 cm. long; perianth 8-10 mm. long, the segments obtuse; capsule 5-6 mm. high.

Apparently this plant is introduced in Guatemala, for it is found in few localities, and not far from dwellings, just as is the case in Costa Rica. Except for its lack of an onion odor, there is little to distinguish the genus from Allium.

Phormium tenax Forest., New Zealand flax (known locally as "lirio de espada"), native of New Zealand, is planted rarely for ornament in Guatemala. It is a coarse acaulescent plant with swordlike leaves $5-12 \mathrm{~cm}$. wide. The form in cultivation here is $P$. tenax var. variegatum Hort., in which the leaves are bordered or striped with creamy white. In its native country the plant is of great economic importance because of the very strong fiber obtainable from its leaves.

Ruscus aculeatus L., native of the Mediterranean region, is seen very rarely in Guatemala as an ornamental plant, usually in pots. It is much grown in southern France and elsewhere for ornamental purposes, the dried branches and leaves being dyed and used to make funeral wreaths and decorative articles.

\section{SANSEVIERIA Thunb.}

Perennial herbs with creeping rootstocks; leaves flat or terete, coriaceous, thick and tough, cespitose, often mottled with light and dark green; scapes simple, much shorter than the leaves, the flowers greenish white, racemose or paniculate; perianth segments united below to form a tube, the lobes narrow, spreading; stamens 6 , inserted at the bases of the perianth segments, the filaments filiform, the anthers oblong or linear; ovary 3-celled, the ovules solitary in each cell; seeds $1-3$, subglobose, fleshy.

About 50 species, in Africa and Asia. The tough fiber of the leaves of some species is utilized commercially.

Sansevieria guineensis (L.) Willd. Sp. Pl. 2: 159. 1799. Aletris hyacinthoides var. guineensis L. Sp. Pl. ed. 2. 456. 1762. Curarina; Oreja de burro; Quina (Escuintla).

Planted commonly for ornament at middle and low elevations, often grown for hedges; thoroughly naturalized in many parts of 
the lowlands, at least in hedges and thickets near dwellings, or on the borders of fields. Native of tropical Africa.

Leaves linear-lanceolate, concave, 50-140 cm. long, 5-9 cm. wide, erect, narrowed at each end, dark green, mottled with white or gray; scapes usually shorter than the leaves and often almost concealed by them, the white flowers forming a narrow panicle, the pedicels 5-8 $\mathrm{mm}$. long; perianth segments linear or linear-spatulate, the whole flower $1.5 \mathrm{~cm}$. long or less, the recurved lobes about equaling the tube.

The fiber of this species has been utilized in some regions where the plant is native or cultivated. The plant is well known in cultivation in the United States, particularly as a pot plant, since it stands the dry heat of apartments in winter time. During the past few years the name "mother-in-law plant"-a name of no apparent application-has come into rather general use for it among United States florists. It would be interesting to know how the name "curarina" came to be applied to this plant, for there is no relationship between Sansevieria and the genus Strychnos, which supplies, in part, the drug curare. The local name is well established, however, and everywhere in Guatemala even the children know the plant as "curarina." It is much used in domestic medicine, being, apparently, one of the most esteemed of local plants. It is even reported to have the properties of quinine, for which there is probably little or no basis. In Salvador Sansevieria is known by the names "espada de Judas" and "espada del diablo."

\section{SCHOENOCAULON Gray}

Reference: Robert R. Brinker, Monograph of Schoenocaulon, Ann. Mo. Bot. Gard. 29: 287-314. 1942.

Bulbs usually narrow, fibrose-tunicate; leaves radical, elongate-linear; scapes tall, simple, leafless, the flowers small, subsessile, forming a long, usually dense spike, the filaments and perianth long-persistent, the bracts small; perianth segments distinct, subequal, narrowly lanceolate or linear, erect-spreading, bearing within at the base a pit or nectary; stamens 6, hypogynous, longer than the perianth, the filaments thick-filiform, erect; anthers small, subglobose, the cells confluent, explanate and orbicular-peltate after emission of the pollen; ovary ovoid, slightly contracted at the base, free from the perianth, shallowly 3-lobate at the apex, 3-celled, the lobes bearing short, introrsely stigmatose styles; ovules 4-8 in each cell; capsule ovoid or oblong, acuminate, separating septicidally into 3 carpels; seeds oblong, often curved, angulate, sometimes acuminate, black or fuscous, the testa thick, lax; endosperm carnose.

About five species, in Texas, Mexico, and Central America, one extending to Venezuela. 
Schoenocaulon officinale (Schlecht. \& Cham.) Gray ex Benth. Pl. Hartweg. 29. 1939. Veratrum officinale Schlecht. \& Cham. Linnaea 6: 45. 1831. Sabadilla officinalis Standl. in Standl. \& Cald. Lista Pl. Salv. 49. 1925. Cebadilla; Cebollajo; Chagüitera (fide Aguilar); Boóm (Huehuetenango).

Brushy or grassy slopes, usually in pine or oak forest, mostly in rather dry and exposed places, sometimes on moist or wet slopes, chiefly at 500-2,000 meters; Zacapa; Chiquimula; Jutiapa; Santa Rosa; Guatemala; Chimaltenango; Huehuetenango; reported from Baja Verapaz. Southern Mexico (Mexico to Veracruz and Chiapas); Salvador; Honduras; reported from Costa Rica, but perhaps only in cultivation; Venezuela.

Bulbs long and narrow, densely covered with very numerous, long, loosely interlaced, black fibers; leaves rather hard and dry, a meter long or less, $1 \mathrm{~cm}$. wide or narrower, closely and conspicuously nerved, glabrous; scape usually about a meter tall, stout, terete, the spikes often $30 \mathrm{~cm}$. long or more, very dense, in flower $1.5 \mathrm{~cm}$. thick, the flowers cream-colored or greenish white, opening from below upward; capsules pale, $11-12 \mathrm{~mm}$. long, the carpels rostrate. (Fig. 17.)

The plant has been referred also to the genera Asagraea and Helonias, and there are numerous synonyms. The seeds are 4-6 mm. long, wrinkled, black or dark brown outside, whitish within, hard, inodorous, and have an exceedingly acrid, burning taste. They contain veratrin and other alkaloids, and are poisonous. They formerly constituted an official drug of the British Pharmacopoeia. They have emetic-cathartic properties, operating sometimes with great violence, and overdoses produce death. They were known in Europe as early as 1752, and were formerly used to some extent to expel tapeworms. The seeds are the chief ingredients of pulvis Capucinorum, sometimes used in Europe for destruction of vermin in the hair. During the first World War there was a great demand in central Europe for the seeds, for use in the armies, especially the German ones. Large amounts of seed are exported from Venezuela, where the plant is cultivated. They are said to be exported also from Mexico, and even from Guatemala, but shipment from the latter country seems doubtful, since persons in the country who were consulted knew nothing of their export, and the people seem to have little or no knowledge of the plant or its properties. Although widely scattered in Guatemala, the plant is not at all plentiful, and we have not found it in quantity anywhere. It flowers and matures seeds during the invierno, and the leaves wither soon after the rains cease. 

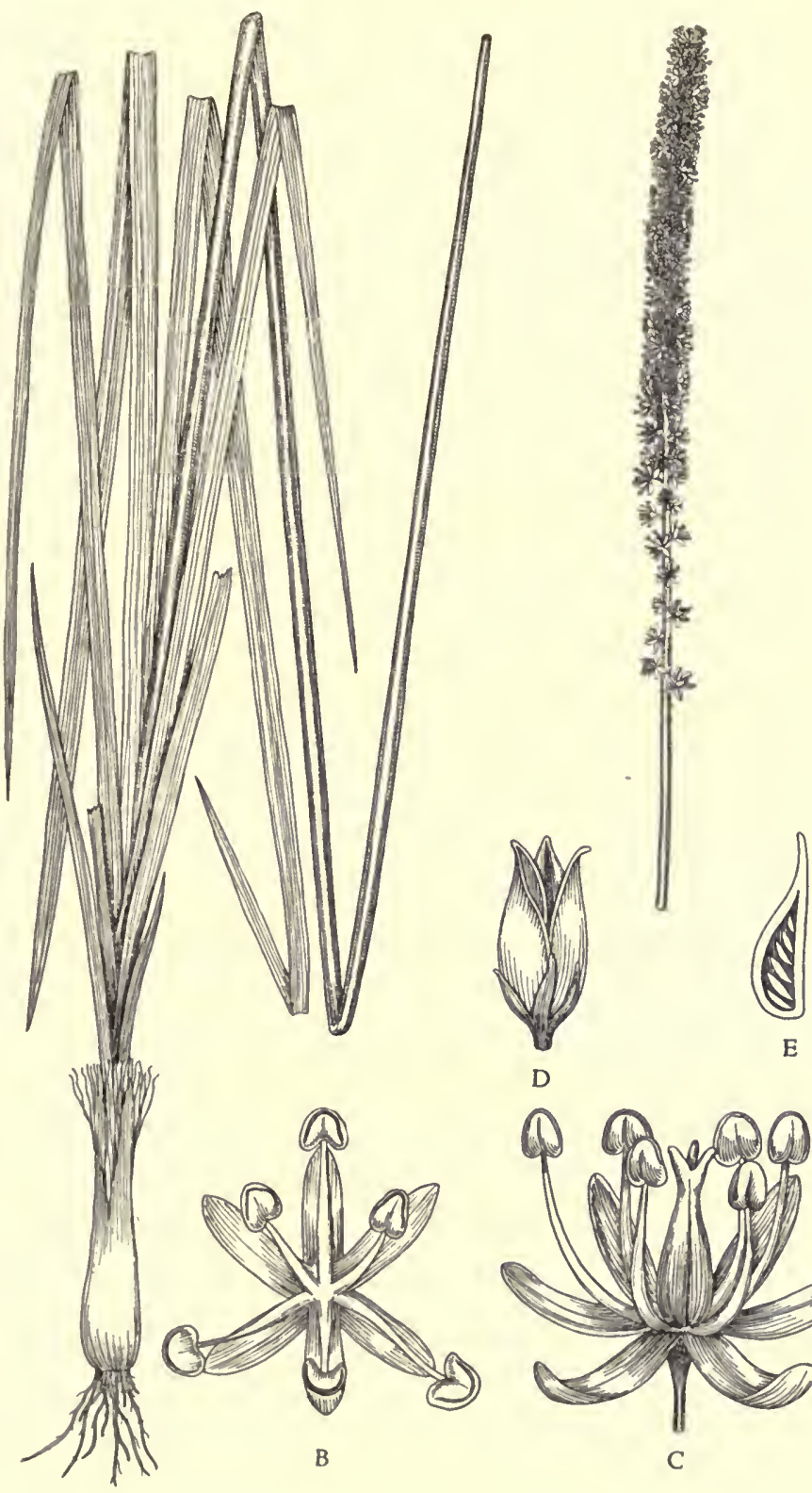

D

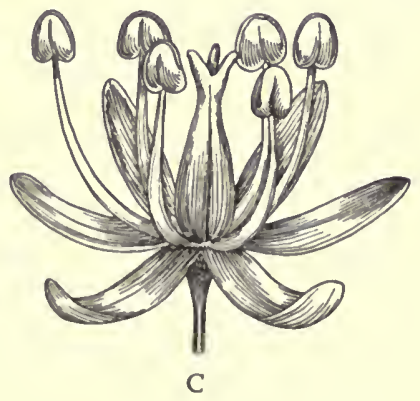

A

Fig. 17. Schoenocaulon officinale. A. Habit of plant with detached inflorescence at right; $\times 1 / 3$. B. Flower viewed from above, with pistil detached; $X 4$; C. Flower viewed from the side, with pistil in natural position; $X 4$. $D$. Capsule, dehiscing; $\times 2$. E. Longitudinal section through portion of pistil; $\times 2$. 


\section{SMILAGINA Desf.}

Reference: Ralph W. Emons, A revision of the Central American species of Smilacina, Ann. Mo. Bot. Gard. 32: 395-411. 1945.

Low herbs, sometimes epiphytic, with short or elongate, thick or slender rhizomes, the stems erect, simple, leafy above; leaves alternate, almost sessile, chiefly ovate or lanceolate; inflorescence terminal, racemose or paniculate, the flowers small, pedicellate, solitary or in fascicles of 2-3 within the bracts; perianth finally deciduous, the segments distinct or nearly so, subequal, spreading; stamens 6 , hypogynous or affixed to the very base of the perianth, the filaments short and broad or elongate and filiform, the anthers ovate, dorsifixed, the cells introrsely dehiscent; ovary sessile, subglobose, 3-celled; style columnar, the stigma small or sometimes 3-lobate; ovules 2 in each cell; fruit baccate, globose; seeds few, often solitary, subglobose.

About 25 species in North America and Asia. In America the genus extends south to Panama, where one additional species, S. gigas Woodson, a giant terrestrial plant, by Emons considered synonymous with $S$. paniculata, is known.

Stems strongly bulbous-thickened at the base; plants epiphytic; inflorescence paniculate or racemose, very dense and many-flowered in anthesis, the pedicels straight, erect or ascending; perianth bright rose............. amoena.

Stems not bulbous-thickened at the base, or only slightly so; plants commonly terrestrial; inflorescence paniculate or racemose, not very dense even at first, sometimes few-flowered, the pedicels often curved; perianth usually white or creamy white, sometimes pale pink.

Inflorescence paniculate.

Perianth 3-4 mm. long; branches of the panicle usually many-flowered, the pedicels mostly very slender..................... paniculata.

Perianth 6-7 mm. long; branches of the panicle few-flowered, the pedicels

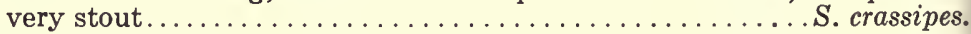

Inflorescence racemose.

Inflorescence few-flowered, the rachis straight or nearly so . . . .S. scilloidea. Inflorescence many-flowered, the rachis zigzag or strongly flexuous. S. flexuosa.

Smilacina amoena Wendl. in Otto \& Dietr. Allg. Gart. Zeit. 18: 137. 1850. Trovaria Salvini Baker, Journ. Linn. Soc. Bot. 14: 567. 1875 (type from Volcán de Atitlán, Sololá, Salvin). S. Salvini Hemsl. Biol. Centr. Amer. Bot. 3: 368. 1884. Convallaria Salvini Druce, Bot. Exch. Club Brit. Isl. 3: 408. 1914. Vagnera Salvini Standl. Journ. Wash. Acad. Sci. 15: 457. 1925. Ramillete de Magdalena (fide Aguilar).

On mossy tree trunks in dense forest, 2,200-3,800 meters; El Progreso; Chimaltenango; Sololá; Quiché; Quezaltenango; San Marcos. Southern Mexico; Costa Rica.

Stems solitary or cespitose on tree trunks, $30-50 \mathrm{~cm}$. tall or even larger, stout, usually much thickened and bulblike at the base, arising from thick and of ten 


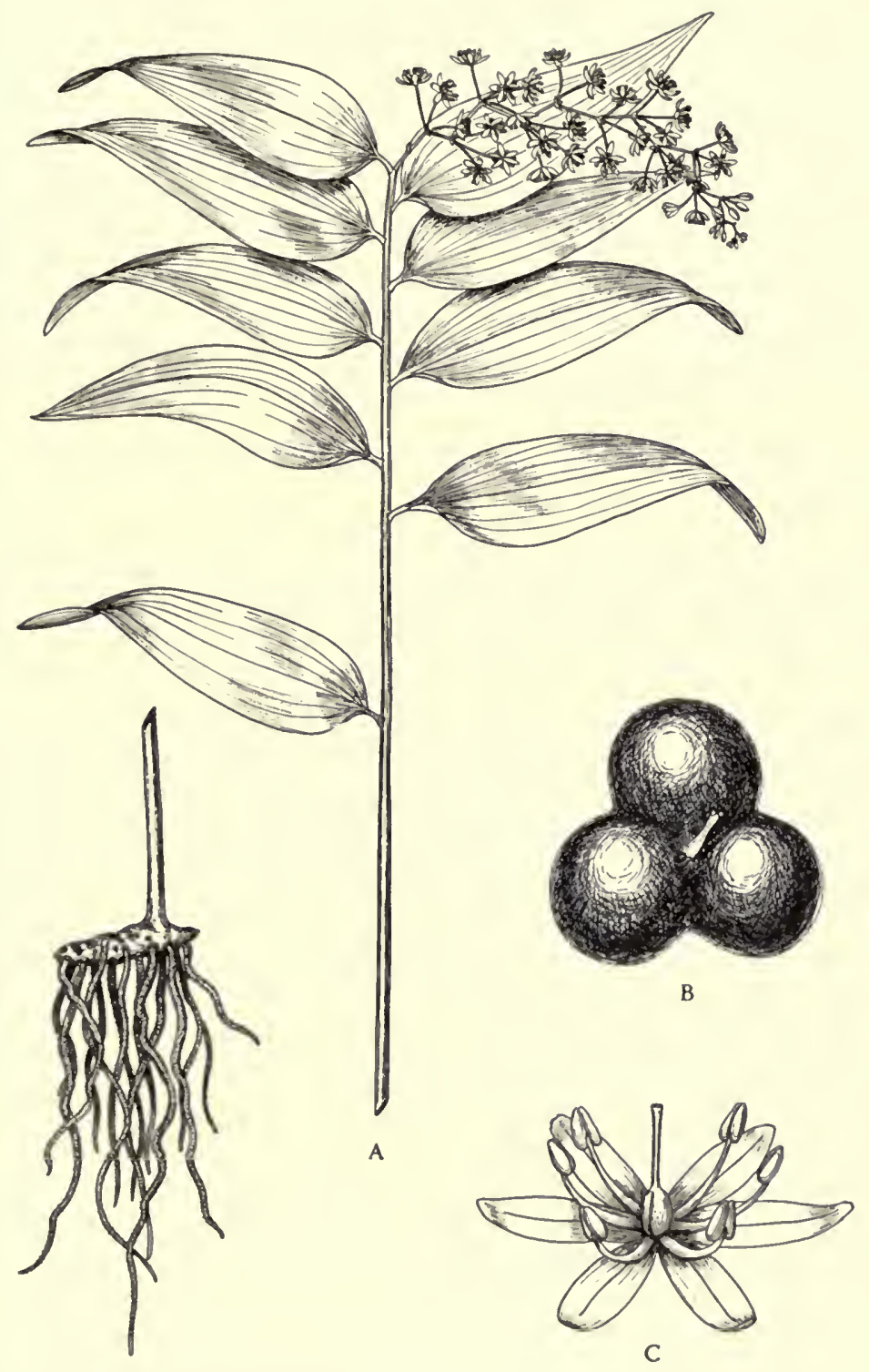

Fig. 18. Smilacina flexuosa. A. Habit of plant; $\times 1 / 3$. B. Fruit; $\times 3$. C. Flower; $\times 4$. 
elongate rhizomes, bearing few or numerous leaves; leaves sessile or nearly so, broadly ovate to elliptic-lanceolate, $5-12 \mathrm{~cm}$. long, commonly $3-4 \mathrm{~cm}$. wide, acute to long-acuminate, glabrous; inflorescence at first very dense and almost headlike, in age more open, the pedicels and short branches straight, erect or strongly ascending, the pedicels mostly $1-1.5 \mathrm{~cm}$. long; perianth deep rose or rose-red, about $5 \mathrm{~mm}$. long, the segments broadly rounded or somewhat emarginate at the apex.

This plant is an exceptionally beautiful one on account of its large clusters of brilliantly colored flowers. Because of its epiphytic habit, frequently it is mistaken for an orchid by the local people or by strangers, and sometimes is offered for sale as one. Emons refers most of the Guatemalan material to var: Salvini (Baker) Emons, but the varietal characters are not obvious.

Smilacina crassipes Standl. \& Steyerm. Field Mus. Bot. 23: 214. 1947.

On rocks or sometimes epiphytic on tree trunks, $1,300-1,900$ meters; endemic; Huehuetenango (type from rocky slopes above La Libertad, on Cerro Pueblo Viejo, Steyermark 51003); San Marcos (Volcán de Tajumulco near Finca El Porvenir).

Plants erect or pendent, sometimes a meter high, the stems stout, almost $1 \mathrm{~cm}$. thick below, somewhat thickened and bulb-like at the base; leaves numerous, membranaceous, lanceolate to oblong-lanceolate or oblong-elliptic, mostly 17-20 $\mathrm{cm}$. long and 4.5-5.5 cm. wide, sometimes as much as $8.5 \mathrm{~cm}$. wide, attenuateacuminate, obtuse or rounded at the base and contracted into a stout petiole 7 $\mathrm{mm}$. long or shorter; inflorescence narrowly paniculate, $10-15 \mathrm{~cm}$. long, 5-6 cm. wide, the axis very stout and angulate, the lateral branches few, divaricate at almost a right angle, very stout, angulate, mostly 2-4-flowered; pedicels $5 \mathrm{~mm}$. long or usually shorter, thick, stout, acutely angulate when dry; perianth pale yellow, campanulate, the segments thick, oval or oblong-oval, 6-7 $\mathrm{mm}$. long, rounded at the apex, suberect in anthesis, more or less persistent; anthers about $1.3 \mathrm{~mm}$. long, the stamens somewhat shorter than the perianth; berries blood-red, about $8 \mathrm{~mm}$. in diameter.

Smilacina flexuosa Bertol. Fl. Guat. 411. pl. 39. 1840. S. Bertolonii Kunth, Enum. Pl. 5: 151. 1850. Convallaria flexuosa Druce, Bot. Exch. Club Brit. Isl. 3: 408. 1914. Vagnera flexuosa Standl. Journ. Wash. Acad. Sci. 15: 457. 1925. Ramillete de la Virgen (fide Aguilar); Diente de perro.

Dense, damp or wet forest, terrestrial or rarely on tree trunks, 1,300-3,000 meters; type collected in the mountains of Guatemala by Velásquez, the locality not specified; Alta Verapaz; Baja Verapaz; Zacapa; Guatemala; Sacatepéquez; Chimaltenango; Sololá; Suchitepequez; Quiché; Huehuetenango; San Marcos; reported from Santa Rosa. Southern Mexico; El Salvador; Honduras; Costa Rica. 
Stems arising from thick elongate rhizomes, not or scarcely thickened at the base, bearing few or numerous leaves, commonly 40-100 cm. tall; leaves narrowly oblong-lanceolate to ovate-elliptic, mostly 11-16 cm. long, bright green, glabrous; inflorescence simply racemose, short and rather few-flowered or sometimes much elongate and many-flowered, often recurved, the slender rachis often zigzag, always strongly flexuous, the slender, more or less curved, rather stiff pedicels 1-2 cm. long, the whole inflorescence in fruit often recurved or pendent by the weight of the fruits; perianth pink, white, or dull purplish, 6-7 $\mathrm{mm}$. long; fruit bright or dull red, subglobose or shallowly trilobate, about $1 \mathrm{~cm}$. broad, usually 3-seeded. (Fig. 18.)

A variety erubescens Emons with pink flowers is known from several departments in Guatemala, typical $S$. flexuosa being maintained by Emons for the more common white-flowered form.

Smilacina paniculata Mart. \& Gal. Bull. Acad. Brux. 9, pt. 2: 388. 1842.

Dense or wet forest, 1,300-3,300 meters, usually terrestrial, rarely epiphytic; Alta Verapaz; Baja Verapaz; El Progreso; Zacapa; Suchitepequez; Quiché; Huehuetenango; San Marcos. Southern Mexico; El Salvador; Costa Rica; Panama.

Plants glabrous, the stems a meter high or less, rarely almost 2 meters tall, not thickened at the base, bearing numerous leaves; leaves short-petiolate, narrowly lanceolate to ovate-elliptic, $8-20 \mathrm{~cm}$. long, gradually or abruptly acuminate; panicles usually pyramidal, large and many-flowered, lax and much branched, the branches dull red or lilac, straight or nearly so, the pedicels $1 \mathrm{~cm}$. long or less, straight, often conspicuously thickened; perianth white or pinkish, 3-4 mm. long; fruit about $8 \mathrm{~mm}$. in diameter, at first green spotted with dark purple, turning blood-red.

Smilacina scilloidea Mart. \& Gal. Bull. Acad. Brux. 9, pt. 2: 388. 1842.

Dense or open pine, Juniperus, or Abies forest of the central and western mountains, 2,700-3,800 meters; Chimaltenango (Volcán de Acatenango); Huehuetenango; Quezaltenango; San Marcos. Southern Mexico; Honduras.

Plants small, with long slender repent rhizomes, the stems mostly $15-30 \mathrm{~cm}$. tall, flexuous, more slender than in other species, with usually few, distant leaves; leaves bright green, thin, glabrous, mostly 5-10 cm. long, oblong-lanceolate to narrowly lanceolate, acute to long-attenuate; racemes small and with very few flowers, the rachis and pedicels straight or nearly so, the pedicels $5 \mathrm{~mm}$. long or less; perianth white to deep purplish, 3-4 mm. long; fruit mostly $8 \mathrm{~mm}$. or less in diameter, bright red.

Part of the Guatemalan material is referred by Emons to var. rosea Emons, which probably is a pink- or purple-flowered form of the species. 


\section{TAETSIA Medic.}

Tall, somewhat shrubby plants, the caudex ligneous, often stoloniferous; leaves crowded at or near the apex of the stem, petiolate or subsessile, lanceolate or narrower; flowers small, paniculate, short-pedicellate, solitary or few within each bract, the bracts small and scarious; perianth cylindric or narrowly campanulate, with a short tube, the lobes oblong, erect or somewhat spreading, equal or the inner slightly longer; stamens 6, inserted on the tube at the base of the lobes, about equaling the perianth, the filaments filiform or complanate; anthers narrowly oblong, dorsifixed, the cells introrsely dehiscent; ovary sessile, 3-celled, the style filiform, the stigma capitate or shallowly 3-lobate; ovules 4-16 in each cell; fruit globose or trilobate, fleshy, 3-celled, indehiscent or sometimes loculicidally dehiscent; seeds in each cell numerous or by abortion 1 , obovoid or somewhat compressed, black and lustrous.

About ten species, chiefly in the East Indies, Pacific islands, and Australia.

Taetsia fruticosa (L.) Merrill, Interpret. Herb. Amboin. 137. 1917. Convallaria fruticosa L. in Stickm. Herb. Amboin. 16. 1754. Asparagus terminalis L. Sp. Pl. ed. 2. 450. 1762. Cordyline terminalis Kunth, Abh. Acad. Berlin 30. 1820. Listón, Croton listado (fide Aguilar).

Planted everywhere in the lowlands, in gardens and in roadside hedges, escaping to thickets and naturalized in many localities; also in gardens of the central and other mountain regions, but not so common or altogether absent above 1,500 meters. Probably a native of Malaya.

Plants 1-3 meters high or even taller, simple, densely leafy, the stems rather slender; leaves elliptic-lanceolate to linear-lanceolate, $30-70 \mathrm{~cm}$. long, $10-15 \mathrm{~cm}$. wide, acute to long-attenuate, narrowed to the base, green or of ten deep red-purple, often green with red margins; petioles often more than half as long as the blades; panicles terminal, large, dense or usually open; pedicels very short or none; perianth white, purplish, or reddish, 10-12 $\mathrm{mm}$. long, the segments linear-oblong; ovules 6-10 in each cell; fruit a large, red or purple berry.

One of the most common ornamental plants throughout the lowlands of Central America. The form most cultivated in Guatemala is var. ferrea (Baker) Standl., in which the leaves are colored with dark red or purple.

\section{YUCGA L.}

Large coarse plants, with a woody caudex, acaulescent or often tall and treelike, simple or branched; leaves crowded at the apex of the caudex or its branches, linear-lanceolate, thick and rigid or rarely thin and soft, usually spinose at the apex, the margins entire or separating into coarse fibers; flowers white or cream, 
n very large, terminal panicles, pedicellate, pendulous; perianth long-persistent, the segments distinct or nearly so, lance-ovate, rather fleshy, more or less conhivent to form a subglobose flower; stamens 6, hypogynous, erect, much shorter than the perianth, the filaments rather stout; anthers small, sessile at the apex of the filament, introrsely dehiscent; ovary sessile, 3-flowered, the cells imperfectly 2-celled, the style columnar, short, divided at the apex into 3 lobes that are stigmatose within; ovules numerous in each cell; fruit fleshy and pulpy or spongious and indehiscent, often dry and loculicidally dehiscent; seeds strongly compressed, black.

About 25 species in southern and especially southwestern United States, Mexico, and West Indies. Only the following one is known in Central America, where it probably is not native.

Yucca elephantipes Regel, Gartenflora 8: 35. 1859. Y. guatemalensis J. G. Baker, Ref. Bot. 5: pl. 313. 1872 (type collected in Guatemala by Ehrenberg). Izote; Palmera (Petén, fide Lundell); Cukil, Quiil, Co'quil (Alta Verapaz, Kekchí); Pasquiy (Chimaltenango, fide Tejada); Pasqui (Totonicapán, fide Tejada).

Common in cultivation or in hedges and thickets throughout the lowlands and ascending commonly in the mountains to middle elevations (about 1,500 meters); often seen up to 2,700 meters or perhaps even higher; Petén; Alta Verapaz; Jalapa; Escuintla; Huehuetenango; San Marcos; probably in all the departments. British Honduras; generally distributed in cultivation in Central America, southward at least to Costa Rica, also in Mexico.

Plants usually treelike, with a thick columnar crown and a few short thick branches, the trunk and lower parts of the branches naked, the bark rather rough; leaves dagger-like, stiff and hard, a meter long or usually much shorter, roughmargined, very sharp-pointed; flowers white or creamy white, campanulate, about $4 \mathrm{~cm}$. long; fruit fleshy, oblong-ovoid, with white or yellowish flesh and a papery core. (Fig. 19.)

Known in Costa Rica as "itabo," an Indian name, but almost everywhere else in Central America as "izote," a word of Nahuatl derivation. The Maya name reported from Yucatan is "tuc." In Guatemala the plant is commemorated geographically by the caserio of El Hizote in the Department of Santa Rosa (the " $\mathrm{H}$ " is quite superfluous). The tree is an ornamental one, and partly for that reason often is planted about houses, especially for tall hedges. In some regions, as about Coatepeque, it is planted thickly on steep high roadside banks to prevent erosion. It is seen frequently, too, in cemeteries. While most of the plants are perhaps 3-4 meters high, often they are much taller and possibly as much as 10 meters high. Many very tall and often much branched individuals are 


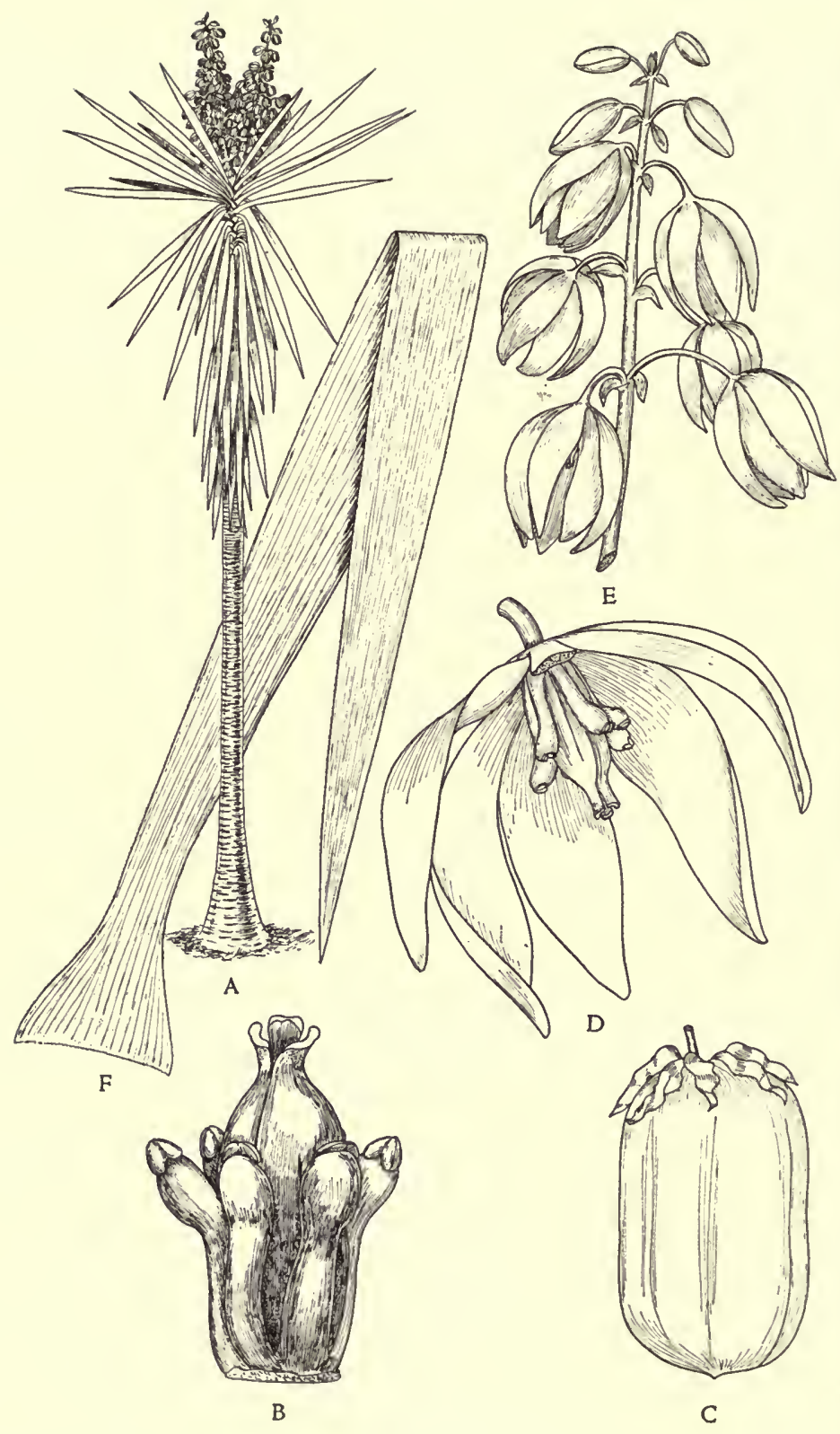

FIG. 19. Yucca elephantipes. A. Habit; $\times 1 / 30$. B. Perianth removed to show stamens and pistil; $\times 3$. C. Fruit; $\times 1 / 3$. D. Flower, with one of perianth segments removed; $\times 1$. E. Portion of inflorescence; $\times 1 / 3$. F. Leaf; $\times 1 / 3$. 
seen about Cobán, Retalhuleu, and Patulul. On the Volcán de Agua izotes are planted above the highest pea fields, at perhaps 2,700 meters. Although the large panicles are a handsome sight when the flowers are open, it is but rarely that they are seen well developed, for almost all the panicles are cut when the flowers begin to open, and the succulent flowers are used for food. They have a slightly bitter but quite agreeable flavor, and constitute a palatable vegetable. Usually they are dipped in egg and fried, or mixed with meat stews, and sometimes they are eaten raw in combination with other raw salad vegetables. The panicles are sold commonly in the markets, and often they are taken to distant markets of regions where the plant is scarce or unknown, for sale, as to Puerto Barrios.

\section{ZYGADENUS Michaux}

Plants with horizontal rhizomes, sometimes also with tunicated bulbs, the stems erect, simple below, often branched above; leaves radical or inserted near the base of the stem, linear and elongate; flowers racemose, the racemes simple or paniculate; perianth persistent, the segments sometimes connate at the base into a short turbinate tube, subequal, rotate-spreading, often bearing 2 glands within near the base; stamens 6 , inserted at the base of the perianth segments, shorter than the perianth, the filaments filiform, connivent about the style, recurved at the apex; anthers small, subglobose, extrorsely dehiscent and orbicular-peltate after dehiscence; ovary ovoid, trilobate, each lobe prolonged into a slender style which is introrsely stigmatose; ovules numerous in each cell; capsule ovoid or oblong, acuminate, septicidally separating into 3 carpels that are introrsely dehiscent; seeds oblong to almost linear, often somewhat curved, brown or blackish.

About fifteen species, one in Siberia, the others North American. Guatemala is the southern limit of distribution for the genus.

Zygadenus volcanicus Benth. Pl. Hartw. 96. 1842. Anticlea volcanica J. G. Baker, Journ. Linn. Soc. 17: 482. 1880.

Alpine meadows or on mossy rocks in alpine Juniperus forest; often on limestone, 3,000-3,700 meters; Sacatepéquez (type from Volcán de Agua, at 3,300 meters, Hartweg 626); Sololá (Los Encuentros); Huehuetenango (Sierra de los Cuchumatanes). Southern Mexico.

Plants glabrous, arising from small bulbs, the outer bulb coats almost black; leaves $30-40 \mathrm{~cm}$. long, glaucous-green, mostly $6-12 \mathrm{~mm}$. wide; scapes leafy below, branched above and forming large open bracted panicles, the flowers pedicellate; perianth segments white or whitish, ovate, 6-8 $\mathrm{mm}$. long, very obtuse, with 2 confluent glands within near the base; capsule about $15 \mathrm{~mm}$. long and 5-6 $\mathrm{mm}$. wide.

One Guatemalan collection (Skutch 1101, from the Cuchumatanes) has been referred by Walsh to $Z$. elegans Pursh, a United 
States species, apparently in error. Certain United States species of this genus are known to be poisonous to stock, sometimes causing serious losses.

\section{SMILAGACEAE. Cat-brier Family}

Vines, woody or herbaceous, the stems prickly or unarmed; leaves alternate, petiolate, the blades reticulate-veined and with conspicuous longitudinal nerves arising from the base, articulate with the petioles, these sheathing and often bearing a pair of tendril-like appendages; flowers dioecious, in axillary pedunculate umbels; perianth segments 6 ; stamens usually 6 , the filaments distinct, inserted at the base of the perianth segments; anthers 2-celled, basifixed, introrsely dehiscent; ovary 3 -celled or rarely 1-celled, the ovules 1-2 in each cell, pendulous; style very short or none, the stigmas 3 or rarely only 1 ; fruit a small, red or black berry, containing 1-6 seeds; endosperm osseous.

A small family of about three genera, in tropical and temperate regions of the whole earth.

\section{SMILAX L.}

Reference: E. P. Killip \& C. V. Morton, A revision of the Mexican and Central American species of Smilax, Carnegie Inst. Wash. Publ. 461: 257-297. pls. 1-11. 1936.

Herbaceous or woody vines, the stems armed with prickles or unarmed, arising from woody or fleshy tubers or from long creeping rhizomes; leaves usually coriaceous, entire or lobate; perianth segments distinct; pedicels borne on a globose or conic receptacle, inserted in small pits among minute bractlets; staminate flowers with or without an abortive ovary; pistillate flowers usually smaller than the staminate, with an ovary and usually several abortive stamens.

More than 200 species, widely distributed in both hemispheres, most abundant in tropical regions. Several additional species occur farther south in Central America. The species, or rather some of them, are of importance as being the source of the drug sarsaparilla (Zarzaparrilla). Although the plants of this genus are widely dispersed in Guatemala and often abundant, few of them, as a rule, are in flower or fruit, and for this reason good specimens are fewer than they should be. On the North Coast the name "cuculmeca" is used for some of the species, and the name "zarzaparrilla" (from which the English "sarsaparilla" is derived) is in common use. Tejada reports the name "quix" as in use for some of the species in Huehuetenango.

Plants more or less pubescent, sometimes glabrate at maturity but with at least a few hairs persistent on the petioles, peduncles, or pedicels; always unarmed.

Branches obtusely quadrangular, glabrate at maturity; staminodia 6 in the

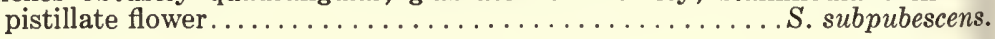


Branches terete (except the lowest), usually abundantly pilose even at maturity.

Stems densely lanate-tomentose; leaves densely tomentose beneath, tripli-

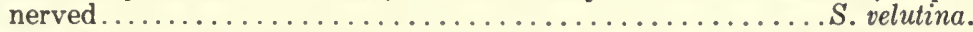

Stems pilose or subtomentose, the hairs coarser and at least part of them spreading; leaves hirsute with long or short hairs, 7-nerved, the nerves all arising from the base of the blade.................. mollis. Plants glabrous throughout, often armed with prickles.

Staminate flowers $2.8 \mathrm{~mm}$. long or less.

Leaves with conspicuous reticulate veins, membranaceous or chartaceous or, if coriaceous, small, often aculeate on the nerves beneath; branches

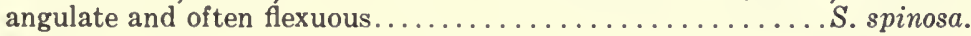

Leaves with obscure veins, coriaceous, large, unarmed; branchlets terete, straight.

Berries globose........................... Lundellii.

Berries elongate, acute at each end ............................

Staminate flowers $4 \mathrm{~mm}$. long or larger.

Peduncles of the pistillate umbels shorter than the subtending petioles,

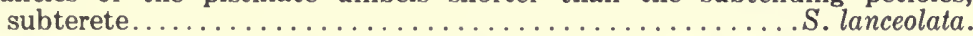

Peduncles of the pistillate umbels longer than the petioles, almost always conspicuously compressed.

Anthers shorter than the filaments; leaves unarmed. Petioles articulate at or below the middle.

Branchlets terete or irregularly subangulate. Leaves drying blackish.

Branchlets quadrangular.

S. jalapensis.

Leaves drying blackish, 7-nerved, the larger often subcordate at the base.................................... jalansis var. Botterii.

Leaves drying pale green, 5-nerved, never subcordate at the base.

Anthers longer than the filaments.

S. Standleyi.

Stems terete; petiole articulate below the middle of the free portion; leaves acute at the base; unarmed............... S. panamensis.

Stems sharply or obtusely quadrangular, at least below; petiole articulate above the middle of the free portion; lower leaves cordate or hastate at the base, often aculeate.

Berries red; stems obtusely quadrangular, subterete above.

S. aristolochiaefolia.

Berries black; stems acutely quadrangular throughout.....S. Regelii.

Smilax aristolochiaefolia Mill. Gard. Dict. ed. 8. No. 7. 1768. S. medica Schlecht. \& Cham. Linnaea 6: 47. 1831. S. ornata Lem. Ill. Hort. 12: pl. 439. 1865. Cocomeca.

\section{Petén (Uaxactún); probably extending into Alta Verapaz.} Southern Mexico and British Honduras.

Lower stems obtusely quadrangular, armed with large, flat, slightly curved prickles $13 \mathrm{~mm}$. long or less, the upper stems obtusely quadrangular or subterete, pale, smooth or nearly so, sparsely aculeate or unarmed; petioles up to $5 \mathrm{~cm}$. long, the free portion articulate above the middle; lower leaves ovate to oblong, as much as $28 \mathrm{~cm}$. long and $14 \mathrm{~cm}$. wide, rounded and mucronate at the apex, deeply cordate or hastate at the base, usually armed on the nerves with stout yellowish prickles, the upper leaves much smaller, usually cordate at the base, entire, pale yellowish green when dry, glabrous, 7-nerved, the veins elevated; staminate pedicels num- 
erous, 5-11 mm. long, much shorter than the peduncle, slender, glabrous; perianth segments oblong, $4 \mathrm{~mm}$. long, spreading; filaments $1-1.3 \mathrm{~mm}$. long, the anthers 1.7-2 mm. long; pistillate peduncles $22 \mathrm{~mm}$. long or less, much exceeding the subtending petiole, compressed, the pedicels $8 \mathrm{~mm}$. long or less; perianth segments $3.5 \mathrm{~mm}$. long; staminodia 6 ; fruiting peduncles as much as $4 \mathrm{~cm}$. long, the pedicels 4-10 $\mathrm{mm}$. long; berries red, globose, 5-8 $\mathrm{mm}$. in diameter.

The name "escoca" is reported from British Honduras, probably Maya. This species is believed to be one of the important sources of commercial sarsaparilla.

Smilax jalapensis Schlecht. Linnaea 18: 451. 1844. S. Botterii A. DC. Monogr. Phan. 1: 89. 1878. S. jalapensis var. Botterii Killip \& Morton, Carnegie Inst. Wash. Publ. 461: 280. 1936. Kixcul (Cobán, Kekchí).

Damp or wet forest or thickets, 1,200-2,700 meters; Alta Verapaz; Zacapa; Guatemala; Chimaltenango; Quiché; Huehuetenango; San Marcos. Southern Mexico.

Branches and branchlets terete and usually straight, sparsely armed with straight yellowish prickles, the younger branchlets often with numerous bristlelike prickles; petioles $2 \mathrm{~cm}$. long or less, articulate about half way between the tendrils and the base of the blade; lower leaves ovate, $12 \mathrm{~cm}$. long and $7 \mathrm{~cm}$. wide or smaller, short-acuminate, subcordate at the base, the upper leaves smaller, ovate-lanceolate, rounded at the base, all rather thin and glabrous, blackening in drying, entire, 7-nerved; staminate flowers numerous in each umbel, the pedicels $13 \mathrm{~mm}$. long or less, the perianth segments linear or linear-lanceolate, 5-6 mm. long, acuminate; filaments $2-3 \mathrm{~mm}$. long, the anthers equaling or shorter than the filaments; pistillate peduncles longer than the subtending petiole, about $15 \mathrm{~mm}$. long at anthesis and as much as $28 \mathrm{~mm}$. in fruit, strongly compressed, the pedicels 3-4 mm. long; perianth segments $3-3.5 \mathrm{~mm}$. long; staminodia 3 or 6 ; berries globose, $8 \mathrm{~mm}$. in diameter; seeds red.

In the typical form of the species the stems are terete; in var. Botterii they are obtusely quadrangular. The variety is represented in Guatemala, but the characters are not very conspicuous or well marked.

Smilax lanceolata L. Sp. Pl. 1031. 1753. S. domingenis Willd. Sp. Pl. 4: 783. 1806.

Moist forest or thickets, ascending from sea level to about 1,200 meters; Alta Verapaz; Baja Verapaz; Izabal; Zacapa; Escuintla; Sacatepéquez. Mexico and British Honduras to Honduras, Salvador, Costa Rica, and Panama; West Indies.

Stems terete, glabrous, the lower ones sparsely armed with stout recurved prickles 5-6 mm. long, the upper ones unarmed; petioles $16 \mathrm{~mm}$. long or less, articulate at about the middle of the free portion; leaves ovate-lanceolate or ovate, 
$9 \mathrm{~cm}$. long and $5 \mathrm{~cm}$. wide or smaller, rather thick, dark green and lustrous above, paler and dull beneath, abruptly acuminate, acute at the base, entire, unarmed, 5-nerved; staminate pedicels 4-7 mm. long; perianth segments ligulate, 4.5-6.5 mm. long, acute; filaments $3-4 \mathrm{~mm}$. long, the anthers $1.2-2 \mathrm{~mm}$. long; pistillate peduncles subterete, $7 \mathrm{~mm}$. long or less, much shorter than the subtending petioles; pedicels 4-7 mm. long; perianth segments oblong-lanceolate, $4 \mathrm{~mm}$. long; staminodia 3 ; fruiting pedicels $4-10 \mathrm{~mm}$. long; berries dull red or brown, globose, 5-10 $\mathrm{mm}$. in diameter.

Called "tietie" and "china-root" in British Honduras, and "zarza" and "corona de Cristo" in Honduras. In Costa Rica known as "bejuco de canasta," the tough flexible stems being utilized for making baskets.

Smilax Lundellii Killip \& Morton, Carnegie Inst. Wash. Publ. 461: 265. pl. 2. 1936. Diente de chucho (San Marcos); Zarza.

Damp forest or thickets, ascending from sea level to about 1,300 meters; Petén (type from Sabana Zis, Lundell 3190); Alta Verapaz; San Marcos. British Honduras.

A large vine, the lower branches stout, terete, striate, glabrous, armed with very stout spreading compressed prickles, the upper branches unarmed, pale; petioles 1-2.5 cm. long, articulate at or above the middle; leaves oblong-lanceolate or lanceolate, the lower as much as $27 \mathrm{~cm}$. long and $13 \mathrm{~cm}$. wide, the upper ones much smaller, acute, at the base obtuse or acute, the lower blades of ten subcordate at the base, thick and hard, unarmed, glabrous, 5-nerved, drying a rather dull brownish green, the veins inconspicuous; staminate pedicels $1 \mathrm{~cm}$. long or less, about equaling the peduncle; perianth segments green, oval, $2 \mathrm{~mm}$. long; filaments $0.8 \mathrm{~mm}$. long, the anthers somewhat shorter; fruiting peduncles $5-11 \mathrm{~mm}$. long, much shorter than the subtending petiole, compressed; fruiting pedicels 7-10 $\mathrm{mm}$. long, exceeding the peduncle; berries globose, 4-6 $\mathrm{mm}$. in diameter, bluish black.

Smilax mollis Humb. \& Bonpl. ex Willd. Sp. Pl. 4: 785.1806. S. mollis var. acuminata A. DC. Monogr. Phan. 1: 68. 1878.

Thickets and forest, ascending from sea level to about 3,000 meters; Petén; Alta Verapaz; Izabal; Chiquimula; Chimaltenango; Quezaltenango; San Marcos. Southern Mexico to Panama.

A small or large vine, unarmed, the stems terete, pilosulous or subtomentose; petioles $18 \mathrm{~mm}$. long or less, densely pubescent, the free portion articulate at or above the middle; lower leaves ovate-oblong or broadly oval or ovate, $18 \mathrm{~cm}$. long and $10 \mathrm{~cm}$. wide or smaller, the upper leaves much smaller, ovate to oblong, acute or apiculate, cordate at the base, rather thin, entire, deep or pale green, sparsely hirsutulous above when young, soon glabrous and shining, persistently hirsutulous beneath on the veins, 7-nerved, the nerves all arising from the base of the blade; staminate peduncle $4 \mathrm{~cm}$. long or less, much exceeding the subtending petiole, densely short-hirsute, the pedicels 3-4 $\mathrm{mm}$. long; perianth segments oblong-linear, about $4 \mathrm{~mm}$. long, sparsely pilose or glabrous except for an apical tuft of hairs; 
filaments 2-3.5 mm. long, the anthers 1-1.2 $\mathrm{mm}$. long; pistillate peduncles $3 \mathrm{~cm}$. long or less, terete or slightly compressed, usually longer than the subtending petioles, the pedicels $3-5 \mathrm{~mm}$. long; perianth segments narrowly oblong, $3.2 \mathrm{~mm}$. long; staminodia 3; berries red or yellow, globose, 4-8 $\mathrm{mm}$. in diameter.

Called "pate" in Honduras, a word of Nahuatl derivation signifying "medicine." It is stated that in that country the large yamlike roots are used as a fish poison.

Smilax munda Killip \& Morton, Carnegie Inst. Wash. Publ. 461: 265. pl. 3. 1936 .

On wooded bluffs, 75 meters; Petén (Río Cancuén, Steyermark 45937). British Honduras (type from the Río Grande, Schipp 1181).

A large vine, sometimes 15 meters long, the stems terete, glabrous, the lower ones armed with a few short straight prickles, the upper branchlets unarmed; petioles $3 \mathrm{~cm}$. long or less, the free portion articulate above the middle; larger leaves ovate-lanceolate, as much as $17 \mathrm{~cm}$. long and $9 \mathrm{~cm}$. wide, most of the leaves much smaller, oblong to narrowly elliptic, acute at the base, coriaceous, unarmed, entire, 5-nerved, the veins inconspicuous; pistillate peduncles 4-7 $\mathrm{mm}$. long, slightly shorter than the petiole, compressed, the pedicels $5-8 \mathrm{~mm}$. long, exceeding the peduncle; perianth segments green, 1-2 mm. long, the outer obovate-oblong, the inner smaller, oblong; staminodia 3; fruiting peduncles $1 \mathrm{~cm}$. long or less, the pedicels to $13 \mathrm{~mm}$. long; berries at first red, turning black, ellipsoid, as much as $17 \mathrm{~mm}$. long and 5-7 mm. thick, acute at each end.

Smilax panamensis Morong, Bull. Torrey Club 21: 441. 1894. Baja Verapaz (Panzal). Honduras; Costa Rica; Panama.

Lower stems stout, terete, smooth, glabrous, pale brown, armed with large straight broad-based prickles $2 \mathrm{~cm}$. long or less, the upper branches unarmed; petioles $3 \mathrm{~cm}$. long or less, the free portion articulate near the base; leaves ovateoblong or the upper lance-oblong, the largest $19 \mathrm{~cm}$. long and $9.5 \mathrm{~cm}$. wide, thickchartaceous, short-acuminate, at the base acute or obtuse, entire, glabrous, unarmed, concolorous, 7-nerved; staminate peduncles $2 \mathrm{~cm}$. long or less, compressed, the pedicels 5-8 $\mathrm{mm}$. long; perianth segments ovate-lanceolate, 4-6 mm. long, green, acute; anthers $2-2.7 \mathrm{~mm}$. long, slightly or much longer than the filaments; pistillate peduncles $1.5 \mathrm{~cm}$. long or less, compressed, the pedicels to $8 \mathrm{~mm}$. in length; perianth segments blackish when dry, $5 \mathrm{~mm}$. long; staminodia 6 ; fruiting peduncles $2.5 \mathrm{~cm}$. long or less, the pedicels $7-15 \mathrm{~mm}$. long; berries probably red, 7.5-10 $\mathrm{mm}$. in diameter.

Smilax papyracea Duham. was reported from the Volcán de Fuego by Hemsley on the basis of a specimen collected by Godman and Salvin. The report probably relates to one of the species listed here, but it is impossible to determine which one without examination of the specimen.

Smilax Regelii Killip \& Morton, Carnegie Inst. Wash. Publ. 461: 272. 1936. S. grandifolia Regel, Ind. Sem. Hort. Petrop. 16. 


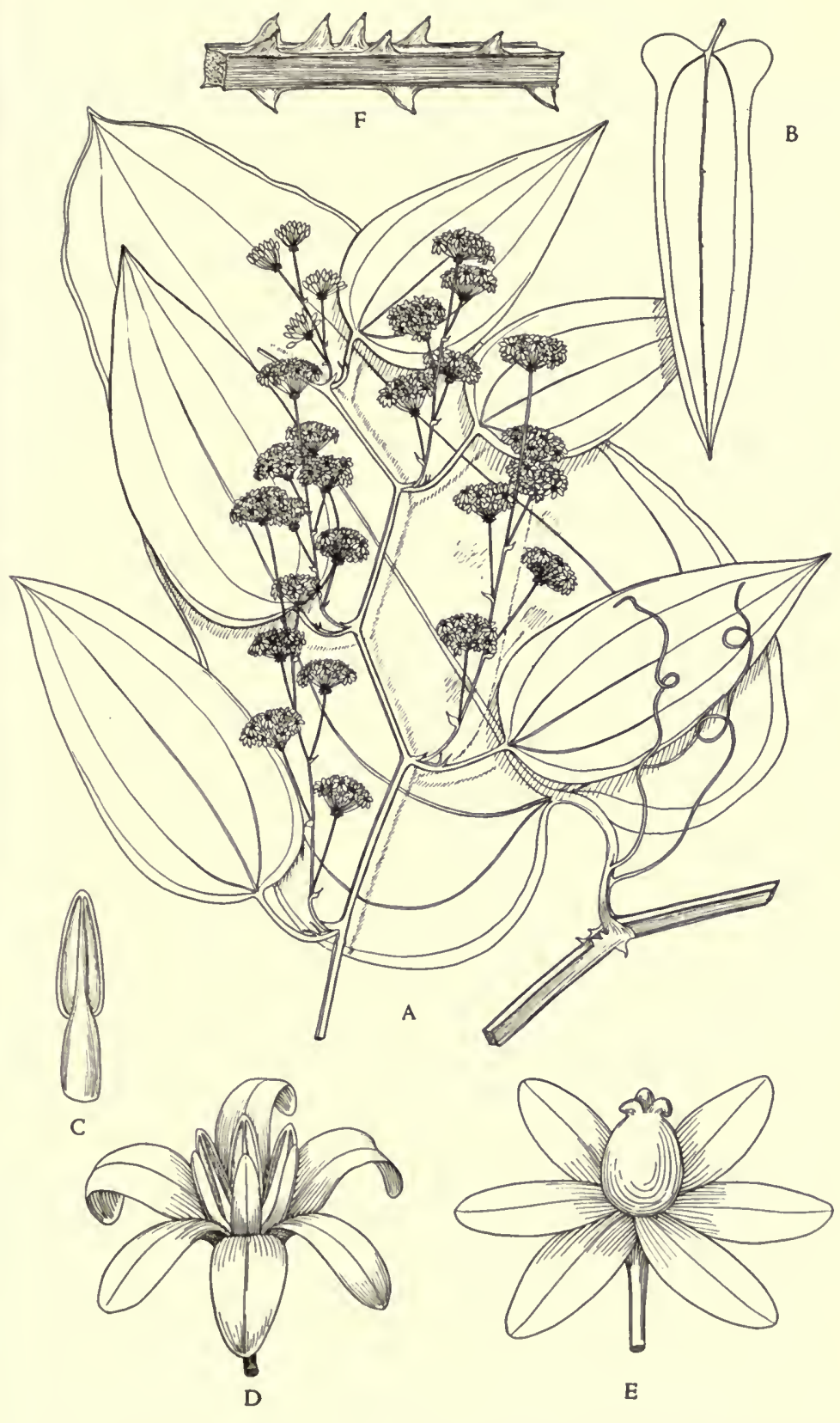

FIG. 20. Smilax Regelii. A. Habit of portion of flowering stem and leaf attached to stem in position; $\times 1 / 3$. B. Leaf of another shape; $\times 1 / 3$. C. Stamen; $\times 6$. D. Staminate flower; $\times 6$. Pistillate flower; $\times 6$. F. Portion of stem showing prickles; $\times 1 / 3$. 
1856, not Buckl. 1843. S. ornata Hook. Bot. Mag. 115: pl. 7054. 1889, not Lem. 1865. S. utilis Hemsl. in Hook. Icon. 26: pl. 2589. 1899, not Wright, 1895. Zarzaparrilla; Bejuco de corona.

In forest or thickets, ascending from sea level to 1,500 meters or more; Petén; Izabal; Jalapa; Santa Rosa; Chimaltenango; Quezaltenango; San Marcos. British Honduras to Honduras.

Often a very large vine, as much as 15 meters long, the lower stems acutely quadrangular, armed, chiefly on the angles, with large, broad, compressed, straight or recurved prickles $1 \mathrm{~cm}$. long, the upper branches acutely quadrangular, sometimes narrowly winged on the angles, aculeate; petioles of lower leaves up to $7 \mathrm{~cm}$. long, aculeate, the free portion articulate at or above the middle; lower leaves often very large, as much as $30 \mathrm{~cm}$. long and $20 \mathrm{~cm}$. wide, ovate to narrowly oblong, rounded or short-acuminate at the apex, shallowly or deeply cordate or hastate at the base, the upper leaves much smaller, oblong-lanceolate or oval, acute at the base, chartaceous, glabrous, often armed beneath with short recurved pale prickles, the larger leaves 7-nerved, the smaller 5-nerved, bright green or rather pale green when dried; staminate peduncles $6.5 \mathrm{~cm}$. long or less, longer than the subtending petioles, the pedicels $7-12 \mathrm{~mm}$. long; perianth segments lanceolate, $3.5-5 \mathrm{~mm}$. long; filaments $1.2 \mathrm{~mm}$. long or less, the anthers $2-2.5 \mathrm{~mm}$. long; pistillate peduncles up to $10 \mathrm{~cm}$. long but usually shorter, compressed; fruiting pedicels 9-19 mm. long; fruits globose, $1.3 \mathrm{~cm}$. or less in diameter, black. (Fig. 20.)

Called "zarza" and "zarzaparrilla" on the Atlantic coast of Honduras. This is believed to be one of the principal sources of sarsaparilla, a product furnished by various species of Smilax but by relatively few of them, the roots of some species being apparently useless commercially. Small quantities of the dried roots are exported from Guatemala to the United States and Europe. In medicine sarsaparilla is used for its stimulant and sudorific properties. Introduced into Spain about 1540, it was long a favorite remedy for venereal diseases. It still is employed for the same purpose, and for rheumatism, scrofulous diseases, and some cutaneous affections. It is much used in the United States for flavoring soft drinks.

Smilax Regelii f. albida (Killip \& Morton) Standl. \& Steyerm., comb. nov., (S. Regelii var. albida Killip \& Standl. Carnegie Inst. Wash. Publ. 461: 273. 1936) is a form with white berries. It has been collected near Tela, on the Atlantic coast of Honduras.

Smilax spinosa Mill. Gard. Dict. ed. 8. No. 8.1768. S. mexicana Griseb. ex Kunth, Enum. Pl. 5: 167. 1850. S.Gaumeri Millsp. Field Mus. 1: 357. 1898 (type from Yucatan, Gaumer 687). Madre de zarzaparrilla; Zarza; Zarzaparrilla macho; Bejuco de la vida.

Damp or wet thickets or forest, ascending from sea level to about 2,800 meters, most plentiful at low elevations; Petén; Alta Verapaz; 
Izabal; Zacapa; Jutiapa; Santa Rosa; Guatemala; Suchitepequez; Retalhuleu; Quezaltenango; Huehuetenango. Mexico and British Honduras to Panama.

Lower stems terete, armed with stout prickles or unarmed, the upper branches usually 4-6-angulate, of ten flexuous; petioles short, rarely more than $1 \mathrm{~cm}$. long, aculeate or unarmed, the free portion usually articulate near the middle but of ten either above or below the middle; lower leaves ovate or broadly elliptic, up to $14 \mathrm{~cm}$. long and $8 \mathrm{~cm}$. wide but usually much smaller, acute to rounded and mucronate at the apex, subcordate at the base, the upper leaves smaller, lanceolate to oval, acute or rounded at the apex, acute at the base, rather thin, concolorous, glabrous, entire, often aculeate on the nerves beneath, 5-nerved; staminate peduncles $8 \mathrm{~mm}$. long or less, shorter than the subtending petioles, compressed, the capillary pedicels $5-13 \mathrm{~mm}$. long, exceeding the peduncle; perianth segments ovate-oblong or oblong, $2.8 \mathrm{~mm}$. long or less; filaments shorter or longer than the anthers; pistillate peduncles to $9 \mathrm{~mm}$. long, shorter than the subtending petiole, compressed, the pedicels 5-9 $\mathrm{mm}$. long; perianth segments oblong or oblonglanceolate, $1.5-2.8 \mathrm{~mm}$. long; staminodia 3 or 6 ; berries black, globose, $4-12 \mathrm{~mm}$. in diameter.

Known in Salvador by the names "bejuco de corona," "zarza," and "espuela de gallo." Maya names reported from Yucatan are "xcoceh," "xcocehac," "coceeh," and "coceh." In Huehuetenango a beverage is made by boiling the root and flavoring the decoction with sugar and cinnamon. The decoction is also considered there to be a preventive of malaria.

Smilax Standleyi Killip \& Morton, Carnegie Inst. Wash. Publ. 461: 280. 1936 .

Damp forest and thickets, 200-1,800 meters; Alta Verapaz; Chimaltenango; Suchitepequez; Quezaltenango; Huehuetenango. Pacific lowlands of Costa Rica (Guanacaste).

A small or large vine, the lower stems quadrangular, slender, pale green, armed with sparse short recurved prickles, the upper stems very slender, pale green, usually unarmed; petioles $2.5 \mathrm{~cm}$. long or less, articulate below the middle of the free portion; leaves ovate-oblong, $24 \mathrm{~cm}$. long and $12 \mathrm{~cm}$. wide or usually much smaller, thin, pale green when dried, unarmed, acute or short-acuminate, obtuse to subcordate at the base, entire, 5-nerved; staminate peduncles $2.5 \mathrm{~cm}$. long or less, longer than the petioles, compressed, the pedicels $9 \mathrm{~mm}$. long or less, very numerous, slender; perianth segments green, lanceolate, $5 \mathrm{~mm}$. long; filaments longer than the anthers; pistillate peduncles $2 \mathrm{~cm}$. long or less, the pedicels 8-9 $\mathrm{mm}$. long; perianth segments lanceolate, $5 \mathrm{~mm}$. long; staminodia 3 ; fruiting peduncles $3 \mathrm{~cm}$. long, the pedicels $1 \mathrm{~cm}$. long; berries red, $8 \mathrm{~mm}$. in diameter, globose.

The young leaves sometimes are marked with blotches of whitish or gray. 
Smilax subpubescens A. DC. Monogr. Phan. 1: 69. 1878.

Damp thickets or forest, 1,500-2,500 meters; Alta Verapaz; Zacapa; El Progreso; Chimaltenango; Suchitepequez; Quiché; Huehuetenango; Quezaltenango; San Marcos. Southern Mexico; Honduras; Costa Rica.

A large or small vine, unarmed, the stems obtusely quadrangular or subterete, rufescent-tomentose when young, almost glabrous at maturity; petioles $7 \mathrm{~cm}$. long or less, tomentose when young, the free portion articulate above the middle; lower leaves broadly ovate, as much as $24 \mathrm{~cm}$. long and $19 \mathrm{~cm}$. wide but usually much smaller, abruptly short-acuminate, deeply cordate at the base, the upper leaves ovate, acuminate, rounded or subtruncate at the base, rather thin, entire, densely reddish-tomentose on both sides when young, soon glabrescent, lustrous above, dull beneath, 9-11-nerved; staminate peduncles $3.5 \mathrm{~cm}$. long or less, usually shorter than the subtending petioles, compressed, reddish-tomentulose; pedicels $15 \mathrm{~mm}$. long or less; perianth segments narrowly oblong, 5-6 mm. long, sparsely or densely tomentulose; filaments $2.5-4 \mathrm{~mm}$. long, the anthers $1.6-2 \mathrm{~mm}$. long; pistillate peduncles about $1 \mathrm{~cm}$. long, compressed, shorter than the subtending petioles, the pedicels $6 \mathrm{~mm}$. long; perianth segments $4 \mathrm{~mm}$. long; staminodia 6 ; fruiting peduncles to $2.5 \mathrm{~cm}$. long, the pedicels $18 \mathrm{~mm}$. long or less; berries bright orange, subglobose or often slightly narrowed at the base and apex.

One Guatemalan collection of the species has been reported incorrectly as Smilax rotundifolia L., a species of the United States.

Smilax velutina Killip \& Morton, Carnegie Inst. Wash. Publ. 461: 283. 1936.

Moist forest or thickets, sometimes in pine forest, ranging from sea level to about 1,500 meters; Alta Verapaz; Izabal; San Marcos(?); Huehuetenango. Chiapas and British Honduras.

A small or large vine, unarmed, the stems terete, densely and softly yellowishpilose, becoming glabrate; petioles $2.5 \mathrm{~cm}$. long or less, the free portion articulate toward the base; leaves oblong to broadly ovate or elliptic, the largest $15 \mathrm{~cm}$. long and $9 \mathrm{~cm}$. wide, the upper much smaller, apiculate or short-acuminate, at the base cordate or subcordate, entire, 7-nerved, subtomentose above when young, soon glabrate, tomentose beneath; staminate peduncles $4 \mathrm{~cm}$. long or less, terete, the pedicels only $3-4 \mathrm{~mm}$. long; perianth segments linear, $6 \mathrm{~mm}$. long, pubescent outside; filaments $4 \mathrm{~mm}$. long, the anthers $1.2 \mathrm{~mm}$. long; fruiting peduncles 6-15 $\mathrm{mm}$. long, shorter or longer than the subtending petiole, terete, densely pilose, the pedicels about $6 \mathrm{~mm}$. long, pubescent; berries black, globose, $6 \mathrm{~mm}$. in diameter.

This species was formerly confused with $S$. tomentosa HBK., and has been reported from British Honduras under that name.

\section{HAEMODORAGEAE}

Perennial herbs, glabrous or often tomentose or pilose, with short, often tuberous rhizomes; leaves crowded at the base or on the lower portion of the scape, 
often distichous, linear or ensiform; inflorescence terminal, various in form, often paniculate or cymose, the bracts mostly small; flowers perfect, regular or nearly so; perianth corolla-like, persistent or circumscissile and deciduous, the six segments free or united to form a tube, distinctly biseriate, induplicate-valvate or slightly imbricate; stamens 6 , inserted on the tube or on the lobes of the perianth, all perfect or 1-3 of them reduced to staminodia, sometimes 3 and opposite the inner perianth lobes; filaments filiform, long or short, free or shortly united at the base, the anthers ovate to linear, often sagittate, erect or versatile, 2-celled, the cells opening by a longitudinal slit or sometimes by terminal pores; ovary inferior or superior, normally 3-celled, the style filiform or rarely short or none, stigmatose at the apex or rarely with 3 short stigmas; ovules 1 to many, affixed to an axial placenta, anatropous; fruit capsular or sometimes fleshy and more or less baccate, usually loculicidally 3-valvate, sometimes indehiscent; endosperm fleshy.

The family is a rather small one, with only a few genera and species in America, most of its representatives being Australian and Asiatic. In Central America a single genus and species are known.

\section{XIPHIDIUM Aublet}

Rather coarse perennials with short or elongate, stout rhizomes, the scape simple below the inflorescence, leafy at the base; leaves broadly linear, flat, succulent, thin when dried, with numerous slender nerves, equitant; flowers small, white, glabrous, secund and pedicellate along the simple branches of the panicle; perianth segments distinct, subequal, oblong, spreading; stamens 3 , affixed to the bases of the inner segments, the filaments short, the anthers oblong, erect; ovary free, 3-celled, the style filiform, stigmatose at the apex; ovules numerous in each cell, pendulous; fruit a fleshy globose capsule, loculicidally 3-valvate; seeds numerous, small, subglobose or slightly angulate, verruculose.

The genus consists of probably a single species.

Xiphidium caeruleum Aubl. Fl. Guian. 33. pl. 11. 1775. X. floribundum Swartz, Prodr. Veg. Ind. Occ. 17. 1788.

Wet or moist forest or thickets, often on shaded banks, chiefly at 1,200 meters or less; Alta Verapaz; Izabal; Chiquimula; Santa Rosa; Escuintla; Guatemala; Chimaltenango (Yepocapa); Suchitepequez; Retalhuleu; Quezaltenango; Huehuetenango. Southern Mexico to British Honduras and Panama; West Indies and South America.

Plants usually 40-70 cm. high, sometimes taller, glabrous except for the weakly pilose inflorescence; leaves ensiform or linear, usually 20-40 cm. long, 1.5-5 cm. wide, long-attenuate; panicles thyrsiform, the scape usually bearing below the panicle a few adventitious buds that fall off and develop into new plants, the branches of the panicle spreading or more often ascending, or even reflexed, rather remotely flowered; perianth segments oblong or obovate, obtuse, 6-8 $\mathrm{mm}$. long, glabrous; fruit subglobose, commonly $7-8 \mathrm{~mm}$. in diameter, varying from green to dull red or finally purple-black. (Fig. 21.) 


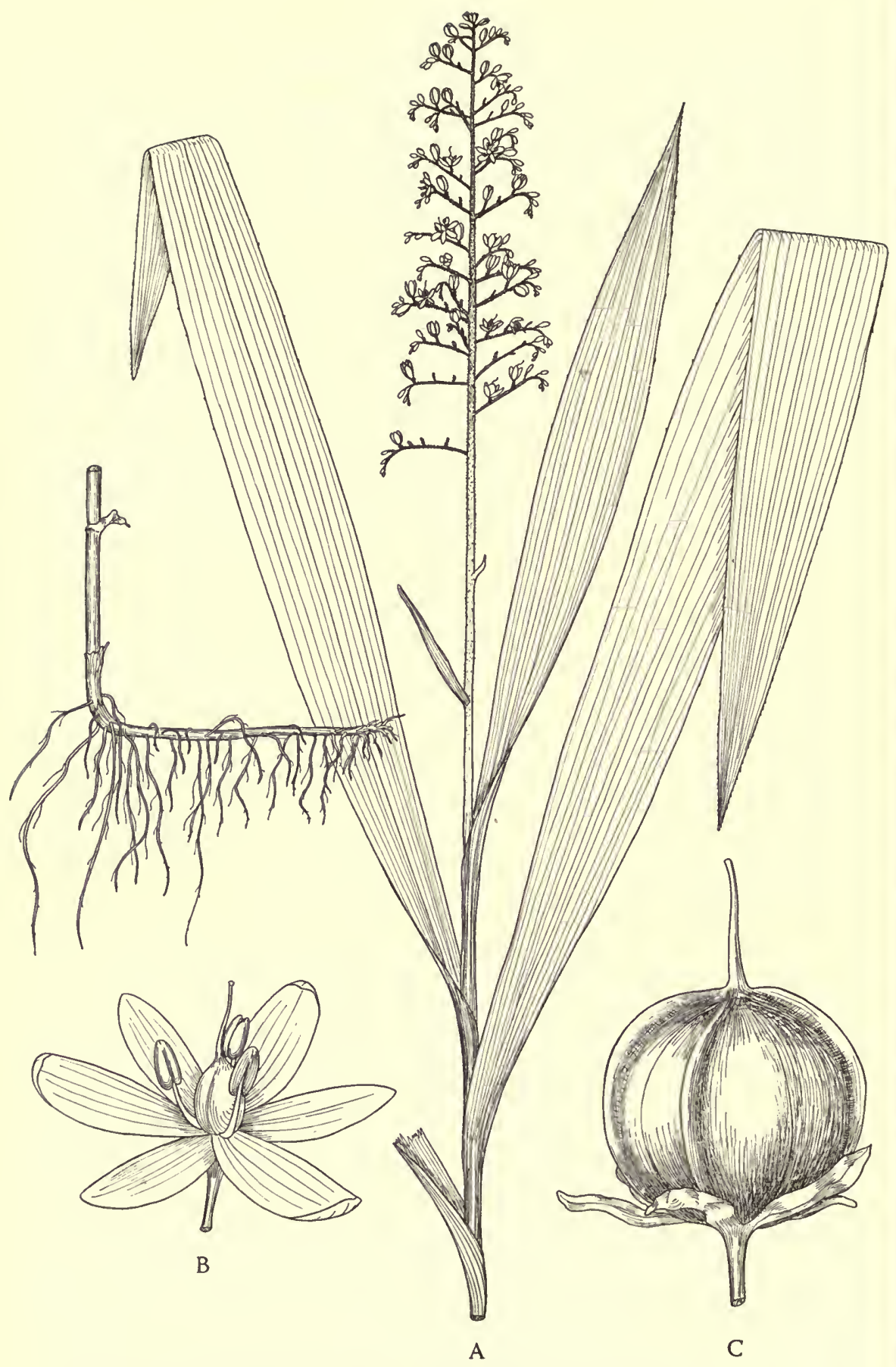

FIG. 21. Xiphidium caeruleum. A. Habit; $\times 2 / 5$. B. Flower; $\times 5$. C. Fruit in position with persistent perianth; $\times 4$. 
Called "palma del norte" in Salvador. A rather ornamental plant, the foliage suggesting somewhat that of the genus Iris. It is sometimes planted for ornament in local gardens. Although essentially a plant of the tierra caliente, on the Pacific coast it does not extend upon the plains, but often grows in abundance in the lower foothills, sometimes covering densely paredones along roadsides or steep banks at the bases of cliffs on stream borders. The small white flowers are neither showy nor handsome. The specific name is a somewhat misleading one. Aublet states that part of the petals are blue at the apex, but no such coloration has been observed in Central American plants.

\section{AMAR YLLIDACEAE. Amaryllis Family}

Perennial herbs, rarely frutescent, with rhizomes or tubers or sometimes with woody, simple or branched caudices, the scapes often tall but sometimes low or almost obsolete; leaves various in form, thin or fleshy, the nerves conspicuous or obscure, the leaves sometimes very thick and long-persistent, their margins often armed with spines; inflorescence terminal, the flowers perfect, variously arranged; bracts mostly scarious, sometimes colored; flowers regular or nearly so, the perianth usually marcescent, rarely persistent, the segments free or more or less connate to form a tube, the segments or lobes 6 , distinctly biseriate, those of the 2 series equal or unequal; stamens generally 6 , inserted upon the perianth tube or at the bases of the segments, the filaments filiform, free or sometimes connected by a membrane; anthers oblong, linear, or rarely ovoid-globose, erect or versatile, 2-celled, the cells dehiscent by longitudinal slits; ovary inferior, 3-celled or rarely 1-celled (not in Guatemalan genera), the placentae axial; style filiform or rarely columnar, usually undivided, the stigma terminal, small and capitate, rarely of 3 branches; ovules numerous in each cell, biseriate, rarely only 1-2, anatropous; fruit capsular, globose to oblong, loculicidally 3-valvate or sometimes indehiscent; seeds usually numerous, sometimes few or only $1-2$, sessile or on very short funicles, globose to angulate or compressed, the testa usually black; endosperm fleshy.

About seventy genera are recognized, widely distributed in tropical and warmer regions of the earth. All the known Central American genera (and most of the species) are represented in Guatemala.

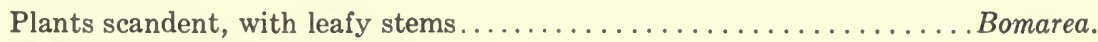

Plants not scandent, the stems not leafy.

Plants with tunicated bulbs.

Scapes 1-flowered. Zephyranthes.

Scapes bearing more than a single flower.

Filaments connected by a thin cuplike membrane. Flowers white.

Perianth lobes linear; leaves usually strap-shaped, not conspicuously

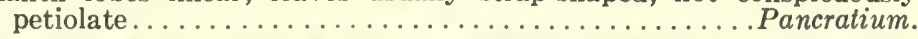

Perianth lobes ovate; leaves elliptic, abruptly contracted at the base into a slender petiole............................. Eucharis. 
Filaments distinct, not connected by a membrane. Flowers often red or pink.

Flowers mostly sessile or nearly so; seeds few, not compressed. . Crinum.

Flowers long-pedicellate; seeds strongly compressed.......Hippeastrum. Plants never with tunicated bulbs.

Leaves thin, membranaceous, conspicuously nerved, not fleshy; flowers bright yellow; capsule indehiscent or circumscissile.

Capsule circumscissile; flowers slender-pedicellate............ Hypoxis.

Capsule indehiscent; flowers sessile................ Curculigo.

Leaves thick and hard or often succulent, not nerved; flowers not bright yellow.

Perianth tube elongate, longer than the lobes, curved; scape leafy.

Polianthes.

Perianth tube short, much shorter than the lobes, not curved; stems merely bracted.

Perianth rotate, the tube almost obsolete............ Furcraea. Perianth funnelform, with an evident tube.............. Agave.

\section{AGAVE L.}

References: William Trelease, The Agaveae of Guatemala, Trans. Acad. Sci. St. Louis 23: 129-152. pls. 6-35. 1915; Agave, in Standl. Contr. U. S. Nat. Herb. 23 (Trees and shrubs of Mexico): 107-142. 1920; Alwin Berger, Die Agaven 1915.

Plants mostly large and coarse, the rhizome short and subterranean, or sometimes erect and short-columnar; leaves all radical or densely clustered at the apex of the caudex, usually thick, rigid, and fibrous, rarely thin and withering, the margins usually armed with spines, the tip of the leaf terminating in a sharp spine; scape terminal, often of gigantic size, the flowers spicate or more often cymose and forming a large thyrse; perianth subfunnelform, the tube usually short, ampliate in the throat, the segments linear or oblong, erect or spreading, usually yellowish white; stamens inserted in the perianth throat at the base of the lobes, longer than the lobes, the filaments filiform or at the base membranaceous-complanate; anthers linear, large, dorsifixed at the middle; ovary globose to oblong, often fleshy, contracted into a beak, 3-celled; style filiform from a short conic base, the stigma small, capitate, more or less trilobate; ovules numerous in each cell, biseriate; capsule globose to ovoid or oblong-cylindric, often 3-sulcate, coriaceous, often crowned by the persistent perianth, loculicidally dehiscent from the apex; seeds numerous, thin and flat, densely crowded, the testa black.

An American genus (some of the species naturalized in the Old World), with 300 or more species. They are relatively few in Central America, the majority being Mexican. About 170 are known from that country, and they are rather numerous also in the West Indies. A few additional species are known from Salvador, but chiefly in cultivation, and two have been described from Panama and Costa Rica. In Central America the plants are not common south of Guatemala, except in the arid interior regions of Honduras. 
The agaves constitute one of the most remarkable of all endemic groups of American plants, and one of great utility and ornamental value. These strange plants, so unlike anything in Europe or adjacent regions, naturally attracted attention of the early explorers. At a very early date, living plants, easily preserved, were carried back to Europe, where they became one of the wonders of Mediterranean gardens and of northern hothouses. In Europe, because of unfavorable growing conditions, the plants often lived for many years without blooming; hence there developed a belief that they bloomed only at the age of 100 years, whence the customary English name of century plant. It is unnecessary to state that in regions where they are native, the plants require but few years to attain full development. When once the flower stalk does arise, its growth is extremely rapid, sometimes a foot or more in a single day. The plants die after flowering, but each one usually leaves about its base suckers that develop into new plants. In Europe the agaves are sometimes known as American aloes, because of their very slight resemblance to some of the species of the Old World genus Aloe.

In Mexico the agaves are of great industrial importance as a source of various qualities of fiber, and of the beverages known as pulque, mescal, and tequila, the last two of which are highly intoxicating. Although species suitable for extraction of these beverages are available in Guatemala, we cannot find a record that their sap was ever used by the Indians for preparing intoxicating drinks, and at the present time it would not be permitted. Some of the local species are of great importance as fiber plants. The fiber varies in quality according to the species, but rope and coarse textiles probably are made from the leaves of all species having leaves of suitable length. The roots contain saponin, and often are used as a soap substitute under the name "amole," but much less frequently in Guatemala than in Mexico.

In Guatemala the plants are of great importance for fences or hedges, and the larger species, such as $A$. tecta, are particularly useful for this purpose. Especially on the plains about Quezaltenango there are long miles of agave hedges (often mixed with tall opuntias) that give a definitely Mexican aspect to the landscape. Wild agave plants are now confined chiefly to rocky or steep hillsides unsuitable for agriculture, but centuries ago they must have been much more plentiful. When the land was cleared for agriculture, the plants were dug out and either dried and burned or else replanted along the margins of the fields to mark the boundaries or, 
after the conquest, to keep out stock. Even today this transplanting of the maguey may be observed occasionally in the Guatemalan highlands. About Huehuetenango one sometimes sees a unique type of fence made by planting on top of low earth walls small agave plants of the species having short broad leaves.

Agaves are grown on a large scale in Alta Verapaz for their fiber, but elsewhere also they are important, and the fiber, raw or manufactured, is one of the important articles in all the markets. Large amounts of it are used for rope and twine, hammocks, halters, carrying nets, carrying bags, and many other articles, even for the strings of violins and guitars at times. The flower stalks are said to attain sometimes a height of 10 meters. About Atitlán notches are cut in them, so that they may be used for ladders. In some regions they are hollowed and used for conducting water, some of these water lines being said to have a length of a kilometer. The sticky sap of the leaves is added to whitewash to make it adhere. The leaves of both Agave and Furcraea are often gnawed during the dry season by mules and horses, perhaps also by cattle and sheep when forage is scant. At Jutiapa the senior author was informed that the seed pods of some species of maguey are used as a fish poison. There, too, the young and more tender leaves are sometimes cooked and eaten, especially when there is a scarcity of maize. Some of the Mexican agaves have been introduced into the gardens of Guatemala City and other parts of the country, but most of the plants seen in local gardens are Guatemalan species.

The following account of Guatemalan species is based upon the treatment by Trelease, who visited the country and spent considerable time in studying the plants in the field. It must be confessed that the following account is far from satisfactory, except for a few of the best-marked species. It is believed that the total number of species is considerably less than is listed here, but the material available does not permit the reduction of many of the names at the present time. The group obviously is one that offers great difficulties in the disposition of species, and the plants need to be studied in the living state rather than from dried specimens, in which all the characters are distorted.

Leaves withering, or disappearing in the dry season, new leaves appearing each season, not spine-tipped, unarmed.................. brachystachys.

Leaves persistent, hard, fleshy, fibrous, tipped with a stiff spine, the margins usually spine-armed.

Inflorescence simple, the flowers spicate. (Subgenus Littaea.)

Leaves with spine-toothed margins................. huehueteca.

Leaves with unarmed margins.................. dasylirioides. 
Inflorescence, so far as known, branched, the flowers in cymes or headlike clusters.

Leaves very large and trough-like, mostly about 2 meters long and $50 \mathrm{~cm}$. broad, very thick and heavy, the marginal teeth usually joined by a

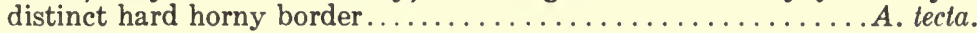

Leaves mostly smaller, at least much narrower, not trough-like, usually without a continuous horny border, or this sometimes present in species with very short and broad leaves.

Leaves rather hard-fibrous, sword-like or dagger-like, very narrow in proportion to their length.

Terminal spine of the leaf stout-conic; leaves gray-green or somewhat

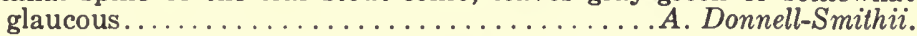
Terminal spine very slender and tapering, subulate.

Leaves green or dark green, almost flat................ sisalana.

Leaves gray-green or glaucous, deeply concave............. nivea.

Leaves fleshy, mostly lanceolate (sometimes very narrowly so) to obovate.

Plants very large, confined to gardens; leaves lanceolate, mostly more than a meter long; panicles open, the flowers loosely clustered at the ends of the branches; introduced species.

Terminal spine of the leaf acicular.................. picta.

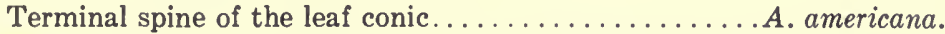

Plants smaller, native species; leaves lanceolate to obovate, usually smaller; panicles usually narrowly oblong, the flowers densely clustered at the ends of the branches.

Leaves short and broad, mostly obovate, very rigid and stiff, usually erect or incurved except during and after anthesis.

Terminal spine of the leaf very tortuous or twisted....A. tortispina. Terminal spine straight or nearly so.

Spine with a very narrow and deep groove on the upper surface, its sides more or less incurved............ Seemanniana.

Spine with a rather flat groove, its sides not incurved. . A. Hurteri. Leaves relatively narrow, elongate, usually not incurved.

Terminal spine of the leaf almost flat on the upper side, scarcely if

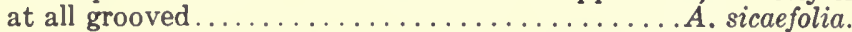

Terminal spine evidently grooved on the upper side, the groove often deep and narrow.

Groove of the terminal spine rounded and rather open.

Teeth of the leaf margins widely separated, red-brown.

A. lagunae.

Teeth of the leaf margins close together, chestnut.

Teeth of the leaf margins abruptly contracted into a slender curved cusp..................... Kellermaniana.

Teeth of the leaf margins broadly triangular, not abruptly

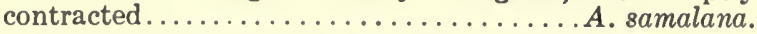

Groove of the terminal spine deep and very narrow, the margins often incurved.

Teeth of the leaf margins large and stout, from elevated bases, usually abruptly contracted into a stout cusp.

Terminal spine of the leaf stout-conic.......... opacidens.

Terminal spine of the leaf long-acicular, slender.A. tenuispina.

Teeth of the leaf margins small and weak, their bases little if at all elevated, not conspicuously contracted into a cusp.

Leaves about $60 \mathrm{~cm}$. long, only about $6 \mathrm{~cm}$. wide, their teeth often easily deciduous................. minarum. 
Leaves $60-100 \mathrm{~cm}$. long, mostly $10-15 \mathrm{~cm}$. wide, their teeth persistent.

Leaves numerous, strongly ascending, about $60 \mathrm{~cm}$. long and $15 \mathrm{~cm}$. wide................. Thomasae.

Leaves few, spreading, about $100 \mathrm{~cm}$. long and $10 \mathrm{~cm}$. wide. A. Deamiana.

\section{Agave americana L. Sp. Pl. 461. 1753. Maguey.}

Planted occasionally for ornament about Guatemala City and elsewhere. Probably native of Mexico, and cultivated there as well as in many parts of Central America; naturalized in many parts of the Old World, especially about the Mediterranean.

Plants very large, the leaves mostly 1-2 meters long and as much as $30 \mathrm{~cm}$. wide, usually upcurved toward the end, gray-green, very thick and heavy; terminal leaf spine stout-conic, about $3 \mathrm{~cm}$. long and $7 \mathrm{~mm}$. thick, often recurved, narrowly grooved below the middle, scarcely decurrent, the marginal teeth narrowly triangular, hardened into the tops of fleshy protuberances between which the margin is somewhat concave; inflorescence very tall, often 5-8 meters high, branched and rather open; perianth $8.5-9 \mathrm{~cm}$. long; ovary cylindric, $4-4.5 \mathrm{~cm}$. long; perianth segments $2.5-3.5 \mathrm{~cm}$. long, linear or linear-lanceolate, obtuse, bright yellow-green; anthers yellow-green, $3 \mathrm{~cm}$. long; capsule $4 \mathrm{~cm}$. long; seeds about $8 \mathrm{~mm}$. long and $6 \mathrm{~mm}$. wide.

Part of the plants cultivated in Guatemala belong to var. marginata Trelease (in L. H. Bailey, Stand. Cycl. Hort. 1: 235. 1914), in which the leaves have white or yellow margins. This species is perhaps better known and more plentiful in southern Europe than it is in America, for there it has become thoroughly naturalized in some regions. It often is grown for ornament in the United States in greenhouses, or in the South out of doors.

Agave brachystachys Cav. Descr. 453. 1802. Manfreda brachystachys Rose, Contr. U. S. Nat. Herb. 8: 20. 1903. Amole; Ixmaxin (San Sebastián, Huehuetenango); Lirio verde (fide Aguilar); Amol chipalcu (Huehuetenango).

Brushy hillsides or in meadows, most often in pine-oak forest, 850-1,800 meters; Chiquimula; Jalapa; Jutiapa; Santa Rosa; Chimaltenango; Sololá; Quiché; Huehuetenango. Mexico; Honduras; Salvador.

Plants acaulescent, arising from a thick underground rhizome; leaves 12-15 or fewer, lance-linear, soft and thin, $25-35 \mathrm{~cm}$. long, 2-4 cm. wide, green or pale green, often lying flat on the ground, frequently spotted with brown-purple, the thin margins entire or nearly so, not spiny, the tip of the leaf unarmed; inflorescence very slender, 1-2 meters tall, with a few remote bracts, the flowers sessile in mostly elongate and interrupted spikes, few; ovary elongate-cylindric; perianth $3.5-4 \mathrm{~cm}$. long, somewhat curved, the lobes slightly longer than the tube, pale green; fila- 


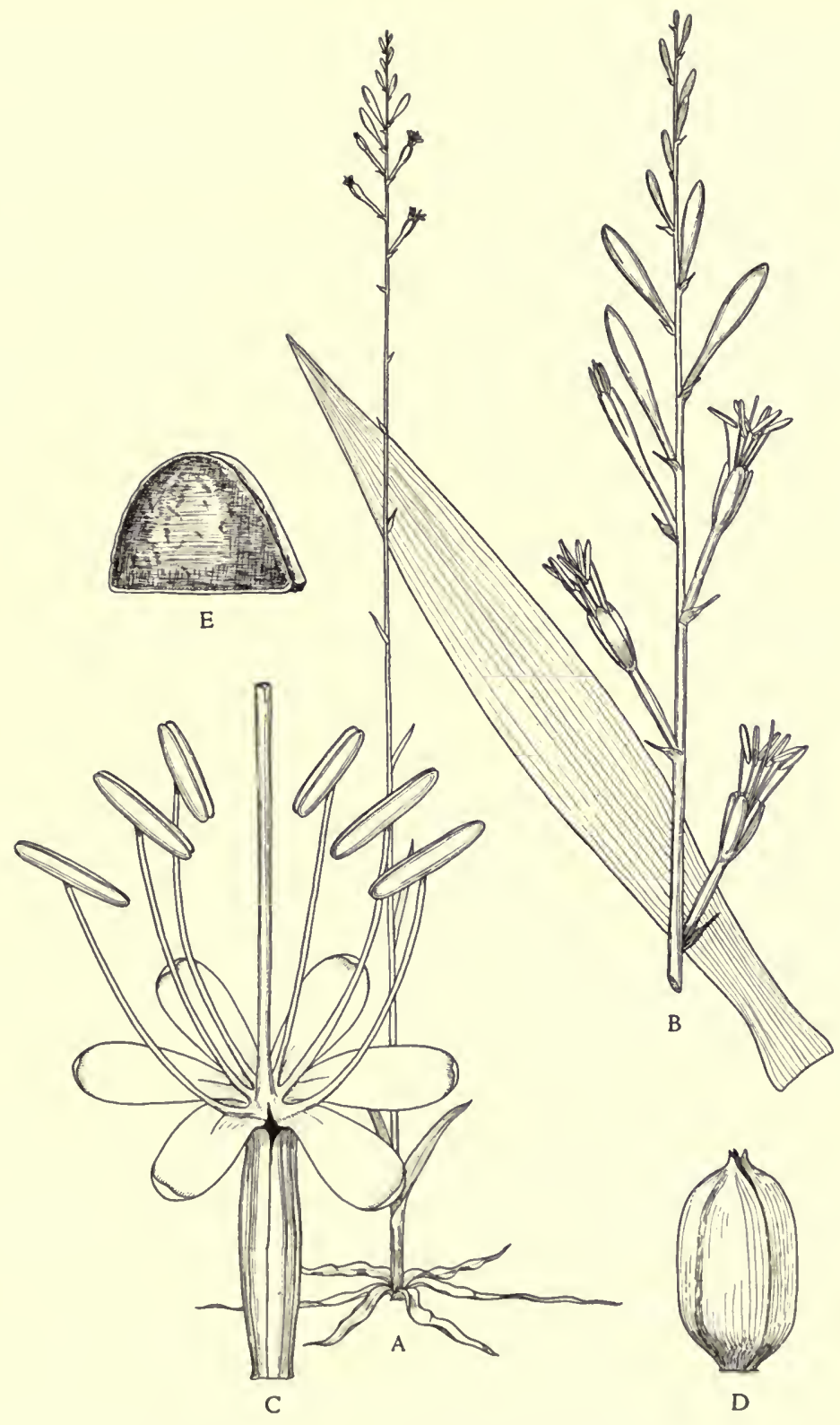

FIG. 22. Agave brachystachys. A. Habit; $\times 1 / 12$. B. Portion of inflorescence and single detached leaf; $\times 1 / 3$. C. Flower; $\times 1$. D. Capsule; $\times 1$. E. Seed; $\times 4$. 
ments dull lavender; capsule oval, $2-2.5 \mathrm{~cm}$. long, in age becoming whitish, subterete. (Fig. 22.)

In general appearance this is very unlike the normal type of Agave species, and there is much justification in giving generic rank to the species of this relationship that have been referred to Manfreda. The fleshy roots are said to be used in Guatemala, especially by the Indians of the highlands, for washing textiles. They are used also for shampooing the hair because it is believed locally that they prevent baldness, something not very common among the Indians. The Indians are said to employ the roots also as a barbasco or fish poison. Although widely scattered in oak and pine forest, we have not found this plant plentiful anywhere, and usually it occurs as isolated individuals. The name "cebolla de cerro" is recorded from Honduras, and the flower stalks are said to be used there as arrow shafts, presumably by some of the Indians.

Agave Deamiana Trelease, Trans. Acad. Sci. St. Louis 23: 139. pl. 13. 1915.

Slopes of ravine, 1,200 meters; endemic; Guatemala (type from Fiscal, C. C. Deam 6154a).

Plants acaulescent, producing few or no offshoots; leaves grayish or slightly glaucous, widely spreading, narrowly oblanceolate, attenuate, somewhat concave, about a meter long and $10 \mathrm{~cm}$. wide, minutely roughened, especially beneath; terminal spine purplish brown, somewhat lustrous above, minutely granular beneath, slender-conic or acicular, sometimes flexuous, involutely grooved from about the middle, with acute edges, decurrent for about its own length, scarcely intruded into the green tissue, $4 \mathrm{~cm}$. long, 3-4 mm. thick; marginal teeth chestnutcolored, 1-2 cm. apart, 2-4 mm. long, straight or curved (usually downward), the slender triangular cusp lenticular-dilated into the straight margin; inflorescence unknown.

This species grows about Fiscal in association with Hechtia, probably on the dry hills northeast of the railroad station. We have examined two collections of this species (Deam 6199 and 6201) determined by Trelease in the United States National Herbarium.

Agave dasylirioides Jacobi \& Bouché, Hamb. Gart. Zeit. 21: 344. 1865.

Described from plants cultivated in Europe; said to have been collected by Warscewicz at the foot of a volcano (Santa María?) near Quezaltenango; cultivated in Europe.

Plants acaulescent; leaves very numerous, linear, ascending or recurved, 60 $100 \mathrm{~cm}$. long, at the base $2.5-4 \mathrm{~cm}$. wide, narrower above, flat, leathery below, thin toward the apex, green or grayish green, smooth, the margins unarmed but some- 
what roughened, the terminal spine small, brown, compressed; inflorescence 1.5-2 meters tall, simple, spicate, often recurved, bearing numerous dry bracts, densely many-flowered, the flowers sessile or nearly so; perianth $4 \mathrm{~cm}$. long, green, the segments lanceolate, subobtuse, 14-16 mm. long, $5 \mathrm{~mm}$. wide, bright green; anthers brownish or golden yellow; capsule $2.5 \mathrm{~cm}$. long, $1 \mathrm{~cm}$. thick; seeds semiorbicular, $3 \mathrm{~mm}$. wide.

Very distinct from other local species in its long narrow unarmed leaves, which are only $1-1.5 \mathrm{~cm}$. wide at the middle. Possibly it may occur on the dry barren rocky mountain sides above Quezaltenango, which we have not explored carefully, but it is somewhat strange that it has not been introduced into cultivation in Quezaltenango if growing wild in that region.

Agave Donnell-Smithii Trelease, Trans. Acad. Sci. St. Louis 23: 144. pls. 23, 24. 1915. Maguey.

Brushy rocky slopes, moist quebradas, or moist thickets, often planted in hedges or for ornament, 200-2,200 meters; endemic; Zacapa (La Fragua); Santa Rosa (Barberena); Escuintla (type from Escuintla, J. D. Smith 2085); Guatemala (Fiscal; planted at Guarda Viejo and elsewhere); Chimaltenango (between Chimaltenango and San Martín Jilotepeque); Huehuetenango (hills north of Chiantla); Retalhuleu; Suchitepequez.

Plants acaulescent, producing numerous offshoots; leaves light green and often whitened above, glaucous beneath, ascending or suberect, sword-shaped, moderately concave, $75-100 \mathrm{~cm}$. long or more, about $8 \mathrm{~cm}$. wide, attenuate, smooth; terminal spine garnet, becoming chestnut, lustrous, smooth, stoutly awl-shaped, terete, flat or shallowly grooved near the base, not decurrent or intruded into the green tissue, 12-15 mm. long, $4 \mathrm{~mm}$. thick; marginal teeth colored like the terminal spine, 1-3 cm. apart, 2-3 mm. long, upcurved, triangular, lenticularly dilated into the straight margin; inflorescence tall, paniculate, the pedicels $5-10 \mathrm{~mm}$. long, the flowers greenish yellow, $4-4.5 \mathrm{~cm}$. long; ovary $2-2.5 \mathrm{~cm}$. long, about equaling the perianth, oblong-fusiform.

This seems to be a fairly common species of the central mountains, especially in hedges. The type collection was originally determined and reported as Agave rigida J. Miller. According to Trelease, A. Donnell-Smithii is related to the Mexican A. tequilana Weber, the common source of the liquor mezcal de Tequila.

Agave huehueteca Standl. \& Steyerm. Field Mus. Bot. 23: 4. 1943. Maguey.

Dry rocky exposed hillsides, mostly or wholly on limestone, 1,700 2,200 meters, Huehuetenango; type collected along Aguacatán road east of Huehuetenango at km. 13-14, Standley 82039; collected also 
on hills north of Chiantla and at the crossing of Río San Juan Ixtán, east of San Rafael Pétzal; endemic.

Leaves forming a very dense rosette, numerous, oblong-ovate or obovate, about $35 \mathrm{~cm}$. long and $10 \mathrm{~cm}$. wide or often larger or smaller, suberect or ascending and usually somewhat incurved, more or less concave, thick, hard, fibrous, grayish green or glaucescent, very rigid; terminal spine conic or elongate-conic, stout, $2.5-4 \mathrm{~cm}$. long, $6 \mathrm{~mm}$. thick, grayish brown, usually dull but sometimes lustrous, terete above, broadly sulcate below, decurrent into the leaf tissue; margin of the leaf with a broad continuous gray border, the large coarse teeth $5-11 \mathrm{~mm}$. long or even larger, compressed, grayish, very broad at the base, often curved or recurved or even flexuous; inflorescence 3-5 meters tall, pole-like, simple, spicate, erect, the spike very dense and many-flowered, the bracts numerous, almost setaceous from a broad base, the flowers almost sessile, clustered; ovary $12 \mathrm{~mm}$. long, $4 \mathrm{~mm}$. thick; perianth tube obconic, $5 \mathrm{~mm}$. long, the lobes narrowly oblong, dark purplish green, $2-2.5 \mathrm{~cm}$. long, obtuse; stamens long-exserted, the filaments dark purplish red, the anthers almost $2 \mathrm{~cm}$. long; capsule globose-oval, about $2 \mathrm{~cm}$. long and 12 $\mathrm{mm}$. broad, very shallowly sulcate, green; seeds semiorbicular, $4 \mathrm{~mm}$. long.

A handsome plant, plentiful locally along the southern base of the cordillera of Huehuetenango, but not common. It may well be that the Guatemalan plant can be identified with some species described from Mexico, but we have not been able to place it among the Mexican species. It is the easternmost species known of the subgenus Littaea. This species is noteworthy for the fact that each blooming plant usually is encircled by a ring of suckers or hijos almost as large as the parent plant.

Agave Hurteri Trelease, Trans. Acad. Sci. St. Louis 23: 136. pls. 8-10. 1915. A. pachycentra Trelease, op. cit. 135. pl. 7. 1915. Maguey.

Usually on dry, open, often rocky or brushy hillsides, sometimes in pine and oak forest, ascending from about 1,000 meters (probably at times even lower) to 3,700 meters (Sierra de los Cuchumatanes); endemic; El Progreso (type of $A$. pachycentra from Cruz, Trelease 2); Jalapa; Totonicapán; Quezaltenango (type from Zunil, Trelease 3); San Marcos; Huehuetenango.

Plants acaulescent, often producing offshoots; leaves grayish or glaucous, ascending or somewhat incurved, forming a large dense rosette, oblong-obovate or broadly oblong-oblanceolate, $35-80 \mathrm{~cm}$. long, mostly $10-20 \mathrm{~cm}$. wide, acute, somewhat concave, smooth; terminal spine chestnut, often lustrous above, stoutconic or sometimes slender, $2-4 \mathrm{~cm}$. long and as much as $8 \mathrm{~mm}$. thick, sometimes even longer, straight or nearly so, more or less intruded below into the green tissue; teeth colored like the spine, 5-10 $\mathrm{mm}$. long, 1-2 $\mathrm{cm}$. apart, straight or usually curved, abruptly cuspidate; inflorescence $2-5$ meters tall, oblong-paniculate, the flowers densely massed in large subglobose clusters, these almost sessile or stoutpedunculate; flowers on pedicels $1 \mathrm{~cm}$. long or less, whitish or pale yellow, 6-7 cm. long; ovary $2.5-3 \mathrm{~cm}$. long; perianth tube obconic, 12-15 mm. long, the segments 
$2.5 \mathrm{~cm}$. long; capsule oblong, about $5 \mathrm{~cm}$. long and $2 \mathrm{~cm}$. thick, neither stipitate nor beaked; seeds $8 \mathrm{~mm}$. long and $5 \mathrm{~mm}$. wide.

The species was dedicated to Mr. G. Hurter of Quezaltenango. It has a remarkably wide distribution, at least altitudinally, its extreme upward limit being in the Sierra de los Cuchumatanes, on the low cedar-clad hills rising above the alpine plains of that region, where it is abundant and constitutes a conspicuous element of the landscape. It is hard to believe that these plants should belong to the same species that is found as low as 1,000 meters. We have collected numerous specimens that are referred here. While it is easy to indicate minor differences between some of these, it has been found impossible to separate them in a key by characters that appear plausible; consequently we have preferred to treat them all as forms of a single not too variable species. For this we have chosen the name $A$. Hurteri, rather than $A$. pachycentra published on an earlier page, because the former is illustrated and was described from complete, rather than sterile, specimens. The plant is a highly ornamental one because of its compact, often almost globose and somewhat cabbage-like clusters of leaves. It abounds in Huehuetenango, especially, but is common also in some parts of Totonicapán, especially about Momostenango, growing usually on exposed rock outcrops, and it is plentiful in many localities in hedge-rows. The flowers often are full of wasps, but these leave the plant when the stalk is cut and falls to the ground.

Agave Kellermaniana Trelease, Trans. Acad. Sci. St. Louis, 23: 142. pl. 18. 1915.

Dept. Guatemala, the type from sides of ravines near Fiscal, 1,110 meters, C. C. Deam 6239 .

Plants acaulescent; leaves very glaucous, elongate-lanceolate, about $100 \mathrm{~cm}$. long and 8-10 $\mathrm{cm}$. wide or larger, acuminate, rather concave, minutely granular beneath; terminal spine chestnut-colored, somewhat lustrous, slender-conic, granular below, round-grooved from above the middle with rather blunt edges, decurrent on the margins for 1-2 times its length, somewhat intruded dorsally into the green tissue, $3-3.5 \mathrm{~cm}$. long, 4-5 mm. thick; marginal teeth $1-2.5 \mathrm{~cm}$. apart, 3-5 mm. long, upcurved, the cusps rather slender, lustrous purple-chestnut, with abrupt bluish bases; inflorescence unknown.

Agave lagunae Trelease, Trans. St. Louis Acad. Sci. 23: 143. pl. 21. 1915.

On gravel, talus, and cliffs, Pacific slope, 700-1,500 meters; Guatemala (type from Amatitlán, above the lake, Trelease 10); Escuintla (between Palín and Escuintla); endemic. 
Plants acaulescent, with few offshoots; leaves very glaucous, spreading, lanceolate, acuminate, moderately concave, minutely granular on the lower surface, about $30-40 \mathrm{~cm}$. long and $8-10 \mathrm{~cm}$. wide; terminal spine garnet-colored, lustrous, granular below, conic, often slightly flexuous, round-grooved from near the apex, with acute short-decurrent edges, somewhat intruded dorsally into the green tissue, 2-3 cm. long, 3-5 mm. thick; teeth colored like the spine, lustrous, $2-4 \mathrm{~cm}$. apart, 3-6 $\mathrm{mm}$. long, upcurved or recurved, the cusps rather slender, mostly uncinate, lenticularly dilated into the margin or on the tops of fleshy prominences between which the margin is almost straight; inflorescence unknown.

Agave minarum Trelease, Trans. Acad. Sci. St. Louis 23: 139. pl. 14. 1915. Maguey.

El Rancho, the type from Sierra de las Minas, 600 meters, Kellerman 5129; Zacapa; at about 200 meters; perhaps also at Jutiapa, 900 meters, in dry thickets.

Plants acaulescent, with few or no offshoots; leaves yellow-green, loosely spreading, lanceolate, acute, smooth, about $60 \mathrm{~cm}$. long and $6 \mathrm{~cm}$. wide; terminal spine brown, lustrous above, conic, smooth, almost straight, round-grooved above, becoming involute as the leaf dries, decurrent for somewhat more than its own length, somewhat intruded dorsally into the green tissue, about $4.5 \mathrm{~cm}$. long and $5 \mathrm{~mm}$. thick; marginal teeth easily detachable, 5-10 $\mathrm{mm}$. apart, the intervening margin straight; inflorescence 2-3 meters tall, loosely few-branched above, the flowers relatively lax at the ends of the branches, the pedicels $2-10 \mathrm{~mm}$. long; flowers yellow, $4 \mathrm{~cm}$. long; ovary $2 \mathrm{~cm}$. long, oblong-fusiform; perianth tube conic, $6 \mathrm{~mm}$. long, the lobes $1.5 \mathrm{~cm}$. long; filaments twice as long as the perianth lobes.

Agave nivea Trelease, Trans. Acad. Sci. St. Louis 23: 143. pl. 22. 1915. Maguey.

Brushy hillsides, rocky slopes, damp thickets, 400-2,000 meters; endemic; El Progreso (type from El Rancho, in hedge-rows, Trelease 11); Zacapa; Jalapa; Jutiapa; Sololá(?); Huehuetenango.

Plants acaulescent, producing numerous offshoots; leaves mostly very glaucous, narrowly lanceolate, ascending or suberect, very concave, usually minutely granular beneath, sometimes 2 meters long and $15 \mathrm{~cm}$. wide, often smaller; terminal spine chestnut-colored or black, somewhat lustrous, slender-conic, very shallowly grooved near the base, 1.5-2 cm. long, $3 \mathrm{~mm}$. thick, scarcely decurrent or intruded into the leaf tissue; teeth colored like the leaves, rather lustrous, $3-5 \mathrm{~cm}$. apart, about $3 \mathrm{~mm}$. long, usually upcurved, the cusps often curved or flexed, slender, broadened below and often from somewhat raised, fleshy bases between which the margin is almost straight; inflorescence said to be an open panicle of yellowish flowers.

Agave opacidens Trelease, Trans. Acad. Sci. St. Louis 23: 140. pl. 16. 1915. 


\section{El Progreso (type from Cruz, Trelease 5); Huehuetenango (fre-} quent at 1,700-1,900 meters, in hedges, open rocky slopes, or oak forest); endemic.

Plants acaulescent, producing few or no offshoots; leaves glaucous, lanceolate, acuminate, roughened beneath, about $75 \mathrm{~cm}$. long and 8-10 $\mathrm{cm}$. wide; terminal spine dull brown, turning grayish, granular below, stoutly triquetrous-conic, almost straight, involutely grooved from above the middle with acute edges, decurrent for 1-2 times its length, somewhat intruded dorsally into the green tissue, $5-6 \mathrm{~cm}$. long, 3-6 mm. thick; marginal teeth gray, rather dull, $2-5 \mathrm{~cm}$. apart, 5-8 $\mathrm{mm}$. long, almost straight, heavily triangular, lenticular-dilated into more or less elevated prominences of the otherwise almost straight margin; inflorescence about 5 meters tall, the upper half oblong-paniculate; bracts broadly triangular, appressed, the pedicels about $1 \mathrm{~cm}$. long; flowers yellow, 4-5 cm. long; ovary 2.5-3 $\mathrm{cm}$. long, fusiform; perianth tube open-obconic, $1 \mathrm{~cm}$. long, the lobes $12-15 \mathrm{~mm}$. long, $5 \mathrm{~mm}$. wide; capsule oblong, stipitate, $4-4.5 \mathrm{~cm}$. long, $2 \mathrm{~cm}$. broad; seeds about $6 \mathrm{~mm}$. long and $5 \mathrm{~mm}$. wide.

Although coming from a region far removed from the type locality, the Huehuetenango specimens seem to agree well with the original description and illustration.

Agave picta Salm-Dyck, Bonplandia 7:88. 1859. A. ingens Berger, Hort. Mortol. 12: 360. 1912.

Planted occasionally for ornament in parks and gardens, as at Guatemala, Antigua, Huehuetenango, Retalhuleu, and elsewhere. Doubtless native of Mexico, but probably unknown in a wild state.

Plants acaulescent or nearly so; leaves numerous, curved upward and outward, dark green, thick, lanceolate, about 2 meters long and 15-35 cm. wide, or often much smaller, attenuate, very convex beneath, the marginal teeth rather small and mostly straight, $2-4 \mathrm{~cm}$. apart, reddish brown or grayish, the terminal spine 4-5 cm. long, slender, acicular, straight; inflorescence sometimes 10 meters tall, the stalk sometimes $15 \mathrm{~cm}$. thick, the inflorescence rather openly paniculate but oblong; flowers similar to those of A. americana.

Agave samalana Trelease, Trans. Acad. Sci. St. Louis 23: 142. pls. 19, 20. 1915.

Quezaltenango (type collected on mountain sides along Río Samalá near Esperanza, between Santa María de Jesús and Zunil, Trelease 7).

Plants acaulescent, scarcely producing offshoots; leaves glaucous, especially beneath, numerous, oblanceolate, acuminate, somewhat concave, minutely roughened beneath, about $60 \mathrm{~cm}$. long and $15 \mathrm{~cm}$. wide; terminal spine reddish, darkening in age, somewhat lustrous, granular below, slender-conic or acicular, almost straight, round-grooved from above the middle with acute edges, decurrent for about its own length, more or less intruded dorsally into the green tissue, $3.5-5.5 \mathrm{~cm}$. long, 3-4 mm. thick; marginal teeth chestnut-colored, dull, 5-20 mm. apart, 1-5 mm. 
long, straight or slightly upcurved, triangular, rather lenticularly widened into the nearly straight, denticulate margin; inflorescence 3-4 meters tall, the upper half narrowly paniculate, with very short branches; capsule oblong, 5-6 cm. long, $2 \mathrm{~cm}$. broad; seeds about $7 \mathrm{~mm}$. long and $5 \mathrm{~mm}$. wide.

Judging from the original habit photograph of this species, it is one of the agaves growing along the very steep hillsides above the road leading down from Zunil to Santa María. Agaves are very plentiful in this region, at least on slopes too steep for planting with corn (which means almost perpendicular), but although we have made numerous Agave collections in this region, none of them are certainly identifiable with $A$. samalana.

Agave Seemanniana Jacobi, Abh. Schles. Ges. Vaterl. Cult. 1868: 154. 1868. Maguey.

Dry, rocky, open or brushy slopes, 400-2,200 meters; Baja Verapaz; Zacapa; Chiquimula; Jalapa; Jutiapa; Guatemala; Sololá. Also in Nicaragua, the type from Segovia.

Plants acaulescent, producing few or no offshoots; leaves glaucous, spreading or somewhat incurved, oblanceolate-oblong or obovate, acute or acuminate, minutely roughened toward the apex, about $35 \mathrm{~cm}$. long and $8 \mathrm{~cm}$. wide; terminal spine purplish brown, somewhat lustrous above, minutely granular below, slenderconic or acicular, sometimes somewhat flexuous, involutely grooved from below the middle with acute edges, decurrent for its own length or less, scarcely intruded into the green tissue, 2-3 cm. long, 2-4 mm. thick; marginal teeth brown or becoming gray, 1-2 cm. apart, 2-3 mm. long or somewhat larger, rather straight but the lower ones directed downward, the slender cusps triangular, abruptly dilated to the tops of fleshy prominences between which the slightly concave margin sometimes bears slender dark denticles; inflorescence about 2-4 meters tall, or sometimes higher, the panicle oblong, the flowers densely crowded into short-stalked subglobose clusters; capsule broadly oblong, deeply trisulcate, about $3.5 \mathrm{~cm}$. long and $1.5 \mathrm{~cm}$. broad.

The seed pods of this species are said to be used in Jutiapa for poisoning fish, and in the same region it is stated that the young and more tender leaves are sometimes roasted and eaten. Such use of Agave leaves for food was formerly common among the Indians of the southwestern United States. The flesh is said to contain a large amount of sugar, thus making it palatable. In Huehuetenango also the leaves are gathered for food, as the authors have observed in the mountains above Chiantla. A. Seemanniana has been introduced into cultivation in Europe, and even carried to Australia. Several minor varieties have been described from cultivated plants.

Agave sicaefolia Trelease, Trans. Acad. Sci. St. Louis 23: 141. pl. 17. 1915. 
Dry open hillsides and in hedges, ascending from about 300 to 3,000 meters; El Progreso (type from El Rancho, Trelease 6); Totonicapán (San Francisco el Alto to Momostenango); endemic.

Plants acaulescent, often forming dense clumps; leaves gray-green or glaucous, numerous, crowded, lanceolate, acuminate, almost flat to deeply concave, slightly granular beneath toward the apex, $60-75 \mathrm{~cm}$. long and 7-8 cm. wide or even larger, rather thick but flexible; terminal spine purplish chestnut to grayish brown, rather lustrous, granular below, triquetrous, almost straight, flattened on the upper surface or very openly grooved, with acute short-decurrent margin, somewhat intruded dorsally and ventrally into the green tissue, $3-4 \mathrm{~cm}$. long, $4 \mathrm{~mm}$. thick; marginal teeth colored like the spine, somewhat lustrous, $1.5-3.5 \mathrm{~cm}$. apart, 3-5 mm. long, mostly upcurved, the cusps rather slender, sometimes uncinate, lenticular-dilated at the base, the rather concave intervening margin sometimes with 1 or more minute brown teeth; inflorescence unknown in details, but in the dry state 3-4 meters tall, the flowers in very dense and large, short-stalked clusters, forming a narrow panicle.

The Momostenango plant grows in a region remote from the type locality, but leaf material of it agrees well with the original diagnosis and illustration. This is a large and conspicuous plant, prominent on the hillsides where it grows.

Agave sisalana Perrine, U. S. Sen. 25th Congr. Sess. 2. Doc. 300: pls. 1, 2, 4. 1838. Maguey.

Planted abundantly in some regions, and, often escaping, seen in many localities in hedges or fence-rows; Petén; Alta Verapaz; Baja Verapaz; El Progreso; Santa Rosa; Escuintla; Suchitepequez. Native of the Yucatan Peninsula, but cultivated in many other tropical regions upon a small or large scale.

Plants acaulescent or with a short caudex (exposed after the leaves have been cut); leaves sword-shaped, about 1.5 meters long and $10 \mathrm{~cm}$. wide, lightly glaucous, becoming green, almost flat, the terminal spine chestnut-colored, conic, sometimes lightly recurved, shallowly round-grooved toward the base, not decurrent upon the green tissue, 2-2.5 $\mathrm{cm}$. long, 4-5 mm. thick, the margins unarmed or with a few rudimentary teeth; flowers $4.5-6 \mathrm{~cm}$. long, the ovary and lobes of about equal length; anthers $2.5 \mathrm{~cm}$. long; bulblets often produced in large numbers.

Called "mescal" in Honduras; the Maya name of Yucatan is "yaxci." The typical form of the species has almost unarmed leaves; f. armata Trelease (Contr. U. S. Nat. Herb. 23: 118. 1920) has the leaf margins rather closely beset with small spiny teeth; both occur in Guatemala. This plant is of great commercial importance, and is the basis of the principal industry and the prosperity of Yucatan. Its fiber is the only one wholly satisfactory for manufacture of the twine used in binding bundles of wheat when that grain is harvested. Although the plant (its product is known in the United States as 
"sisal" or "sisal hemp") has been introduced into various parts of the tropics and planted more or less extensively, Yucatan continues to be the chief source of the fiber. Sisal has been planted in small amounts in various parts of the Guatemalan lowlands, but the principal and only large plantation is one in Alta Verapaz near Santa Cruz. This produces sufficient fiber, it is said, for manufacture of a large part of the coffee sacks used in Guatemala. Rope also is made of it, and the rope of Cobán is sold all over Guatemala. It is impossible to say what part of the rope and textiles sold in Guatemala are made of sisal and what part of Furcraea, for the two sometimes are grown together, and it is not certain that ordinarily any distinction is made between them.

Agave tecta Trelease, Trans. Acad. Sci. St. Louis 23: 145. pls. 26, 27. 1915. Maguey.

Abundant in hedges in many regions in the western highlands, and not observed in a truly wild state, 1,500-2,600 meters; Chimaltenango; Totonicapán; Huehuetenango; Quezaltenango (type from Quezaltenango, Trelease 17); probably also in Quiché and San Marcos, although we have no notes or specimens to authenticate its occurrence there; reported by Trelease also from Sacatepéquez and Guatemala; endemic.

Plants very large and coarse, acaulescent, producing offshoots; leaves grayish green or rather dark green, lanceolate or broadly lanceolate, ascending and then often outcurved, acuminate, very concave and trough-like, smooth, 1-2 meters long, $50 \mathrm{~cm}$. wide or narrower, very thick; terminal spine chestnut-colored, becoming gray, dull, smooth, conic or subacicular, often slightly flexuous, shallowly grooved below the middle, $4.5-6.5 \mathrm{~cm}$. long, 5-7 mm. thick, long-decurrent, somewhat intruded dorsally into the green tissue; marginal teeth colored like the spine, of ten lustrous, 4-7 cm. apart, about $8 \mathrm{~mm}$. long, recurved, the cusps triangular, often curved, abruptly dilated into low bases $15 \mathrm{~mm}$. wide or more, the smooth intervening margin almost straight; inflorescence 5-6 meters tall, the panicle ellipsoid, rather openly branched, the bracts broadly triangular, densely imbricate below and sometimes completely covering the scape, those of the panicle smaller and spreading, the thick pedicels $1 \mathrm{~cm}$. long or less; flowers yellow, about $7 \mathrm{~cm}$. long, the ovary $3-3.5 \mathrm{~cm}$. long; perianth tube obconic, 1-1.5 $\mathrm{cm}$. long, the lobes about $2 \mathrm{~cm}$. long; filaments long-exserted; capsule oblong, about $6 \mathrm{~cm}$. long and $3 \mathrm{~cm}$. broad.

This is one of the few easily recognizable Agave species of Guatemala, distinguished by its massive leaves of trough-like form. It is perhaps the most conspicuous plant of the plains about Quezaltenango, where there are many miles of hedges composed of it and Opuntia, imposing in appearance but none too handsome, at least during the dry months when the leaves are more than ordinarily 
gray with dust. The species is related to the Mexican group of agaves that supply pulque, and it may have been introduced into Guatemala from Mexico. While this is possible, it is less probable, because the size of the plants would make their transportation from such a distance difficult. It seems more likely that the plant was originally native in the Quezaltenango region and perhaps elsewhere in Guatemala, but that the wild plants have all been reset in the hedges. It is recorded by Fuentes y Guzmán (Recordación Florida 1: 289. Madrid, 1882; fide Trelease) that two centuries ago excellent pulque was produced at Almolonga or Ciudad Vieja in Sacatepéquez and at San Gaspar. Quite possibly this was the result of the influence of the Mexican mercenaries who took part in the conquest of Guatemala. Trelease is of the opinion that Agave tecta must have been the species used for the purpose. Of course, it is conceivable that there may have been large plantations formerly about Antigua and that the plants were destroyed when pulque was no longer demanded or permitted. From the few plants of Nopalea now surviving about Antigua, one would never suppose that in the valley there were formerly hundreds or thousands of acres of Nopalea grown for production of cochineal. The concave leaves of Agave tecta are sometimes lapped end over end to make troughs for conducting water short distances. Their irregular form makes them rather unsatisfactory for this purpose.

Agave tenuispina Trelease, Trans. St. Louis Acad. Sci. 23: 140. pl. 15. 1915. Maguey.

At about 1,200-1,500 meters; El Progreso (type from Cruz, on mountain sides, Trelease 4); Jalapa; Huehuetenango.

Plants acaulescent, with few or no offshoots; leaves glaucous, forming a rather compact rosette, narrowly lanceolate, acuminate, smooth, about $70 \mathrm{~cm}$. long and as much as $20 \mathrm{~cm}$. wide, stiff; terminal spine dull brown, acicular, smooth or somewhat roughened at the base, slightly undulate or straight, involutely grooved from above the middle with rather blunt edges, decurrent for hardly half its length and not intruded into the green tissue, 6-7 $\mathrm{cm}$. long, $3 \mathrm{~mm}$. thick; marginal teeth brown, somewhat lustrous, 2-4 cm. apart, 5-10 mm. long, curved in either direction, rather narrowly triangular, somewhat deltoidally dilated into fleshy prominences; inflorescence unknown.

The determination of the Huehuetenango material is perhaps questionable, but it agrees well enough with the original description and illustration of the species.

Agave Thomasae Trelease, Trans. Acad. Sci. St. Louis 23: 138. pl. 12. 1915. 
Described from a plant cultivated at Quezaltenango, said to have come from the mountains, Trelease 19, in April, 1915; a collection from hillsides near Zunil, 2,200 meters, probably represents the same species.

Plants acaulescent, producing offshoots; leaves green or slightly grayish, ascending with an outcurved tip, spatulate-oblanceolate, acute or acuminate, not very thick, flexible or rather stiff, concave, smooth above, finely roughened beneath, about $60 \mathrm{~cm}$. long and $15 \mathrm{~cm}$. wide or sometimes larger; terminal spine chestnutcolored, somewhat roughened, acicular, almost straight, involutely grooved below the middle with acute edges, little decurrent or intruded into the green tissue, about $2.5 \mathrm{~cm}$. long and $2 \mathrm{~mm}$. thick; marginal teeth colored like the spine, 5-10 $\mathrm{mm}$. apart, 1-3 mm. long, almost straight, the slender cusp slightly dilated at the base, the straight intervening margin with numerous minute needle-like teeth; inflorescence unknown.

A plant that probably represents this species has been noted in patios at several places in Quezaltenango. The leaves are much less armed, except apically, than in most of the other species. The species was named for Sra. Dora Thomas, who owned the type plant.

Agave tortispina Trelease, Trans. Acad. Sci. St. Louis 23: 135. pl. 6. 1915.

El Rancho (type from Cruz, Trelease 1).

Plants acaulescent, producing few offshoots; leaves very blue-glaucous, ascending in a close rosette, broadly oblong-oblanceolate, acute, concave, minutely granular beneath, 35-60 cm. long, 15-20 cm. wide; terminal spine gray, dull or slightly lustrous, more or less granular, stoutly half-conic or triquetrous, strongly undulate and twisted, very openly grooved from near the apex with acute edges, usually carinate dorsally and ventrally, decurrent for about its own length, more or less intruded into the green tissue, 5-6 cm. long, $8 \mathrm{~mm}$. thick; teeth colored like the spine, rather dull, 2.5-5 cm. apart, 5-10 mm. long, more or less curved, especially downward, heavily triangular, abruptly dilated into fleshy prominences, the intervening margin somewhat concave; inflorescence unknown.

At first glance this would seem to be a distinct species, but there is some question whether the undulate and twisted form of the terminal spine is a dependable character, rather than a freak. It is doubtful whether the plant is really different from $A$. Seemanniana.

The following species were described by Berger almost immediately after publication of the Trelease paper. All were based upon young plants growing in Germany, sent from Guatemala by W. Eichlam. No illustrations were published, and the identity of the plants named is uncertain, although it is to be presumed that they are synonymous with some of the species described above. 


\section{Agave Caroli-Schmidtii Berger, Agaven 199. 1915.}

Based on plants sent from Guatemala by W. Eichlam and grown at Erfurt, Germany.

Plants acaulescent, without offshoots; leaves erect, ovate-spatulate, strongly narrowed toward the base, broadest above the middle, short-pointed, flat but with somewhat incurved margins, smooth, or somewhat roughened near the base, bright gray, almost white beneath; terminal spine $2.5-3 \mathrm{~cm}$. long, short-decurrent, somewhat intruded beneath into the green tissue, blackish brown, lustrous; marginal teeth on elevated projections, spreading, the cusp narrow-deltoid, upcurved or down-curved, blackish brown, 8-10 $\mathrm{mm}$. long.

\section{Agave Eichlami Berger, Agaven 200. 1915.}

Described from a plant grown at Erfurt, Germany, sent from Guatemala by W. Eichlam.

Plants acaulescent, without offshoots; leaves erect, lance-spatulate, acuminate, concave above, bright gray, especially beneath, smooth or rough above, very rough beneath; terminal spine straight, long-decurrent, roughened dorsally, blackish brown, about $3 \mathrm{~cm}$. long; marginal teeth with a lenticular base, the cusp deltoid, curved downward or less frequently upward, $8-10 \mathrm{~mm}$. long, blackish brown, 5-8 $\mathrm{mm}$. apart, the intervening margin usually straight, the spine bases more rarely fleshy.

Berger described also a var. interjecta (loc. cit.), with less decurrent terminal spine.

\section{Agave guatemalensis Berger, Agaven 201. 1915.}

Type grown at Erfurt, Germany, sent from Guatemala by W. Eichlam.

Plants acaulescent, without offshoots; leaves erect, more or less recurved from the middle, thick-fleshy, ovate-spatulate, acute, concave above, more or less gray-green, smooth, rough beneath, pale gray; terminal spine strong, soon becoming gray, somewhat flexuous or straight, flat below and decurrent upon the blade, about $3 \mathrm{~cm}$. long, decurrent for about $2 \mathrm{~cm}$.; marginal teeth with semilunate base, the cusp gray, deltoid and straight or curved downward, about $8 \mathrm{~mm}$. long, 1-2 $\mathrm{cm}$. apart.

\section{Agave Weingartii Berger, Agaven 200. 1915.}

Type cultivated at Erfurt, Germany, sent from Guatemala by W. Eichlam.

Plants acaulescent, the leaves not very dense, lanceolate or lance-spatulate, rather thin, acuminate, concave above, usually smooth and apple-green shaded with gray, beneath bright gray and mostly rough; terminal spine $3 \mathrm{~cm}$. long, slender, finely roughened, lustrous blackish brown, decurrent on the green tissue for 2-3 $\mathrm{cm}$; marginal teeth on the upper fourth or fifth of the leaf, the teeth $8-20 \mathrm{~mm}$. apart, deltoid from a lenticular base, less often on fleshy projections, blackish brown, mostly 2-5 $\mathrm{mm}$. long. 


\section{BOMAREA Mirbel}

Scandent herbs, often with greatly elongate stems, glabrous or pubescent, the roots slender, often bearing at the tip large tubers; leaves narrow or broad, many-nerved, acute, abruptly short-petiolate; flowers large and showy, usually red and yellow, often spotted, in simple or compound umbels; perianth funnelform, the segments distinct, those of the 2 series dissimilar; stamens attached to the bases of the segments, about equaling them, the filaments filiform, the anthers oblong, basifixed; ovary 3-celled, the ovules numerous, the style filiform, the stigma trifid; capsule turbinate or subglobose, truncate at the apex, 6-costate, tardily dehiscent; seeds subglobose, covered with a bright red, pulpy testa.

A large American genus, with probably one hundred or more species, most of them Andean. One or two besides those listed here occur in Costa Rica and Panama. In Costa Rica the name Papa de venado is given to the plants. The watery tubers are said to be edible but almost flavorless.

Rays of the umbel 1-flowered, usually without bractlets, very densely shortvillous........................................ Rays of the umbel mostly 2-3-flowered, usually bracteolate, glabrate or sparsely

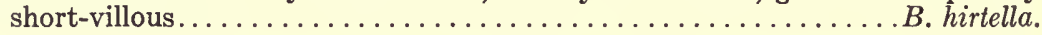

Bomarea acutifolia (Link \& Otto) Herb. Amaryll. 112. 1837. Alstroemeria acutifolia Link \& Otto, Icon. 1: 5. pl. 29. 1820. Granadillo de canté (fide Aguilar).

Damp forest or thickets in the mountains, 1,800-3,500 meters; El Progreso; Zacapa; Jalapa; Sacatepéquez; Chimaltenango; Sololá; Quiché; Huehuetenango; Quezaltenango; San Marcos. Mexico; perhaps also in Costa Rica and Panama.

A small or large vine, the soft herbaceous stems glabrous or nearly so, bearing many leaves; leaves ovate to lanceolate, mostly $5-15 \mathrm{~cm}$. long, acuminate or attenuate, on short slender petioles, obtuse or rounded at the base, paler beneath and glabrous or sparsely pilose; rays of the umbel 5-30, 2-5 cm. long, densely villous with brownish hairs, naked or bracteolate at or near the base; ovary villous; perianth 2.5-4 $\mathrm{cm}$. long, the outer segments oblong, orange-red with green tip, or sometimes greenish throughout, the inner segments cuneate-spatulate, clawed, orange-yellow and brick-red, truncate at the apex.

Like other species of the genus, this is a handsome and showy plant because of its vividly colored flowers. When occurring in quantity, it affords a fine display of color, but in Guatemala, at least during the drier months, plants of the genus seldom are found in profusion.

Bomarea hirtella (HBK.) Herb. Amaryll. 112. 1837. Alstroemeria hirtella HBK. Nov. Gen. \& Sp. 1:284. 1815. B. miniata Kunth, 


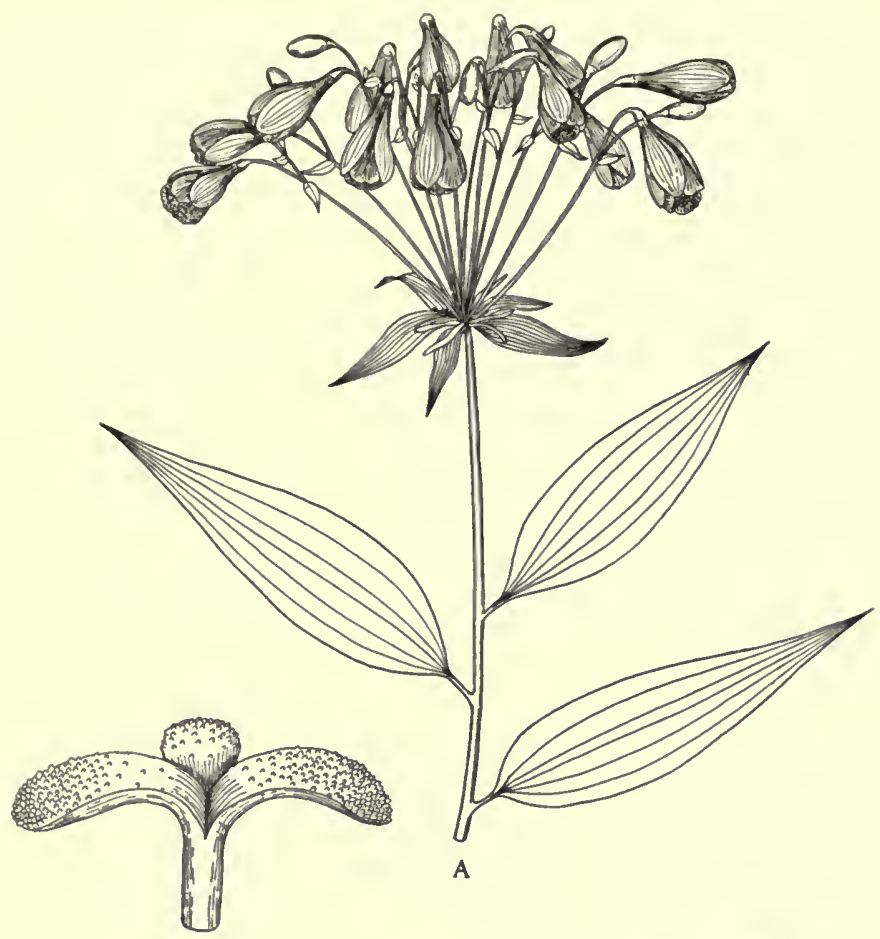

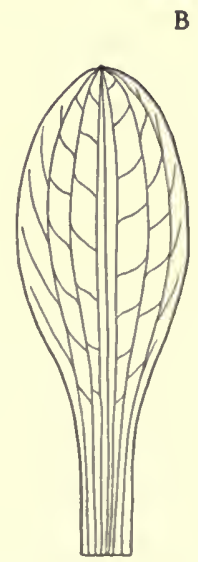

C

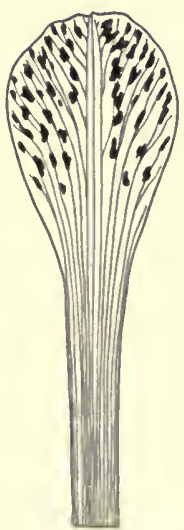

D

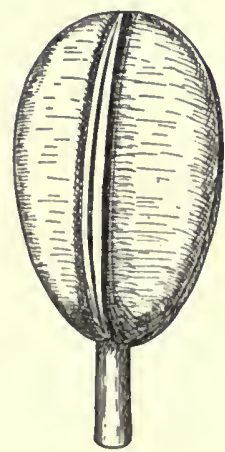

E

FIG. 23. Bomarea hirtella. A. Upper portion of flowering stem; $\times 1 / 3$. B. Stigma and upper part of style; $\times 13$. C. Outer perianth segments; $\times 2$. D. Inner perianth segments; $\times 2$. E. Anther and upper portion of filament; $\times 13$. 
Enum. Pl. 5: 792. 1850. Granadillo de monte (Guatemala, fide Aguilar); Bate (San Ildefonso Ixtahuacán, Huehuetenango).

Damp or wet forests or thickets, $800-3,000$ meters, rarely at lower elevations; Petén (La Libertad); Alta Verapaz; Zacapa; Chiquimula; Jalapa; reported from Santa Rosa; Guatemala; Sacatepéquez; Chimaltenango; Sololá; Huehuetenango; San Marcos. Mexico; Honduras; perhaps farther southwäard into Costa Rica.

A small or rather large vine, the slender stems usually glabrous, sometimes sparsely villous; leaves evidently petiolate, usually elongate-lanceolate, as much as $16 \mathrm{~cm}$. long and $1.5-2.5 \mathrm{~cm}$. wide, acuminate or attenuate, usually abruptly contracted and rounded at the base, glabrous above, paler beneath and of ten hirtellous or villous; umbels usually large and with elongate rays, these glabrous or sparsely short-villous, bearing one or more green ovate bracts and mostly 2-3 flowers, some of the rays only 1-flowered; ovary commonly sparsely shortpilose or almost glabrous; perianth $3-3.5 \mathrm{~cm}$. long, the outer segments pale red, rose-pink, or salmon, the inner ones pale green or pale pink with dark brown spots, spatulate; capsule $2-3 \mathrm{~cm}$. broad, soon opening and exposing the bright red seeds. (Fig. 23.)

By some authors $B$. miniata is recognized as a distinct species, but the characters by which it is separable from $B$. hirtella are not apparent to the writers. Guatemalan material of $B$. hirtella has been variously referred to $B$. Caldasiana Herb., B. Caldasii (HBK.) Stand., and $B$. ovata (Cav.) Mirb., species not known to occur in Central America. This plant, like others of its genus found in Central America, usually attains its best development not within the forest but on bushes at the outer forest edge, where it is more or less exposed to the sun.

\section{CRINUM L.}

Plants arising from large tunicated bulbs having many coats and usually an elongate neck; leaves persistent, strap-shaped, often broad, succulent, the scape solid; flowers umbellate, few or numerous, white or reddish, the pedicels short or none; spathe valves 2, broad, membranous; perianth salverform or funnelform, the tube long and slender, often greatly elongate, straight or somewhat curved, the segments linear or lanceolate, subequal; stamens inserted in the throat of the perianth tube, the filaments long and filiform, the anthers linear, versatile; ovary 3-celled, with few, sometimes only 2, ovules in each cell; style long and filiform, the minute stigma capitate; fruit irregular in shape, tardily dehiscent; seeds large, green and bulblike, with very thick endosperm.

About eighty species are listed, widely distributed in the tropics of both hemispheres, but they are poorly known for the most part, and the true number is very uncertain. One other Central American species has been described from Panama. 
Perianth funnelform, the segments often equaling the tube, linear-lanceolate; flowers distinctly pedicellate.................... longifolium. Perianth salverform, the segments usually much shorter than the tube; flowers sessile.

Perianth segments narrowly linear....................... cruentum.

Perianth segments linear-lanceolate, usually $1 \mathrm{~cm}$. wide or more. .C. erubescens.

\section{Grinum cruentum Ker in Lindl. Bot. Reg. pl. 171. 1817.}

Seen in cultivation at Quiriguá (Izabal) and elsewhere, and probably native along the north coast. Reported from Mexico; British Honduras: Atlantic coast of Honduras; Costa Rica.

Bulbs large, with only a short neck, stoloniferous; leaves sometimes a meter long, 4-7 cm. wide, dark green, gradually narrowed to the acute apex; scape stout, somewhat compressed, 60-90 cm. long; flowers commonly 6-8, sessile and crowded, the spathe valves lance-deltoid, $7 \mathrm{~cm}$. long; perianth tube very slender, $10-20 \mathrm{~cm}$. long, $2-3 \mathrm{~mm}$. thick in the dry state, the lobes pink or white, 7-13 cm. long, $3 \mathrm{~mm}$. wide; filaments red; anthers linear, about $12 \mathrm{~mm}$. long.

Grinum erubescens Ait. Hort. Kew. 1: 413. 1789. Lirio silvestre; Reina blanca, Reina rosa (fide Aguilar).

Wet soil or shallow water, usually at the margins of streams or lakes, chiefly at low elevations, but collected as high as 1,800 meters, perhaps only in cultivation; Alta Verapaz; Izabal; Santa Rosa; Guatemala; Suchitepequez; Retalhuleu. Mexico to Panama; West Indies; South America.

Bulbs ovoid, 7-10 cm. in diameter, with a short neck; leaves numerous, thin, 60-90 cm. long, 4-7 cm. wide, rather blunt at the apex, the margins slightly roughened; scape $60 \mathrm{~cm}$. high or more, stout; flowers 4-12 in the umbel, sessile or essentially so, the spathe valves lance-deltoid, green, about $7 \mathrm{~cm}$. long; perianth tube very slender, $10-15 \mathrm{~cm}$. long, $3-4 \mathrm{~mm}$. thick in the dry state, the segments half as long as the tube or shorter, linear-lanceolate, about $1 \mathrm{~cm}$. wide, usually white within and red-purple outside, sometimes wholly white; filaments bright red, at least above; anthers linear, about $12 \mathrm{~mm}$. long.

Called "lirio" in Salvador and doubtless also in Guatemala. It is questionable whether the plant is native much above sea level, but it is frequent in cultivation in many of the gardens of mountain regions. It is particularly plentiful about Tactic, Alta Verapaz, and has run wild in that region.

Crinum longifolium (L.) Thunb. Prodr. 39. 1794. Amaryllis longifolia L. Sp. Pl. 421. 1753. C. longiflorum Herb. Amaryll. 271. 1837. A. longifolia var. longiflora Ker, Bot. Reg. pl. 303. 1818. Lirio; Reina de las flores; Reina.

Cultivated for ornament throughout the lowlands and up to the central highlands, at 1,500 meters or more; escaped from cultivation 
and more or less naturalized in some parts of the lowlands, at least about the sites of former dwellings. Native of South Africa, but now generally cultivated in tropical regions.

Plants sometimes forming dense clumps, the bulb 7-10 $\mathrm{cm}$. thick, narrowed into a very long and thick neck; leaves few or numerous, ensiform, acute or acuminate, sometimes 1.5 meters long but usually shorter, recurved, $4-8 \mathrm{~cm}$. wide, rather pale, often slightly roughened on the margins; flowers $6-8$ or more, on short stout pedicels, the spathe valves deltoid, 7-10 cm. long; perianth tube greenish, 10-12 cm. long, the segments linear-lanceolate, usually white within, rose-purple outside, mostly $1-1.5 \mathrm{~cm}$. wide, acute, often connivent; filaments much shorter than the perianth lobes, the anthers linear, about $12 \mathrm{~mm}$. long.

This species is much planted in the gardens of the lowlands, and it thrives with little or no attention. It is planted frequently also in the uplands, especially in parks. The long bulbs, projecting far above the ground, are conspicuous, as are also the large broad leaves. The flowers are rather showy, but scarcely handsome enough to warrant the name of "reina de las flores" so often given in Guatemala to the plant.

\section{CURCULIGO Gaertner}

Plants with short, sometimes tuberous or corm-like rhizomes covered with reticulate fibers; leaves radical, usually elongate-lanceolate, plicate-veined, small and grasslike or sometimes large; flowers spicate, the spikes sessile among the leaves and few-flowered or sometimes long-pedunculate, the bracts linear, the whole inflorescence often villous; perianth 6-parted, borne at the apex of a very long and slender, tube-like elongation of the ovary, this resembling a corolla tube, the perianth segments subequal, spreading; stamens 6 , attached at the base of the segments, the filaments short, the anthers linear, erect, shorter than the perianth; ovary 3-celled, usually produced into a long tube-like beak, the style short, columnar, the 3 stigmas oblong, erect; ovules 2-many in each cell; fruit somewhat succulent, indehiscent; seeds subglobose, black.

About a dozen species in the tropics of America, Asia, Africa, and Australia. A single species is native in Central America.

Curculigo scorzoneraefolia (Lam.) J. G. Baker, Journ. Linn. Soc. Bot. 17: 124. 1878. Hypoxis scorzoneraefolia Lam. Encycl. 3: 183.1789 .

Mostly in savannas or other grassy places, chiefly at 1,000 meters or less; Petén; Alta Verapaz; Santa Rosa; Huehuetenango. Southern Mexico; Honduras; Nicaragua; Costa Rica; Panama; West Indies; South America.

Plants small and low, with oblong corms; leaves few, usually 2-3, erect, linearlanceolate, mostly $10-30 \mathrm{~cm}$. long and 5-20 mm. wide, long-attenuate, narrowed downward into a distinct slender petiole, thin, many-nerved, sparsely pilose; 


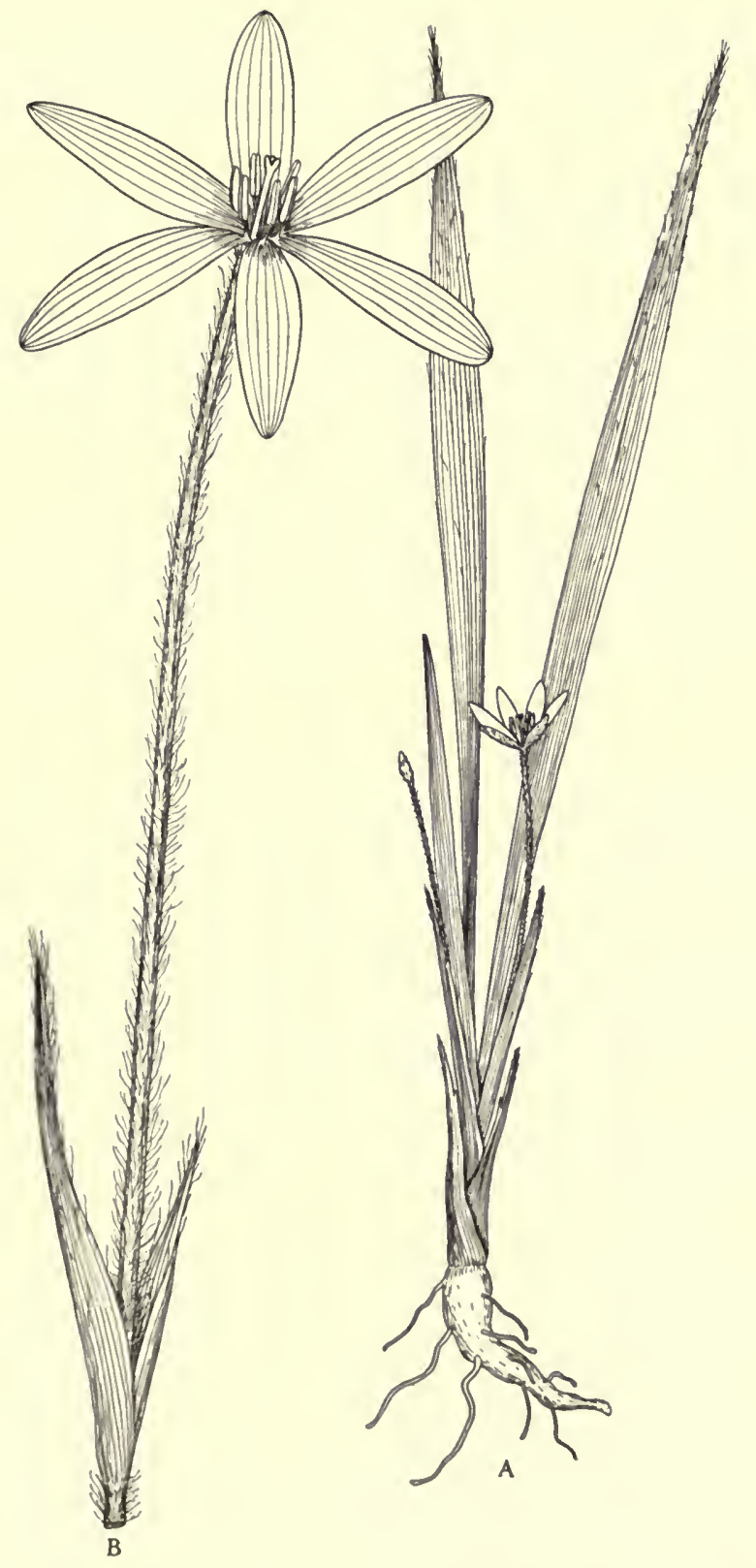

FIG. 24. Curculigo scorzoneraefolia. A. Habit of plant; $\times 2 / 3$. B. Flower with bracts; $\times 3$. 
flowers sessile, only 1 developing at a time, the false perianth tube almost filiform, usually $1.5-2.5 \mathrm{~cm}$. long, appressed-pilose; perianth yellow, the segments ellipticlanceolate, 1-1.5 cm. long, acute or acuminate, sparsely pilose outside. (Fig. 24.)

Curculigo capitulata (Lour.) Kuntze, Rev. Gen. 703. 1891. Leucojum capitulatum Lour. Fl. Cochinch. 199. 1790. C. recurvata Dryand. in Ait. Hort. Kew. ed. 2. 2: 253. 1811.

This species, native of southeastern Asia and tropical Australia, is sometimes cultivated for ornament in Guatemala and in other parts of Central America. It has a tendency to spread and establish itself, and is rather well naturalized in the cemetery at Retalhuleu and in the Jardín Botánico, Guatemala.

A coarse plant of somewhat palm-like appearance, the bright yellow, starlike flowers in dense short-pedunculate clusters at the bases of the leaves. The erect thin leaves are long-petiolate and as much as a meter tall, and 4-12 cm. wide.

In Salvador the plant is called "coquillo."

\section{EUCHARIS Planch. \& Linden}

Plants arising from a tunicated bulb; leaves few, broad, abruptly contracted at the base into a slender petiole; flowers few, large and showy, pure white, umbellate; outer spathe valves 2 , ovate-lanceolate, the inner numerous, linear; perianth tube cylindric, with a dilated throat, somewhat curved; perianth segments equal, oblong or ovate, spreading; stamens inserted at the throat of the perianth tube, shorter than the segments, the filaments variously appendaged downward, the anthers versatile; ovary globose, 3-celled; ovules many in each cell, rarely 2, superposed; style filiform, the stigma capitate, 3-lobate; capsule deeply 3-lobate, tardily dehiscent; seeds large, bulbiform, sometimes solitary.

Half a dozen species, chiefly in the northern Andes. One species is native in Costa Rica.

Eucharis grandiflora Planch. \& Linden, Fl. Serres I. 9: 255. 1853-54. Eucaria.

Planted frequently in gardens for ornament, especially in the lowlands, but also as high as Guatemala (1,500 meters). Native of the Andes of Colombia.

Bulbs globose, about $5 \mathrm{~cm}$. in diameter; leaves 2-4, the petiole $15-30 \mathrm{~cm}$. long; leaf blades oblong to elliptic or oval, often $30 \mathrm{~cm}$. long, 10-15 cm. wide, abruptly short-acuminate, rounded to attenuate at the base; scape terete, $35-60 \mathrm{~cm}$. tall; flowers 4-6 in the umbel, on pedicels $1-2.5 \mathrm{~cm}$. long; outer spathe valves ovatelanceolate; perianth tube somewhat curved, $5 \mathrm{~cm}$. long, the throat $12-15 \mathrm{~mm}$. broad; perianth lobes oblong-ovate, $3.5-5 \mathrm{~cm}$. long, pure white, obtuse; stamen cup of 6 quadrate connate segments, with a short lanceolate filament at the center of the base of each; ovules about 20 in each cell. 
The plant is a handsome one because of its pure white flowers, but it appears to be a rather shy bloomer.

\section{FURGRAEA Ventenat}

Reference: William Trelease, Trans. Acad. Sci. St. Louis 23: 147150. 1915.

Large plants with an erect, hypogaean or subterranean caudex; leaves densely crowded at the apex of the caudex, long and narrow, thin or rather thick, the margins spinose-dentate or subentire; panicles large, terminal, usually pyramidal, the flowers pedicellate in the axils of bracts, solitary or fasciculate, white or greenish white, often replaced by bulblets; perianth rotate, cleft almost to the base, the segments equal, oval-oblong; stamens affixed to the bases of the perianth segments and shorter than them, the filaments dilated below the middle, subulate above, the anthers linear-oblong, dorsifixed, shallowly bilobate at the base; ovary oblong, 3-celled, usually short-rostrate at the apex, the style columnar, thickened below the middle, the stigma small, obscurely trilobate; ovules numerous in each cell, biseriate; capsule oblong or ovoid, loculicidally 3 -valvate; seeds numerous, flattened.

About fifteen species, in Mexico, Central America, and western South America. The generic name has often been written Fourcroya or Furcroea. The leaves, as in Agave, contain a tough fiber, which is sometimes used commercially as well as locally. The fiber of the Brazilian $F$. gigantea Vent. has been exploited under the name of Mauritius hemp. Some of the Central American species reproduce principally by bulblets that replace the flowers. The bulblets often are found in great quantities beneath the plants, where under favorable conditions they take root and grow rapidly, soon forming a dense thicket of large plants. Plants so grown are said sometimes to flower in only three years. As with the Agaves, the species of Furcraea are poorly understood, and the following treatment is far from satisfactory, although based upon the fullest data now available. Unless flowers are available, it often is difficult to determine whether a certain plant is a Furcraea or an Agave.

Leaves without spine-like teeth, the margins somewhat roughened, the leaves thin and flexible, scarcely fleshy; plants usually with short or elongate trunks.

Plants treelike, the trunk becoming sometimes 15 meters tall; flowers pubescent. F. longaeva.

Plants acaulescent or with a trunk 2 meters tall or less; flowers glabrous.

F. quicheensis.

Leaves with large or small, spine-like teeth, the margins between the teeth not roughened, smooth; plants usually acaulescent.

Leaves without teeth on the upper third or two-thirds..........F. samalana.

Leaves with spine-like teeth nearly or quite throughout. 
Leaves flattish, not very concave, the marginal teeth red or brown, rather

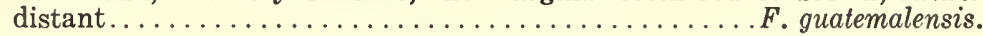

Leaves very concave, the marginal teeth blackish, close together.

F. melanodonta.

Furcraea guatemalensis Trelease, Trans. Acad. Sci. St. Louis 23: 149. pls. 32-34. 1915. Maguey; Icaj (Cobán, Quecchí); Mecate (Huehuetenango).

Open hillsides, dry rocky hills, sometimes in pine-oak forest, probably most often seen in hedges or fencerows, 900-2,300 meters; Alta Verapaz (perhaps only in cultivation); Zacapa; Jalapa; Santa Rosa; Guatemala (type from Guarda Viejo, Trelease 23); Sacatepéquez; Chimaltenango; Huehuetenango; Quezaltenango. Salvador, but probably only in cultivation.

Plants acaulescent or practically so; leaves lanceolate or sword-shaped, 2 meters long or less, 10-15 cm. wide, dull green above and grayish beneath, or sometimes rather bright green, acute, smooth or nearly so, moderately concave or often almost flat; terminal spine of the leaf short and stout, awl-shaped, the marginal teeth red-brown or paler, in age often chestnut, upcurved and compressed, 1-3 cm. apart, about $3 \mathrm{~mm}$. long, often with a very broad base; inflorescence large, 2-5 meters tall, openly paniculate, glabrous or nearly so; perianth pale green or greenish white, about $3 \mathrm{~cm}$. long, the segments oblong-elliptic, acutish, about $1 \mathrm{~cm}$. wide; capsules globose-cubical, short-stipitate or almost sessile, about $5 \mathrm{~cm}$. long and broad; seeds about $20 \mathrm{~mm}$. in greatest breadth; bulblets often abundant, globose-ovoid, with dark green, lustrous scales. (Fig. 25.)

This species is abundant in hedgerows in the vicinity of Guatemala as well as in many other parts of the central and western departments. No data are available in general regarding use made of the leaves, but doubtless fiber is extracted from them. In Alta Verapaz, however, it seems that this species has been introduced and planted' rather extensively in some places. Apparently it is planted with Agave sisalana, and perhaps no distinction is made between the two.

Furcraea longaeva Zucc. Acad. Caes. Leop. Carol. 16, pt. 2: 665. 1833; Trelease, Trans. Acad. Sci. St. Louis 23: pl. 28.

Huehuetenango (Villa Cyrnos, Cap Martín near Nentón, May 17, 1909, herb. of Alwin Berger). Southern Mexico.

The Guatemala collection cited was found in the United States National Herbarium and is the only herbarium material examined by the authors. Skinner reported it for Guatemala and his drawing accompanying one of his orchid plates is presumed to represent this species. 


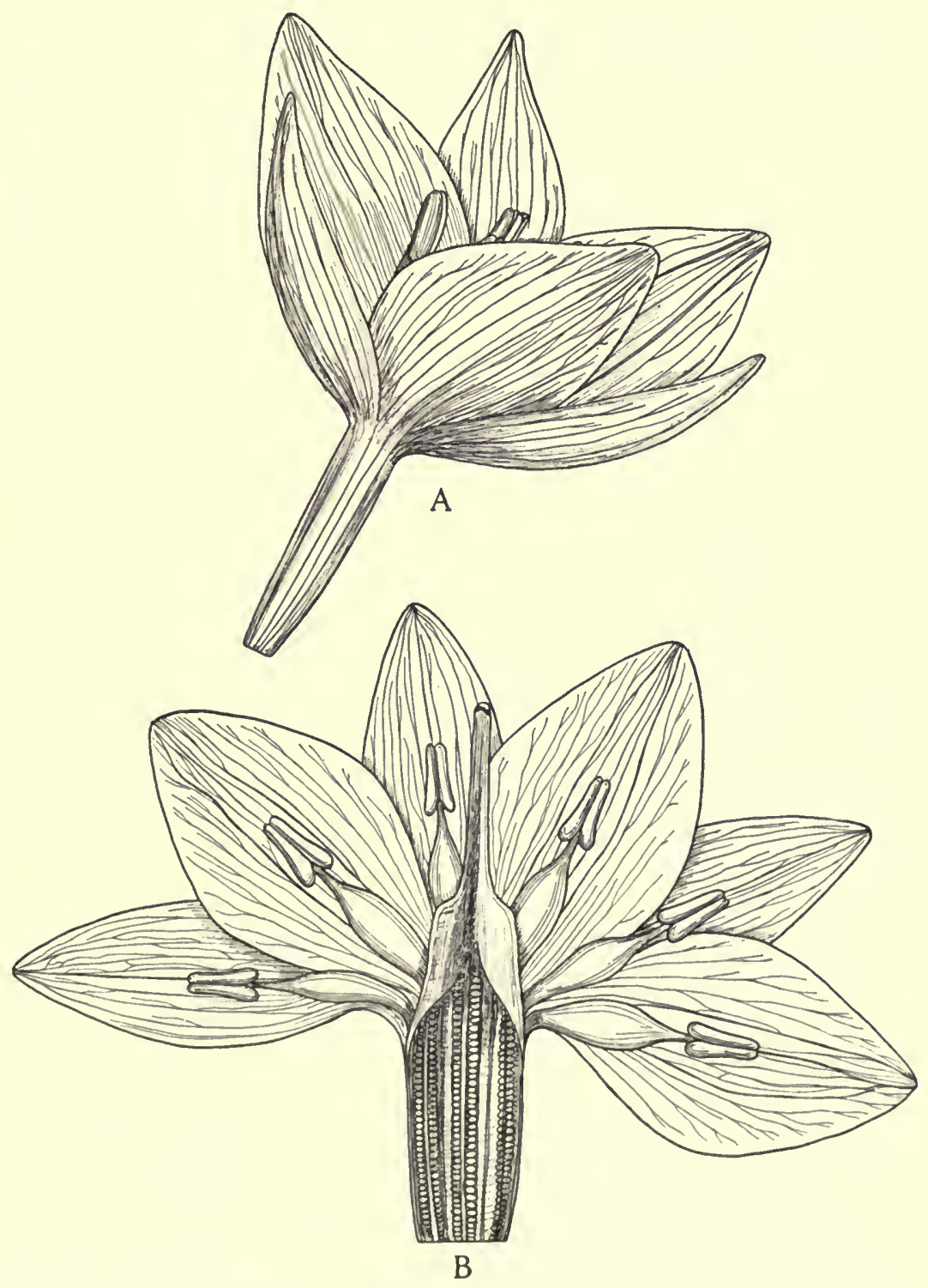

Fig. 25. Furcraea guatemalensis. A. Flower, with parts in position; $\times 11 / 2$. B. Flower opened to show position and arrangement of parts with ovary opened; $\times 11 / 2$. 
Arboreous, with a tall simple trunk sometimes 15 meters tall, the old and dead leaves reflexed and long-persistent, the younger leaves erect or spreading, grayish, sword-shaped, concave, subacuminate, as much as 2 meters long and $8-15 \mathrm{~cm}$. wide, minutely rough-margined; inflorescence to 5 meters in height, broadly conic, short-stalked; perianth $2.3-3 \mathrm{~cm}$. long, the outer segments elliptic-oblong, acutish or subacute, $8-9 \mathrm{~mm}$. wide, the inner segments ovate or elliptic-ovate, obtuse to subacute, $12-15 \mathrm{~mm}$. wide; ovary $2-2.5 \mathrm{~cm}$. long, slightly exceeding the perianth; capsule oblong, narrowed to the base; seeds about $6^{\circ} \mathrm{mm}$. long and $4 \mathrm{~mm}$. wide.

The pubescent ovary and outer surface of the perianth segments are noteworthy characteristics of this species.

Furcraea melanodonta Trelease, Trans. Acad. Sci. St. Louis 23: 150. pl. 35. 1915. Maguey.

Dry rocky hillsides or in pine-oak forest, mostly at 1,200-1,800 meters; Baja Verapaz; El Progreso (type from Cruz, Trelease 26); Chimaltenango; endemic.

Plants essentially acaulescent, the caudex in exposed places sometimes a meter high; leaves sword-shaped, grayish or bluish or sometimes rather bright green, acute, sometimes slightly roughened, 1.5 meters long or less, $7-8 \mathrm{~cm}$. wide, rather thin and almost flat or often concave; terminal spine short and stout, blunt, grooved at the base, slightly decurrent, the marginal teeth blackish or chestnut, 1-2 cm. apart, $5 \mathrm{~mm}$. long or less, strongly upcurved, broad-based and decurrent on fleshy elevations; inflorescence and capsules unknown.

It is doubtful whether this can be separated from $F$. guatemalensis, for the characters used originally to separate the two seem variable and not dependable.

Furcraea quicheensis Trelease, Trans. Acad. Sci. St. Louis 23: 148. pl. 29. 1915. Mecate; Mecatle; Cheche; Mecatl; Maguey.

Open mountain slopes, often on exposed white-sand mountain sides, sometimes in oak forest, most often, perhaps, seen in fencerows, and much planted in some regions for hedges, chiefly at 2,4003,300 meters; Sololá; Quiché (type collected between Quiché and Totonicapán, $O . F$. Cook in May, 1906); Huehuetenango; Totonicapán; Quezaltenango; San Marcos. Probably in Chiapas.

Plants acaulescent at first, but in age developing a thick naked trunk, this rarely more than 1.5 meters tall, simple or sometimes with a few branches, densely leafy at the apex; leaves very glaucous and whitish, thin and soft, in texture resembling those of Yucca filamentosa, not fleshy, linear-lanceolate, 1.2 meters long or less, mostly 6-10 cm. wide, long-attenuate, spreading or reflexed, the yellowish margins minutely and remotely denticulate and rough to the touch, the tip of the leaf narrowly rounded and blunt, without a terminal spine; panicles $2-5$ meters tall, rather narrow, the flowers pedicellate, the bracts much exceeding the pedicels; these, like the peduncles, often red; perianth pale green, $3-4 \mathrm{~cm}$. long, the segments 
suberect or somewhat spreading; anthers pale green; ovary $2.5-3 \mathrm{~cm}$. long, often purplish red; capsule about $6 \mathrm{~cm}$. long and $3 \mathrm{~cm}$. broad, contracted at the base, short-beaked, somewhat lustrous; seeds thin, black and lustrous, about $10 \mathrm{~mm}$. long and $6 \mathrm{~mm}$. wide.

This is in some respects one of the most interesting of Guatemalan plants, limited in its distribution to the highlands, where it often forms a conspicuous feature of the landscape. Westward from Guatemala, the plant is first seen in the bleak mountains of the Los Encuentros region, and from there on westward it may be observed here and there. It is most abundant in the highlands of Huehuetenango, especially above Chiantla up to the rim of the alpine region of Los Cuchumatanes, and in certain parts of Quezaltenango and San Marcos. In general appearance Furcraea quicheensis suggests a Yucca more than one of the Agaves, because of its habit and its exceedingly thin pale leaves. The pale foliage makes the plant easily recognizable even from a long distance in the mountains. It is hard to determine in just which regions the plant is native, for most of the individuals occur in fencerows or hedges, but their absence in adjoining fields probably is accounted for by the fact that the Indians have removed them to the field borders in order to clear the soil for cultivation, a clearing that in most regions took place centuries ago. In some parts of the whitesand mountains of San Marcos it seems that the Furcraea has been planted to prevent drifting of the sand that is so hard to control in these desolate regions. The plant is a very decorative and handsome one. The short trunks sometimes bear at the apex a number of perhaps adventitious buds that develop into dense clusters of leaves. The young leaves are at first cream-colored and remain so for some time, or at least until fully exposed to the sun. In this state they are much used for decorations, often like ribbon, to make bows for trimming coronas or wreaths, or to make crosses for Palm Sunday, like those of palm leaves used in the United States. For this purpose the leaves are taken by cargadores from the Occidente even to Guatemala City. The senior author saw quantities of the pale leaves used in decorating arches across the road between San Marcos and Quezaltenango on the occasion of the President's visit in January, 1941. The name mecatl is pure Nahuatl, and is the word from which the term mecate, now applied in many regions of Mexico and Central America to string of any kind, is derived. Strips of the leaves of this Furcraea are much used in the Occidente as a substitute for twine, and large bunches for this purpose were noted on sale in the market of Momostenango. 
Furcraea samalana Trelease, Trans. Acad. Sci. St. Louis 23: 149. pls. 30, 31. 1915. Maguey.

Brushy or rocky slopes, often in moist thickets but more often in dry places, ascending from sea level to about 1,650 meters, only in the Occidente; Suchitepequez; Quezaltenango (type collected in the barranco of Río Samalá between Zunil and Santa María de Jesús, Trelease 20). Salvador, perhaps only in cultivation.

Plants usually acaulescent, said to have sometimes a trunk 2 meters high, but this probably very unusual; leaves sword-shaped, green or slightly grayish, mostly 1-2 meters long and 10-15 $\mathrm{cm}$. wide, acute, almost smooth, with flat or outcurved margins, rather thin; terminal spine very short and small, usually abortive, the marginal teeth red-brown, usually none on the upper part of the leaf, 1-6 $\mathrm{cm}$. apart, $4 \mathrm{~mm}$. long or smaller, mostly upcurved, decurrent on low fleshy elevations; panicles 3-5 meters tall, narrow; perianth $2.5-3 \mathrm{~cm}$. long, the segments greenish white with a green central stripe; flowers often replaced by large bulblets, these ovoid, with dull gray-green scales, leafy-tufted at the apex.

Called "magueyón" and "magueyón macho" in Salvador, where the leaves are said to be an important source of fiber. This is perhaps the species collected in Quezaltenango by Warscewicz and reported by Hemsley under the name Furcraea Selloa K. Koch.

\section{HIPPEASTRUM Herb. Amaryllis}

Plants arising from tunicated bulbs; leaves linear or strap-shaped; scape hollow, bearing an umbel of 2 or more flowers, these pedicellate, the flowers red or whitish; perianth funnelform, commonly declinate, the tube usually short, rarely long, the segments subequal or the lowest one of the inner series narrower; stamens inserted in the throat of the perianth tube, somewhat declinate, the filaments filiform, the anthers linear or narrowly oblong, versatile; ovary 3-celled; ovules many in each cell, superposed; style long, declinate, the stigma capitate or 3 -fid; capsule globose, loculicidally 3 -valvate; seeds usually compressed, with a thin black testa.

About forty species, all apparently native of South America. Because of their handsome large flowers, many of the species have long been favorites in cultivation, and many fine forms with exceptionally large and beautifully colored flowers have been developed by hybridization or otherwise. Some of these "improved" forms may be seen in cultivation in Guatemala, especially about Cobán.

Perianth tube very slender, commonly $7-12 \mathrm{~cm}$. long......... solandriflorum. Perianth tube funnelform, usually $2.5 \mathrm{~cm}$. long or shorter........ H. puniceum.

Hippeastrum puniceum (Lam.) Urban, Symb. Antill. 4: 151. 1903. Amaryllis punicea Lam. Encycl. 1: 122. 1783. A. equestris 
Ait. Hort. Kew. 1: 417. 1789. H. equestre Herb. App. 31. 1821. Amarilis; Azucena roja.

Cultivated generally in gardens, often in large quantities, for ornament, in the lowlands and far up into the highlands; one of the most popular garden flowers of Guatemala and other parts of Central America. Native of South America, but cultivated in almost all regions of the earth, either out of doors or as a house plant.

Bulbs globose or ovoid, stoloniferous, $4-5 \mathrm{~cm}$. long or larger, the outer coats brown; leaves strap-shaped, $30-60 \mathrm{~cm}$. long, $2.5-5 \mathrm{~cm}$. wide, gradually narrowed to the apex; scape terete, pale, 40-60 cm. high, the umbel usually 2-4-flowered; spathe valves lanceolate; pedicels $3-7 \mathrm{~cm}$. long; perianth commonly $10 \mathrm{~cm}$. long or larger, usually bright red or orange-red, the segments obovate or elliptic-obovate; stamens shorter than the perianth.

Called "amapola" and "búcaro" in Salvador. Large quantities of the flowers are offered for sale in Guatemalan markets. The flowers are most plentiful about March, toward the end of the dry season, and they often appear when no leaves have yet developed. The plant frequently escapes in the lowlands, and sometimes is found in thickets, especially about Cobán and in the Pacific bocacosta. It grows luxuriantly in the lowlands where it receives little or no attention, in great contrast to the carefully tended house plants of the North.

Hippeastrum solandriflorum Herb. App. 31. 1821. Amarilis.

Cultivated commonly for ornament, especially in the Cobán region. Native from Colombia to the Guianas and northern Brazil.

Bulbs ovoid, 7-10 cm. in diameter, with a short neck; leaves strap-shaped, $35-50 \mathrm{~cm}$. long, 2.5-3.5 cm. wide; scape somewhat 2-edged, $35-60 \mathrm{~cm}$. tall or more, the umbel 2-4-flowered, the pedicels $2.5-3.5 \mathrm{~cm}$. long; spathe valves lanceolate, 5-7 cm. long; perianth narrowly funnelform, the limb $15-25 \mathrm{~cm}$. long, the slender greenish tube commonly $7-12 \mathrm{~cm}$. long; perianth segments greenish white, usually with obscure darker stripes and often tinged, especially outside, with pink or purple; anthers linear-oblong.

This is one of the favorite garden flowers of Cobán, where it is often grown in abundance for market. Large quantities of the handsome flowers appear in the Cobán market during Holy Week, when they are carried as decorations in the many religious processions, and appear upon the altars of the churches.

\section{HYPOXIS L.}

Reference: A. Brackett, Revision of the American species of Hypoxis, Rhodora 25: 120-147. 1923. 
Small plants, often pilose, with corms or short rhizomes; leaves linear, grasslike; scapes very slender and few-flowered; perianth 6-parted, the segments equal or nearly so, distinct, withering-persistent; stamens inserted on the bases of the perianth segments, the filaments short, the anthers erect, sagittate or entire; ovary 3-celled, the style short, with 3 erect stigmas; ovules numerous, in 2 rows in each cell; capsule thin-walled, circumscissile below the apex; seeds subglobose, tuberculate or echinate.

About fifty species, in temperate and tropical regions of both hemispheres. No other species are known from Central America.

Mature seeds black; outer coat of the seed firm and close, covered with crowded

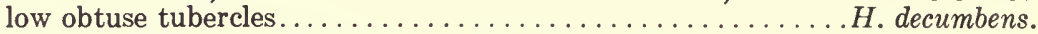

Mature seeds brown; outer coat of the seed of loose texture, rugose and contracted into rather remote minute tubercles.............. rugosperma.

Hypoxis decumbens L. Pl. Jam. Pugill. 11. 1759. H. decumbens var. major Seub. in Mart. Fl. Bras. 3, pt. 1: 51. pl. 7, fig. 1. 1847. H. racemosa Donn. Smith, Bot. Gaz. 14: 30.1889 (type from Cobán, Alta Verapaz, Türckheim 33). Cebollin de coyote (fide Aguilar).

Mostly in moist open grassy places, sometimes on dry rocky hillsides or in pine forest, 3,500 meters or lower; Petén; Alta Verapaz; Baja Verapaz; Zacapa; Jalapa; Guatemala; Sacatepéquez; Chimaltenango; Sololá; Quiché; Huehuetenango. Mexico to British Honduras; Honduras; Costa Rica; Panama; West Indies; South America.

Plants arising from cylindric or ellipsoid corms 1-2 cm. thick; leaf sheaths not separating into fibers, the blades $10-40 \mathrm{~cm}$. long, 2-12 mm. wide, sparsely pilose or glabrate; peduncles filiform, 2-12 cm. long, 1-4-flowered; perianth segments lanceolate, acute, 4-10 mm. long; fruiting pedicels $2 \mathrm{~cm}$. long or less; capsule clavate, cylindric, or oblong-ellipsoid, usually densely pilose, 6-17 mm. long; seeds black, dull or slightly lustrous, covered with low tubercles. (Fig. 26.)

Var. major (of which $H$. racemosa is a synonym) is a more robust form with relatively wide leaves. A collection from Huehuetenango (Standley 82627) is very close to $H$. hirsuta (L.) Cov. in its seed characters. It may be remarked that the American species of Hypoxis are all closely related and separated by minute characters.

Hypoxis rugosperma Brackett, Rhodora 25: 142. fig. 11. 1923.

Santa Rosa, Dept. Santa Rosa, 900 meters, Heyde \& Lux 2934 (cited by Brackett). Known otherwise only from the type, collected at Guadalajara, Jalisco, Mexico.

Corms globose or subcylindric, 6-15 $\mathrm{mm}$. thick; outer leaves separating into tufts of brown fibers, the leaves $27 \mathrm{~cm}$. long or less, $2-5 \mathrm{~mm}$. wide, pilose; peduncles pilose, 4-12 cm. long; ovary and capsule densely pilose; perianth segments narrowly elliptic or lanceolate, acute, 3-7 mm. long; capsule subcylindric or ellipsoid, 6-9 


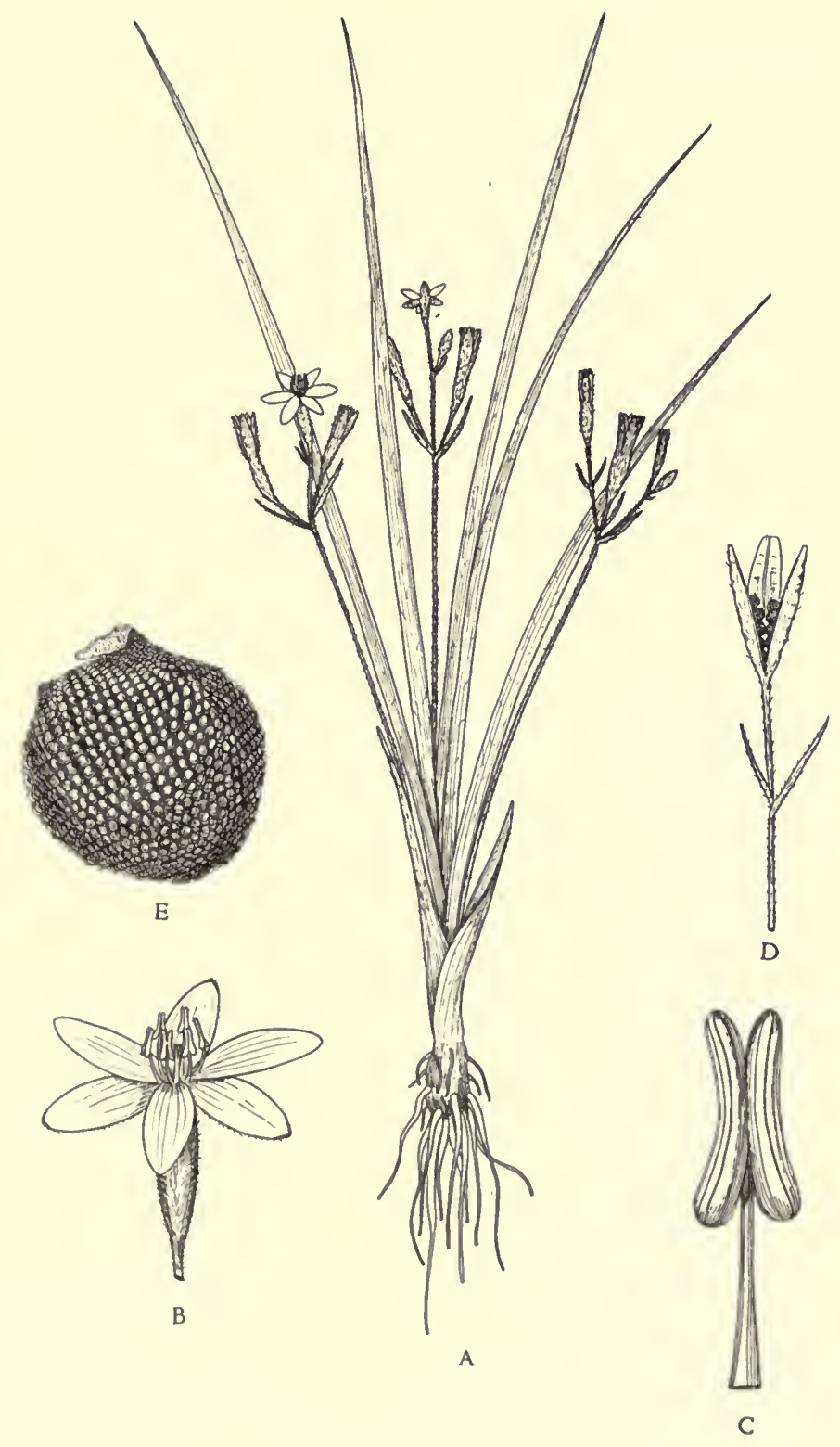

FIG. 26. Hypoxis decumbens. A. Habit of plant; $\times 2 / 3 . \quad$ B. Flower; $\times 3$. C. Stamen; $\times 15$. D. Fruiting stalk with bracts and dehiscent capsule; $\times 3$. E. Seed; $\times 30$. 
$\mathrm{mm}$. long; seeds brown, the testa loose, irregularly covered with confluent, thin, slightly jagged crests.

We have seen no material of this species.

Narcissus. A species of Narcissus with pale yellow "single" flowers was seen in bloom in March, 1939, in an Indian garden near San Marcos, where there were numerous plants. Undoubtedly it is cultivated elsewhere in the same region, since garden plants are passed on from one grower to another. No doubt the plant has been in cultivation a long time in this isolated locality, where it was surprising to find it, since the so-called "spring bulbs," such as tulips and hyacinths, are believed not to thrive anywhere in Central America. If imported, the bulbs produce flowers but once, ordinarily, and often fail to bloom at all.

\section{PANCRATIUM L. Spider Lily}

Plants with tunicated bulbs; leaves linear or usually strap-shaped, not contracted into a petiole; scapes solid; flowers usually pure white, few or many in an umbel, fragrant, commonly sessile; outer spathe valves 2, lanceolate; perianth tube elongate, dilated above, the segments equal, spreading, linear or lanceolate; filaments inserted in the throat of the perianth tube, united to form a cup, usually with an entire or bifid process between each 2 filaments; anthers linear, versatile; ovary 3 -celled, the ovules 2 -many in each cell; style long, filiform, the stigma capitate; capsule usually large and subglobose, often bulb-like and somewhat fleshy, finally loculicidally 3 -valvate; seeds angulate, usually black.

About fifty species, in the tropics of both hemispheres. By most recent authors the American species have been treated as a distinct genus, Hymenocallis, based upon the number of ovules. This character, however, does not hold, and there being left for segregation of the two genera nothing but their geographic distribution, it seems necessary to unite them, as was done by most of the older workers upon American plants.

Perianth segments lanceolate, mostly $12 \mathrm{~mm}$. wide or more; staminal cup but little shorter than the perianth segments, its lobes large, broadly rounded or

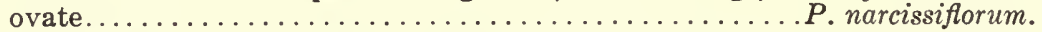

Perianth segments linear, commonly $2-6 \mathrm{~mm}$. wide; staminal cup less than onethird as long as the perianth segments, its lobes, if any, small and inconspicuous.

Leaves strap-shaped, not contracted into a petiole........... littorale.

Leaves contracted into a distinct narrow petiole.

Perianth tube about $6 \mathrm{~cm}$. long, the segments slightly longer than the tube. $P$. Skinnerianum.

Perianth tube about $20 \mathrm{~cm}$. long, the segments shorter than the tube. $P$. guatemalense. 
Hymenocallis bistubata Herb. Bot. Reg. 1844: Misc. 53. 1844. This was based upon plants sent by Hartweg to England and cultivated there. It may have been collected in Guatemala, or perhaps in some other country in which Hartweg collected. A similar but apparently distinct species has been collected in Salvador.

\section{Pancratium guatemalense Standl. \& Steyerm. Field Mus.} Bot. 23: 38. 1944.

Wet soil, mostly along the borders of streams in mixed forest, 900 meters or lower; endemic; Izabal (type collected between Escobas and Montaña Escobas, across the bay from Puerto Barrios, Steyermark 39288).

Bulbs subglobose or broadly ovoid, 10-12 cm. in diameter; leaves at anthesis usually 15-16, mostly distichous, gradually narrowed below into a petiole, $48-90$ $\mathrm{cm}$. long, 11-19 cm. wide, broadly elliptic-oblong or broadly oblanceolate, abruptly caudate at the apex; scapes $75-100 \mathrm{~cm}$. tall, the flowers about 20 , sessile; valves of the spathe membranaceous, reflexed in anthesis; flowers fragrant, $30-40 \mathrm{~cm}$. long, the tube 16-20 cm. long, $7 \mathrm{~mm}$. thick; perianth segments white, linearlanceolate, recurved and twisted, 10-12 cm. long, $8 \mathrm{~mm}$. wide, acute; stamen cup $2 \mathrm{~cm}$. long, dentate; filaments white, green near the apex, $6 \mathrm{~cm}$. long; anthers linear, yellow, $2.5 \mathrm{~cm}$. long; style $25 \mathrm{~cm}$. long; ovary oblong, $2.5-3 \mathrm{~cm}$. long, obtusely angulate; ovules $4-5$ in each cell.

The plant is a handsome and showy one. Bulbs taken to the Garfield Park Conservatory in Chicago produced luxuriant plants that bloomed profusely.

Pancratium littorale Jacq. Sel. Stirp. Amer. 99. pl. 179, f. 94. 1766. Hymenocallis littoralis Salisb. Trans. Hort. Soc. Lond. 1: 338. 1812. H. tenuiflora Herb. Amaryll. 44. 1837. H. panamensis Lindl. Bot. Reg. 1841: Misc. 67. 1841. H. insignis Kunth, Enum. Pl. 5: 675. 1850. Lirio; Lirio zac (Petén fide Lundell).

Marshy savannas, often abundant in salt marshes and swamps, or at the edges of streams, frequently at the borders of mangrove swamps, also frequent in cultivation inland, and sometimes escaping to thickets and waste ground, plentiful along both coasts, at or little above sea level; Petén; Alta Verapaz; Izabal; El Progreso; Santa Rosa; Escuintla; Suchitepequez; Retalhuleu; Huehuetenango; San Marcos. Mexico to British Honduras and Panama; South America; naturalized in some parts of the Old World.

Bulbs 7-10 cm. thick; leaves few, suberect or recurved, bright green, strapshaped or ensiform, acute, not narrowed into a petiole, usually $60-75 \mathrm{~cm}$. long and 2.5-4 cm. wide; scape somewhat compressed and 2-edged, about $60 \mathrm{~cm}$. tall; flowers usually 4-8 in each umbel, sessile, the outer spathe valves deltoid, 5-7 cm. 


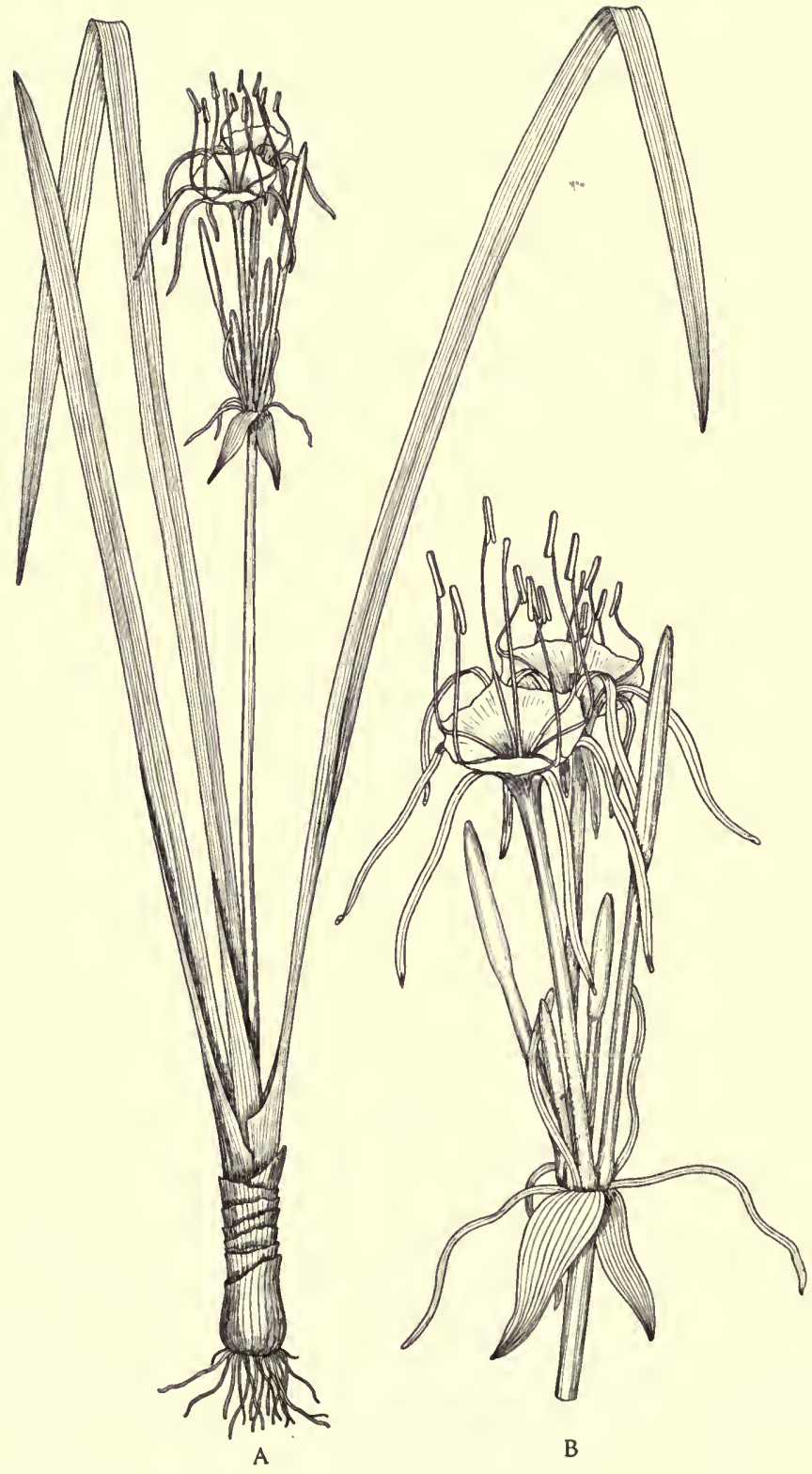

FIG. 27. Pancratium littorale. A. Habit of plant; $\times 1 / 6$. B. Inflorescence; $\times 1 / 3$. 
long; perianth tube $10-25 \mathrm{~cm}$. long, very slender, the linear segments recurved, about $10 \mathrm{~cm}$. long; staminal cup broadly funnelform, about $2 \mathrm{~cm}$. long, irregularly dentate along the margin; anthers linear, $12 \mathrm{~mm}$. long; ovules 4-6 in each cell; capsule rather large, green, resembling a small bulb. (Fig. 27.)

Called "lirio montés" in Salvador. The plant is a handsome one, like other members of the genus, and on this account is often planted in gardens. In the salt-water marshes along the coasts it sometimes forms large colonies.

Pancratium narcissiflorum Jacq. Fragm. Bot. pl. 138. 1809. P. calathinum Ker, Bot. Reg. 3: pl. 215. 1817. Ismene calathina Herb. Bot. Reg. App. 46. 1821. Hymenocallis calathina Nichols. Dict. Gard. 2: 165. 1885. H. narcissiflora Macbride, Field Mus. Bot. 11: 11. 1931. Azucena blanca.

Cultivated for ornament in gardens at Tactic, Alta Verapaz, Guatemala, and probably elsewhere. Supposed to be native in the Andes of Peru and Bolivia; said to have been introduced into cultivation in Europe in 1794.

Plants rather coarse and stout, the bulbs globose, with a cylindric neck; leaves few, subdistichous, bright green, strap-shaped, about $60 \mathrm{~cm}$. long, 3-5 cm. wide, acute or subobtuse; scape about $60 \mathrm{~cm}$. tall, 2-edged and somewhat compressed; flowers $2-5$, sessile, the outer spathe valves large, ovate; perianth tube bright green, dilated and funnelform above, $7-10 \mathrm{~cm}$. long, the segments pure white within, lanceolate, about equaling the tube; staminal cup obconic, white striped with green, $5 \mathrm{~cm}$. long, the large lobes rounded or broadly ovate, dentate; anthers linear, $12 \mathrm{~mm}$. long; style long-exserted, very slender.

The flowers are exceptionally beautiful, and have more substance than those of other species because of the broad perianth segments and large staminal cup. The plant was noted in cultivation only at Tactic, and was said to be uncommon there. Strangely enough, J. G. Baker (Handb. Amaryll. 129. 1888) states that he had seen Guatemalan specimens, probably from cultivation, and these may well have come likewise from Alta Verapaz.

Pancratium Skinnerianum (Herb.) Standl. \& Steyerm. Field Mus. Bot. 23: 39. 1944. Hymenocallis Skinneriana Herb. Bot. Reg. 1843: Misc. 45. 1843.

Collected in Guatemala by Skinner, the locality unknown; introduced into cultivation in England.

Bulbs of medium size; leaves oblong, acute, about $30 \mathrm{~cm}$. long and $12 \mathrm{~cm}$. wide, contracted at the base into a petiole; flowers about 6 , sessile, the spathe valves lanceolate, $3.5 \mathrm{~cm}$. long; perianth tube about $6 \mathrm{~cm}$. long, the segments slightly longer; staminal cup narrowly funnelform, dentate between the filaments, the 
free portion of the filament scarcely longer than the cup; anthers linear; style longer than the stamens.

Apparently a rare plant, not obtained by any recent collectors.

\section{POLIANTHES L. Tuberose}

Rootstock tuber-bearing; leaves mostly basal, few, lanceolate or linear, elongate, succulent but thin, the cauline leaves mostly reduced and bract-like; flowers white or reddish, mostly in pairs and racemose, the pedicels articulate at the apex; perianth with a long narrow funnelform tube, more or less curved, the segments short, subequal; stamens inserted about the middle of the tube, included, the filaments filiform, short, the anthers erect, linear, dorsifixed; ovary 3-celled, free at the apex, the ovules numerous, superposed; style filiform, the 3 stigmas ovate, falcate; capsule crowned by the persistent perianth; seeds flat, with a lax testa.

About a dozen species have been described, all natives of Mexico.

\section{Polianthes tuberosa L. Sp. Pl. 453. 1753. Nardo.}

Common in gardens almost throughout Guatemala, and grown in large quantities for the larger markets. Native of Mexico, but probably unknown in a wild state.

Plants tall and strict, usually $60-90 \mathrm{~cm}$. high, the basal leaves linear, pale green, $30-45 \mathrm{~cm}$. long, deeply channeled in the lower half, spotted with dark brown on the back; cauline leaves usually $8-12$, smaller and shorter than the basal ones; flowers double, waxy white, forming a long lax spike; perianth $3.5-6 \mathrm{~cm}$. long, the segments oblong-lanceolate, spreading, much shorter than the tube.

The tuberose is one of the favorite garden flowers of Guatemala, perhaps because of its intense but often rather cloying fragrance. Large bunches of the flower spikes are generally to be seen in the Guatemala market, where the flowers are colored with synthetic dyes in vivid shades of blue, yellow, pink, and green. The plant presumably has been in cultivation in Mexican gardens, at least, for many centuries. It is often grown in the United States.

Sprekelia formosissima (L.) Herb. App. 35. 1821. Amaryllis formosissima L. Sp. Pl. 293. 1753. This plant has been noted by the writers only in cultivation in Cobán. J. G. Baker reports it as a native of Mexico and Guatemala. It is known to be native in Mexico, but there is no evidence that it is native also in Guatemala. This may well be the case, however, for the blooming period is short, and the plant on that account could easily be missed. It is a bulbous plant somewhat suggestive of Hippeastrum, with a single large horizontal flower at the apex of the scape. The perianth is about 
$10 \mathrm{~cm}$. long, with narrow, bright crimson segments. Leaves are absent when the flowers open.

\section{ZEPHYRANTHES Herb.}

Plants with tunicated bulbs; leaves mostly linear and almost grasslike, contemporary with the flowers or developing after them; scape elongate, slender, hollow, bearing a single flower, this red, white, or yellow; spathe membranous, tubular below, bilobate above; perianth funnelform, erect or slightly inclined, the tube short or elongate, the segments subequal; stamens inserted in the throat or the middle of the perianth tube, slightly declinate, somewhat unequal; filaments filiform, the anthers linear-oblong, versatile; ovary 3-celled, the ovules numerous, superposed; style filiform, the stigma usually trifid; capsule subglobose, loculicidally bivalvate; seeds flat or compressed, black.

About forty species, in tropical and temperate America. Only the following ones occur in Central America.

Perianth white, $3.5-5 \mathrm{~cm}$. long. ................... tubispatha. Perianth bright pink, or sometimes white tinged with pink, but then 6-7 $\mathrm{cm}$. long.

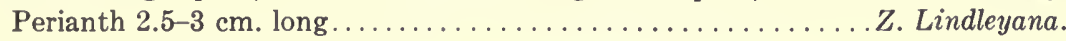

Perianth usually 6-7 $\mathrm{cm}$. long.

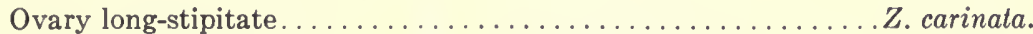

Ovary almost sessile.......................... brevipes.

Zephyranthes brevipes (J. G. Baker) Standl. Field Mus. Bot. 4: 199. 1929. Z. carinata var. brevipes J. G. Baker ex Donn. Smith, Enum. Pl. Guat. 3: 80. 1893, nomen nudum. Flor de Mayo.

Open grassy places, 1,200-1,800 meters, endemic; Alta Verapaz, the type from Santa Cruz, 1,380 meters, J. D. Smith 1671; Chimaltenango; doubtless also in other departments.

Bulbs about $2 \mathrm{~cm}$. in diameter, with an elongate neck; leaves equaling the scape, $1.5-5 \mathrm{~mm}$. wide; scapes slender, about $25 \mathrm{~cm}$. high, the spathe $2 \mathrm{~cm}$. long; stipe of the ovary only $3-5 \mathrm{~mm}$. long; perianth pink or white tinged with pink, 6-7.5 cm. long, the segments narrow, oblanceolate, $1 \mathrm{~cm}$. wide or narrower.

Some of the specimens have been referred, almost certainly in error, to $Z$. sessilis Herb. The species is said to be abundant in some of the cultivated fields of Chimaltenango during the rainy months.

Zephyranthes carinata Herb. Bot. Mag. pl. 2594. 1825. Atamosco carinata Standl. in Standl. \& Calderón, Lista Pl. Salv. 51. 1925. Mañanitas (Escuintla); Jacinto; Ceboy-ac (Cobán, Kekchí; the "ceboy" is the Spanish cebolla).

Frequent in gardens, planted for ornament, also in open fields or thickets, especially of the Cobán region; perhaps not native in 

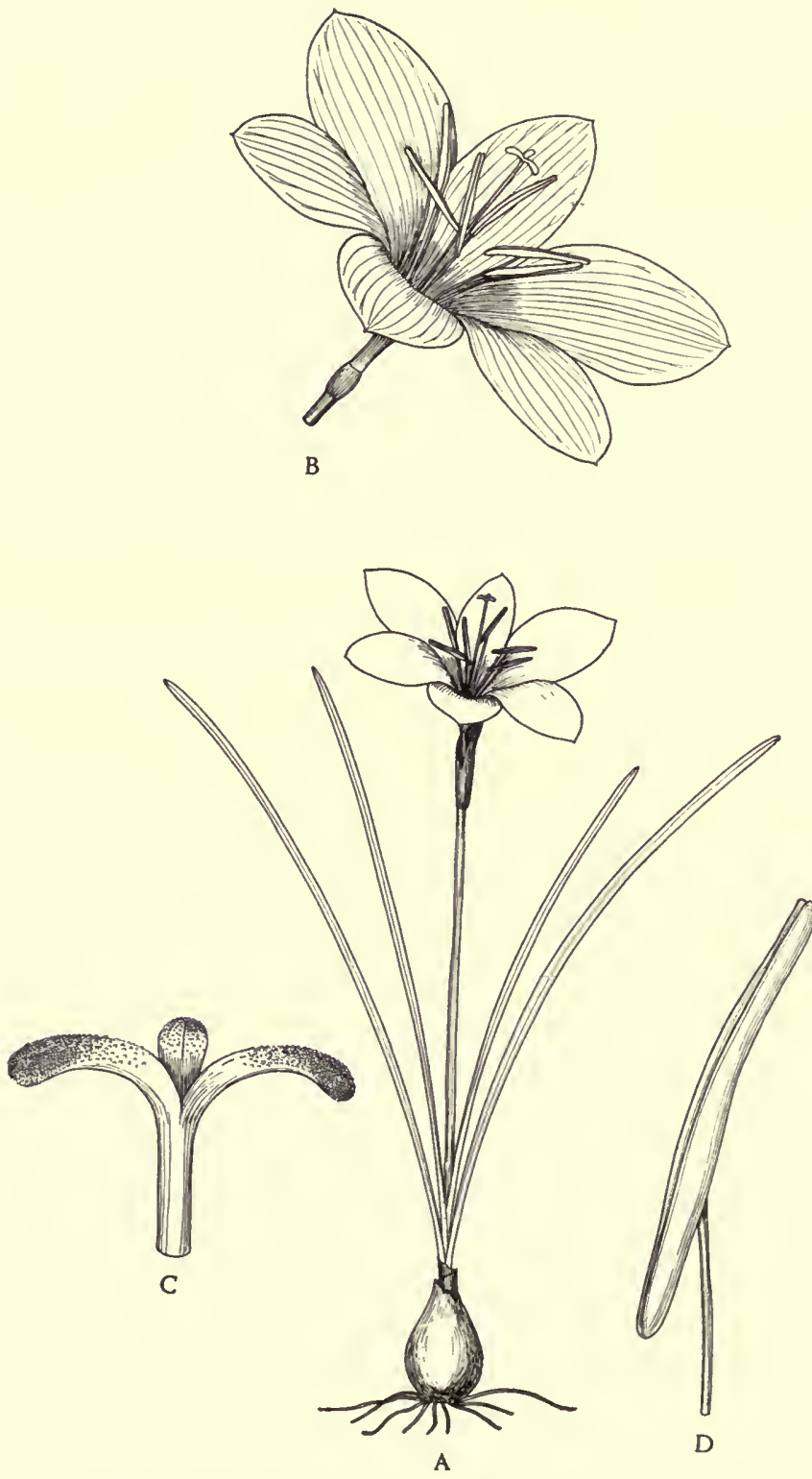

FIG. 28. Zephyranthes carinata. A. Habit of plant; $\times 1 / 3 . \quad$ B. Flower; $\times 2 / 3$. C. Stigmas and upper part of style; $\times 4$. D. Stamen, showing anther and upper part of filament; $\times 3$. 
Guatemala; collected more or less wild in Alta Verapaz and Quezaltenango, and cultivated generally. Mexico; Costa Rica; West Indies.

Bulbs ovoid, about $2.5 \mathrm{~cm}$. in diameter, with an elongate neck; leaves 15-30 $\mathrm{cm}$. long, 2-5 mm. wide, shallowly channeled on the upper surface, often absent at time of flowering; scapes $10-30 \mathrm{~cm}$. long, the spathe $3-5 \mathrm{~cm}$. long; stipe of the ovary usually well over $1 \mathrm{~cm}$. long; perianth rose-pink, the segments obovate, usually 6-7 cm. long, 12-20 mm. wide. (Fig. 28.)

The plant seems to lie dormant through much of the dry season, and blooms during the spring months. It bursts into flower quickly if supplied with water. Baker states that this is the commonest species in cultivation in Europe.

Zephyranthes Lindleyana Herb. Amaryll. 174. pl. 35, f. 5. 1837. Guatemala, at 1,350 meters; reported also from Chimaltenango; sometimes cultivated for ornament. Southern Mexico; Honduras.

Bulbs globose, $1.5 \mathrm{~cm}$. in diameter, with a short neck; leaves 15-20 cm. long, usually present at anthesis, 1-6 mm. wide; scapes slender, 10-30 $\mathrm{cm}$. long, the spathe $2.5-3 \mathrm{~cm}$. long, trifid at the apex only; perianth deep rose-pink, $2.5-3 \mathrm{~cm}$. long, the segments cuneate-obovate, about $12 \mathrm{~mm}$. wide; stigma 3-fid.

Called "jacinto" in Salvador.

Zephyranthes tubispatha (Ker) Herb. App. 96. 1821. Amaryllis tubispatha Ker, Bot. Mag. pl. 1586. 1813.

Petén (La Libertad, perhaps only in cultivation, but quite possibly native on the savannas). West Indies; Colombia and Venezuela.

Bulb globose, $2.5 \mathrm{~cm}$. in diameter, with a short neck; leaves few, appearing with the flowers, $30 \mathrm{~cm}$. long or less, 2-5 mm. wide; scapes slender, about $15 \mathrm{~cm}$. long, the spathe $2.5-3 \mathrm{~cm}$. long, cut only at the apex; stipe of the ovary much elongate, usually exceeding the spathe; perianth $3.5-5 \mathrm{~cm}$. long, white, slightly tinged with green, with no red or pink, the tube almost obsolete, the segments obovate, about $12 \mathrm{~mm}$. wide; style deeply 3-fid; capsule $12 \mathrm{~mm}$. broad.

The plant has been reported from Petén under the name $Z$. citrina J. G. Baker.

\section{DIOSCOREACEAE. Yam Family}

References: R. Knuth, Dioscoreaceae, Pflanzenreich IV. 43: 99. 1924. C. V. Morton, Notes on Dioscorea, with special reference to the species of the Yucatan Peninsula, Carnegie Inst. Wash. Publ. 461: 241-253. 1936. 
Chiefly perennial herbaceous vines, often arising from large tuberous roots; leaves alternate or opposite, petiolate, usually cordate, palmately 3-13-nerved and also reticulate-veined, entire or palmately lobate or foliolate, the petiole articulate at the base; flowers small, sessile or pedicellate, solitary or fasciculate, sometimes capitate-congested, arranged in spikes or racemes, generally unisexual, dioecious or rarely monoecious, regular; bracts minute or none; racemes or spikes axillary, often paniculate; perianth 6-parted, 2-seriate, the staminate deeply parted, campanulate or explanate, the lobes subequal; stamens central, inserted at the base of the perianth segments or on them, sometimes 6 and perfect, sometimes 3 perfect with 3 alternating staminodia, or only 3 and all perfect, free or connate into a column; anthers generally small, subglobose or oblong, or the cells distinct but contiguous, or the anthers didymous; pistillate perianth 6-parted, persistent; staminodia minute or 3 or 6 , sometimes none; ovary inferior, linear or oblong, triquetrous, 3-celled; style 3, very short, distinct or connate, the stigmas 3 , very short, entire or 2-fid; ovules 2 in each cell or rarely more, superposed, pendulous, anatropous or almost amphitropous; fruit capsular, 3-valvate, rarely by abortion monocarpic and winged above, sometimes baccate; seeds compressed or globose, the testa appressed, usually broadly winged; endosperm almost cartilaginous, the embryo enclosed in the endosperm, small.

Genera about eight, the species widely distributed, chiefly in tropical regions. Only one genus is represented in continental North America.

\section{DIOSGOREA L.}

Vines, usually herbaceous and twining, arising from underground tubers or thick rhizomes; leaves alternate or opposite; flowers small, regular, unisexual, dioecious; staminate perianth campanulate to rotate or tubuliform, the lobes equal, linear to lanceolate or rounded; anthers small, the cells contiguous or somewhat separated, free or rarely united; pistillate perianth 6-parted, persistent, the staminodia minute and 3 or 6 , or none; ovary linear or oblong, triquetrous, 3 -celled, the 3 styles very short, reflexed, entire or 2-fid; ovules usually 2 in each cell, sometimes more numerous, laterally attached below the apex; capsule triquetrous, 3-winged, the wings vertical, loculicidally dehiscent; seeds compressed, winged.

Species $400-500$, almost all confined to the tropics, in both hemispheres. Other species are known from Central America.

Leaves lobate or 3-foliolate.

Leaves 3-foliolate. D. tenebrosa.

Leaves merely lobate.

Leaves deeply 3-5-lobate, the lobes all acuminate; cultivated plants. $D$. trifida.

Leaves hastately 3-lobate, the lateral lobes short, obtuse or rounded, native

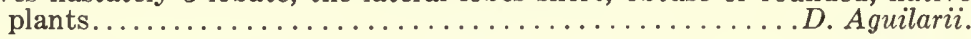

Leaves entire.

Stems conspicuously winged $\ldots \ldots \ldots \ldots \ldots \ldots \ldots \ldots \ldots \ldots \ldots \ldots \ldots \ldots \ldots \ldots$ ata Stems not winged.

Mature fruit very asymmetric, samaroid, one of the wings broad and well developed, the others abortive and very narrow......... D. cyphocarpa. 
Mature fruit symmetric, not samaroid, all the angles or wings subequal.

Staminate flowers sessile or essentially so, often glomerate in small dense clusters or heads (see $D$. hondurensis).

Stems usually bearing large aerial bulbs or bulblets in the leaf axils; plants cultivated or rarely escaping ............ bulbifera.

Stems not bearing bulblets in the leaf axils.

Seeds winged on the lower side only. Fertile stamens 6; perianth puberulent......................... Bartlettii.

Seeds winged all around.

Fertile stamens 3, alternating with 3 staminodia.

Staminate flowers solitary.

Leaves mostly 6-8 $\mathrm{cm}$. long; perianth segments $3-4 \mathrm{~mm}$. long.

D. dicranandra.

Leaves mostly $3 \mathrm{~cm}$. long or shorter; perianth segments $1.5 \mathrm{~mm}$. long. ....................... yucatanensis.

Staminate flowers glomerate.

Leaf blades mostly about $4 \mathrm{~cm}$. long.......... D. cyanisticta.

Leaf blades mostly 7-12 cm. long.

Cells of the anthers separated............. polygonoides.

Cells of the anthers coherent........... D. matagalpensis.

Fertile stamens 6.

Staminate flowers in cymose clusters; rudiment of the style large.

Leaves ovate-cordate, 7-9-nerved, glabrous...D. Bernoulliana.

Leaves orbicular-cordate, 11-nerved, pubescent beneath.

D. cymosula.

Staminate flowers in fasciculate heads; rudiment of the style obsolete or nearly so.

Stamens unequal, 3 of them longer than the others. D. floribunda. Stamens equal or nearly so.

Leaves stipulate................ Friedrichsthalii.

Leaves not stipulate.

Leaf blades abruptly cuneate-decurrent, elongate triangularcordate...................D. Tuerckheimii.

Leaf blades not decurrent upon the petiole, usually broadly cordate.................... macrostachya.

Staminate flowers conspicuously pedicellate.

Seeds winged only on the lower side. Stamens $3 \ldots \ldots D$. convolvulacea.

Seeds winged all around.

Fertile stamens 6.

Flowers solitary....................... belizensis.

Flowers cymulose...................... Nelsonii.

Fertile stamens 3, sometimes with 3 alternating staminodia.

Staminodia none....................... Standleyi.

Staminodia 3, alternating with the stamens.

Bracts of the staminate inflorescence about $6 \mathrm{~mm}$. long.

D. densiflora.

Bracts of the staminate inflorescence $2-3 \mathrm{~mm}$. long. .D. Carionis.

Dioscorea Aguilarii Standl. \& Steyerm. Field Mus. Bot. 22: 133. 1940. $\widetilde{N} a m e$ de ratón.

Known only from the type, Dept. Guatemala, about 1,500 meters, José Ignacio Aguilar 90. 
Plants very slender, the stems glabrous or shortly spreading-pilosulous; leaves rather thin, on slender petioles $2-3.5 \mathrm{~cm}$. long, the petiole short-pilose; leaf blades hastate-lobate, $4.5-8.5 \mathrm{~cm}$. long, $2.5 \mathrm{~cm}$. wide near the base, glabrous above, rather densely hirsute beneath, the middle lobe narrowly lance-oblong, 14-22 $\mathrm{mm}$. wide at the base, narrowly long-attenuate, 3-nerved, the basal lobes as much as $2 \mathrm{~cm}$. long, somewhat rectangular, divergent, rounded on the angles, the outer sides of the lobes subtruncate or broadly concave, 2 -nerved; staminate spikes slender and elongate, tortuous, geminate, long-pedunculate, the floriferous portion 2-5 $\mathrm{cm}$. long, the rachis pilose with short spreading hairs; flowers sessile, in fewmany-flowered spikelets as much as $7 \mathrm{~mm}$. long, these rather dense; perianth segments scarcely $1 \mathrm{~mm}$. long, oval, obtuse, glabrous; stamens 6 , with very short filaments.

\section{Dioscorea alata L. Sp. Pl. 1033. 1753. ̃̃ame.}

Native of tropical Asia or Africa, cultivated in most tropical regions for its edible roots; planted commonly in Guatemala, especially in the lowlands, and sometimes at higher elevations, as in the Department of Guatemala; sometimes escaping from cultivation to second-growth thickets, as at Puerto Barrios.

Plants stout, glabrous, the stems narrowly 4-winged, sometimes producing bulblets in the leaf axils; leaves long-petiolate, ovate-cordate or sagittate-cordate, with a broad or narrow, usually very deep basal sinus, mostly $10-20 \mathrm{~cm}$. long, acuminate or caudate-acuminate; staminate spikes branched, elongate, the spikelets verticillate, the flowers sessile; perianth $1.5 \mathrm{~mm}$. in diameter, pale green, the segments unequal; fertile stamens 6 , very short; capsule lustrous, $3 \mathrm{~cm}$. broad.

Sometimes called "ñame blanco" in Honduras; "macal," "maxcal," "akilmaxcal" (Yucatan, Maya). This is one of two or three yams of Old World origin that are planted commonly in Central America, chiefly along the Atlantic coast where there is Carib or West Indian influence. They doubtless were introduced first to the West Indies by African slaves or slave ships, and later probably were carried to the continent by Caribs or perhaps by the Spaniards. In Guatemala yams are scarcely known to the majority of the people on the Pacific coast, many of whom do not understand the term "ñame," which probably is of African origin. The roots, however, are sold in the markets of central Guatemala, most of them brought probably from the lower parts of the Atlantic slope. Yams somewhat resemble large sweet potatoes, and often reach a great size. The outside of the hard tuberous root bears many black hair-like roots, while the inside usually is white. It is cooked and eaten like a potato, generally boiled. When on the table, a yam is firm and solid, and to many people not attractive, although in flavor it probably is not much inferior to a white potato. The roots are so large that often they are cut into pieces for sale, and for cutting 
them an axe or machete is needed. In the United States the name "yam" (derived obviously from ñame) is often given to large sweet potatoes (Ipomoea Batatas), which do not resemble very closely true yams.

Dioscorea Bartlettii Morton, Carnegie Inst. Wash. Publ. 461: 242. 1936. Cocomeca; Cocomeca blanca (Petén).

Moist or wet thickets and forest, often or perhaps always on limestone, chiefly at 1,000 meters or less; Petén (type from Uaxactún, H. H. Bartlett 12425); Alta Verapaz; Izabal. Tabasco; British Honduras.

Rhizome woody, epigaean, semi-ellipsoid, very large, covered with dark-colored bark-like plates; stems sinistrorsely twining, minutely puberulent, spiny near the base; leaves alternate, long-petiolate, the petioles $7 \mathrm{~cm}$. long or less; leaf blades ovate, entire, the larger ones about $16 \mathrm{~cm}$. long and $14 \mathrm{~cm}$. wide, chartaceous, abruptly acuminate or caudate-acuminate, broadly cordate or almost truncate at the base, 7-nerved, glabrous; staminate inflorescences as much as $20 \mathrm{~cm}$. long, usually much branched, the branches densely puberulent; flowers sessile, aggregate, 2-3-nate or rarely solitary, purple; perianth $1.5 \mathrm{~mm}$. long, puberulent, the lobes ovate, subobtuse; fertile stamens 6 , the filaments very short, the anther cells contiguous, discrete; style rudiment none; pistillate inflorescence spicate, sometimes branched, as much as $23 \mathrm{~cm}$. long; sterile stamens 6 ; styles 3 , very short; capsule oblong, as much as $4.5 \mathrm{~cm}$. long and $2 \mathrm{~cm}$. broad, subligneous; seeds 2.5 $\mathrm{cm}$. long, winged only on the lower side.

It is of some interest to find that the name "cocolmeca," of Nahuatl origin, is used in Petén. This name is given in southwestern Mexico to other species of the genus that arise from epigaean tubers whose surface is covered with plates in such a manner as to suggest a turtle shell. There the sap of the young shoots is used in the preparation of pozonque, a beverage made from chocolate and soft corn, and this juice beaten into a foamy mass. The large root is used there also as a barbasco, for stupefying fish, and perhaps contains the alkaloid dioscorine that has been found in other species. Asiatic species of Dioscorea are sometimes used likewise as fish poisons, and some of them produce roots that are poisonous to man if eaten, at least when raw.

Dioscorea belizensis Lundell, Contr. Univ. Mich. Herb. 6: 5 . 1941.

Moist or wet thickets, 900 meters or less; Alta Verapaz (?); Zacapa. British Honduras, the type from Carib Reserve, Stann Creek District, P. H. Gentle 2998. 
A small or large vine with thick hypogaean roots, the stems often stout; leaves on petioles $10.5 \mathrm{~cm}$. long or less, the petioles glabrous; leaf blades thickchartaceous, glabrous above, puberulent or glabrous beneath, broadly ovate, as much as $22 \mathrm{~cm}$. long and $17 \mathrm{~cm}$. wide, cuspidate-acuminate or rounded and cuspidate at the apex, deeply cordate at the base, 11-nerved, the veins often impressed on the upper surface; staminate inflorescences solitary, as much as $150 \mathrm{~cm}$. long, the racemes paniculate; bractlets broadly ovate, cuspidate, $2 \mathrm{~mm}$. long or less; pedicels $1 \mathrm{~mm}$. long or longer, the flowers dark red, $3 \mathrm{~mm}$. long; perianth segments broadly ovate; fertile stamens 6 .

Dioscorea Bernoulliana Prain \& Burkill, Kew Bull. 1916: 192. 1916.

Moist or wet thickets or forest, 1,000 meters or less; Petén; Izabal. Collected also between "Escomillas" and Palo Hueco (department uncertain), Bernoulli \& Cario 847. British Honduras.

Plants glabrous, the stems sinistrorsely twining; leaves on petioles $4 \mathrm{~cm}$. long or less, ovate-cordate, acutely acuminate, broadly and shallowly cordate at the base, membranaceous or rather firm, 7-9-nerved, about $8 \mathrm{~cm}$. long and wide; staminate racemes solitary or 2-4-nate, simple, as much as $16 \mathrm{~cm}$. long; flowers cymulose, the cymules on very short peduncles, 2-4-flowered, the bracts $1 \mathrm{~mm}$. long; perianth $1.5 \mathrm{~mm}$. broad, the outer segments oblong, the inner ones slightly broader; stamens 6 , the filaments adnate to the base of the segments, the anthers suborbicular; ovary rudiment trigonous, half as long as the filaments; capsule glabrous, dark brown, about $14 \mathrm{~mm}$. long and $17 \mathrm{~mm}$. broad; seeds orbicular, completely surrounded by a thin, dark brown wing $2-4 \mathrm{~mm}$. wide.

Dioscorea bulbifera L. Sp. Pl. 1035. 1753. Papa del aire; Name montaraz; Papa voladora.

Probably native of tropical Asia and perhaps also of Africa; often cultivated in other tropical regions; planted in Guatemala for ornament or as a curiosity, or sometimes for food, at low and middle elevations.

Plants glabrous, the stems producing numerous large or small bulblets, these succulent, somewhat compressed, sometimes $10 \mathrm{~cm}$. broad, smooth or somewhat verrucose; leaves alternate, long-petiolate, rounded-cordate-ovate, $7-15 \mathrm{~cm}$. wide, cuspidate-acuminate, about 9-nerved, membranaceous; stipules present, membranaceous, oblong-lanceolate; staminate spikes slender, simple, $3-10 \mathrm{~cm}$. long, sometimes paniculate, the flowers solitary, approximate, variable in size; perianth segments lanceolate, spreading; stamens 6, minute, the anthers oblong-elliptic; style rudiments 3 , subulate; pistillate spikes simple, $10-25 \mathrm{~cm}$. long, fasciculate, the flowers erect and of ten appressed to the rachis; capsule $2.5 \mathrm{~cm}$. long and $1.5 \mathrm{~cm}$. broad, oblong, rounded at each end or sometimes subacute at the apex.

The Maya name of Yucatan is reported as "bauiac." In central Guatemala this plant is grown principally as a curiosity, but it is said to be grown rather commonly for food in the Oriente, often planted with "huisquil" (Sechium) and allowed to climb over the same 
supports with it. The large fleshy roots are cooked and eaten, and the often very large and heavy, greenish bulblets are used in the same manner.

Dioscorea Carionis Prain \& Burkell, Kew Bull. 1916: 193. 1916.

Moist or wet forest or thickets, 400-1,800 meters; endemic; El Progreso; Zacapa; Escuintla; Suchitepequez; Quezaltenango; San Marcos.

A slender vine, glabrous or nearly so, sometimes finely and sparsely puberulent, the stems sinistrorsely twining; leaves long-petiolate, ovate-cordate or roundedcordate, sometimes $15 \mathrm{~cm}$. long and $13 \mathrm{~cm}$. wide, abruptly acuminate or cuspidateacuminate, membranaceous, rather deeply and broadly cordate, 7-9-nerved, sometimes puberulent beneath on the nerves; flowers pale green, the staminate racemes axillary, solitary or fasciculate, as much as $20 \mathrm{~cm}$. long, the flowers solitary, the pedicels $2 \mathrm{~mm}$. long, puberulent; bracts ovate-lanceolate, $3 \mathrm{~mm}$. long or less; perianth $5 \mathrm{~mm}$. broad, the segments ovate-lanceolate, acute, $3-4 \mathrm{~mm}$. long, subequal; stamens 3 , the anthers suborbicular; staminodia 3; capsule about $13 \mathrm{~mm}$. long and $12 \mathrm{~mm}$. broad, brownish.

Dioscorea convolvulacea Schlecht. \& Cham. Linnaea 6: 49. 1831. D. capillaris Hemsl. Biol. Centr. Amer. Bot. 3: 354. 1884. D. capillaris var. glabra Hemsl. loc. cit. D. esurentium Uline, Bot. Jahrb. 22:429. 1897 (type locality given erroneously as Guatemala). D. convolvulacea var. glabra Uline ex Knuth, Pflanzenreich IV. 43: 99. 1924. D. convolvulacea var. esurentium Uline ex Knuth, loc. cit. Madre de maiz.

Moist or wet thickets or forest, 2,000 meters or less, most common at rather low elevations; Alta Verapaz; Zacapa; Chiquimula; Jalapa; Santa Rosa; Escuintla; Guatemala; Quiché. Southern Mexico; British Honduras to Costa Rica; Trinidad.

Plants arising from small or large, tuberous roots, the stems short-hirtellous or glabrous, the plants often glabrous throughout or nearly so; leaves long-petiolate, rounded-ovate or ovate-cordate, sometimes $30 \mathrm{~cm}$. long and wide but usually much smaller, acuminate or caudate-acuminate, shallowly or rather deeply cordate, 7-13-nerved, glabrous above or nearly so, glabrous beneath or often rather densely pubescent or puberulent; staminate inflorescences long and slender, simple or branched below, the rachis puberulent, the flowers solitary, green or purplish, on pedicels 2-3 $\mathrm{mm}$. long; perianth $3-4 \mathrm{~mm}$. broad, the segments spreading or finally reflexed, oblong, obtuse; fertile stamens 3 , divaricate, the anthers minute; capsule oblong or oblong-elliptic, glabrous, $12-14 \mathrm{~mm}$. long and $9 \mathrm{~mm}$. broad or somewhat larger; seeds winged on the lower side.

Probably the most common species of the genus in Guatemala, abundant in some localities, flowering during the wet months. The material is somewhat variable, but the varieties that have been 
proposed seem to be of little importance. This and perhaps some of the other similar wild species of Dioscorea are of considerable economic importance in Guatemala, and they are well known, especially in the Occidente, under the name "madre de maíz." In some years because of unfavorable weather or insect attacks the corn crop fails in regions of Guatemala, a very serious event indeed, considering that maize is the most important food of the country. In recent years the national government has done much to alleviate the resultant suffering, but in former times local famines resulted. In such periods the starving people had to go to the fields and forest to find any plants that could be used as emergency foods. Very important on the Pacific slope was madre de maíz, whose tuberous roots were grated and made into a kind of tortilla or tamal. It is said that they are an unappetizing food, but that they serve to relieve hunger and at least prevent death by starvation. This species has been reported from Guatemala as $D$. propinqua Hemsl. and as D. hirsuta var. glabra Uline.

Dioscorea cyanisticta Donn. Smith, Bot. Gaz. 20: 10. 1895. Tzahuacax (Huehuetenango).

At 1,400-2,100 meters; Huehuetenango (Sierra de los Cuchumatanes, between Chaculá and Canquintic, Steyermark 51779; determined by Morton). Costa Rica.

Plants slender, glabrous or nearly so; leaves membranaceous, small, pellucidlineolate, broadly ovate-cordate, mostly $4 \mathrm{~cm}$. long or shorter, acuminate or longacuminate, deeply cordate at the base, with 11 or fewer nerves, glandular beneath at the base; staminate spikes mostly simple, clustered in the leaf axils or forming a lax panicle, subsessile, $10-15 \mathrm{~cm}$. long, the rachis scabrous-puberulent; flowers in clusters of $2-3$, rarely solitary, equaling the elongate-lanceolate bract, sessile or nearly so, the glomerules approximate; perianth campanulate, $3 \mathrm{~mm}$. in diameter, the segments oblong-ovate, spreading, twice as long as the tube, 1-nerved; fertile stamens 3, short, the anthers globose, extrorse; staminodia 3, filiform, equaling the fertile stamens.

Dioscorea cymosula Hemsl. Biol. Centr. Amer. Bot. 3: 355. pl. 90. 1884 .

At 1,500 meters, Santa Rosa, Buena Vista, Heyde \& Lux 6391 (recorded from Guatemala as D. composita Hemsl.). Mexico; Panama.

Stems rather stout, puberulent; leaves long-petiolate, membranaceous, orbicular-cordate, $14 \mathrm{~cm}$. wide or less, acute or apiculate, 11-nerved, whitish-pubescent, especially beneath, the petiole as much as $7.5 \mathrm{~cm}$. long; staminate racemes elongate, sometimes $30 \mathrm{~cm}$. long, simple; flowers sessile or nearly so in small cymules, $3-4$ 
mm. broad, the cymules 2-6-flowered; bracts narrow, longer than the flowers; perianth segments almost free, lance-oblong, subobtuse, villosulous outside, erectpatent; stamens 6 , inserted at the base of the segments, the anthers elliptic; style rudiment rather large, conic; pistillate flowers with 6 sterile stamens, the ovary densely tomentose; capsule elliptic, densely tomentose, $2.5 \mathrm{~cm}$. long and $2 \mathrm{~cm}$. broad or perhaps larger.

The single Guatemalan collection cited was reported by Knuth. The specimens, deposited in the United States National Herbarium, were examined by the authors.

Dioscorea cyphocarpa Robinson ex Knuth, Notizbl. Bot. Gart. Berlin 7: 209. 1917. D. tacanensis Lundell, Lloydia 2: 78. 1939 (type from Volcán de Tacaná, Chiapas, at 1,000-2,000 meters, E. Matuda 2416).

Doubtless on Volcán de Tacaná in San Marcos. Southern and western Mexico.

Plants glabrous or nearly so, the stems slender or rather stout; leaves membranaceous, on petioles $10 \mathrm{~cm}$. long or less, ovate-cordate, $12.5 \mathrm{~cm}$. long or shorter, acuminate, deeply cordate at the base, glabrous, 11-13-nerved; staminate spikes $5 \mathrm{~cm}$. long, simple, rather remotely flowered, solitary or binate, pedunculate, the rachis puberulent, the pedicels 3-4 $\mathrm{mm}$. long; perianth 3-4 $\mathrm{mm}$. broad, campanulate-rotate, the lobes lanceolate, subobtuse; stamens 3 , erect, central; style rudiment none; pistillate spikes in fruit $6 \mathrm{~cm}$. long or more, solitary, simple, pedunculate, the flowers in fruit on long filiform pedicels; capsule $2 \mathrm{~cm}$. long and $1.5 \mathrm{~cm}$. wide or smaller, cuneately narrowed at the base, very asymmetric, 2 of the cells sterile and with very narrow wings, the third cell with a broad wing; seeds $7-8 \mathrm{~mm}$. long, $5 \mathrm{~mm}$. wide.

Dioscorea densiflora Hemsl. Biol. Centr. Amer. Bot. 3: 356. 1884 .

Moist or wet thickets or forest, 1,300 meters or less; Alta Verapaz; Izabal. Southern Mexico; British Honduras; Honduras (Cozumel Island).

Plants glabrous except for the puberulent racemes, the stems slender, somewhat succulent; leaves on slender petioles 3-4 cm. long, membranaceous, bright green when dried, ovate-cordate, $8-15 \mathrm{~cm}$. long or smaller, acuminate, openly cordate, 7-nerved; staminate racemes slender, many-flowered, $20 \mathrm{~cm}$. long or shorter, solitary or 2-4-nate, simple or furcate at the base, densely flowered; pedicels solitary, 2-3 mm. long, the bracts linear-filiform, longer than the flowers; perianth segments membranaceous, cream-colored, lanceolate, acuminate; fertile stamens 3 , inserted in the throat of the perianth; staminodia clavate or spatulate, equaling the fertile stamens; style rudiment 3-tuberculate; pistillate spikes simple; perianth segments ovate-oblong; sterile stamens 6 ; capsule elliptic, $2.5 \mathrm{~cm}$. long, $1.7 \mathrm{~cm}$. broad; seeds oblong, irregularly winged on all sides, $8-10 \mathrm{~mm}$. long. 
Dioscorea dicranandra Donn. Smith, Bot. Gaz. 19: 13. 1894. D. albicaulis Uline, Bot. Jahrb. 22: 425. 1896 (type from Cerro Gordo, Santa Rosa, Heyde \& Lux 3869).

Moist forest or thickets, sometimes in oak forest, 800-2,050 meters; endemic: Alta Verapaz; Santa Rosa; Escuintla.

Plants herbaceous, glabrous, the stems rather stout and succulent, sinistrorsely twining; leaves on slender, rather short petioles, membranaceous, ovate-cordate or broadly cordate, $6-8 \mathrm{~cm}$. long and wide, long-acuminate, broadly and shallowly cordate, 7-nerved; staminate inflorescences simple or sometimes sparsely branched below, as much as $20 \mathrm{~cm}$. long, solitary, the flowers $2-4 \mathrm{~mm}$. apart, sessile; perianth rotate, the segments rather thick, purplish or when dried brownish, lance-oblong, obtuse, 3-4 mm. long, twice as long as the bracts; fertile stamens 3 ; staminodia 3 , clavate; style rudiment none.

Dioscorea floribunda Mart. \& Gal. Bull. Acad. Brux. 9, pt. 2: 391. 1842.

Moist or wet thickets or forest, sometimes in oak forest, 1,500 meters or less; Baja Verapaz; Izabal; Santa Rosa; Suchitepéquez; Huehuetenango. Southern Mexico.

Plants glabrous, the stems slender or stout, sinistrorsely twining; leaves alternate, on petioles $7 \mathrm{~cm}$. long or less, rather thick and firm, broadly ovate or triangular-ovate, medium-sized, long-acuminate or caudate-acuminate, shallowly or deeply cordate, 9-nerved; staminate spikes approximate, usually paniculate, the rachises very slender, the flowers solitary or 2-3-nate, sessile or nearly so, dark green, 2-3 $\mathrm{mm}$. long, the perianth membranaceous, tubular, the segments erect, shorter than the tube, elliptic, obtuse; fertile stamens 6 , central, 3 of them equaling the tube, the other 3 much shorter; anthers didymous; style rudiment none; pistillate spikes rather short, solitary; perianth distinctly stipitate, campanulate; sterile stamens 6 .

Dioscorea Friedrichsthalii Knuth, Pflanzenreich IV. 43: 169. 1924.

Known only from the type, said to have been collected in Guatemala by Friedrichsthal, the locality not indicated.

Plants glabrous, the stems slender; leaves alternate, on petioles about $4 \mathrm{~cm}$. long, papyraceous, brownish when dried, $13 \mathrm{~cm}$. long, $10 \mathrm{~cm}$. wide, obtuse or acuminate, deeply cordate, 7-9-nerved, the basal lobes rounded; pistillate racemes 10-15 cm. long, pedunculate; capsule quadrangular-rounded, broadly cuneatenarrowed at the base, broadly incised at the apex, coriaceous, brown, $22 \mathrm{~mm}$. long and broad, somewhat lustrous; seeds winged, $10 \mathrm{~mm}$. long, $8 \mathrm{~mm}$. wide, fuscous, the wings $2-3 \mathrm{~mm}$. wide.

There is no certainty that this plant was collected in Guatemala, since the "Guatemala" heading on Friedrichsthal's labels is not dependable, and the type may well have come from Honduras, Nicaragua, or Costa Rica. 
Dioscorea hondurensis Knuth, Repert. Sp. Nov. 38: 120. 1935.

Known only from the type, upper Moho River, British Honduras, M. E. Peck 549.

Stems stout; leaves alternate, on petioles about $7 \mathrm{~cm}$. long, firm-papyraceous, cordate-ovate, $16 \mathrm{~cm}$. long and $11 \mathrm{~cm}$. wide, acute, rather deeply cordate, subdecurrent on the petiole, 9-nerved; pistillate spikes sometimes $50 \mathrm{~cm}$. long, floriferous to the base; capsule obtriquetrous, as much as $4.5 \mathrm{~cm}$. broad and $3 \mathrm{~cm}$. long, almost retuse at the apex, borne on a pedicel $1 \mathrm{~cm}$. long.

The species is known only from fruiting specimens, and on that account it is not included in the key to species presented on the preceding pages.

Dioscorea macrostachya Benth. Pl. Hartweg. 73. 1839. D. composita Hemsl. Biol. Centr. Amer. Bot. 3: 354. 1884. D. astrostigma Uline, Bot. Jahrb. 22: 3. 1896 (type from Volcán de Fuego, Sacatepéquez, J. D. Smith 2565). Peng (Huehuetenango).

Moist or dry thickets or forest, 1,500 meters or less; Alta Verapaz; Izabal; Jalapa; Santa Rosa; Sacatepéquez; Quezaltenango; San Marcos; Huehuetenango. Southern Mexico to Salvador and Panama.

Plants glabrous or nearly so, the stems stout or slender, usually dextrorsely twining; leaves alternate, long-petiolate, membranaceous or chartaceous, $20 \mathrm{~cm}$. long and $18 \mathrm{~cm}$. wide or usually much smaller, abruptly acute or cuspidateacuminate, shallowly or deeply cordate, 7-9-nerved; staminate inflorescences simple or branched, 15-30 cm. long, the flowers fasciculate-glomerate, the fascicles short-stipitate, 2-3-flowered, dense, the flowers sessile or nearly so; perianth rotate, 1.5-2 mm. broad, the segments somewhat carnose, rounded and obtuse, dark brownish when dried; fertile stamens 6 , subcentral, the anthers subsessile; pistillate spikes simple; sterile stamens 6 , minute; stigmas subsessile, thick, divergent, furcate or stellate-bifurcate at the apex; capsule oblong or oval, $2.5 \mathrm{~cm}$. long, the angles marginate; seeds oblong, winged on all sides. (Fig. 29.)

Called "camotillo" in Honduras, where the root is used as a fish poison; "cuculmeca” (Salvador).

\section{Dioscorea matagalpensis Uline, Bot. Jahrb. 22: 432. 1897.}

Moist or wet thickets or forest, 750 meters or less; Petén; Zacapa. Yucatan Peninsula of Mexico; British Honduras; Nicaragua.

Plants slender, the stems sinistrorsely twining; leaves on long slender petioles, membranaceous, green when dried, rounded-cordate, $10 \mathrm{~cm}$. long and $7 \mathrm{~cm}$. wide or smaller, acuminate or narrowly long-acuminate, deeply cordate at the base, 7-nerved, glabrous; staminate spikes $10 \mathrm{~cm}$. long, simple or sparsely branched, the flowers in 3-4-flowered glomerules; perianth $1.5 \mathrm{~mm}$. broad, the segments ovate-oblong, obtuse, equal; fertile stamens 3 , the anthers small, the cells not 

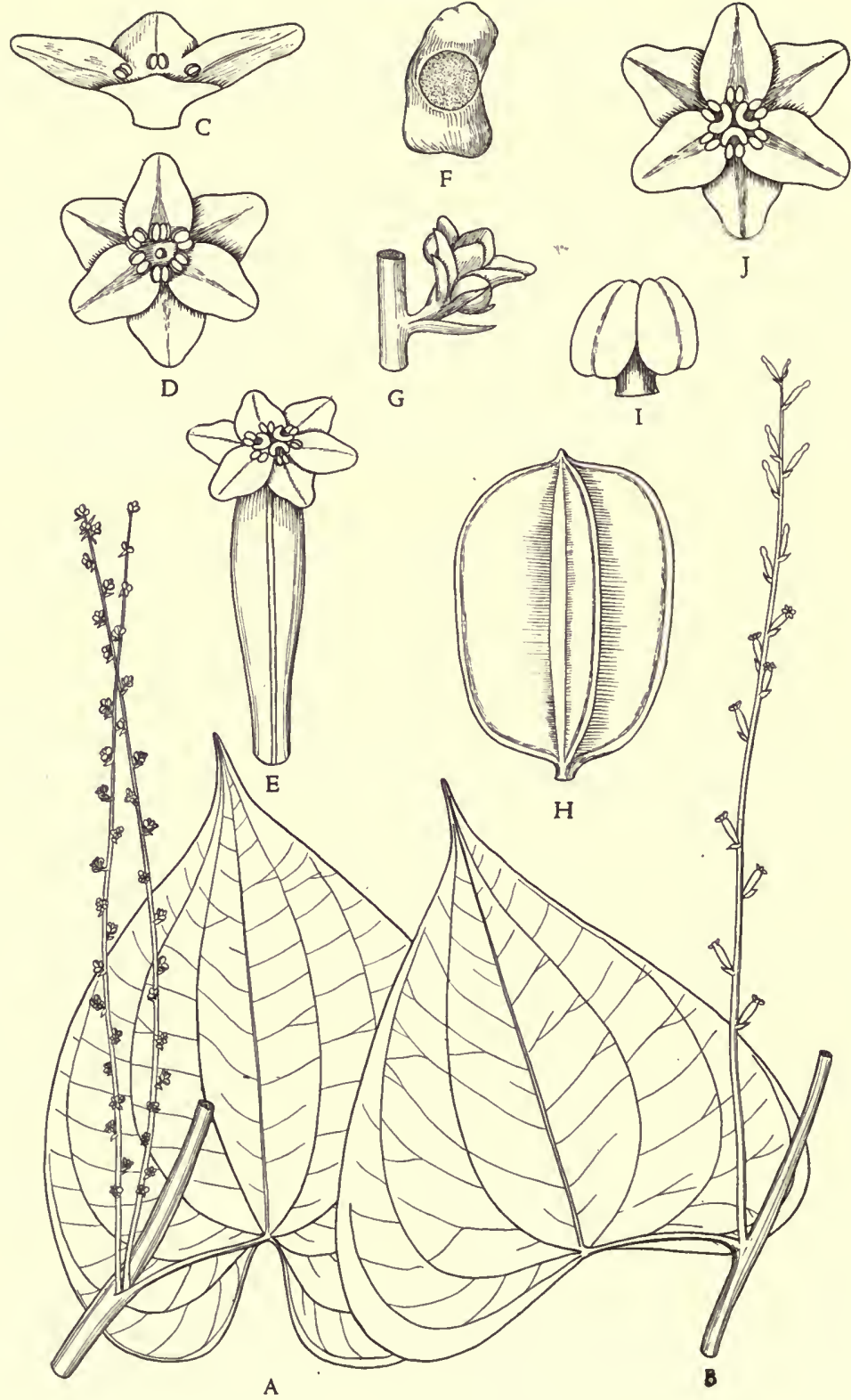

Fig. 29. Dioscorea macrostachya. A. Habit of portion of staminate plant; $\times 2 / 3$. B. Habit of portion of pistillate plant; $\times 2 / 3$. C. Staminate flower, half of it viewed from within; $\times 5$. D. Staminate flower, viewed from above; $\times 3$. E. Pistillate flower; $\times 6$. F. Seed; $\times 1$. G. Staminate flowers in position, viewed from side; $\times 4$. H. Capsule; $\times 1$. I. Stamen; $\times 18$. J. Pistillate flower, viewed from above; $\times 3$. 
discrete; sterile stamens 3 , spatulate, all the stamens inserted on the perianth tube above its base; style rudiment none; pistillate racemes solitary, simple, 8-12 $\mathrm{cm}$. long; perianth subrotate, fuscous, $1.5 \mathrm{~mm}$. broad, the segments ovate-orbicular, obtuse, membranaceous; sterile stamens 6; capsule glabrous, about $14 \mathrm{~mm}$. long and $11 \mathrm{~mm}$. broad; seeds winged on all sides.

Dioscorea Nelsonii Uline ex Knuth, Notizbl. Bot. Gart. Berlin 7: 202. 1917.

Moist or wet, mixed forest, sometimes in pine forest, 1,000-1,500 meters; Sololá; San Marcos; determinations of both collections are questionable. Southern and western Mexico.

Stems stout, sinistrorsely twining, glabrous except sometimes at the nodes; leaves large, long-petiolate, membranaceous or chartaceous, orbicular-cordate, $18 \mathrm{~cm}$. long and wide or smaller, 11-nerved, glabrous, rather shallowly cordate at the base, acuminate; racemes elongate, the flowers in 3-5-flowered fascicles, short-pedicellate or almost sessile; staminate perianth $2.5 \mathrm{~mm}$. long, the segments spreading, narrowly oblong; fertile stamens 6 , subincurved, slightly shorter than the perianth, inserted at the base of the segments, the anthers oblong, introrse; style rudiment rather large; pistillate perianth obscurely puberulent; capsule elliptic, acute at the base and apex, about $33 \mathrm{~mm}$. long and $22 \mathrm{~mm}$. broad.

Dioscorea polygonoides Humb. \& Bonpl. ex Willd. Sp. Pl. 4: 795. 1805.

Wet to dry thickets or forest, 2,000 meters or less; Chiquimula; Santa Rosa; Escuintla; Retalhuleu. Southern Mexico; Panama; West Indies; northern South America.

Plants glabrous, the stems sinistrorsely twining; leaves on long or short petioles, membranaceous, usually pale green when dry, cordate-ovate, mostly 8-12 $\mathrm{cm}$. long and almost as wide, cuspidate-acuminate, deeply or shallowly cordate, 7-9-nerved; staminate spikes simple or with a few branches, sometimes much elongate, the rachis scaberulous, the flowers sessile, glomerulate, the glomerules rather remote, 3-5-flowered; perianth membranaceous, green, glandular-puncticulate outside, turbinate-rotate, the lobes short-ovate, often auriculate at the base; stamens 6 , inserted on the perianth tube, 3 of the stamens fertile, the anthers extrorse, with distinct cells; sterile stamens 3, entire or 2-fid at the apex, slightly shorter than the fertile ones; style rudiments 3 , distinct, minute; pistillate racemes simple, sterile stamens 6 , with 3 of them antheriferous; stigmas 2-lobate at the apex; capsule glabrous, broadly elliptic, $2-2.5 \mathrm{~cm}$. long, $1.7-2.2 \mathrm{~cm}$. wide, or sometimes smaller; seeds winged on all sides.

Dioscorea Standleyi Morton, Carnegie Inst. Wash. Publ. 461: 252. 1936.

At 500-1,500 meters; Chiquimula (Cerro Tixixí, north of Jocotán, Steyermark 31622; determined by Morton). Mountains of Costa Rica. 
Stems glabrous; leaves alternate, long-petiolate, ovate-cordate, $12 \mathrm{~cm}$. long and $10 \mathrm{~cm}$. wide or smaller, papyraceous, acuminate, rather shallowly cordate at the base, 9-nerved, glabrous; staminate spikes solitary or binate, $14-15 \mathrm{~cm}$. long, glabrous, the flowers arranged in 2-3-flowered cymules, the pedicels $2-4 \mathrm{~mm}$. long; staminate perianth green, glabrous, the segments linear-oblong, $2 \mathrm{~mm}$. long; stamens 3, the anthers globose, extrorse, the cells distinct; style rudiment none; pistillate inflorescence racemose, spike-like, solitary, simple, $11 \mathrm{~cm}$. long or less, the flowers on very short pedicels, the bracts lanceolate; perianth stipitate, the segments linear-oblong, $1.5 \mathrm{~mm}$. long; staminodia none; ovary glabrous; capsule (immature) $15 \mathrm{~mm}$. long, $5 \mathrm{~mm}$. wide; seeds winged on all sides.

Dioscorea tenebrosa Morton, Carnegie Inst. Wash. Publ. 461: 247. 1936.

Known only from the type, Pansamalá, Alta Verapaz, 1,100 meters, Türckheim 1241.

Stems sinistrorsely or dextrorsely twining, glabrous; leaves alternate, on petioles $3 \mathrm{~cm}$. long or less, membranaceous, glabrous, 3-parted, the middle segments lanceolate, up to $8 \mathrm{~cm}$. in length and $3.5 \mathrm{~cm}$. wide, acuminate, narrowed and cuneate at the base, 3-nerved, the lateral segments shorter, the largest $5 \mathrm{~cm}$. long and $2.5 \mathrm{~cm}$. wide, somewhat oblique and falcate; staminate inflorescences racemose, solitary or binate, simple, $10 \mathrm{~cm}$. long or less, the flowers solitary, approximate, the pedicels $1-1.5 \mathrm{~mm}$. long, glabrous; perianth rotate, $5-6 \mathrm{~mm}$. broad, the segments almost free, oblong, glabrous; stamens 3 , inserted on the margin of a fleshy disk, the anthers sessile; style rudiment none.

This has been recorded from Guatemala as D. trifoliata HBK., a South American species.

Dioscorea Tuerckheimii Knuth, Notizbl. Bot. Gart. Berlin 7: 203. 1917.

Moist or wet thickets or forest, Alta Verapaz (known only from the type, Cubilguiitz, Türckheim 7787).

Plants glabrous; leaves alternate, slender-petiolate, papyraceous, elongatecordate-triangular, about $10 \mathrm{~cm}$. long and $6 \mathrm{~cm}$. wide, gradually narrowed to the acuminate apex, very shallowly cordate or subtruncate at the base, the blade usually abruptly short-decurrent upon the petiole, 9-nerved; staminate spikes 5-7 cm. long, solitary, dense, the bracts lance-acuminate; flowers fasciculate, the fascicles mostly 2-3-flowered, the pedicels $0.5-3 \mathrm{~mm}$. long; perianth campanulate-globose, $1.5 \mathrm{~mm}$. broad, somewhat fleshy, the segments broadly ovate, often broader than long, rounded at the apex or almost retuse; fertile stamens 6 , attached to the base of the perianth tube, the filaments short; style rudiment conoid; capsule about $2 \mathrm{~cm}$. long and $1.5 \mathrm{~cm}$. broad, glabrous.

This has been reported from Guatemala as D. propinqua Hemsl.

Dioscorea yucatanensis Uline, Field Mus. Bot. 1: 416. 1899.

Reported with some doubt by Morton from Duck Run, El Cayo District, British Honduras, H. H. Bartlett 11560. Yucatan. 
Plants slender, glabrous; leaves alternate, on petioles $1-5 \mathrm{~cm}$. long, membranaceous, orbicular-cordate, very small, 7-nerved; staminate spikes solitary, much longer than the leaves, the flowers minute, sessile, subsolitary, dark purple; perianth $1.5 \mathrm{~mm}$. in diameter, the segments membranaceous, oblong; fertile stamens 3 , short, subcentral, alternating with 3 spatulate staminodia, erect-divergent, the anthers minute, introrse; style rudiment none; pistillate spikes few-flowered, twice as long as the leaves in age, $7-10$-flowered; sterile stamens 3 , alternating with 3 minute ones; ovary glabrous.

\section{IRIDACEAE. Iris Family}

\section{Reference: J. G. Baker, Handbook of the Irideae, London. 1892.}

Perennial herbs, with elongate or bulb-like rootstocks, rarely annuals with fibrous roots or perennials with a cluster of tuberous-thickened roots; leaves usually equitant, 2-ranked; flowers perfect, regular or irregular, small or large, solitary or in clusters from spathe-like bracts; perianth of 6 lobes or distinct segments, the tube adnate to the ovary, the segments 2 -seriate, convolute in bud, withering-persistent; stamens 3 , inserted on the perianth opposite the outer segments, the filaments distinct or partially united, the anthers 2-celled, extrorse; ovary inferior, 3-celled; ovules numerous, anatropous; styles distinct, entire or parted, sometimes petaloid; fruit capsular, loculicidally 3 -valvate; seeds numerous, in 1-2 rows in each cell; embryo straight, the endosperm carnose or corneous.

Genera about 55, with 800 species or more, widely distributed in tropical and temperate regions. No other genera are known to be native in Central America.

Plants arising from rootstocks or from a cluster of fibrous or fleshy-thickened tuber-like roots, never from bulb-like corms; leaves not plicate.

Plants without rootstocks, arising from a cluster of fibrous or fleshy tuber-like roots; flowers small, blue, white, or yellow............ Sisyrinchium.

Plants with short or elongate rootstocks; flowers usually large.

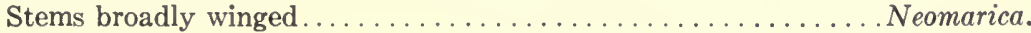
Stems not winged.

Leaves with a conspicuous costa. Flowers yellow, about $2 \mathrm{~cm}$. long.

Trimeza.

Leaves not with an evident costa, the nerves all about equally prominent.

Style branches opposite the stamens and the outer perianth segments; cultivated plants, sometimes naturalized................ Iris.

Style branches alternate with the anthers; native plants. . Orthrosanthus. Plants arising from bulb-like corms covered with membranaceous or firm tunics; leaves often plicate.

Leaves not plicate; cultivated plants, rarely becoming naturalized.

Perianth 3-4 $\mathrm{cm}$. long; spathes about $8 \mathrm{~mm}$. long; perianth orange-red.

Tritonia.

Perianth much larger; spathes large; perianth variously colored. . Gladiolus. Leaves evidently plicate.

Style branches opposite the stamens and outer perianth segments.

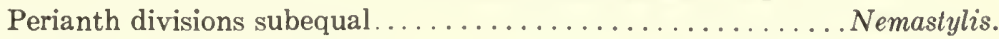

Perianth divisions unequal. 
Perianth about $7 \mathrm{~cm}$. long, the inner segments large, spreading, panduriform, the outer ones orange-red and yellow............ Tigridia.

Perianth $3-3.5 \mathrm{~cm}$. long, the inner segments small, appressed, ovate, the

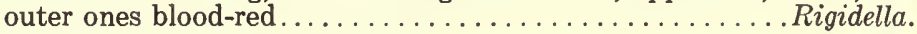

Style branches alternate with the anthers.

Perianth segments very unequal, the inner ones small; style-arms not linear-subulate; spathes sessile. Perianth white or bluish white.

Cipura.

Perianth segments subequal; spathes usually pedunculate; style-arms linear to subulate.

Filaments united.

Gelasine.

Filaments free.

Leaves broad, strongly plicate; inflorescence pseudolateral; tunics purple or purple-brown; very thick............. Eleutherine.

Leaves very narrow, or, if broader, not strongly plicate; inflorescence not pseudolateral, or if so, spathes 1-flowered; tunics castaneous or blackish-brown, thin ........................

\section{CAL YDOREA Herbert}

Plants perennial, glabrous, arising from membranous, thin, castaneous or blackish-brown tunicate bulbs; leaves few, very narrow, or, if broader, not strongly plicate; spathes 1-flowered, the inflorescence terminal, not pseudolateral, pedunculate; perianth tube none, the segments equal or subequal, spreading, obovatecuneate; stamens attached at the base of the segments, alternate with the stylearms, the filaments erect, free, the anthers linear, rolling up spirally at the tip; ovary oblong, 3-celled; style filiform, the style-arms narrowly linear, of the same width throughout, entire, or rarely briefly bifid at the apex, stigmatose at apex; capsule obovoid or turbinate, exserted, loculicidally 3-valvate; seeds small, globose or angulate.

\section{About 8 species, all but the following South American.}

Calydorea guatemalensis (Standl.) Foster, Contr. Gray Herb. 155: 46. 1945. Eleutherine guatemalensis Standl. Field Mus. Bot. 4: 200. 1929.

Moist shaded soil, sometimes in pine forest, 1,200-2,000 meters; endemic; Alta Verapaz (type from Cobán, Türckheim II. 1885); Baja Verapaz; Zacapa; Chiquimula; Escuintla.

Bulb about $3.5 \mathrm{~cm}$. long, with firm brown tunics; basal leaves 2-3, petiolate, broadly linear, $30-70 \mathrm{~cm}$. long, $1-2.5 \mathrm{~cm}$. wide; scapes $40-70 \mathrm{~cm}$. high, slender, the bract at the base of the inflorescence similar to the basal leaves but narrower; spathes one or more, $4.5-6.5 \mathrm{~cm}$. long, the peduncles mostly $8-20 \mathrm{~cm}$. long; perianth white, turning bluish in age, $3 \mathrm{~cm}$. broad or less; capsule obpyramidal-obovoid, 12-15 mm. long.

\section{CIPURA Aublet}

Rootstock a small ovoid bulb-like corm with thin loose brown tunics; radical leaves few, plicate; scape terete, naked, bearing at the apex a dense head-like cluster of spathes, the inflorescence subtended by a reduced plicate leaf; perianth parted 


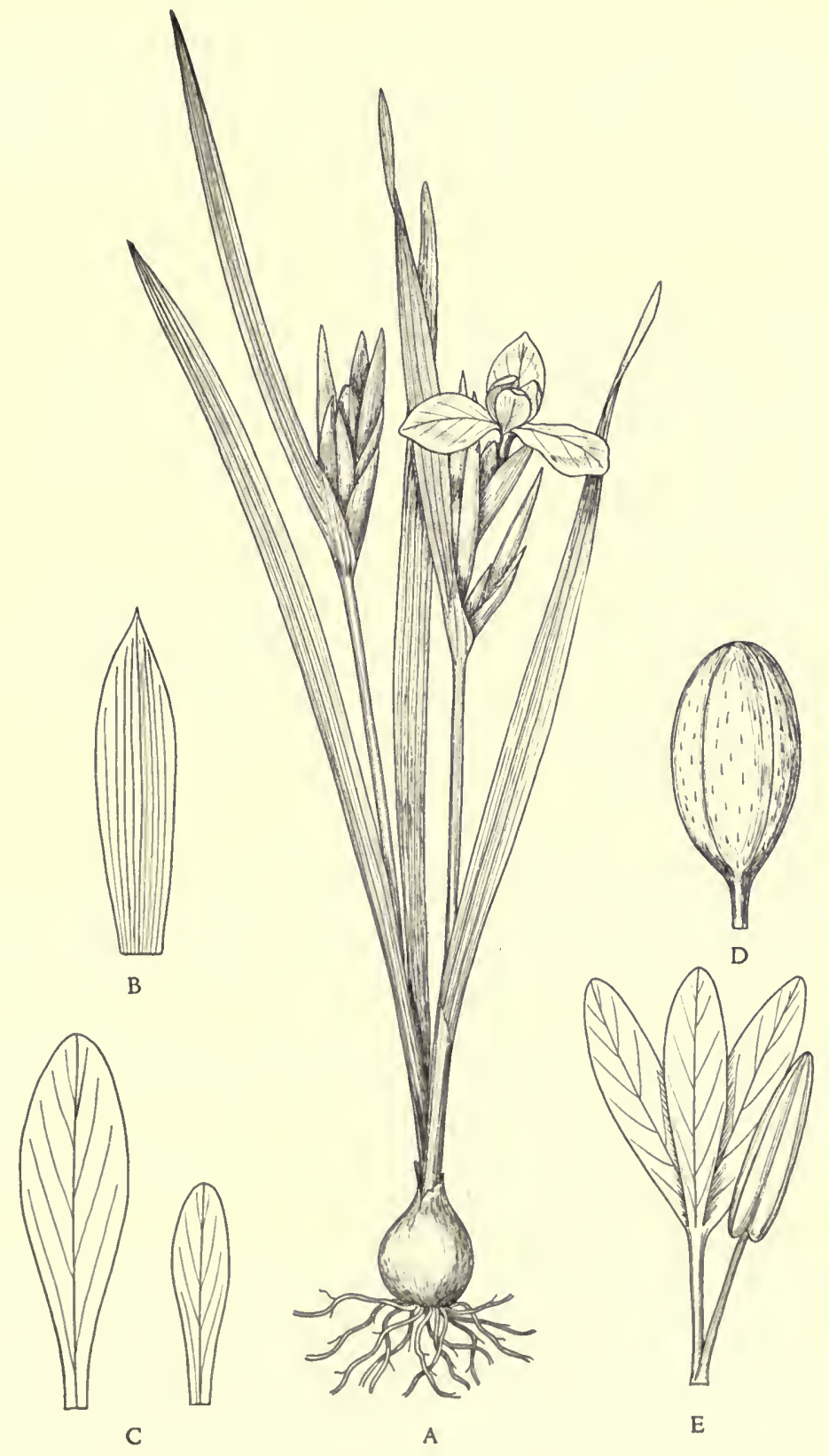

Fig. 30. Cipura paludosa. A. Habit of plant; $\times 2 / 3$. B. Spathe; $\times 4$. C. Outer (left) and inner (right) perianth segments; $\times 4$. D. Capsule; $\times 4$. E. Stamen and style-branches; $X 4$. 
to the ovary, the outer segments obovate-cuneate, becoming reflexed, the inner segments shorter, connivent; stamens inserted at the base of the inner segments, the anthers as long as the free filaments; ovary clavate, the ovules numerous, superposed; style filiform, the branches oblong, petaloid; capsule oblong-turbinate, membranous; seeds numerous, small, angulate.

The genus consists of a single species.

Cipura paludosa Aubl. Pl. Guian. 38. pl. 13. 1775. C. cubensis Griseb. Cat. Pl. Cub. 251. 1866.

Open grassy places, often in savannas or thin pine forest, sometimes a weed about dwellings or in cultivated ground, 1,500 meters or less; Petén; Alta Verapaz; Izabal; Chiquimula; Suchitepequez; Quiché; Huehuetenango. Mexico; British Honduras to Panama; West Indies; South America.

Basal leaves usually 2-3 and 20-40 cm. long, 3-12 mm. wide, glabrous; scape not winged, very slender, $15-45 \mathrm{~cm}$. high; spathes cylindric, $2.5-5 \mathrm{~cm}$. long, green, the outer one short; pedicels slender, about equaling the spathe; perianth white or tinged with lavender, very delicate and fugacious, somewhat campanulate, nutant, the outer segments $12-20 \mathrm{~mm}$. long, the inner ones much shorter, with yellow blotches near the base; capsule 1-2 cm. long; seeds dark brown, hard, obtusely angulate. (Fig. 30.)

\section{ELEUTHERINE Herbert}

Plants perennial, glabrous, arising from membranous, very thick, purple or purple-brown tunicate bulbs; leaves few, broad, strongly plicate; spathes one or two, several-flowered, the inflorescence pseudolateral, pedunculate; perianth tube none, the segments equal or subequal, spreading, obovate-cuneate; stamens attached at base of the segments, alternate with the style-arms, the filaments short, free, anthers linear; ovary oblong, 3-celled; style very short, style-arms subulate, entire, broadest at or near the middle, stigmatose at apex; capsule oblong, loculicidally 3-valvate; seeds small, angulate.

Probably 2 species ranging from Mexico, Central America and the West Indies to South America.

Eleutherine bulbosa (Mill.) Urban, Repert. Sp. Nov. 15: 305. 1918. Sisyrinchium bulbosum Mill. Gard. Dict. ed. 8: no. 3. 1768. Sisyrinchium palmifolium L. Mant. Pl. 1: 122. 1767. Eleutherine plicata Herb. ex Klatt in Mart. Fl. Bras. 3, pt. 1: 514. 1871. E. palmifolia (L.) Merrill, Philip. Journ. Sci. 7: Bot. 233. 1912.

At about 900 meters in shady places; Quezaltenango. Mexico; Salvador; Honduras; West Indies. South America.

Bulbs ovoid, $3 \mathrm{~cm}$. or more in diameter, the tunics firm, red-brown; basal leaves 1-2, linear-lanceolate, $15-40 \mathrm{~cm}$. long, 1-3.5 cm. wide, plicate; scape $10-30 \mathrm{~cm}$. 
high, not winged, usually bearing a single 6-12-flowered spathe, this subtended by a leaf similar to the basal ones; spathes about $1.5 \mathrm{~cm}$. long, the flowers slenderpedicellate; perianth white, $2-2.5 \mathrm{~cm}$. broad, the segments obovate, spreading; capsule about $2 \mathrm{~cm}$. long.

Called "coquillo" in Salvador.

\section{GELASINE Herbert}

Plants small or large, from a tunicate corm; leaves plicate; flowers blue, fugitive, several subtended by each spathe; perianth tube very short, the segments equal, obovate; stamens inserted at the base of the perianth segments, the filaments united to the apex to form a cylindric column; anthers basifixed, erectpatent; ovary clavate, the ovules numerous, superposed; style short, subulate, the stigmas linear, simple; capsule turbinate, loculicidally 3-valvate.

One other species is known, in Uruguay and southern Brazil.

Gelasine trichan tha J. G. Baker, Bot. Jahrb. 8: 215. 1887.

Known only from the type, Sipicapa, San Marcos, F. C. Lehmann 1541 ; known to us only from description.

Corm globose, the tunics brown, membranaceous, produced above the neck of the corm, the stem very slender, bearing a single head of flowers, $3.5-5 \mathrm{~cm}$. high; basal leaf 1 or none, linear, the cauline leaf 1 , linear, erect, dilated and clasping at the base; outer valve of the spathe firm, lanceolate, scarious above, the inner valves membranaceous, the pedicels equaling the valves; ovary turbinate, glabrous; perianth blue, the segments equal, oblanceolate, densely pilose; stamens shorter than the perianth, the filaments very short, the anthers large, yellow; style very short, the 3 branches patent, filiform, stigmatose at the apex, shorter than the anthers.

Flowers of the genus Freesia (probably F. hybrida Hort.) are sometimes seen on sale in the markets of Guatemala City, but the plants are not common in Central America.

\section{GLADIOLUS L. Gladiolus}

Plants arising from tunicate corms; leaves distichous, narrow, mostly superposed on the stem, linear or ensiform; inflorescence spicate, the flowers 1 to each spathe, sessile, of various colors, the valves of the spathe linear or lanceolate; flowers very variable in size and color; perianth tube generally funnelform, the segments of the limb more or less unequal in shape and direction; stamens inserted in the throat of the perianth tube, contiguous and arching, the filaments short, free, the anthers linear, basifixed; ovary 3-celled, the ovules numerous, superposed; seeds globose or discoid, sometimes winged.

About 150 species, all natives of the Old World. A number of them are grown for ornament. 


\section{Gladiolus hortulanus L. H. Bailey, in Hortus 277. 1930. Gladiola.}

Grown commonly for ornament and often in large numbers for sale in the markets, principally at middle or fairly high elevations; sometimes found more or less wild in thickets, as about Cobán, also in cornfields of the highlands, perhaps there only the remnants of commercial planting.

The gladioli of gardens are largely of hybrid origin and of confused ancestry. The flowers sell well in the larger markets, as they do in the United States, and the Indian gardeners of such places as San Juan Sacatepéquez and the vicinity of Quezaltenango often plant good-sized patches of the bulbs. Gladioli thrive particularly well about Cobán and Tactic, as do most other cultivated flowers, and in that region some fine large-flowered varieties may be seen, probably introduced by German gardeners. The gladiolus is much used for decorating wayside crosses and shrines because the flowers last a long time without water.

\section{IRIS L. Iris}

Perennial herbs, usually with thick, elongate, often horizontal rootstocks; leaves linear or ensiform, thin or rather thick and fleshy, equitant; stems simple or branched, the flowers often large and showy, 1-2 in each spathe, the outer valves of the spathe large, ovate, herbaceous or membranous; perianth tube cylindric, long, short, or obsolete, the segments of the 2 series more or less dissimilar in shape and size, the 3 outer ones cuneate-obovate, reflexed in anthesis, the 3 inner ones unguiculate, usually erect; stamens inserted at the base of the outer perianth segments opposite the petaloid styles; filaments short, the anthers linear, basifixed; ovary 3-celled, the ovules numerous; style branches petaloid, with a terminal stigma and 2 deltoid petaloid crests; capsule oblong, trigonous or hexagonous; seeds globose.

About 150 species, widely distributed, chiefly in temperate regions. A good many species are native in temperate North America, but none in tropical America. Many are cultivated for their handsome flowers.

\section{Iris germanica L. Sp. Pl. 38. 1753. Lirio.}

Native of Europe, but grown in many temperate regions for its handsome flowers; planted commonly in Guatemala at middle and high elevations; naturalized in many places along roadsides and in thickets.

Plants erect from a thick rootstock, the stems stout, usually branched, mostly $70 \mathrm{~cm}$. high or less, bearing several large ensiform leaves; leaves glaucescent, 1.5- 
$5 \mathrm{~cm}$. wide, finely many-nerved, the basal ones usually shorter than the stems; flowers almost sessile in the bracts, large and showy, deep violet-blue to pale blue or often white, veined with yellow.

This iris is common in the gardens of Cobán, and abundant in many parts of the Occidente. It was noted as thoroughly naturalized in the mountains of Quezaltenango and San Marcos. On the plains of Quezaltenango there are many long dense rows of the plants, bordering roads and separating fields. This is the plant to which the name "lirio" is most commonly applied in Central America.

\section{NEMASTYLIS Nuttall}

Reference: Robert F. Foster, A revision of the North American species of Nemastylis, Contr. Gray Herb. 155: 26-44. 1945.

Herbaceous perennials with simple or branched stems from an ovoid or subglobose bulb; leaves linear to lance-ensiform, often plicate; flowers blue, white, or lavender, sometimes marked with irregular splotches and lines, fugitive, rotate, 1-several subtended by the spathes; perianth tube very short, the segments regular, equal or unequal; stamens inserted near the base of the perianth segments, the filaments free or more or less united; anthers longer than the filaments, with a narrow connective coiling downward from the apex at maturity; ovary oblongellipsoid, subclavate, or subturbinate; style filiform, equal to or usually shorter than the 3 style branches, the style branches bifid, opposite the stamens; stigmas apical, subcapitate or tufted, or minutely 2-parted; capsule oblong-ellipsoid, dehiscent by 6 deltoid teeth at the apex.

About 15 species, all native of the New World. Of this number, Foster limits his treatment, based upon Nuttall's concept of the genus, to four North American species, of which only one, N. tenuis, reaches Guatemala. The remaining species from Guatemala treated below by the present authors were all determined as Nemastylis by Dr. Foster, but may eventually have to be transferred to other genera, in accordance with his future monographic studies. $\mathrm{He}$ considers the South American species previously assigned to Nemastylis to be better placed in other genera.

Perianth rotate; style shorter than style-arms or barely equal to them; antherconnective narrow, anthers coiling downward from the apex with age.

N. tenuis.

Perianth broadly campanulate to crateriform; style much longer than style-arms; anther-connective broad, anthers seldom coiling downward from the apex with age.

Depressed plant, 2-5 cm. tall; perianth segments strongly unequal. N. Seleriana. Plant 10-40 cm. tall; perianth segments subequal.

Basal leaf solitary; perianth blue-violet without specks............ triflora.

Basal leaves usually 2; perianth blue or lilac marked with reddish-brown

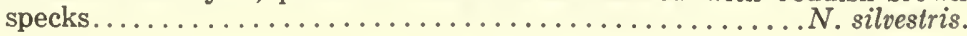


Nemastylis Seleriana Loes. Verh. Bot. Ver. Brand. 58: 137. 1916. Nemastylis Lehmannii Standl. Field Mus. Bot. 4: 199. 1929 (type collected between Volcan de Tajumulco and Tacaná, $F$. $C$. Lehmann 1556).

Open moist meadows, 3,100-3,600 meters; endemic; Totonicapán; Quezaltenango (type collected between Zihá and Calel, Seler 3155); San Marcos.

Subacaulescent plant, $2-5 \mathrm{~cm}$. tall, bulb ovoid-conic, the tunics dark brown, the stem 1-2-flowered; leaves basal, 1-3, narrowly linear, subulate-acuminate, 3-10 $\mathrm{cm}$. long, 1-4 mm. wide; spathe dilated at base, the expanded portion leaflike, linear-oblanceolate, subulate-acuminate, $2.5-4.5 \mathrm{~cm}$. long; bracts 2 , subscarious, linear-oblong, $2.5-3.5 \mathrm{~cm}$. long; peduncle very short, $0.5-2.5 \mathrm{~cm}$. long; pedicels 1-3 cm. long; ovary cylindric-obconic, 4-6 $\mathrm{mm}$. long; perianth white with dull purple blotches and transverse marks, the tube none, outer segments ovate- or broadly elliptic-oblong, obtuse, $10-13 \mathrm{~mm}$. long, $6 \mathrm{~mm}$. wide, inner segments $1 \mathrm{~mm}$. long, abruptly unguiculate, the blade broadly ovate or suborbicular-ovate, acute at apex, subtruncate or rounded at base, 5-6 $\mathrm{mm}$. long, $5 \mathrm{~mm}$. wide; filaments connate in a long narrow tube $3 \mathrm{~mm}$. long, anthers linearoblong, 5-6 mm. long; style branches 2-parted, not equaling the length of the anthers.

Nemastylis silvestris Loes. in Fedde, Repert. Spec. Nov. 16: 200. 1919. Nemastylis Bequaertii Standl. Journ. Arn. Arb. 11: 47. 1930 (type from Chichen Itzá, Yucatan, J. Bequaert 109).

Open pine-oak woodland or clearings, near or slightly above sea-level. British Honduras; Southern Mexico (Yucatan and Chiapas).

Glabrous plant 3-4 dm. tall, bulb ovoid-conic, up to $2 \mathrm{~cm}$. long, the tunics dark or dull brown, the stem 4-6-flowered; leaves conspicuous, elongated, broadly linear to narrowly lanceolate, the usually 2 basal ones long-attenuate, acuminate at apex, narrowed at the base to an obscure petiole up to $8 \mathrm{~cm}$. long, $2.8-4.7 \mathrm{~cm}$. long, 1.3-1.6 $\mathrm{cm}$. wide, 5-nerved, cauline shorter, $0.6-1 \mathrm{~cm}$. wide, inserted about or above the middle; spathes subcymbiform, somewhat rounded at base, rather sharply pointed at apex, $2-3 \mathrm{~cm}$. long, long-pedunculate; bracts very unequal, erect, the interior twice shorter or sometimes almost equaling the outer, $2-3 \mathrm{~cm}$. long, long-attenuate at apex; peduncle erect or ascending, slender, 4-8 cm. long; pedicels slender, $2-2.5 \mathrm{~cm}$. long, included or shortly exserted; flowers glomerulate; ovary oblong or obconic-subovoid, $5 \mathrm{~mm}$. long; perianth blue or lilac, marked with reddish-brown specks, $9-10 \mathrm{~mm}$. long, the tube almost none, the segments obovate or cuneate-obovate, broadly rounded at the apex; filaments about $2.5 \mathrm{~mm}$. long, anthers linear, straight, $4-5 \mathrm{~mm}$. long.

Nemastylis tenuis (Herb.) Baker, Handb. Irid. 112. 1892. Nemastylis coelestina var. tenuis Herb. in Bot. Mag. 66. pl. 3779. 1840. Chlamydostylis tenuis (Herb.) Baker, in Journ. Bot. 14: 185. 1876. 
Open oak or pine slopes, 1,000-1,800 meters; Jalapa; Santa Rosa. Mexico north to Chihuahua and Coahuila.

Bulb ovoid to subglobose, up to $2.5 \mathrm{~cm}$. long, $2 \mathrm{~cm}$. wide, the tunics castaneous or dark brown, the stem terete, 1-5-flowered, 1-3 dm. tall, glabrous; basal leaves 2-3, linear, acute, up to $25 \mathrm{~cm}$. long, 1-3 mm. wide, often scabrous on the margins, cauline shorter, 6-9 cm. long; spathes unequal, the outer $1-2 \mathrm{~cm}$. long, acute, the inner up to $2.5 \mathrm{~cm}$. long; pedicels included at anthesis or slightly exserted; ovary ovoid or ellipsoid, 3-4 mm. long; perianth blue, segments subequal, obovate, obtuse, up to $20 \mathrm{~mm}$. long, $6-8 \mathrm{~mm}$. wide; filaments entirely united, $1.5-2.5 \mathrm{~mm}$. long, anthers 6-7 mm. long; style equaling the filament column, style branches up to $4 \mathrm{~mm}$. long; capsule oblong-ellipsoid or turbinate, up to $1.5 \mathrm{~cm}$. long; seeds dark brown, more or less pyriform, $2 \mathrm{~mm}$. long.

The Guatemalan specimens are referred by Dr. Foster to typical $N$. tenuis, which is distinguished from most of the other varieties in having the filaments entirely united.

\section{Nemastylis triflora Herb. in Benth. Pl. Hartw. 95. 1842.}

Known only from the type, oak woods in the mountains of Comalapan, Hartweg 625.

Bulb ovoid, $1.8 \mathrm{~cm}$. wide, the stem 3-flowered, 3-4.5 dm. tall; basal leaf solitary, linear, acute, up to $30 \mathrm{~cm}$. long, 5-6 $\mathrm{mm}$. wide, very plicate, cauline shorter; spathes subequal, acuminate at apex, up to $5 \mathrm{~cm}$. long; perianth blueviolet, 18-25 mm. long, the segments broadly cuneate-obovate, the larger erose; anther about $5.5 \mathrm{~mm}$. long; style branches filiform, $8 \mathrm{~mm}$. long.

This species is known to the authors only from description.

\section{NEOMARICA Sprague}

Plants perennial, from short rhizomes; leaves broadly linear, ensiform, distichous, flabellate, with a prominent costa; peduncle compressed and leaf-like, with 1 or few subsessile or pedunculate flower clusters, the peduncle long-produced beyond the inflorescence; flowers fugitive, blue, yellow, or white; perianth tube obsolete, the segments of the 2 rows very unlike, the outer ones obovate, spreading, the inner ones much smaller, panduriform, convolute; stamens short, erect, the filaments distinct; ovary clavate, 3-celled, the ovules numerous, superposed; style subulate at the base, cyathiform with 3 angles in the upper half to which the anthers adhere loosely; style crests lanceolate, with the transverse stigmas at their base; capsule oblong, loculicidally 3-valvate; seeds subglobose or angled by pressure, with a brown testa and corneous endosperm, surrounded by a fleshy aril.

About ten species, in tropical America.

Neomarica gracilis (Herb.) Sprague, Kew Bull. 1928: 280. 1928. Marica gracilis Herb. Bot. Mag. pl. 3713. 1839. Cucquén (Quecchí). 


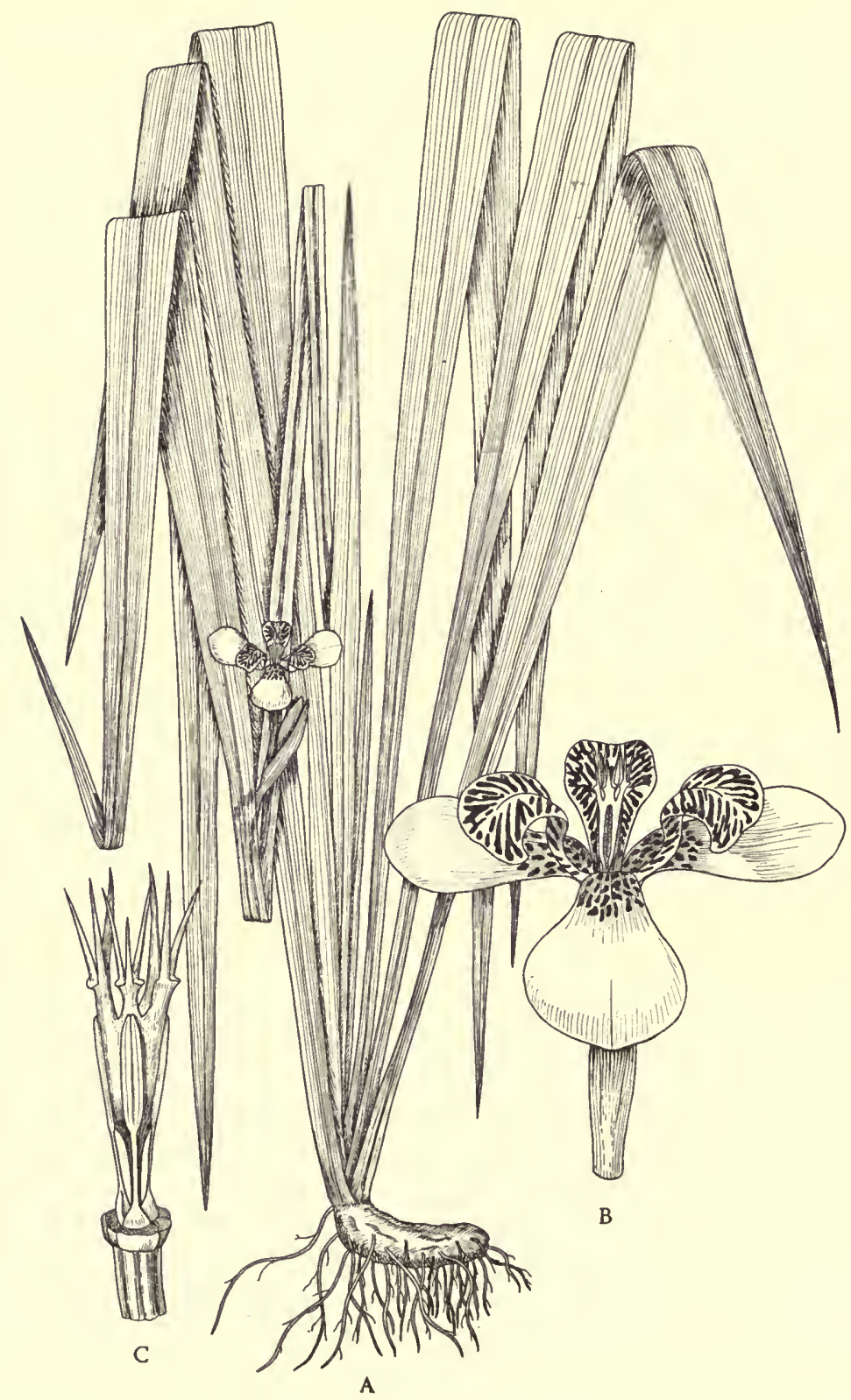

FIG. 31. Neomarica gracilis. A. Habit of plant; $\times 1 / 3 . \quad$ B. Flower; $\times 1$. C. Androecium and gynoecium in position, with perianth removed; $\times 3$. 
Mostly in dense wet forest, 900 meters or less; Petén; Alta Verapaz; Izabal; Huehuetenango. Southern Mexico; British Honduras, along the Atlantic coast to Panama; southward to Brazil.

Plants erect, or weak and reclining; leaves $30-80 \mathrm{~cm}$. long, thin, deep green, 1.5-2.5 cm. wide, with a conspicuous elevated costa; peduncle about as long as the leaves, flat and leaf-like, bearing a cluster of flowers far below the apex, simple, the tip of the leaf often taking root in the soil; flower clusters sessile or nearly so, the spathes about $3.5 \mathrm{~cm}$. long, the outer valves green, lance-acuminate; open flowers $5 \mathrm{~cm}$. broad, delicate, the outer segments obovate, pale yellow, sometimes white, with cross bars of yellow and brown near the base, the small inner segments blue; capsule about $2.5 \mathrm{~cm}$. long, the seeds subtended by a red aril. (Fig. 31.)

In Alta Verapaz the Indians administer a decoction of the crushed roots as a supposed remedy for affections of the stomach.

\section{ORTHROSANTHUS Sweet}

Reference: Julian A. Steyermark, Orthrosanthus chimboracensis and its varieties, Lloydia, 11: 14-20. 1948.

Plants perennial from short thick rootstocks, in general appearance like Iris; leaves rather thick and firm, linear, equitant, many-nerved, glabrous; flower clusters few or numerous, many-flowered, paniculate; flowers pale blue, fugitive, the pedicels usually very short; perianth tube very short, the segments oblong, subequal, spreading; stamens inserted at the base of the perianth, the filaments free or connate at the very base; anthers linear, erect; ovary clavate, 3 -celled, the ovules numerous, superposed; style very short, the branches subulate, stigmatose at the apex; capsule oblong-trigonous, loculicidally 3-valvate.

About seven species, two in the mountains of tropical America, the others in western Australia. Only the following occurs in Central America.

Orthrosanthus chimboracensis var. centro-americanus Steyermark, in Lloydia, 11: 17-18. 1948. Gladiolin de monte (fide Aguilar).

Brushy or grassy, often rocky hillsides, common in pine-oak forest, 1,500-3,400 meters; Zacapa; Jalapa; Jutiapa; Sacatepéquez; Suchitepequez; Sololá; Quiché; Huehuetenango; Totonicapán; Quezaltenango; San Marcos. Southern Mexico; Costa Rica.

Rhizome usually short and stout but sometimes elongate and rather slender; leaves numerous, pale bluish green, $20-50 \mathrm{~cm}$. long, $1 \mathrm{~cm}$. wide or less; scape not winged, 25-60 cm. high, leafy below, simple or branched, bearing few or numerous, sessile or pedunculate spathes; bracts of the spathe $0.8-1.3 \mathrm{~cm}$. long, 3-4-flowered; perianth pale blue, very delicate, the segments $1-1.5 \mathrm{~cm}$. long; capsule more or less pubescent, 0.8-1.6 cm. long. (Fig. 32.) 

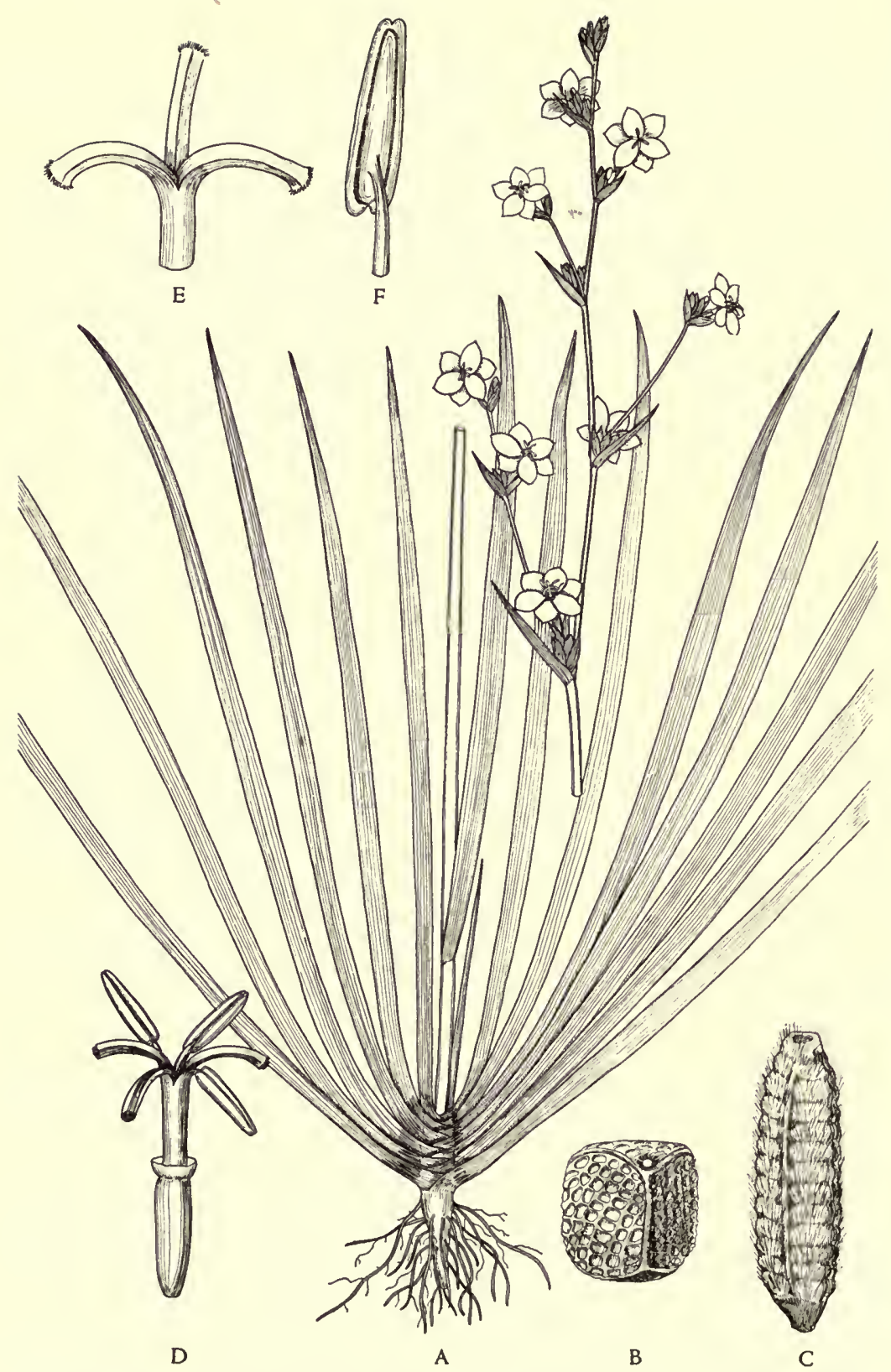

Fig. 32. Orthrosanthus chimboracensis var. centro-americanus. A. Habit of plant; $\times 1 / 3$. B. Seed; $\times 20$. C. Capsule; $\times 3$. D. Androecium and gynoecium in position; $\times 3$. E. Upper portion of style and branches; $\times 7$. F. Stamen; $\times 8$. 
A rather handsome, iris-like plant, often forming large dense colonies.

Typical O. chimboracensis (HBK.) J. G. Baker is confined to the Andes of South America and the volcanoes of Costa Rica. It has glabrous ovaries and capsules, the latter larger than in the Central American variety.

\section{RIGIDELLA Lindley}

Plants perennial from a corm having membranous tunics; leaves broad, plicate, the stems slender, branched; pedicels protruded from the spathes; flowers fugitive, red; perianth tube none, the segments very unequal, the outer ones oblong, connivent into a cup in the lower third, then spreading or reflexed, the inner ones very small, erect, ovate, with a narrow claw; filaments united throughout into a cylindric column, the anthers linear, ascending; ovary clavate, 3 -celled, the ovules numerous, superposed; style slender, bifid above the middle; capsule oblong, 3-valvate toward the apex; seeds subglobose, with a conspicuous raphe.

In southern Mexico one other species is known, $R$. flammea Lindl., from which Baker states that the Guatemalan species may not be distinct.

Rigidella immaculata Herb. in Lindl. Bot. Reg. 27: pl. 68. 1841.

Dense or open forest of oak, pine, Juniperus, or Abies, sometimes in moist meadows, 1,700-3,500 meters; described originally from plants grown in England, the corms collected in the mountains of Guatemala by Hartweg; Sacatepéquez (Volcán de Agua); Chimaltenango(?); Huehuetenango. Southern Mexico.

Plants sometimes a meter high or nearly so, usually lower, arising from a small corm covered with thin brown tunics; leaves few, broadly linear, mostly 1-3 $\mathrm{cm}$. wide, conspicuously plicate and with numerous conspicuous nerves; peduncles bearing 2 or more spathes, not winged; spathes several-flowered, $5-8 \mathrm{~cm}$. long; outer perianth segments blood-red, $3-3.5 \mathrm{~cm}$. long, oblong, the inner segments yellow, ovate, unguiculate, very small; capsule $2.5-3 \mathrm{~cm}$. long.

\section{SIS YRINCHIUM L.}

Plants annual or perennial, the rhizomes none or very short, the roots fibrous or often thickened and fleshy; leaves linear or narrowly ensiform; peduncles flattened or terete, often winged, leafy or naked; flowers blue or yellow, small, usually several in a cluster, the clusters solitary or fasciculate, rarely spicate or paniculate; capsules exserted from the spathe; perianth tube very short or none, the segments oblong, subequal, spreading from above the base; stamens inserted at the base of the perianth, the filaments more or less connate, the anthers erect or versatile; ovary turbinate or globose, 3-celled, the ovules numerous, super- 
posed; style short, subulate, the branches subulate, stigmatose at the apex; capsule subglobose or turbinate, loculicidally 3-valvate; seeds numerous, minute.

Species number uncertain but sixty or more, in temperate and tropical America; in tropical regions found mostly in the mountains. The species are often difficult of segregation, and the whole genus is badly in need of critical study. In temperate North America the number of species has been fantastically increased, but from Central America, fortunately, comparatively few species have as yet been published.

Peduncles simple, each bearing a single spathe or cluster of spathes.

Perianth yellow; peduncles rather broadly winged; leaves thin and delicate.

Perianth blue or white; peduncles not winged or scarcely so; leaves rather thick

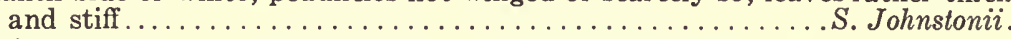

Peduncles branched above, bearing 2 or more separated spathes.

Capsules about $3 \mathrm{~mm}$. high; plants annual, the root fibers very slender; perianth

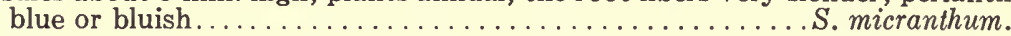

Capsules 5-20 mm. high; plants perennial, the roots usually much thickened and fleshy; perianth yellow.

Valves of the spathe $2.5-3 \mathrm{~cm}$. long; capsule $12-20 \mathrm{~mm}$. long.S. convolutum. Valves of the spathe mostly $2 \mathrm{~cm}$. long or shorter; capsule usually less than $8 \mathrm{~mm}$. long.

Peduncles narrowly winged; cauline leaves somewhat dilated at the base.

S. guatemalense.

Peduncles not winged but usually sharp-edged; cauline leaves not dilated at the base.........................................

Sisyrinchium convolutum Nocca, Pl. Select. Hort. Ticin. sub pl. 1. 1800 .

Moist forest or meadows, often in open pine forest, sometimes a weed in cornfields, 1,300-3,350 meters; Zacapa; Chiquimula; El Progreso; Jalapa; Sacatepéquez; Quiché; Huehuetenango. Honduras; Panama; western South America, southward to Peru.

Plants arising from a dense cluster of roots, these slightly thickened but not tuber-like, the plants $30-75 \mathrm{~cm}$. high or sometimes taller, the stems branched, conspicuously winged; leaves blackening when dried, rather thick and firm, mostly 5-8 mm. wide; spathes several, 4-6-flowered, the pedicels short-exserted; valves of the spathe mostly $2.5-4 \mathrm{~cm}$. long, somewhat inflated and enlarged below; perianth yellow, as much as $2.5 \mathrm{~cm}$. broad, the segments $12 \mathrm{~mm}$. long or more; capsule ellipsoid, as much as $2 \mathrm{~cm}$. long and $1.5 \mathrm{~cm}$. broad but usually somewhat smaller.

This has been confused with the South American S. iridifolium HBK., whose actual status is somewhat uncertain. At any rate, S. convolutum is a much earlier name, and may serve satisfactorily to designate the plant here described. 
Sisyrinchium guatemalense (J. G. Baker) Standl. \& Steyerm. Field Mus. Bot. 23: 39. 1944. S. alatum Hook. var. guatemalense J. G. Baker, Handb. Irid. 130. 1892 (type from mountains of Guatemala, the locality and collector not indicated).

Moist meadows or open woods, 750-2,100 meters; Santa Rosa; Guatemala; Chimaltenango; Sololá; Quiché; Quezaltenango. Southern Mexico; Honduras; Costa Rica.

Plants arising from a dense cluster of very thick and fleshy, tuber-like roots, generally low and $20 \mathrm{~cm}$. high or less but sometimes $50 \mathrm{~cm}$. high; basal leaves few, usually blackening when dried, often $15-20 \mathrm{~cm}$. long and $5 \mathrm{~mm}$. wide; stems 1several, often tortuous, narrowly winged, bearing 2 -several spathes, the spathes long-pedunculate, 2-5-flowered, the slender pedicels partly exserted; valves of the spathe 1.5-2 cm. long, relatively broad, somewhat dilated below, scarious-marginate; perianth bright yellow; capsule subglobose, about $8 \mathrm{~mm}$. long.

While treated by Baker merely as a variety of $S$. alatum Hook. (S. Marchio Steud.), this is so different in general appearance from South American material of that species that there can be little doubt that a distinct species is represented. It may be that some neglected older name for the plant, based on Mexican collections, will be discovered later, but we have found none.

Sisyrinchium Johnstonii Standl. Field Mus. Bot. 17:229. 1937.

Moist or wet, chiefly alpine meadows, 2,500-4,000 meters; Sacatepéquez (type from crater of Volcán de Agua, J.R. Johnston 805); Huehuetenango (Sierra de los Cuchumatanes); San Marcos (volcanoes of Tajumulco and Tacaná). Chiapas (Volcán de Tacaná).

Plants stiffly erect from a dense cluster of small tuberous-thickened roots, the weathered fibers of old leaves often persistent at the base of the plant; leaves all basal, linear, thick and rather stiff, sometimes $17 \mathrm{~cm}$. long but usually much shorter, about $2.5 \mathrm{~mm}$. wide, erect; scapes stiff, longer or shorter than the leaves, bearing at the apex 1-2 sessile spathes, the spathe or pair of spathes subtended by an erect bract; valves of the spathe about $2 \mathrm{~cm}$. long; flowers 1-few, the pedicels rather long-exserted; perianth white with bluish lines, the segments $1 \mathrm{~cm}$. long or more.

Sisyrinchium micranthum Cav. Monad. Diss. 6: 345. pl. 191, f. 2. 1790 .

Moist or wet fields, pastures, or thickets, often on open or brushy banks, sometimes on sandbars along streams, 300-2,400 meters; Alta Verapaz; Baja Verapaz; Chiquimula; Jalapa; Guatemala; Sacatepéquez; Chimaltenango; Huehuetenango; Quezaltenango; San Marcos. Southern Mexico; Honduras; Costa Rica; Panama; South America. 


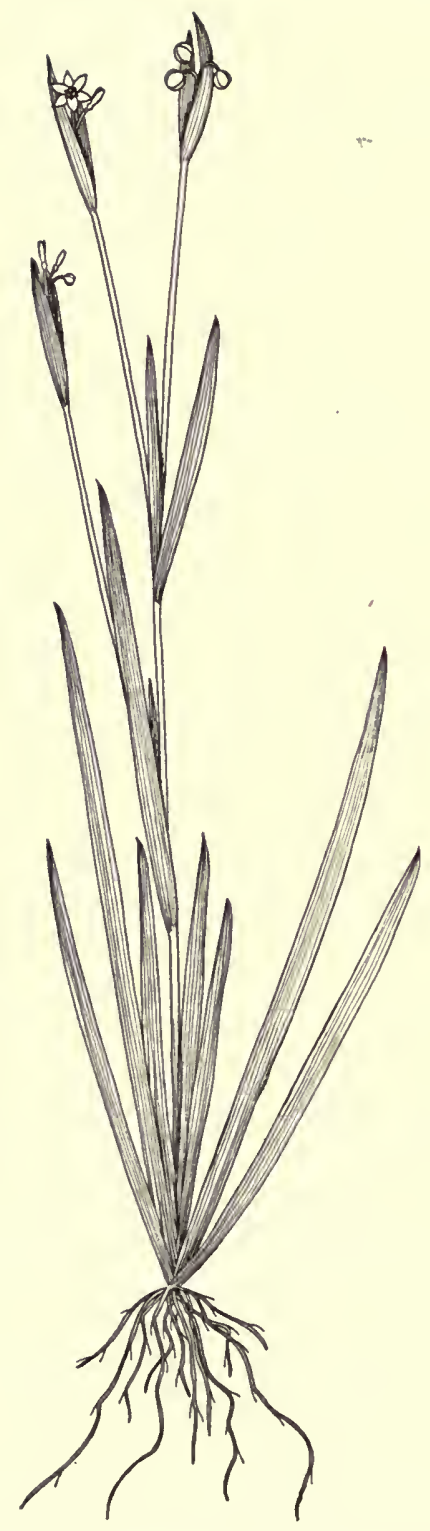

FIG. 33. Sisyrinchium micranthum. Habit of plant; $\times^{2 / 3}$. 
Plants very slender, annual, with a cluster of very slender, fibrous roots, erect or ascending, often much branched from the base, the stems mostly $5-20 \mathrm{~cm}$. high, sharp-edged but scarcely winged; leaves linear, 2-4 $\mathrm{mm}$. wide, the basal ones few or numerous, much shorter than the stems, the cauline leaves shorter; spathes few or rather numerous, solitary, long-pedunculate, 2-6-flowered, the pedicels partly exserted; valves of the spathe $2 \mathrm{~cm}$. long or less, very narrow, not dilated below; perianth blue or white, often pale dirty bluish, the segments $6 \mathrm{~mm}$. long or less; capsule globose, usually not more than $3 \mathrm{~mm}$. in diameter. (Fig. 33.)

An inconspicuous and rather weedy plant with unattractively colored flowers.

Sisyrinchium tenuifolium Humb. \& Bonpl. ex Willd. Hort. Berol. 2: pl. 92. 1816.

Grassy open slopes or meadows, often in alpine meadows, sometimes in forest of pine and Abies, 1,600-3,500 meters; Chiquimula; Jalapa; Sacatepéquez; Chimaltenango; Quiché; Huehuetenango; Quezaltenango. Mexico.

Plants erect or ascending from a dense cluster of tuberous-thickened roots, the stems usually several, 6-30 cm. high or even taller, very slender; leaves usually shorter than the stems, 1-4 mm. wide; spathes generally 2 or more, long-pedunculate, 3-4-flowered, the outer spathe valves $1-2 \mathrm{~cm}$. long, often somewhat dilated below; perianth yellow, 6-9 $\mathrm{mm}$. long; capsule oblong or oval, 5-8 $\mathrm{mm}$. long.

Sisyrinchium tinctorium HBK. Nov. Gen. \& Sp. 1: 324. 1815.

Moist or wet fields or open wet banks, 750-3,500 meters; Alta Verapaz; Sololá; Quezaltenango; Huehuetenango. Southern Mexico; British Honduras; Costa Rica; Panama; South America.

Plants perennial or perhaps sometimes annual, from a cluster of slender fibrous roots; stems naked, weak, often numerous, $20-40 \mathrm{~cm}$. high, broadly winged; leaves thin and soft, 3-10 mm. wide, sometimes equaling the stems, often numerous; spathe 1 on each stem, 4-10-flowered, the outer spathe valve $3-5.5 \mathrm{~cm}$. long; pedicels very slender and usually long-exserted; perianth yellow, 8-12 mm. long; capsule oval or obovoid, $8-12 \mathrm{~mm}$. long, or sometimes almost $2 \mathrm{~cm}$. long.

\section{TIGRIDIA Jussieu}

Rootstock an ovoid corm with brown membranous tunies; leaves linear or lance-linear, plicate; stems terete, not winged, simple or branched; flowers fugitive, often very large; perianth tube none, the segments of the 2 series dissimilar, connivent in a cup at the base, then spreading; filaments united to the apex in a long cylindric column, the anthers linear, erect-patent; ovary clavate, 3-celled, the ovules numerous, superposed; style long, filiform, its branches divided into 2 slightly flattened, falcate forks; capsule clavate-oblong, shortly 3-valvate at the apex; seeds angulate by pressure.

Species ten or fewer, one in South America, the others Mexican, one of them extending to Guatemala and Costa Rica. 
Tigridia Pavonia (L. f.) Ker in Konig \& Sims, Ann. Bot. 1:246. 1805. Ferraria Pavonia L. f. Suppl. Pl. 407. 1781. Cebollin; the name Cochol is reported from Guatemala.

Moist forest, sometimes in oak forest, swampy thickets, or open meadows; often a weed in cultivated ground, especially cornfields, 1,600-3,000 meters; Jalapa; Chimaltenango; Quiché; Huehuetenango; Quezaltenango; San Marcos. Mexico; Salvador (probably only in cultivation); introduced into Costa Rica as a weed in cornfields; often grown for ornament in temperate or warm regions of other parts of the earth.

Plants erect from a rather large corm; basal leaves long-sheathing, severalnerved, linear-lanceolate, $1-2.5 \mathrm{~cm}$. wide; stems leafy, mostly $35-60 \mathrm{~cm}$. high, leafy; spathes 1-2, few-flowered, 6-10 cm. long, the flowers long-pedicellate; outer perianth segments obovate, about $7 \mathrm{~cm}$. long, orange-red above, pale yellow heavily spotted with dull red below; inner perianth segments pale yellow, the basal part heavily spotted with dull red, the apical portion more lightly spotted; capsule 3-5 cm. long, $1 \mathrm{~cm}$. broad.

Called "flor del tigre" in Salvador; "Guatemala" (Costa Rica). The Nahuatl name of Mexico is "oceloxóchitl," "tiger" or "ocelot flower," given because of the spots on the perianth segments. The roots were formerly much used in the mountains of Mexico as food, and are said to have a flavor similar to that of chestnuts. In Huehuetenango and doubtless elsewhere the mucilaginous sap of the corms is used like glue for joining small articles. The plant is an exceptionally showy and handsome one, and is often planted in Guatemalan gardens. It flowers only during the wet months, no traces of the plants appearing in the dry season. In some areas, as about Chimaltenango and in Huehuetenango, it is an abundant weed in cornfields.

\section{TRIMEZA Salisbury}

Plants perennial from a short thick erect rootstock, the peduncle bearing a few long-stalked spathes; leaves usually broadly linear, not plicate, thin, with a conspicuous costa; perianth tube none, the outer and inner segments very dissimilar, the outer ones obovate, with a broad concave claw, the inner ones much smaller, convolute, with a small deflexed blade; stamens short, erect, the filaments free; ovary clavate, 3-celled, the ovules many, superposed; style subulate at the base, the 3 branches ending in small tubercles or cusps, these over-topping the small horizontal stigmas; capsule oblong, loculicidally 3-valvate.

About six species, in tropical America, only one of them in Central America.

Trimeza martinicensis (Jacq.) Herb. in Lindl. Bot. Reg. 1844: Misc. 88. 1844. Iris martinicensis Jacq. Enum. Pl. Carib. 12. 1760. 
T. lurida Salisb. Trans. Hort. Soc. 1: 308. 1812. Purga de los fríos (Huehuetenango); Sholol-canti (Cubilgüitz, Alta Verapaz).

Mostly in dense wet mixed forest, $200-1,600$ meters; Alta Verapaz; Huehuetenango. Southern Mexico; West Indies; South America.

Plants arising from small fibrous-coated corms; basal leaves linear, much elongate, 1-2 $\mathrm{cm}$. wide, thin and rather soft, with a conspicuous costa; stems subterete, not winged, $30-80 \mathrm{~cm}$. high, simple or branched, usually with a large leaf at the base of the inflorescence; spathes few, on very long peduncles, manyflowered, the pedicels usually partly exserted, the bracts about $2 \mathrm{~cm}$. long; outer perianth segments $2 \mathrm{~cm}$. long, spreading, deep or bright yellow with purple-brown spots in the lower third; inner perianth segments erect-ascending, with brownpurple spots at the base and along the middle; anthers yellow, the connective purple-brown; capsule 12-20 $\mathrm{mm}$. long.

In Huehuetenango it is stated that a decoction of the root is administered as a domestic remedy for chills.

\section{- TRITONIA Ker}

Rootstock a corm with fibrous or reticulate tunics; leaves mostly linear and plicate; flowers spicate, the spikes simple or branched; valves of the spathe oblong, brownish, emarginate; perianth tube short or elongate, dilated above, the segments obovate or oblong, subequal or somewhat unequal; stamens unilateral, arcuate, parallel, inserted in the perianth tube; filaments filiform, the anthers usually versatile; ovary 3 -celled, the ovules superposed; style filiform, the branches simple, short, spreading; capsule small, oblong, membranous, loculicidally 3valvate; seeds small, globose, or angulate by pressure.

About thirty species, mostly native in South Africa.

Tritonia crocosmiiflora Nichols. Gard. Dict. 4: 1887. Montbretia crocosmiiflora (often written crocosmiflora and crocosmaeflora) Hort. Fl. Mag. n. ser. pl. 472. 1881. Ccam (Cobán, Quecchí).

Planted commonly for ornament at almost all elevations; thoroughly naturalized in some localities about Cobán, often forming large colonies in thickets or on open banks.

Plants usually large and erect, a meter high or less, from a fibrous-coated corm; leaves ensiform, often numerous, 1-2 cm. wide, with a conspicuous elevated costa; stems not winged, leafy below, paniculately branched above, the spathes small and calyx-like, $8 \mathrm{~mm}$. long; perianth orange-red, 3-4 cm. long, the tube very slender below, strongly curved, the lobes oblong, spreading, about equaling the tube.

Called "zacatillo" and "iris" in Salvador. This plant is a bigeneric hybrid, the result of a cross between two African plants, Crocosmia aurea Planch. and Tritonia Pottsii Benth. It may be remarked, however, that some authors consider the two generic 
names synonymous. The plant is a showy and rather handsome one, popular throughout Central America, thriving under almost all conditions with little or no care. It is thoroughly established in some places about Cobán, possibly on the sites of former dwellings, and appears well able to maintain itself in competition with native vegetation.

\section{MUSACEAE. Banana Family}

Reference: K. Schumann, Pflanzenreich IV. 45. 1900.

Perennial herbs, often very large and treelike; stems at first or always very short, much surpassed by the leaf sheaths, these often tightly rolled together and forming a false trunk; leaves distichous or spirally arranged, large, petiolate, the petiole vaginate, the sheath without a ligule, the blades broadly linear to oblong, obtuse, pinnately nerved; inflorescence simple, bracteate, usually spikelike, sometimes branched, the flowers sessile or pedicellate, bracteolate or ebracteolate; flowers zygomorphic, usually perfect; sepals equal or sometimes separated into sepaloid and petaloid series, free or somewhat united, imbricate, colored; fertile stamens 5, rarely 6 , the highest often reduced to a staminode; anthers narrowly linear, 2-celled, the cells dehiscent by longitudinal slits; ovary inferior, 3-celled; ovules solitary in each cell or several, anatropous, erect or horizontal; style simple, the stigma deeply trilobate or simple or capitate; fruit baccate or capsular; seeds very hard, sometimes surrounded by an aril.

Six genera, only two of which, Heliconia and Ravenala, are represented by species native in America. Only one genus is native in Central America. The treatment of the family by Schumann, constituting the first number of the Pflanzenreich, is now long out of date, hence of limited value for study of American plants of the family.

Leaves spirally arranged; flowers unisexual................... Leaves distichous; flowers perfect.

Cells of the ovary 1-ovulate; capsule separating into 3 cocci; seeds not arillate;

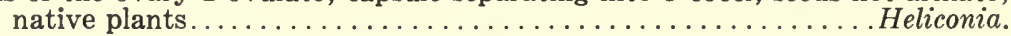

Cells of the ovary several-ovulate; capsule loculicidally 3-valvate; seeds surrounded by an aril; cultivated plants.

Inner equal sepals free but forming a sagittate organ; plants low, herbaceous.

Strelitzia.

Inner equal sepals not forming a sagittate organ; plants very large and tree-

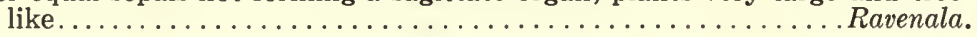

\section{HELICONIA L.}

References: Robert F. Griggs, On some species of Heliconia, Bull. Torrey Club 30:641-664. pls. 29, 30. 1903; Some new species and varieties of Bihai, Bull. Torrey Club 42: 315-330. pl. 19. 1915. 
Large or small, coarse, perennial herbs; leaves small or large, distichous, petiolate, the petioles vaginate; inflorescence terminal, compound, with large and usually brightly colored, cymbiform bracts subtending the several-flowered individual inflorescences; flowers perfect; outer sepals more or less unequal, the posterior one largest, the 2 anterior ones equal, narrower, free or united with the interior perianth segments to form a 5-dentate boat-shaped organ; perfect stamens 5 , the anthers linear, basifixed, the cells introrse; staminode petaloid, small; ovules solitary in each cell, erect from its base; style filiform, the stigma clavate or subclavate, 3-lobulate; capsule usually blue, sometimes by abortion 1-2-celled, separating into usually 3 cocci; seeds obtusely trigonous, the embryo straight.

Probably fifty species, natives of tropical America. Several others besides those listed here occur in other parts of Central America, and the genus extends northward into southern Mexico. The larger plants are somewhat like the banana in habit, the smallest ones more suggestive of the genus Canna. They are confined to the lowlands in Central America, never extending far upward on the mountain slopes. In some parts of the tierra caliente they constitute an important and conspicuous part of the undergrowth in the forest or of the coarse second growth thickets, forming colonies of wide extent. The concave bracts of those species with erect inflorescences hold water, and it has been stated that mosquitoes breed in them.

Bracts of the inflorescence densely crowded and overlapping, appressed, concealing the rachis. Plants very large, of ten 5 meters tall or more; inflorescence very large and heavy, pendent, often a meter long or more; bracts about as broad

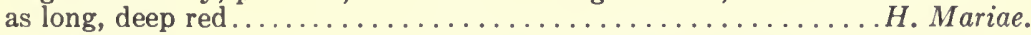
Bracts of the inflorescence not or scarcely overlapping, mostly spreading or reflexed, not concealing the rachis, usually much longer than wide.

Inflorescence pendent, the bracts deep red.

Rachis of the inflorescence densely brown-villous; leaves green beneath.

H. rostrata.

Rachis of the inflorescence puberulent or closely tomentulose or sometimes

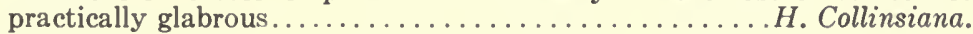

Inflorescence erect, the bracts variously colored.

Rachis of the inflorescence mostly $1-1.5 \mathrm{~cm}$. thick; bracts close together, the top of one usually reaching the base of the one next above, the middle bracts mostly $3-6 \mathrm{~cm}$. high at the point of attachment, the bracts rela-

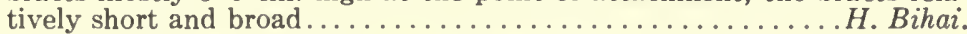

Rachis of the inflorescence usually much less than $1 \mathrm{~cm}$. thick; bracts rather widely spaced, not approximate, the middle bracts mostly $1.5-3 \mathrm{~cm}$. high, long and narrow.

Plants small, generally about a meter high; leaves mostly $10 \mathrm{~cm}$. wide or less, sometimes broader; bracts relatively few and short.

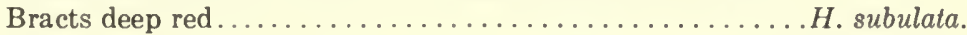

Bracts yellow or orange........................ psittacorum.

Plants larger, mostly more, often much more, than a meter high; leaves usually much more than $10 \mathrm{~cm}$. wide; bracts often numerous and usually elongate.

Inflorescence persistently villous, especially on the rachis.

Bracts yellow.............................. spissa.

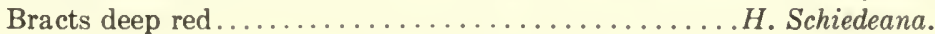


Inflorescence glabrous or nearly so, at least not villous.

Inflorescence elongate, the bracts broad, widely spreading or even reflexed, not curved inward or upward. Bracts red.H. latispatha.

Inflorescence short and rather deltoid, the bracts very narrow, distinctly curved upward and inward.

Bracts yellow. ............................ librata.

Bracts deep red...................... adflexa.

Heliconia adflexa (Griggs) Standl. Journ. Wash. Acad. Sci. 17: 162. 1927. Bihai adflexa Griggs, Bull. Torrey Club 42: 325. f. 5. 1915.

Known only from Alta Verapaz, dense wet forest, 1,400-1,650 meters; type from Cobán, Türckheim II.2356.

Plants 1.5-2.5 meters tall; leaves large and elongate, commonly $15-20 \mathrm{~cm}$. wide, short-acuminate, rounded at the base, green above, slightly paler beneath but not glaucous; inflorescence stiffly erect, long-pedunculate, somewhat deltoid in outline, the rachis rather stout, slightly or rather strongly zigzag, densely puberulent, with very short internodes; bracts deep red, linear, close together, usually 12 or more, ascending and often somewhat incurved, obtuse, sparsely puberulent or glabrate, revolute, the middle bracts $7-10 \mathrm{~cm}$. long, $1.5-2 \mathrm{~cm}$. high, the upper ones much shorter; perianth $4 \mathrm{~cm}$. long, yellow, sparsely pilose.

The species is well marked because of the compact inflorescence and the long narrow bracts.

Heliconia Bihai L. Mant. Pl. 2: 211. 1771. H. elongata Griggs, Bull. Torrey Club 30:653. f. 2. 1903 (type from Río Polichic, between Panzós and Sepacuité, Alta Verapaz, R.F. Griggs 790). H. Champneiana Griggs, op. cit. 657. pl. 30 (type collected between Panzós and Sepacuité, Griggs 528). Bihai Champneiana Griggs, Bull. Torrey Club 31: 445. 1904. B. elongata Griggs, loc. cit.

Wet forest or thickets of the Atlantic lowlands, 900 meters or lower; Petén; Alta Verapaz; Izabal; Huehuetenango. Southern Mexico; British Honduras, along the Atlantic coast to Panama; West Indies; South America; said to be naturalized in some parts of the Old World tropics.

Plants glabrous, coarse and stout, 1.5-4 meters tall, usually with a well developed, stout stem; leaf blades elongate-oblong, usually $20 \mathrm{~cm}$. wide or more, cuspidate-acuminate, rounded to acute at the base, green on both sides or when young slightly glaucescent, sometimes 2 meters long; inflorescence erect, sessile or nearly so, very thick, succulent, and heavy, oblong in outline; bracts 9-12 or more, boat-shaped, spreading, close together, usually touching one another, the margins apple-green, the sides bright red or orange, shading into yellow, the middle ones $13 \mathrm{~cm}$. long, the lower much longer, attenuate; flowers about $3 \mathrm{~cm}$. long, the segments bright green, linear-oblong; fruit turquoise-blue. (Fig. 34.) 


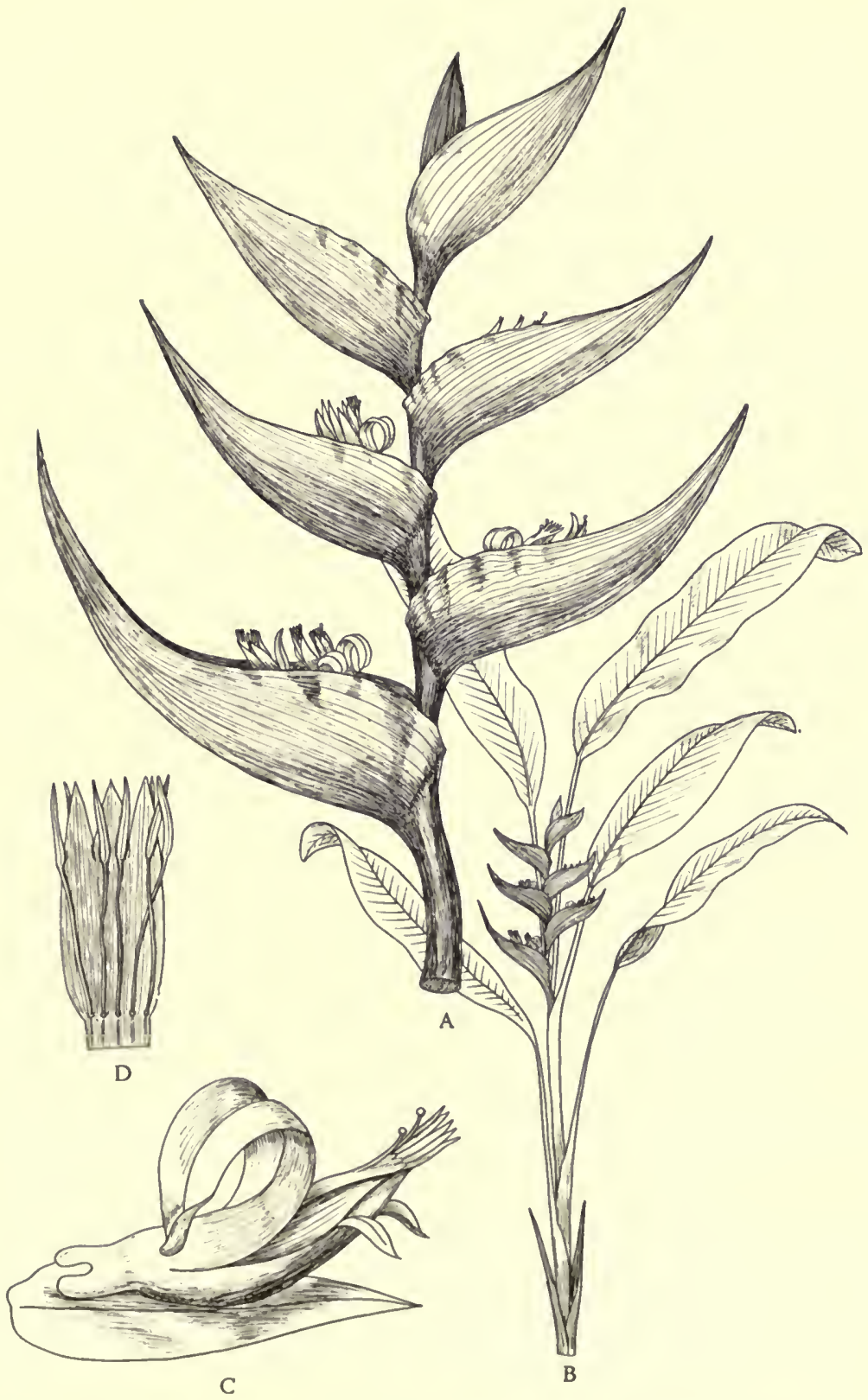

FIG. 34. Heliconia Bihai. A. Inflorescence; $\times 1 / 3$. B. Habit of plant; $\times 1 / 15$. C. Flower with bract; $\times 2$. D. Interior perianth segments from within, showing stamens; $\times 1$. 
This is perhaps the handsomest species of Central America and certainly one of the showiest. The coloring of the bracts is more vivid and fresh than that of most other species. The plant often forms large dense stands in the lowlands of Alta Verapaz and Izabal, and it is frequent in many localities all along the Atlantic coast of Central America. There are many fine displays of it visible from the railway in the Atlantic banana region of Guatemala.

Heliconia Collinsiana Griggs, Bull. Torrey Club 30: 648. 1903. Cachuco (Santa Rosa); Platanillo. Bihai Collinsiana Griggs, Bull. Torrey Club 31: 445. 1904.

Wet forest or thickets, chiefly at 600 meters or less, rarely ascending to about 2,000 meters; type from banks of Río Cahabón, 5 miles below Cahabón, Griggs 352; Alta Verapaz; Zacapa; Chiquimula; Santa Rosa; Escuintla; Suchitepequez; Retalhuleu; Quezaltenango; San Marcos; Huehuetenango. British Honduras; probably extending into southern Mexico; Salvador.

Plants 2-3 meters tall or sometimes as much as 5 meters; leaves long-petiolate, the blades narrowly oblong, often a meter long or more and as much as $40 \mathrm{~cm}$. wide, short-acuminate, rounded and often unequal at the base, usually very glaucous and pale beneath, sometimes puberulent or short-pilose beneath on the costa, the under surface sometimes becoming green in age; inflorescence pendent, deep or bright red, glabrous or often densely puberulent or short-pilose, especially on the rachis, pedunculate, the rachis flexuous or almost zigzag, often $45 \mathrm{~cm}$. long, the bracts widely spaced, lanceolate, spreading or even reflexed, long-attenuate, the lowest $30 \mathrm{~cm}$. long and about $2 \mathrm{~cm}$. high at the base, the middle ones about $15 \mathrm{~cm}$. long; flowers long-pedicellate, pale yellow; fruit pale yellow or reddish.

Sometimes known in Salvador by the name "hoja de sal," presumably because the leaves are used for wrapping salt and other articles for market. The handsome inflorescences are sold in the markets to be used for decorating altars, especially at Christmas time, when they are carried from the lowlands up into the highlands. The species has been listed from Guatemala under the name $H$. vaginalis Benth. Here is probably referable Guatemalan material reported under the name Heliconia platystachys Baker, which has broader bracts. The material here referred to $\mathrm{H}$. Collinsiana is somewhat variable in pubescence of the inflorescence and in color of the lower leaf surface, so that it is possible although not probable that two species are represented.

Heliconia latispatha Benth. Bot. Voy. Sulph. 170. 1844. Pico de gurrión (Santa Rosa); Bijao (Petén); Platanillo; Suc (Quecchí). 
Wet forest or thickets, often abundant in second growth, ascending from sea level to about 1,400 meters, but most abundant at low elevations; Petén; Alta Verapaz; Izabal; Santa Rosa; Escuintla; Suchitepequez; Retalhuleu. Southern Mexico; British Honduras to Panama; Colombia.

Plants glabrous or nearly so, rather stout, commonly 1.5-2.5 meters high; leaves long-petiolate, oblong, of ten a meter long, mostly $20-30 \mathrm{~cm}$. wide, shortacuminate, rounded to subacute and usually oblique at the base, slightly glaucous or green beneath; inflorescence erect, pedunculate, the bracts deep or bright red, widely spaced, narrowly lanceolate, spreading, the lowest often dilated at the apex into large green blades, often tinged with orange or yellow, or sometimes yellow or orange throughout, the middle ones about $15 \mathrm{~cm}$. long and 1.5-2 cm. high at the base, long-attenuate; flowers $3-3.5 \mathrm{~cm}$. long, pedicellate, the pedicels glabrous or pilose, the perianth greenish yellow.

The inflorescences are sometimes called "cuchillos" in Salvador. On the Pacific slope this species is particularly plentiful, growing not only in ravines of the foothills but far out upon the plains, in either forest or open places. Some of these habitats become very dry in the verano but are doubtless exceedingly wet during the rainy season.

Heliconia librata Griggs, Bull. Torrey Club 30: 649. 1903. Bihai librata Griggs, Bull. Torrey Club 31:445. 1904.

Type from "Cherujija Oxec," valley of Río Oxec, Alta Verapaz, Griggs 696. Tabasco; Atlantic coast of Honduras.

Plants 1.5-3 meters tall; leaves long-petiolate, the larger ones a meter long or more and about $30 \mathrm{~cm}$. wide, abruptly short-acuminate, rounded and somewhat decurrent at the base, glabrous, glaucous beneath or in age merely pale green; inflorescence erect, long-pedunculate, somewhat deltoid in outline, the bracts close together, usually 12-16, spreading or slightly ascending, ovate, the lowest often prolonged into a large green blade, the middle ones ovate or ovate-lanceolate, attenuate to an obtuse tip, $10 \mathrm{~cm}$. long or usually shorter, yellow or orange; pedicels $1-1.5 \mathrm{~cm}$. long, puberulent; rachis stout, almost straight, densely puberulent.

The color of the inflorescence was unknown when the species was described, for it was based upon aged specimens, and there is some uncertainty regarding the identity of the material here referred to $H$. librata. In Honduras the species is sometimes called "bijagüillo."

Heliconia Mariae Hook. f. Journ. Linn. Soc. 7: 69. 1864.

Usually in dense wet forest near sea level; Alta Verapaz; Izabal. British Honduras, along the Atlantic coast to Panama; Colombia. 
Plants very large, often as tall as a banana plant and attaining a height of 12 meters or even more, with a thick heavy trunk like that of a banana plant; leaves long-petiolate, the blades long and very large, glabrous, pale green beneath; inflorescence pendent, very thick and heavy, oblong, usually $30 \mathrm{~cm}$. long or more and 8-12 cm. wide, but said to attain sometimes a length of even 2 meters; bracts very numerous, broadly ovate, obtuse, close together and densely imbricate, spreading at about a right angle, deep rose-red or in age deep dark red, thinly villoustomentose; flowers dull red, the pedicels villous.

Called "bijaguiillo" in Honduras. This is by far the largest of all Central American Heliconias, and unlike all of them in its very dense and thick, heavy, pendent inflorescence. The plants are equal in size to the tallest banana plants, and resemble them somewhat when seen from a distance. In some parts of the Panama lowlands the plants form such dense stands that it is impossible to force one's way between them without use of a machete. In Guatemala this species is conspicuous in some localities along the main railroad line through the banana country. The very appropriate English name of "beefsteak Heliconia" has been suggested for H. Mariae, since the inflorescences by their coloring do suggest a large chunk of raw beefsteak.

Heliconia psittacorum L. f. Suppl. Pl. 158. 1781. H. hirsuta L. f. loc. cit. H. aurantiaca Ghiesbr. ex Lem. Ill. Hort. 9: pl. 332. 1862. H. crassa Griggs, Bull. Torrey Club 30: 646. 1903 (type collected between Sepacuité and Secanquím, Alta Verapaz, R. F . Griggs 356 and 376). Bihai crassa Griggs, Bull. Torrey Club 31: 445. 1904.

Wet forest of the Atlantic lowlands, 480 meters or lower; Petén; Alta Verapaz; Izabal. Tabasco; British Honduras, along the Atlantic coast to Panama; South America.

Plants glabrous, usually about a meter tall, rarely as much as 2 meters; leaves often numerous, the blades divaricate from the stem, narrowly oblong, about $30 \mathrm{~cm}$. long and $9 \mathrm{~cm}$. wide, or often narrower or longer, abruptly acuminate, rounded or subcordate at the often oblique base, thin, bright green; inflorescence erect, sessile or pedunculate; bracts about 6, orange-yellow, the lowest bract often ending in a small green blade, the others close together, $3-6 \mathrm{~cm}$. long, about $1 \mathrm{~cm}$. high at the base, attenuate; flowers about 15 in each bract, yellow; pedicels $1 \mathrm{~cm}$. long; fruit $5 \mathrm{~mm}$. in diameter or larger.

Because of its small size and rather pale coloring, this plant is much less conspicuous than other species.

Heliconia rostrata Ruiz \& Pavón; Fl. Peruv. 3: 71. pl. 305. 1803. H. pendula Wawra, Oesterr. Bot. Zeitschr. 13: 8. 1863. Guineo de montaña (Quezaltenango); Platanillo. 
Wet forest or thickets, 600-1,400 meters; Alta Verapaz; Escuintla; Quezaltenango. British Honduras, along the Atlantic coast to Panama; southward to Peru and Brazil.

Plants coarse and stout, usually 2-3 meters tall; leaves long-petiolate, glabrous, oblong, 1-1.5 meters long, mostly $25-35 \mathrm{~cm}$. wide, abruptly short-acuminate, green or glaucescent beneath; inflorescence pendent, the rachis terete, rather slender, very flexuous, densely brown-villous with rather short hairs; bracts cardinal-red or dull red, lance-linear, widely spaced, divaricate or even somewhat reflexed, long-attenuate, glabrous or nearly so, the middle ones about $15 \mathrm{~cm}$. long and $2 \mathrm{~cm}$. high at the base; flowers pedicellate, the stout pedicels villous, the perianth pale yellow or greenish yellow.

Heliconia Schiedeana Klotzsch, Linnaea 20: 463. 1847. $H$. tortuosa Griggs, Bull. Torrey Club 30:650. pl. 29, f. 1. 1903 (type from Sepacuité, Alta Verapaz, R. F. Griggs 17). Bihai tortuosa Griggs, Bull. Torrey Club 31:445. 1904. Platanillo; Xackel (Alta Verapaz, Quecchí).

Moist or wet forest or thickets, 500-1,500 meters; Alta Verapaz; Chiquimula; Quezaltenango; San Marcos. Southern Mexico.

Plants stout, 1.5-2.5 meters tall; leaves long-petiolate, often much elongate, as much as $50 \mathrm{~cm}$. wide but mostly narrower, glabrous, paler green beneath but not glaucous; inflorescence pedunculate, erect, the rachis flexuous, densely pubescent, the bracts widely spaced, dull red, very narrow and elongate, divaricate or somewhat curved upward, sparsely pubescent or almost glabrous; flowers pale, dull yellow, the ovary green; pedicels villous-pilose.

Heliconia spissa Griggs, Bull. Torrey Club 30:652. 1903. Bihai spissa Griggs, Bull. Torrey Club 31: 445. 1904.

Petén; Alta Verapaz (type collected between Cahabón and Senahú, on steep river bank, Griggs 359); endemic.

Plants about 2 meters tall; leaf blades about $75 \mathrm{~cm}$. long and $20 \mathrm{~cm}$. wide, oblong-oval, acute, rounded at the base, green, glabrous except beneath on the costa, there sparsely brown-hirsute; inflorescence erect, subsessile, densely covered with soft brown hairs except on the edges of the bracts, the rachis almost straight; bracts widely separated, oblong-lanceolate, acute or obtuse, the lowest $17 \mathrm{~cm}$. long and $1.5 \mathrm{~cm}$. wide, the middle bracts almost linear, bright yellow shading to orange; flowers $4 \mathrm{~cm}$. long, yellow, densely villous, the pedicels $1 \mathrm{~cm}$. long, villous; fruit villous.

Heliconia subulata Ruiz \& Pavón, Fl. Peruv. 3: 70. pl. $303 b$. 1802. H. acuminata L. Rich. Nov. Act. Acad. Nat. Cur. 15: Suppl. 26. pls. 11, 12. 1831. H. choconiana Wats. Proc. Amer. Acad. 23: 284. 1888 (type from Río Cocón, Izabal, S. Watson). 
Wet forest of the North Coast, near sea level; Izabal. British Honduras, along the Atlantic coast to Panama; southward to Bolivia and Brazil.

Plants glabrous, usually about a meter high, "sometimes taller and as much as 2 meters; leaves oblong, mostly $10 \mathrm{~cm}$. wide or narrower and $30-40 \mathrm{~cm}$. long, bright green; inflorescence erect, on a long or short stalk; bracts deep red, few, rather close together, the middle ones $7-9 \mathrm{~cm}$. long, at the base scarcely more than $1 \mathrm{~cm}$. high, narrow, long-attenuate, the lowest bracts elongate and sometimes bearing a small green blade at its apex; ovary yellow, tinged at the top with grassgreen; perianth rich yellow.

\section{MUSA L.}

Reference: E. E. Cheesman, Kew Bull. 1948, no. 2: 145-153. 1948.

Large herbs with thick perennial roots, the stems often tall and thick but consisting principally of tightly rolled leaf sheaths; leaves petiolate, arranged spirally, long-sheathing, the blades usually oblong, very large, penninerved; inflorescence terminal, rising among the convolute sheaths, consisting of a compound spike; bracts large, at first completely enclosing the inflorescences; lower flowers pistillate, the middle ones sometimes perfect or, like the upper ones, staminate; 4 of the sepals unequal, united to form a shallowly 5-lobate tube, this slit dorsally, the fifth (dorsal) sepal free, entire or 3-lobate; perfect stamens 5 , the filaments thick-filiform, the anthers linear, introrsely dehiscent; ovary 3-celled, the cells many-ovulate; ovules anatropous, attached horizontally; style filiform or subangulate from a thickened base, the stigma subcapitate, 6-lobate; fruit baccate, fleshy, containing few or many seeds, in cultivated plants usually seedless; seeds subglobose or angulate, imbedded in pulp, the testa osseous.

About forty species, natives of the Old World tropics. Two of them are cultivated on a large scale in the American tropics. $M$. textilis Née is exploited extensively in the East Indies for its fiber, Manila hemp of commerce, noted for its strength and fineness. Some of the other species are planted occasionally in Guatemala and other parts of Central America for ornament or as curiosities. The cultivated bananas and plantains have seedless fruits, i.e., the seeds are abortive, but some of the less usual forms cultivated have fruits filled with hard shot-like seeds.

\section{Musa paradisiaca L. Sp. Pl. 1043. 1753. Plátano, plantain.}

The plantain and banana are considered by some authors as varieties of a single species, but commercially and economically they are so different that it is at least convenient to consider them as distinct species. While the banana is quite as well known in many temperate regions as it is in the tropics, the plantain, one of the important food plants of tropical America, is practically unknown in North America and Europe. Plantains can be purchased at times 
in some cities of the United States, but there is little demand for them since few people know how to utilize them, and they are expensive, a fact that would seem fantastic to people familiar with the tropics. It is unfortunate that plantains are not available in the United States, because they probably could become a popular vegetable, being easy of preparation for the table, and of a flavor that most people would consider agreeable. The fruits ordinarily are larger than bananas, and they are green when cut, usually turning black as they ripen, and never of a pure yellow color. Both green and ripe plantains are prepared for the table. The most usual method of preparing them is perhaps by boiling, when they are not particularly appetizing, but have a slightly tart flavor. If boiled plantains are eaten with honey, as they are often served in Guatemala, they are much more palatable. Various desserts are made by boiling or baking plantains with sugar, chocolate, or various fruits. By the poor people plantains are often baked or toasted upon a gridiron. Fried plantains are probably the most palatable of all, and they constitute a most agreeable vegetable, liked by most foreigners. Plantains are grown in most of the departments of Guatemala, but almost wholly at low or less than middle elevations, principally on the plains or in the foothills. They are much less resistant to cold than bananas. According to data supplied by the Department of Agriculture of Guatemala, there were produced in 1938-39 in the country 2,395,912 racimos or stems (bunches) of plantains. About half of these came from the departments of Santa Rosa and Escuintla, and more than 375,000 stems from San Marcos. Other departments producing more than 100,000 stems were Suchitepequez, Quezaltenango, and Izabal, while for Jalapa only 576 stems were reported, and only 57,000 for Alta Verapaz. Several varieties are recognized in Guatemala, but to the inexperienced eye they seem to differ little except in size.

Musa sapientum L. Sp. Pl. ed. 2. 1477. 1763. Guineo; Banano, banana. Tul (Quecchí); Ts'ahlec, Tulul (Poconchí); Haaz, Sachaaz, Boxhaaz (Maya). M. paradisiaca var. sapientum Kuntze, Rev. Gen. 2: 692. 1891.

As in all or most other parts of Central America, the banana in its various varieties is one of the most important of all cultivated plants, not only as a source of food for the inhabitants but as an article of export. For export the only variety of any importance is the well known Gros Michel, the common banana of United States markets, known in Guatemala generally as "banano," or sometimes 
as "mínimo" or "guineo de seda." It is grown to some extent in all departments of Guatemala except Totonicapán, from sea level up to at least 2,400 meters, but very sparingly and hardly commercially at the higher elevations. The great majority of the fruit is produced at or near sea level, but the plantations thrive up to probably 1,000 meters or more, and for local use the plants are cultivated considerably higher. Bananas and coffee together account for about 90 per cent of the exports of Guatemala. The greater part of the exported bananas is produced by the United Fruit Company and its affiliates in two regions of the North and Pacific coasts, the first with headquarters at Bananera in Izabal, and the second at Tiquisate, in Suchitepequez, but on the border of Escuintla. Bananas produced by private growers are shipped by the same company, but in recent years, because of changes in methods of cultivation resulting principally from attacks of the Panama and Sigatoka diseases, cultivation of bananas suitable for export has become a business requiring such heavy investment that few private growers can afford to engage in it. The export banana industry of Guatemala began to develop about 1900 in the lower Motagua Valley and around Lake Izabal. This region is still a great producer of bananas, but in very recent years the Pacific coast region about Tiquisate has attained even greater production. Only a few years ago large quantities of fruit were produced by independent planters for export in the plains and foothills of almost the whole Pacific coast, but the ravages of disease, resulting in fruit that was perfectly edible but not exportable have greatly circumscribed the area in which fruit is produced for export.

For 1938-39 the production of bananas (i.e., Gros Michel) for Guatemala is reported as 14,353,572 stems or bunches (racimos). The leading departments in production were Escuintla, 4,830,896 stems; Izabal, 4,460,276; Suchitepequez, 2,887,640; and Retalhuleu, 1,058,244. Most of these were exported. The other departments produced only limited amounts for local consumption.

The common banana is the one most esteemed everywhere in Central America for eating raw. It is also cooked in various ways, and is much in demand in all parts of the country. The fruit is naturally much cheaper than in the United States, and it is possible to buy a dozen of the large, handsome, delicious bananas of San Felipe for a cent. Large quantities of the fruit are carried on the backs of cargadores from the lowlands up into Quezaltenango and other towns of the highlands for sale, as return loads by men who 
have taken down to the tierra caliente loads of earthenware, woollen goods, and other manufactures. Since only a few cents-less than a dime - is paid for carrying such a load, transportation adds little to the price of the fruit. While the fruit thus transported is ripe, bananas, of course, always are cut from the plant while still very green. In fact, those cut for local use are just as green as those shipped to the United States. Only by infrequent accident do bananas ripen on the plant anywhere in Guatemala or elsewhere in Central America. Birds and mammals would consume them long before they were fully ripe, if this practice were followed. Alta Verapaz, or at least Cobán, is quite as poorly supplied with bananas as with most other desirable fruits, and the bananas sold in the Cobán market are usually of poor appearance and even worse flavor. The Quecchí name for the common banana is reported as "Mines."

Plants of the various varieties of bananas are much used as coffee shade in some regions. The growing of bananas in coffee plantations of the Pacific bocacosta promised to be a profitable industry until the plants became diseased. In the spring of 1941 many of the bananas planted for export in the bocacosta were being cut from the cafetales, on a large scale. There have been noticed, especially in the Cobán region, banana plants with teratological inflorescences that give an unusual appearance to the plants. While not investigated carefully, it appeared that the whole inflorescence had been transformed into a mass of foliaceous, much imbricated bracts. In the small fincas such plants are left until the foliage withers, when they have a fantastic appearance.

Besides the production data for "banano," the Guatemalan Department of Agriculture reports for 1938-39 the production of "guineo" as 3,405,896 stems. The term guineo (probably from Guinea of Africa) in Central America embraces all forms of bananas, but these figures evidently are intended to cover varieties other than Gros Michel, and of these additional forms several are cultivated upon a large scale, for food. There is, so far as we know, no good account of the cultivated varieties of bananas, at least of those grown in Central America, and we do not know what Latin names should be applied to them. The local names vary from one part of Guatemala to another. The fruit characters are not well preserved in herbarium specimens, and we have not taken detailed notes of the varieties found in different parts of the country. Some of the principal varieties, however, are enumerated below. We have had 
references also to some other forms, such as the "cantiado," "habanero," "datil," and "criollo," whose characters are unknown to us.

Musa sapientum var. Champa Baker. Guineo manzano; Guineo de oro; Guineo manzanita.

Plants smaller than in the common banana; fruits much smaller, rather pale or bright yellow; pulp rather deep yellow, very soft and fine-grained, fairly sweet. This banana is much esteemed by some persons, and most people will agree that it is the best banana to eat raw, after the common one. It is much used as food for cage birds, and is usually plentiful in the markets, but it is a variety of relatively little economic importance. The guineo de oro and guineo manzano are sometimes considered as distinct varieties, the former having a very yellow skin and deep yellow, sweet flesh, the guineo manzano being slightly larger and having a pale yellow skin like the common banana. The two are not easy to recognize when so separated unless specimens of both are at hand for comparison. This type of banana seems to flourish at high elevations and is planted, for instance, about Huehuetenango, where the leaves sometimes are severely frosted.

Musa sapientum var. rubra (Firm.) Baker. Guineo morado; banano morado, red banana.

Easily recognized by its reddish petioles and the reddish or purplish tinting of the leaves. The fruits are large, the skin conspicuously colored dull red or purplish. The flesh is rather coarse but of fair quality for eating. The ripe fruits are eaten raw, the green ones cooked in various ways. This form is planted abundantly in all the lowland regions, and is especially abundant about San Pedro Carchá and beyond, where it is planted to shade coffee in many of the fincas. The red banana is exported in small quantities to the United States, where it commands a higher price than the common banana, presumably because of its scarcity. In Central America it is considered inferior to the common banana, as it must be if the flavor and texture of the two varieties are compared.

Guineo blanco; Sakitul (Quecchí); Guineo de pájaro. A variety not very common except about Cobán, where it is highly esteemed. The fruit is of a very pale yellow, and a little larger and thicker than the "Guineo de oro." The pulp is pale orange and rather tart.

Guineo de coche (Huehuetenango, Cobán; "pig banana," Guineo de San Antonio, central region). This is the commonest banana of 
the Cobán market, and abundant in that of Huehuetenango. It is said to be the variety most planted in all the Huehuetenango region. The fruit is short and thick, of a bright but pale green when ripe. It is eaten raw, but in quality is decidedly inferior.

Guineo majonche; Majonche; Majoncho. This is one of the most important fruits of the Guatemalan lowlands, especially of the Oriente, and equally or more important in Salvador and some other parts of Central America, being the banana most often cooked for the table. After maize, rice, and frijoles negros it is possibly the most important article of food among the poorer people. The fruit is relatively thicker than the common banana, pale buff or pinkish buff, the pulp coarse, fibrous, and of poor flavor. When cooked, however, the fruit is fairly palatable, with at least as much flavor as ordinary potatoes, and it serves at least to diversify the sadly monotonous diet of the working classes of Central America.

Ravenala madagascariensis Sonn. Palma de viajero (fide Aguilar). This, the famous traveler's tree, native of Madagascar, is planted occasionally for ornament in gardens of Guatemala City, in the bocacosta of Quezaltenango and San Marcos, and doubtless in other places. It is easily recognized by the fan-like arrangement of the huge banana-like long-stalked leaves. The larger plant has a well-developed trunk. The genus Ravenala consists of two species, one of which, strangely enough, is native in the Guianas.

Strelitzia reginae Banks. Native of the Cape region of Africa, occasionally cultivated for ornament in Guatemala City and probably elsewhere, but rare. In general appearance it somewhat resembles the smaller Heliconias, and has a similar, brightly colored inflorescence of but few narrow spreading bracts.

\section{ZINGIBERACEAE. Ginger Family}

Reference: K. Schumann, Pflanzenreich IV. 46. 1904.

Perennial herbs, usually tall and often very large and stout; true stems usually very short, but stemlike organs often formed by the tightly rolled leaf sheaths; leaves commonly long-sheathing, the blades sessile or petiolate, broad or narrow, frequently with a large ligule; flowers bracteate, often large and showy, the bracts subtending 1 or several flowers, the inflorescence racemose, spicate, capitate, or paniculate, terminating a leafy stem or arising from the base of the plant on a short, bracteate peduncle; flowers irregular, perfect; calyx tubular, usually trilo- 
bate, commonly cleft on one side, often marcescent after anthesis; corolla funnelform, trilobate, the posterior lobe usually larger than the others and enclosing them in bud; stamens 6 , but only 1 fertile, the others consisting of petal-like or dentiform staminodia; anther introrse, 2-celled, dehiscent by longitudinal slits; ovary normally 3-celled; fruit capsular, loculicidally trivalvate or dehiscent by loculicidal slits, the exocarp often fleshy; seeds few or numerous, variable in form, arillate.

The family is a tropical one, abundantly represented in both hemispheres, but with relatively few genera and species in Central America. Besides the genera reported here, one other, Dimerocostus, is represented in Central America, in Panama and Costa Rica.

Leaves arranged spirally. Large and tall, coarse plants with elongate, leafy stems; flowers arranged in a terminal and conelike, headlike or spikelike

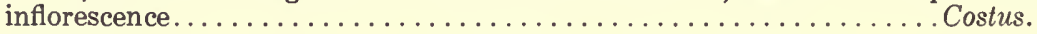

Leaves 2-ranked.

Lip of the corolla trilobate; cultivated plant with the odor and taste of ginger. Zingiber.

Lip of the corolla not trilobate; plants not with the odor and taste of ginger.

Flowers in dense spikes or racemes terminating leafy stems; introduced plants.

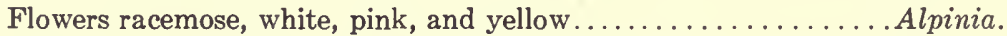

Flowers in dense spikes, the perianth pure white...........Hedychium.

Flowers in panicles arising on short leafless scapes from the base of the tall leafy sterile stems, or in one species the inflorescence cone-like and

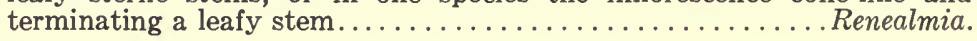

\section{ALPINIA Roxburgh}

Robust herbs of medium size with leafy stems, usually growing in dense clumps; leaves large, distichous, petiolate or sessile; inflorescence racemose or subspicate, sometimes paniculate, terminating the stem, the bracts large and imbricate, the flowers large and showy; calyx turbinate to tubular, with 3 teeth or small lobes, often cleft above on one side; corolla tube equaling or longer than the calyx, the lobes commonly unequal, the posterior one much larger; lip usually broad and much larger than the corolla lobes, the lateral staminodia small and inconspicuous; ovules numerous; fruit capsular, dry, the seeds angulate.

The species are all natives of the Old World, chiefly of the East Indies.

Alpinia speciosa (Wendl.) Schum. Fl. Kaiser-Wilhelmsl. 29. 1887. Zerumbet speciosum Wendl. Sert. Hann. pl. 19. 1798. A. nutans Roscoe in Sm. Exot. Bot. 2: pl. 106. 1805. Languas speciosa Merrill, Enum. Philip. Pl. 234. 1922. Perlas; Perlas del Oriente; Collar de la reina.

Planted commonly in gardens for ornament, principally in the lowlands but also at middle elevations, doubtless naturalized in some places, as elsewhere in Central America. Native of China and Japan. 
Plants usually about a meter high and forming dense clumps; leaves shortpetiolate, acuminate, narrowed at the base, $70 \mathrm{~cm}$. long and $10 \mathrm{~cm}$. wide or smaller, glabrous except on the puberulent margin, the ligule $1 \mathrm{~cm}$. long or less; panicles up to $30 \mathrm{~cm}$. long, the bracts 2-3-flowered, broadly elliptic, whitish, about $3 \mathrm{~cm}$. long; calyx almost $2 \mathrm{~cm}$. long, white; corolla white, the tube $1 \mathrm{~cm}$. long, the lobes broadly elliptic, obtuse, $3 \mathrm{~cm}$. long, red at the apex; lip broadly ovate, $4 \mathrm{~cm}$. long, subtrilobate, spotted and streaked with red and yellow; capsule globose, $2 \mathrm{~cm}$. in diameter.

Known elsewhere in Central America as "lirio de Colón," "grano de oro," "lágrimas de San Juan," "lágrimas de Nazareno," etc. The plant is much planted about the humbler dwellings of Central America, and often persists where they have disappeared. The large and showy inflorescences are brought to the markets, especially for use as decorations during religious and other fiestas.

\section{COSTUS L.}

Reference: Rowlee, The genus Costus in Central America, Bull. Torrey Club 49: 283. 1922.

Tall or low herbs, often very large, rarely acaulescent, the stout stems consisting of the tightly sheathing leaf bases; leaves spirally arranged, sessile or shortpetiolate, glabrous or pilose; flowers yellow, red, or white, disposed in a dense, cone-like spike, this terminal or borne on a short, leafless scape at the base of the leafy stem, the bracts broad, 1-2-flowered, coriaceous, closely imbricate, sometimes with leafy, terminal appendages; calyx tubular, coriaceous or membranaceous, more or less trilobate at the apex; corolla tube slender, equaling or longer than the calyx, the lobes imbricate, subequal; outer stamens or staminodia none, the lip large, obovate, more or less bilobate at the apex; stamen with a broad, petaloid filament, the anther 2-celled, usually shorter than the free portion of the filament; ovary with numerous ovules; capsule trigonous, trivalvate, usually dehiscent by loculicidal slits; seeds angulate.

About fifteen species are known from Central America. The genus is a large one, of approximately one hundred species, widely dispersed in the tropics of the various continents. The plants often constitute a conspicuous element of the undergrowth of the wet lowland forests of Guatemala, being prominent because of their unusual appearance and showy inflorescences, that persist for a long time. In Central America generally the succulent stems are variously used in domestic medicine, particularly for treating gonorrhea and related diseases, for which the common people believe them to be highly effective.

Inflorescences borne on short leafless scapes arising at the base of the leafy stem. Inflorescences terminating the leafy stems.

C. sepacuitensis.

Bracts of the spikes bearing spreading leafy appendages. 
Plants densely hirsute with long spreading hairs.......... . villosissimus. Plants with sparse pubescence of short appressed hairs.......... C. Bakeri. Bracts of the spikes not appendaged, closely appressed, at least during anthesis. Spikes ovoid .......................... pulverulentus. Spikes fusiform, cylindric, or globose.

Spikes fusiform, the bracts closely appressed in age........ sanguineus. Spikes cylindric or globose, the bracts in age lax and often spreading.

Spikes about $7 \mathrm{~cm}$. thick; plants tall, usually much more than 2 meters

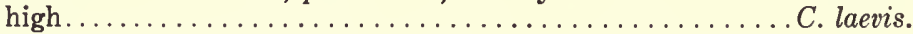

Spikes about $4 \mathrm{~cm}$. thick; plants smaller, commonly 1-2 meters high.

Spikes red, cylindric.................... ruber. Spikes green, often globose ................ congestus.

Costus Bakeri Schum. Pflanzenreich IV. 46: 387. 1904. Caña de Cristo; Caña de la Virgen.

Wet thickets, especially in ravines along small streams, mostly at 400-1,400 meters; Santa Rosa; Escuintla; Guatemala (type from Barranco Eminencia, J. D. Smith 2802); Suchitepequez; Retalhuleu; Quezaltenango; San Marcos. Chiapas; reported from Costa Rica.

Plants stout, 1.5-2.5 meters high; leaves short-petiolate or sessile, lanceolate, oblong, or oblanceolate, $30 \mathrm{~cm}$. long or less, caudate-acuminate, narrowed at the base, usually glabrous above, sparsely sericeous beneath, the ligule very short, villous; spikes subglobose, about $5 \mathrm{~cm}$. broad, the bracts dull red, rarely green or yellow, the foliaceous appendages lanceolate, spreading, acuminate, the inner sterile bracts erect and comose, the bracts all rather densely appressed-pilose; calyx $1 \mathrm{~cm}$. long, puberulent; corolla tube $1 \mathrm{~cm}$. long, the lobes oblong, about twice as long.

The plant has been reported from Guatemala as C. comosus Roscoe. It is abundant and conspicuous in many parts of the bocacosta, where it sometimes forms large colonies on open hillsides, especially in the Department of Quezaltenango. While the normal color of the bracts is dull red, scattered plants have pale yellow or even green bracts.

Costus congestus Rowlee, Bull. Torrey Club 49: 291. pl. 14. 1922. Caña de Cristo.

Moist or wet thickets, 1,350 meters or lower; Alta Verapaz; Jutiapa; Escuintla (type from Escuintla, J. D. Smith 2036); Sololá; Suchitepequez; Quezaltenango; Huehuetenango. Reported from Oaxaca.

Plants low, usually about a meter high, rarely somewhat taller; leaves sessile, oblanceolate, $24 \mathrm{~cm}$. long and $6 \mathrm{~cm}$. wide or smaller, acuminate, narrowed to the base, glabrous; spikes green, subglobose or ellipsoid, about $4 \mathrm{~cm}$. long; bracts 
in flower closely imbricate, obtuse, glabrous; ovary glabrous; petals large, pale yellow, hyaline, obtuse; lip about $4 \mathrm{~cm}$. long.

This is very close to $C$. ruber, from which it may not be specifically distinct.

Costus laevis Ruiz \& Pavón, Fl. Peruv. 1: 3. 1798. C. splendens Donn. Smith \& Türckh. Bot. Gaz. 33: 260. 1902 (type from Cubilgüitz, Alta Verapaz, Türckheim 8015). Caña de Cristo.

Wet forest or thickets, 1,300 meters or lower; Alta Verapaz; Izabal; Santa Rosa; Escuintla; Sacatepéquez; Quezaltenango; San Marcos. Probably in Chiapas; Costa Rica; Panama; southward to Peru and Brazil.

A coarse stout plant, commonly $2-3$ meters high, often forming large colonies; leaves mostly oblanceolate, on petioles as much as $2 \mathrm{~cm}$. long, caudate-acuminate, narrowed to the base, glabrous or nearly so, mostly about $25 \mathrm{~cm}$. long and 6-7 cm. wide, or larger, the ligule $5 \mathrm{~mm}$. long; spikes cylindric or oblong, as much as $22 \mathrm{~cm}$. long and $7 \mathrm{~cm}$. broad, the bracts red and green, broadly elliptic, very obtuse, coriaceous, somewhat sericeous or glabrate; ovary sericeous-tomentose; calyx $1 \mathrm{~cm}$. long, glabrous; capsule obpyramidal, $2.5 \mathrm{~cm}$. long, $1.5 \mathrm{~cm}$. broad, the seeds $3 \mathrm{~mm}$. long.

Costus pulverulentus Presl, Rel. Haenk. 1: 41. 1830.

At 390 meters; Suchitepequez (Río Sis, J. D. Smith 2800). Originally described from southern Mexico.

Leaves sessile, oblong-lanceolate, abruptly acuminate, attenuate to the base, 13-16 $\mathrm{cm}$. long and 4.5-5.5 $\mathrm{cm}$. wide, glabrous above, squamulose-puberulent beneath, the ligule short, truncate; spikes terminal, sessile, $6.5 \mathrm{~cm}$. long, subtended at the base by 3 or more leaves; bracts closely imbricate, ovate-rounded, retuse or emarginate or obtuse and mucronate, short-scabrous, $2 \mathrm{~cm}$. long and wide.

A little known species, its systematic position doubtful. The Guatemalan collection was referred by Baker to $C$. Malortieanus Wendl., a Costa Rican species.

Costus ruber Griseb. Cat. Pl. Cub. 256. 1866. Caña de Cristo; Caña agria; Cu, Pacuite (Quecchí); Cooltze (Petén, Maya, fide Lundell).

Wet forest or thickets, 1,400 meters or lower, most plentiful at low elevations; Petén; Alta Verapaz; Izabal; Zacapa; Escuintla; Suchitepequez; Retalhuleu. Southern Mexico; British Honduras to Panama; Colombia; West Indies.

Plants stout, commonly 1-1.5 meters high; leaves subsessile, elliptic to oblanceolate, mostly $10-20 \mathrm{~cm}$. long and $5-7 \mathrm{~cm}$. wide, abruptly short-acuminate, tapering to the base, glabrous or nearly so, the ligule $3-5 \mathrm{~mm}$. long; spikes ellipsoid, 
about 5-7 $\mathrm{cm}$. long and $4 \mathrm{~cm}$. thick, the bracts coriaceous, broadly ovate, acute or usually obtuse, dull red or orange-red, 1-flowered; ovary puberulent; calyx shallowly trilobate, glabrous; corolla yellow or orange-red, the tube $1 \mathrm{~cm}$. long, the lobes oblong, acute, the broader posterior one $2 \mathrm{~cm}$. long; capsule subtrigonous, puberulent, the seeds numerous.

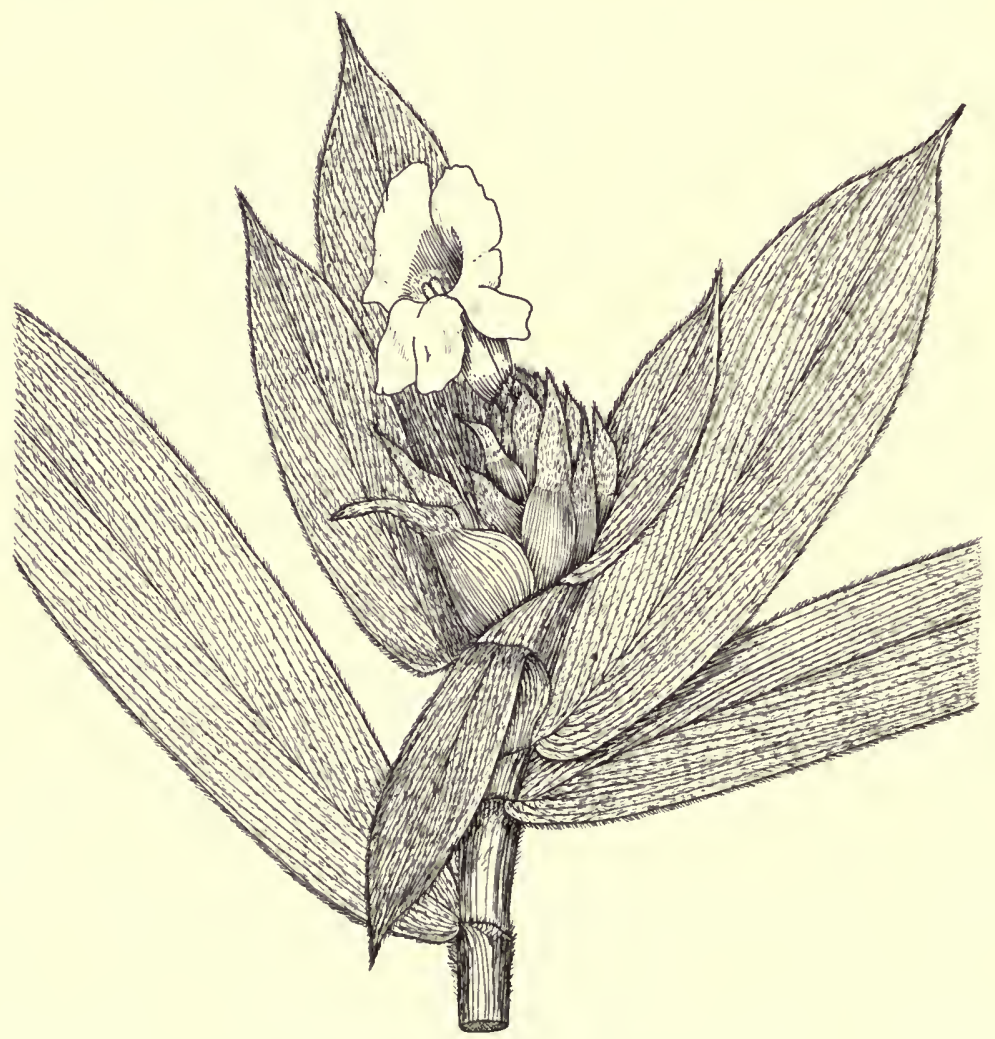

FIG. 35. Costus villosissimus. Habit of uppermost portion of plant; $\times 1 / 3$.

This is a very common plant in the wet forests of the North Coast region, as it is also in many other parts of Central America. It has been reported frequently from Guatemala and other parts of Central America as C. spicatus Jacq.

Costus sanguineus Donn. Smith, Bot. Gaz. 31: 122. 1901.

Wet thickets and mixed forest, 450 meters or lower; Alta Verapaz (type from Cubilgüitz, Türckheim 7686); Izabal; Huehuetenango. Honduras; Nicaragua; Costa Rica. 
Plants stout, 1-2 meters high; leaves subsessile, oblanceolate, about $20 \mathrm{~cm}$. long and $6 \mathrm{~cm}$. wide, short-acuminate, narrowed to the base, pilose-sericeous, especially beneath, the short ligule villous; spikes fusiform, or elongate-cylindric, up to $10 \mathrm{~cm}$. long and $3-4 \mathrm{~cm}$. thick, or of ten much more elongate; bracts dull red, orange, or green, thick-coriaceous, rather closely imbricate and not at all spreading in age, rounded or very obtuse at the apex, often tomentose on the margins; ovary sericeous-tomentose; calyx campanulate, $8-9 \mathrm{~mm}$. long, pilose; corolla purplish red, $5.5-6 \mathrm{~cm}$. long, the lobes lanceolate, acute, equaling the tube; lip truncate, 5-lobate.

Called "caña de Cristo" in Honduras. A showy plant because of the unusually long and often brightly colored spikes. 1922.

Costus sepacuitensis Rowlee, Bull. Torrey Club 49: 286. pl. 13.

Type from Finca Sepacuité, Alta Verapaz, O. F. Cook \& R. F. Griggs 596. Known only from the original collection.

Leaves sessile, narrowly elliptic-oblong, about $30 \mathrm{~cm}$. long and $9 \mathrm{~cm}$. wide, acute or short-acuminate, soft-pilose on both surfaces, ciliate, the ligule $1.7 \mathrm{~cm}$. long; flowering scapes arising at the base of the plant, $40 \mathrm{~cm}$. long or more, leafless but bearing numerous puberulent sheaths; spikes somewhat elongate, the bracts broadly ovate, $4 \mathrm{~cm}$. long and $3-4 \mathrm{~cm}$. wide, obtuse or rounded, glabrous; fruit pubescent, obovoid, $15 \mathrm{~mm}$. long, $8 \mathrm{~mm}$. wide; calyx deeply lobate, the unequal lobes about $13 \mathrm{~mm}$. long, ovate, acute.

Costus villosissimus Jacq. Fragm. Bot. 55. pl. 80. 1800-1809.

Wet mixed lowland forest, 350 meters or lower; Alta Verapaz; Izabal. Southern Mexico; British Honduras along the Atlantic coast to Panama; Lesser Antilles; South America.

Plants stout, 1-2.5 meters high, the sheaths rufous-hirsute; leaves sessile or nearly so, lanceolate, acuminate, acute at the base, about $30 \mathrm{~cm}$. long and $10 \mathrm{~cm}$. wide, rufous-hirsute or pilose on both surfaces, more densely so beneath; spikes ovoid, dark red, the outer bracts rufous-villous, leafy-appendaged, as much as $9 \mathrm{~cm}$. long and $4 \mathrm{~cm}$. wide, acute; calyx $1.5 \mathrm{~cm}$. long, the lobes only $4 \mathrm{~mm}$. long; corolla tube 1.5-2 cm. long, the lobes oblong, acute, $6 \mathrm{~cm}$. long, yellow; lip as much as $9 \mathrm{~cm}$. long. (Fig. 35.)

Called "choschogo" in Veracruz.

It is probable that Curcuma longa L., turmeric, native of India, is cultivated occasionally in Guatemala, as it is in some other parts of Central America. In general appearance it is much like ginger. The thick roots are the source of turmeric, employed as a dye and condiment. In Guatemala the plant is called "camotillo" and "tintura de yodo." 
Elettaria cardamomum Maton, cardamom, native of the East Indies, has been planted on a rather large scale in the lowlands of Alta Verapaz, about Cubilguiitz and elsewhere, and it is reported as in cultivation in Escuintla. Its aromatic seeds have long been an article of commerce, for use as a spice. The plant is a coarse, tall perennial with large, aromatic, lanceolate leaves. The recumbent flowering branches (concinni) arise from the fleshy base of the plant and are distinct from the upright leafy stems. The flowers of the concinnus consist of small lanceolate greenish sepals and a prominent enlarged white labellum, veined reddish-purple along the middle. It is stated that several "varieties" are grown in Alta Verapaz. The plants there are said to be much subject to disease, but quantities of the seeds have been harvested for export.

\section{HED YCHIUM Koenig}

Herbs of medium size, usually cespitose or forming dense colonies, with leafy stems, the leaves distichous, sessile or petiolate; flowers large and showy, arranged in a dense, terminal spike, subtended by broad, imbricate bracts, the flowers solitary or several from each bract; calyx tubular, more or less trilobate or entire, usually cleft on one side; corolla tube long and slender, much exceeding the calyx, the lobes linear, imbricate; outer 2 staminodia petaloid and resembling corolla lobes, the lip large or small, broad, usually unguiculate; filament commonly elongate, the anther linear; capsule loculicidal.

The species are all or chiefly native in the East Indies.

Hedychium coronarium Koenig in Retz. Obs. Bot. 3: 73. 1783. Perlas de Oriente; Tzi (Quecchí).

Often planted in gardens for ornament; abundantly naturalized in marshes and wet thickets along the Pacific bocacosta, in Alta Verapaz, and doubtless in other places; native, according to Schumann, of the Himalayan region, but now naturalized widely in tropical America and other regions; Alta Verapaz; Izabal; Escuintla; Suchitepequez; Retalhuleu; San Marcos.

A coarse herb about a meter high with leafy stems; leaves sessile, lanceolate or oblong-lanceolate, $10-50 \mathrm{~cm}$. long, 3-10 cm. wide, acuminate, acute at the base, glabrous above, sparsely pilose beneath, the ligule $2-3 \mathrm{~cm}$. long; spikes ellipsoid, dense, with the flowers $10-20 \mathrm{~cm}$. long and $4-8 \mathrm{~cm}$. broad, the bracts green, 4-5.5 $\mathrm{cm}$. long, ovate, obtuse, subcoriaceous, 2-3-flowered; calyx $4 \mathrm{~cm}$. long; corolla tube very slender, $8 \mathrm{~cm}$. long, the lobes $3-3.5 \mathrm{~cm}$. long.

Called "mariposa" in Salvador. A handsome and showy plant because of the large, pure white flowers which, however, are delicate and soon wither. In many places along the Pacific slope at low and 
middle elevations the plant forms vast colonies, sometimes of several acres, through the marshes. It grows in association with Calathea and other native plants in areas far from dwellings where no other imported plants are to be seen. With the marsh plants it makes a typical association of perfectly natural appearance. Under such conditions it is difficult to believe that it is not a native plant, and it is not easy to judge how it has been dispersed so widely, if introduced. There is no good reason, however, for supposing that it is not an escape from cultivation.

Kaempferia rotunda L., native of the East Indies, is grown rarely for ornament in Guatemalan gardens. The plant is acaulescent, and usually leafless at time of flowering. The few large orchid-like flowers arise from the rootstock and appear just above the ground, one at a time. The petals are white and lavender, the sepals whitish and reflexed. The leaves are purple beneath.

\section{RENEALMIA L. f.}

More or less aromatic, often very tall herbs, the stems leafy; leaves petiolate or sessile, lanceolate or oblong, glabrous, long-sheathing, the ligule usually short; inflorescence borne on a short, leafless scape arising at or near the base of the leafy stem, or conelike and terminating a leafy stem; bracts relatively small, withering after anthesis, the flowers in loose or dense racemes or panicles, the peduncles and pedicels commonly dark red, the flowers white, yellow, or red, small; calyx tubular or turbinate, closed in bud, later tridentate or trilobate, of ten cleft on one side; corolla tube usually longer than the calyx, the lobes equaling or longer than the tube, obtuse; lip short, more or less trilobate, the lateral staminodia short and dentiform; anther sessile or on a very short filament; ovary commonly glabrous, 3-celled, the ovules numerous; capsule 3-celled, crowned by the persistent calyx, 3-valvate; seeds angulate, enclosed in a large, fleshy, usually red or orange aril.

A genus of about sixty species, in tropical America and Africa. Several species besides those listed here are native in southern Central America.

Inflorescences terminal on leafy stems........................ cernua. Inflorescences borne on leafless scapes arising at the base of the leafy stems.

Plants very large, sometimes 4 meters high; capsule $2-3 \mathrm{~cm}$. long; calyx almost

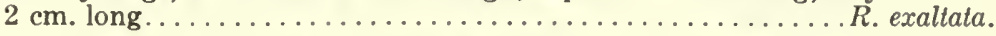

Plants smaller, 2 meters high or less; calyx about $5 \mathrm{~mm}$. long....R. aromatica.

Renealmia aromatica (Aubl.) Griseb. Fl. Brit. W. Ind. 601. 1864. Alpinia aromatica Aubl. Pl. Guian. 3. 1775. A. occidentalis Swartz, Prodr. Veg. Ind. Occ. 9. 1788. R. occidentalis Sweet, Hort. 


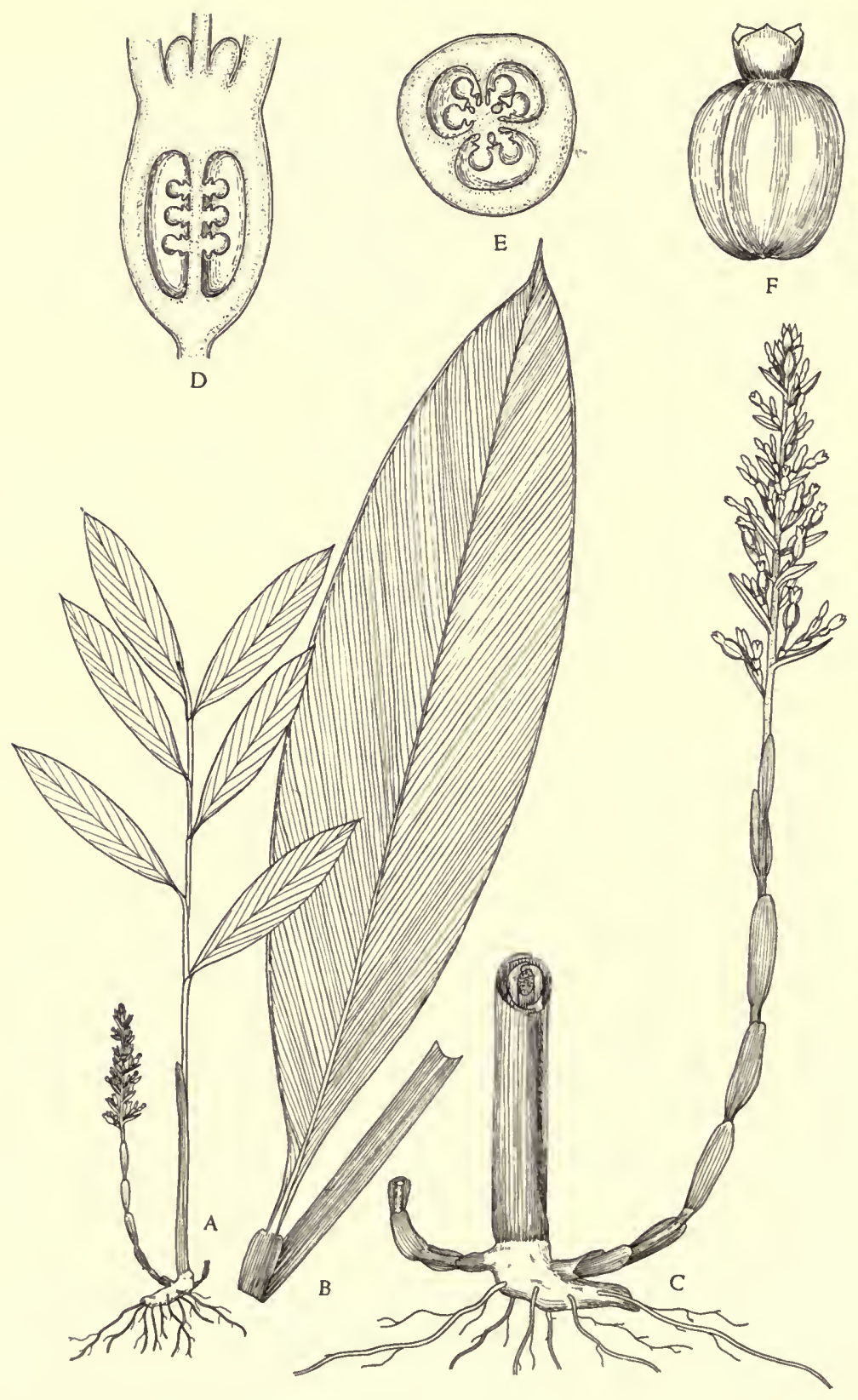

FIG. 36. Renealmia aromatica. A. Habit of plant; $\times 1 / 9 . \quad$ B. Leaf detached from stem; $\times 1 / 3$. C. Inflorescence in position, and base of stem; $\times 1 / 3$. D. Ovary in longitudinal section; $\times 2$. E. Ovary in transverse section; $\times 2$. F. Fruit; $\times 2$. 
Brit. ed. 2. 493. 1830. Tzi (Alta Verapaz); Chucho (Alta Verapaz); Nabay (Petén, Maya).

Wet mixed forest, 1,500 meters or lower; Petén; Alta Verapaz; Izabal; Jutiapa; Santa Rosa; Escuintla; Suchitepequez; Sololá; Huehuetenango. Southern Mexico; British Honduras to Panama; West Indies; northern South America.

Sterile stems sometimes 2 meters high but commonly lower; leaves sessile or subsessile, lanceolate or oblong, acuminate, acute at the base, $15-50 \mathrm{~cm}$. long, 5-12 cm. wide, glabrous; panicles arising at the base of the plant, 15-30 cm. long, long-pedunculate, the rachis puberulent, the lower bracts as much as $8 \mathrm{~cm}$. long, lanceolate, acute, glabrous, usually dark red, pedicels $1 \mathrm{~cm}$. long or less; calyx 5-6 mm. long, red; ovary pilosulous or glabrate; corolla yellow, the elliptic lobes equaling the tube; capsule subglobose, red, diameter about $1 \mathrm{~cm}$. (Fig. 36.)

A characteristic species of the wet lowland forests, abundant in many places. Here probably are to be referred collections reported by Captain Smith as $R$. mexicana Klotzsch and $R$. breviscapa Poepp. \& Endl. The latter is a South American species, unknown in North America. It is questionable whether $R$. mexicana, separated by Schumann from $R$. aromatica because of its smaller size, is really different from that species. At least, all the Guatemalan specimens of this alliance appear to be conspecific, and properly referable to $R$. aromatica. The Indians of Alta Verapaz use the pulp of the fruit, it is said, for flavoring meat soup. The leaves are covered with tallow and applied to fractures, sprains, and surface inflammation to reduce them.

Renealmia cernua (Swartz) Macbride, Field Mus. Bot. 11: 14. 1931. Costus cernuus Swartz ex Roem. \& Schult. Syst. Veg. 1: 25. 1817. R. strobilifera Poepp. \& Endl. Nov. Gen. \& Sp. 2: 26. pl. 136. 1838.

Wet mixed forest, at or near sea level; Izabal (Puerto Barrios). Ranging to Panama and southward to Peru.

Stems very leafy, commonly about a meter high but sometimes 2 meters; leaves sessile, lanceolate or linear-lanceolate, acuminate, acute at the base, glabrous, about $30 \mathrm{~cm}$. long and $6 \mathrm{~cm}$. wide or smaller; inflorescence spicate, terminating the stem, ovoid or ellipsoid, $5-10 \mathrm{~cm}$. long, at first erect, later nutant, the bracts coriaceous, orange, closely imbricate, striate, lanceolate; flowers solitary, the ovary glabrous; calyx tubular, $1.5 \mathrm{~cm}$. long; corolla yellow, coriaceous, the tube shorter than the calyx, the lobes ovate, equaling the tube; lip $1 \mathrm{~cm}$. long, linearoblong; capsule ellipsoid, 10-12-seeded.

Very common in lowland forests of Costa Rica and Panama, and known also from Nicaragua, but strangely enough, no specimens have been seen from Honduras. 
Renealmia exaltata L. f. Suppl. Pl. 79. 1781. Huehuechucha; Jazmin de monte (Huehuetenango).

Wet thickets or dense mixed forest, 1,200 meters or lower; reported from Alta Verapaz (Cobán); Chiquimula; Santa Rosa; Sololá; Huehuetenango; Quezaltenango; Santa Rosa. Southern Mexico; southward to Panama and the Guianas; West Indies.

Plants very large and coarse, usually 2 meters high or more, often forming large colonies; leaves sessile or short-petiolate, elongate-lanceolate or oblanceolate, up to a meter long and 6-12 $\mathrm{cm}$. wide, short-acuminate, long-attenuate at the base, glabrous; panicles basal, 20-30 $\mathrm{cm}$. long, red, subtomentose, long-pedunculate; flowers in small, pedunculate inflorescences, the bracts lanceolate, $8 \mathrm{~cm}$. long or less, the pedicels about $5 \mathrm{~mm}$. long; calyx almost $2 \mathrm{~cm}$. long, bilobate, sparsely sericeous; corolla pink, the tube equaling the calyx, the lobes obtuse, $1 \mathrm{~cm}$. long; capsule ellipsoid, striate, $2-3 \mathrm{~cm}$. long, striate; seeds large, yellowish, lustrous, 3-4 $\mathrm{mm}$. in diameter, surrounded by a white aril.

\section{ZINGIBER Adans. Ginger}

Perennial herbs with aromatic rhizomes, the floriferous stems usually distinct from the leafy ones, or the inflorescence sometimes terminating a leafy stem; flowers commonly solitary in the bracts, subtended by a spathaceous bractlet, the bracts dense or lax; calyx tridenticulate, usually cleft on one side; corolla tube slender, dilated toward the apex, the lobes imbricate, often very unequal, the posterior one concave and erect, the anterior ones narrower; lateral staminodia small or large, colored, the lip deflexed, entire, emarginate, or shallowly bilobate; ovules numerous; capsule subglobose or ellipsoid, the pericarp thin, trivalvate or irregularly ruptured; seeds large, surrounded by a lacerate aril.

The species are all natives of the Old World, and chiefly of the East Indies.

Zingiber officinale Roscoe, Trans. Linn. Soc. 7: 348. 1807. Amomum Zingiber L. Sp. Pl. 1. 1753. Gengibre; Xenxibre (Quecchí).

Planted frequently in gardens and perhaps naturalized locally. Probably native of the East Indies, but cultivated in all tropical regions.

Stems a meter high or more, from a tuberous rhizome; leaves numerous, sessile, lanceolate or linear-lanceolate, long-acuminate, narrowed at the base, as much as $20 \mathrm{~cm}$. long and $2 \mathrm{~cm}$. wide; flower spikes long-pedunculate, ellipsoid, dense, about $5 \mathrm{~cm}$. long and $2-2.5 \mathrm{~cm}$. thick, the bracts ovate, cuspidate, pale green, $2.5 \mathrm{~cm}$. long; calyx crenate, almost $1 \mathrm{~cm}$. long; corolla yellowish green, the tube $2 \mathrm{~cm}$. long or less, the lobes subequal, lanceolate, acute; lip oblong-obovate, purplish, yellow-dotted.

The rhizomes of ginger are widely used as a condiment and drug. The plant usually is propagated by pieces of the rhizome, and in 
Central America it is said to flower rarely or not at all. Schumann states that the capsules are unknown. The dried rhizomes are offered for sale commonly in the markets. It is said that the Quecchí Indians of Lanquín grow the plants in some quantity and carry the roots for sale to the capital and other remote markets.

\section{GANNACEAE. Canna Family}

Reference: Fr. Kraenzlin, Cannaceae, Pflanzenreich IV. 47. 1912.

Large erect leafy herbs, the thick stems arising from slender rhizomes or usually from thick tuberous rhizomes; inflorescences terminal, usually branched, sometimes simple, the flowers spicate, asymmetric, mostly red or yellow; sepals 3, imbricate, subequal or one of them smaller, generally herbaceous; petals 3, alternate with the sepals, one of them always smaller than the others, more or less connate at the base into a tube, 1 or 2 reflexed, or all sometimes reflexed; androecium more or less altered into petal-like staminodia, or the outer staminodia sometimes absent, usually $2-3$, the inner staminodia 2 , one (the lip) revolute, the other petaloid, bearing a dimidiate 1-celled anther on one side, connate at the base or to the middle with a usually linear, petaloid style; style inserted obliquely on the ovary, the stigma terminal, obliquely inserted on the style, deeply sulcate; ovary inferior, subglobose, papillose; capsule subglobose or ellipsoid, 3-celled, loculicidally dehiscent, membranaceous at maturity; seeds several in each cell, extremely hard; endosperm white, very hard.

A single genus, with about fifty species, mostly natives of tropical America, a few in tropical Africa and Asia, some of them naturalized in the Old World tropics.

\section{GANNA L. Canna}

Staminodia besides the lip always 2 ; flowers yellow.

Leaves glaucous beneath........................... discolor.

Leaves green beneath.

Flowers spotted; bracts about $1 \mathrm{~cm}$. long................. lutea.

Flowers not spotted; bracts about $2 \mathrm{~cm}$. long............ sanctaerosae. Staminodia always 3 , variously connate; flowers red or orange.

Flowers about $15 \mathrm{~cm}$. long....................... Tuerckheimii. Flowers mostly 5-7 cm. long.

Plants large and coarse, generally $2-3$ meters high, sometimes lower; flowers orange or orange-red .......................... edulis.

Plants low and relatively slender, usually about a meter high; flowers bright or pale red, with no orange tint ...................... indica.

Canna discolor Lindl. Bot. Reg. pl. 1231. 1829.

Reported as collected in Guatemala, without specific locality, by Bernoulli; Suchitepequez (Río Sis, J. D. Smith 2799); also from Retalhuleu. West Indies; Colombia. 
Plants large, 2-3 meters high, purplish, glabrous; leaves long-sheathing, the blades as much as $90 \mathrm{~cm}$. long and $40 \mathrm{~cm}$. wide, filiform-apiculate, deep green above, purple-marginate, vinous-purple beneath; racemes many-flowered, the branches purplish-pruinose; bracts 2-flowered, oblong, short-acute, the lowest $2.5-3 \mathrm{~cm}$. long, 10-12 mm. wide; sepals lanceolate, obtuse, $1.5 \mathrm{~cm}$. long; petals lanceolate, connate only at the base, acuminate, $4 \mathrm{~cm}$. long; staminodia 2 , cuneateoblong, purple above or within, yellow outside, about $6 \mathrm{~cm}$. long; lip of about the same length, shallowly 2-lobate; whole flower $7 \mathrm{~cm}$. long or more; capsule $3-4 \mathrm{~cm}$. long, more than $2 \mathrm{~cm}$. broad.

Canna edulis Ker, Bot. Reg. 9: pl. 775. 1823. Platanillo; Cucuyús; Lirio.

Moist or wet thickets, sometimes in rather open forest, often in second growth, 2,500 meters or less, most common at lower elevations; Alta Verapaz; Zacapa; Santa Rosa; Escuintla; Guatemala; Quiché; Quezaltenango; San Marcos. Southern Mexico; British Honduras to Panama; West Indies; South America.

Plants large and coarse, usually 2-3 meters high, the rhizomes very large, thick, and tuber-like; leaves large, oblong or ovate-oblong, acute, green, $60 \mathrm{~cm}$. long and $18 \mathrm{~cm}$. wide or sometimes larger; inflorescence simple or branched; sepals oblong-lanceolate, subacute, $12 \mathrm{~mm}$. long; petals oblong-lanceolate, $4 \mathrm{~cm}$. long, 7-8 mm. wide; 3 upper staminodia oblong, much longer than the petals, more than $6 \mathrm{~cm}$. long, $12 \mathrm{~mm}$. wide; lip slightly shorter, recurved into almost a circle, orange-red or orange; capsule obovoid; whole flower connivent and little spreading, $7.5 \mathrm{~cm}$. long.

Called "bijao" in Honduras; "chancala" (Yucatan, Maya). This plant is common and widely distributed in the lowlands of Guatemala, and often is more or less a weed. Like most of the native species, it has small flowers, as compared with cultivated cannas. In the field it is easy of recognition by its large size and orange-red flowers. The starchy rhizomes are cooked and eaten in some parts of tropical America, but so far as we know, no use is made of them in Central America.

Canna generalis L. H. Bailey, Hortus 118. 1930. Bandera española; Bijagua.

This is the common large-flowered canna of gardens, of which very many varieties are known, distinguished by size, coloring of the foliage, and size, form, and color of the flowers. Most of the cultivated cannas are believed to be of hybrid origin and of probably very mixed ancestry. One of the principal elements in the ancestry of the large-flowered plants is C. flaccida Salisb., native in the southeastern United States, which has as handsome flowers as most cultivated forms. The native species, especially $C$. indica, often 


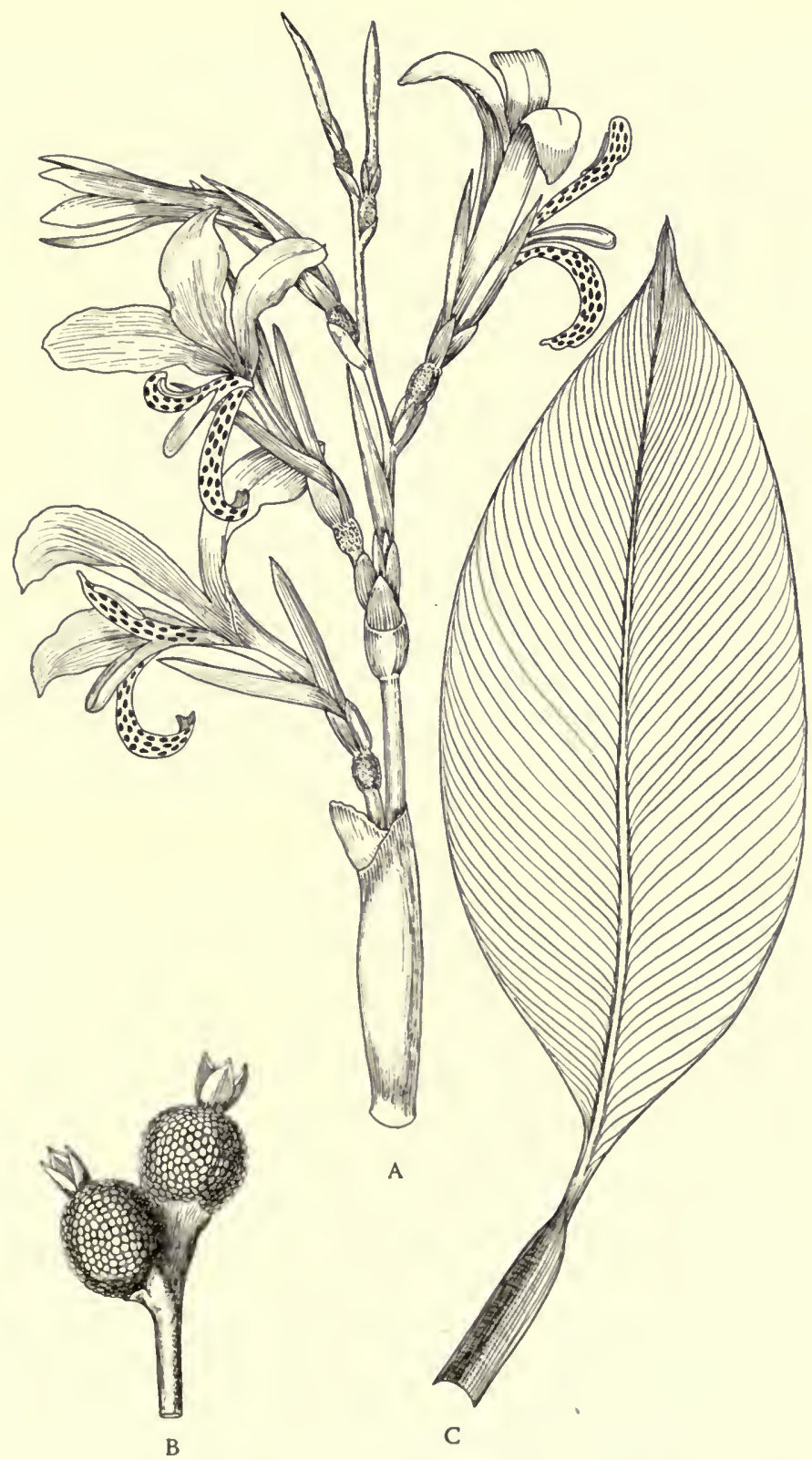

FIG. 37. Canna indica. A. Inflorescence; $\times 2 / 3$. B. Fruit in position; $\times 1$. C. Leaf; $\times 1 / 3$. 
are planted in Guatemalan gardens, but the majority of the cultivated plants are of "improved" varieties. They are planted in all inhabited regions, but thrive best at middle or low elevations. They often are seen half wild in hedges and in thickets near dwellings, and normally spread so rapidly that the plants must be dug out in order to protect less aggressive vegetation.

\section{Canna indica L. Sp. Pl. 1. 1753. Bijagua; Bijao; Cucuyús.}

Mostly in moist or wet thickets, or along streams, frequent in second growth, often invading cultivated ground, especially coffee plantations, 1,900 meters or less, rarely naturalized at higher elevations; Alta Verapaz; Izabal; Zacapa; Jutiapa; Santa Rosa; Escuintla; Sacatepéquez; Quiché; Huehuetenango; Suchitepequez; Retalhuleu; Quezaltenango; San Marcos. Mexico; British Honduras to Salvador and Panama; West Indies; South America.

Plants mostly 1-1.5 meters high; leaves oblong or ovate-oblong, the larger about $50 \mathrm{~cm}$. long and $20-25 \mathrm{~cm}$. wide, green, acute, more or less unequal at the base; racemes simple or sparsely branched, the bracts pruinose, the upper ones broadly oblong, very obtuse, $1.5 \mathrm{~cm}$. long; sepals $1 \mathrm{~cm}$. long, much shorter than the bracts, obtuse; petals lanceolate, acuminate, 3-4 cm. long, bright or deep red, united only at the base; 3 outer staminodia obovate-spatulate or oblanceolate, the lip narrower. (Fig. 37.)

Called "platanillo" in Honduras and elsewhere. This species often is planted for ornament in Central America, and even in the United States, but the flowers are too small to make the plant a desirable one for cultivation. It was noted as growing abundantly in a wet barranco near Chichicastenango, where it doubtless is introduced.

Canna lutea Mill. Gard. Dict. ed. 8. no. 4. 1768.

Moist or wet thickets, 350 meters or less; Retalhuleu; reported from Escuintla. Mexico; Costa Rica and Panama; West Indies; South America.

Plants usually about a meter high; leaves green, oblong or broadly lanceolate, the larger about $40 \mathrm{~cm}$. long and $13-15 \mathrm{~cm}$. wide, acute; racemes mostly simple; bracts pruinose, about $1 \mathrm{~cm}$. long and wide, or the uppermost much smaller; sepals oblong, acute; petals slightly connate at the base, lanceolate, acuminate, pale or bright yellow; upper 2 staminodia connate at the base, ligulate, obtuse, longer than the petals; whole flower $6 \mathrm{~cm}$. long; capsule ellipsoid or obovoid, about $2.5 \mathrm{~cm}$. long and $2 \mathrm{~cm}$. broad.

This species seems to be rare in Central America, and few collections of it have been made there. 
Canna sanctaerosae Kraenzlin, Pflanzenreich IV. 47: 40. 1912.

Known only from the type, Santa Rosa, Dept. Santa Rosa, 1,000 meters, Heyde \& Lux 4290.

Plants large, glabrous; leaves oblong, $50 \mathrm{~cm}$. long or more, about $23 \mathrm{~cm}$. wide; racemes simple or sparsely branched, the bracts oblong, obtuse or subacute, as much as $2 \mathrm{~cm}$. long; sepals oblong, subobtuse, 9-12 mm. long; petals lanceolate, acuminate, short-connate at the base, $3.5-4 \mathrm{~cm}$. long; staminodia 2, lanceolate, acute, $5.5 \mathrm{~cm}$. long, $7 \mathrm{~mm}$. wide; lip linear, coiled into a circle; parts of the flower connivent in anthesis except for the lip.

\section{Perhaps only a form of C. lutea.}

Canna Tuerckheimii Kraenzlin, Pflanzenreich IV. 47: 70. 1912.

Known only from the type, Cubilgüitz, Alta Verapaz, 350 meters, Türckheim II.513.

Plants very large, 4-5 meters high; leaves very large, more than $70 \mathrm{~cm}$. long and $36 \mathrm{~cm}$. wide, slightly paler beneath; inflorescence simple, elongate; bracts early deciduous, the pedicels $13 \mathrm{~mm}$. long; sepals subequal, ovate, obtuse, $13 \mathrm{~mm}$. long, accrescent in age; petals ovate-lanceolate, acuminate, connate only at the base, the largest $6 \mathrm{~cm}$. long and $1 \mathrm{~cm}$. wide; staminodia 3 , connate to the middle, obtuse, reflexed at almost a right angle, $8 \mathrm{~cm}$. long, toward the apex 8-9 $\mathrm{mm}$. wide; whole flower about $6 \mathrm{~cm}$. broad, deep orange.

\section{MARANTACEAE}

\section{2. \\ Reference: K. Schumann, Marantaceae, Pflanzenreich IV. 48.}

Perennial herbs, small or often very large, acaulescent or often with elongate stems; leaves distichous, penninerved, usually vaginate, the sheath rarely ligulate at the apex, the petiole commonly callose at the apex; flowers small or large, perfect, dichlamydeous, very irregular, generally geminate, arranged in heads, spikes, racemes, or panicles, each flower or group of flowers subtended by a conspicuous bract and usually by several bractlets; sepals free, equal or slightly unequal; petals united below into a usually long tube, contorted, the outermost one usually largest and more or less cucullate at the apex, white or colored; fertile stamen 1, dimidiate, the anther 1-celled, dehiscent by a longitudinal slit; staminodia 2 , another one usually present, this cucullate, all the staminodia free or connate with the stamen, outer petaloid staminodia often also present; ovary inferior, 3-celled or 1-celled; ovules solitary in each cell, erect, anatropous; style simple, recurved at the apex and concealed by the cucullate staminodium, elastically exserted in anthesis; fruit capsular, loculicidal, sometimes nut-like or baccate, 1-3-seeded; seeds hard and osseous, provided with a lobulate or lamellate aril; embryo hippocrepiform, the endosperm abundant.

About 23 genera, in the tropics of both hemispheres. The genus Myrosma also is represented in Central America. 
Ovary 3-celled, the fruit usually 3-seeded. Inflorescence usually of one or more dense simple spikes, rarely (in one species) branched but then dense and

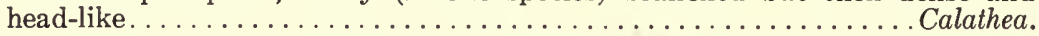
Ovary 1-celled, the fruits 1-seeded. Inflorescence often much branched and open. Perianth purple; rachis of the inflorescence zigzag...............Thalia. Perianth usually white or yellowish, rarely purple; rachis of the inflorescence not zigzag.

Bracts of the inflorescence early deciduous..................... Bracts of the inflorescence persistent.

Staminodia 1; bracts of the inflorescence about $4 \mathrm{~cm}$. long...Ischnosiphon. Staminodia 2; bracts of the inflorescence $1.5 \mathrm{~cm}$. long or less. . Stromanthe.

\section{CALATHEA G. F. W. Meyer}

Perennial herbs, the stems leafy at the base, simple or rarely branched; leaves vaginate, on long or short petioles, the sheath not produced at the apex; flowers spicate, the spikes sessile or pedunculate, the peduncle naked or bearing a single leaf or rarely 2 leaves; bracts usually spirally arranged and closely imbricate, rarely distichous; pairs of flowers usually more than 3 in each bract, the bractlets membranaceous or indurate, rarely none; sepals equal or nearly so, small or large; corolla tube equaling or much longer than the sepals; outer staminode solitary, usually large; ovary 3-celled; fruit capsular, small, cartilaginous-thickened at the apex, sometimes 3-corniculate, crustaceous or harder, 3-celled; seeds trigonous, convex dorsally, arillate.

Species about one hundred, all in tropical America. A few besides those listed here are found in other parts of Central America.

Bracts of the flower spike few, usually 5 or fewer, the whole spike $2 \mathrm{~cm}$. long or less. Plants low, the peduncle leafless, very slender.........C. microcephala. Bracts of the flower spike usually numerous, at least more than 5 , the whole spike usually much more than $2 \mathrm{~cm}$. long.

Bracts distichous, usually coriaceous or pergamentaceous, not green. Plants usually very tall and coarse.

Bracts hard, coriaceous, as much as $4 \mathrm{~cm}$. long, the spikes subterete or at least not strongly compressed........................... lutea.

Bracts soft and scarious or parchment-like, $3 \mathrm{~cm}$. long or shorter, the spikes strongly compressed.......................... insignis.

Bracts spirally arranged, not at all distichous.

Scape leafless.

Flower heads about $8 \mathrm{~cm}$. broad, about as broad as long...... . altissima. Flower heads or spikes $3.5 \mathrm{~cm}$. broad or less, longer than broad.

Bracts mostly $6 \mathrm{~cm}$. long or longer, long-attenuate.......... verapax.

Bracts less than $1 \mathrm{~cm}$. long, obtuse or acute............. coccinea. Scape bearing one or more large leaves.

Scape bearing several leaves; leaves small, $6 \mathrm{~cm}$. wide or less.

C. Warscewiczii.

Scape bearing a single leaf or, if $2-3$, the leaves much larger.

Inflorescence sessile; lowest bract much longer than the upper ones, usually exceeding the inflorescence............. . macrochlamys.

Inflorescence long-pedunculate; lowest bract similar to the upper ones and always much shorter than the inflorescence......... Allouia. 
Calathea Allouia (Aubl.) Lindl. Bot. Reg. 14: sub pl. 1210. 1828. Maranta Allouia Aubl. Pl. Guian. 3. 1775. C. macrosepala Schum. Pflanzenreich IV. 48: 83. 1902. Phrynium violaceum Roscoe, Monandr. Pl. pl. 37. 1828. C. violacea Lindl. Bot. Reg. 11: sub pl. 932. 1825. C. Allouia var. violacea Woodson, Ann. Mo. Bot. Gard. 29: 332. 1942. Mox, Max (Cobán, Quecchí); Chufle; Platanillo.

Moist or wet, mixed forest, 1,400 meters or less, most frequent at low elevations; Izabal; Zacapa; Santa Rosa; Escuintla; Sacatepéquez; Suchitepequez; Huehuetenango. Southern Mexico; British Honduras to Panama; West Indies; northern South America.

Plants large and coarse, 1-1.5 meters high, glabrous, the slender roots terminating in small tubers; radical leaves long-petiolate, the petioles slender, the callus $2 \mathrm{~cm}$. long, puberulent above or glabrous; leaf blades oblong or ovate-oblong, somewhat inequilateral, short-acuminate, as much as $60 \mathrm{~cm}$. long and $20 \mathrm{~cm}$. wide, rounded at the base, thin, slightly paler beneath; scape bearing a single leaf similar to the basal ones and long-petiolate; flower spike ellipsoid, 5-10 cm. long, longpedunculate, the peduncles short-pilose; bracts green, membranaceous, numerous, spirally arranged, $2 \mathrm{~cm}$. long, rounded at the apex, glabrous or sparsely appressedhirtellous; bractlets $12 \mathrm{~mm}$. long, lanceolate; ovary villous at the apex; sepals lanceolate, obtuse, $8 \mathrm{~mm}$. long; corolla pale yellow or whitish, the tube $2.5 \mathrm{~cm}$. long, hirsute, the lobes oblong-lanceolate, $1 \mathrm{~cm}$. long; outer staminode white, $12 \mathrm{~mm}$. long, obovate, 2-lobate; capsule turbinate, $8 \mathrm{~mm}$. long, stramineous, the exocarp crustaceous; seeds trigonous, sulcate, grayish yellow.

The young tender flower spikes are cooked and eaten commonly in Guatemala as well as in other parts of Central America. They are seen frequently in the lowland markets. It is reported that in the West Indies the tubers borne on the roots are cooked and eaten, but we have no data to the effect that they are utilized in Central America. About Cobán and elsewhere the leaves are much used for wrapping tamales and other foods. The nerves of the leaves leave their impression upon the tamalitos, and this pattern is much admired. The leaves remain soft and pliable, unlike those of some other species, and have no unpleasant flavor. In some localities of the Pacific bocacosta the cultivation of this and other Calatheas for their leaves is an agricultural operation second only to the growing of maize. In Salvador the plant is sometimes called "macús." Var. violacea is a form differing only in its purplish corollas. It is common in Panama but probably does not extend so far north as Guatemala.

Calathea altissima (Poepp. \& Endl.) Koernicke, Bull. Soc. Nat. Moscou 35, pt. 1: 141. 1862. Phrynium altissimum Poepp. \& Endl. Nov. Gen. \& Sp. 2: 20. 1838. Hoja de cuero. 
Moist or wet, mixed forest, 350 meters or less; Petén; Alta Verapaz; Suchitepequez. Honduras; Costa Rica; Panama; southward to Peru.

Plants large and coarse, 2 meters high or less; leaves long-petiolate, the callus $13 \mathrm{~cm}$. long or less, complanate or subterete, glabrous; leaf blades ovaloblong or oval, $60 \mathrm{~cm}$. long and $30 \mathrm{~cm}$. wide, rounded and abruptly short-pointed at the apex, rounded at the base and abruptly short-decurrent, glabrous, almost concolorous, thin but stiff; flower spike head-like, about as broad as long, $8 \mathrm{~cm}$. broad, long-pedunculate, the scape naked, about as long as the leaves; bracts spirally arranged, green, the outer ones coriaceous, oblong-ovate or broader, as much as $10 \mathrm{~cm}$. long, acuminate, appressed-hispidulous, often cleft in age, the inner ones shorter and narrower, densely pubescent; ovary sericeous; sepals 18 $\mathrm{mm}$. long, lanceolate, pubescent at the apex; corolla cream-colored, pubescent, the tube $3 \mathrm{~cm}$. long, the lobes lanceolate, $13 \mathrm{~mm}$. long; outer staminode yellowish, broadly obovate, $18 \mathrm{~mm}$. long.

Called "bijagüillo" in Honduras.

Calathea coccinea Standl. \& Steyerm. Field Mus. Bot. 23: 39. 1944.

Known only from the type, Dept. San Marcos, wooded rocky slopes above Finca El Porvenir, along Río Cabús, southern slopes of Volcán de Tajumulco, 1,300-1,500 meters, Steyermark 37945.

A low perennial, the roots numerous, long and slender, each ending in an ellipsoid tuber $2.5 \mathrm{~cm}$. long; leaves absent at anthesis, unknown, the young leaves sparsely and minutely puberulent beneath; scapes naked, very slender, glabrous, about $30 \mathrm{~cm}$. long; spikes $3.5-5 \mathrm{~cm}$. long, $1.5-2 \mathrm{~cm}$. broad, the bracts $7-8$, red, subdistichous or spirally inserted, imbricate, broadly ovate, abruptly acuminate, glabrous or nearly so, $1 \mathrm{~cm}$. long; bractlets elliptic-ovate, subobtuse, 8-9 $\mathrm{mm}$. long; ovary glabrous; sepals elliptic-oblong or oblong-oblanceolate, subobtuse, $10 \mathrm{~mm}$. long, 5-nerved, glabrous; corolla red, glabrous, $3 \mathrm{~cm}$. long, the lobes half as long as the tube, acute; outer staminode 10-12 mm. long, obovate.

Calathea eximia (Mathieu) Koernicke, Gartenflora 7: 87. 1858. Maranta eximia Mathieu, Cat. 1853. This was grown in Europe from plants collected by Warscewicz, probably in Central America, and has been ascribed to Guatemala. There is no evidence that it is native here, and both its habitat and specific status are uncertain.

Calathea insignis Peters. in Mart. Fl. Bras. 3, pt. 3: 124. 1890. P. crotalifera Wats. Proc. Amer. Acad. 24: 86.1889 (type collected near Izabal, Izabal, Sereno Watson). C. sclerobractea Schum. Pflanzenreich IV. 48: 73. 1902 (type collected between San Andrés Osuna and Rochela, Escuintla, Preuss 1446). Machán; Mohán (Izabal, fide Blake). 


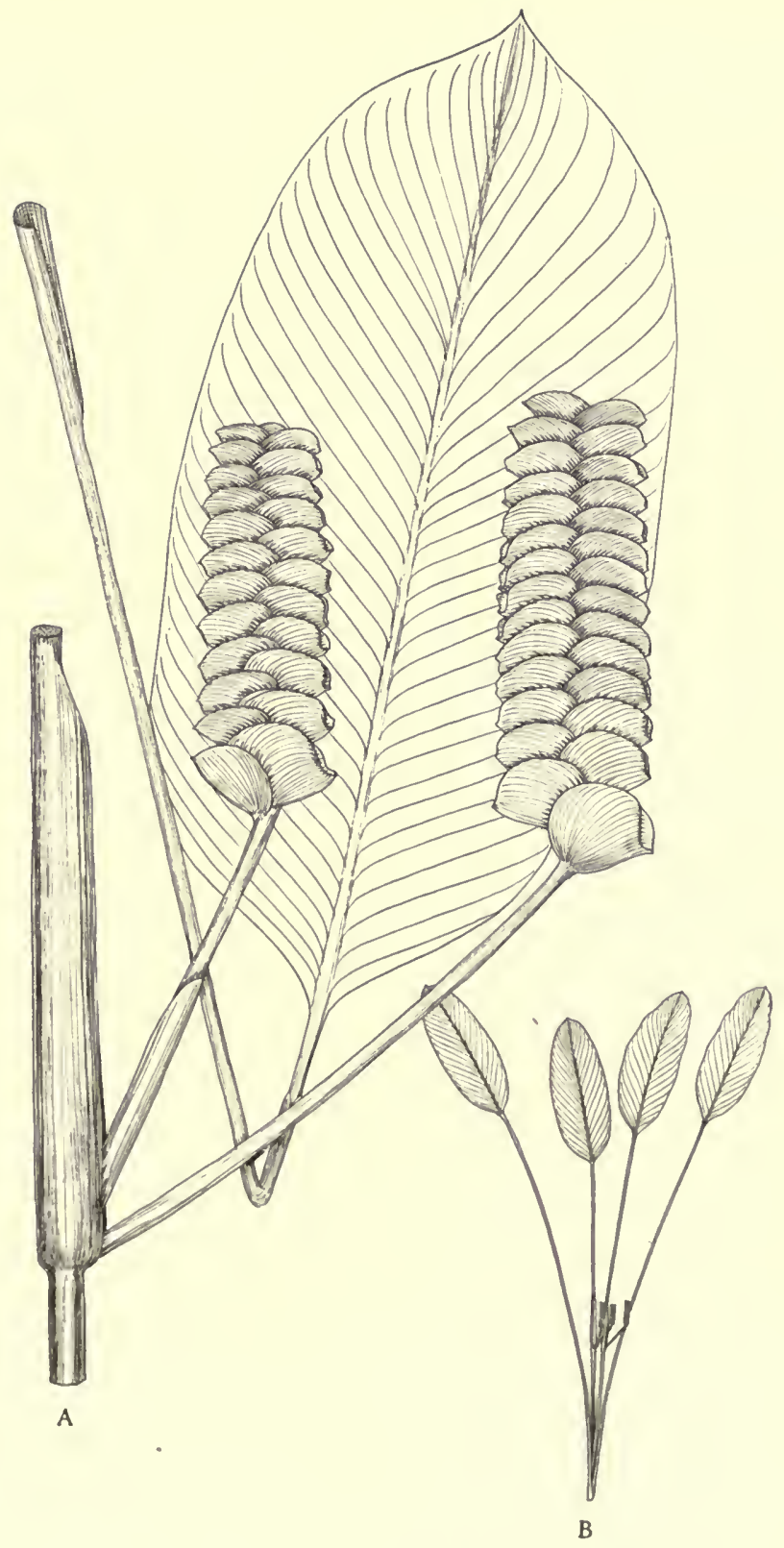

FIG. 38. Calathea insignis. A. Inflorescence, $\times 1 / 3$, and detached leaf, $\times 1 / 6$. B. Habit of plant; $\times^{1} / 36$. 
Dense wet forest or wet thickets, 1,500 meters or less, most common at low elevations; Izabal; Alta Verapaz; Escuintla; Suchitepequez; Retalhuleu; Sololá; San Marcos. "Southern Mexico; British Honduras to Panama; southward to Ecuador.

Plants large and coarse, often 2 meters high and probably even larger; leaves long-petiolate, the callus about $10 \mathrm{~cm}$. long, terete; leaf blades oblong or oval, about $60 \mathrm{~cm}$. long and $25 \mathrm{~cm}$. wide or even larger, rounded and abruptly shorttipped at the apex, rounded at the base, glabrous, concolorous or somewhat paler beneath, stiff and paper-like; stems bearing 1 or more leaves, the spikes several or numerous, long-pedunculate, $25 \mathrm{~cm}$. long or shorter, $5-6 \mathrm{~cm}$. wide, much compressed, the bracts numerous, bronze-colored, about $3 \mathrm{~cm}$. long, as broad as long, rounded or emarginate at the apex, distichous, densely imbricate, coriaceous, glabrous or pubescent only at the apex; ovary glabrous; sepals $1 \mathrm{~cm}$. long, linearoblong, obtuse, glabrous; corolla pale yellow; capsule ellipsoid, $9 \mathrm{~mm}$. long, stramineous; seeds trigonous, convex dorsally, castaneous, aril white. (Fig. 38.)

Called "bijaguiillo" in Honduras; "hoja blanca" (Veracruz). The leaves are used like those of $C$. lutea. In describing $C$. crotalifera Watson stated that the specific name was given because the inflorescences suggested the rattles of a rattlesnake, and the resemblance is rather suggestive. C. sclerobractea was separated by Schumann on tenuous characters that seem to have little importance.

Calathea lutea (Aubl.) G. F. W. Meyer, Prim. Fl. Esseq. 10. 1818. Maranta lutea Aubl. Pl. Guian. 3. 1775. C. discolor G. F. W. Meyer, op. cit. 7. Hoja de sal; Maxán, Moxán (Quecchí and Maya); Hoja de cuero; Platanillo.

Wet forest or open or forested swamps and marshes, 300 meters or less, but often planted at higher elevations; Petén; Alta Verapaz; Izabal; Escuintla; Suchitepequez; Retalhuleu; Quiché; probably in all the Pacific coast departments. Southern Mexico; British Honduras to Panama; southward to Peru; West Indies.

Plants large and coarse, often 3 meters high or more; leaves large, on very long petioles, the callus often $13 \mathrm{~cm}$. long, glabrous; leaf blades often more than a meter long and $60 \mathrm{~cm}$. wide but mostly smaller, elliptic or oval, usually rounded and apiculate at the apex, rounded at the base, thick and stiff, glabrous, pruinose beneath but the pale coat often deciduous in large sheets; scapes bearing one or more leaves, the spikes slightly compressed, numerous, often $20 \mathrm{~cm}$. long; bracts numerous, mostly dark reddish brown, broad, $4 \mathrm{~cm}$. long, coriaceous and very hard, distichous, glabrous or nearly so; ovary villous at the base; sepals linear, obtuse, $1 \mathrm{~cm}$. long; corolla pale yellow, the tube almost $3 \mathrm{~cm}$. long, the lobes elliptic, $1.5 \mathrm{~cm}$. long, sericeous; outer staminode pale yellow, obovate, $2 \mathrm{~cm}$. long; capsule usually 1-seeded; seed $8 \mathrm{~mm}$. long, grayish castaneous, the aril white.

Called "bijao" in Honduras. Although growing most often in open swamps, this plant grows perfectly well in well drained soil, 
and sometimes grows naturally on open hillsides in regions of heavy and continuous rainfall. It is of great economic importance in Guatemala, especially along the Pacific foothills, where it often is planted on a large scale. In some places from Retalhuleu to Escuintla there are good-sized fields, with the plants set in rows. Great quantities of the leaves are gathered, piled flat, and tied in large bunches, which are transported to all parts of the country, and are to be seen in almost all the markets. They serve in place of paper for wrapping all kinds of articles, especially salt and soap. Banana leaves when green are much used as temporary wrappers but when dry they are altogether useless. Calathea leaves are tough, and serve very well for this purpose. They are much used, too, as thatch on small temporary structures.

Calathea macrochlamys Woodson \& Standl. Field Mus. Bot. 22: 134. 1940. Hoja de cuero.

Wet forest, 150-200 meters; Huehuetenango (between Ixcán and Río Ixcán, Steyermark 49250). Oaxaca; Tabasco.

Plants large and coarse, a meter high or more, the scape bearing a large leaf, sparsely pilose with subappressed hairs; leaves long-petiolate, stiff and paperlike, the callus $8.5-11 \mathrm{~cm}$. long; leaf blades oval or broadly oblong, about $50 \mathrm{~cm}$. long and 18-20 cm. wide, rounded and apiculate at the apex, rounded and abruptly contracted at the base, almost concolorous; inflorescence arising from the axil of the cauline leaf, sessile, at first 5-6 $\mathrm{cm}$. long and 3-4 cm. broad, after anthesis recurved and somewhat elongate, subpaniculate, with few short branches; basal bract lance-oblong, 5.5-11 cm. long, long-attenuate, appressed, the inner bracts numerous, oblong or ovate-oblong, $12-20 \mathrm{~mm}$. long, pale brown, sparsely sericeous or almost glabrous; sepals ovate-oblong, obtuse or subacute, $11 \mathrm{~mm}$. long; ovary glabrous, 3-celled; petals 3 .

Called "pozolillo" in Oaxaca. The species is anomalous in Calathea because of its branched inflorescence, but the 3-celled ovary necessitates its reference here unless a new genus is erected for it.

Calathea microcephala (Poepp. \& Endl.) Koernicke, Bull. Soc. Nat. Moscou 35, pt. 1: 125. 1862. Phrynium microcephalum Poepp. \& Endl. Nov. Gen. \& Sp. 3: 20. pl. 128, figs. a, b. 1838. Maranta micans Mathieu, Cat. 1853. C. micans Koernicke, op. cit. 126. C. albicans Brongn. ex Schum. Pflanzenreich IV. 48: 112. 1902. Yuquilla silvestre.

Dense wet forest, 200 meters or less; Alta Verapaz; Izabal; Huehuetenango (near Ixcán). Tabasco; British Honduras along the Atlantic coast to Panama; southward to Peru and the Guianas. 
Plants small, about $30 \mathrm{~cm}$. high, from a thick rootstock; radical leaves usually numerous, on very long and slender petioles, thin, the petioles densely puberulent; leaf blades asymmetric, elliptic to lance-oblong, mostly 15-19 $\mathrm{cm}$. long and 3.5-6 cm. wide, acute or acuminate at each end; scape naked, very slender, equaling or shorter than the leaves; bracts 3 or sometimes as many as 5, spirally inserted, imbricate, ovate, short-acuminate, green, glabrous, $1 \mathrm{~cm}$. long or less; ovary glabrous; sepals linear-lanceolate, $7 \mathrm{~mm}$. long; corolla white, the tube $8 \mathrm{~mm}$. long, the lobes oblong-lanceolate, $5 \mathrm{~mm}$. long; outer staminode obovate, $7 \mathrm{~mm}$. long, unguiculate.

Calathea verapax Donn. Smith, Bot. Gaz. 31: 124. 1901.

Wet mixed forest, 1,000 meters; Alta Verapaz (type from Rubelcruz, Türckheim 1269; collected also at Sacolal). Honduras.

Plants tall, slender, from a thick rootstock, the scape naked, the callus $4 \mathrm{~cm}$. long, puberulent or glabrous; leaf blades elliptic to oblong, about $40 \mathrm{~cm}$. long and $16 \mathrm{~cm}$. wide, rounded and short-acuminate at the apex, rounded at the base, glabrous; spike turbinate, 10-12 cm. long, the bracts numerous, spirally arranged, ovate-lanceolate, scarlet, glabrous, long-acuminate, as much as $6.5 \mathrm{~cm}$. long; ovary glabrous; sepals lanceolate, acuminate, $2 \mathrm{~cm}$. long; corolla tube $3 \mathrm{~cm}$. long, the lobes lanceolate, acuminate, $1.5 \mathrm{~cm}$. long.

Calathea Warscewiczii (Mathieu) Koernicke, Gartenflora 7: 87. 1858. Maranta Warszewiczii Mathieu, Cat. 1853. Culebrin.

Wet mixed forest, $500-800$ meters; Suchitepequez; often grown for ornament. Costa Rica.

Plants slender, $90 \mathrm{~cm}$. high or less; cauline leaves usually numerous, on petioles $12 \mathrm{~cm}$. long or shorter, often crowded on short lateral shoots, the callus $3 \mathrm{~cm}$. long or shorter, puberulent or glabrate; leaf blades lanceolate to elliptic-oblong, as much as $30 \mathrm{~cm}$. long and $13 \mathrm{~cm}$. wide but mostly $15 \mathrm{~cm}$. long or shorter; spikes 3-6 cm. long, generally short-pedunculate, the bracts broadly ovate, spirally arranged, acute or rounded at the apex, few, about $1.5 \mathrm{~cm}$. long, with conspicuous scarious margins; ovary glabrous; sepals lanceolate; corolla tube $3 \mathrm{~cm}$. long, or shorter, the lobes oblong-lanceolate, $1.5 \mathrm{~cm}$. long.

This plant is much grown in Guatemala and other parts of Central America because of its handsome leaves. These are of a beautiful velvety appearance on the upper surface, with broad alternating stripes of light and dark green, while beneath they are deep purple or brownish purple.

\section{ISCHNOSIPHON Koernicke}

Perennial herbs, often very large, the stems sometimes much branched; leaves often very large, coriaceous or herbaceous; inflorescence consisting of few or very numerous, terete or more or less compressed spikes, these solitary or clustered; bracts coriaceous, strongly imbricate, appressed; sepals 3 , free, equal, linear; 


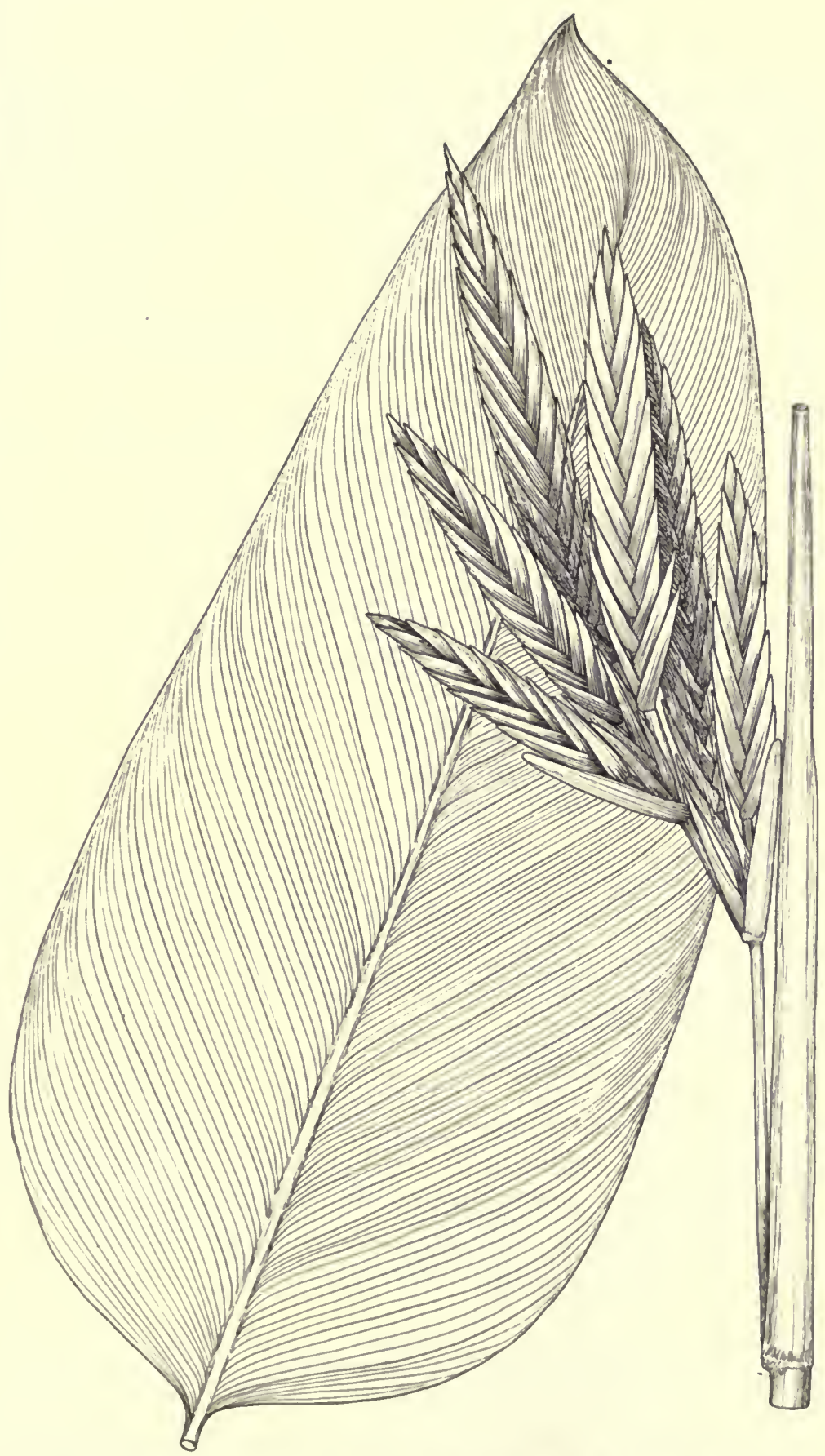

FIG. 39. Ischnosiphon pruinosus. Inflorescence and detached leaf; $\times 2 / 5$. 
corolla tube elongate, the lobes lanceolate or oblong-lanceolate; stamen tube almost obsolete; outer staminode solitary, petaloid, obovate; anther with an often very short, adnate appendage; ovary 1-celled, fruit capsular, crustaceous, elongate, unequally 3-valvate; seed 1, elongate, acute, arillate at the base.

About fifteen species, in tropical America. Two or three others are found in southern Central America.

Ischnosiphon pruinosus (Regel) Peters. Bot. Tidskr. 18: 264. 1892. Pleiostachya pruinosa Schum. Pflanzenreich IV. 48: 165. 1902. Platanillo.

Wet mixed forest, at or little above sea level; Petén; Izabal. Chiapas; British Honduras, along the Atlantic coast to Panama.

A tall coarse herb 1.5-2.5 meters high; leaves long-petiolate, the callus at the apex of the petiole terete, glabrous, about $6.5 \mathrm{~cm}$. long; leaf blades mostly $40 \mathrm{~cm}$. long or less, as much as $22 \mathrm{~cm}$. wide, acute or cuspidate, glabrous or essentially so, green above, often purplish beneath; spikes $17 \mathrm{~cm}$. long or less, $2-3 \mathrm{~cm}$. wide, usually several or numerous and forming a flabellate panicle; bracts $4 \mathrm{~cm}$. long or larger, glabrous, often pruinose; sepals $3 \mathrm{~cm}$. long; corolla purple, the tube almost $3 \mathrm{~cm}$. long, the lobes lanceolate, $1.5 \mathrm{~cm}$. long; outer staminode elliptic, emarginate, purple, $17 \mathrm{~mm}$. long. (Fig. 39.)

Called "bijaguiillo" in Honduras.

\section{MARANTA L. Arrowroot}

Perennial or perhaps sometimes annual herbs, often with large starchy roots, usually erect and branched; leaves small or large, thin, petiolate; flowers white, racemose, the racemes sometimes paniculate, the bracts few, usually appressed, green, finally deciduous; pairs of flowers several in each bract, pedunculate, the terminal flower usually longer-pedicellate, the other one subsessile; bractlets none; sepals equal, lanceolate or lance-oblong, striate; corolla tube longer or shorter than the sepals, usually ampliate and gibbous at the base, often curved, the 3 lobes subequal, short-cucullate at the apex; stamen tube usually short; outer 2 staminodia petaloid, usually large and obovate, the other slightly shorter; stamen free; style stout, the stigma obliquely 2-lobate; ovary glabrous or sericeous, 1-celled; fruit nut-like, indehiscent or sometimes 3-valvate, the epicarp coriaceous; seed trigonous or short-pyramidal, often sulcate, arillate.

About twelve species, all native in tropical America. One other species is known from southern Central America.

Ovary glabrous or pubescent only on the angles............. arundinacea. Ovary densely white-sericeous or puberulent.............. divaricata.

Maranta arundinacea L. Sp. Pl. 2. 1753. Yuquilla; Chuchute (Huehuetenango); Tamalera (fide Aguilar).

Moist or wet thickets, sometimes on brushy rocky slopes, 1,300 meters or less, chiefly at lower elevations; Petén; Alta Verapaz; 

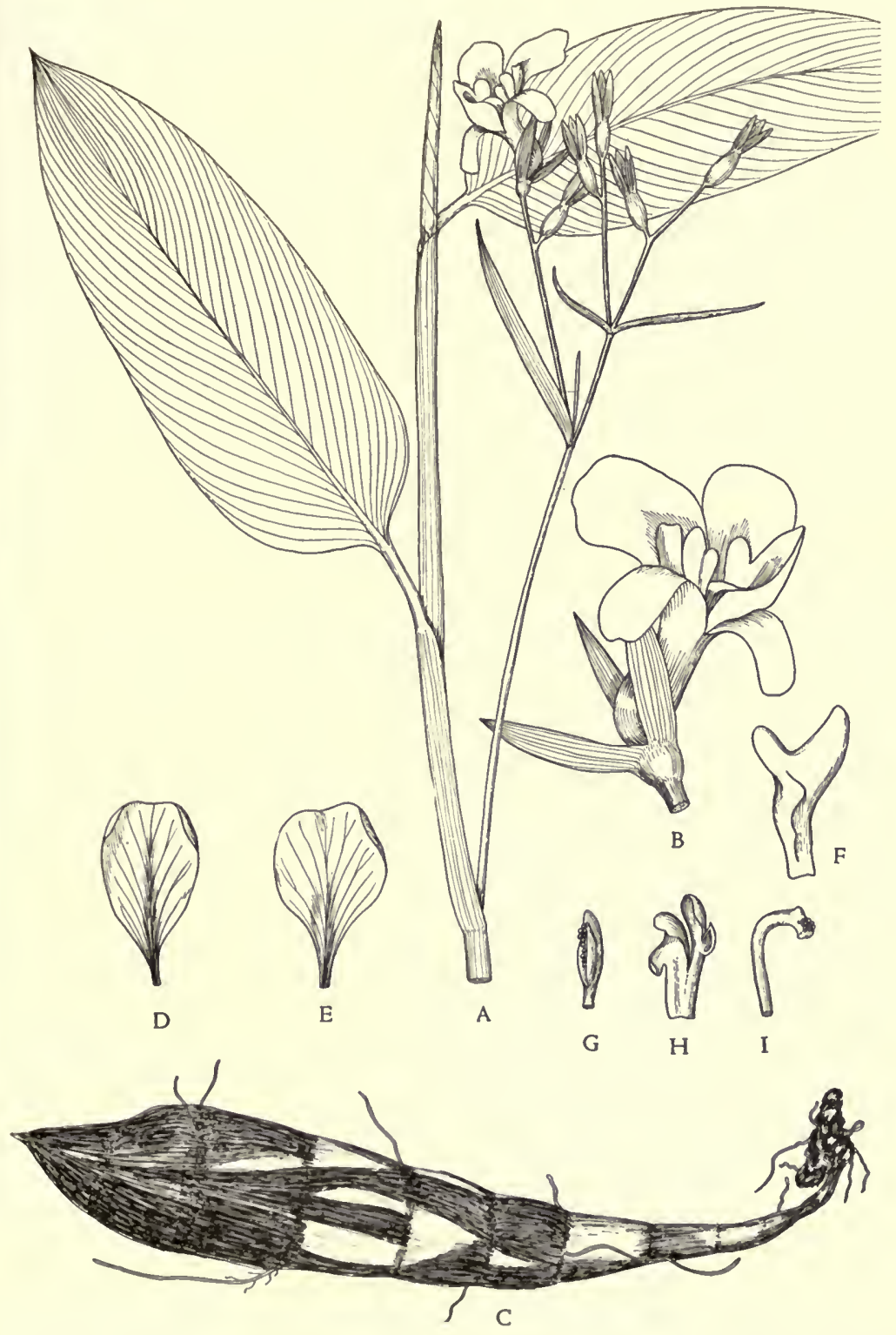

FIG. 40. Maranta arundinacea. A. Uppermost flowering portion of plant; $\times 1 / 3$. B. Flower; $\times 2$. C. Tuberous rhizome; $\times 2 / 3$. D and E. Outer petaloid staminodia; $\times 1 \frac{1}{2}$. F. Staminodium; $\times 1 \frac{1}{2}$. G. Anther; $\times 1 \frac{1}{2}$. H. Staminodium; $\times 1 \frac{1}{2}$. I. Style; $\times 1 \frac{1}{2}$. 
Izabal; Zacapa; Chiquimula; Jutiapa; Santa Rosa; Escuintla; Suchitepequez; Huehuetenango. Mexico; British Honduras to Salvador and Panama; South America.

Plants slender, erect, often much branched, usually a meter high or less, often with rather large, tuberous rhizomes, glabrous or sparsely pilose; sheaths long, broadly winged, the callus about $7 \mathrm{~mm}$. long, terete, pilose at the apex; ligule usually conspicuous, short, rounded; leaf blades ovate-lanceolate or lanceolate, thin, mostly $20 \mathrm{~cm}$. long and $8 \mathrm{~cm}$. wide or smaller, attenuate-acuminate, rounded at the base; inflorescence often large and much branched; bracts linear-lanceolate, $5 \mathrm{~cm}$. long or shorter; pairs of flowers on peduncles $5 \mathrm{~cm}$. long or shorter, the terminal flowers on a pedicel $1 \mathrm{~cm}$. long or shorter; ovary glabrous or pubescent only on the angles; sepals about $15 \mathrm{~mm}$. long, lanceolate; corolla pure white, the tube ampliate at the base, about $13 \mathrm{~mm}$. long, the lobes $8-10 \mathrm{~mm}$. long; outer staminodia obovate, emarginate, $10 \mathrm{~mm}$. long, the inner half as long; fruit ellipsoid or obovoid, $7 \mathrm{~mm}$. long; seed pale red, rugulose, the aril yellowish. (Fig. 40.)

The Maya name of Yucatan is recorded as "chaac." This is a common wild plant in the lowlands of Guatemala, where it is presumably native, and also is cultivated for its starchy roots. From them is extracted arrowroot starch, which is used locally for starching cloth, and also as food. In some parts of the earth the plant is cultivated extensively for the purpose. Many of the wild plants have the appearance of annuals, and apparently have no starchy rhizomes. During the dry season the stems and leaves wither and die. The starch is much used in Guatemala in preparing atol and other foods given to invalids, since it is easy of digestion.

Maranta divaricata Roscoe, Monandr. Pl. pl. 27. 1828. Platanillo; doubtless called also Yuquillo.

Moist or wet thickets, 1,300 meters or less; Alta Verapaz; Izabal; Chiquimula; Suchitepequez; Huehuetenango. Southern Mexico; British Honduras to Costa Rica; South America.

Plants perennial, erect, in most respects exactly like the preceding species, often much branched; bracts of the inflorescence linear, 2-4 cm. long; sepals lanceolate, $13 \mathrm{~mm}$. long; corolla pure white, the tube slightly longer than the sepals; capsule $8 \mathrm{~mm}$. long.

It is doubtful whether this is at best more than a poor variety of $M$. arundinacea. Schumann separates it on the basis of smaller leaves and slender, not thickened rhizomes. The leaves are of the same size in both plants, and since the roots are seldom found with herbarium specimens, it is not possible to use the root character for practical purposes of identification. 
Maranta Friedrichsthaliana Koern. has been published and listed from Guatemala but the plant is actually from Cerro de Aguacate, Costa Rica.

\section{STROMANTHE Sonder}

Mostly tall and coarse, perennial herbs arising from thick rhizomes, often branched; leaves large, thin but stiff and paper-like, the cauline ones 2 or more; inflorescences simply racemose or paniculate, open and lax or dense and congested, the bracts rather remote or sometimes crowded, complicate, finally deciduous; pairs of flowers usually numerous; bractlets none; sepals 3 , free, lanceolate or broader; corolla tube short, the lobes oblong; stamen tube very short; outer staminodia shorter or longer than the inner ones; anther usually apiculate, the filament appendaged; ovary 1-celled, smooth or tuberculate, glabrous or villous; fruit capsular, 3-valvate; seed rugulose, arillate.

Species 15-20, in tropical America. A very few additional ones are found in southern Central America.

Stromanthe lutea (Jacq.) Eichl. Abh. Akad. Berlin 1882: 81. 1883. Maranta lutea Jacq. Coll. Bot. 4: 117. 1794. Myrosma guapilense Donn. Smith, Bot. Gaz. 23: 251. 1897. Mojón.

Dense wet mixed forest, at or little above sea level; Izabal. British Honduras along the Atlantic coast to Panama; Colombia, Venezuela, and northern Brazil.

A coarse herb 1-3 meters high, arising from a thick rhizome; basal leaves long-petiolate, the cauline ones somewhat smaller and short-petiolate, the callus about $2 \mathrm{~cm}$. long, pubescent or glabrate; leaf blades elliptic or lance-oblong, $30-60 \mathrm{~cm}$. long, 11-18 cm. wide, abruptly short-acuminate, rounded and abruptly short-contracted at the base, green on both surfaces, puberulent or glabrous; influrescences long-pedunculate, lax and open, many-flowered, the racemes geminate, forming large panicles, the rachises glabrous; bracts yellowish, oblong, obtuse, $2.5 \mathrm{~cm}$. long or shorter, pilose or glabrate, finally deciduous; pairs of flowers on peduncles $6 \mathrm{~mm}$. long or less, the terminal flower on a pedicel as much as $3 \mathrm{~mm}$. long; ovary glabrous or pubescent; sepals oblong-lanceolate, yellowish, $9 \mathrm{~mm}$. long; corolla yellowish, the tube $2 \mathrm{~mm}$. long, the lobes oblong, $6.5 \mathrm{~mm}$. long; capsule trigonous, $8 \mathrm{~mm}$. long, yellowish; seeds dark castaneous, with a yellow aril. (Fig. 41.)

\section{THALIA L.}

Tall coarse aquatic herbs, often waxy-pruinose; leaves few, petiolate, thin but stiff; inflorescence paniculate, usually lax and much interrupted, generally subtended by a solitary leaf or a sheathing bract, the bracts deciduous or persistent; pairs of flowers subtended by a bract, no bractlets present; sepals small, equal, hyaline; corolla tube very short, the lobes hyaline; outer staminode obovate, colored, usually unguiculate; stamen bearing a lateral appendage adnate to the filament and equaling or longer than the anther; ovary 1-celled, 1-ovulate; style 


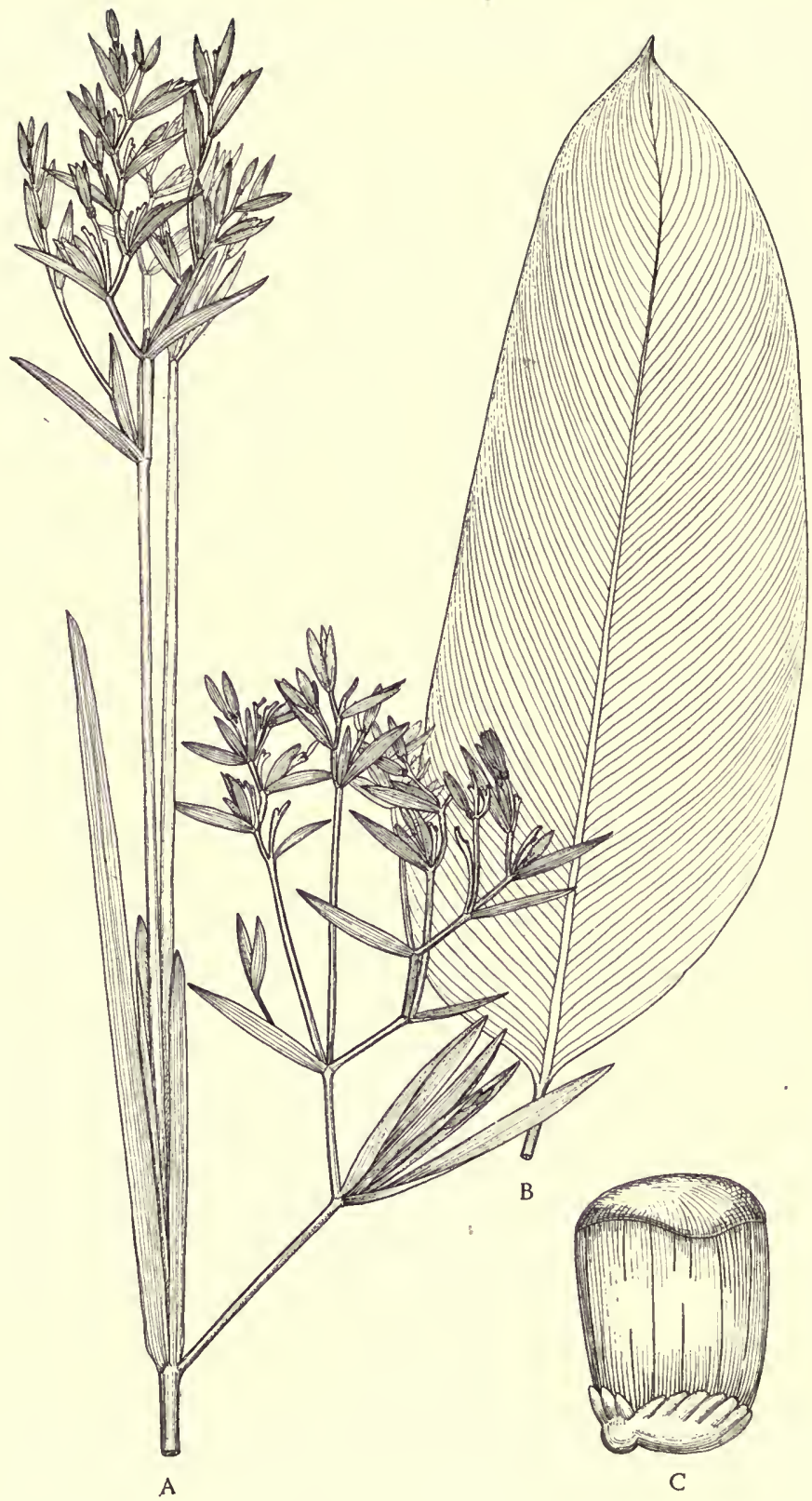

FIG. 41. Stromanthe lutea. A. Inflorescence; $\times 2 / 3 . \quad B$. Leaf; $\times 1 / 3 . \quad$ C. Fruit; $\times 4$. 
with a sometimes 2-lobate appendage at the apex; fruit nut-like, indehiscent, the exocarp membranaceous; seed globose or ellipsoid, with a small aril at the base.

Species about seven, five in tropical America, one extending northward into the southern United States, and one extending to Africa. Only one is found in Central America.

\section{Thalia geniculata L. Sp. Pl. 3. 1753.}

In shallow water of open swamps, at or near sea level; Petén; Izabal. Florida; Mexico; British Honduras to Salvador and Panama; West Indies; South America; tropical Africa.

A tall, nearly glabrous perennial, usually 2-3 meters high; basal leaves longpetiolate; callus of the petiole $1.5 \mathrm{~cm}$. long, terete, glabrous or puberulent; leaf blades rather stiff and paper-like, ovate-lanceolate or oblong-lanceolate, as much as $60 \mathrm{~cm}$. long and $20 \mathrm{~cm}$. wide but mostly smaller; sheath of the petiole broad, membranaceous, glabrous, not auriculate; panicles usually large, subtended by a single large leaf, the racemes lax, with internodes $1 \mathrm{~cm}$. long or less, the rachis usually zigzag; bracts about $2 \mathrm{~cm}$. long, oblong-lanceolate; ovary glabrous; sepals oblong-ovate, $2 \mathrm{~mm}$. long; corolla purple, the tube very short, the lobes $7 \mathrm{~mm}$. long; outer staminode purple, $14 \mathrm{~mm}$. long, the inner staminodia half as long or shorter; fruit ellipsoid, $1 \mathrm{~cm}$. long, the exocarp membranaceous; seed grayish, minutely tuberculate or smooth, subtended by a small whitish aril. (Fig. 42.)

Called "quentó" in Tabasco; "platanillo" (Salvador). This is a common and characteristic plant of the large open swamps along the North Coast of Guatemala, and along the whole Atlantic coast of Central America.

\section{BURMANNIACEAE}

Reference: F. P. Jonker, A monograph of the Burmanniaceae, Utrecht, 1938.

Small, annual or perennial, often saprophytic herbs, usually without chlorophyll, the stems commonly very slender, the leaves alternate, generally reduced to minute scales; flowers perfect, sometimes zygomorphic, usually regular; stem bearing at its apex a single flower or a capitate or branched, usually bifid, inflorescence; perianth corolla-like, the limb consisting of 2 whorls of 3 segments, the tube cylindric or trigonous, often winged or costate; anthers usually 3 , sessile or nearly so in the perianth throat, the anthers laterally dehiscent; style 3-branched; ovary inferior, 1-celled, with axial placentae; ovules numerous; fruit commonly capsular, irregularly dehiscent, or with transverse slits at the top, the seeds numerous, very small.

The family is an essentially tropical one, with few representatives in Central America. The plants are little collected, chiefly because they are rather tenuous, and grow among grasses and other herbs where it is difficult to discover them. One other genus is known from Central America, Thismia, with a single species in Panama. 


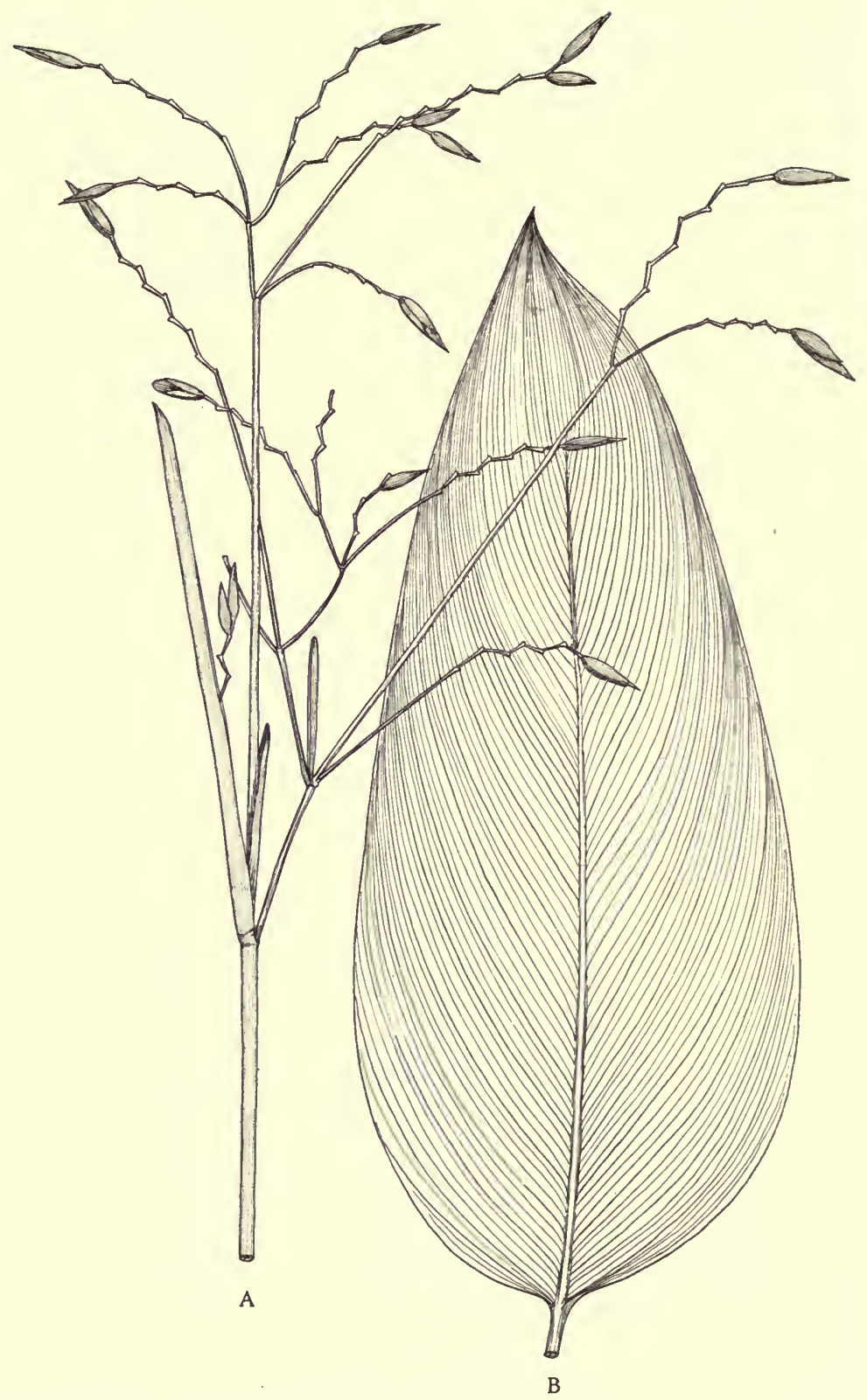

FIG. 42. Thalia geniculata. A. Inflorescence; $\times 1 / 3$. B. Leaf; $\times 1 / 3$. 
Flowers subcapitate, clustered at the top of the stem..........Burmannia. Flowers not capitate, in simple or bifid racemes.

Perianth limb deciduous; seeds subglobose to ellipsoid.......... Gymnosiphon. Perianth limb persistent; seeds linear.

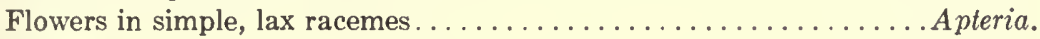

Flowers chiefly in bifid inflorescences..................

\section{APTERIA Nuttall}

Slender annuals with almost filiform stems, the roots short, threadlike, the stems usually simple, bearing few racemosely disposed flowers; leaves reduced to small scales; flowers often nutant, the perianth campanulate or salverform, the lobes 6 , the outer ones ovate, the inner ones narrower but of the same length, linear-lanceolate; tube of the corolla more than 3 times as long as the lobes; stamens inserted in sacs in the perianth tube below the inner lobes, the filaments short and thick, with a wing on the external side, the anther cells transversely dehiscent; style filiform, elongate, trifid at the apex; capsule dehiscent between the placentae, crowned by the persistent corolla; seeds minute, oblong to ovoid or ellipsoid.

The genus consists of three species, the others South American.

Apteria aphylla (Nutt.) Barnhart ex Small, Fl. Southeast. U. S. 309. 1903. Lobelia aphylla Nutt. Amer. Journ. Sci. 5: 297. 1822.

In swamps, at sea level; Izabal. Southern United States; Mexico; British Honduras; Costa Rica; West Indies; Brazil; Bolivia.

Plants glabrous, usually simple, 5-20 cm. high, whitish or purplish; leaves 1.5-3 mm. long, scale-like; flowers 1 to several, long-pedicellate; perianth purple or blue, sometimes white, 8-13 mm. long, the outer lobes one-third as long as the tube, ovate, acute, the inner lobes lanceolate or linear-lanceolate, obtuse; capsule ovoid or obovoid, $6 \mathrm{~mm}$. long and $4 \mathrm{~mm}$. broad or smaller; seeds brown, reticulate.

Perhaps the typical habitat for this delicate plant is grassland, but the few plants found at Puerto Barrios were growing in a dark Manicaria swamp.

\section{BURMANNIA L.}

Annual or perennial, usually saprophytic plants with or without chlorophyll; stems simple or branched; leaves in the saprophytic species reduced to scales; flowers solitary or clustered at the top of the stem in cyme-like or headlike inflorescences; perianth tube cylindric-trigonous, the 3 outer lobes much larger than the inner, the latter sometimes minute or absent; anthers 3 , sessile in the perianth throat below the inner lobes; style filiform, shortly trifid; ovary trigonous; capsule crowned by the persistent perianth, irregularly dehiscent; seeds numerous, oblong or ellipsoid. 
The genus is a large one, in tropical and subtropical regions of both hemispheres. In Central America has been found one other species, $B$. Wercklei Schlechter, in Costa Rica, with green leaves and blue flowers.

Flowers about $3.5 \mathrm{~mm}$. long, 2-many on each stem.............. capitata. Flowers $9-11 \mathrm{~mm}$. long, usually solitary on the stems.

B. flava.

Burmannia capitata (Walt.) Mart. Nov. Gen. \& Sp. 1: 12. 1824. Anonymos capitatus Walt. Fl. Carol. 69. 1788.

Wet grassland, usually in pine forest, at or little above sea level; British Honduras (Honey Camp; All Pines). Southern United States; Chiapas; Panama; West Indies; South America.

Plants slender, $3-30 \mathrm{~cm}$. high, the wiry stems usually simple, bearing at the apex a dense, headlike inflorescence of few or numerous small flowers; a few basal, linear or linear-lanceolate leaves usually present, the cauline leaves scalelike, $2 \mathrm{~mm}$. long; flowers wingless, usually white or yellowish, erect, subsessile, $3.5 \mathrm{~mm}$. long; perianth tube $1.5 \mathrm{~mm}$. long, the outer lobes triangular, with involute margins, $0.5 \mathrm{~mm}$. long, the inner lobes linear or narrowly oblanceolate, obtuse, not much shorter than the outer ones; seeds brownish yellow.

Burmannia flava Mart. Nov. Gen. \& Sp. 1: 11. pl. 5. 1824.

Open pine ridges, at or little above sea level; British Honduras (Toledo District, Swasey Branch, Monkey River, P. H. Gentle 3788). Southern Florida; Cuba; Costa Rica; Colombia to Paraguay.

Plants erect, very slender, annual, 6-25 cm. high; stems usually simple, sometimes branched, mostly 1-flowered but sometimes 2-9-flowered; basal leaves linear, $7 \mathrm{~mm}$. long and $1.5 \mathrm{~mm}$. wide or smaller, obscurely 3-nerved; stem leaves few, scale-like, acute or acuminate, 2-4 mm. long; bracts lanceolate, acute or subobtuse, 4-5 mm. long; flowers pale yellow, erect, sessile or short-pedicellate, 9-11 $\mathrm{mm}$. long; outer perianth lobes erect, triangular, obtuse, $1.5-2 \mathrm{~mm}$. long, the inner lobes 1.5-2 mm. long, oblong or subspatulate; perianth tube trigonous-cylindric, $3.5-4 \mathrm{~mm}$. long; wings of the perianth narrow, extending from the base of the limb to the base of the ovary; capsule obovoid, $4-5.5 \mathrm{~mm}$. long, irregularly dehiscent; seeds numerous, minute, oblong, yellowish brown, sometimes slightly curved.

\section{DICT YOSTEGA Miers}

Slender saprophytes, without chlorophyll, usually simple, glabrous, the rootstock bearing ovate, acute or acuminate scales; leaves reduced to minute, attenuate scales; inflorescence usually bifid, the flowers more or less secund along the branches; perianth tube often constricted, the limb 6-lobate, the outer lobes erect, ovate, acute, the inner ones smaller and shorter, ovate, obtuse to rounded at the apex, erect or reflexed; anthers 3, sessile in the upper part of the perianth tube below the inner lobes, not in sacs, the cells bursting transversely in the constriction; style elongate, filiform in the lower part, dilated at the top and trifid; ovary 3- 
sulcate, with 3 parietal placentae; perianth persistent upon the fruit, the limb not deciduous; capsule dehiscent by 3 irregular valves; seeds numerous, linearlanceolate, minute, the testa reticulate.

The genus consists of only two species, the other one South American. The generic name has often been written Dictyostegia.

Dictyostega orobanchoides (Hook.) Miers, Proc. Linn. Soc. 1: 61. 1840. Apteria orobanchoides Hook. Icon. Pl. 3: pl. 254. 1840. D. campanulata Karst. Linnaea 28: 422. 1856.

Dense, moist or wet, mixed forest, 1,500 meters or lower, Chiquimula (Cerro Tixixí, Steyermark 31589). Southern Mexico; British Honduras; Costa Rica; South America.

Stems stouter than in most Central American plants of the family, yellowish white, 7-30 cm. high; leaves reduced to ovate acute scales 1-4 $\mathrm{mm}$. long, appressed; pedicels 1-4 mm. long, curved or spreading; flowers white or pinkish, $2.5-5 \mathrm{~mm}$. long; perianth tube often constricted, the outer lobes $0.5 \mathrm{~mm}$. long, the inner ones smaller, at first erect, later reflexed; capsule obovoid or subglobose, $2.5 \mathrm{~mm}$. long or shorter; seeds yellowish.

\section{GYMNOSIPHON Blume}

Annual, erect saprophytes with very slender stems, usually simple in the Central American species; inflorescence terminal, with few or numerous flowers, bifid, the flowers somewhat secund, sessile or short-pedicellate, leaves minute, scale-like; perianth limb 6-lobate, the outer lobes much larger than the inner ones; stamens inserted below the inner perianth lobes, the anthers dehiscent by a median, horizontal cleft; ovary ovoid or subglobose, the ovules numerous; style elongate, shortly trifid at the apex; perianth limb circumscissile after anthesis below the insertion of the stamens, the tube persistent upon the capsule; capsule dehiscent at the apex or irregularly and longitudinally; seeds ovoid or subglobose, reticulate.

About thirty species are known, widely distributed in the tropics of America, Africa, Asia, and the East Indies. In Central America one other species is reported, G. panamensis Jonker, of Panama.

Flowers $8-12 \mathrm{~mm}$. long; stems stout...................... suaveolens. Flowers $9 \mathrm{~mm}$. long or less; stems almost filiform............. Tuerckheimii.

Gymnosiphon suaveolens (Karst.) Urban, Symb. Antill. 3: 438. 1903. Benitzia suaveolens Karst. Linnaea 28: 420. 1928.

Dense wet forest, 1,800 meters or lower; Alta Verapaz; Huehuetenango. Southern Mexico; British Honduras; Costa Rica; Panama; Colombia to Brazil.

Plants relatively stout, $8-30 \mathrm{~cm}$. high, whitish, simple; inflorescence bifid, 3-17-flowered; leaves 1-3 mm. long, ovate or lanceolate, obtuse; pedicels $2-6 \mathrm{~mm}$. 
long, the flowers 8-12 mm. long, white or blue; perianth tube $2-3.5 \mathrm{~mm}$. long, the limb 4-5 $\mathrm{mm}$. long, the outer lobes ovate, obtuse, with lanceolate lateral lobes equaling or surpassing the midlobe, the inner perianth lobes clavate, half as long as the outer ones or shorter; capsule ellipsoid or obovoid, 3.5-5 $\mathrm{mm}$. long.

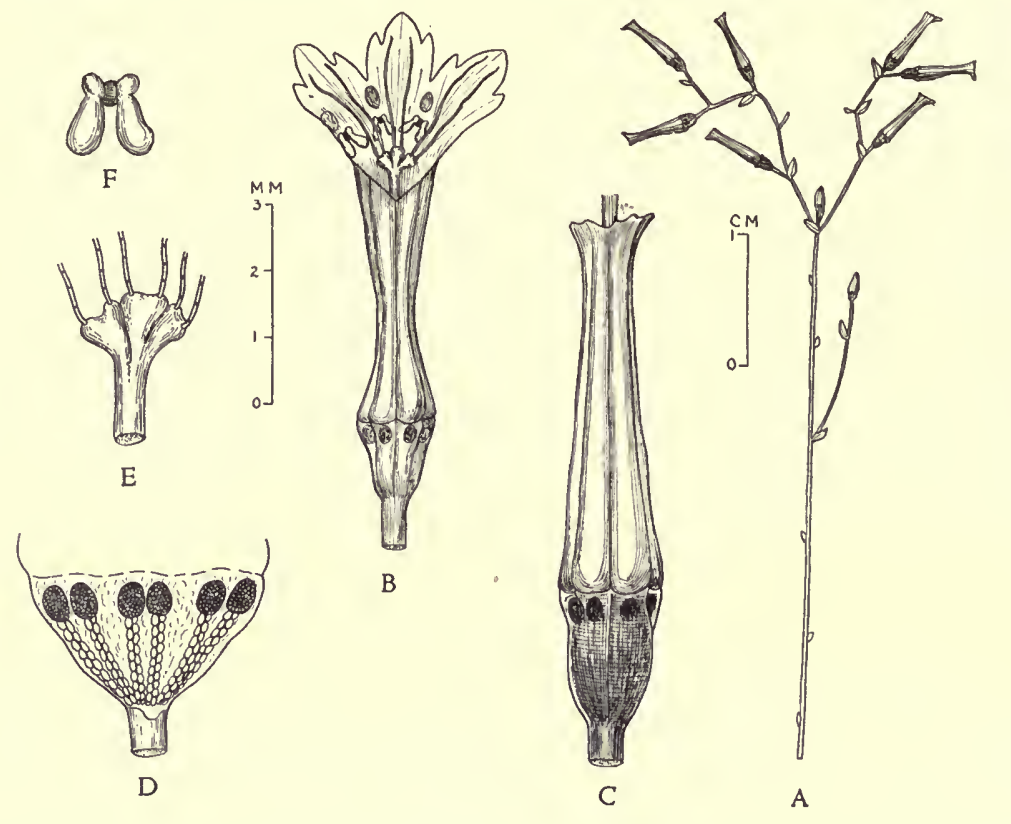

FIG. 43. Gymnosiphon Tuerckheimii. A. Habit of plant; $\times 1$. B. Flower partly dissected; $\times 5$. C. Fruit with attached perianth; $\times 5$. D. Ovary, opened; $\times 9$. E. Upper part of style with stigmas; $\times 7$. F. Stamen; $\times 7$.

Gymnosiphon Tuerckheimii Jonker, Monogr. Burmann, 197. 1938.

Wet mixed forest, 350-1,700 meters; Alta Verapaz (type from Cubilgüitz, Türckheim II.475); Sololá, British Honduras; Atlantic lowlands of Honduras.

Plants white or purplish, 7-9 $\mathrm{cm}$. high, usually simple, the inflorescence bifid, 3-16-flowered, the branches $2 \mathrm{~cm}$. long or less, the pedicels $1 \mathrm{~mm}$. long; leaves ovate, 1-1.5 $\mathrm{mm}$. long; flowers up to $9 \mathrm{~mm}$. long, the tube $4 \mathrm{~mm}$. long, the limb to $4 \mathrm{~mm}$. long, the outer lobes ovate, obtuse, the lateral lobes lanceolate, about equaling the midlobe, the inner lobes small, ovate, acute; capsule subglobose or obovoid, $1.5 \mathrm{~mm}$. long. (Fig. 43.)

Guatemalan material has been reported under the name $G$. tenellus (Benth.) Urban, which pertains to a South American plant. 


\section{CASUARINACEAE. Beefwood Family}

Trees, the leaves reduced to scales, the branchlets rigid, erect or pendulous, often deciduous, frequently verticillate, usually jointed at the nodes; leaf scales verticillate, small, appressed, of ten short-connate into a sheath; flowers unisexual, the staminate in cylindric or 4-angulate, simple or compound spikes, terminal, the pistillate forming globose or ovoid spikes or cones, these terminal or lateral; flowers of both kinds solitary in the verticillate bracts or scales, sessile, bibracteolate; perianth segments 1-2 in the staminate flower, concave or cucullate, circumscissile at the base and pushed off by the expanding stamen; stamen 1, the filament inflexed in bud, the anther large, the cells distinct, longitudinally dehiscent; perianth none in the pistillate flower, the ovary 1-celled; style short, the branches linear, stigmatose from base to apex; ovules 2 , affixed collaterally above the base of the cell, ascending; fruit an ovoid or cylindric cone, the bracts and bractlets in age indurate and accrescent, crowded, the whole cone somewhat woody; nut laterally compressed, smooth, produced into a wing at the apex, indehiscent; seed solitary, the testa membranaceous; endosperm none; embryo straight, the cotyledons equal, complanate, the short radicle superior.

The family consists of a single genus, with about twenty-five species, chiefly in Australia.

\section{GASUARINA Forster. Beefwood}

Casuarina equisetifolia Forst. Char. Gen. Pl. 104. 1776. Pino de Australia; Pinabete (Jutiapa).

Planted commonly in Guatemala, in parks, plantations, along roadsides, and elsewhere, in the lowlands and in the mountains up to at least 2,400 meters. Native of tropical Asia and Australia.

A large pine-like tree, sometimes 20 meters tall or more with a trunk a meter in diameter, the branches pale green, slender, verticillate, often drooping, the bark dark gray or blackish; branchlets very slender, resembling the stems of Equisetum, somewhat angulate, the scales in whorls of 6-8, 1-3 mm. long, acute, appressed, ciliate; staminate spikes $1-4 \mathrm{~cm}$. long; fruit heads subglobose, about $2 \mathrm{~cm}$. in diameter.

Called "pino" and "ciprés" in Yucatan. One of the common park trees of Guatemala and all Central America. The tree is most distinctive in appearance because of its unusual foliage. It gives but little shade, because of the absence of normal leaves. It is one of the trees that thrives in the vicinity of salt water. Probably it grows without cultivation in some parts of Guatemala. The wood is creamy yellow or pale pink, hard and strong. It is valued in regions where the trees are native, but is not utilized in America, even when available in some quantity, as in Florida. Some other species besides $C$. equisetifolia are planted in Guatemala City, but their determination is doubtful. It is not known how long $C$. equiseti- 
folia has been planted in Central America, but specimens were collected in Mexico more than a century ago. The bark is said to be rich in tannin, and to give reddish and blue-black dyes in the regions where the trees grow naturally.

\section{PIPERACEAE. Pepper Family}

References: C. De Candolle, Piperaceae (of the West Indies), in Urban, Symb. Bot. 3: 159-274. 1902; Piperacearum clavis analytica, Candollea 1: 65-415. 1923. William Trelease, The Piperaceae of Panama, Contr. U. S. Nat. Herb. 26: 15-50. 1927; The Piperaceae of Costa Rica, op. cit. 115-226. 1929.

Herbs or shrubs, terrestrial or often epiphytic, rarely (in America) scandent, pubescent or glabrous; leaves simple, alternate, opposite, or verticillate, entire, palmate-nerved or penninerved; stipules present or none; flowers minute, usually green, often whitish or pale yellowish, rarely dark red, bracteolate, without a perianth, arranged in usually very dense, ament-like spikes, these pedunculate, terminal or opposite the leaves, or sometimes axillary, rarely several together and borne on a common peduncle; stamens commonly $2-6$, hypogynous, the anthers erect, the 2 cells distinct or confluent into one, longitudinally dehiscent, the filaments free or rarely adnate at the base to the ovary; ovary superior, sessile or rarely stipitate, 1 -celled, 1 -ovulate; style 1 , the stigmas $2-5$, or the stigma often simple and penicillate; ovule erect, orthotropous; fruit small, berry-like, indehiscent; seed small, with a membranaceous testa, the endosperm copious, the embryo minute.

Genera 5 or fewer, only two of them reaching continental North America.

The following account of the Guatemalan Piperaceae has been prepared wholly by the senior author, and is based almost exclusively upon the very ample material in the Herbarium of Chicago Natural History Museum. The work has been greatly facilitated by the loan of a substantial number of type specimens from the University of Michigan Herbarium, and by about 200 sheets lent by the United States National Herbarium. The latter group included a large number of collections not represented in the Herbarium of Chicago Natural History Museum, all or most of which had been marked as new species by Trelease.

This family of plants, so far as it is represented in North America, has had a rather unusual and decidedly unfortunate history which can be appreciated fully only by one who has attempted recently to work with the group, which, contrary to what some might think after superficial study of the literature, is not one of the most difficult families of tropical American plants. Its apparent difficulty results 
from the actually very large number of specific entities involved, a number that has been exaggerated by the somewhat eccentric methods used in study of the Piperaceae by the two men who have done the most work with the family.

Practically all the American Piperaceae were described during the years 1869-1944, and during these years the group received attention from only two men, Casimir De Candolle and William Trelease. Most of the papers by the former were published in the period from 1860 to 1923 ; most of those by the latter from 1927 to the 1940's. The only good account of North American Piperaceae, excluding an account of Peperomia mentioned under that genus, is that by De Candolle describing the West Indian species. De Candolle's earliest work upon the family, in the Prodromus, also is good. In later years, however, the same author, with more abundant new material for study, became too enthusiastic in proposing new continental species, and named a very large number without apparent reference to West Indian species, presumably assuming they must be new because of their remote occurrence. Trelease believed that the species of Piperaceae were extremely local, as many of them are. However, he went still further, and assumed that those of one country were distinct from all those (except a very few widespread and more or less "weedy" species) of the adjoining countries. Such narrow limits of distribution are not found in any other group of Central American plants, nor, in the opinion of the writers, does it exist in the Piperaceae. In his recognition of limiting geographic units, Trelease was scarcely consistent. He treated the whole of Mexico as one Piperaceous unit, and each of the Central American countries as a unit of equal standing. Now each of these Central American countries is about equal in area to one of the states of Mexico, obviously making such an alignment improbable.

We are inclined to believe that instead of being local in their occurrence the species of Piper and Peperomia, at least large numbers of them, range very widely. Certainly many are common to the West Indies and the mainland, and many of them extend from Mexico to Costa Rica and Panama, and probably far southward into South America. The treatment of the Guatemalan Piperaceae here presented is a rather liberal one as regards specific lines, but it is believed to afford an idea of the number of species of the family occurring in the region. Ultimately some of the species here recognized probably will have to be reduced, but this reduction in numbers will be compensated by the discovery of species at present unknown 
from the country, and by the division in some cases of groups of plants here treated as a single species. So far as concerns the names here used for the species of both Piper and Peperomia, the matter is different. Aside from the few names whose original authors were Linnaeus and Swartz, there are few that may not be supplanted by some earlier name published from the West Indies, South America, or Panama and Costa Rica.

In preparation of this account we have had available authentic material in good quantity from Mexico, Salvador, Honduras, and the West Indies, and the names from those regions have been used when applicable. There have been available for study also photographs of most of the species described from Costa Rica and Panama, but not usually actual specimens. Because of the slight characters on which many of the species are based, names from those regions have not been adopted here unless their application was obvious. The nomenclature of the Central American species can not be stabilized until all the West Indian and South American species are considered, and such a task, involving monographic study of the American Piperaceae, was out of the question.

Guatemala has been fortunate in that few Piperaceae have been described from the country. Those that have been published seem to be for the most part valid species, and it seems necessary to publish here a number, fortunately not very large, of new Guatemalan species. If, however, Trelease had lived to complete and publish his studies upon the Guatemalan Piperaceae, the case would have been very different. We submitted to him a large part of the Piperaceae collected on the first three of the four Guatemalan expeditions of this Museum, and he had completed their study at the time of his death. He did not receive any of the material from the fourth expedition.

The Piperaceae are a shining example of certain groups of tropical plants that possess little or no practical or even esthetic importance, yet occupy much space in a regional flora and require the expenditure of a large amount of time for their treatment. The one important member of this large family of plants is black pepper, Piper nigrum L. (called in Guatemala “pimienta de Castilla"), whose dried fruits are used throughout the earth as a condiment. Black pepper has been grown at various places in the lowlands of Alta Verapaz, but apparently it has not proved successful there. In the Quecchí language black pepper is said to be called "caxlanén." The fruits of some of the native species of Piper have a faint taste of pepper, 
but they are not used locally for flavoring, so far as we know. The dried spikes of various native species of Piper often are on sale in the Guatemalan markets, for use in household medicine. The plants find a good deal of use in country medicine for treating various ailments. Dieseldorff reports the Quecchí name of one such medicinal Piper as "ticrac ha," but the usual name for the species throughout Guatemala and other parts of Central America is "cordoncillo," an allusion to the cord-like spikes. Usually the country people have no names for any of the species of Peperomia.

Plants herbaceous, usually epiphytic; leaves generally very thick and fleshy;

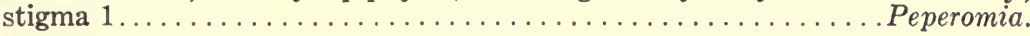

Plants woody, or rarely herbaceous but then usually very large plants, almost always terrestrial; leaves not fleshy; stigmas $2-5$ (usually $3-4$ ) ...... Piper.

\section{PEPEROMIA Ruiz \& Pavón}

References: Hugo Dahlstedt, Studien über Süd- und CentralAmerikanische Peperomien, Svensk. Vet. Akad. Handl. 33, no. 2: 11-218. pls. 1-18. 1900; Arthur W. Hill, A revision of the geophilous species of Peperomia, with some additional notes on their morphology and seedling structure, Ann. Bot. 21: 139-160. pl. 15. 1907. William Trelease, The peltate Peperomias of North America, Bot. Gaz. 73 : 133-147. pls. 1-4. 1922.

Mostly small, pereninial or rarely annual herbs, erect to prostrate, generally epiphytic, rarely terrestrial; leaves alternate, opposite, or of ten verticillate, usually thick and succulent; flowers very small, green, spicate, the spikes slender, solitary or clustered, subtended by orbicular or elliptic bracts; stamens 2 , the filaments short or rarely longer than the bracts; anthers transverse-oblong or subglobose, the two cells confluent to form one 2-valvate one; ovary sessile or contracted at the base and substipitate, obtuse to rostrate at the apex; stigma undivided, generally penicillate, terminal or lateral near the apex; ovule one, erect from the base of the cell; fruit usually almost minute, with a thin pericarp, almost dry; endosperm farinose.

Species probably almost 1,000 , widely distributed in the tropics of both hemispheres, but the great majority of them American. Many others besides those listed here are found in other parts of Central America. The plants of this genus are of little or no economic importance, but some of them are much used in Guatemala in domestic medicine, especially in the Cobán region. Some of the plants are of rather handsome appearance and suitable for cultivation. It may be remarked that of all Central American plants the Peperomias are probably the most difficult to make into herbarium specimens, since they yield up their moisture only under extreme 
desiccation. Without artificial heat it is almost impossible to dry them. Even if the leaves are scored or punctured at close intervals, the openings quickly are filled with a sticky sap that hardens and retains the internal sap indefinitely.

Leaves verticillate or opposite.

Flower spikes racemose; leaf blades cordate at the base. P. Treleasei. Flower spikes solitary; leaf blades not cordate at the base.

Leaves opposite (those at the apex of the branches sometimes verticillate). Stems and leaves glabrous.

Leaves 3-nerved........................ pseudopereskiifolia. Leaves 5-nerved (the nerves sometimes obscured in drying).P. glutinosa. Stems and leaves densely or sparsely pubescent, at least over part of their surfaces.

Leaf blades orbicular, as broad as long or broader.

Leaves less than $1 \mathrm{~cm}$. wide.................. lenticularis. Leaves about $1 \mathrm{~cm}$. wide................... pecuniifolia.

Leaf blades various in shape but not orbicular.

Leaves very obtuse or rounded at the apex, mostly broadest slightly above the middle........................ humilis.

Leaves mostly acute or subacute or at least somewhat pointed at the apex, broadest at or usually below the middle...P. guatemalensis.

Leaves all or mostly verticillate.

Stems pubescent, usually densely so but the hairs often minute and inconspicuous.

Leaves small, mostly $7 \mathrm{~mm}$. wide or narrower, chiefly cuneate-oblong or oblanceolate-oblong, rounded or emarginate at the apex.P. galioides.

Leaves larger, mostly 10-20 mm. wide or wider, mostly broadest at or near the middle.

Leaf blades orbicular or nearly so, broadly rounded at the apex, coriaceous when dried....................... pecuniifolia.

Leaf blades various but not orbicular, mostly obtuse or subacute, at least somewhat pointed at the apex, drying thin and not at all coriaceous.

Stems very densely pilose with long spreading hairs ...P. hondoana.

Stems merely puberulent or sparsely pilose with short, mostly subappressed hairs, never densely long-pilose.

Lower leaves very unlike the upper ones, rounded-obovate and about $1 \mathrm{~cm}$. long or less, the upper ones elliptic or ovateelliptic and $2.5 \mathrm{~cm}$. long................... heterodoxa.

Lower leaves little if at all different from the upper ones.

Stems pubescent with very short, incurved hairs.P. Liebmannii. Stems pilose with slender, spreading or subappressed hairs.

Stems glabrous or essentially so.

P. blanda.

Leaves mostly cuneate-obovate, narrowed to the base, broadest above the middle, broadly rounded or emarginate at the apex.

Spikes glabrous........................... quadrifolia.

Spikes puberulent......................... Deppeana.

Leaves variable in shape but not cuneate-obovate, usually broadest at the middle and about equally narrowed to each end, usually narrowed at the apex and never broadly rounded or emarginate. 
Leaves thin when dried and usually blackish, narrowly acuminate.

Leaves coriaceous when dried, not blackening, obtuse.

$P$. tacticana.

Leaf blades rhombic-ovate or rhombic-elliptic, acute at the base, somewhat narrowed to the narrow obtuse apex.P. crassiuscula.

Leaf blades oval or elliptic, mostly very obtuse at the base, scarcely narrowed to the very obtuse or narrowly rounded apex.

Spikes glabrous....................... staminea.

Spikes densely and finely puberulent............... reflexa.

Leaves alternate, or some of the uppermost opposite or at least appearing so because of shortening of the branches, or the leaves sometimes all basal.

Leaf blades peltate, at least most of them; plants often acaulescent.

Plants with elongate stems, these usually rooting at the nodes; leaves acute or acuminate, or at least subacute.

Leaves very large, the principal ones $12-20 \mathrm{~cm}$. long or larger. .P. maculosa.

Leaves much smaller, mostly $4-10 \mathrm{~cm}$. long.

Leaves conspicuously pilose or villous beneath.

Leaves pilose on the upper surface................ vegana.

Leaves glabrous on the upper surface.

Leaf blades broadly rounded at the base, villous beneath with long spreading multicellular hairs.................. agitata.

Leaf blades merely obtuse at the base, pilosulous beneath with very short, often curved, not conspicuously multicellular hairs.

Leaves glabrous beneath or obscurely puberulent.

P. Griggsii.

Leaf blades small, mostly $3.5-4.5 \mathrm{~cm}$. long.

Leaves very obtuse, peltate far above the base; spikes fusiform to subglobose, obtuse or rounded at the apex.......P. clavigera.

Leaves acute, peltate slightly above the base; spikes obconic, flat or depressed at the broad apex.............. dorstenioides.

Leaf blades larger, mostly $6-8 \mathrm{~cm}$. long............. peltilimba.

Plants acaulescent, or with short erect stems.

Leaf blades orbicular, not pointed, peltate at or very close to the middle, glabrous.................................... campylotropa.

Leaf blades mostly broadly ovate and acute or at least pointed, often peltate far below the middle, rarely suborbicular but then pilose.

Leaves conspicuously pilose or pilosulous on one or both surfaces.

Leaf blades small, $2 \mathrm{~cm}$. long or less, rounded at the apex.

P. Tuerckheimii.

Leaf blades large, mostly $3.5-8 \mathrm{~cm}$. long, acute......... molithrix.

Leaves glabrous, or rarely obscurely and finely puberulent.

Inflorescences branched; fruits sessile.............. claytonioides.

Inflorescences simple; fruits short-pedicellate.

Leaf blades small, mostly less than $2.5 \mathrm{~cm}$. long; fruits with a long slender style........................... mexicana.

Leaf blades large, mostly $3.5-7 \mathrm{~cm}$. long; fruits with a very short style................................ peltata.

Leaves not peltate; plants not acaulescent.

Leaf blades cordate or subcordate at the base.

Leaf blades small, $3 \mathrm{~cm}$. long or usually shorter.

Stems usually conspicuously hispidulous; leaf blades mostly reniform and slightly broader than long, broadly rounded at the apex.

P. hispidula. 
Stems usually quite glabrous; leaf blades mostly as long as broad or usually somewhat longer, acute to rounded at the apex.

Leaf blades mostly acute or subacute at the apex and subcordate at

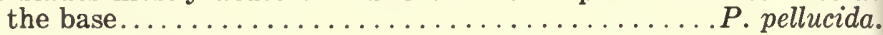

Leaf blades mostly rounded or very obtuse at the apex and rounded

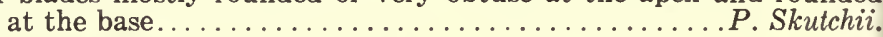

Leaf blades larger, mostly 4-7 cm. long.

Leaves somewhat penninerved or plinerved, the innermost nerves arising well above the base of the blade.

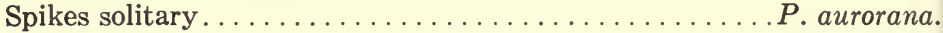

Spikes geminate................... gymnophylla.

Leaves palmate-nerved, the nerves all arising at the very base of the blade or close to it.

Leaf blades narrowly and deeply cordate at the base....P. asarifolia.

Leaf blades shallowly and broadly cordate at the base or only subcordate.

Plants prostrate, with elongate, creeping and rooting stems.

Plants erect or suberect, with very short stems.

$P$. praetenuis.

Leaf blades $2.5-4.5 \mathrm{~cm}$. long; spikes 5-9 cm. long...P. Bernoullii. Leaf blades $1 \mathrm{~cm}$. long or less; spikes $1.5 \mathrm{~cm}$. long or shorter.

P. major.

Leaf blades rounded to long-attenuate at the base, not at all cordate.

Leaves small, mostly $1 \mathrm{~cm}$. long or shorter, orbicular or broadly oval. Stems very slender, almost filiform, creeping.

Leaf blades narrowed to an obtuse, apiculate, of ten subemarginate apex, the petioles very short................. suchitanensis.

Leaf blades broadly rounded at the apex, neither apiculate nor emarginate; petioles long and slender............. rotundifolia.

Leaves larger, usually much more than $1 \mathrm{~cm}$. long.

Leaves conspicuously pubescent on one or both surfaces.

Leaves penninerved.

Petioles mostly $3.5-6.5 \mathrm{~cm}$. long.

Leaf blades mostly $5.5-7 \mathrm{~cm}$. long............ Griggsii.

Leaf blades mostly $12-18 \mathrm{~cm}$. long. . . . . . . frigidula.

Petioles mostly $2 \mathrm{~cm}$. long or shorter.

Leaves conspicuously long-ciliate, oval or broadly ovate.

P. minarum.

Leaves not evidently ciliate, lance-oblong or ovate-oblong.

Leaves palmately nerved.

P. floresensis.

Nerves evident beneath in the dried leaves.......P. santa-helenae.

Nerves obsolete or nearly so beneath in the dried leaves.

Leaves narrow, mostly oblanceolate to cuneate-oblong or cuneateobovate, acute to attenuate-cuneate at the base, mostly broadest toward the apex.............. pilitimba.

Leaves broad, broadly ovate to suborbicular or broadly elliptic, rarely broadly obovate, mostly rounded or very obtuse at the base, sometimes acute.

Leaves pilose on both surfaces with straight spreading hairs. $P$. flagitans.

Leaves merely puberulent on both surfaces, often obscurely so. 
Leaves glabrous on both surfaces or practically so, rarely obscurely puberulent, sometimes ciliate.

Spikes paniculate or racemose or geminate or solitary but then borne on a long erect nodose peduncle bearing much reduced, foliaceous bracts.

Spikes paniculate; leaf blades rounded or very obtuse at the base. $P$. huitzensis.

Spikes not paniculate or, if so, the leaves acute to long-attenuate at the base.

Leaves acute to long-acuminate, with a very acute apex.

Spikes solitary on a stout terminal leafy-bracteate peduncle, $3-4 \mathrm{~mm}$. thick....................... limana. Spikes paniculate, $2 \mathrm{~mm}$. thick or less.

Leaf blades mostly 5-6 times as long as wide...P. floribunda.

Leaf blades 3 times as long as wide or broader....P. cobana. Leaves broadly rounded or emarginate to obtuse or subacute at the apex, if acute the tip of the leaf obtuse...P. obtusifolia .

Spikes solitary on the peduncles, the peduncles mostly solitary, axillary or terminal, if terminal and clustered the peduncles not with foliaceous bracts.

Leaves densely and conspicuously black-punctate beneath.

Plants normally terrestrial, erect, with a stout thick, trunk-like main stem, the internodes very short, the leaves crowded.

Leaf blades acute or acuminate at the base......P. petrophila.

Leaf blades rounded or very obtuse at the base.P. jilotepequeana. Plants normally epiphytic, never with a trunk-like main stem, usually procumbent or repent, the internodes much elongate.

Petioles and stems glabrous.............. . nigropunctata.

Petioles and stems sparsely short-pilose or hispidulous.

P. glabella.

Leaves not black-punctate beneath or very sparsely and inconspicuously so.

Leaves somewhat penninerved, with conspicuous strong branches diverging from the costa above the basal nerves.

Leaf blades rounded or very obtuse at the apex, or merely subacute, often emarginate, broadly ovate or roundedovate, mostly $2.5-4.5 \mathrm{~cm}$. long.

Leaves conspicuously emarginate at the apex .P. condormiens. Leaves acute or subacute, not emarginate.P. praeteruentifolia.

Leaf blades acute to long-acuminate, mostly lance-oblong to oblong-ovate, generally $6-12 \mathrm{~cm}$. long.

Leaves not ciliate.................... granulosa.

Leaves, at least most of them, conspicuously ciliate near the base or throughout.

Leaf blades lance-oblong, on petioles $1 \mathrm{~cm}$. long or shorter. $P$. sisiana.

Leaf blades elliptic or ovate-elliptic, the petioles mostly $1.5 \mathrm{~cm}$. long or longer................P. luisana.

Leaves palmately nerved, the nerves all arising at or very close to the base.

Stems conspicuously winged.................. alata. Stems not winged.

Plants procumbent or repent, with often much elongated stems rooting at the nodes; leaves very unequal on the 
same plant, part of them suborbicular, others lanceolate or ovate................... aggravescens.

Plants mostly erect or ascending, not rooting at the nodes; leaves mostly almost uniform in shape.

Leaves lanceolate or oblong-lanceolate.......P. coarctata.

Leaves variable in shape but mostly narrowly to broadly ovate or elliptic............... collocata.

\section{Peperomia aggravescens Trelease in Yuncker, Field Mus.} Bot. 17: 330. 1938.

Dense, moist or wet, mixed, mountain forest, 1,400-2,300 meters; Alta Verapaz; El Progreso. Honduras (type from El Achote, near Siguatepeque).

Plants slender, growing on tree trunks or on logs, glabrous throughout or nearly so, the stems simple or branched, mostly $30 \mathrm{~cm}$. long or shorter, usually repent and rooting at the nodes, the tips sometimes erect, the internodes short or elongate; leaves alternate, on short slender petioles, often fuscescent when dried, not pellucidpunctate, very variable upon the same plant; blades of the lower leaves orbicular or rounded-obovate, mostly $1-1.5 \mathrm{~cm}$. long, rounded at the apex, rounded to broadly cuneate at the base; blades of the upper leaves lanceolate to ovate, generally 2-5 cm. long, acute to acuminate or sometimes obtuse, obtuse or acute at the base, slightly paler beneath, obscurely 3-5-nerved; peduncles slender, terminal, generally solitary, simple, naked; spikes very slender, mostly $6 \mathrm{~cm}$. long or shorter, $1 \mathrm{~mm}$. thick, glabrous; bracts rounded, centrally peltate; ovary somewhat obliquely apiculate, the stigma subapical.

\section{Peperomia agitata Trelease \& Standley, sp. nov.}

Moist or wet, mixed, mountain forest, terrestrial or sometimes epiphytic, 1,500-2,400 meters; endemic; Quezaltenango; San Marcos (type from Barranco Eminencia, above San Rafael Pie de la Cuesta, Standley 68629; in Herbarium of Chicago Natural History Museum).

Plants slender, simple or sparsely branched, the stems succulent, prostrate or repent, rooting at most of the nodes, the internodes elongate, glabrous, often finely and rather conspicuously granular; leaves alternate, rather small, the petioles slender, equaling or shorter than the blades; leaf blades thick and fleshy when fresh, thin when dried and often fuscescent, not pellucid-punctate, broadly ovate or rounded-ovate, mostly $5-8 \mathrm{~cm}$. long and $3.5-4.5 \mathrm{~cm}$. wide, rather abruptly acuminate, rounded at the base, peltate well above the base, deep green and glabrous above, somewhat paler beneath, pilose or villous-hirsute with rather sparse but conspicuous, long, spreading, mostly yellowish hairs, about 7-nerved; spikes unknown.

Planta gracilis, caulibus simplicibus vel sparse ramosis prostratis vel repentibus, ad nodos radicantibus, internodiis elongatis glabris; folia inter minora alterna longipetiolata in sicco saepe fuscescentia non pellucido-punctata, late ovata vel rotundo-ovata, subabrupte acuminata, basi rotundata, 7-nervia, supra glabra, subtus sparse pilosa vel villoso-hirsuta; spicae non visae. 
Peperomia alata Ruiz \& Pavón, Fl. Peruv. 1: 31. pl. 48, f. b. 1798.

On wet shaded limestone rocks, 300-900 meters; Alta Verapaz. British Honduras (Valentín); West Indies; South America.

Plants glabrous, the stems erect, solitary or clustered, simple or sparsely branched, narrowly but evidently winged by the decurrent bases of the petioles, succulent, with short or elongate internodes, sometimes decumbent at the base and rooting at the lowest internodes; leaves alternate, on petioles $1 \mathrm{~cm}$. long or shorter, usually fuscescent when dry, pellucid-punctate, slightly paler beneath, lanceolate to lance-oblong or oblong-elliptic, commonly $6-10 \mathrm{~cm}$. long and $3-4 \mathrm{~cm}$. wide, abruptly acuminate or narrowly long-acuminate, attenuate to the base, ciliolate, 3-5-nerved; peduncles terminal, longer than the petioles; spikes very slender, densely flowered, sometimes $12 \mathrm{~cm}$. long or more but usually shorter, 1-1.5 mm. thick, glabrous; bracts orbicular, centrally peltate, subsessile; ovary half immersed in the rachis; fruits sparsely glandular, globose, obliquely and obscurely mucronate at the apex.

Peperomia asarifolia Schlecht. \& Cham. Linnaea 5: 75. 1830. P. Heydei C. DC. in Donn. Smith, Bot. Gaz. 19: 9. 1894 (type from Laguna de Ayarza, Jalapa, Heyde \& Lux 3834). P. Heydei var. minor C. DC. op. cit. 10 (type from Estanzuela, Santa Rosa, Heyde \& Lux 3835).

Terrestrial in moist or rather dry forest, often growing on rocks, 1,000-1,800 meters; Zacapa; Jalapa; Santa Rosa; Huehuetenango. Southern Mexico.

Plants succulent, erect or suberect, about $30 \mathrm{~cm}$. high or lower, glabrous throughout, the stems solitary or several, simple or sparsely branched, very thin, inconspicuously pellucid-punctate or epunctate, somewhat paler beneath, the petioles very slender, those of the lowest leaves as much as $15 \mathrm{~cm}$. long, those of the upper leaves mostly much shorter; leaf blades ovate-orbicular or almost reniform, mostly $6-11 \mathrm{~cm}$. long and $4.5-11 \mathrm{~cm}$. wide, broadly rounded to somewhat pointed at the apex, rather deeply and narrowly cordate at the base, 9-11nerved, the innermost nerves sometimes arising slightly above the base of the blade; peduncles terminal and axillary, about equaling the petioles; spikes very slender, equaling or exceeding the leaves, as much as $19 \mathrm{~cm}$. long but often much shorter, $1.5 \mathrm{~mm}$. thick, glabrous; flowers mostly arranged in rather remote whorls, the bracts orbicular; ovary obovoid, obliquely complanate at the apex and obliquely stigmatiferous, pale-glandular; fruits emersed and very shortly stipitate, subglobose.

Peperomia aurorana Trelease \& Standley, sp. nov.

Known only from the type, Dept. Guatemala, perhaps in the barranco near La Aurora, alt. about 1,400 meters, Ignacio Aguilar 517 in 1940; in Herbarium of Chicago Natural History Museum. 
Plants small, erect, about $15 \mathrm{~cm}$. high, the stems rather stout, simple or with a few thick succulent branches, glabrous; petioles very slender, $7.5 \mathrm{~cm}$. long or shorter, glabrous; leaf blades thin, green when dried, paler beneath, not pellucidpunctate, ovate or broadly ovate, $4.5-6.5 \mathrm{~cm}$. Iong, $3.5-4.5 \mathrm{~cm}$. wide, acute, broadly rounded at the base and shallowly cordate, 7-9-plinerved, the inner nerves arising far above the base of the blade but below the middle; peduncles axillary, short, slender, glabrous, simple, naked; spikes very slender, glabrous, pale green, about $3 \mathrm{~cm}$. long, little more than $1 \mathrm{~mm}$. thick, laxly flowered, the bracts broadly ovate, peltate, short-pedicellate, subacute.

Planta nana erecta, caule simplici vel pauciramoso crasso glabro; folia tenuia longipetiolata epunctata, subtus paullo pallidiora, ovata vel late ovata, acuta, basi late rotundata et breviter cordata, 7-9-plinervia, nervis interioribus bene supra basin laminae nascentibus; pedunculi axillares breves simplices nudi, spicis gracillimis glabris ca. $3 \mathrm{~cm}$. longis vix ultra $1 \mathrm{~mm}$. crassis laxifloris; bracteae late ovatae peltatae breviter pedicellatae subacutae.

The type was presumably collected in the Department of Guatemala but possibly at some distance from Guatemala City.

Peperomia Bernoullii ("Bernouillii") C. DC. Linnaea 37: 367. 1871-73. P. violaefolia C. DC. in Donn. Smith, Bot. Gaz. 19: 8. 1894 (type from Palín, Guatemala, J. D. Smith 2580). P. izalcoana Trelease in Standl. Journ. Wash. Acad. Sci. 13: 366. 1923 (type from Izalco, Salvador). P. Uphofii Trelease in Standl. Field Mus. Bot. 22: 10. 1940 (type from Salvador).

Terrestrial, on moist or wet, shaded banks in forest, 1,000 meters or lower; Escuintla; Guatemala; Suchitepequez (type from Mazatenango, Bernoulli 37). El Salvador.

Plants small, erect, mostly $12 \mathrm{~cm}$. high or less, with a very short, succulent, simple or sparsely branched stem, glabrous; leaves slender-petiolate, the petioles $4.5 \mathrm{~cm}$. long or shorter; leaf blades green when dried, thin, not pellucid-punctate, mostly rounded-ovate or rounded-deltoid, commonly $2.5-4.5 \mathrm{~cm}$. long, acute or narrowed to an obtuse apex, rounded to subcordate at the base, usually 5-nerved; peduncles solitary, simple, naked, terminal and axillary, the spikes very slender and laxly flowered, much exceeding the leaves; bracts orbicular, peltate at the middle, subsessile; ovary emersed, ovoid, the stigma apical, papillose; fruits subsessile.

Peperomia blanda (Jacq.) HBK. Nov. Gen. \& Sp. 1: 67.1815. Piper blandum Jacq. Icon. Pl. Rar. 2: 2. 1786-93. ?Peperomia blanda var. cobana C. DC. Candollea 1: 380. 1923; 3: 122. 1926 (type from Cobán, Alta Verapaz, Türckheim II.1754).

On trees or rocks in moist or wet, mountain forest, 900-2,400 meters; Alta Verapaz(?); Jalapa; Guatemala; San Marcos. Central and southern Mexico; probably southward in Central America; South America. 
Plants succulent, erect or ascending, the stems usually branched above, rather densely pilose with long slender lax hairs, the internodes mostly elongate; leaves generally quaternate, on short or elongate petioles, green or fuscescent when dried, obscurely if at all pellucid-punctate, elliptic or ovate-elliptic, mostly $3-6.5 \mathrm{~cm}$. long and 1-3 cm. wide, narrowed to the obtuse or subacute apex, obtuse or acute at the base, 3-nerved, thin when dried, thinly short-pilose on both surfaces; peduncles mostly terminal and clustered, equaling or much longer than the petioles; spikes slender, erect or recurved, 4-8 cm. long, 1-1.5 mm. thick, remotely flowered, glabrous; bracts suborbicular, peltate near the middle, subsessile.

Peperomia campylotropa A. W. Hill, Ann. Bot. 21: 156. 1907. P. bracteata A. W. Hill, Ann. Bot. 21: 155. 1907 (type from Huehuetenango, Sactós, C. \& E. Seler 2731).

Terrestrial, in open or shaded, wet to rather dry places, often in alpine meadows or on or about rocks, mostly at $2,400-3,600$ meters; Huehuetenango. Central and southern Mexico.

Plants glabrous, acaulescent, arising from a hypogaean tuber, this subglobose, 1-2 cm. in diameter, emitting fibrous roots; leaves few or numerous, erect, the petioles very slender, $3-8 \mathrm{~cm}$. long, or sometimes as much as $20 \mathrm{~cm}$.; leaf blades orbicular or ovate-orbicular, $1.5-3.5 \mathrm{~cm}$. long, peltate at the middle, not or very obscurely pellucid-punctate, rather thin when dried, fleshy when fresh, 6-9-nerved; peduncles slender, simple, naked, equaling or longer than the petioles; spikes pale green, rather densely flowered, equaling or usually exceeding the leaves; bracts ovate, acuminate, $1.5 \mathrm{~mm}$. long; fruit globose-ovoid, $1.7 \mathrm{~mm}$. long, verruculose.

Dahlstedt and most other authors have referred this plant to P. umbilicata Ruiz \& Pavón, which it much resembles, and it may be preferable to treat it as a form or variety of that species. The species is distinct from all other Central American ones. In general appearance it is highly suggestive of Hydrocotyle umbellata (Umbelliferae). In Guatemala it is noteworthy as being the only truly alpine Peperomia. The Guatemalan specimens may be referable to $P$. bracteata A. W. Hill, but the material appears to be conspecific with that of the Mexican specimens referred by Hill to P. campylotropa.

\section{Peperomia cilibractea C. DC. Candollea 1: 360. 1923.}

This name was published in a key to the species of Peperomia. The type, according to a photograph of a specimen in the Berlin Herbarium, is Bernoulli \& Cario 2686, said to be from Guatemala. The specimen is a poor one, consisting mostly of detached leaves, and the key characters give so few details regarding the specimen that we have been unable to associate it definitely with any of the 
Guatemalan plants we have seen. The name is probably synonymous with one of those listed here.

\section{Peperomia clavigera Standl. \& Steyerm., sp. nov.}

Terrestrial on wet limestone cliffs, 300-500 meters; Alta Verapaz (type collected along road between Chajmayic and Sebol, Steyermark 45738, in Herbarium of Chicago Natural History Museum).

Plants glabrous, with more or less elongate stems, or the stems sometimes short, the internodes often elongate; leaves alternate, the petioles slender, $5 \mathrm{~cm}$. long or less; leaf blades very thick and fleshy when fresh, fuscescent when dry, sparsely pellucid-punctate, when fresh grayish green above and silvery white beneath, rounded-ovate, mostly $3-4.5 \mathrm{~cm}$. long and $3-4 \mathrm{~cm}$. wide, very obtuse at the apex, broadly rounded at the base, peltate some distance above the base, doubtless palmate-nerved but the nerves wholly obscured in the dry leaves; peduncles axillary, simple, bearing a small fleshy bract above or below the middle, equaling or shorter than the petioles, slender; spikes fusiform to obovoid, sometimes ellipsoid, usually 7-15 mm. long, 5-7 mm. thick, obtuse or rounded at the apex, acute or subacute at the base, very succulent, very densely many-flowered; anthers borne on short filaments; fruits emersed, densely crowded, spreading, globoseovoid, obtuse at the apex, contracted into the short capitellate apical stigma.

Planta glabra, caule brevi vel elongato et prostrato vel repente, internodiis interdum elongatis; folia alterna in sicco fuscescentia, in vivo crasse carnosa, longipetiolata, sparse pellucido-punctata, rotundato-ovata parva obtusissima, basi late rotundata, bene supra basin laminae peltata, nervis obsoletis; pedunculi axillares simplices supra vel infra mediam bracteatae, petiolis aequilongis vel brevioribus; spicae fusiformes, obovoideae vel interdum subglobosae, carnosae, dense multiflorae, 7-15 mm. longae 5-7 mm. crassae; fructus emersus globosoovoideus obtusus, stigmate apicali capitellato.

A distinct species, remarkable for the very short and thick, globose to club-shaped flower spikes.

Peperomia claytonioides Kunth, Ind. Sem. Hort. Berol. 11. 1847 (described from cultivated plants said to be of Guatemalan origin). P. ovatopeltata C. DC. Journ. Bot. 4: 133.1866. P. pinulana C. DC. Bot. Jahrb. 10: 289. 1888 (type collected above Pinula, Jalapa, F. C. Lehmann 1693). P. claytonioides var. longiscapa C. DC. ex Trelease, Bot. Gaz. 73: 138. 1922 (type from Guatemala, the locality unknown). P. claytonioides var. pinulana Trelease, op. cit. 139.

On shaded rocks or in rather dry soil, sometimes epiphytic, 1,200 1,600 meters; Baja Verapaz; Jalapa; Huehuetenango. El Salvador.

Plants acaulescent, from a small globose hypogaean tuber; leaves usually few, erect, glabrous, the petioles very long and slender; leaf blades ovate-orbicular, $3-7 \mathrm{~cm}$. long, somewhat narrowed to an obtuse tip, broadly rounded or subcordate 
at the base, peltate near or far below the middle, thin when dried, slightly paler beneath; peduncles long and slender, sometimes $30 \mathrm{~cm}$. long but mostly shorter, erect, usually sparsely branched, sometimes simple; spikes very slender, sparsely and remotely flowered, short-pedunculate, little more than $1 \mathrm{~mm}$. thick, short or usually elongate, glabrous; bracts ovate-orbicular, acute; fruits subglobose, $0.8 \mathrm{~mm}$. in diameter, rugose, produced at the apex into a slender appendage, or the appendage sometimes very short.

\section{Peperomia coarctata Trelease \& Standley, sp. nov.}

On trees in moist or wet, mountain or lowland forest, rarely terrestrial, 300-2,000 meters; endemic; Sacatepéquez; Suchitepequez; Retalhuleu; Quezaltenango (type from Quebrada San Gerónimo Finca Pirineos, lower southern slopes of Volcán de Santa María, Steyermark 33365, in Herbarium of Chicago Natural History Museum).

Stems erect or pendent, usually much branched, slender or rather stout, very sparsely and inconspicuously pubescent or glabrous, with short or elongate internodes; leaves small, usually blackish when dried and thin, slightly paler beneath, sparsely pellucid-punctate, the petioles slender, glabrous, $7 \mathrm{~mm}$. long or shorter; leaf blades lanceolate to elliptic-lanceolate or ovate, mostly $2.5-6 \mathrm{~cm}$. long and 1-2 cm. wide, acute to long-acuminate and with an obtuse or narrowly rounded tip, cuneate at the base, glabrous, obscurely 3-nerved; peduncles solitary and axillary or terminal and clustered, longer than the petioles; spikes very slender, pale green, erect, remotely or densely flowered, mostly $3.5-6 \mathrm{~cm}$. long, scarcely $1 \mathrm{~mm}$. thick, glabrous; bracts very small, orbicular, centrally peltate, sessile; ovaries semi-immersed.

Herba erecta vel pendens ramosa, sparsissime inconspicue pubescens vel glabra; folia parva in sicco vulgo nigrescentia atque tenuia, subtus paullo pallidiora, sparse pellucido-punctata; lamina lanceolata usque elliptico-lanceolata vel ovata acuta vel longiacuminata basi cuneata glabra, inconspicue 3-nervia; pedunculi singuli et axillares vel terminales et aggregati petiolis longiores; spicae gracillimae erectae laxiflorae vel densiflorae, plerumque $3.5-6 \mathrm{~mm}$. longae, vix $1 \mathrm{~mm}$. crassae, glabrae; bracteae parvae orbiculares centro peltatae sessiles; ovaria semi-immersa.

\section{Peperomia cobana C. DC. in Donn. Smith, Bot. Gaz. 19: 260. 1894.}

On trees in moist or wet forest, 250-1,450 meters; endemic; Alta Verapaz (type collected near Cobán, Türckheim 78; known only from the Cobán region).

Plants glabrous, rather slender, the stems simple or sparsely branched, erect or procumbent and rooting at the lower nodes; leaves alternate, the slender petioles as much as $5 \mathrm{~cm}$. long but mostly shorter; leaf blades thick and fleshy when fresh, rather thick when dried and often fuscescent, opaque, elliptic to elliptic-lanceolate or oblong-elliptic, mostly $10-13 \mathrm{~cm}$. long, acute or acuminate, usually with an acute tip, acute to attenuate at the base, the costa emitting 4-6 slender nerves on each side, these often obsolete or obscure; peduncles terminal, half as long as 
the leaves, bearing usually 3 slender-pedunculate erect spikes, the peduncles naked, the spikes long and slender, densely flowered, $1 \mathrm{~mm}$. thick; bracts orbicular, centrally peltate; ovary partly immersed, obliquely subulate at the apex, stigmatiferous anteriorly.

Peperomia collocata Trelease in Yuncker, Field Mus. Bot. 17: 332.1938 (type from El Achote, above Siguatepeque, Honduras). $P$. laudabilis Trelease in Yuncker, op. cit. 335 (type from El Achote, Honduras). P. tressis Trelease in Yuncker, op. cit. 339 (type from El Achote, Honduras). Siempreviva (Quezaltenango).

Dense, moist or wet, mixed, mountain forest, usually epiphytic but sometimes terrestrial, 500-2,900 meters; Alta Verapaz; Zacapa; Chiquimula; Jalapa; Guatemala; Sacatepéquez; Chimaltenango; Retalhuleu; Quezaltenango; San Marcos; Huehuetenango. Honduras, and perhaps farther southward in Central America.

Plants erect or decumbent, the stems usually stout, simple or sparsely branched, with short or elongate internodes, solitary or clustered, the plants glabrous throughout; leaves alternate, thick and succulent when fresh, thin when dried and often fuscescent, not pellucid-punctate, on petioles $1 \mathrm{~cm}$. long or shorter; leaf blades variable in size and shape, elliptic to rounded-elliptic, rhombic-ovate, or rhombic-lanceolate, mostly $3.5-7 \mathrm{~cm}$. long and $1.5-3 \mathrm{~cm}$. wide, very obtuse to acuminate with an obtuse tip, obtuse or broadly cuneate at the base, 3-5-nerved, somewhat paler beneath; peduncles terminal and axillary, the terminal ones sometimes clustered, slender, longer than the petioles, simple, naked; spikes pale green, sometimes $9 \mathrm{~cm}$. long but usually shorter, 1-1.5 mm. thick, glabrous, erect or recurved; remotely flowered; bracts orbicular, centrally peltate; ovary partly immersed, obliquely apiculate, the stigma subapical.

The plant is a common one in many of the mountain areas, and one of the most abundant of all the local Peperomia species. The extensive collections that we have referred to this form include 27 sheets annotated by Trelease as types of new species. It is highly probable that a much older name can be found for this plant. Two of the collections we place here were determined by De Candolle as $P$. chrysocarpa C. DC., a Costa Rican species to which all the material may be referable.

Peperomia condormiens Trelease in Yuncker, Field Mus. Bot. 17: 332. 1938 (type from El Achote, above Siguatepeque, Honduras). P. inaudax Trelease in Yuncker, op. cit. 334 (type from El Achote, Honduras).

Moist or wet forest, sometimes in forest of pine and Liquidambar, 1,500-2,400 meters, usually epiphytic; endemic; Zacapa (Sierra de las Minas); Huehuetenango. Mountains of Honduras. 
Plants glabrous throughout, the stems erect, decumbent, or sometimes pendent, slender, only slightly succulent, with mostly short internodes, often rooting at the lower nodes; leaves small, somewhat coriaceous when dried, alternate, not pellucid-punctate, mostly green when dried, the petioles slender, $5 \mathrm{~mm}$. long or shorter; leaf blades orbicular to rounded-ovate, $1.5-3 \mathrm{~cm}$. long, $1.5-3 \mathrm{~cm}$. wide, rounded at the apex and conspicuously emarginate, rounded to broadly cuneate at the base, paler beneath, essentially penninerved but perhaps more accurately 5-7-plinerved with the inner nerves arising far above the base; peduncles terminal, solitary, equaling or slightly longer than the petioles; spikes slender, pale green, glabrous, densely flowered, erect, 3-7 cm. long, little more than $1 \mathrm{~mm}$. thick; bracts orbicular, centrally peltate, short-pedicellate; ovaries ovoid, semi-immersed, glabrous, abruptly contracted at the apex into a short but distinct style.

A closely related species is $P$. tenella (Swartz) A. Dietr. of the West Indies, which has very similar but narrower leaves. The leaves of the West Indian species are uniformly much smaller than those of the continental material, which apparently constitutes a fully distinct species.

Peperomia crassiuscula Millsp. Field Mus. Bot. 2: 33. 1900. P. Lundellii Trelease in Standl. Field Mus. Bot. 12: 406. 1936 (type from Honey Camp, British Honduras, C. L. Lundell 96a). P. Wagneri Trelease in Yuncker, Field Mus. Bot. 9: 276. 1940 (type collected near Coyoles, Honduras).

Epiphytic or on moist rocks, 400 meters or lower; Petén; Alta Verapaz; Zacapa. Yucatan Peninsula of Mexico; British Honduras; Atlantic lowlands of Honduras.

Plants stout and coarse, erect or sometimes pendent, very succulent, glabrous throughout, the stems sometimes $8 \mathrm{~mm}$. thick, sulcate when dried; leaves very thick and fleshy, coriaceous when dried, in verticils of $4-6$, short-petiolate, opaque, mostly rhombic-ovate, $2.5-7 \mathrm{~cm}$. long, $1.5-4 \mathrm{~cm}$. wide, subacute with an obtuse tip, acute or subacute at the base, 3-5-nerved, but the nerves usually obscure; peduncles terminal, solitary or several, simple, stout, generally much longer than the petioles; spikes erect, straight or somewhat curved, mostly 5-11 cm. long, often several times exceeding the leaves, laxly or densely flowered; fruits partly immersed, globose-ovoid, somewhat obliquely apiculate at the apex.

The Maya name of Yucatan is reported as "exlabon ac." This species and $P$. glutinosa may eventually be united as a single species. For this it is probable that an earlier name may be found among West Indian species.

Peperomia Deppeana Schlecht. \& Cham. Linnaea 5: 180. 1830. P. chucanebana Trelease ex Standl. Field Mus. Bot. 10: 156. 1931.

On tree trunks in moist or wet, lowland forest, 900 meters or lower; Petén; Alta Verapaz; Izabal; Escuintla(?); Huehuetenango. 
Southern Mexico; British Honduras; Honduras and probably farther southward in Central America; reported from Brazil.

Plants glabrous, perennial, often forming dense clumps or mats, the stems slender, with rather short internodes, short or often elongate, sometimes pendent, generally rooting at the nodes; leaves thick and fleshy, pale green, usually very pale when dried, opaque, in whorls of 3-4, rounded-obovate, mostly 5-7 mm. long, rounded at the apex, subacute to almost rounded at the base, 1-nerved or obscurely 3-nerved from the base; spikes terminal, on long slender simple peduncles, erect, densely flowered, much exceeding the leaves, chiefly $1-1.5 \mathrm{~cm}$. long, $1.5 \mathrm{~mm}$. thick, densely and rather conspicuously puberulent; bracts orbicular, centrally peltate; ovary immersed; fruits very small, immersed, ovoid, with a conspicuous, somewhat elongate style.

Trelease has labeled some of the Guatemalan material as representing two unpublished species. The name Peperomia polochicana Trelease has been reported for a plant of Petén, but the name has not been published formally.

Peperomia dorstenioides Standl. \& Steyerm., sp. nov. Hoja de culebra.

Known only from the type, Huehuetenango, on rocky bluffs in dense wet forest, between Ixcán and Finca San Rafael, 200-800 meters, Steyermark 49410 (type in Herbarium of Chicago Natural History Museum).

Plants acaulescent or nearly so, arising from a short slender creeping rhizome, glabrous throughout; leaves small, fuscescent when dried, when fresh dark green above with 3 silver-gray longitudinal bands, silvery beneath, the petioles slender, $3 \mathrm{~cm}$. long or less; leaf blades thick and succulent when fresh, rather thin when dry, densely pellucid-punctate, ovate or ovate-elliptic, mostly $3-4.5 \mathrm{~cm}$. long and $1.5-2.5 \mathrm{~cm}$. wide, acute or subacute, rounded at the base, peltate slightly above the base, 3-nerved; peduncles very slender, terminal or axillary, about equaling the petioles; inflorescence (spike) obconic or funnelform, about $9 \mathrm{~mm}$. high and broad, subacute at the base, truncate or depressed at the apex, naked outside, the upper or inner surface densely flowered; fruits at least partly inmersed, globose, scarcely $0.5 \mathrm{~mm}$. in diameter, rounded at the apex, slightly granular, the minute stigma subapical.

Plantae subacaulescentes rhizomatosae glabrae; folia parva in sicco fuscescentia, graciliter longipetiolata in vivo carnosa; lamina dense pellucido-punctata acuta vel subacuta, basi rotundata, paullo supra basin laminae peltata, 3-nervia; pedunculi gracillimi petiolis subaequilongi terminales vel axillares; inflorescentia obconica vel infundibuliformis ca. $9 \mathrm{~mm}$. alta et aequilata basi acutiuscula, apice truncata vel depressa, extus nuda, apice intusque densiflora; fructus subimmersus parvus subglobosus apice rotundatus, stigmate minuto subapicali.

A most curious and unusual plant, its inflorescences strongly suggestive of those of some species of Dorstenia. 
Peperomia flagitans Trelease in Yuncker, Field Mus. Bot. 17: 334. 1938. Xaxpec (Cobán, Quecchí).

Moist or wet forest, on trees or on mossy rocks or cliffs, often on limestone, 1,500 meters or lower; Alta Verapaz; Izabal; Chiquimula; Sacatepéquez(?); Huehuetenango. British Honduras; Honduras, the type collected near Siguatepeque.

Plants erect to procumbent and rooting at the lower nodes, the stems stout or slender, mostly $35 \mathrm{~cm}$. long or less, densely pilose with soft spreading hairs, the internodes short or elongate; leaves alternate, thick and succulent when fresh, rather thin and often fuscescent when dry, pellucid-punctate, on short or elongate petioles, variable in shape, orbicular to rounded-ovate or broadly elliptic or rhombic-elliptic, mostly broadest at or below the middle, broadly rounded to very obtuse at the apex, cuneate to rounded at the base, densely pilose on both surfaces with long spreading soft hairs, mostly 5-nerved; peduncles terminal, simple, naked, mostly solitary, densely pilose; spikes erect, rather stout, much exceeding the leaves, about $6 \mathrm{~cm}$. long and $2 \mathrm{~mm}$. thick, densely flowered; bracts centrally peltate, orbicular, pedicellate, densely ciliate.

There is some confusion between Trelease's description of $P$. flagitans (which he describes as glabrous) and the plant here treated under that name, which is densely pilose. The abundant Guatemalan material agrees with a specimen of the Yuncker Honduran collection cited as the type of $P$. flagitans.

Peperomia floresensis Trelease in Yuncker, Field Mus. Bot. 9: 275.1940.

Epiphytic or on rocks or banks, sometimes on limestone, 500 1,000 meters or lower; Alta Verapaz; Escuintla. British Honduras; Honduras, the type from Las Flores, Department of Yoro.

Stems often much elongate, usually pendent, sometimes rooting at the nodes, the internodes elongate, sparsely or rather densely pilose with chiefly spreading hairs; leaves alternate, the stout petioles 1-2 cm. long, rather sparsely pilose; leaf blades very thick and fleshy when fresh, rather thick and fuscescent when dried, narrowly to broadly lance-oblong, mostly $4.5-10 \mathrm{~cm}$. long and $1.5-4 \mathrm{~cm}$. wide, rather abruptly acuminate or acute, obtuse or rounded at the base, sparsely hirsute on both surfaces with slender white spreading hairs, or in age sometimes glabrate; peduncles axillary, solitary, equaling or longer than the petioles, pilose, simple, naked; spikes slender, densely flowered, 6-15 cm. long, often pendulous, in fruit as much as $6 \mathrm{~mm}$. thick, the rachis glabrous; bracts pale green, orbicular, centrally peltate; fruits emersed, cylindric, about $2 \mathrm{~mm}$. long, oblique at the apex, spreading at almost a right angle, often granular.

Peperomia floribunda (Miq.) Dahlstedt, Svensk. Vet. Akad. Handl. 33, no. 2: 154. 1900. Erasmia floribunda Miq. Inst. Versl. Med. 1842: 81. 1843. Peperomia miradoresiana C. DC. in DC. 
Prodr. 16, pt. 1: 395. 1869. Piper patulum Mart. \& Gal. Bull. Acad. Brux. 10, pt. 2: 128. 1843, non P. patulum Bertol. 1840. Piper miradorense C. DC. in DC. Prodr. 16, pt. 1: 380. 1869. Peperomia macrophylla C. DC. in Donn. Smith, Bot. Gaz. 19: 8. 1894 (type from Palín, Guatemala, J. D. Smith 2579). Peperomia floribunda var. macrophylla Dahlstedt, loc. cit.

Most often terrestrial but sometimes epiphytic, in moist or wet, mixed forest, often on cliffs, sometimes on limestone, 500-2,500 meters; Alta Verapaz; Izabal; Escuintla(?); Guatemala; Chimaltenango; Suchitepequez; Retalhuleu; Quezaltenango; San Marcos. Southern Mexico.

Plants glabrous, erect or nearly so, or sometimes with decumbent and rooting bases, the stems simple or very sparsely branched, with mostly short internodes; leaves alternate, on petioles mostly $3 \mathrm{~cm}$. long or shorter, thin, narrowly oblanceolate or oblong-oblanceolate, mostly $12-25 \mathrm{~cm}$. long and $2.5-4 \mathrm{~cm}$. wide, attenuately long-acuminate, long-attenuate to the base, pellucid-punctate, usually somewhat paler beneath, penninerved, the nerves 10 or fewer on each side, ascending at a very narrow angle; inflorescences axillary, slender-pedunculate, mostly equaling or even longer than the leaves, paniculate, lax, bearing mostly 3-5 spikes, these on rather short, slender peduncles, mostly 4-8 cm. long, very slender, at anthesis scarcely $1.5 \mathrm{~mm}$. thick; bracts usually close together, orbicular, peltate, almost sessile; fruits narrowly cylindric, obliquely ascending, subacute, $1.5 \mathrm{~mm}$. long.

A common plant of the more humid forests of the Pacific slopes of the volcanoes, abundant in many localities, especially on very wet banks. The ample Guatemalan material is remarkably uniform, and Trelease indicated only one new species among the specimens we refer here. He used the name P. macrophylla for the Guatemalan plant, but there is no obvious reason for supposing that it is different from the Mexican plant whose name we use for the species.

Peperomia frigidula Trelease \& Standley, sp. nov.

Terrestrial in dense wet mixed mountain forest, 1,400-1,600 meters; endemic; Alta Verapaz (type collected near Tactic, above bridge across Río Frío, Standley 89493, in Herbarium of Chicago Natural History Museum; known only from this general region).

Plants stout, erect, 40-70 cm. high, the stems about $7 \mathrm{~mm}$. thick, succulent, generally simple, with short internodes, rather densely pilose with slender, mostly appressed hairs; leaves alternate, thick and fleshy when fresh, rather thin and green or fuscescent when dried, the petioles mostly 4-6 cm. long, appressedpilose; leaf blades elliptic or oblong-elliptic, commonly 9-16 cm. long and 4-7 cm. wide, rather abruptly and shortly acute-acuminate, acute or subobtuse at the base, scarcely if at all pellucid-punctate, deep green above, thinly appressedpilose with rather long hairs, slightly paler beneath, sparsely appressed-pilose or 
glabrate, penninerved, the nerves $4-5$ on each side, ascending at an acute angle; spikes unknown.

Planta alta erecta, caule vulgo simplice crasso, internodiis brevibus subdense pilis adpressis pilosis; folia magna alterna longipetiolata in vivo crassa carnosa, in sicco tenuia, elliptica vel oblongo-elliptica, subabrupte breviter acuto-acuminata, basi acuta vel subobtusa, supra sparse pilis longiusculis adpresso-pilosa, subtus paullo pallidiora sparse adpresso-pilosa vel glabrata, penninervia, nervis utroque latere 4-5 angulo angusto adscendentibus; spicae ignotae.

Peperomia galioides HBK. Nov. Gen. \& Sp. 1: 71. pl. 17. 1815. P. galioides var. longifolia DC. ex Donn. Smith, Enum. Pl. Guat. 4: 134. 1895, nomen.

Usually epiphytic in forest, often on oak trees, frequently in rather dry regions, sometimes on rocks or on soil, 1,300-3,300 meters; Alta Verapaz; El Progreso; Zacapa; Chiquimula; Guatemala; Sacatepéquez; Chimaltenango; Huehuetenango; Quezaltenango; San Marcos. Central and southern Mexico; El Salvador and Honduras to Panama; northwestern South America.

Plants erect, perennial, succulent, mostly $30 \mathrm{~cm}$. high or less, often forming dense clumps on the branches or trunks of trees, the stems mostly simple below but bushy-branched above, densely and finely puberulent, the internodes equaling or mostly shorter than the leaves; leaves thick, generally pale green and often yellowish, mostly in whorls of $4-5$, spreading or often reflexed, sessile or nearly so, the upper ones generally oblanceolate or linear-oblanceolate, the lower ones cuneate-oblong or cuneate-obovate, chiefly $1-2 \mathrm{~cm}$. long and $3-7 \mathrm{~mm}$. wide, obtuse or rounded at the apex, 1-nerved or obscurely 3-nerved, glabrous or practically so, slightly paler beneath, pellucid-punctate and usually finely dark-punctate; spikes terminal and axillary, usually several times as long as the leaves, solitary at the apex of the stem or often geminate or several, on slender, short or elongate, naked peduncles, $1-1.5 \mathrm{~mm}$. thick, mostly $2-5 \mathrm{~cm}$. long, remotely flowered; bracts minute, orbicular, centrally peltate, sessile or nearly so; ovaries semiimmersed, the stigma glandular, papillose; fruit ovoid, subrostellate at the apex.

This is a species of wide distribution, as here limited, only slightly variable, of distinctive appearance and easy of recognition. We find no basis for separating Mexican and Central American material from that of South America, whence the species was described originally. Trelease has described a number of its forms, if such they are, from farther south in Central America, and has assigned new names to about twenty of the Guatemalan collections. Like many other local species, this plant sometimes sheds its leaves during the dry season. The new leaves that develop after the next rains fall are often longer and relatively narrower than the preceding ones. In this and many other species the mature fruits are very glutinous and adhere tenaciously to the fingers when the plants are handled. 
Peperomia glabella (Swartz) A. Dietr. Sp. Pl. 1: 156. 1831. Piper glabellum Swartz, Prodr. Veg. Ind. Occ. 16. 1788. Peperomia caulibarbis Miq. Syst. Piper. 98. 1843. ?P. glabella var. microphylla C. DC. ex Donn. Smith, Enum. Pl. Guat. 7: 30. 1905, nomen. Peperomia longeacuminata Trelease ex Standl. Field Mus. Bot. 10: 157. 1931 (described from Lancetilla Valley near Tela, Honduras). Peperomia pololensis Trelease in Standl. Field Mus. Bot. 12: 406. 1936 (type from Monte Polol, Petén, C. L. Lundell 3040). Peperomia rubefacta Trelease in Yuncker, Field Mus. Bot. 17: 338. 1938 (type from El Rincón, near Siguatepeque, Honduras). P. rubefacta var. cangrejalensis Trelease in Yuncker, Field Mus. Bot. 9: 276. 1940 (type from Mount Cangrejal, near La Ceiba, Honduras). Verdolaga (Izabal).

On trees in moist or wet, mixed, mountain or lowland forest, 2,100 meters or lower; Petén; Alta Verapaz; Izabal; Zacapa; San Marcos. British Honduras; Honduras and probably farther southward in Central America; West Indies; South America.

Stems prostrate, procumbent, or often pendent, rooting at the lower nodes, slender but succulent, black-punctate, simple or branched, with elongate internodes, almost glabrous but sparsely hispidulous on the angles made by the decurrent petiole bases; leaves small, alternate, on slender petioles $1 \mathrm{~cm}$. long or less, the petioles hispidulous or at least ciliate; leaf blades obovate-elliptic to ellipticrhombic, mostly $4.5 \mathrm{~cm}$. long and $2.5 \mathrm{~cm}$. wide or smaller, short-acuminate to very obtuse at the apex, more or less cuneate at the base, glabrous, densely blackpunctate, 5-plinerved, the inner nerves arising little above the base of the blade; peduncles axillary, mostly solitary, simple, naked, about $1 \mathrm{~cm}$. long, glabrous; mature spikes $12 \mathrm{~cm}$. long or shorter, $1 \mathrm{~mm}$. thick, glabrous, rather sparsely flowered, finely black-puncticulate; bracts rounded, centrally peltate, subsessile; ovary emersed, obliquely stigmatiferous below the apex; fruit ovoid, smooth, obliquely acute at the apex, sessile.

This is very closely related to $P$. nigropunctata, and separated only on trifling characters, but it is maintained as a distinct species by both Dahlstedt and De Candolle, who, however, differ as to the nomenclature of the two forms.

Peperomia glutinosa Millsp. Field Mus. Bot. 1: 293. pl. 12. 1896.

Usually epiphytic in moist or wet forest, sometimes on banks or rocks, 1,400 meters or lower; Petén; Izabal; Zacapa; Chiquimula; Jutiapa; Huehuetenango; San Marcos. Yucatan Peninsula of Mexico; British Honduras.

Plants glabrous, stout, erect, as much as $40 \mathrm{~cm}$. high, or sometimes procumbent, or with elongate pendent stems, these simple or sparsely branched, angulate 
when dried, with elongate internodes; leaves all or mostly opposite, or the uppermost ternate, very thick and fleshy when fresh, subcoriaceous when dry, opaque, on stout petioles $1 \mathrm{~cm}$. long or shorter, rhombic-ovate or elliptic-ovate, mostly $3.5-7.5 \mathrm{~cm}$. long and $2-4 \mathrm{~cm}$. wide, obtuse to acuminate with an obtuse tip, cuneate at the base, 3-5-nerved, the nerves sometimes prominent beneath but often almost wholly obscured; peduncles terminal, mostly solitary and simple, generally several times as long as the petioles; spikes erect or sometimes curved, as much as $13 \mathrm{~cm}$. long but mostly shorter, little more than $2 \mathrm{~mm}$. thick, pale green, rather densely or often sparsely flowered; bracts oval or suborbicular, centrally peltate; ovaries partly immersed, globose-ovoid, somewhat obliquely apiculate.

Peperomia granulosa Trelease, Journ. Wash. Acad. Sci. 19: 328. 1929 (type from Lancetilla Valley near Tela, Honduras). P. chicbulana Trelease in Standl. Field Mus. Bot. 17: 230. 1937 (type from La Libertad, Petén, C. L. Lundell 3099). P. dantoana Trelease in Yuncker, Field Mus. Bot. 9: 274. 1940 (type from Río Danto near La Ceiba, Honduras). P. riocangrejalensis Trelease in Yuncker, op. cit. 275 (type collected near La Ceiba, Honduras).

On trees in moist or wet, lowland forest, 1,000 meters or lower; Petén; Alta Verapaz; Izabal; Suchitepequez; Retalhuleu; Huehuetenango. Southern Mexico; British Honduras; Honduras and probably farther southward.

Plants usually pendent, glabrous throughout or nearly so, the branches slender, elongate, simple or sparsely branched, with of ten much elongate internodes; leaves thick and fleshy when fresh, thick when dried and often blackish, usually opaque, on petioles $2.5 \mathrm{~cm}$. long or usually much shorter, lance-oblong or ellipticoblong, mostly $5-10 \mathrm{~cm}$. long and $2-4.5 \mathrm{~cm}$. wide, acuminate or long-acuminate, acute or obtuse at the base, not ciliate or very obscurely so, paler beneath, penninerved or 5-7-plinerved with the inner nerves arising far above the base, the nerves usually not visible except against a strong light; peduncles terminal, solitary, simple, naked, generally $1.5 \mathrm{~cm}$. long; spikes slender, often pendent, densely flowered, commonly $5-10 \mathrm{~cm}$. long, scarcely $2 \mathrm{~mm}$. thick at anthesis but thicker in fruit, often curved, glabrous; bracts orbicular, centrally peltate, short-pedicellate; fruits emersed, widely ascending, oblong, about $1.5 \mathrm{~mm}$. long or even larger, obliquely short-rostrate, granular.

It is probable that there are several earlier names for this plant, which is common and probably of wide range in the Central American lowlands. We are using a name whose application is certain, instead of referring the material with question to one of the West Indian or South American species. The present species has been reported from Guatemala under the name Peperomia distachya (L.) A. Dietr.

Peperomia Griggsii C. DC. Candollea 1: 364, 390. 1923; ex Schroeder, Candollea 3: 125. 1926. 
Moist or wet, lowland forest, on logs or rocks, 900 meters or lower; endemic; Alta Verapaz (type from Finca Sepacuité, O. F. Cook \& R. F. Griggs 253); Izabal.

Plants rather small and slender, the stems elongate, branched, repent, rooting at the nodes, sparsely puberulent, the internodes elongate; leaves alternate, the petioles slender, $3.5 \mathrm{~cm}$. long or shorter, puberulent with mostly curved hairs; leaf blades thick and succulent when fresh, thin when dried, green and only slightly fuscescent, not pellucid-punctate, ovate or elliptic-ovate, 5-7 cm. long, $2.5-4 \mathrm{~cm}$. wide, acute or short-acuminate, rounded at the base, peltate very slightly above the base, glabrous above, paler beneath, densely puberulent with chiefly curved hairs, about 7-plinerved, the innermost nerves arising far above the base; peduncles terminal, short or elongate, each bearing 2 geminate secondary peduncles and at their base a small foliaceous bract; immature spikes longer than the secondary peduncles, very slender, erect, $2-3 \mathrm{~cm}$. long, $1 \mathrm{~mm}$. thick, glabrous, very densely flowered.

Peperomia guatemalensis C. DC. in Donn. Smith, Bot. Gaz. 19: 10. 1894.

Epiphytic or terrestrial on soil or rocks, moist or wet, usually mixed, mountain forest, 600-3,300 meters; endemic; Alta Verapaz; Zacapa; Sacatepéquez (type from Acatepeque, J. D. Smith 2587); Chimaltenango; Quezaltenango; San Marcos.

Plants rather slender but succulent, mostly $30 \mathrm{~cm}$. high or less, the stems simple or sparsely branched, erect or decumbent, sometimes rooting at the lower nodes, the nodes elongate, sparsely or densely pilose; leaves thin when dried, chiefly opposite, the uppermost sometimes verticillate, on short or elongate, slender petioles, lanceolate to broadly ovate, mostly $3-6 \mathrm{~cm}$. long, acute or subacute, with a usually obtuse tip, cuneate to obtuse at the base, pellucid-punctate, green above, usually glabrous, somewhat paler beneath, sparsely or densely pilosulous, generally 5-nerved; peduncles axillary or terminal, usually simple, solitary or clustered, equaling or shorter than the petioles, naked; spikes slender, glabrous, pale green, densely or sparsely flowered, about $1.5 \mathrm{~mm}$. thick, often $10 \mathrm{~cm}$. long; bracts elliptic, peltate near the middle, subsessile; ovary partly immersed in the rachis, obovoid, obliquely stigmatiferous at the apex; fruit minute, subglobose, glabrous.

The material referred here is somewhat variable and includes a dozen sheets marked by Trelease as types of new species or varieties. It is questionable whether it would not be preferable to combine all the material with $P$. humilis, from which it is by no means sharply or satisfactorily separable.

Peperomia gymnophylla C. DC. Candollea 1: 363, 390. 1930; ex Schroeder, Candollea 3: 126. 1926.

Known only from the type, Alta Verapaz, Finca Sepacuité, O.F. Cook \& R.F. Griggs 256. 
Plants glabrous, slender, the stems suberect or procumbent and rooting at the nodes, with elongate internodes; leaves alternate, the petioles slender, sometimes $6 \mathrm{~cm}$. long but mostly shorter; leaf blades broadly ovate or rounded-ovate, 4-5.5 $\mathrm{cm}$. long, 3-4.5 cm. wide, acute or rounded and subapiculate at the apex, broadly rounded or usually subcordate at the base, green above, somewhat paler beneath, multiplinerved, the inner nerves arising only slightly above the base of the blade; peduncles terminal, as much as $4 \mathrm{~cm}$. long, the spikes geminate, slender, about $7 \mathrm{~cm}$. long and $2 \mathrm{~mm}$. thick, rather closely flowered, the secondary peduncles 1-1.5 cm. long; bracts minute, rounded, peltate; ovaries ovoid, obliquely truncate at the apex, the stigma anterior.

We know this species only by a photograph of the type, in the United States National Herbarium. It does not seem to agree with any recent Guatemalan collections.

\section{Peperomia heterodoxa Standl. \& Steyerm., sp. nov.}

Known only from the type, Huehuetenango, Sierra de los Cuchumatanes, between Santa Ana Huista and Rancho Lucas, 800900 meters, Steyermark 51340 (in Herbarium of Chicago Natural History Museum).

Plants erect, the stems stout, simple below, sparsely branched above, as much as $4 \mathrm{~mm}$. thick below, the branches divaricate, with short or elongate internodes, finely puberulent or in age glabrate; leaves mostly quaternate, the lower leaves rather thick and fleshy, very shortly petiolate, oval, elliptic, or oval-obovate, mostly 8-10 mm. long, rounded at the apex, subacute at the base, densely granular; blades of the upper leaves thin, on slender petioles $4 \mathrm{~mm}$. long or shorter, elliptic or ovate-elliptic, mostly $2-2.5 \mathrm{~cm}$. long and 7-12 mm. wide, acute with an obtuse tip, acute at the base, green when dried, opaque or nearly so, deep green above, pale beneath, glabrous, 3-nerved; peduncles terminal, solitary or clustered, about as long as the petioles or elongate, the spikes very slender, longer than the leaves, $6 \mathrm{~cm}$. long or more, scarcely $1 \mathrm{~mm}$. thick, remotely flowered; fruits emersed, minute, ovoid, slightly narrowed to the apex, the stigma subapical.

Planta erecta, caulibus crassis inferne simplicibus, superne sparse ramosis, ramis gracilibus divaricatis, internodiis brevibus vel elongatis minute puberulis vel glabratis; folia plerumque quaternata biformia, inferiora brevissime petiolata crassa ovalia, elliptica vel ovali-obovata plerumque $8-10 \mathrm{~mm}$. longa, apice rotundata, basi subacuta, dense granulosa; folia superiora tenuia breviter graciliter petiolata, elliptica vel ovato-elliptica, vulgo $2-2.5 \mathrm{~cm}$. longa et $7-12 \mathrm{~mm}$. lata, acuta, acumine obtuso, basi acuta, subtus pallida, glabra, 3-nervia; pedunculi terminales singuli vel aggregati simplices nudi, spicis gracillimis vix $1 \mathrm{~mm}$. crassis laxifloris; fructus minutus ovoideus, stigmate subapicali.

The plant is noteworthy for its strongly dimorphous leaves, the variation being much greater than we have observed in any other species of the region. It bears some resemblance to $P$. Liebmannii C. DC.

Peperomia hispidula (Swartz) A. Dietr. Sp. Pl. 1: 165. 1831. Piper hispidulum Swartz, Prodr. Veg. Ind. Occ. 15. 1788. 
Moist or wet mountain forest, 2,600 meters; Huehuetenango (Sierra de los Cuchumatanes, between Todos Santos and San Juan Atitán, Steyermark 51941). Southern Mexico; West Indies; South America.

Plants terrestrial, small and very slender, usually repent, the stems succulent, sparsely branched, hispidulous, at least near the nodes; leaves very small, alternate, slender-petiolate, thin and translucent when dried, rounded or subreniform, mostly 6-10 $\mathrm{mm}$. long and 7-12 $\mathrm{mm}$. wide, broadly rounded at the apex, emarginate at the base, sparsely pilosulous on the upper surface, glabrous and minutely punctulate beneath, obscurely 5-nerved; peduncles opposite the leaves, much longer than the petioles, pilosulous below; spikes about three times as long as the leaves, filiform, glabrous, sparsely flowered; bracts orbicular, centrally peltate, subsessile; style about equaling the ovary; fruit ellipsoid, hispidulous, stipitate at the base, mucronate at the apex; stigma small, glabrous.

Peperomia hondoana Trelease \& Standley, sp. nov.

On shaded rocks or rather dry bluffs, 400-1,800 meters; endemic; Zacapa (type from base of Sierra de las Minas, between Río Hondo and the waterfall, Steyermark 29401, in Herbarium of Chicago Natural History Museum; also at Aguas Calientes); Huehuetenango (between La Libertad and Paso del Boquerón).

Plants forming dense clumps, the stems erect or sometimes decumbent at the base, stout, simple below, sparsely branched above, with very slender branches, very densely villous-hirsute with long slender brownish spreading multicellular hairs, the upper branches much less copiously villous, the internodes short or elongate; leaves verticillate, mostly in whorls of 4-6, on short stout petioles; lower leaves broadly obovate or rounded-obovate, mostly $1.5-2 \mathrm{~cm}$. long, rounded at the apex, broadly cuneate at the base, fuscous when dry, rather thin, not pellucid-punctate, very densely pilose on both surfaces with slender spreading hairs; upper leaves larger, on longer petioles, appearing thinner, cuneate-obovate to obovate-elliptic, mostly 3-4 cm. long and $1.5-2 \mathrm{~cm}$. wide, obtuse or rarely subacute, acute at the base, sparsely short-pilose chiefly on the nerves, 3-nerved; peduncles terminal, generally clustered, very slender, sparsely pilose, several times as long as the petioles, the spikes longer than the leaves, sparsely flowered, $6 \mathrm{~cm}$. long or shorter, less than $1 \mathrm{~mm}$. in diameter, glabrous; bracts centrally peltate, sessile or nearly so, suborbicular.

Caules vulgo caespitosi crassiusculi erecti vel basi decumbentes, inferne simplices, superne sparse ramosi, densissime pilis longis patentibus multilocularibus brunneis villoso-hirsuti; folia plerumque 4-6-nata, breviter crasseque petiolata, inferiora minora late obovata vel rotundo-obovata apice rotundata, basi late cuneata, utrinque dense pilis tenuibus patentibus pilosa; folia superiora majora tenuiora longius petiolata, cuneato-obovata vel obovato-elliptica, obtusa vel rare subacuta, basi acuta, sparse praesertim ad nervos pilosa, 3-nervia; pedunculi terminales aggregati sparse pilosi, spicis foliis longioribus gracillimis sparsifloris glabris vix $1 \mathrm{~mm}$. diam.; bracteae centro peltatae suborbiculares. 


\section{Peperomia huitzensis Standl. \& Steyerm., sp. nov.}

Known only from the type, Huehuetenango, Cerro Huitz, between Mimanhuitz and Yulhuitz, Sierra de los Cuchumatanes, 1,500-2,000 meters, Steyermark 48613 (type in Herbarium of Chicago Natural History Museum).

Plants terrestrial, erect, about $30 \mathrm{~cm}$. high, the stems rather slender, simple, with short internodes, thinly pilose with weak yellowish hairs; leaves alternate, the petioles rather slender, $2-3.5 \mathrm{~cm}$. long, sparsely pilose or glabrate; leaf blades broadly oval or elliptic, about $12 \mathrm{~cm}$. long and 6-7 $\mathrm{cm}$. wide, the apex not seen, rounded at the base, rather densely pilose above with short weak hairs, slightly paler beneath and similarly pilose, very sparsely and coarsely pellucid-punctate, penninerved, the nerves about 6 on each side, obscure; peduncles terminal, about equaling the petioles, sparsely and weakly pilose, bearing about 7 racemosely disposed secondary peduncles, these slender, $2.5 \mathrm{~cm}$. long or shorter; spikes very slender, greenish white, $13-17 \mathrm{~cm}$. long, little more than $1 \mathrm{~mm}$. thick, rather densely flowered, glabrous; ovules immersed in the rachis.

Planta terrestris erecta, internodiis brevibus sparse fulvescenti-pilosis; folia modica alterna in sicco fuscescentia, graciliter longipetiolata, late ovalia vel elliptica, basi rotundata, sparse grosse pellucido-punctata, utrinque sat dense pilis gracillimis fulvescentibus laxis pilosa, penninervia, nervis utroque latere ca. 6; pedunculi terminales singuli erecti, pedunculis secundariis ca. 7 racemose dispositis; spicae gracillimae vix ultra $1 \mathrm{~mm}$. crassae glabrae sat densiflorae, bracteis orbicularibus centro peltatis.

None of the few leaves present on the single plant of the type sheet shows a perfect apex, and it is uncertain whether the leaves are acute or obtuse. The species represented seems to be a very distinct one.

Peperomia humilis (Vahl) A. Dietr. Sp. Pl. 1: 168. 1831. Piper humile Vahl, Enum. Pl. 1: 349. 1804. Peperomia Langsdorffi Miq. Syst. Piper. 116. 1843. Peperomia Johnstonii Trelease in Standl. Field Mus. Bot. 22: 9. 1940 (type from Volcán de Agua, Sacatepéquez, John R. Johnston 220). Verdolaga (Jalapa).

Epiphytic or terrestrial in moist or wet, mountain forest, 1,6002,850 meters; Chiquimula; Jalapa; Guatemala; Sacatepéquez; Chimaltenango; Sololá; Suchitepequez; Quezaltenango; San Marcos; Huehuetenango. Probably extending farther southward in Central America and northward into southern Mexico; West Indies; South America.

Plants usually erect and $40 \mathrm{~cm}$ : high or less, the stems slender or stout, simple or sparsely branched, succulent, with mostly elongate internodes, rather sparsely short-pilose with weak hairs or glabrate; leaves rather small, opposite or the uppermost ternate, on slender petioles $1.5 \mathrm{~cm}$. long or shorter; leaf blades thin, at least when dried, obovate to elliptic or rounded-elliptic, generally broadest 
above the middle, mostly $2-6 \mathrm{~cm}$. long and $1-2.5 \mathrm{~cm}$. wide, rounded or very obtuse at the apex, cuneate at the base, sparsely or densely short-pilose on both surfaces with slender, of ten yellowish hairs, green above, paler beneath, 3-nerved; peduncles terminal, solitary or often clustered, mostly simple, short, the spikes very slender, 4-12 cm. long, 1-1.5 mm. thick, glabrous, laxly flowered; bracts suborbicular, centrally peltate, short-pedicellate; ovary emersed, ovoid, obliquely stigmatiferous slightly below the apex, the stigma globose, papillose.

As here treated this is a rather variable species, but not unreasonably so. Ten of the sheets were annotated by Trelease as types of new species or varieties, but the material seems to be referable satisfactorily to the common West Indian species, which heretofore has not been recorded definitely from the mainland of North America.

Peperomia jilotepequeana Trelease \& Standley, sp. nov. Cigarrillo (Chiquimula).

Moist or wet banks, usually in dense forest, 1,500-2,000 meters; Chiquimula (Cerro Brujo); Sacatepéquez; Chimaltenango (type collected along the road between Chimaltenango and San Martín Jilotepeque, Standley 80901; also on Volcán de Fuego; type in Herbarium of Chicago Natural History Museum). Southern Mexico.

Plants terrestrial, erect, $50 \mathrm{~cm}$. high or less, the stems very thick, long-enduring, with very short internodes, simple and naked below, sometimes with a few branches above, leafy near the apex, the internodes when dry ochraceous and closely and conspicuously transverse-rugose; leaves thin, not pellucid-punctate, densely and finely black-punctate beneath, on long slender petioles $7 \mathrm{~cm}$. long or shorter; leaf blades ovate to oblong-ovate or elliptic-ovate, mostly $8.5-14 \mathrm{~cm}$. long and 4-5.5 $\mathrm{cm}$. wide, acuminate, rounded or very obtuse at the base, penninerved or plinerved, with 3-4 nerves on each side, these all arising well below the middle of the blade, ascending at a very narrow angle; peduncles terminal, simple, naked, solitary or clustered, very slender, about equaling the petioles, $14 \mathrm{~cm}$. long or shorter, $2 \mathrm{~mm}$. thick, rather densely flowered, the rachis glabrous; bracts small, orbicular, peltate at the center, sessile or nearly so, black-punctate; ovaries immersed.

Planta terrestris erecta, caule crasso inferne simplici atque aphyllo, superne interdum sparse ramoso, internodiis brevissimis transverse rugosis; folia tenuia longe graciliter petiolata, opaca, utrinque dense nigro-puncticulata, ovata, oblongoovata vel elliptico-ovata, acuminata, basi rotundata vel obtusissima, 7-9-plinervia, supra glabra, subtus paullo pallidiora ad nervos breviter patenti-pilosa; pedunculi terminales petiolis subaequilongi simplices nudi, solitarii vel pauci, spicis usque ad $14 \mathrm{~cm}$. longis, $2 \mathrm{~mm}$. crassis densifloris; bracteae orbiculari-peltatae nigropuncticulatae.

Part of the material we refer here was marked by Trelease as representing four other species and varieties. The plants apparently lose all their leaves during the dry season, developing new ones each wet season at the apex of the rather hard and almost woody stem. 
Peperomia lenticularis Dahlstedt, Svensk. Vet. Akad. Handl. 33, no. 2: 154. pl. 5, f. 2. 1900 .

On trees in moist or rather dry forest, 300-600 meters; Santa Rosa; Retalhuleu (type from Retalhuleu, Bernoulli \& Cario 2703). El Salvador; Honduras; Brazil.

Plants very succulent, glabrous almost throughout, the stems much elongate and slender, creeping and rooting at the nodes, bearing a few curved hairs; leaves opposite, or the uppermost rarely ternate, lenticular and very thick, almost sessile, suborbicular, broadly rounded at the apex, broadly rounded or somewhat subcordate at the base, 5-10 mm. long and wide, sparsely ciliate; spikes mostly terminal, the peduncles simple and solitary, short, hirtellous, the spikes dense, $4 \mathrm{~cm}$. long or shorter, $1-1.5 \mathrm{~mm}$. thick, the rachis glabrous; bracts small, rounded; fruits $0.7 \mathrm{~mm}$. long, obliquely appendaged at the apex.

\section{Peperomia Liebmannii C. DC. Linnaea 37: 383. 1871-73.}

On rocks in shaded moist places, $1,000-1,600$ meters; Alta Verapaz; Huehuetenango (Sierra de los Cuchumatanes). Southern Mexico, the type from Oaxaca.

Plants erect, $35 \mathrm{~cm}$. high or less, the stems slender but succulent, simple below, sparsely branched above, puberulent with short curved hairs, the internodes elongate; leaves small, in verticils of $3-5$, the petioles slender, $12 \mathrm{~mm}$. long or less, puberulent; leaf blades thin, often brownish when dried, obovate-rhombic or broadly elliptic, mostly $2-2.5 \mathrm{~cm}$. long and $10-13 \mathrm{~mm}$. wide, very obtuse or subacute at the apex, acute or subacute at the base, puberulent or pilosulous on both surfaces, somewhat paler beneath, ciliate, 3-nerved; peduncles axillary and terminal, simple, the terminal ones often clustered, about equaling the petioles, puberulent, naked; spikes longer than the leaves, slender, about $1 \mathrm{~mm}$. thick, densely flowered, the rachis glabrous; bracts suborbicular, centrally peltate, sessile; ovary partly immersed, obliquely stigmatiferous at the apex, puberulent.

\section{Peperomia limana Trelease \& Standley, sp. nov.}

Terrestrial or epiphytic in moist or wet, mixed or pine, mountain forest, 1,800-2,800 meters; endemic; El Progreso (Sierra de las Minas); Zacapa (type from Sierra de las Minas, in canyon along Río Lima, below Finca Alejandría, Steyermark 30048; in Herbarium of Chicago Natural History Museum); Quiché; Huehuetenango (Sierra de los Cuchumatanes); San Marcos (volcanoes of Tacaná and Tajumulco).

Plants glabrous, erect, $40 \mathrm{~cm}$. high or less, the stems simple, sometimes decumbent at the base, very stout, with short internodes; leaves alternate, green or fuscescent when dry, thick and fleshy when fresh, finely and densely pellucidpunctate, the petioles stout or slender, $3 \mathrm{~cm}$. long or shorter; leaf blades elliptic to lance-elliptic or oblong-elliptic, mostly $10-14 \mathrm{~cm}$. long and 4-5 cm. wide, acuminate, with an acute tip, acute to attenuate at the base, deep green above, paler beneath, penninerved, the nerves about 5 on each side, very slender, ascend- 
ing at a very narrow angle, some of them arising above the middle of the blade; peduncles terminal, solitary, very stout and thick, mostly $1 \mathrm{~cm}$. long or shorter, bearing near the apex a small or large leaf; spikes stout, erect or in age recurved, commonly 8-20 cm. long, 3.5-4 mm. thick, very densely flowered; bracts orbicular, centrally peltate, conspicuously granular.

Planta terrestris vel epiphytica glabra, caulibus simplicibus erectis vel basi decumbentibus, internodiis brevibus; folia alterna longiuscule crasseque petiolata crassiuscula, dense minuteque pellucido-punctata, in sicco viridia vel fuscescentia, elliptica usque ad lanceolato-elliptica vel oblongo-elliptica, majuscula, acute acuminata, basi acuta vel attenuata, penninervia, nervis utroque latere ca. 5; pedunculi terminales singuli simplices crassi prope apicem folio parvo vel magno onusti, spicis crassis erectis vel recurvis $3.5-4 \mathrm{~mm}$. crassis densifloris; bracteae orbiculares centro peltatae granulosae.

The plant has been reported from Quiché (on the basis of Heyde \& Lux 3456) as P. adscendens C. DC.

\section{Peperomia luisana Trelease \& Standley, sp. nov.}

On trees or cliffs in lowland forest, 500 meters or lower; endemic; cultivated in Chiquimula; Escuintla (type from San Luis, north of Escuintla, Standley 60134; in Herbarium of Chicago Natural History Museum); Retalhuleu.

Stems often much elongate, pendent from cliffs or from the branches of trees, stout, with mostly elongate internodes, often rooting at the lower nodes, glabrous or when young sparsely pilose; leaves alternate, thick and fleshy when fresh, rather thick and blackish when dried, inconspicuously or not at all pellucid-punctate, the stout petioles mostly $1-2.5 \mathrm{~cm}$. long, white-hirsute; leaf blades oval to broadly ovate or oblong-ovate, mostly 5-8 cm. long and $2-5 \mathrm{~cm}$. wide, acute or short-acuminate, rounded or very obtuse at the base, glabrous, conspicuously ciliate, penninerved or 5-7-plinerved, with the inner nerves arising far above the base of the blade; peduncles slender, terminal, glabrous, simple, naked, solitary, about $2 \mathrm{~cm}$. long; spikes slender, as much as $8 \mathrm{~cm}$. long, glabrous, densely flowered; bracts orbicular, centrally peltate; fruits emersed, obliquely ascending, oblong, about $2 \mathrm{~mm}$. long, obliquely subrostrate, glabrous.

Caules elongati vulgo penduli crassiusculi, internodiis elongatis, glabris vel juvenilibus sparse pilosis; folia alterna modica longiuscule petiolata crasse carnosa in sicco fuscescentia, ovalia usque late ovata vel oblongo-ovata, acuta vel breviter acuminata, basi late obtusa vel rotundata, glabra, ciliata, 5-7-plinervia, nervis interioribus bene supra basin laminae nascentibus; pedunculi terminales singuli simplices nudi glabri, spicis longis gracilibus densifloris; bracteae rotundatae centro peltatae; fructus anguste oblongus oblique adscendens glaber oblique subrostratus.

Each of the four sheets of this species was marked by Trelease as the type of a new species.

Peperomia maculosa (L.) Hook. Exot. Fl. pl. 92. 1833. Piper maculosum L. Sp. Pl. 30. 1753. Peperomia variegata Ruiz \& Pavón, 
Fl. Peruv. 1: 33. 1798. $P$. suavis var. hondurensis Trelease in Yuncker, Field Mus. Bot. 17: 338. 1938 (type from El Achote, above Siguatepeque, Honduras). Culantro (Quezaltenango).

Moist or wet forest, epiphytic or sometimes terrestrial, often on limestone, 1,100-1,500 meters; Alta Verapaz; Chiquimula; Quezaltenango; Huehuetenango. Honduras; West Indies; South America.

Plants usually large, coarse, and very succulent, the stems simple or sparsely branched, short or somewhat elongate, usually very thick, glabrous or pilose, procumbent or repent and rooting at the lower nodes; petioles stout, mostly long, often exceeding the blades, sparsely pilose or glabrous; leaf blades extremely thick and fleshy when fresh, deep green above, pale beneath, opaque, subcoriaceous when dry, oblong-ovate or elliptic-ovate, mostly $12-23 \mathrm{~cm}$. long or even larger, acuminate or long-acuminate, rounded at the base, peltate a short distance above the base, glabrous above, glabrous or sparsely puberulent beneath, about 7-plinerved, the costa conspicuous but the lateral nerves often obsolete; peduncles rather short and stout, several times shorter than the spikes, terminal; spikes slender, erect, often much longer than the leaves, of ten $20 \mathrm{~cm}$. long or more, $3 \mathrm{~mm}$. thick, rather densely flowered; bracts orbicular, centrally peltate; fruits ovoidglobose, verrucose, protracted at the apex into a somewhat curved, beak-like appendage.

Among the Guatemalan collections that we refer here Trelease indicated three or four unpublished species, but all the material appears conspecific and we find no definite character to justify our separating it from the common West Indian P. maculosa. The plants when fresh have a strong and distinctive spicy odor, suggestive of ginger. About Cobán this plant is well known, and the leaves often are peddled on the streets by the Indians. The very thick leaves are bound on the head to relieve headache. The plant is one of the most celebrated medicinal plants of the Cobán region, and is used in treating a variety of other ailments besides headache. The species $P$. suavis Trelease, of which a variety is cited above in synonymy, has not been published formally, although a Latin diagnosis of the variety was published, as cited.

Peperomia major (Miq.) C. DC. in DC. Prodr. 16, pt. 1: 432. 1869. Acrocarpidium majus Miq. Syst. Piper. 60. 1843. $P$. tremulaeformis Trelease in Yuncker, Field Mus. Bot. 9: 276. 1940 (type from Mount Cangrejal near La Ceiba, Honduras). Yepasetas (Alta Verapaz).

On tree trunks or rocks in moist or wet, mixed, lowland or mountain forest, 2,400 meters or lower; Alta Verapaz; Izabal; Quezaltenango; Huehuetenango. Southern Mexico; British Honduras; Atlantic lowlands of Honduras; West Indies; South America. 
Plants repent or subscandent, the stems slender, often much elongate, with elongate internodes, rather densely pubescent with fine appressed hairs; leaves on long slender petioles as much as $4 \mathrm{~cm}$. long, broadly ovate or usually reniformovate, commonly $3-4.5 \mathrm{~cm}$. long and $3-4 \mathrm{~cm}$. wide, pointed or subacute at the apex, shallowly cordate at the base or sometimes only rounded, rather thick and succulent when fresh, obscurely if at all pellucid-punctate, deep green above, paler beneath, often yellowish green, usually 7-nerved, the nerves evident beneath, sparsely or rather densely pubescent on both surfaces with short appressed hairs; peduncles bracteate, axillary, solitary, equaling or only half as long as the spikes; spikes short, densely flowered, the bracts small, rounded, centrally peltate, subsessile; ovary subimmersed; fruits cylindric-ellipsoid, papillose below, spreading, rather long-rostrate, the beak often equaling the body of the fruit.

This species has been reported from Guatemala as $P$. urocarpa (Miq.) Fisch. \& Mey. The Central American material is somewhat variable but probably all of it is conspecific. Some of the collections approach rather closely $P$. serpens Swartz, a plant widely distributed in the West Indies and South America, with somewhat smaller leaves than P. major.

\section{Peperomia mexicana Miquel, Syst. Piper. 75. 1843.}

Terrestrial in moist or wet, shaded places, often on cliffs, 3002,600 meters; Izabal; Zacapa; Santa Rosa; Quezaltenango. Southern Mexico.

Plants glabrous, arising from a small globose hypogaean tuber, acaulescent or with a very short, tuberous stem; leaves few, green, erect on long slender petioles, the petioles mostly $2.5 \mathrm{~cm}$. long or shorter; leaf blades very thin when dried, slightly paler beneath, broadly ovate or rounded-ovate to oblong-ovate, mostly $2.5 \mathrm{~cm}$. long or shorter, acute, broadly rounded at the base, peltate slightly above the base, obscurely 3-nerved; peduncles very slender, simple, usually $4-5 \mathrm{~cm}$. long; spikes very slender, pale green, mostly $4-5 \mathrm{~cm}$. long; bracts ovate or ovate-lanceolate, acute, $1 \mathrm{~mm}$. long; stamens with distinct filaments; fruits cylindric, $1 \mathrm{~mm}$. long, obscurely reticulate, short-stipitate, the style slender, cylindric, half as long as the fruit, the stigma apical, capitellate.

\section{Peperomia minarum Standl. \& Steyerm., sp. nov.}

Known only from the type, El Progreso, Sierra de las Minas, along trail between Finca Piamonte and Cimiento, Steyermark 43747 (in Herbarium of Chicago Natural History Museum).

Plants epiphytic, the stems elongate and pendent, about $5 \mathrm{~mm}$. thick, with short or elongate internodes, sparsely pilose with long slender spreading whitish hairs; leaves alternate, thick and fleshy when fresh, rather thick and blackish when dried, finely punctate on both surfaces but not pellucid-punctate, the petioles stout, about $1 \mathrm{~cm}$. long, thinly pilose; leaf blades broadly ovate or oval-ovate, mostly 5-7 cm. long and 3-4 cm. wide, rather abruptly acute, rounded at the base, deep green on the upper surface and sparsely hirsute with long spreading hairs, 
conspicuously ciliate, somewhat paler beneath, glabrous or nearly so, 5-7-plinerved or almost penninerved, the inner nerves arising far above the base of the blade, visible only against a strong light; spikes unknown.

Planta epiphytica, caulibus elongatis pendulis crassis, internodiis brevibus vel elongatis, sparse pilis longis patentibus albidis pilosis; folia alterna crasse petiolata in sicco fuscescentia non pellucido-punctata, petiolis pilosis; lamina late ovata vel ovali-ovata subabrupte acuta, basi rotundata, ciliata, supra sparse pilis patentibus hirsuta, subtus paullo pallidior glabra vel glabrata, 5-7-plinervia, nervis obscuris; spicae ignotae.

\section{Peperomia molithrix Trelease \& Standley, sp. nov.}

Epiphytic on tree trunks or growing among or on rocks in dense, moist or rather dry forest, 200-1,700 meters; endemic; Zacapa (type collected near Zacapa, Standley 74685; in Herbarium of Chicago Natural History Museum); Chiquimula (near Concepción de las Minas); Jalapa (Chahuite, northwest of Jalapa); Santa Rosa.

Plants erect or ascending, $25 \mathrm{~cm}$. high or less, the stems very thick and stout, usually simple, naked below, leafy near the apex, with very short internodes, sparsely pilose or glabrate; leaves apparently deciduous during the dry season, very thin, alternate, translucent but not pellucid-punctate, the petioles very slender, $7.5 \mathrm{~cm}$. long or shorter, glabrous or short-pilose; leaf blades somewhat paler beneath, ovate or broadly ovate, mostly $5-8 \mathrm{~cm}$. long and $3.5-4.5 \mathrm{~cm}$. wide, acute, rounded or subcordate at the base, peltate a short distance above the base, sparsely and inconspicuously short-pilose above, glabrous beneath or sparsely short-pilose on the nerves, about 7-nerved, the nerves arising at the point of attachment of the petiole; peduncles terminal, simple, naked, very slender, about as long as the petioles, glabrous; spikes very slender, much exceeding the leaves, $14 \mathrm{~cm}$. long or shorter, $1.5 \mathrm{~mm}$. thick, densely flowered, the rachis glabrous or sparsely and minutely puberulent; fruits emersed, subglobose or ovoid-globose, about $0.7 \mathrm{~mm}$. long, the stigma apical or nearly so.

Planta erecta vel adscendens, caule crasso vulgo simplici prope apicem foliato, internodiis brevissimis sparse pilosulis vel glabratis; folia tenuia longissime graciliter petiolata epunctata alterna, ovata vel late ovata, acuta, basi rotundata vel subcordata, supra sparse breviter pilosula, subtus glabra vel ad nervos sparse breviter pilosula, ca. 7-nervia; pedunculi terminales longi gracillimi nudi petiolis subaequilongi, spicis gracilibus foliis multo longioribus $1.5 \mathrm{~mm}$. crassis densifloris, rhachi glabra vel minute puberula; fructus emersus subglobosus, apice stigmatiferus.

Of the four sheets of this plant seen by Trelease, each was inscribed as a new species, but all of them, with one later collection, appear to us to represent a single species. The plant has been reported from Guatemala as $P$. Muelleri C. DC.

Peperomia nigropunctata Miquel, Syst. Piper. 188. 1843. Piper acuminatum L. Sp. Pl. 30. 1753. Peperomia acuminata Dahlst. Stud. 123. 1900, not Ruiz \& Pavón, 1794. P. sanfelipensis C. DC. 
in Donn. Smith, Bot. Gaz. 19: 9. 1894 (type from San Felipe, Retalhuleu, J. D. Smith 2583). Hierba de águila (Suchitepequez, fide Morales).

Moist or wet, mixed forest, chiefly in the mountains, on trees or rocks, 1,800 meters or lower; Alta Verapaz; Izabal; Zacapa; Escuintla; Guatemala; Suchitepequez; Retalhuleu; Quezaltenango; San Marcos; Huehuetenango. Southern Mexico; British Honduras; doubtless extending farther southward in Central America; West Indies; South America.

Plants glabrous throughout, the stems branched or simple, short or elongate, often pendent, generally rooting at the lower nodes, black-punctate, the internodes short or elongate; leaves small, on petioles $1.5 \mathrm{~cm}$. long or shorter, mostly lanceolate or rhombic-lanceolate, generally $4-8 \mathrm{~cm}$. long and 1-3 cm. wide, acute or acuminate, acute or attenuate at the base, densely black-punctate on both surfaces, 5-plinerved, the nerves usually obscure, the leaves mostly blackening when dried; peduncles axillary and terminal, simple, naked, equaling or longer than the petioles; spikes slender, black-punctate, sometimes $14 \mathrm{~cm}$. long but usually shorter, $1 \mathrm{~mm}$. thick, pale green; bracts rounded, centrally peltate, subsessile; ovary subimpressed in the rachis, ovoid, acutish, bearing below the apex the small puberulent stigma; fruit ovoid-globose, smooth, obliquely rostellate at the apex.

This plant has been reported from Guatemala under the erroneous name "Peperomia nigropunctula Miq."

Peperomia obtusifolia (L.) A. Dietr. Sp. Pl. 1: 154. 1831. Piper obtusifolium L. Sp. Pl. 30. 1753. P. magnoliaefolium Jacq. Coll. Bot. 3: 210. 1789. Peperomia magnoliaefolia A. Dietr. op. cit. 153. P. Gollii Trelease ex Standl. Field Mus. Bot. 10: 156. pl. 31. 1931 (description based on Honduran material, but no type cited). P. petenensis Trelease in Standl. Field Mus. Bot. 17: 230. 1937 (type collected near La Libertad, Petén, C. L. Lundell 2129). $P$. lancetillana Trelease in Yuncker, Field Mus. Bot. 17: 334. 1938 (type from Lancetilla Valley near Tela, Honduras). P. lancetillana var. spathifolia Trelease, op. cit. 335. P. Yousei Trelease in Yuncker, Field Mus. Bot. 17: 339. 1938 (type collected at El Achote, above Siguatepeque, Honduras). P. Yunckeri Trelease, op. cit. 340. 1938 (type collected near Siguatepeque, Honduras). P. romaensis Trelease in Yuncker, Field Mus. Bot. 9: 275. 1940 (type from Roma siding, east of La Ceiba, Honduras). Culantro de montaña; Sakixacpec (Cobán, Quecchí); Chunupcaac (Petén, Maya).

Moist or wet forest, usually epiphytic but sometimes on banks or rocks, 2,600 meters or lower; Petén; Alta Verapaz; Izabal; Zacapa; Chiquimula; Guatemala; Sololá; Suchitepequez; Retalhuleu; Quezaltenango; San Marcos; Huehuetenango. Southern Mexico; British 
Honduras to Honduras and Salvador, and probably southward throughout Central America; West Indies; South America.

Plants stout, glabrous, usually erect, sometimes decumbent, the stems simple or sparsely branched, with short or somewhat elongate internodes; leaves alternate, very thick and fleshy when fresh, subcoriaceous when dry, not pellucid-punctate or very inconspicuously so, usually not darkening when dried, on stout, short or elongate petioles; leaf blades rounded-obovate to spatulate-obovate, mostly 5-12 $\mathrm{cm}$. long and 3-5 $\mathrm{cm}$. wide, variable in shape and size, broadly rounded to very obtuse at the apex, sometimes emarginate, cuneate or attenuate at the base, the costa emitting 3-5 inconspicuous nerves on each side; peduncles $2-5 \mathrm{~cm}$. long or longer, bearing 1-2 spikes or rarely more, terminal, solitary or clustered; spikes densely flowered, much exceeding the leaves, mostly $6-14 \mathrm{~cm}$. long and 3-4 $\mathrm{mm}$. thick; bracts suborbicular, centrally peltate, very shortly pedicellate; ovary immersed; fruits ovoid-cylindric or ovoid-globose, more or less rostrate at the apex.

The material referred here is decidedly variable in foliage and also in the size and disposition of the spikes, but none of the more obvious characters by which species might be segregated seem to be constant, and it seems better to place all the very numerous Guatemalan collections in a single, not unusually variable species. No fewer than 21 of the Guatemalan specimens have been marked by Trelease as types of new species and varieties.

\section{Peperomia pecuniifolia Trelease \& Standley, sp. nov.}

Epiphytic or on rather dry rocks, 1,500-2,800 meters; endemic; Quezaltenango (type from Volcán de Santa María, above Santa María de Jesús, Steyermark 34235, in Herbarium of Chicago Natural History Museum); San Marcos (Volcán de Tajumulco, near Tajumulco).

Plants stout, the stems elongate, apparently pendent or procumbent, sparsely branched, pubescent, at least around the nodes, the nodes elongate; leaves mostly ternate or quaternate, or some of the lower ones opposite, on stout petioles $8 \mathrm{~mm}$. long or shorter, very thick and fleshy when fresh, coriaceous when dried and greenish or yellowish, opaque, orbicular to rounded-oval, mostly $2.5-4 \mathrm{~cm}$. long and $1.5-4 \mathrm{~cm}$. wide, broadly rounded at the apex, sometimes slightly emarginate, rounded at the base, usually lustrous above, glabrous or nearly so, ciliate, 5-nerved; spikes unknown.

Planta epiphytica vel clivicola, caulibus crassis elongatis ut videtur pendulis, sparse ramosis, saltem ad nodos pubescentibus, internodiis elongatis; folia plerumque 3-4-nata, inferiora interdum opposita, crassissima, non pellucido-punctata, crasse petiolata, petiolis pubescentibus, orbicularia vel rotundo-ovalia, apice late rotundata, interdum breviter emarginata, basi rotundata, 5-nervia, glabra vel glabrata, ciliata; spicae ignotae.

The relationship of this Guatemalan plant is clearly with $P$. trifolia (L.) A. Dietr. of the West Indies. A different species may not be represented, but the plant of the Antilles has consistently 
smaller leaves than the continental one, and the latter probably constitutes a distinct species.

Peperomia pellucida (L.) HBK. Nov. Gen. \& Sp. 1: 64.1815. Piper pellucidum L. Sp. Pl. 30. 1753. Choec (Huehuetenango); Mazamorra (Petén, fide Lundell).

Moist or wet thickets or mixed forest, often a weed in waste ground about dwellings, most common below 1,000 meters but ascending to 2,500 meters or more; Petén; Alta Verapaz; Izabal; Jutiapa; Santa Rosa; Escuintla; Suchitepequez; Retalhuleu; Quezaltenango; San Marcos; Huehuetenango. Mexico; British Honduras to El Salvador and Panama; West Indies; South America; introduced in tropical Africa.

Plants slender and low, mostly $25 \mathrm{~cm}$. high or less, erect or ascending, sometimes procumbent, appearing glabrous throughout, the stems very succulent and brittle, the plants annual or sometimes probably more enduring and with decumbent and rooting bases, sparsely branched; leaves thin, on long slender petioles, deltoid-ovate or rounded-ovate, mostly $1.5-3 \mathrm{~cm}$. long, acute or obtuse, shallowly cordate to broadly rounded at the base, sparsely pellucid-punctate or epunctate, often pale green, especially beneath, glabrous or sometimes inconspicuously ciliate and with a few scattered hairs on the upper surface, palmately 5-nerved; flower spikes simple, pale green, very slender and usually remotely flowered, mostly $1.5-5 \mathrm{~cm}$. long, scarcely more than $1 \mathrm{~mm}$. thick, slender-pedunculate; bracts minute, orbicular, peltate at the center, almost sessile; fruits subglobose, about $0.5 \mathrm{~mm}$. in diameter.

Sometimes called "lombricilla" and "hierba de sapo" in El Salvador. The plant is a common weed in many parts of the Central American lowlands.

Peperomia peltata C. DC. Ann. Cons. Jard. Bot. Genève 2: 277. 1898. P. pedicellata Dahlstedt, Svensk. Vet. Akad. Handl. 33, no. 2: 35. 1900 (based on the same collection as $P$. peltata). Agria (Chiquimula).

On moist or wet cliffs or rocks, 900-2,400 meters; endemic; Chiquimula; Jalapa; Santa Rosa (type from Santa Rosa, Heyde \& Lux 3829); San Marcos.

Plants acaulescent, arising from a hypogaean tuber, glabrous; leaves few, basal, erect, the petioles very slender, twice as long as the blades or often much longer; leaf blades broadly ovate, mostly $4-8 \mathrm{~cm}$. long, acute or short-acuminate, broadly rounded or subcordate at the base, peltate a short distance above the base, very thin, translucent, sparsely pellucid-punctate, usually 7-nerved; peduncles slender, arising from the tuber, erect, usually longer than the leaves; spikes very laxly flowered, with a rather thick, glabrous rachis; bracts small, ovate, pointed 
at the apex, peltate; fruit oblong-cylindric, slightly verruculose, long-stipitate, bearing at the apex a slender suboblique conic appendage.

The type collection was once listed from Guatemala as $P$. ovatopeltata C. DC.

Peperomia peltilimba C. DC. ex Trelease, Bot. Gaz. 73: 145. 1922. P. hernandifolia var. cryptocarpa Trelease, Bot. Gaz. 73: 145. 1922 (type from Finca Sepacuité, Alta Verapaz, O. F. Cook \& R. F. Griggs 533). Culantro (Chimaltenango); Culantro de monte (Quezaltenango); Cordoncillo.

Generally in dense wet mixed mountain forest, terrestrial or epiphytic, often on rocks, 1,200-2,000 meters; Alta Verapaz; Chimaltenango; Huehuetenango; San Marcos. Costa Rica.

Plants very succulent, glabrous, the stems usually much elongate and with elongate internodes, stout, repent and rooting at most of the lower nodes, the tips of the branches erect or ascending; leaves alternate, the petioles slender, mostly somewhat shorter than the blades; leaf blades thick and succulent when fresh but when dried rather thin, blackish, opaque or nearly so, broadly ovate or roundedovate, mostly 5-9.5 $\mathrm{cm}$. long and $3.5-5.5 \mathrm{~cm}$. wide, rather abruptly acuminate or long-acuminate, rounded at the base, peltate near or somewhat above the base, mostly 7-nerved, somewhat paler beneath; peduncles terminal, solitary or geminate, equaling or shorter than the petioles, glabrous or puberulent, bearing a rather conspicuous, foliaceous bract; spikes mostly $2.5-4 \mathrm{~cm}$. long, erect, $2.5-3 \mathrm{~mm}$. thick, very densely flowered; ovary ovoid, obliquely short-rostrate, the stigma anterior on the beak.

An earlier name may eventually be found for this plant among some of the species of West Indies or other regions. We place here specimens referred by Trelease to five unpublished Guatemalan species.

\section{Peperomia petrophila C. DC. Linnaea 37: 369. 1866.}

Moist or wet, mixed, mountain forest, sometimes along streams or in pine forest, 1,200-2,100 meters; Alta Verapaz; Zacapa (Sierra de las Minas); Guatemala (Volcán de Pacaya). Veracruz.

Plants erect, $30 \mathrm{~cm}$. high or less, the stems thick, with very short internodes, naked below, densely leafy above, the lower leaves deciduous, the stems simple or with a few short branches above, the plants glabrous throughout; leaves thin and soft, on very slender petioles $1.5-3.5 \mathrm{~cm}$. long, lanceolate or linear-lanceolate, mostly $6-14 \mathrm{~cm}$. long and $1-3 \mathrm{~cm}$. wide, attenuate-acuminate, acute or attenuate at the base, not pellucid-punctate, green above when dried, somewhat paler beneath and black-puncticulate, 5-plinerved; peduncles terminal, solitary or clustered, about equaling the petioles or of ten longer, slender, glabrous; spikes rather stout, equaling or exceeding the leaves, $9.5 \mathrm{~cm}$. long and $3 \mathrm{~mm}$. thick or smaller, densely flowered; bracts orbicular, centrally peltate, subsessile; ovary emersed, obovoid, somewhat obliquely stigmatiferous at the apex, the stigma punctiform. 
In Veracruz this plant grows on wet rocks in the margins of streams. Probably it has the same habitat in Guatemala, although the scant notes accompanying the three Guatemalan specimens are not conclusive regarding this point.

Peperomia pililimba C. DC. Candollea 1: 335, 403. 1923. P. Matapalo Trelease in .Standl. Journ. Wash. Acad. Sci. 13: 366. 1923 (type from San Salvador, El Salvador).

Moist, wet, or rather dry forest, epiphytic or on rocks or rocky banks, 200-3,000 meters; Alta Verapaz (type from Cobán, Türckheim II.1383); Baja Verapaz; Zacapa; Chiquimula; Santa Rosa; Escuintla; Quezaltenango; Huehuetenango. Honduras; El Salvador.

Plants erect or sometimes decumbent and rooting at the lower nodes, the stems stout, often clustered, simple below, often sparsely branched above, sparsely or densely pilose with spreading or subappressed hairs, the internodes short or elongate; leaves alternate, on stout or rather slender pilose petioles $1 \mathrm{~cm}$. long or shorter, very variable in shape, oblanceolate to cunea te-oblong or cuneate-obovate, mostly 1.5-4 cm. long and 1-2 $\mathrm{cm}$. wide, generally broadest toward the apex, rounded or obtuse at the apex, acute to attenuate at the base, rather thick and fleshy when fresh, finely pellucid-punctate, paler beneath and often tinged with red or pink, sparsely pilose above, mostly along the costa, more densely pilose beneath, obscurely 3-nerved, the nerves obscure or obsolete beneath; peduncles terminal, solitary or geminate, naked, pilose or glabrate, $1.5 \mathrm{~cm}$. long or shorter; spikes erect, densely flowered, slender, $10 \mathrm{~cm}$. long or shorter, about $2 \mathrm{~mm}$. thick, the rachis glabrous; bracts orbicular, centrally peltate, pale green; ovary subglobose, the stigma oblique.

In leaf and pubescence characters, the species of this alliance are variable, and it is difficult to decide whether they should be divided more finely or whether several of those here recognized should be united.

Peperomia praetenuis Trelease in Standl. Field Mus. Bot. 12: 406. 1936.

Known only from the type, British Honduras, in a clearing, Belize, C. L. Lundell 1929.

Plants very small, glabrous, $4 \mathrm{~cm}$. high or less, erect, with fibrous roots or with a very short rhizome, the internodes short; leaves alternate, pale green and very thin when dried, pellucid-punctate, the petioles about $3 \mathrm{~mm}$. long; leaf blades broadly deltoid-ovate-cordate, 5-10 $\mathrm{mm}$. long and wide, subacute, shallowly cordate at the base, obscurely 3-nerved; peduncles little longer than the petioles, terminal, simple, naked; spikes mostly 1-1.5 cm. long, $1 \mathrm{~mm}$. thick, remotely flowered, pale green; bracts rounded, centrally peltate, short-pedicellate; fruits ellipsoid-globose, only slightly immersed, carnose, the stigma apical. 
This is the smallest of all the Guatemalan Piperaceae, the individual plants so small that they probably have been overlooked by other collectors. However, the species may be only a stunted form of $P$. pellucida.

Peperomia praeteruentifolia Trelease in Yuncker, Field Mus. Bot. 17: 337. 1938.

Moist or wet, mixed, mountain forest, 1,200-2,000 meters; Chiquimula; Jalapa; Guatemala; San Marcos. Honduras, the type from Siguatepeque.

Plants usually terrestrial, sometimes epiphytic, the stems erect or decumbent, slender, mostly $30 \mathrm{~cm}$. long or less, simple below, branched above, with mostly elongate internodes, finely puberulent or almost wholly glabrous; leaves alternate, the petioles slender, $3 \mathrm{~cm}$. long or shorter, puberulent or glabrate; leaf blades thin when dried, usually green, broadly rhombic-ovate to ovate or elliptic-ovate, mostly 3-6 cm. long and 2-5 cm. wide, acute or subacute or sometimes obtuse, obtuse or more often rounded at the base, glabrous or nearly so, paler beneath, obscurely 5-7-plinerved, the inner nerves arising far above the base of the blade; peduncles axillary or often terminal and clustered, usually much longer than the petioles, puberulent or glabrate; spikes very slender, $3-9 \mathrm{~cm}$. long, scarcely $1 \mathrm{~mm}$. thick, glabrous, very remotely flowered; bracts orbicular, centrally peltate.

Peperomia pseudopereskiifolia C. DC. in DC. Prodr. 16, pt. 1: 448. 1860 .

Lowland forest; Alta Verapaz (between Sepacuité and Secanquím, H. Pittier, May 18, 1905). Cuba.

Plants glabrous, stout, erect or ascending, with elongate internodes; leaves mostly opposite, the uppermost ternate, on rather long, stout petioles; leaf blades lanceolate or elliptic-lanceolate, mostly $5.5-9.5 \mathrm{~cm}$. long and $2-3 \mathrm{~cm}$. wide, longacuminate, narrowly cuneate-attenuate to the base, thick and fleshy when fresh, rather thick when dried, conspicuously 5-nerved or sometimes with 2 obscure additional nerves; spikes axillary and terminal, about twice as long as the leaves, densely flowered, the peduncles longer than the petioles; bracts rounded, centrally peltate; flowers immersed, the ovary ovoid, contracted below the apex, the stigma apical, puberulent, capitellate; fruits globose, mucronulate at the apex, pedicellate.

The single Guatemalan collection agrees so well with a photograph of the Cuban type that we believe there is little doubt that it should be referred here.

Peperomia puberula J. G. Baker in Saunders, Ref. Bot. 5: pl. 302. 1871.

Described from plants cultivated in England, said to be from Alta Verapaz. 
Plants short-caulescent, somewhat succulent, velutinous-puberulent; leaves alternate, broadly ovate, 4-7 cm. long, 3-6 cm. wide, subacute or abruptly acute, peltate toward the rounded or subcordate base, the petioles about equaling the blades; spikes terminal and axillary, 5-10 cm. long, long-pedunculate; fruits obovoid, the stigmas subsessile, somewhat oblique.

We have seen no material referable to this species, which is not included in the key. There, apparently, it would run to $P$. peltata, for which species, indeed, puberula may be the oldest name.

Peperomia quadrifolia (L.) HBK."Nov. Gen. \& Sp. 1: 69. 1815. Piper quadrifolium L. Sp. Pl. ed. 2. 43. 1762. Peperomia edulis Miquel, Linnaea 18: 711. 1844. P. santarosana C. DC. in Donn. Smith, Bot. Gaz. 19: 10. 1894 (type from Santa Rosa, Santa Rosa, Heyde \& Lux 3454). P. Luxii C. DC. in Donn. Smith, Bot. Gaz. 19: 260. 1894 (type from Ojo de Agua, Santa Rosa, Heyde \& Lux 3828). P. Standleyi Trelease in Standl. Journ. Wash. Acad. Sci. 13: 366. 1923 (type from Tonacatepeque, Salvador). P. circulifolia Trelease in Yuncker, Field Mus. Bot. 17: 331. 1938 (type from El Achote, near Siguatepeque, Honduras). P. conocarpa Trelease, op. cit. 332 (type from El Achote, Honduras). Retoño; Colchón de peña.

On trees in moist or wet forest, often on oaks, 3,000 meters or lower, most common at middle elevations; Alta Verapaz; Baja Verapaz; El Progreso; Izabal; Zacapa; Chiquimula; Jalapa; Santa Rosa; Escuintla; Guatemala; Sacatepéquez; Chimaltenango; Sololá; Quiché; Suchitepequez; Retalhuleu; Quezaltenango; San Marcos; Huehuetenango. Mexico; El Salvador and Honduras to Panama; West Indies; South America.

Plants glabrous, very succulent, mostly $20 \mathrm{~cm}$. high or less, often forming dense bushy clumps on the trunks or branches of trees, the stems sometimes procumbent and rooting at the nodes, with short or elongate nodes; leaves pale green, very thick and fleshy, quaternate, on short thick petioles, narrowly to very broadly cuneate-obovate, mostly $7-13 \mathrm{~mm}$. long but variable in size, broadly rounded and usually emarginate at the apex, broadly or narrowly cuneate at the base, obscurely 3-nerved, generally opaque; spikes terminal, solitary, on rather long and slender peduncles, erect, densely or rather remotely flowered, mostly $1.5-4 \mathrm{~cm}$. long, little more than $1 \mathrm{~mm}$. thick; bracts orbicular, centrally peltate, short-stipitate; ovary subimmersed, ovoid, attenuate, stigmatiferous at the tip; fruits oblong-ovoid, emersed, mucronate at the apex. (Fig. 44.)

This is one of the most common of Guatemalan species, and is represented by a large number of collections that show considerable variation in shape and size of the leaves and in the length of the spikes. It is believed, however, that all the not very different forms may be referred satisfactorily to a single widespread species. The 


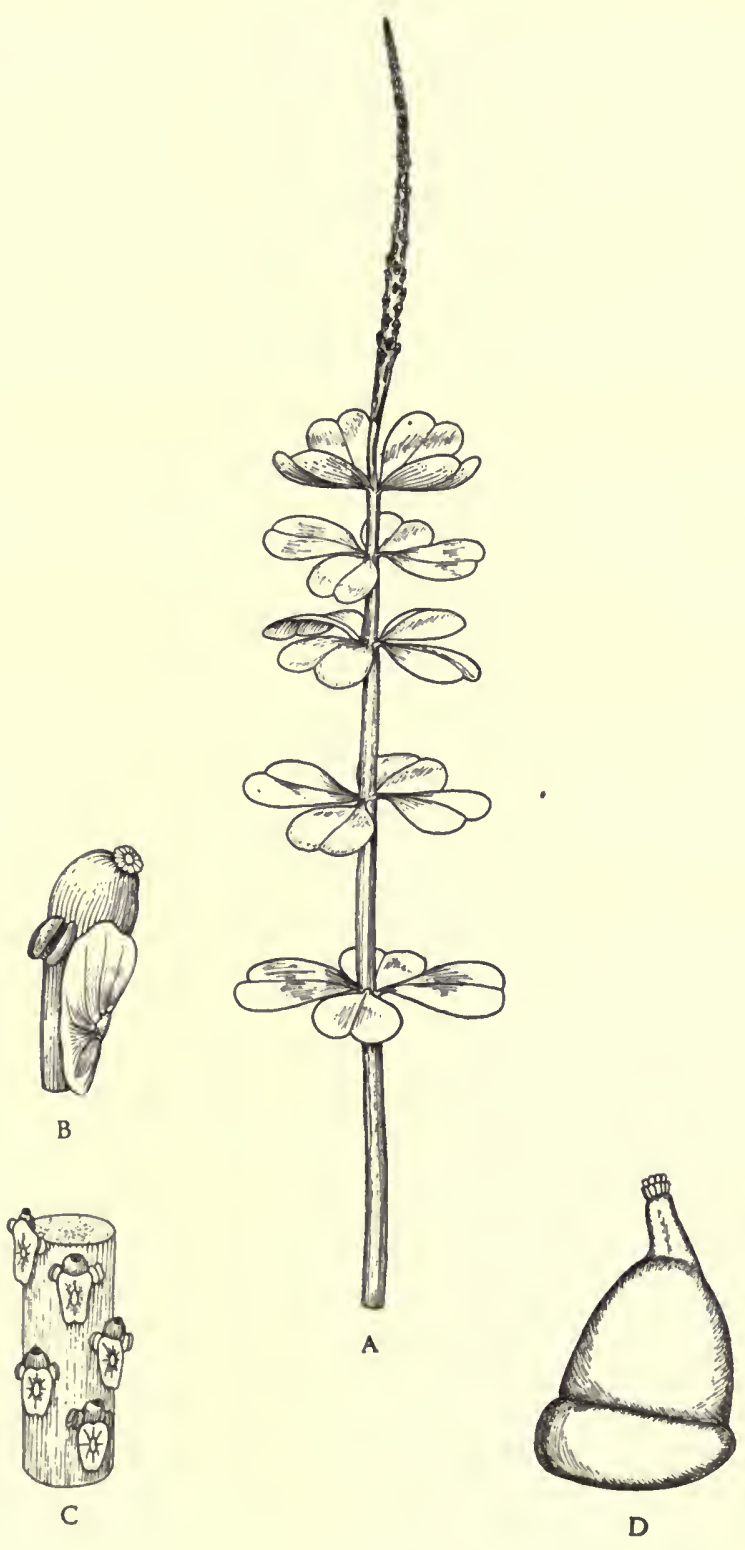

FIg. 44. Peperomia quadrifolia. A. Habit of portion of flowering stem; $\times 1$. B. Flower with bract; $\times 12$. C. Portion of inflorescence with flowers in position; $\times 3$. D. Pistil; $\times 30$. 
plant has been reported from Guatemala as $P$. Lindeniana Miquel, which is probably still another synonym of $P$. quadrifolia, and as $P$. tenerrima Miq. Some 24 sheets that we place here have been marked by Trelease as new species or varieties. According to Schiede, collector of the Mexican type of $P$. edulis, this plant was eaten, either raw or cooked, by the inhabitants of the mountains of central Mexico, and he stated that the plant had an aromatic odor suggestive of coriander. So far as we know, Peperomias are not eaten in Central America, although they might make a satisfactory pot herb.

Peperomia reflexa (L. f.) A. Dietr. Sp. Pl. 1: 180. 1831. Piper reflexum L. f. Suppl. Pl. 91. 1781. Peperomia opaca Trelease, var. ciliata Trelease in Yuncker, Field Mus. Bot. 17: 336. 1938 (type from El Achote, near Siguatepeque, Honduras).

Epiphytic on trunks or branches of trees in wet to rather dry forest, often on oaks, 1,000-2,500 meters; Alta Verapaz; Baja Verapaz; Chiquimula; Jalapa; Guatemala; Sacatepéquez; Chimaltenango; Suchitepequez; Quezaltenango; San Marcos; Huehuetenango. Central and southern Mexico; widely distributed in Central America; West Indies; South America; also in the Old World tropics.

Plants perennial, very succulent, usually erect, often forming dense clumps of numerous stems, generally less than $20 \mathrm{~cm}$. high, the stems sometimes rooting at the lower nodes, sparsely dichotomous or trichotomous, sulcate, glabrous or hirtellous; leaves small, in whorls of $3-4$, very shortly petiolate, when dry rigid or somewhat coriaceous, usually lustrous, mostly glabrous, rhombic-elliptic or broadly elliptic or rarely ovate, spreading or reflexed, obtuse or rounded at the apex, acute or obtuse at the base, most often glabrous, impressed-punctate beneath, obsoletely 3-nerved; petioles pubescent; spikes terminal, pale green, long-pedunculate, much longer than the leaves, mostly $2-4 \mathrm{~cm}$. long but variable in length, the peduncles glabrous or hirtellous, the rachis densely hirtellous; bracts orbicular, centrally peltate, pedicellate; ovary ovoid, acute, the stigma apical, capitellate, puberulent; fruits ovoid-cylindric, somewhat spreading or ascending.

A common plant in many parts of Guatemala. Around Cobán the crushed leaves of this and doubtless other species are applied as poultices to relieve the cutaneous irritation produced by Rhus striata. The specific name $P$. opaca Trelease has not been validly published, in spite of the fact that a variety of it was published from Honduras. Most of the Guatemalan specimens were determined by Trelease as $P$. opaca.

Peperomia rotundifolia (L.) HBK. Nov. Gen. \& Sp. 1: 65. 1815. Piper rotundifolium L. Sp. Pl. 30. 1753. Peperomia Koepperi 
Trelease in Yuncker, Field Mus. Bot. 9: 275. 1940 (type from Mount Cangrejal near La Ceiba, Honduras). Cuartillo de palo.

On trees in moist or wet forest, 1,700 meters or lower, often creeping among mosses; Petén; Alta Verapaz; Izabal; Chiquimula; Retalhuleu; Quezaltenango; San Marcos. Southern Mexico; British Honduras to Panama; West Indies; South America.

Stems very slender, with mostly elongate internodes, repent and rooting at the nodes, puberulent or glabrate; leaves thin or when fresh thick and lenticular, orbicular or oval-orbicular, 6-10 mm. long and almost or quite as wide, not pellucidpunctate, sparsely blackish-puncticulate beneath, broadly rounded at base and apex, sparsely or rather densely pilose or sometimes glabrate, ciliate, obscurely 3-nerved; spikes terminal, short-pedunculate, longer than the leaves, scarcely $1 \mathrm{~mm}$. thick, the rachis glabrous, the peduncles about as long as the petioles; bracts orbicular, centrally peltate, subsessile; ovary stigmatiferous slightly below the apex, obtuse, the stigma minute, glabrous; fruit subglobose.

This has been reported from Alta Verapaz as $P$. matlaleucaensis C. DC.

Peperomia Sandersii C. DC., perhaps native of Brazil, is grown occasionally as a pot plant in Guatemala and the United States. It is small, with very thick and fleshy, peltate, ovate-rounded leaves, handsomely striped on the upper surface with green and silver. Aguilar reports the local name of "cebranita."

Peperomia santa-helenae Trelease in Standl. Field Mus. Bot. 22: 9. 1940.

Moist or wet, mixed, mountain forest, sometimes in Cupressus forest, epiphytic or rarely terrestrial, rarely in lowland forest little above sea level; 1,500-3,200 meters; endemic; Alta Verapaz(?); Izabal; El Progreso; Zacapa; Jalapa; Guatemala; Chimaltenango (type from Santa Elena, Cerro de Tecpám, J. R. Johnston 421); Quiché; Huehuetenango; Quezaltenango; San Marcos.

Plants erect or decumbent, the stems generally simple below but often or usually somewhat branched above, stout, rather densely pilose with short, mostly fulvescent and incurved hairs, the internodes short or elongate; leaves alternate, rather thick and succulent when fresh, somewhat paler beneath, green or fuscescent when dried, not pellucid-punctate, generally black-puncticulate beneath, the petioles $1.5 \mathrm{~cm}$. long or usually much shorter, incurved-pubescent; leaf blades variable in size and shape, mostly elliptic or lance-elliptic, sometimes rhombicovate to broadly ovate or obovate, mostly $2-5 \mathrm{~cm}$. long and 1.5-3.5 cm. wide, acute or acuminate with an obtuse tip, rounded to subacute at the base, 3-nerved, pilose on both surfaces with spreading or subappressed hairs or in age rarely glabrate; peduncles axillary and terminal, solitary or the terminal ones clustered, simple, naked, $1.5 \mathrm{~cm}$. long or shorter, sparsely pilose; spikes pale green, slender, mostly 
5-10 $\mathrm{cm}$. long and $1.5 \mathrm{~mm}$. thick, glabrous, remotely flowered; bracts centrally peltate, orbicular, sessile; fruits minute, ovoid-globose, glabrous, the stigma subobliquely apical.

Peperomia sisiana C. DC. in Donn. Smith, Bot. Gaz. 19: 9. 1894.

On trees in lowland forest, 700 meters or lower; endemic; Suchitepequez (type from Río Sis, J. D. Smith 2584; collected also at San Antonio).

Plants with elongate, probably pendent stems; the stems sometimes rooting at the lower nodes, sparsely hirsute or glabrate, the internodes elongate; leaves alternate, on stout petioles $1 \mathrm{~cm}$. long or shorter, oblong-lanceolate, mostly 7-9 $\mathrm{cm}$. long, acuminate or narrowly long-acuminate, obtuse at the base, glabrous, conspicuously ciliate, penninerved or 5-7-plinerved with the inner nerves arising far above the base of the blade and little below the middle of it, usually fuscescent when dried, not or obscurely pellucid-punctate; peduncles terminal, simple, naked; spikes slender, glabrous, densely flowered, about $6 \mathrm{~cm}$. long, in fruit $6 \mathrm{~mm}$. thick; bracts orbicular, centrally peltate, subsessile; ovary emersed, obliquely rostrate; fruits cylindric, widely ascending, as much as $2.5 \mathrm{~mm}$. long, somewhat tuberculate.

\section{Peperomia Skutchii Trelease \& Standley, sp. nov.}

Terrestrial in moist or wet, mixed, mountain forest, 1,500-2,900 meters; endemic; Alta Verapaz; Chimaltenango; Quezaltenango (type from western slopes of Volcán de Zunil, above Santa María de Jesús, Steyermark 35144); San Marcos; Huehuetenango.

Plants very slender, weak, succulent, and fragile, erect or procumbent, glabrous almost throughout, the stems simple or often abundantly branched, mostly less than $20 \mathrm{~cm}$. long, sometimes hispidulous at the nodes, the internodes short or elongate; leaves very small, alternate but often opposite at the ends of the branches, translucent when dried but not pellucid-punctate, the slender petioles mostly 3-7 mm. long, glabrous or hispidulous near the apex; leaf blades orbicular, ovaterounded, or rounded-rhombic, mostly $8-23 \mathrm{~mm}$. long and $8-16 \mathrm{~mm}$. wide, rounded or broadly rounded at the apex, rounded at the base, glabrous throughout or often with a few scattered short white hairs on the upper surface, sometimes hispidulous beneath near the base, 5-7-plinerved or penninerved, the nerves very inconspicuous; peduncles filiform, axillary, solitary, simple, naked, glabrous, generally longer than the petioles; spikes filiform, mostly about $1 \mathrm{~cm}$. long, pale green, remotely few-flowered, less than $1 \mathrm{~mm}$. thick, glabrous; fruits minute, stipitate, emersed, obliquely ascending, fusiform, rather long-mucronate, the stigma broader than the style.

Planta gracilis vulgo ramosa erecta vel procumbente carnosa fere glabra, caulibus interdum ad nodos hispidulis; folia parva longipetiolata alterna sed ad apices ramorum saepe opposita, orbicularia, ovato-orbicularia vel rotundo-rhombea, apice rotundata vel late rotundata, basi rotundata, glabra vel supra pilis paucis brevibus albis conspersa, subtus interdum prope basin hispidula, 5-7-plinervia 
vel penninervia; pedunculi filiformes axillares singuli plerumque petiolis longiores, spicis filiformibus vulgo ca. $1 \mathrm{~cm}$. longis laxe paucifloris glabris; fructus stipitatus fusiformis emersus oblique adscendens longimucronatus.

A small and delicate plant of the high wet mountain forests, collected numerous times in the Occidente.

Peperomia staminea Trelease, Journ. Wash. Acad. Sci. 19: 328. 1939.

Epiphytic on trees in wet mixed lowland forest, 500 meters or lower; Izabal. British Honduras; Atlantic coast of Honduras (type from Lancetilla Valley near Tela).

Plants rather small, glabrous almost throughout but often puberulent on the petioles and peduncles and at the nodes, the stems slender, elongate, usually repent and rooting at the nodes, the internodes elongate; leaves mostly quaternate, on petioles $2-4 \mathrm{~mm}$. long, very thick and succulent when fresh, subcoriaceous when dry, usually not at all pellucid-punctate, elliptic to oblong-lanceolate, mostly 2-2.5 $\mathrm{cm}$. long and $1-1.5 \mathrm{~cm}$. wide, somewhat narrowed to the very obtuse apex, acute or obtuse at the base, 3-nerved, the nerves conspicuous beneath but obsolete above; spikes terminal, on peduncles as much as $3.5 \mathrm{~cm}$. long, densely flowered, about $3 \mathrm{~cm}$. long and $2 \mathrm{~mm}$. thick, pale green; bracts suborbicular, peltate at the middle.

\section{Peperomia suchitanensis Trelease \& Standley, sp. nov.}

Known only from the type, Jutiapa, Volcán de Suchitán, on wet rocks among mosses and on bark of trees in forest at the summit, 2,050 meters, Steyermark 31940 (type in Herbarium of Chicago Natural History Museum).

Plants very slender, the stems repent or procumbent, rooting at the lower nodes, short, simple or sparsely branched, with short internodes, sparsely pilose with slender spreading hairs; leaves alternate, numerous, the petioles about $1 \mathrm{~mm}$. long; leaf blades rather thick, elliptic-ovate, 6-11 $\mathrm{mm}$. long, $3-8 \mathrm{~mm}$. wide, narrowed to the obtuse, often subemarginate, minutely apiculate apex, rounded at the base, green when dried, not pellucid-punctate, very obscurely 3-nerved, conspicuously hispidulous on the upper surface with rather long, spreading hairs, somewhat paler beneath and glabrous; peduncles terminal, solitary, simple, slender, glabrous, longer than the petioles; spikes (very immature) rather stout, about $6 \mathrm{~mm}$. long, scarcely $1 \mathrm{~mm}$. thick, very densely flowered, glabrous.

Planta parva gracillima, caulibus repentibus vel procumbentibus brevibus, sparse pilis patentibus pilosis, internodiis brevibus; folia parva alterna brevissime petiolata elliptico-ovata, 6-11 $\mathrm{mm}$. tantum longa, apicem obtusum saepe subemarginatum minute apiculatum versus paullo angustata, basi rotundata, obscure 3-nervia, supra hispidula, subtus glabra; pedunculi terminales singuli glabri petiolis longiores, spicis immaturis erectis crassiusculis erectis glabris ca. $6 \mathrm{~mm}$. longis. 


\section{Peperomia tacanana Trelease \& Standley, sp. nov.}

Epiphytic or terrestrial in moist or wet, mountain forest, sometimes growing on rocks, 1,500-2,700 meters; Zacapa; El Progreso; Chiquimula; Jalapa; Guatemala; Chimaltenango; Quezaltenango; San Marcos (type from Volcán de Tacaná, along Río Vega, between San Rafael and the Mexican boundary, Steyermark 36351; in Herbarium of Chicago Natural History Museum). El Salvador.

Plants usually very slender, the stems erect or often long-repent, frequently $30 \mathrm{~cm}$. long or more, simple or sparsely branched, densely and finely puberulent, the internodes mostly elongate; leaves small, alternate, long-petiolate, succulent when fresh but rather thin when dried, the petioles $2 \mathrm{~cm}$. long, slender, often longer than the blades, puberulent; leaf blades broadly ovate or rounded-ovate, acute or subacute or sometimes obtuse, rounded or truncate at the base, mostly 12-25 mm. long and 10-27 mm. wide, finely and usually sparsely puberulent on both surfaces or sometimes glabrate, paler beneath, sparsely pellucid-punctate, obscurely 3-nerved; peduncles very slender, terminal, solitary or often ternate, naked, puberulent, simple, $1.5 \mathrm{~cm}$. long or shorter; spikes pale green, erect, slender, commonly 2-4 cm. long and 1-1.5 mm. thick, remotely flowered, glabrous; bracts orbicular, centrally peltate; fruits ovoid-globose, minute, emersed, glabrous, subapiculate at the apex, the stigma slightly oblique.

Caules graciles erecti vel saepius repentes et ad nodos radicantes, simplices vel sparse ramosi, dense minute puberuli; folia parva longipetiolata late ovata vel rotundo-ovata, acuta vel subacuta vel interdum obtusa, basi rotundata vel truncata, utrinque sparse puberula vel glabrata, subtus pallidiora, sparse pellucidopunctata, obscure 3-nervia; pedunculi terminales saepe ternati nudi puberuli simplices, spicis gracilibus erectis $2-4 \mathrm{~cm}$. longis $1-1.5 \mathrm{~mm}$. crassis glabris; bracteae rotundatae peltatae; fructus emersus ovoideo-globosus suboblique apiculatus.

\section{Peperomia tacticana Trelease \& Standley, sp. nov.}

Terrestrial or epiphytic in moist or wet, mixed, mountain forest, 1,500-2,300 meters; endemic; Alta Verapaz (type from mountains east of Tactic, on the road to Tamahú, Standley 71389; in Herbarium of Chicago Natural History Museum); Zacapa (Sierra de las Minas); San Marcos; Huehuetenango (Cerro Negro, Sierra de los Cuchumatanes).

Plants erect or ascending, glabrous throughout or nearly so, the stems slender, mostly $40 \mathrm{~cm}$. long or less, simple or sparsely branched, with elongate internodes; leaves mostly in verticils of $3-4$, or often partly opposite, on slender petioles $1 \mathrm{~cm}$. long or shorter, somewhat fuscescent when dried and thin, finely pellucidpunctate, oblong-lanceolate or oblong-ovate, mostly $6-8.5 \mathrm{~cm}$. long and $2-3 \mathrm{~cm}$. wide, rather abruptly long-acuminate, acute to subobtuse at the base, 3-nerved or sometimes 5-nerved; peduncles terminal, solitary, simple, about $1.5 \mathrm{~cm}$. long; spikes erect, slender, about $6.5 \mathrm{~cm}$. long and $2 \mathrm{~mm}$. thick, densely flowered, the bracts suborbicular, sessile, centrally peltate; fruits mostly emersed, broadly ovoid, minute, sessile, somewhat obliquely apiculate at the apex, glabrous. 
Caules erecti vel adscendentes graciles, simplices vel sparse ramosi, plantis glabris; folia plerumque 3-4-nata, interdum pro parte opposita, graciliter petiolata, in sicco tenuia fuscescentia, pellucido-punctata, oblongo-lanceolata vel oblongoovata, subabrupte longiacuminata, basi acuta vel subobtusa, 3-nervia vel interdum 5-nervia; pedunculi terminales solitarii petiolis longiores simplices nudi; spicae erectae graciles $2 \mathrm{~mm}$. crassae densiflorae; bracteae suborbiculares sessiles centro peltatae; fructus emersus late ovoideus sessilis suboblique apice apiculatus.

\section{Peperomia Treleasei Standl. \& Steyerm., sp. nov.}

Type from Guatemala, cultivated in the garden of Don Mariano Pachecho H., Guatemala, May 14, 1942, Steyermark 46398 (in Herbarium of Chicago Natural History Museum). Represented also by Sessé \& Mociño 2, 320, and 330, presumably from Mexico (Herb. Madrid).

Plants slender, erect, the stems simple, $35 \mathrm{~cm}$. high or less, very finely and densely puberulent, the internodes few, often greatly elongate and as much as $14 \mathrm{~cm}$. long; leaves in verticils of $3-5$, thin when dried and green, not pellucidpunctate, the petioles slender, $3 \mathrm{~cm}$. long or shorter, sometimes longer than the blades; leaf blades broadly cordate or rounded-cordate, $2.5-3.5 \mathrm{~cm}$. long, about $2.5 \mathrm{~cm}$. wide, subacute to very obtuse at the apex, shallowly cordate at the base, mostly 7-nerved, densely and minutely puberulent on both surfaces or sometimes glabrate; peduncles terminal, usually ternate, the central one much longer than the lateral ones and as much as $7.5 \mathrm{~cm}$. long, minutely puberulent, naked; spikes very numerous, pedunculate, laxly or densely flowered, the lower ones as much as $1 \mathrm{~cm}$. long (including the peduncles), forming a dense raceme as much as $4 \mathrm{~cm}$. long, the upper spikes of the raceme gradually shorter, the racemes thus attenuateacute, the secondary peduncles bracteate at the base.

Caulis gracilis erectus simplex dense minuteque puberulus, internodiis elongatis interdum longissimis; folia verticillata 3-5-nata longe graciliter petiolata tenuia non pellucido-punctata, late cordata vel rotundo-cordata apice subacuta usque obtusissima, basi breviter cordata, plerumque 7-nervia, utrinque dense minute puberula vel interdum glabrata; pedunculi terminales vulgo ternati, centrali elongato nudo, minute puberuli; spicae numerosae racemose dispositae $1 \mathrm{~cm}$. longae vel breviores basi bracteatae laxiflorae vel densiflorae patentes.

This is related to P. Fraseri C. DC., which was described from Ecuador. Casimir De Candolle referred to it also a collection from "Nova Hispania," collected by Pavón, which is doubtless the plant that was collected by Sessé and Mociño, as cited above. The Ecuador and Mexican plants are evidently closely related, and form a very distinct group, with inflorescences quite unlike those of other species of the genus. Two of the Madrid collections were seen by Trelease, who labeled them P. Fraseri. We have seen a photograph of the type of that species, and believe that it is quite distinct from the plant of Guatemala and Mexico. It has leaves that were described by De Candolle as cordate-lanceolate, and they are 
gradually attenuate to a long narrow apex; the leaves of $P$. Treleasei are rather abruptly narrowed to a much broader apex, and decidedly different in appearance. All the four collections of P. Treleasei are uniform in leaf characters, and we have no doubt that they represent a form quite distinct from the plant of Ecuador. It still is uncertain where $P$. Trelease $i$ is native. The plant cultivated in Guatemala was said to have come from the Department of Jutiapa. It has not been found wild anywhere in the country, and may well have been in cultivation in Jutiapa. The Sessé and Mociño collections, as usual, bear no locality data.

Peperomia Tuerckheimii C. DC. ex Donn. Smith, Enum. Pl. Guat. 2: 96. 1891, nomen; Ann. Conserv. Jard. Bot. Genève 2: 279. 1898.

On shaded wet cliffs or rocks, usually in dense forest, 900-1,500 meters; endemic; Alta Verapaz (type from Pansamalá, Türckheim 433; also in the region of Chirriacté); Huehuetenango (Maxbal).

Plants very small, the stems short, slender, prostrate, rooting at the nodes, pilosulous; leaves small, thin, the slender petioles as much as $4 \mathrm{~cm}$. long, mostly shorter; leaf blades thin, rounded-ovate, $2.5 \mathrm{~cm}$. long and $2 \mathrm{~cm}$. wide or smaller, subacute, rounded at the base, peltate shortly above the base, translucent but not punctate, pilosulous on both surfaces, ciliate; peduncles axillary, solitary, simple, about equaling the petioles; spikes very slender, twice as long as the leaves, the rachis puberulent; bracts orbicular; ovary emersed, ovoid, stigmatiferous at the very apex, acute.

The plant seems to be a rare one. It probably is confined to limestone regions.

Peperomia vegana Trelease \& Standley, sp. nov.

Moist or wet, mixed, mountain forest, on shaded banks or sometimes on rocks, 2,500-2,700 meters; endemic; San Marcos (type from Volcán de Tacaná, along Río Vega, between San Rafael and the Mexican boundary, Steyermark 36350 (type in Herbarium of Chicago Natural History Museum; collected also in Barranco Eminencia, near the base of Volcán de Tajumulco).

Plants slender, the stems elongate, prostrate or repent, rooting at the nodes, the internodes elongate, sparsely pilose or glabrate, often conspicuously granular; leaves rather small, alternate, the slender petioles $4.5 \mathrm{~cm}$. long or shorter, pilose with long spreading hairs; leaf blades thin when dried, fuscescent, not pellucidpunctate, ovate or broadly ovate, $4.5-7.5 \mathrm{~cm}$. long, $2.5-4.5 \mathrm{~cm}$. wide, rather abruptly acute or acuminate, broadly rounded at the base, peltate far above the base, villous-hirsute on both surfaces with long slender spreading multicellular hairs, about 7-nerved, paler beneath; spikes unknown. 
Planta gracilis, caulibus elongatis prostratis vel repentibus ad nodos radicantibus, internodiis elongatis, sparse pilosis vel glabratis, saepe conspicue granulosis; folia inter minora alterna longipetiolata, in sicco tenuia, non pellucido-punctata, ovata vel late ovata, subabrupte acuta vel acuminata, basi late rotundata, bene supra basin laminae peltata, utrinque dense pilis longis patentibus laxis plurilocularibus villoso-hirsuta; spicae ignotae.

\section{PIPER L.}

Shrubs or small trees, generally terrestrial, sometimes scandent (very rarely in American species), sometimes herbaceous almost throughout but always woody about the base, the branches generally nodose; leaves alternate, often very unequal at the base, palmately nerved or penninerved; stipules sometimes adnate to the petiole and wing-like, or the two united into one opposite the petiole, sometimes almost obsolete; flowers perfect or unisexual, adnate to the subtending peltate bracts, solitary at each bract, sessile or rarely stipitate; spikes generally pedunculate, at first terminal, becoming opposite the leaves, rarely collected on a common peduncle; stamens $2-4$ or rarely more numerous, the filaments short or rarely exceeding the bracts, the anthers ovate or shorter, usually opening by longitudinal slits; ovary sessile or nearly so, obtuse or rostrate, the stigmas $2-5$, usually $3-4$, distinct, erect or recurved; ovule erect from the base of the cell; fruit baccate, very small, ovoid or globose, smooth, sometimes partly immersed, sometimes sessile and exserted or rarely long-stipitate, the pericarp very juicy or with scant, only slightly succulent flesh; testa of the seed thin, the endosperm farinose.

Because of the different treatments of the genus by different authors, and because no recent monograph of the genus as a whole has been attempted, or is likely to be undertaken very soon, the number of species is very uncertain, but the genus is one of the largest of the plant kingdom.

Flower spikes fasciculate at the apex of a distinct peduncle, or rarely fasciculate in the leaf axils. Leaves large and thin, ovate-rounded or orbicular, peltate or epeltate. Subgenus Heckeria.

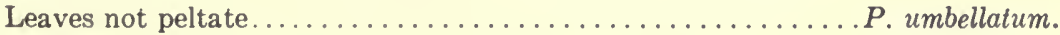

Leaves conspicuously peltate.

Leaves sparsely villous on the upper surface, densely villosulous beneath on

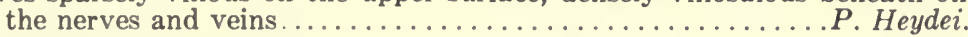

Leaves glabrous or nearly so.................. peltatum.

Flower spikes solitary, axillary or opposite the leaves.

Leaves conspicuously peltate.

Branches and lower leaf surface densely pubescent; spikes mostly $3-5 \mathbf{~ c m}$. long............................. Tuerckheimii.

Branches and lower leaf surface glabrous or nearly so; spikes 7-12 cm. long or longer.

Leaves lance-oblong, $5-6.5 \mathrm{~cm}$. wide................ imberbe.

Leaves broadly ovate, mostly $10-20 \mathrm{~cm}$. wide........P. grandilimbum.

Leaves not peltate.

Leaves palmate-nerved, the 3 (sometimes more) principal nerves extending nearly or quite to the apex of the leaf blade.

Flowers conspicuously pedicellate. Subgenus Arctottonia. 
Leaf blades conspicuously cordate at the base, pilose beneath on the nerves....................... guazacapanense.

Leaf blades acute to rounded at the base, glabrous or minutely puberulent.

Leaves, at least the upper ones, acute or subacute at the base, thick and stiff, lustrous on the upper surface.......... sempervirens.

Leaves obliquely rounded or very obtuse at the base, membranaceous, scarcely lustrous. .................. yucatanense.

Flowers sessile.

Leaf blades acute to rounded at the base, the base usually symmetric or nearly so, never very conspicuously oblique.

Leaves abundantly pilosulous or puberulent beneath, at least on the nerves.

Leaves pilose or pilosulous beneath with rather long, spreading hairs. $P$. Martensianum.

Leaves finely and densely puberulent beneath on the nerves.

$P$. vaccinum.

Leaves glabrous or at most granular beneath on the nerves, rarely very minutely and sparsely puberulent.

Principal leaves oblong or lance-oblong, mostly 9-15 cm. long and $2.5-4.5 \mathrm{~cm}$. wide, little if at all narrowed toward the base.

Leaves densely and prominently reticulate-veined beneath.

$P$. Schippianum.

Leaves very laxly and inconspicuously reticulate-veined beneath.

$P$. vergelense.

Principal leaves ovate or broadly ovate to elliptic or oval-elliptic,

if rather narrow then conspicuously narrowed toward the base.

Bracts and rachis of the inflorescence densely or conspicuously pubescent.

Peduncles several times as long as the petioles....P. jumayense.

Peduncles little if at all longer than the petioles, sometimes shorter... . . . . . . . . . . . . . . . . ..P. Amalago.

Bracts and rachis of the inflorescence glabrous or essentially so.

Peduncles almost half as long as the spikes; leaves with a very long and narrow, tail-like acumination.......P. stillans.

Peduncles short, usually much less than one-fourth as long as the spikes; leaves mostly acuminate but not with a long narrow tail-like tip.

Spikes all or mostly $3-5 \mathrm{~cm}$. long.......... psilorhachis. Spikes 7-15 cm. long (except the undeveloped ones).

Peduncles filiform, mostly $2.5-5 \mathrm{~cm}$. long.

$P$. perlongipedunculum.

Peduncles stouter, scarcely filiform, rarely as much as $1 \mathrm{~cm}$. long....................... Amalago.

Leaf blades all or mostly cordate or subcordate at the base, at least on one side, often very unequal, one side produced much lower on the petiole than the other side.

Leaf blades unequal at the base, one side produced lower on the petiole than the other; leaves lance-oblong to ovate-oblong, all or most of them $2-5 \mathrm{~cm}$. wide.

Leaves glabrous beneath.............. tajumulcoanum.

Leaves more or less pubescent beneath, at least on the nerves, sometimes only minutely puberulent.

Leaves merely puberulent beneath on the nerves, the hairs minute and scarcely with any appreciable length. .P. oblique-ovatum.

Leaves pilosulous beneath along the nerves, the hairs of very appreciable length. 
Peduncles $2-3 \mathrm{~cm}$. long.................. santae-clarae. Peduncles mostly $1-1.5 \mathrm{~cm}$. long............. Standleyi. Leaf blades equal and symmetric at the base or nearly so or, if somewhat unequal, the blade produced on each side to the same point on the petiole.

Leaves abundantly pilose or pilosulous beneath, at least on the nerves.

Leaves hirsute on the upper surface............ cristinanum. Leaves not hirsute on the upper surface.

Leaf blades lance-oblong, about 3 times as long as wide.

$P$. tacananum.

Leaf blades ovate to rounded-ovate, mostly twice as long as wide or shorter.

Leaves all rather deeply cordate at the base; plants herbaceous throughout or nearly so, usually low, weak, and straggling, or sometimes more or less scandent.

$P$. retalhuleuense.

Leaves not all cordate at the base, the upper ones, and sometimes also the lower ones, rounded; plants erect shrubs.

$P$. Martensianum.

Leaves glabrous beneath, or merely puberulent on the nerves, the hairs very short and scarcely with appreciable length.

Some nerves arising from sides of midrib.......... variabile. All nerves arising palmately from base of blade.

Leaves thin, usually blackish when dry, densely and finely pellucid-punctate.......................... patulum.

Leaves thick and firm, not blackening when dried, epunctate or nearly so ........................ diandrum.

Leaves penninerved, the lateral nerves not extending to the apex of the blade, the lower ones usually terminating below the middle of the blade. Leaves glabrous on both surfaces, at most minutely granular beneath on the costa.

Leaf blades acute to attenuate at the base, $1-2 \mathrm{~cm}$. wide, the nerves arising at an extremely narrow angle.............. flavidum.

Leaf blades cordate to obtuse at the base or, if acute, much more than $2 \mathrm{~cm}$. wide.

Spikes at anthesis $1-2.5 \mathrm{~cm}$. long. Leaves mostly $3.5-4.5 \mathrm{~cm}$. wide.

Leaf blades unequal and shallowly cordate at the base.

$P$. ixocubvainense.

Leaf blades acute or subacute at the base............ telanum.

Spikes at anthesis more than $2.5 \mathrm{~cm}$. long, mostly 5-10 cm. long or longer. Leaves often very large and broad.

Leaves large, mostly 9-18 cm. wide, acuminate or abruptly shortacute.

Petiole vaginate only at base; leaf blades broadest at base.

$P$. variabile.

Petiole vaginate throughout; leaf blades broadest at or about middle............................. yzabalanum.

Leaves mostly $7 \mathrm{~cm}$. wide or much narrower, if rather wide the blades narrowly long-acuminate.

Principal leaves cordate or subcordate at the base, at least on one side.

Leaf blades subequal at the base, the two sides of about equal length......................... instabilipes.

Leaf blades very oblique or unequal at the base. 
Leaves mostly obtuse or rounded at the apex. .P. tuberculatum. Leaves acuminate at apex.

Leaves mostly $8-11 \mathrm{~cm}$. long, short-acuminate.P. pinetorum. Leaves mostly $12-20 \mathrm{~cm}$. long, narrowly long-acuminate.

$P$. pergamentifolium.

Principal leaves acute to rounded at the base, not at all cordate.

Primary nerves more or less impressed on the upper surface, often deeply so, strongly elevated beneath.

$P$. xanthostachyum.

Primary nerves not impressed on the upper surface, not very prominent beneath.

Leaves usually with 3 pairs of principal nerves.

Leaf blades lance-oblong, narrowly long-acuminate, not blackening when dried.............. curvatipes.

Leaf blades ovate or elliptic-ovate, rather abruptly shortacuminate, blackening when dried....P. brevilimbum.

Leaves all or mostly with 5-6 pairs of conspicuous lateral nerves.

Leaf blades very unequal at the base, one of the sides decurrent on the petiole and almost $1 \mathrm{~cm}$. lower than the other..............................

Leaf blades not very unequal at the base or, if so, one side decurrent but little below the other.

Leaves conspicuously paler beneath, glaucescent.

P. subeburneum.

Leaves not or scarcely paler beneath, not glaucescent.

Spikes short, in fruit as much as $5.5 \mathrm{~cm}$. long, at anthesis usually shorter.

Leaves lanceolate or ovate-lanceolate, broadest near the base............... pergamentifolium.

Leaves oblong-elliptic, broadest at or near the middle................ ixocubvainense.

Spikes elongate, mostly 6-9 $\mathrm{cm}$. long in anthesis.

Leaf blades acute at the base.......P. coronanum.

Leaf blades rounded or very obtuse at the base.

Leaves rather small, mostly $3-5.5 \mathrm{~cm}$. wide.

P. Donnell-Smithii.

Leaves large, mostly $6-9 \mathrm{~cm}$. wide.

Leaf blades mostly $12-15 \mathrm{~cm}$. long. . P. frioense. Leaf blades large, mostly 17-22 cm. long.

Petioles 2-3.5 cm. long. . . . .P. cheyennense.

Petioles 8-15 mm. long.......P. virginicum.

Leaves evidently pubescent on one or both surfaces, or at least puberulent or pilosulous beneath on the nerves.

Leaves glabrous on the upper surface or nearly so, smooth to the touch.

Leaf blades conspicuously cordate at the base, at least on one side.

Nerves, and often veins, conspicuously impressed on the upper surface, very prominent beneath, the blades often strongly bullate.

Leaves not bullate, glabrous beneath or sometimes sparsely hirsute on the nerves toward the base of the blade. $P$. xanthostachyum.

Leaves conspicuously bullate, densely pubescent beneath on the veins with short, mostly appressed hairs.

Leaf blades lanceolate or oblong-lanceolate, mostly 11-22 cm.

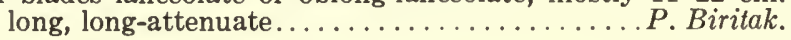


Leaf blades oblong-elliptic, 7-10 $\mathrm{cm}$. long, acute or shortacuminate......................... zacapanum.

Nerves and veins not impressed on the upper surface, not strongly elevated beneath, the blades not at all bullate.

Leaves large, mostly $13-25 \mathrm{~cm}$. wide, shallowly or deeply cordate at the base, the basal lobes subequal, or sometimes unequal, but one of the lobes then 5-8 cm. long or larger.

Base of the leaf blade deeply cordate, the sinus $3-5 \mathrm{~cm}$. deep or more; leaves pubescent beneath over the whole surface. $P$. pansamalanum.

Base of the leaf blade shallowly cordate, the sinus usually less than $2 \mathrm{~cm}$. deep, often very broad and open; leaves pubescent beneath chiefly or wholly on the nerves.

Leaves densely black-punctate beneath.....P. punctulatum. Leaves inconspicuously pale-punctate beneath or epunctate. Leaf blades shallowly and very narrowly cordate at the base, thin....................... exactum.

Leaf blades very broadly and openly cordate at the base, thick....................... philodendroides.

Leaves smaller, mostly $4-7 \mathrm{~cm}$. wide, sometimes as much as 9.5 $\mathrm{cm}$., the base very unequal, one side usually acute or obtuse, the other cordate, with a small lobe usually much less than $1 \mathrm{~cm}$. long.

Leaf blades dull on the upper surface, not lustrous.

Pubescence of the veins on the lower leaf surface of rather long, spreading, whitish hairs............ patzulinum.

Pubescence of the veins of the lower surface of very short, sordid, appressed or subappressed hairs.

Leaves oblong-lanceolate, $2.5-4.5 \mathrm{~cm}$. wide ...P. brujoense.

Leaves elliptic, $6-7 \mathrm{~cm}$. wide........... Planadosense.

Leaf blades very lustrous on the upper surface.

$P$. aeruginosibaccum.

Leaf blades not at all cordate at the base, acute to obtuse or rounded.

Young branchlets densely pubescent or short-pilose.

Leaves very lustrous on the upper surface...P. aeruginosibaccum. Leaves dull on the upper surface, at least when dried.

$P$. uspantanense.

Young branchlets glabrous or sparsely and very minutely puberulent or granular.

Leaves conspicuously lustrous on the upper surface when dried. $P$. subcitrifolium.

Leaves dull on the upper surface when dried.

Leaves strigillose or appressed-pubescent beneath on the costa.

Leaf blades broadest somewhat above the middle, somewhat rhombic-obovate, bright green when dried .P. misantlense.

Leaf blades broadest below or near the middle, lance-oblong or lance-ovate, darkening when dried.

Leaf blades acute at the base...........P. Chamissonis. Leaf blades very obtuse at the base.

Leaf blades lance-oblong. . . . . . . . . . . . . . . P. come.

Leaf blades lance-ovate................ tacticanum.

Leaves pilosulous or villosulous beneath along the costa, the hairs spreading.

Leaves large, mostly $6-9 \mathrm{~cm}$. wide.........P. patzulinum. 
Leaves relatively small, mostly $3-5 \mathrm{~cm}$. wide.

Leaf blades very acute on both sides at the base.

$P$. lanciferum.

Leaf blades obtuse or rounded on both sides at the base.

P. Hermes.

Leaves obviously pubescent on the upper surface, at least along the lower part of the costa, or often almost invisibly scabrous or scaberulous, but then more or less rough to the touch, often very scabrous and rough.

Leaves smooth to the touch on the upper surface, either glabrous between the veins or softly pubescent, not at all scabrous or scaberulous.

Spikes normally conspicuously curved or recurved.....P. aduncum. Spikes straight or nearly so.

Leaves with about 10 pairs of primary nerves, oblong-lanceolate.

$P$. barriosense.

Leaves with mostly 3-4 pairs of primary nerves, rarely with as many as 7 pairs, but the leaves then broadly oval or elliptic.

Leaves deeply and narrowly cordate at the base, with a sinus 3-7 cm. deep or deeper, velutinous-pilosulous on the upper surface, mostly $20-30 \mathrm{~cm}$. wide............ auritum.

Leaves shallowly and often very broadly cordate at the base, or else not cordate, the sinus, if any, very short, the blades not velutinous-pilosulous on the upper surface.

Leaf blades acute on both sides at the base...P. georginum. Leaf blades cordate to very obtuse at the base, at least on one side.

Pubescence of the nerves on the lower leaf surface of closely appressed or subappressed hairs ......P. oradendron.

Pubescence of the nerves of the lower leaf surface pilosulous or villosulous with spreading hairs.

Leaves lanceolate or lance-oblong, mostly $4-6 \mathrm{~cm}$. wide, conspicuously bullate.............. jactatum.

Leaves broadly ovate to oval or broadly elliptic, mostly 8-20 cm. wide.

Leaves with 5-7 pairs of principal lateral nerves.

Leaf blades mostly $7-11 \mathrm{~cm}$. wide, very oblique at the base................... tecutlanum.

Leaf blades mostly $15-20 \mathrm{~cm}$. wide, almost equal at the base............... calophyllum.

Leaves with 3-4 pairs of principal nerves.

Petioles less than $1.5 \mathrm{~cm}$. long........P. minarum.

Petioles 2-5 cm. long or longer.......P. adamatum.

Leaves rough to the touch on the upper surface, usually very rough, obviously scabrous or scaberulous between the veins, at least on the younger leaves.

Nerves of the lower leaf surface strigose with closely appressed or subappressed hairs.

Leaves lanceolate or lance-oblong, 2-5 cm. wide.

Leaves conspicuously bullate, the nerves and veins impressed on the upper surface................... cayoense.

Leaves not obviously bullate, the nerves and veins little or not at all impressed on the upper surface.....P. phaeophyllum.

Leaves broadly ovate to ovate or elliptic, mostly 5-11 cm. wide, if less than $5 \mathrm{~cm}$. wide broader than lanceolate or lanceoblong.......................... scabrum. 
Nerves of the lower leaf surface pubescent, pilosulous, or hispidulous with spreading hairs.

Leaves, at least when young, villous-pilose on the upper surface with long spreading multicellular hairs........P. fallens.

Leaves short-pilose or scabrous on the upper surface, never with long spreading hairs.

Spikes, at least when young, with a conspicuous tail-like naked

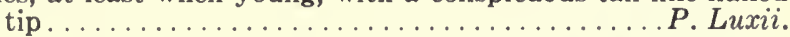

Spikes obtuse or rounded at the apex, not with a naked taillike tip.

Leaves, at least the older ones, conspicuously bullate, very rough to the touch on the upper surface.

Leaves very finely and closely areolate beneath, the ultimate veinlets very strongly elevated.....P. alveolatifolium.

Leaves coarsely bullate, the ultimate veinlets not or but slightly elevated.

Leaves lanceolate or ovate-lanceolate, broadest near the base....................................

Leaves variable in shape but mostly elliptic-ovate or somewhat rhombic-elliptic, broadest at or near the middle................. pseudoasperifolium.

Leaves not at all bullate, even in age, or, if rarely slightly bullate, soft to the touch on the upper surface, or at least not very scabrous.

Leaves, at least the young ones, densely hispidulous with subappressed hairs over the whole upper surface, or else densely and finely pubescent and then rather soft and velvety to the touch, neither scabrous nor scaberulous.

Upper leaf surface very densely hispidulous throughout, both surfaces grayish when dried and almost concolorous..................... indignum.

Upper leaf surface finely and densely pubescent, almost velvety to the touch, usually green when dried or sometimes blackish............. atlantidanum.

Leaves scabrous or scaberulous on the upper surface, rough to the touch.

Leaf blades acute or short-acuminate, $3-4 \mathrm{~cm}$. wide.

$P$. achoteanum.

Leaf blades abruptly acuminate or long-acuminate, usually much wider.

Young branches finely short-hispidulous, the hairs stiff, spreading or often in part subreflexed.

$P$. fraguanum.

Young branches villous-pilosulous with long spreading multicellular hairs.

Leaf blades acute at the base on both sides.

$P$. chiquihuitense.

Leaf blades rounded or subcordate on at least one side of the base........... pogonioneuron.

Piper achoteanum Trelease, Journ. Wash. Acad. Sci. 19: 328. 1929 (type from El Achote, near Siguatepeque, Honduras). $P$. pictamentum Trelease in Yuncker, Field Mus. Bot. 17: 352. 1938 
(type from Siguatepeque, Honduras). P. Yunckeri Trelease, op. cit. 355. 1938 (type from El Achote, Honduras). Cola de ratón.

At 400-1,100 meters, probably in moist or dry thickets; Alta Verapaz; Guatemala (Amatitlán). Mountains of Honduras.

A rather stout, erect shrub 1-3 meters high, the branches strongly nodose, with short internodes, densely hirtellous with spreading, whitish or fulvescent hairs; petioles stout, not winged, $5 \mathrm{~mm}$. long or usually shorter, often concealed by the basal lobes of the blade; leaf blades lance-oblong or oblong, mostly 9-13 $\mathrm{cm}$. long and $3-5 \mathrm{~cm}$. wide, acute or subobtuse, very thick, yellowish green when dry, densely and rather coarsely pellucid-punctate, very unequal and oblique at the base, rather deeply cordate on one side, cordate to obtuse on the other, coarsely granular and very scabrous on the upper surface, not bullate, coarsely granular beneath and scabrous, usually hispidulous on the nerves and veins with somewhat spreading or subappressed hairs, penninerved, the nerves $3-5$ on each side, elevated, arcuate-ascending, the veins prominent and coarsely reticulate; peduncles opposite the leaves, stout, $1 \mathrm{~cm}$. long or somewhat shorter, densely hirsutulous; spikes mostly 5-9 cm. long, 2.5-3 mm. thick, obtuse or subacute and submucronate; bracts rounded-peltate at the apex, densely ciliate, pale.

A very distinct species, whose foliage reminds one somewhat of certain species of Celtis.

\section{Piper adamatum Trelease \& Standley, sp. nov.}

Dense, moist or wet, mixed, mountain forest, 1,500-2,900 meters; so far as known, endemic, but doubtless extending to Chiapas; Alta Verapaz; Guatemala; Chimaltenango; Quezaltenango; San Marcos (Volcán de Tacaná, along Río Vega, near the Mexican boundary, Steyermark 36354; type in Herbarium of Chicago Natural History Museum).

An erect, sparsely branched shrub 1-3 meters high, the branches stout or rather slender, with short or mostly elongate internodes, densely villous-pilose with spreading, fulvous or brownish hairs; petioles stout or slender, $2.5-7 \mathrm{~cm}$. long, dilated and clasping at the base, not winged, densely villous-pilose or sometimes glabrate in age; leaf blades large, thin or rather thick, usually fuscescent when dried, minutely pellucid-punctate or almost wholly opaque, conspicuously and finely bullate, at least in age, broadly ovate to rounded-ovate, rarely lanceovate, mostly $14-19 \mathrm{~cm}$. long and 7-14 cm. wide, abruptly acuminate, subequal at the base and shallowly cordate, the two sides of about the same size, dull above, villous-pilosulous over almost the whole surface or in age glabrate, often brownish or fulvescent beneath, villous-pilosulous throughout, often between as well as upon the veins, penninerved, the nerves 3-4 on each side, arcuate-ascending at an angle of 45 degrees or more, the veins closely and conspicuously reticulate, impressed on the upper surface, very prominent beneath; peduncles opposite the leaves, stout, densely hirsutulous with spreading fulvescent hairs, at anthesis $1 \mathrm{~cm}$. long or shorter; young spikes very stout, about $3.5 \mathrm{~cm}$. long, 5-6 mm. thick, mucronate at the apex with a tail-like tip $3 \mathrm{~mm}$. long, the bracts very densely fulvous-hirsutulous. 
Frutex, ramis crassiusculis vel gracilibus dense pilis patentibus fulvis vel brunnescentibus villoso-pilosis; petioli exalati basi dilatati $2.5-7 \mathrm{~cm}$. longi, dense villoso-pilosi vel interdum glabrati; lamina magna in sicco fuscescens tenuis vel crassiuscula minute pellucido-punctata vel fere omnino epunctata, late ovata usque rotundo-ovata, abrupte acuminata, basi subaequali cordata, lateribus fere aequalibus, supra ubique villoso-pilosa, nervis venisque impressis, subtus ubique saepe quoque inter venas villoso-pilosula, penninervia, nervis utroque latere vulgo 3-4 angulo semirecto vel latiore arcuato-adscendentibus, venis prominentibus arcte reticulatis, lamina inter venas profunde areolata; pedunculi oppositifolii dense hirsutuli $1 \mathrm{~cm}$. longi vel breviores; spicae juveniles crassae $3.5 \mathrm{~cm}$. longae $5-6 \mathrm{~mm}$. crassae, apice longe caudato-mucronatae, bracteis dense fulvo-hirsutulis.

Piper aduncum L. Sp. Pl. 29. 1753. P. multinervium Mart. \& Gal. Bull. Acad. Brux. 10, pt. 2:130.1843. P. Stevensonii Trelease ex Standl. Field Mus. Bot. 12: 104. 1936, without Latin description (type from Toledo District, British Honduras, N. S. Stevenson 93). P. multinervium var. amplum Trelease in Yuncker, Field Mus. Bot. 17: 347.1938 (type from La Libertad, Petén, C. L. Lundell 2556). P. multinervium var. kantelolense Trelease, op. cit. 348 (type from La Libertad, Petén, Lundell 3008). P. multinervium var. Skutchii Trelease, op. cit. 350 (type from Colomba, A. F. Skutch 1299). Cordoncillo; Cuturo (North Coast, fide Blake); Cordoncillo blanco; Biritac (Cobán, Quecchí).

Wet to dry thickets, often in second growth, sometimes in pine forest, 1,600 meters or lower; Petén; Alta Verapaz; Baja Verapaz; Izabal; Zacapa; Chiquimula; Jalapa; Jutiapa; Santa Rosa; Escuintla; Guatemala; Chimaltenango; Suchitepequez; Retalhuleu; Quezaltenango; San Marcos; Huehuetenango. Southern Mexico; British Honduras to El Salvador and Panama and probably farther southward; West Indies; widely distributed in South America.

An erect shrub or small tree, 1-5 meters high or perhaps even larger, often with a rather thick and clean, distinct trunk and a rather narrow and elongate crown, the branchlets mostly straight and elongate, strigillose or hirtellous with very short, white, spreading hairs, glabrate in age, the larger branches often somewhat pendent; petioles short, usually much less than $1 \mathrm{~cm}$. long, strigose or short-hispidulous; leaves narrowly to broadly lance-oblong, mostly $13-20 \mathrm{~cm}$. long and 4.5-8 $\mathrm{cm}$. wide, rather abruptly and narrowly long-acuminate, very scabrous and rough to the touch on the upper surface, often somewhat lustrous, slightly paler beneath, rather densely scabrous or appressed-hispidulous beneath, strigose on the nerves and veins, the primary lateral nerves usually $3-4$, sometimes 5 , on each side, ascending at a very narrow angle, the uppermost arising near the middle of the blade, the nerves and veins plane on the upper surface, the lateral nerves strongly elevated beneath, the ultimate veins scarcely at all elevated, inconspicuous; spikes solitary opposite the leaves, on slender or stout peduncles $1.5 \mathrm{~cm}$. long or shorter, slender, normally very conspicuously curved, when mature 
mostly 10-13 cm. long, about $3 \mathrm{~mm}$. thick; flowers crowded in dense verticils, the bracts puberulent, the spikes in anthesis pale green or greenish white.

Known in British Honduras by the names "Spanish elder," "Spanish Ella," and "cow's-foot." This species is one of the most common ones of Guatemala and other parts of Central America, abundant in many localities, easily recognized by its combination of penninerved leaves and strongly curved flower spikes. It has been reported from the region as $P$. elongatum Vahl, a synonym of $P$. aduncum. The mature flower spikes of this, and doubtless of other species, are used in Guatemala and British Honduras for flavoring food, having more or less the properties of black pepper. Schipp reports that in the latter country they are sometimes boiled and eaten. The leaves of $P$. aduncum are of a lighter green than those of most Central American species of Piper.

Piper aeruginosibaccum Trelease, Journ. Wash. Acad. Sci. 19: 328. 1929 (type from La Ceiba, Honduras). P. citrifolium var. Cookii C. DC. Bot. Gaz. 70: 186. 1920 (type collected near Finca Sepacuité, Alta Verapaz, O.F. Cook \& R.F.Griggs 697). P. onerosum Trelease, Journ. Wash. Acad. Sci. 19: 335. 1929 (type from Tela, Honduras). P. praeterlatum Trelease, loc. cit. (type from Lancetilla Valley near Tela, Honduras). $P$. dimorphophyllum Trelease in Standl. Field Mus. Bot. 12: 407. 1936 (type from Craig Point, Sibun River, British Honduras, P. H. Gentle 1387). P. Gentlei Trelease, loc. cit. (type from San Andrés, Corozal District, British Honduras, Gentle 1077). P. nitidulifolium Trelease in Standl. op. cit. 408 (type from Tower Hill, British Honduras, J. S. Karling 26). $P$. kantelulense Trelease, in Standl. loc. cit. (type from Kantelul, Petén, C. L. Lundell 3173). P. kantelulense var. Gentlei Trelease in Standl. loc. cit. (type from Prospect, Northern River, British Honduras, Gentle 947). P. discolor Trelease in Standl. Field Mus. Bot. 17: 231. 1937 (type from La Libertad, Petén, Lundell 2565). P. emancipationis Trelease in Standl. loc. cit. (type from La Libertad, Petén, Lundell 3658). P. emancipationis var. longum Trelease in Standl. loc. cit. (type collected near La Libertad, Petén, Lundell 3052). P. nitidulilaminum Trelease in Standl. op. cit. 232 (type from Remate, Petén, Lundell 2077). P. plumbeicolor Trelease in Standl. op. cit. 233 (type from La Libertad, Lundell 2554). Cordoncillo; Pooczuyaax (Petén, Maya, fide Lundell).

Moist or wet thickets or forest, sometimes in pine forest or in Manicaria swamps, 900 meters or lower; Petén; Alta Verapaz; Izabal. Campeche; British Honduras. 
A shrub, commonly about 2 meters high, sometimes a small tree, the young branches densely hispidulous or hirsutulous, sometimes glabrate in age or occasionally almost glabrous from the first; petioles mostly $1 \mathrm{~cm}$. long or less, sometimes longer in the lower leaves, stout, densely hispidulous or rarely glabrate; leaf blades ovate-oblong or ovate-elliptic, mostly $12-20 \mathrm{~cm}$. long and $4.5-9 \mathrm{~cm}$. wide, rather abruptly acuminate or long-acuminate, very unequal at the base and more or less oblique, usually rounded or more or less cordate on one side and obtuse on the other, one side much lower decurrent than the other, thick and firm, very lustrous on the upper surface and often lustrous beneath, slightly paler beneath, drying grayish green or sometimes blackish, finely pellucid-punctate, glabrous above, smooth to the touch, hispidulous beneath, especially on the nerves, with short sordid subappressed hairs, rather harsh to the touch, penninerved, the nerves usually 3 on each side, arcuate-ascending, the upper ones arising at or above the middle of the blade, the veins prominent beneath, laxly reticulate; peduncles short, thick, densely puberulent or hispidulous; spikes rather stout, mostly 5-7 cm. long and 3-4 mm. thick, erect, obtuse, the bracts densely pubescent.

The material we refer here is somewhat variable but not more so than is to be expected in a tropical species. Some of the characters by which the various species were separated by Trelease are more or less obvious, but apparently they are individual variations. Seven or eight other species, not listed here but described by Trelease, are clearly referable to the same species, for which it is quite possible that a still earlier name may be found.

Piper alveolatifolium Trelease, Journ. Wash. Acad. Sci. 19: 329. 1929 (type from Siguatepeque, Honduras). P. faviculiferum Trelease in Yuncker, Field Mus. Bot. 17: 345. pl. 11. 1938 (type from El Achote, above Siguatepeque, Honduras).

Moist or wet forest, often in pine-oak forest, 1,000-1,600 meters; Zacapa; Chiquimula; Jalapa; Guatemala; Quiché. Honduras.

A shrub or small tree 2-7 meters high, the young branches very densely fulvoushirsute with short spreading hairs, the internodes mostly short; petioles stout, commonly $1-1.5 \mathrm{~cm}$. long, densely hispidulous; leaf blades ovate or lance-ovate, mostly $16-23 \mathrm{~cm}$. long and $6.5-9 \mathrm{~cm}$. wide, gradually acuminate to very longacuminate, very unequal at the base, rounded on one side, cordate or subcordate at the other, opaque, very finely and deeply bullate, not blackening when dry, very scabrous on the upper surface, densely hirtellous beneath with spreading whitish hairs, penninerved, the lateral nerves $3-4$ on each side, very prominent, the veins exceedingly prominent and very closely and finely reticulate, the lower surface of the blade deeply alveolate; peduncles stout, equaling or shorter than the petioles, densely fulvous-hispidulous; spikes stout, erect, greenish white, mostly 6-10 $\mathrm{cm}$. long, $4 \mathrm{~mm}$. thick, the bracts very densely hispidulous.

One of the most distinct and clearly marked of all local species, easily recognized by its finely and closely bullate leaves, the veins of the lower surface being greatly elevated and areolate, with deep 
depressions between them. Three of the Guatemalan collections were indicated as new species by Trelease, but all of them appear to be identical with the two Honduran plants described as distinct species.

Piper Amalago L. Sp. Pl. 29. $1753 . \quad$ P. medium Jacq. Icon. PI. Rar. 1: 2. 1781. P. cubilquitzianum C. DC. Bot. Gaz. 70: 174. 1920 (type from Cubilgüitz, Alta Verapaz, Türckheim II.1440). P. Gaumeri Trelease, Journ. Wash. Acad. Sci. 19: 332.1929 (type from Yucatan). P. Lundellii Trelease in Standl. Field Mus. Bot. 12: 408.1936 (type from Honey Camp, British Honduras, C. $L$. Lundell 570). P. lundelliifolium Trelease, op. cit. 17:232. 1927 (type from La Libertad, Petén, Lundell 3524). Cordoncillo.

Moist or wet thickets or mixed forest, 2,600 meters or lower; Petén; Alta Verapaz; Baja Verapaz; Izabal; Zacapa; Escuintla; Guatemala; Sacatepéquez; Chimaltenango; Sololá; Suchitepequez; Retalhuleu; Quezaltenango; San Marcos; Huehuetenango. Southern Mexico; British Honduras and southward, probably to Panama; West Indies; South America.

A rather slender, often much branched shrub or small tree, commonly 1.5-3 meters high or sometimes as much as 6 meters, the branches glabrous or minutely and often only sparsely puberulent; petioles about $1 \mathrm{~cm}$. long, or often longer or shorter, glabrous, vaginate only at the base; leaf blades green or blackish when dried, minutely pellucid-punctate or almost wholly epunctate, rather thin but usually rather firm and stiff, variable in shape, lance-elliptic to ovate-elliptic or rounded-ovate, mostly $7-14 \mathrm{~cm}$. long and $3.5-7 \mathrm{~cm}$. wide, gradually or abruptly acuminate or long-acuminate, obtuse to broadly rounded at the base, palmately 5-nerved, the nerves slender, prominent on both surfaces, the lateral ones sometimes much weaker than the others and inconspicuous or very irregular, the blades symmetric at the base or only slightly oblique, the veins generally prominulous, laxly reticulate, the leaves glabrous or sometimes minutely puberulent beneath on the nerves; peduncles slender, equaling or usually somewhat longer than the petioles, glabrous or puberulent; spikes cream-colored or greenish, slender, $3-7 \mathrm{~cm}$. long or longer, $2.5 \mathrm{~mm}$. thick, the rachis puberulent or hirtellous, the bracts ciliate, sometimes hirtellous; stamens 4 , the anthers reniform; fruits glabrous.

It is quite possible that the material we refer here represents more than a single species, but we do not find fixed characters by which the forms, if there are any definite ones, may be distinguished. Trelease has annotated many of the sheets as representing new species. The shrub is known in British Honduras by the names "Spanish elder" and "cordoncillo chico."

Piper atlantidanum Trelease, Journ. Wash. Acad. Sci. 19: 329. 1929 (type from La Ceiba, Honduras). P. praemollitum Tre- 
lease in Yuncker, Field Mus. Bot. 17: 352.1938 (type from Lake Yojoa, Honduras). P. viae-marginis Trelease, op. cit. 355. 1938 (type from Siguatepeque, Honduras). $P$. coyolense Trelease in Yuncker, Field Mus. Bot. 9: 278. 1940 (type from Coyoles, Honduras). P. elasmophyllum Trelease, op. cit. 278. 1940 (type from Mount Cangrejal, Honduras). P. subaequilaterum Trelease, op. cit. 280. 1940 (type from region of La Ceiba, Honduras). P. atlantidanum var. sibunense Trelease in Standl. Field Mus. Bot. 12: 406. 1936 (type from Craig Point, Sibun River, British Honduras, $P$. $H$. Gentle 1381). P. quadratilimbun Trelease in Standl. Field Mus. Bot. 17: 233.1937 (type from El Paso, Petén, C. L. Lundell 1488).

Moist or wet thickets or mixed forest, 1,000 meters or lower; Petén; Alta Verapaz. British Honduras; Honduras.

An erect shrub 1.5-3.5 meters high, the branches rather slender, with mostly short internodes, densely pilose with short, spreading or somewhat reflexed, usually fulvescent hairs; petioles stout, about $1 \mathrm{~cm}$. long, sometimes longer or shorter, densely short-pilose, not winged, dilated at the base; leaf blades mostly green when dried, not bullate, rather thin, minutely pellucid-punctate, elliptic to ovate or obovate-elliptic, mostly $10-16 \mathrm{~cm}$. long and $5-8.5 \mathrm{~cm}$. wide, rather abruptly acuminate or long-acuminate, conspicuously unequal and oblique at the base, generally cordate to rounded on one side, rounded to acate on the other, densely scabrous-puberulent on the upper surface but soft and almost velvety to the touch, densely velutinous-pubescent beneath, penninerved, the nerves $3-4$ on each side, very slender but prominent, ascending at an angle of 45 degrees or less, slightly arcuate or almost straight, the veins usually not conspicuous, rather laxly reticulate; peduncles opposite the leaves, stout, $8 \mathrm{~mm}$. long or usually shorter, densely hirtellous; spikes slender, erect-spreading, mostly 6-7 cm. long, $2.5 \mathrm{~mm}$. thick, cream-colored; bracts triangular-peltate at the apex, ciliolate; anthers short-exserted; fruits mostly trigonous, somewhat depressed at the apex, glabrous or nearly so.

Piper auritum HBK. Nov. Gen. \& Sp. 1: 54. 1816. Santa Maria (the usual name); Cordoncillo; Hoja de jute; Juniapra (fide Pittier); Xaclipur (reported as Quecchí name); Obet (Cobán, Quecchí); Caña de oro (Quezaltenango).

Moist or wet thickets or forest, often in second growth, 1,800 meters or lower, most common at 900 meters or below; Petén; Alta Verapaz; Izabal; Zacapa; Santa Rosa; Escuintla; Guatemala; Sacatepéquez (probably only introduced); Chimaltenango; Sololá; Suchitepequez; Retalhuleu; Quezaltenango; San Marcos. Southern Mexico; British Honduras to Salvador and Panama; Colombia; described originally from Mexico.

A large, coarse, somewhat succulent herb, sparsely branched, or rarely woody below and becoming tree-like, commonly about 2 meters high but occasionally 
as much as 6 meters, the branches stout, sparsely pubescent or glabrate; leave on short or elongate, stout petioles, the petioles broadly winged, more or les: dilated and clasping at the base; leaf blades very large, thin and soft, usually drying bright yellowish green, broadly ovate or oblong-ovate, as much as $60 \mathrm{~cm}$ long and $35 \mathrm{~cm}$. wide but usually much smaller, acute or abruptly short-acuminate, deeply and narrowly cordate at the base, the basal lobes rounded, one of them extending 1.5-3 cm. lower on the costa than the other, slightly paler beneath, softly puberulent or short-pilosulous on both surfaces, with usually 3 pairs of nerves above the basal ones; peduncles simple, opposite the leaves, about $3 \mathrm{~cm}$. long; spikes pale green, $4 \mathrm{~mm}$. thick, commonly $20-25 \mathrm{~cm}$. long, the pale peltate scales finely puberulent.

In British Honduras called "bullhoof" and "maculán" (Maya); "matarro" (Honduras); "momo" (Yucatan). This is one of the commonest and most widespread species of the genus, found in the lowlands almost throughout Central America, at least where there is abundant shade. The plants often form dense thickets in abandoned land, partly, no doubt, on account of the great abundance of seeds produced. The fruits of many or most of the Piperaceae are extremely viscid, and so small that they can be dispersed by all kinds of animals, even insects. This plant is a conspicuous and rather handsome one because of its large leaves, but these become limp immediately, if they are broken from the branch. Large plants, particularly those that become really woody, often shed their lower branches, so that only a small number of them are left at the very top of the trunk. The crushed leaves and stems have a strong odor similar to that of sarsaparilla, and the leaves are much used to flavor food of all kinds, particularly meat dishes, and especially the common local snails or jutes of the small streams.

\section{Piper barriosense Trelease \& Standley, sp. nov.}

Moist or wet, lowland thickets or mixed forest, at or near sea level; endemic; Izabal (type from Entre Ríos, Standley 72611, in Herbarium of Chicago Natural History Museum; also at Puerto Barrios).

A shrub 2 meters high, the branches stout or slender, with short or elongate internodes, conspicuously pale-lenticellate, densely and softly sordid-pilosulous when young, conspicuously nodose; petioles strongly dilated at the base, when young broadly winged throughout, the shorter side 7-12 $\mathrm{mm}$. long, the longer side as much as $2 \mathrm{~cm}$. long, densely pilosulous; leaf blades thin, brownish and blackish when dried, minutely pellucid-punctulate, dull, lanceolate or narrowly lanceolate, mostly $14-22 \mathrm{~cm}$. long and $3.5-7 \mathrm{~cm}$. wide, gradually long-acuminate, sparsely short-pilosulous above when young but soon glabrate, rather densely and softly short-pilosulous beneath over the whole surface, very unequal at the base, rounded or obtuse on either side, penninerved, the nerves about ten on each 
side, divergent at wide angle, arcuate, very slender and inconspicuous, the veins very slender and inconspicuous, laxly reticulate; spikes unknown.

Frutex erectus, ramis pallido-lenticellatis, statu juvenili dense molliter sordidopilosulis; petioli late alati crassi; lamina lanceolata vel anguste lanceolata longe sensimque attenuato-acuminata, basi insigniter inaequalis utroque latere obtusa vel rotundata, rarius latere altero subacuta, penninervia, nervis utroque latere ca. 10, supra sparse pilosula vel glabrata, subtus sat dense breviter molliterque pilosula.

In general appearance this is like $P$. geniculatum Swartz, of which it may be only a variety, but it differs conspicuously from other material of that species in its abundant pubescence.

Piper Biritak Trelease \& Standley, sp. nov. Biritak (Cobán, Quecchí).

Moist or wet, mixed or pine, mountain forest, sometimes on limestone, 900-1,500 meters; endemic; Alta Verapaz (type from Cobán, Standley 69345; in Herbarium of Chicago Natural History Museum); Huehuetenango (Maxbal).

A slender shrub 1-2 meters high, often with long straggling branches, the upper internodes usually short, sometimes elongate, very densely hispidulous with short sordid spreading hairs; petioles stout, mostly 5-10 $\mathrm{mm}$. long, sometimes longer, vaginate only at the base, densely hispidulous; leaf blades strongly bullate, at least in age, grayish or sometimes fuscescent when dry, lustrous on the upper surface, finely pellucid-punctate, mostly lanceolate or narrowly lanceolate, sometimes ovate-lanceolate, mostly $13-25 \mathrm{~cm}$. long and $4-7.5 \mathrm{~cm}$. wide, narrowly and gradually very long-attenuate, strongly unequal and oblique at the base, usually cordate or subcordate on one side and rounded or obtuse on the other, glabrous above or nearly so, the nerves and veins strongly impressed, at least in age, densely hispidulous or strigose beneath on the nerves and veins, glabrous or nearly so between them and strongly granular, penninerved, the nerves 3 or 4 on each side, strongly elevated, the veins conspicuously elevated and closely reticulate; spikes unknown.

Frutex, ramis gracilibus interdum elongatis, internodiis plerumque brevibus pilis brevibus sordidis patentibus dense hispidulis; folia breviter petiolata, petiolo vulgo 5-10 $\mathrm{mm}$. longo dense hispidulo, basi tantum vaginante, insigniter bullata, supra lucida, minute pellucido-punctata, anguste lanceolata usque ovato-lanceolata modica vel magna subcoriacea, sensim longeque attenuato-acuminata, basi inaequalia et obliqua, uno latere cordata vel subcordata, altero obtusa vel rotundata, penninervia, nervis utroque latere $3-4$, venis supra impressis, subtus elevatis arcte reticulatis; spicae ignotae.

A rather common and well-marked plant of the forests of Alta Verapaz, represented by about a dozen collections.

Piper brevilimbum C. DC. Candollea 1: 128, 238. 1923; ex Schroeder, Candollea 3: 136. 1926. 
Wet, mixed, mountain forest, 1,250-1,500 meters; endemic; Alta Verapaz (type from Cobán, Türckheim II.1625; collected several times in the Cobán region); Chiquimula (Cerro Tixixí).

A slender branched erect shrub 1.5-2.5 meters high, the branches slender, with short internodes, sparsely and inconspicuously pubescent or glabrate; petioles slender, mostly $5 \mathrm{~mm}$. long or less; leaf blades ovate-elliptic or lance-elliptic, $5.5-12 \mathrm{~cm}$. long, $3-5.5 \mathrm{~cm}$. wide, rather abruptly acuminate, acute at the base and slightly unequal, blackish when dried, dull, opaque, penninerved, the nerves usually three on each side, slender and very inconspicuous, arcuate-ascending, arising from the middle of the blade or lower, the blades glabrous throughout; peduncles slender, glabrous, about $1 \mathrm{~cm}$. long; spikes rather stout, $3.5-6 \mathrm{~cm}$. long, $3 \mathrm{~mm}$. thick; bracts rounded-subpeltate, ciliate.

Piper brevipedunculatum C. DC. Ann. Cons. Jard. Bot. Genève 2: 266. 1898.

Known only from the type, Suchitepequez, banks of the Río Grande, Mazatenango, Bernoulli 470.

Branches glabrous; leaves glabrous, on petioles 1-2.5 cm. long, firm-membranaceous, ovate, as much as $15 \mathrm{~cm}$. long and $9 \mathrm{~cm}$. wide, rather long-acuminate, unequally rounded at the base, pellucid-punctate, the costa emitting four lateral nerves on each side; peduncles shorter than the petioles, $1 \mathrm{~cm}$. long or less, the spikes about half as long as the leaves, $5 \mathrm{~mm}$. thick in anthesis; bracts truncate at the apex, sparsely ciliolate; fruits trigonous-obpyramidal, glabrous.

We have seen no material of this species and have not attempted to include it in the key. It probably antedates some species listed here, but from the description alone we could not determine its relationship.

Piper brujoense Trelease \& Standley, sp. nov. Santa María (Chiquimula).

Moist or wet, mixed, mountain forest, 1,700-2,500 meters; endemic; Zacapa (Sierra de las Minas); Chiquimula (type from middle slopes of Montaña Norte to El Jutal, on Cerro Brujo, southeast of Concepción de las Minas, Steyermark 31049; in Herbarium of Chicago Natural History Museum).

A shrub or small tree 1.5-6 meters high, the branches slender, rather densely hispidulous with spreading hairs or glabrate, the internodes mostly short; petioles stout, scarcely more than $3 \mathrm{~mm}$. long, densely hispidulous; leaf blades rather thick, grayish green when dry, densely and minutely pellucid-punctate, oblonglanceolate, $10-17 \mathrm{~cm}$. long, 3-4.5 cm. wide, narrowly attenuate-acuminate, conspicuously unequal and oblique at the narrow báse, shallowly cordate on one side, acute or obtuse on the other, dull and glabrous above, much paler beneath, hispidulous with short spreading hairs on the nerves and veins, glabrous or nearly so between them, penninerved, the nerves $2-3$ on each side, arcuate-ascending 
at an angle of about 45 degrees, the veins prominulous or obscure, laxly reticulate; peduncles opposite the leaves, rather stout, $12 \mathrm{~mm}$. long or shorter, glabrous; spikes rather stout, erect, about $7.5 \mathrm{~cm}$. long and $3 \mathrm{~mm}$. thick, obtuse; bracts pale, densely puberulent; ovaries glabrous or nearly so.

Frutex, ramis gracilibus pilis patentibus subdense hispidulis vel glabratis; petioli vix ultra $3 \mathrm{~mm}$. longi dense hispiduli; lamina crassiuscula in sicco griseoviridis dense minute pellucido-punctata, oblongo-lanceolata anguste longeque attenuato-acuminata, basi manifeste inaequali et obliqua uno latere breviter cordata, altero acuta vel obtusa, supra glabra, subtus pallidior ad nervos venasque dense hispidula, penninervia, nervis utroque latere 2-3 angulo angusto arcuatoadscendentibus; pedunculi oppositifolii usque ad $12 \mathrm{~mm}$. longi, glabri, spicis crassiusculis ca. $7.5 \mathrm{~cm}$. longis et $3 \mathrm{~mm}$. crassis.

Piper calophyllum C. DC. in Donn. Smith, Bot. Gaz. 33: 257. 1902.

Moist or wet, mixed, lowland forest, sometimes or perhaps always on limestone, 900 meters or lower; Alta Verapaz (type from Cubilgüitz, Türckheim 7959; collected also about Chirriacté).

A rather coarse shrub 2-3.5 meters high, with few branches, the young branches very thick and stout, villous-hirsute, as much as $11 \mathrm{~mm}$. thick; petioles very stout, about $4 \mathrm{~cm}$. long, vaginate throughout, sparsely villous-hirsute; leaf blades very large, rather thick, somewhat blackish when dried, ovate, 25-35 cm. long, 15-20 $\mathrm{cm}$. wide, abruptly acute or short-acuminate, rounded at the base and shallowly and narrowly cordate, with small rounded lobes, green above, somewhat lustrous, villous-pilose along the nerves and veins or glabrate, somewhat paler beneath, brownish when dried, densely and softly short-pilose, penninerved, the nerves 8-9 on each side, prominent beneath, the veins prominent and laxly reticulate; spikes white or greenish white, erect, borne on a very thick, pilose or glabrate peduncle about $1 \mathrm{~cm}$. long, very stout, conspicuously caudate at the apex, 5-6.5 $\mathrm{cm}$. long, $6 \mathrm{~mm}$. thick, the bracts truncate-triangular, glabrous; stamens 4 , the anthers reniform, much shorter than the filaments; ovary glabrous, somewhat narrowed at the apex, the 3 stigmas sessile, linear, short, recurved.

Piper cayoense Trelease in Standl. Field Mus. Bot. 12: 407. 1936 (type from San Antonio, El Cayo District, British Honduras, H. H. Bartlett 13070). P. tikalense Trelease in Standl. Field Mus. Bot. 17: 234. 1937 (type from Tikal, Petén, H. H. Bartlett 12595). $P$. yalochanum Trelease in Standl. loc. cit. (type collected between Dos Arroyos and Yaloch, Petén, Bartlett 12849). Biritak.

Moist or wet forest or thickets, sometimes in pine forest, often on limestone, 1,200-1,450 meters or lower; endemic; Petén (Laguna de Mexico); Alta Verapaz. British Honduras.

A slender shrub 1-2.5 meters high, sparsely branched, often with elongate and rather weak branches, the young branches densely pale-hispidulous, the internodes short or often elongate; petioles very stout, $7 \mathrm{~mm}$. long or shorter, densely hispidulous, not winged, dilated at the base; leaf blades rigid, subcoriaceous, 
strongly and rather closely bullate, opaque or nearly so, mostly lanceolate or oblong-lanceolate, rarely ovate, usually $7-14 \mathrm{~cm}$. long and $2.5-5 \mathrm{~cm}$. wide, narrowly long-acuminate or attenuate-acuminate, very unequal and oblique at the base, cordate on both sides or cordate on one side and rounded on the other, densely pustulate on the upper surface, scabrous and very rough to the touch, dull or slightly lustrous, often fuscescent when dried, the nerves and veins, strongly impressed, densely appressed-pilose beneath on the nerves and veins, or rarely pilose with spreading hairs, usually short-pilose with spreading hairs between them, penninerved, the nerves 3-4 on each side, very prominent, arcuate-ascending at an angle of 45 degrees or usually more, the veins strongly elevated and closely reticulate, the surface areolate between them; peduncles opposite the leaves, stout, about $6 \mathrm{~mm}$. long, hispidulous; spikes erect-ascending, rather stout, very obtuse, at anthesis about $4.5 \mathrm{~cm}$. long and $3 \mathrm{~mm}$. thick; bracts pale, densely hispidulous.

Piper Chamissonis (Miq.) Steud. Nom. Bot. ed. 2. 2: 340. 1841; ex C. DC. in DC. Prodr. 16, pt. 1:283. 1869. Artanthe Chamissonis Miq. Syst. Piper. 457. 1844.

Dense, moist or wet, mixed, mountain forest, $900-2,500$ meters; Alta Verapaz; Quezaltenango; San Marcos. Southern Mexico.

A shrub 1.5-2.5 meters high, sparsely branched, erect, the branches glabrous or glabrate, rather stout, often granular; petioles stout, $1.5 \mathrm{~cm}$. long or shorter, often much less than $1 \mathrm{~cm}$. long, glabrous or sparsely strigose or hirtellous, vaginate only at the base; leaf blades usually thin, generally dark green when dry, minutely pellucid-punctate or almost wholly opaque, dull when dried, oblong-elliptic to elliptic or sometimes ovate-elliptic, mostly $13-22 \mathrm{~cm}$. long and $4.5-9.5 \mathrm{~cm}$. wide, rather abruptly acuminate or long-acuminate, rather conspicuously unequal and often oblique at the base, one side usually much longer decurrent than the other, acute on both sides, green above, glabrous, somewhat paler beneath, more or less strigose or hirtellous beneath on the nerves and veins or almost wholly glabrous, penninerved, the nerves 3-4 on each side, arcuate-ascending at an angle of about 45 degrees or less, very slender but prominent, the veins mostly inconspicuous, very laxly reticulate; peduncles opposite the leaves, rather slender, mostly 10-14 $\mathrm{mm}$. long, glabrous or nearly so; spikes erect-spreading, rather slender, white or greenish, mostly 7-10 $\mathrm{cm}$. long when fully developed and $3 \mathrm{~mm}$. thick, obtuse; bracts triangular-peltate at the apex, densely ciliate, pale; fruit glabrous.

\section{Piper cheyennense Trelease \& Standley, sp. nov.}

Wet mixed forest, at or little above sea level; endemic; Izabal (type collected along Río Juyamá, southeast of Cheyenne, about 15 miles southwest of Bananera, Steyermark 39154; in Herbarium of Chicago Natural History Museum).

A shrub 1.5-2.5 meters high, glabrous throughout, the branches rather slender, with short internodes; petioles stout, $2-3.5 \mathrm{~cm}$. long, vaginate only at the base; leaf blades rather thick and firm, green when dried, opaque, oblong-ovate, 18-23 $\mathrm{cm}$. long, 7-10.5 cm. wide, abruptly acuminate, subequal and rounded or broadly rounded at the base, concolorous, penninerved, the nerves mostly 5 on each side, 
slender, prominent on both surfaces, ascending at an angle of 45 degrees or more, slightly arcuate, the veins prominent beneath, laxly reticulate; peduncles about $8 \mathrm{~mm}$. long or even shorter, the spikes erect-spreading, 10-11.5 cm. long, $3 \mathrm{~mm}$. thick, mucronate at the apex; bracts with an ovate apex, pale green, glabrous, ciliate.

Frutex omnino glaber, ramis subgracilibus, internodiis brevibus; folia magna 2-3.5 $\mathrm{cm}$. longe petiolata, petiolo basi tantum vaginante, oblongo-ovata abrupte acuminata, basi subaequali et symmetrica rotundata vel late rotundata, penninervia, opaca, in sicco viridia, nervis utroque latere saepius 5 arcuato-adscendentibus; spicae oppositifoliae breviter pedunculatae graciles 10-11.5 cm. longae $3 \mathrm{~mm}$. crassae.

Besides the type, we have seen one other collection, gathered between Dartmouth and Morales, which Trelease designated as the type of another new species, but the two collections are identical.

\section{Piper chiquihuitense Trelease \& Standley, sp. nov.}

Moist or wet thickets or mixed mountain forest, 1,200-1,500 meters; endemic; Quezaltenango (type from Chiquihuite, Standley 68146; in Herbarium of Chicago Natural History Museum; also in the region of Finca Pirineos).

An erect shrub about 3 meters high, densely pilose with very unequal hairs, some of the hairs long, soft, and spreading, fulvescent; petioles mostly $1.5-2 \mathrm{~cm}$. long, not winged, dilated at the base, densely pilose with soft spreading hairs; leaf blades thin, scarcely fuscescent when dried, opaque or nearly so but with translucent veins, elliptic or ovate-elliptic, mostly $14-25 \mathrm{~cm}$. long and $6-10 \mathrm{~cm}$. wide, long-acuminate, somewhat unequal and conspicuously oblique at the base, acute on each side, densely scabrous and very rough to the touch, hispidulous along the nerves, not at all rugose, densely scabrous beneath, pilose on the nerves and veins, part of the hairs long, soft, and spreading, penninerved, the nerves $3-5$ on each side, ascending at an angle of 45 degrees or less, slightly arcuate, very slender, the veins very slender, not conspicuous, laxly reticulate; peduncles opposite the leaves, $10-18 \mathrm{~mm}$. long, scabrous and often short-hispidulous; spikes erect or ascending, $8-9.5 \mathrm{~cm}$. long, $4 \mathrm{~mm}$. thick, obtuse; bracts rounded-peltate at the apex, pale, densely pubescent; anthers short-exserted; fruits obtusely angulate, about $1 \mathrm{~mm}$. long, somewhat depressed at the apex, sparsely puberulent or granulate above.

Frutex, ramis dense pilis inaequalibus pro parte longis mollibus patentibus pilosis, internodiis plerumque elongatis; petioli $1.5-2 \mathrm{~cm}$. longi crassiusculi exalati basi dilatati dense patenti-pilosi; lamina sat magna opaca, venis pellucidis, in sicco vix fuscescens, elliptica vel ovato-elliptica, longiacuminata, basi inaequali atque obliqua utroque latere acuta, supra dense scabra et asperrima, ad nervos venasque hispidula, subtus dense scabra, ad nervos venasque pilis pro parte longis mollibus patentibus pilosa, penninervia, nervis utroque latere $3-5$ angulo angusto adscendentibus subarcuatis, venis laxe reticulatis; pedunculi oppositifolii 10-18 mm. longi, spicis $8-9.5 \mathrm{~cm}$. longis $4 \mathrm{~mm}$. crassis. 


\section{Piper come Trelease \& Standley, sp. nov.}

Known only from the type, Jalapa, Volcán de Jumay, moist or wet forest, about 2,000 meters, Steyermark 32350 (in Herbarium of Chicago Natural History Museum).

A shrub 3 meters high, erect, the branches stout, with short internodes, almost glabrous but when young with sparse appressed hairs; petioles stout, about $1 \mathrm{~cm}$. long, glabrous or nearly so, not winged, dilated at the base; leaf blades dark green when dried, dull, densely and finely pellucid-punctate, lance-oblong, 13-22 cm. long, 5-7.5 cm. wide, gradually long-acuminate, conspicuously unequal and somewhat oblique at the base, rounded or obtuse on either side, not at all bullate, glabrous above, the nerves inconspicuous, scarcely paler beneath, sparsely strigose along the nerves and principal veins, glabrous elsewhere, penninerved, the nerves 3-4 on each side, arcuate-ascending at an angle of more than 45 degrees, the veins inconspicuous, often brownish, laxly reticulate; spikes unknown.

Frutex, ramis crassiusculis internodiis brevibus in statu juvenili sparse strigosis cito glabratis; petioli crassi ca. $1 \mathrm{~cm}$. longi exalati, basi dilatati; lamina tenuis in sicco obscure viridis pellucido-punctata lanceolato-oblonga modica, sensim longiacuminata, basi inaequali atque obliqua utroque latere rotundata vel obtusa, supra glabra, subtus ad nervos venasque sparse strigosa, penninervia, nervis utroque latere 3-4 arcuato-adscendentibus, venis non conspicuis laxe reticulatis; spicae ignotae.

Piper coronanum Trelease \& Standley, sp. nov.

Known only from the type, San Marcos, moist mixed forest, Volcán de Tajumulco, between Finca El Porvenir and Loma Corona, nine miles northwest of El Porvenir, 1,300-2,000 meters, Steyermark 37741 (in Herbarium of Chicago Natural History Museum).

A shrub, glabrous throughout, the upper internodes short; petioles stout, 8-10 mm. long, vaginate only at the base; leaf blades thin, dull green when dried, very minutely pellucid-punctate or almost opaque, elliptic-oblong, $13-20 \mathrm{~cm}$. long, $5.5-8.5 \mathrm{~cm}$. wide, broadest at or slightly below the middle, acuminate, acute at the base and somewhat decurrent on the petiole, equal or nearly so, penninerved, the nerves mostly five on each side or sometimes only four, arcuateascending at an angle of 45 degrees or slightly more, very slender, prominent beneath, the veins obscure, very laxly reticulate; peduncles very stout, about $1 \mathrm{~cm}$. long; spikes green, spreading, stout, straight, about $9 \mathrm{~cm}$. long and $4 \mathrm{~mm}$. thick, obtuse or subapiculate; bracts small, densely pale-ciliate; ovaries glabrous.

Frutex erectus omnino glaber; folia breviter petiolata tenuiter membranacea in sicco sordide viridia, minutissime punctata vel fere epunctata, elliptico-oblonga, majuscula, acuminata, basi subaequali acuta et subdecurrentia, penninervia, nervis utroque latere saepius 5 arcuato-adscendentibus tenerrimis, venis obscuris laxissime reticulatis; spicae oppositifoliae breviter crasseque pedunculatae ca. 9 cm. longae atque $4 \mathrm{~mm}$. crassae.

Piper cristinanum Trelease \& Standley, sp. nov.

Moist or wet, brushy hillsides, 225 meters or lower; endemic; Izabal (type collected between Milla 49.5 and Cristina, about 70 
meters, Steyermark 38677; in Herbarium of Chicago Natural History Museum).

A branched shrub 1.5-2.5 meters high, the branches slender, very sparsely short-hirsute or glabrous, the upper internodes short; petioles stout, $10 \mathrm{~mm}$. long or mostly shorter, vaginate for their whole length, densely hirsute; leaf blades drying grayish, sparsely and minutely pellucid-punctate or mostly opaque, rather thick and firm, lance-oblong or ovate-oblong, 9-15 cm. long, $3.5-5.5 \mathrm{~cm}$. wide, rather abruptly and narrowly caudate-acuminate, equal or somewhat unequal at the base, rounded or broadly rounded and subcordate, hirsute on the upper surface and very rough to the touch, or most of the hairs deciduous in age, concolorous beneath, hirsute or short-hispid beneath, at least on the nerves and veins, palmately 5-nerved, the nerves slender but prominent, the veins divaricate at a right angle from the costa, at least the principal ones strongly elevated, coarsely reticulate; spikes unknown.

Frutex erectus ramosus, ramis gracilibus sparse breviter hirsutis vel glabris; petioli crassiusculi $10 \mathrm{~mm}$. longi vel breviores tota longitudine vaginantes; lamina in sicco griseo-viridis crassiuscula sparse minute pellucido-punctata vel fere opaca, lanceolato-oblonga vel ovato-oblonga, modica, subabrupte angusteque caudatoacuminata, basi aequali vel paullo inaequali rotundata vel late rotundata atque subcordata, supra hirsuta et asperrima, subtus concolor saltem ad nervos venasque hirsuta vel breviter hispida, palmatim 5-nervia; spicae ignotae.

Among local species with palmate nervation this may be recognized at once by the coarse and very rough pubescence of the leaves.

Piper curvatipes Trelease in Standl. Field Mus. Bot. 17: 231. 1937.

Moist or wet thickets or forest, 150 meters or lower; Petén (type from Nictun, Lago de Petén, C.L. Lundell 3122). British Honduras (Vaca).

A shrub, glabrous throughout, the branches rather slender, nodose, often tortuous, the internodes short, somewhat granular; petioles stout, $8 \mathrm{~mm}$. long or shorter, slightly dilated at the base but scarcely vaginate; leaf blades firm, drying green, coarsely pellucid-punctate, lance-oblong, often narrowly so, 8-12 cm. long, $2.5-4.5 \mathrm{~cm}$. wide, rather abruptly long-acuminate, obtuse or subacute at the base, conspicuously unequal, one of the sides decurrent, lower than the other, slightly lustrous above, the nerves prominent, scarcely paler beneath, the nerves usually three on each side, ascending at a very narrow angle, the veins prominent, laxly reticulate; peduncles rather slender, mostly less than $1 \mathrm{~cm}$. long; spikes rather stout, 3-4 cm. long, 3-4 $\mathrm{mm}$. thick, short-pointed at the apex, erect or recurved, straight or nearly so; bracts rounded and subpeltate, densely pubescent; stigmas 3.

\section{Piper diandrum C. DC. Linnaea 37: 364. 1871-73.}

Moist or wet to rather dry forest or sometimes on brushy hillsides, 1,650 meters or lower, most common below 900 meters; Petén; Alta Verapaz; Baja Verapaz; El Progreso; Izabal; Zacapa; 
Santa Rosa; Escuintla; Guatemala; Suchitepequez; Retalhuleu; Quezaltenango; San Marcos; Huehuetenango. Southern Mexico. British Honduras; Salvador.

A shrub or tree, commonly 2-6 meters high, rather sparsely branched, appearing glabrous to the naked eye, the young branches stout, glabrous; petioles rather stout, very variable in length, mostly $2.5-7 \mathrm{~cm}$. long but sometimes even longer, usually glabrous; leaf blades broadly ovate to orbicular-ovate, mostly $15-22 \mathrm{~cm}$. long and 8.5-19 $\mathrm{cm}$. wide, rather thick and firm, obscurely if at all pellucidpunctate, abruptly acuminate, subcordate to rather deeply and sometimes narrowly cordate at the base, or sometimes rounded in the upper leaves, not blackening when dried, green above, glabrous or practically so, very slightly paler beneath, glabrous or often puberulent on the nerves, usually palmately 9-nerved, the nerves slender but prominent, the costa emitting numerous veins, these all slender and equally prominent, divergent at a right angle or some of the uppermost often arcuate and upcurved; peduncles opposite the leaves, mostly $1.5-2.5 \mathrm{~cm}$. long, glabrous or nearly so; spikes very slender, of ten equaling or exceeding the leaves, mostly $12-25 \mathrm{~cm}$. long, $2-3 \mathrm{~mm}$. thick or in fruit as much as $4 \mathrm{~mm}$., often curved or pendent, the rachis pubescent; bracts truncate-peltate at the apex, hirtellous on the margins; stamens 2; stigmas 4, short; fruit glabrous, very small.

Much of the material we place here was referred by Trelease to $P$. patulum or its unpublished varieties. It is, however, fully distinct from that species, or at least is easily separated by its general appearance, although definite characters for separating the two are not so obvious. Some of the specimens were referred by Trelease to $P$. variabile to which $P$. diandrum also is closely related, but the two can be separated fairly well by the characters given in the key.

Piper Donnell-Smithii C. DC. ex Donn. Smith, Enum. Pl. Guat. 2: 95. 1891, nomen; in Donn. Smith, Bot. Gaz. 19: 259. 1894; P. eldoradense Trelease ex Standl. Field Mus. Bot. 12: 103. 1936, without Latin description (type from Eldorado Road, British Honduras, W. A. Schipp 1005).

Moist or wet, mixed forest, 1,600 meters or lower; Petén; Alta Verapaz (type from Pansamalá, Türckheim 975); Izabal; Huehuetenango (region of Ixcán). British Honduras.

A slender branched erect shrub or small tree, 1.5-6 meters high, glabrous throughout; petioles slender, $1 \mathrm{~cm}$. long or usually shorter, scarcely vaginate but slightly dilated at the base; leaf blades lanceolate to ovate-oblong, usually somewhat blackish and dull when dry, scarcely at all lustrous, opaque, mostly 11-15 $\mathrm{cm}$. long and $3.5-5.5 \mathrm{~cm}$. wide, very narrowly long-acuminate, acute or subacute at the base and subequal, slightly paler beneath, penninerved, the nerves 3-5 on each side, arcuate-ascending, the veins prominent beneath, laxly reticulate; peduncles about as long as the petioles, the spikes whitish or dull green, erect, mostly 4-8 cm. long, $3 \mathrm{~mm}$. thick, very obtuse; bracts truncate-peltate at the apex, hirtellous on the margin; stamens 3 ; fruit obpyramidal-trigonous, sparsely hirtellous. 


\section{Piper exactum Trelease \& Standley, sp. nov.}

Known only from the vicinity of the type locality, Quezaltenango, moist or wet forest, slopes of Volcán de Zunil at or above Aguas Amargas, 2,450-2,850 meters (type, Standley 65462 in Herbarium of Chicago Natural History Museum).

An erect, sparsely branched shrub about 2.5 meters high, the branches rather slender, sparsely hirtellous or almost wholly glabrous; petioles mostly $5-7 \mathrm{~cm}$. long, rather stout, thinly hirtellous or glabrate, vaginate only at the base; leaf blades large, thin, blackening when dried, very obscurely and minutely if at all pellucid-punctate, deep green and glabrous above, smooth, somewhat paler beneath, rather sparsely or densely strigillose and hispidulous beneath on the nerves and veins, glabrous or nearly so between the veins, broadly ovate or roundedovate, mostly 14-20 cm. long and 9.5-12 cm. wide, abruptly acuminate, broadly rounded at the base and shallowly and narrowly cordate, with subequal, broadly rounded basal lobes, penninerved, the principal nerves 3-4 on each side, very slender but rather prominent, strongly arcuate, ascending at an angle of $\mathbf{4 5}$ degrees or slightly more, the veins rather prominent beneath, laxly reticulate; spikes unknown.

Frutex altus, ramis subgracilibus sparse hirtellis vel fere glabris; petioli crassiusculi 5-7 cm. longi basi tantum vaginantes; lamina tenuis magna in sicco fuscescens obscure minuteque pellucido-punctata vel fere epunctata, supra intense viridis glabra, subtus paullo pallidior ad nervos venasque sat dense strigillosa et sparse hirtella, abrupte acuminata, basi subaequali late rotundata et breviter angusteque cordata, penninervia, nervis utroque latere $3-4$ arcuato-adscendentibus; spicae ignotae.

Piper fallens Trelease, Journ. Wash. Acad. Sci. 19: 332. 1929.

Moist or wet, mixed, mountain or lowland forest, 1,500 meters or lower; Alta Verapaz; Izabal; Chiquimula; Sololá; Quezaltenango; San Marcos. Honduras, the type from Lancetilla Valley near Tela.

An erect shrub 1.5-3 meters high, sparsely branched, the branches rather slender, densely villous-pilose with long, slender, spreading, multicellular, mostly brownish hairs, the internodes usually elongate; petioles stout, about $7 \mathrm{~mm}$. long, densely villous-pilose, not winged; leaf blades rather thin and often flaccid, dull green or fuscescent when dried, dull, minutely pellucid-punctate, lance-oblong to lance-elliptic or ovate-elliptic, mostly $14-24 \mathrm{~cm}$. long and 4-9 cm. wide, narrowly long-attenuate or attenuate-acuminate, conspicuously unequal and oblique at the base, cordate or rounded on one side, rounded or obtuse on the other, densely long-pilose on the upper surface, at least when young, with rather weak, mostly spreading, multicellular hairs, densely villous-hirsute beneath with long spreading hairs, at least on the nerves and veins, penninerved, the nerves $3-4$ on each side, ascending at an angle of $\mathbf{4 5}$ degrees or less, somewhat arcuate or almost straight, the veins not very conspicuous, laxly reticulate; peduncles stout or rather slender, opposite the leaves, mostly $1-1.5 \mathrm{~cm}$. long, sometimes $2.5 \mathrm{~cm}$. long, densely hirsute; spikes slender, mostly $8-10 \mathrm{~cm}$. long, almost $3 \mathrm{~mm}$. thick, mucronate or obtuse; bracts triangular-subpeltate at the apex, pale, densely hirtellous, at least 
on the margins; fruits depressed and papillose at the apex; stigmas 2, slender, borne on a short style.

Piper flavidum C. DC. ex Donn. Smith, Enum. Pl. Guat. 2: 66. 1891, nomen; Bot. Gaz. 19: 258. 1894. Monte de agua.

Usually on rocks in the edges of swift streams, 1,350 meters or lower; endemic; Alta Verapaz (type from Barranco de Rubelcruz, J. D. Smith 1744); Izabal; Quiché; Huehuetenango.

An erect shrub, commonly a meter high or less, with rather few, erect branches, the branches strongly nodose, glabrous, with short internodes; leaves on petioles $6 \mathrm{~mm}$. long or shorter, linear-lanceolate, mostly $8-13 \mathrm{~cm}$. long and $1.5-2 \mathrm{~cm}$. wide, narrowly long-attenuate, attenuate to the base, glabrous, usually yellowish green when dried, the costa and nerves impressed on the upper surface, prominent beneath, the lateral nerves $2-3$ on each side, ascending at an extremely narrow angle, the upper ones extending nearly or quite to the apex, the veins prominent, laxly reticulate; peduncles glabrous, equaling or longer than the petioles; spikes mostly 3-4 $\mathrm{cm}$. long, $3 \mathrm{~mm}$. thick, the bracts pubescent on the margins; berries somewhat tetragonous, short-hirtellous at the apex.

One of the best marked of Guatemalan species, and the only local Piper that grows in its peculiar habitat-large rocks in the edges of swift mountain streams. It is one of several plants confined to this habitat, its associates being Cuphea, Aster, and representatives of a few other genera of diverse families.

Piper fraguanum Trelease, Journ. Wash. Acad. Sci. 19: 332. 1929 (type from La Fragua, Atlántida, Honduras). P. hispidiseptum Trelease, loc. cit. (type from Lancetilla Valley near Tela, Honduras). $P$. imperspicuibracteum Trelease, loc. cit. (type collected near Tela, Honduras). P. obsessum Trelease, op. cit. 334. 1929 (type from Lancetilla Valley, Honduras). P. prodigum Trelease, op. cit. 335. 1929 (type from Lancetilla Valley, Honduras). P. scabriseptum Trelease, op. cit. 336. 1929 (type from Lancetilla Valley, Honduras). P. speratum Trelease, loc. cit. (type from Tela, Honduras). P. tesseraespicum Trelease in Yuncker, Field Mus. Bot. 17: 354. 1938 (type from Siguatepeque, Honduras). P. puentealtoanum Trelease in Yuncker, Field Mus. Bot. 9: 280. 1940 (type collected near La Ceiba, Honduras). P. cocquericotense Trelease in Standl. Field Mus. Bot. 12: 407. 1936 (type from Little Cocquericot, Belize River, British Honduras, C. L. Lundell 3829).

Moist or wet thickets or mixed forest, 1,650 meters or lower, most frequent at rather low elevations; Alta Verapaz; Izabal; Escuintla; Guatemala; Suchitepequez; San Marcos. Honduras; British Honduras. 
An erect shrub 1.5-2.5 meters high, the branches slender, often flexuous or somewhat geniculate, densely hispidulous with short, whitish or fulvous, spreading or somewhat reflexed hairs; petioles $1 \mathrm{~cm}$. long or usually shorter, densely hispidulous, not winged, dilated at the base; leaf blades thin, usually green or dark green when dried, finely pellucid-punctate, dull, mostly elliptic or ovate-elliptic, sometimes lance-oblong or lance-ovate, mostly $12-23 \mathrm{~cm}$. long and $5.5-11 \mathrm{~cm}$. wide, rather narrowly and abruptly long-acuminate, conspicuously unequal and oblique at the base, cordate to obtuse on one side, rounded to acute on the other, conspicuously granular on the upper surface and very scabrous, harsh to the touch, not at all bullate, granular beneath, finely hispidulous with spreading hairs on the nerves and veins, often also between them, rough to the touch, penninerved, the nerves 3-5 on each side, slender, prominent, arcuate-ascending at an angle of about 45 degrees, the veins not conspicuous but often prominulous, laxly reticulate; peduncles opposite the leaves, stout, $1 \mathrm{~cm}$. long or shorter, hirtellous or glabrate; spikes spreading or ascending, rather slender, cream-colored or greenish, mostly 6-10 $\mathrm{cm}$. long and 3-3.5 mm. thick, obtuse or submucronate; bracts rounded-peltate at the apex, puberulent or ciliate.

This has been reported as $P$. jalapense C. DC. from both Guatemala and Honduras, where it is a rather common species. The species of this general alliance are all much alike, and it is probable that several of those tentatively recognized in this treatment ultimately will have to be combined.

Piper Friedrichsthalii C. DC. (in DC. Prodr. 16, pt. 1: 327. 1869) was based on a collection by Friedrichsthal, ascribed by De Candolle to Guatemala, but the plant was actually from Orosi, Costa Rica.

\section{Piper frioense Standl. \& Steyerm., sp. nov.}

Known only from the type, Alta Verapaz, wet forest near Tactic, above the bridge across Río Frío, 1,500 meters, Standley 90328 (in Herbarium of Chicago Natural History Museum).

A shrub 2 meters high, glabrous throughout, the branches rather slender, with short internodes; petioles stout, $1-2.5 \mathrm{~cm}$. long, vaginate only near the base; leaf blades rather thick, brownish when dried, minutely pellucid-punctate or almost wholly opaque, not at all bullate, ovate or broadly ovate, mostly $10-15 \mathrm{~cm}$. long and 5-8 cm. wide, abruptly short-acuminate, equal at the base and symmetric or nearly so, rounded to subacute, penninerved, the nerves 5-6 on each side, prominent beneath, arcuate-ascending at an angle of about 45 degrees, with a few stout intermediate nerves, the veins prominent beneath, laxly reticulate; peduncles opposite the leaves, rather slender, about $1 \mathrm{~cm}$. long; spikes slender, probably erect, about $6.5 \mathrm{~cm}$. long and $2 \mathrm{~mm}$. thick, subacute; bracts glabrous, ciliolate; anthers slightly exserted.

Frutex fere omnino glaber; petioli crassi $1-2.5 \mathrm{~cm}$. longi tantum prope basin vaginantes; lamina crassiuscula in sicco brunnescens minute pellucido-punctata vel fere omnino opaca, ovata vel late ovata, majuscula, abrupte breviterque 
acuminata, basi fere aequali et symmetrica roundata usque subacuta, penninervia, nervis utroque latere $5-6$, aliis minus prominentibus interjectis, venis laxe reticulatis; pedunculi oppositifolii, spicis gracilibus ca. $6.5 \mathrm{~cm}$. longis $2 \mathrm{~mm}$. crassis.

Piper geniculatum Swartz, Prodr. Veg. Ind. Occ. 15. 1788.

Dense, wet, mixed, lowland forest, 350 meters or lower; Alta Verapaz (Cubilgüitz); Izabal (Cerro San Gil). British Honduras, and probably along much of the Atlantic coast of Central America; West Indies; South America.

A shrub or small tree of 2-6 meters, sometimes with a trunk $7 \mathrm{~cm}$. in diameter, glabrous throughout or nearly so; petioles stout, $1-2 \mathrm{~cm}$. long, vaginate throughout and at least when young broadly winged; leaf blades thin, blackening when dried, dull, densely and minutely pellucid-punctate, lance-oblong or ovate-oblong, mostly $12-20 \mathrm{~cm}$. long and $3.5-6.5 \mathrm{~cm}$. wide, gradually or rather abruptly acuminate, usually very unequal at the base with one side often $1 \mathrm{~cm}$. longer than the other, rounded or obtuse on each side, slightly paler beneath and often blackpuncticulate, penninerved, the nerves usually 5-6 on each side, very slender and inconspicuous, arcuate-ascending, irregular, scarcely at all elevated, the veins very obscure and distant; peduncles stout, about $1 \mathrm{~cm}$. long; spikes cream-colored or greenish, very slender, about $12-13 \mathrm{~cm}$. long and scarcely $3 \mathrm{~mm}$. thick, obtuse; bracts lunulate-peltate, hirtellous on the margins; fruit glabrous, laterally compressed.

Although one of the Guatemalan collections was designated (but not published) as a new species by Trelease, the mainland material seems to agree well enough with the West Indian $P$. geniculatum. Called "cordoncillo" in British Honduras.

\section{Piper georginum Trelease \& Standley, sp. nov.}

Moist or wet, mixed, mountain forest, 2,400-2,850 meters; endemic; Escuintla; Quezaltenango (type from Fuentes Georginas, western slope of Volcán de Zunil, Standley 67355; type in Herbarium of Chicago Natural History Museum); San Marcos.

A shrub of 2-3.5 meters, the branches rather slender, sparsely villous or in age glabrate, the internodes elongate; petioles stout, $2-3.5 \mathrm{~cm}$. long, densely villous-pilose with rather long, spreading, brownish hairs, not winged, scarcely dilated at the base; leaf blades thin, large, fuscescent when dry, very minutely pellucid-punctate, dull, elliptic, broadly elliptic, or broadly ovate-elliptic, mostly 20-25 cm. long and 10-13 cm. wide, cuspidate-acuminate, acute at the base and only slightly unequal, villous-pilosulous on the upper surface along the costa, elsewhere glabrous or nearly so, not paler beneath, villous-pilose beneath on the nerves and veins, glabrous between them, penninerved, the nerves 3-4 or sometimes $\mathbf{5}$ on each side, very slender, prominent, arcuate-ascending at an angle of 45 degrees or less, the veins very slender but often conspicuous, very laxly reticulate; peduncles opposite the leaves, $13-20 \mathrm{~mm}$. long, villosulous, slender or stout; spikes erect, at maturity stout, $5.5-6 \mathrm{~cm}$. long, $5 \mathrm{~mm}$. thick at anthesis, bearing a 
tail-like apical mucro 4-6 $\mathrm{mm}$. long; bracts densely pubescent; fruits densely puberulent about the apex.

Frutex, ramis sparse villosis vel glabratis, internodiis elongatis; petioli 2-3.5 $\mathrm{cm}$. longi dense villoso-pilosi non alati; lamina magna tenuis in sicco fuscescens minute pellucido-punctata, late elliptica vel ovato-elliptica, cuspidato-acuminata, basi vix inaequali acuta, supra ad costam villoso-pilosula, subtus ad nervos venasque villoso-pilosula, penninervia, nervis utroque latere $3-5$; pedunculi oppositifolii $13-20 \mathrm{~mm}$. longi; spicae erectae crassiusculae ca. $6 \mathrm{~cm}$. longae et 5 $\mathrm{mm}$. crassae, apice 4-6 $\mathrm{mm}$. longe mucronatae; bracteae dense pubescentes; fructus apice dense puberulus.

Trelease assigned a distinct name to each of the four sheets we refer here, but all seem to be conspecific.

Piper grandilimbum C. DC. Bot. Gaz. 70: 172. 1920.

Moist or wet, mixed forest or thickets, 150-1,150 meters; endemic; Petén; Alta Verapaz (type collected near Cubilgüitz, Türckheim II.1400); Huehuetenango (regions of Barillas and Ixcán).

A coarse shrub 1-2.5 meters high, the young branches glabrous; petioles rather short or much elongate, often vaginate well above the base, glabrous; leaf blades peltate far above the base or in some of the leaves epeltate, broadly ovate, mostly 18-36 $\mathrm{cm}$. long and 11-22 $\mathrm{cm}$. wide, rather abruptly acuminate, shallowly and broadly cordate or subcordate at the base, with broadly rounded basal lobes, glabrous above and pale-granular, the nerves rather prominent, almost concolorous beneath, minutely hirtellous or puberulent on the nerves and veins, palmately nerved at the base with 13 or fewer nerves, penninerved above the base with 3-4 nerves on each side, these arcuate-ascending at a wide angle; peduncles hirtellous or glabrate, $2 \mathrm{~cm}$. long or shorter, several times shorter than the petioles; spikes slender, straight or slightly curved, mostly $11-14 \mathrm{~cm}$. long, $4 \mathrm{~mm}$. thick, the bracts hirtellous on the margins; stamens 3 ; fruit glabrous, obpyramidal-globose.

One of the very distinct local species, easily recognized by its large peltate leaves, which appear glabrous or nearly so to the naked eye.

\section{Piper guazacapanense Trelease \& Standley, sp. nov.}

Known only from the vicinity of the type locality, Santa Rosa, along the Avellana road, south of Guazacapán, on wooded plains or in quebradas, 150 meters, Standley 79461 (type in Herbarium of Chicago Natural History Museum).

Plants chiefly herbaceous, much branched, the stems procumbent and rooting at the nodes, glabrous; stipules lanceolate, about $8 \mathrm{~mm}$. long, free, hirsute; petioles slender, very unequal, $10-15 \mathrm{~mm}$. long, hirsute; leaf blades thin, drying grayish green, orbicular-ovate, $5-7.5 \mathrm{~cm}$. long, $3.5-6.5 \mathrm{~cm}$. wide, abruptly acuminate or long-acuminate, deeply but openly cordate at the base with rounded basal lobes, epunctate, sometimes obscurely bullate, palmately 5-nerved, with the inner nerves 
protracted almost to the apex, deep green on the upper surface, puberulent on the nerves, paler beneath, sparsely puberulent or hirtellous on the nerves, the veins almost obsolete, epunctate; inflorescences opposite the leaves, racemose, often few-flowered, 8-18 $\mathrm{mm}$. long, the rachis short-hirsute, the pedicels short, stout, divaricate; fruit globose, glabrous, white at maturity, when dry about 2 $\mathrm{mm}$. in diameter.

Herba vel suffrutex, caulibus procumbentibus et radicantibus glabris; stipulae lanceolatae liberae hirsutae; folia graciliter petiolata, petiolo hirsuto, orbiculariovata subito acuminata, basi profunde aperte cordata, palmatim 5-nervia, utrinque ad nervos sparse puberula vel breviter hirtella; flores racemosi, racemis oppositifoliis saepe paucifloris, rhachi breviter hirsuta, pedicellis crassis divaricatis; fructus glaber.

Referable to Trelease's genus Arctottonia, under which it was designated as a new species. It is quite different from any other Central American species of that group but is rather similar to some of the Mexican ones, although clearly distinct from all of them that we have seen. The plant is distinctive in habit, being herbaceous almost throughout, and forming dense colonies of procumbent stems that take root at many of the nodes. It formed a rather dense ground cover in the lowland forest where it was collected. The small fruits, white when ripe, have a rather faint but distinct flavor of black pepper.

\section{Piper Hermes Trelease \& Standley, sp. nov.}

Known only from the type, San Marcos, Volcán de Tajumulco, between Todos Santos and Finca El Porvenir, 1,300 meters or higher, Steyermark 37009 (type in Herbarium of Chicago Natural History Museum).

A shrub 3-4.5 meters high, the branches rather stout, with very short internodes, glabrous or nearly so; petioles about $1.5 \mathrm{~cm}$. long, winged for their whole length, hirsute dorsally; leaf blades thick, dull, grayish green when dried, opaque, lance-oblong or narrowly elliptic-oblong, widest at or slightly below the middle, 8-11 cm. long, 3-4 cm. wide, acute or short-acuminate, very unequal and slightly oblique at the base, one side 5-6 $\mathrm{mm}$. longer than the other, obtuse or rounded on each side, glabrous above, the costa and nerves sometimes slightly impressed, brownish beneath when dried, sparsely villous-hirsute on the costa, elsewhere glabrous, penninerved, the nerves usually 3 on each side, very slender, prominent, arcuate-ascending at an angle of $\mathbf{4 5}$ degrees or slightly more, the veins inconspicuous, laxly reticulate; very young spikes (about $1 \mathrm{~cm}$. long) mucronate, borne on a slender peduncle $7 \mathrm{~mm}$. long, the peduncles sparsely hispidulous or glabrate, opposite the leaves; bracts glabrous, ciliolate.

Frutex, ramis crassiusculis, internodiis brevibus glabris; petioli tota longitudine alati ca. $1.5 \mathrm{~cm}$. longi dorso hirsuti; lamina crassa non lucida opaca lanceolato-oblonga vel anguste elliptico-oblonga, acuta vel breviter acuminata, basi solemniter inaequalis et obliqua, utroque latere obtusa vel rotundata, supra glabra, 
subtus ad costam villoso-hirsuta, penninervia, nervis utroque latere vulgo 3; spicae apice mucronatae.

Piper Heydei C. DC. in Donn. Smith, Bot. Gaz. 19: 7. 1894. Palo de jute (fide Aguilar); Santa María.

Dense, wet, mixed, mountain forest, 1,800-2,850 meters; endemic; Zacapa; El Progreso; Chimaltenango; Quiché (type from San Miguel Uspantán, Heyde \& Lux 3461); Quezaltenango; San Marcos.

A coarse stout herb 1-2.5 meters high, simple or with few branches, sometimes suffrutescent below, the branches thick and somewhat succulent, villous-hirsute; leaves very large and thin, the petiole long and stout, vaginate for most of its length, 15-20 cm. long or more; leaf blades ovate-rounded, mostly $25-40 \mathrm{~cm}$. long and nearly or quite as wide, rounded at the apex and abruptly short-acute or at least pointed, broadly rounded and rather obscurely cordate at the base, deep green above, sparsely villous, much paler beneath, densely short-villous along the nerves and veins, peltate far above the base, radiately palmate-nerved at the base, the costa emitting usually 4 lateral nerves above the basal ones; peduncles rather slender, erect, mostly $13-17 \mathrm{~cm}$. long, bearing 2-12 spikes, these on secondary peduncles $3-6 \mathrm{~cm}$. long, erect; spikes green, rather slender, mostly $6-15 \mathrm{~cm}$. long, in anthesis $4 \mathrm{~mm}$. thick, very obtuse, the bracts densely puberulent; stamens 3 , the anthers subglobose; ovary ovoid, attenuate at the apex, glabrous.

This is a distinct species, related to $P$. peltatum but very different in appearance when growing, and readily distinguishable by the abundant pubescence of the leaves and by the villous-hirsute stems. We refer here, not without some question, one collection that Trelease indicated as a new species. It is distinguished by having the slender secondary peduncles all arising from the axil of the leaf, and as much as $15 \mathrm{~cm}$. long. In the type of the species the secondary peduncles are much shorter and are borne at the apex of a long primary peduncle. Since the plants are exactly alike in their leaves and pubescence, we suspect that these differences are only individual variations, especially since both forms have been collected in the same general region.

\section{Piper imberbe Trelease \& Standley, sp. nov.}

Known only from the type, Izabal, wet mixed forest, between Escobas and the waterfall, near sea level, across the bay from Puerto Barrios, Steyermark 39857 (in Herbarium of Chicago Natural History Museum).

Stems spreading or pendent, very slender, green, sparsely and obscurely puberulent when young or practically glabrous, a meter long or shorter, suffirutescent, with elongate internodes; petioles very slender, $4-4.5 \mathrm{~cm}$. long, glabrous; leaf blades thin, lance-oblong, $17.5-23 \mathrm{~cm}$. long, 5-6.5 cm. wide, attenuate at the apex into a very long and slender, tail-like acumen, rounded or obscurely sub- 
cordate at the base, peltate about $1.5 \mathrm{~cm}$. above the base, palmately few-nerved about the point of attachment, penninerved above the base, with about 5 nerves on each side, these very slender, divergent at a wide angle, arcuate, prominent beneath, scarcely elevated above, the veins very slender and inconspicuous, laxly reticulate, the blades glabrous on both surfaces; spikes opposite the leaves, the peduncle very slender, about $1 \mathrm{~cm}$. long, glabrous; spikes very slender, $7.5 \mathrm{~cm}$. long, scarcely more than $2 \mathrm{~mm}$. thick, the bracts suborbicular, glabrous or practically so.

Frutex, ramis obscure puberulis vel fere omnino glabris; folia tenues longe graciliter petiolata, bene supra basin peltata, lanceolato-oblonga, apice anguste longissime attenuato-acuminata, basi rotundata vel obscure subcordata, basi palmatinervia, costa supra basin utroque latere nervos 3-4 emittente; spicae breviter graciliter pedunculatae, elongatae, gracillimae.

Piper indignum Trelease, Journ. Wash. Acad. Sci. 19: 333. 1929. P. micoense Trelease, op. cit. 334 (type from Sierra del Mico, Izabal, W. A. Kellerman 6715).

Moist or rather dry thickets or forest, 1,400 meters or lower; Izabal; Jutiapa; Santa Rosa. Honduras, the type from Siguatepeque.

A stout erect shrub 1.5-2 meters high, the branches very densely short-hirsute with spreading whitish hairs, the internodes usually short; petioles stout, mostly 7-10 $\mathrm{mm}$. long, not winged, somewhat dilated at the base, very densely shorthirsute; leaf blades rather thick, pale grayish green or somewhat fulvescent when dry, minutely pellucid-punctate, broadly elliptic to ovate-elliptic or obovateelliptic, mostly $10-16 \mathrm{~cm}$. long and $4-8 \mathrm{~cm}$. wide, rather abruptly acute to longacuminate, conspicuously oblique and unequal at the base, usually cordate or subcordate on one side and rounded or obtuse on the other, very densely and rather softly pilose on the upper surface with short, spreading or subappressed, fulvescent or whitish hairs, not at all bullate, or only slightly so, densely and softly pilose beneath between as well as upon the nerves and veins, penninerved, the nerves 3-4 on each side, slender, prominent, ascending at an angle of about 45 degrees, slightly arcuate or almost straight, the veins often prominent, sometimes rather closely reticulate; peduncles opposite the leaves, stout, about $1 \mathrm{~cm}$. long or somewhat shorter, densely hirtellous; spikes erect or ascending, commonly $3.5-5.5 \mathrm{~cm}$. long, short-mucronate, $2.5 \mathrm{~mm}$. thick; bracts triangular-peltate at the apex, densely fulvescent-puberulent; fruits trigonous, glabrous, slightly depressed at the apex.

Piper instabilipes Trelease in Standl. Field Mus. Bot. 17: 232. 1937.

Known only from the type, Petén, high upland forest near Santa Teresa, Río Subín, C. L. Lundell 2776.

A rather slender shrub, glabrous throughout, the internodes short or elongate; petioles slender, 1-1.5 cm. long, vaginate only at the base; leaf blades thin, darkening when dried, oblong-ovate to elliptic-oblong, mostly $12-16 \mathrm{~cm}$. long and 4.5$7.5 \mathrm{~cm}$. wide, rather abruptly caudate-acuminate, rounded to subtruncate at the 
base, the two sides equal or nearly so, penninerved, the nerves 4-6 on each side, very slender, prominulous on both surfaces, arcuate, ascending at an angle of 45 degrees or more, the veins prominulous but not very conspicuous beneath, laxly reticulate, the blades epunctate or nearly so, dull when dried, concolorous; peduncles $5 \mathrm{~mm}$. long or more, shorter than the petioles; young spikes about $8 \mathrm{~cm}$. long and $2 \mathrm{~mm}$. thick, obtuse, slender, the bracts rounded-subpeltate, ciliolate; ovary glabrous; stigmas 3 , sessile.

\section{Piper ixocubvainense Standl. \& Steyerm., sp. nov.}

Dense, wet, mixed forest, 300-1,600 meters; endemic; Alta Verapaz (type from Montaña Ixocubvain, 2.5 miles west of Cubilgüitz, Steyermark 44987; in Herbarium of Chicago Natural History Museum; collected also in the Tactic region).

A rather densely branched shrub 1-1.5 meters high, glabrous throughout, the upper internodes short, the lower ones elongate; petioles slender or stout, mostly $2 \mathrm{~cm}$. long or slightly shorter, vaginate for all or most of their length, narrowly winged; leaf blades drying dark green but scarcely fuscescent, rather thick, minutely pellucid-punctate, dull, elliptic-oblong, mostly 9.5-12 cm. long and $3.5-5.5 \mathrm{~cm}$. wide, acute or short-acuminate, slightly unequal and somewhat oblique at the base, narrowly rounded or shallowly cordate or subcordate, penninerved, the nerves mostly 5 on each side, sometimes only 4 on one side, arcuateascending at an angle of slightly more than $\mathbf{4 5}$ degrees, very slender, prominulous beneath, the veins obscure, very laxly reticulate; spikes opposite the leaves, small, on peduncles 3-4 mm. long, rather stout, at anthesis $1.5-2.5 \mathrm{~cm}$. long, about 2.5 $\mathrm{mm}$. thick, long-mucronate at the apex; bracts small, glabrous, ciliate; anthers slightly exserted.

Frutex erectus glaber; folia ca. $2 \mathrm{~cm}$. longe petiolata crassiuscula in sicco intense viridia vix fuscescentia minute pellucido-punctata, elliptico-oblonga, acuta vel breviter acuminata, basi paullo inaequali et plus minusve obliqua anguste rotundata vel breviter cordata, penninervia, nervis saepius utroque latere 5 tenerrimis subtus prominulis, arcuato-adscendentibus, venis obscuris laxissime reticulatis; spicae oppositifoliae parvae ad anthesin $1.5-2.5 \mathrm{~cm}$. tantum longae longe apice mucronatae.

\section{Piper jactatum Trelease \& Standley, sp. nov.}

Dense, wet, mixed, mountain forest, sometimes in wooded swamps, 1,400-1,600 meters; endemic; Alta Verapaz (type collected in mountains along the road between Tactic and the divide on the road to Tamahú, Standley 90614; in Herbarium of Chicago Natural History Museum; known only from the Tactic region).

A sparsely branched, erect shrub about 2 meters high, the branches very densely hispidulous with short spreading sordid hairs, the upper internodes short; petioles stout, about $8 \mathrm{~mm}$. long, densely hispidulous, not winged, somewhat dilated at the base; leaf blades fuscous when dried, thick, not or scarcely lustrous, densely and minutely pellucid-punctate, lanceolate or oblong-lanceolate, mostly $12-18 \mathrm{~cm}$. long and $4.5-6 \mathrm{~cm}$. wide, very narrowly and gradually long-attenuate, 
slightly unequal and oblique at the base or sometimes subequal, rounded or usually somewhat cordate on each side, conspicuously bullate, hispidulous above along the costa and nerves but elsewhere glabrous or nearly so and smooth to the touch, the nerves and veins more or less impressed, brownish beneath, densely and rather softly hispidulous or hirtellous almost throughout, penninerved, the nerves mostly 3-4 on each side, slender but very prominent, arcuate-ascending at a narrow angle, the veins very prominent and rather stout, openly reticulate; peduncles opposite the leaves, about $1 \mathrm{~cm}$. long, stout, densely hispidulous; spikes (perfect ones not seen) rather stout, spreading or erect-spreading, about $5.5 \mathrm{~cm}$. long and $3 \mathrm{~mm}$. thick; bracts densely pubescent; fruits depressed at the apex, puberulent above.

Rami pilis brevibus patentibus sordidis dense hispiduli; petioli ca. $8 \mathrm{~mm}$. longi non alati dense hispiduli; lamina in sicco fusca crassa non lucida dense minute pellucido-punctata, lanceolata vel oblongo-lanceolata modica, sensim longeque attenuata, basi paullo inaequali et obliqua vel fere symmetrica utroque latere plus minusve cordata, insigniter bullata, supra ad costam nervosque hispidula, aliter glabra vel fere glabra, subtus ubique dense molliter hispidula vel hirtella, penninervia, nervis utroque latere 3-4 angulo angusto arcuato-adscendentibus elevatis, venis prominentibus conspicue reticulatis, supra saepe impressis; pedunculi oppositifolii ca. $1 \mathrm{~cm}$. longi dense hispiduli, spicis (perfectis non visis) crassiusculis ca. $5.5 \mathrm{~cm}$. longis et $3 \mathrm{~mm}$. crassis; bracteae dense pubescentes; fructus apice depressus superne puberulus.

\section{Piper jumayense Trelease \& Standley, sp. nov.}

Known only from the type, Jalapa, south-facing slopes of barranco, Volcán de Jumay, 2,000 meters, Steyermark 32449 (Herbarium of Chicago Natural History Museum).

A slender shrub 3 meters high, glabrous throughout or nearly so, the internodes mostly elongate; petioles slender, 5-6 mm. long, vaginate only at the base; leaf blades thin but rather stiff, minutely pellucid-punctate, drying somewhat blackish, ovate or elliptic-ovate or lance-ovate, mostly $8-10 \mathrm{~cm}$. long and 4-5.5 cm. wide, gradually or somewhat abruptly long-acuminate, obliquely rounded or very obtuse at the base, somewhat paler beneath, palmately 5-nerved, the nerves very slender but prominent beneath, the outermost somewhat irregular but conspicuous, the veins pale, obscure or prominent, laxly reticulate; peduncles almost filiform, $2.5 \mathrm{~cm}$. long, sparsely puberulent or glabrate, rather laxly flowered, the rachis densely puberulent; spikes about $2.5 \mathrm{~cm}$. long, in fruit fully $4 \mathrm{~mm}$. broad; fruits oval, $2 \mathrm{~mm}$. long, minutely puberulent or almost glabrate; stigmas 3 , large, sessile.

Frutex gracilis fere omnino glaber; folia graciliter petiolata, petiolo basi tantum vaginante, in sicco nigrescentia, minute pellucido-punctata, ovata usque elliptico-ovata vel lanceolato-ovata, modica, sensim vel subabrupte longiacuminata, basi oblique rotundata vel obtusissima, palmatim 5 -nervia, venis inconspicuis vel prominentibus laxe reticulatis; pedunculi fere filiformes $2.5 \mathrm{~cm}$. longi, puberuli vel glabrati, rhachi dense puberula; spicae sublaxiflorae breves; fructus ovalis minute puberula vel glabrata; stigmata 3 sessilia.

This may be only a form of $P$. Amalago, but the collection is noteworthy for the very long and slender peduncles. 


\section{Piper lanciferum Standl. \& Steyerm., sp. nov.}

Known only from the type, Suchitepequez, Volcán de Santa Clara, between Finca El Naranjo and the upper slopes, 1,300-2,600 meters, Steyermark 46696 (type in Herbarium of Chicago Natural History Museum).

A shrub 3 meters high, the branches rather stout, with very short upper internodes, glabrous or at first sparsely short-hispidulous; petioles rather stout, mostly 8-14 mm. long, sparsely hispidulous or glabrate, not winged; leaf blades lanceolate or elliptic-lanceolate, broadest near the middle, mostly $10-14 \mathrm{~cm}$. long and 3-4.5 $\mathrm{cm}$. wide, narrowly long-acuminate, gradually attenuate to the base, somewhat unequal and oblique at the base, very acute on both sides, fuscescent when dried, rather thick, minutely pellucid-punctate or almost wholly opaque, dull on the upper surface, glabrous, sometimes minutely granular, somewhat brownish beneath, villous-pilosulous on the nerves and veins with rather long, soft, spreading hairs, penninerved, the nerves $3-4$ on each side, slightly arcuate, ascending at an angle of less than 45 degrees, the veins somewhat prominent but not very conspicuous, laxly reticulate; peduncles opposite the leaves, stout, glabrous, about $8 \mathrm{~mm}$. long; spikes erect-ascending, stout, mostly $7-8 \mathrm{~cm}$. long and 4-5 mm. thick; bracts triangular-peltate at the apex, densely pale-pubescent on the margins; fruits small, subglobose, glabrous.

Frutex, ramis crassiusculis, internodiis brevibus glabris vel primo sparse breviter hispidulis; folia modica crassiuscula in sicco fuscescentia minute pellucidopunctata vel fere omnino opaca, non lucida, lanceolata vel anguste ellipticolanceolata, anguste longiacuminata, basi inaequali et obliqua utroque latere acuta, supra glabra, subtus in sicco brunnescentia, ad nervos venasque pilis longiusculis mollibus villoso-pilosula, penninervia, nervis utroque latere 3-4 angulo angusto arcuato-adscendentibus; pedunculi oppositifolii crassi glabri ca. $8 \mathrm{~mm}$. longi, spicis erecto-patentibus plerumque 7-8 $\mathrm{cm}$. longis, $4-5 \mathrm{~mm}$. crassis.

\section{Piper Luxii C. DC. in Donn. Smith, Bot. Gaz. 19: 5. 1894.}

Moist or wet, mixed forest, 1,800-2,400 meters; endemic; Chimaltenango; Quiché (type from San Miguel Uspantán, Heyde \& Lux $3462)$.

A rather stout, erect shrub 1.5-2.5 meters high, the young branches densely short-villous with brownish or sordid, spreading hairs, the internodes short or elongate, often glabrate in age; petioles rather stout, mostly $2-4 \mathrm{~cm}$. long, brownishvillous, vaginate at the base; leaf blades large, lance-elliptic to elliptic or obovateelliptic, mostly $15-20 \mathrm{~cm}$. long and 9-10.5 cm. wide, abruptly short-acuminate, often broadly narrowed to the base and rounded or obtuse, sometimes narrowly subcordate, opaque, often somewhat bullate, villous-hirsute above when young but in age merely scabrous and rough to the touch, rather densely villosulous beneath, especially on the nerves and veins, blackish when dry, penninerved, the nerves $3-5$ on each side, arising below the middle of the blade, ascending at a very narrow angle, the veins prominent beneath, laxly or closely reticulate, of ten deeply impressed on the upper surface; peduncles erect, villosulous, sometimes $2.5 \mathrm{~cm}$. long but generally shorter; spikes stout, mucronate at the apex, 5-6 $\mathrm{cm}$. long, 4-5 mm. thick; bracts obovate-oblong, rounded at the apex, densely villosulous; 
stamens 4, the filaments exserted, the anthers elliptic; stigmas 3; ovary sparsely pilosulous.

Piper Martensianum C. DC. in DC. Prodr. 16, pt. 1: 251. 1869. P. santarosanum C. DC. ex Donn. Smith, Enum. Pl. Guat. 2: 96. 1891, nomen; in Donn. Smith, Bot. Gaz. 19: 258. 1894 (type from Santa Rosa, Baja Verapaz, Türckheim 1174.) ?P. Savagii C. DC. Ann. Cons. Jard. Bot. Genève 2: 252. 1898 (type said to have been collected in Guatemala by Savage). $P$. andresense Trelease in Standl. Field Mus. Bot. 17: 230. 1937 (type from San Andrés, Lago de Petén, Petén, C. L. Lundell 3203). P. andresense var. subclavescens Trelease in Standl. op. cit. 231 (type from Yaxha, Petén, Lundell 2011). P. rematense Trelease in Standl. op. cit. 233 (type from Remate, Lago de Petén, Lundell 2087). P. simulhabitans Trelease in Standl. op. cit. 233 (type from Remate, Petén, Lundell 2073). P. yaxhanum Trelease in Standl. op. cit. 234 (type from Yaxha-Remate road, Petén, Lundell 3286). Cordoncillo.

Wet to dry thickets or forest, usually in open forest, sometimes in pine-oak forest, ascending from sea level to about 2,300 meters, most common at middle elevations; Petén; Alta Verapaz; Baja Verapaz; Zacapa; Chiquimula; Jalapa; Jutiapa; Santa Rosa; Escuintla; Guatemala; Sacatepéquez; Chimaltenango; Suchitepequez; Retalhuleu; Quezaltenango; Huehuetenango; Quiché. Southern Mexico; El Salvador and probably farther southward.

An openly branched shrub or rarely a small tree, 1.5-6 meters high, the branches slender, densely hirtellous, at least when young; leaves on hirtellous petioles $1 \mathrm{~cm}$. long or often slightly longer, rather thin and flaccid, very minutely pellucid-punctate, rounded-ovate to oblong-ovate, mostly $10-15 \mathrm{~cm}$. long and 5-14 cm. wide, abruptly acute or acuminate, at least the larger leaves cordate at the base, the upper ones often merely rounded, slightly or conspicuously oblique, deep green above and more or less puberulent, somewhat paler beneath, usually densely velutinous-pubescent, often with yellowish hairs, palmately 5-7-nerved, the veins very slender, laxly reticulate; peduncles opposite the leaves, densely hirtellous, 1-2 cm. long; spikes whitish or pale green, slender, variable in length, mostly 7-10 cm. long, $3 \mathrm{~mm}$. thick; bracts spatulate, rounded at the apex, densely hirtellous; ovary hirtellous; stamens 4 , the anthers reniform-globose; fruit small, globose-ovoid, hirtellous at the apex.

Sometimes called "candelillo" in El Salvador. This is one of the most common species of Piper in Guatemala. It grows in somewhat drier and less shaded habitats than most species of the genus. The plant is so common and widely distributed that some older name than $P$. Martensianum may eventually be found for it among the names based on Mexican collections. A synonym here is 


\section{P. decrescens (Miq.) C. DC. var. ovatum C. DC. (in DC. Prodr. 16, pt. 1: 251. 1869), reported as Guatemalan but actually from Nicaragua.}

\section{Piper minarum Standl. \& Steyerm., sp. nov.}

Known only from the type, Zacapa, Sierra de las Minas, slopes of Monte Virgen, 2,200-2,400 meters, Steyermark 42667 (in Herbarium of Chicago Natural History Museum).

A shrub of 3 meters, the branches slender, with short internodes, when young densely villous-pilosulous with soft, spreading, fulvescent or sordid hairs; petioles stout, $1.5 \mathrm{~cm}$. long or shorter, densely villous-pilosulous, vaginate only at the base; leaf blades thin, fuscous when dried, elliptic or obovate-elliptic, about 21 $\mathrm{cm}$. long and 9-10 $\mathrm{cm}$. wide, rather long-acuminate, somewhat narrowed to the somewhat oblique and unequal base, subcordate or rounded on one side, obtuse on the other, villosulous-pilosulous above along the costa and when young often sparsely pilosulous, in age glabrous or nearly so, slightly lustrous, not rugose, slightly paler beneath, villous-pilose with soft spreading hairs along the costa, very shortly pilosulous on the veins, glabrous or nearly so between them, penninerved, the nerves usually 4 on each side, arcuate-ascending at an angle of 45 degrees or less, the veins prominulous, laxly reticulate; spikes (only very young ones seen) borne on stout villous-pilosulous peduncles 6-7 $\mathrm{mm}$. long, stout, about $3.5 \mathrm{~cm}$. long and $4 \mathrm{~mm}$. thick, erect, rounded at the apex, the bracts densely sordidpubescent.

Rami graciles dense villoso-pilosuli, internodiis brevibus; petioli crassiusculi $1.5 \mathrm{~cm}$. longi vel breviores dense villoso-pilosuli basi tantum vaginantes; lamina tenuis in sicco fuscescens minutissime pellucido-punctata, elliptica vel obovatoelliptica, majuscula, longiuscule acuminata, basin versus aliquanto angustata, basi ipsa inaequali atque obliqua uno latere subcordata vel rotundata, altero obtusa, supra ad costam villoso-pilosula, non bullata, subtus ad costam pilis longis patentibus villoso-pilosa, ad venas minute pilosula, inter venas glabra vel glabrata, penninervia, nervis utroque latere vulgo 4 angulo angusto arcuato-adscendentibus; spicae (juveniles tantum visae) crassae apice rotundatae, bracteis dense sordidopubescentibus.

\section{Piper minutantherum C. DC. Bot. Gaz. 70: 171. 1920.}

Known only from the type, Alta Verapaz, Cubilgüitz, 350 meters, Türckheim II.1441.

Branchlets glabrous, minutely verruculose; leaves glabrous, on petioles $2 \mathrm{~cm}$. long, membranaceous when dried, minutely pellucid-punctate, elliptic-lanceolate, as much as $21 \mathrm{~cm}$. long and $7.7 \mathrm{~cm}$. wide, rather long-acuminate, slightly unequal at the base and acute on each side, the costa emitting 4-5 lateral nerves on each side; peduncles glabrous, shorter than the petioles, as much as $13 \mathrm{~mm}$. long; spikes about $10 \mathrm{~cm}$. long and almost $4 \mathrm{~mm}$. thick, short-acute at the apex, the rachis glabrous; bracts hirtellous; stamens 3 ; fruits obovoid, glabrous, $1.5 \mathrm{~mm}$. long, narrowed to the style.

We have seen no material of this species, which is not included in the key. 
Piper misantlense C. DC. in DC. Prodr. 16, pt. 1: 286. 1869.

Moist forest or in second growth thickets, 1,100-1,600 meters; Quiché; Huehuetenango. Southern Mexico.

A shrub about 3 meters high, the branches rather slender, glabrous, with short or somewhat elongate internodes; petioles slender, $6-15 \mathrm{~mm}$. long, glabrous, not winged, dilated and sheathing at the base; leaf blades rather thick and firm, green when dried, finely pellucid-punctate, elliptic-oblong to elliptic or obovateelliptic, mostly broadest at or above the middle, $14-14 \mathrm{~cm}$. long, 4-7.5 cm. wide, abruptly acuminate, oblique and somewhat unequal at the narrow base, obtuse on each side, green above, glabrous, slightly paler beneath, puberulent or strigillose on the nerves and veins, glabrous between them, penninerved, the nerves 3-4 on each side, slender, prominent, arcuate-ascending at an angle of about 45 degrees, the veins very slender, usually inconspicuous, very laxly reticulate; peduncles opposite the leaves, about $1 \mathrm{~cm}$. long or somewhat shorter, glabrous; spikes erect or spreading, slender, $5.5-10.5 \mathrm{~cm}$. long, at anthesis little more than $2 \mathrm{~mm}$. thick, obtuse; bracts triangular-peltate at the apex, ciliolate; fruit glabrous.

One of the two Guatemalan collections was marked by Trelease as a new species, but it agrees perfectly with specimens from Mexico that he determined as $P$. misantlense.

Piper oblique-ovatum Trelease in Standl. Field Mus. Bot. 22: 10. 1940. Cordoncillo.

Moist or wet, mixed forest or thickets, 1,250 meters or lower; endemic; Alta Verapaz; Izabal; Santa Rosa; Escuintla; Sacatepéquez; Chimaltenango (type from Concepción, J. R. Johnston 557); San Marcos.

A branched erect shrub 1-2.5 meters high, the young branches densely and very minutely puberulent, slender, with short or elongate internodes; petioles stout, $1 \mathrm{~cm}$. long or usually shorter, puberulent, narrowly vaginate below; leaf blades thick and firm, usually grayish when dried, epunctate, the veins translucent against strong light, oblong-ovate to lance-ovate or broadly ovate, mostly 8-12 cm. long and 3-6 cm. wide, acute or acuminate, very unequal at the base, the shorter side rounded or subcordate, the longer side deeply cordate, often equaling and concealing the petiole, glabrous on the upper surface, slightly lustrous, somewhat paler beneath, finely puberulent on the veins, palmately 5-nerved, the nerves slender but prominent, the veins slender, not very conspicuous, laxly reticulate, the blades often slightly bullate in age; peduncles slender, mostly 1.5-2 $\mathrm{cm}$. long, minutely puberulent; spikes slightly curved, $5-6 \mathrm{~cm}$. long, $2.5 \mathrm{~mm}$. thick, obtuse, the bracts glabrous except on the margins.

This is closely related to P. Lindenii (Miq.) C. DC. of Tabasco and may not be distinct, although, to judge from a photograph of the type of that species, it has much more slender flower spikes, and somewhat different leaf venation. We place here three forms that have been indicated by Trelease as new species, but most of the specimens we have referred here are sterile, and it is possible that 
fertile specimens will show that more than one species really is represented by the dozen collections now at hand.

\section{Piper oradendron Trelease \& Standley, sp. nov. Cordoncillo.}

Wet to dry thickets or mixed forest, 1,200 meters or lower; so far as known, endemic; Izabal; Santa Rosa; Escuintla (type collected below Las Lajas, Standley 64817; in Herbarium of Chicago Natural History Museum); Guatemala; Sacatepéquez; Retalhuleu; San Marcos.

A shrub 1-2.5 meters high, the branches slender, densely hispidulous with short, spreading or reflexed, usually fulvous hairs, the upper internodes short; petioles slender, 1-2 $\mathrm{cm}$. long, not winged, hispidulous, dilated at the base; leaf blades thin, usually green or dark green when dry, densely and minutely pellucidpunctate, not or very slightly lustrous, ovate or ovate-elliptic, mostly $13-18 \mathrm{~cm}$. long and 6-9 $\mathrm{cm}$. wide, abruptly acuminate or long-acuminate, oblique and conspicuously unequal at the base, usually acute on one side and obtuse or even rounded on the other, not bullate, scabrous or hirtellous above along the costa, elsewhere glabrous or nearly so, usually quite smooth to the touch, sparsely strigillose beneath on the nerves and veins or in age glabrate, smooth to the touch, penninerved, the nerves $3-4$ on each side, ascending at an angle of usually less than 45 degrees, slightly arcuate or almost straight, very slender, prominent, the veins prominent, usually pale, laxly reticulate; peduncles opposite the leaves, rather stout, about $6 \mathrm{~mm}$. long, hispidulous or glabrate; spikes slender, the immature ones 5-6 $\mathrm{cm}$. long and $2 . \mathrm{mm}$. thick, obtuse; bracts densely pubescent.

Frutex, ramis gracilibus dense pilis brevibus patentibus vel reflexis fulvis hispidulis; petioli $1-2 \mathrm{~cm}$. longi exalati hispiduli basi tantum dilalati; lamina in sicco viridis vel obscure viridis tenuis dense minuteque pellucido-punctata ovata vel ovato-elliptica modica, abrupte acuminata vel longiacuminata, basi inaequali et obliqua uno latere acuta, altero obtusa vel rotundata, supra ad costam hirtella vel scabra, tactu laevis, subtus ad costam venasque strigillosa vel glabrata, penninervia, nervis utroque latere 3-4 anguste adscendentibus subarcuatis vel fere rectis, venis manifestis laxe reticulatis; spicae bene evolutae non visae, juveniles 5-6 $\mathrm{mm}$. longae $2 \mathrm{~mm}$. crassae erectae vel patentes; bracteae dense pubescentes.

A common shrub of the foothills and plains of the Pacific slope. It may not be fully distinct from some of the other forms here treated as species, and probably an older name will be found for it among the described Mexican species.

Piper pansamalanum C. DC. Bot. Gaz. 70: 177. 1920. $P$. mayanum Lundell, Phytologia 1: 337.1939 (type from Stann Creek District, Middlesex, British Honduras, P. H. Gentle 2866).

Dense, moist or wet, mixed, mountain forest, 150-1,500 meters; Alta Verapaz (type from Pansamalá, Türckheim 940); Izabal; Huehuetenango. British Honduras. 
A coarse shrub or a small tree, 2.5-6 meters high, with few stout branches, the young branches densely short-villous with sordid multicellular hairs; petioles stout, $6 \mathrm{~cm}$. long or shorter, vaginate throughout or nearly so, villosulous; leaf blades very large, rather thick, blackening when dried, oval-ovate to somewhat rhombic-ovate, mostly $25-40 \mathrm{~cm}$. long and 17-26 cm. wide or even larger, abruptly short-acuminate, deeply and narrowly cordate at the base, with large, rounded, often overlapping basal lobes, glabrous above, densely sordid-villosulous beneath at least on the nerves and veins and often over the whole surface, palmately about 7 -nerved at the base, the costa very stout, with about 3 nerves on each side above the basal ones, the nerves scarcely elevated on the upper surface but very coarse and prominent beneath, the veins laxly reticulate, the larger ones elevated; peduncles villosulous or glabrate, in the type $5.5 \mathrm{~cm}$. long but sometimes as much as $10 \mathrm{~cm}$.; spikes nutant, brick-red, as much as $40 \mathrm{~cm}$. long or even longer and $8 \mathrm{~mm}$. or less in diameter, equaling or longer than the leaves; bracts triangularpeltate, hirtellous on the margins; stamens 4 , adnate to the base of the fruit; stigmas 3 , sessile; fruit somewhat tetragonous, glabrous.

Easy of recognition because of the much elongate spikes and the very large, deeply cordate leaves, abundantly pubescent beneath but glabrous on the upper surface. Piper species of this type are rare in Central America, but they are more plentiful in Panama and Costa Rica than in Guatemala. The plant has been reported from Guatemala under the name Piper gigantifolium var. cubilquitzanum C. DC.

Piper patulum Bertol. Fl. Guat. 407. pl. 36. 1840. P. quiriguanum Trelease in Standl. Field Mus. Bot. 10: 160. 1931 (type from Quiriguá, Izabal). Cordoncillo.

Moist to wet or rather dry, mountain or lowland forest or thickets, 1,200 meters or lower; Alta Verapaz; Jutiapa; Santa Rosa; Escuintla; Chimaltenango; Suchitepequez; Retalhuleu; Quezaltenango. Southern Mexico; British Honduras; Salvador; Honduras; perhaps even farther southward.

A rather slender shrub, commonly 2-3 meters high, erect, rather sparsely branched, glabrous throughout or practically so; petioles slender, mostly 2.5-7 $\mathrm{cm}$. long, vaginate for half their length or more, often almost throughout; leaf blades thin and when fresh often flaccid, finely and densely pellucid-punctate, broadly cordate-ovate to rounded-cordate, commonly $10-20 \mathrm{~cm}$. long and $7.5-$ $15 \mathrm{~cm}$. wide, rather abruptly acuminate or long-acuminate, shallowly or rather deeply and openly cordate at the base, with rounded basal lobes, deep green above, somewhat paler beneath, palmately about 9-nerved, the nerves slender, prominent beneath, the veins rather prominent, laxly reticulate; peduncles opposite the leaves, rather stout, about $1 \mathrm{~cm}$. long or less; spikes very long and slender, often or usually somewhat curved, about $12-16 \mathrm{~cm}$. long and 2.5-3 mm. thick, the bracts densely pilosulous or tomentulose.

A very common plant in many regions, especially on the Pacific plains and foothills. It is one of the well-marked and easily recog- 
nized local species. This is presumably the Piper that has been reported from Guatemala as $P$. marginatum Jacq.

Piper patzulinum Trelease \& Standley, sp. nov. Cordoncillo.

Moist or wet, mixed, usually dense, mountain forest, sometimes on white-sand slopes, 650-2,600 meters; Chimaltenango; Retalhuleu; Quezaltenango (type from lower southern slopes of Volcán de Santa María, along the barranco between Finca Pirineos and Patzulín, Steyermark 33629; in Herbarium of Chicago Natural History Museum); San Marcos.

Usually an erect shrub of 1.5-2.5 meters, the branches slender, thinly villosulous or glabrate, the internodes mostly short; petioles rather slender, mostly 1-2 cm. long, villosulous or glabrate, naked or nearly so, slightly dilated at the base; leaf blades thin and often flaccid, drying green or blackish green, minutely pellucid-punctate or opaque, narrowly elliptic to elliptic-oblong or ovate-oblong, mostly $15-20 \mathrm{~cm}$. long and $4.5-8.5 \mathrm{~cm}$. wide, rather abruptly long-acuminate, conspicuously unequal and oblique at the base, usually cordate or subcordate on one side and obtuse or acute on the other, or sometimes rounded or obtuse on both sides, green and glabrous above, somewhat paler beneath, villosulous or pilosulous with soft spreading hairs on the nerves and veins, glabrous or nearly so between them, penninerved, the nerves $3-4$ on each side, arcuate-ascending at an angle of 45 degrees or slightly more, very slender, prominent, the veins very slender, little elevated, often inconspicuous, very laxly reticulate; peduncles opposite the leaves, rather stout, about $8 \mathrm{~mm}$. long, glabrous or nearly so; spikes erect, white or greenish white, slender, mostly 8-9 $\mathrm{cm}$. long and 2.5-3 mm. thick, obtuse; bracts very densely pubescent, pale.

Rami graciles sparse villosuli vel glabrati; petioli vulgo $1-2 \mathrm{~cm}$. longi villosuli vel glabrati non alati; lamina tenuis et saepe flaccida in sicco viridis vel fuscescens, minute pellucido-punctata vel opaca, anguste elliptica usque elliptico-oblonga vel ovato-oblonga modica, subabrupte longiacuminata, basi manifeste inaequali et obliqua uno latere cordata vel subcordata, altero obtusa vel acuta, supra glabra, subtus paullo pallidior ad nervos venasque pilis mollibus patentibus villosula vel pilosula, penninervia, nervis utroque latere 3-4; pedunculi oppositifolii ca. $8 \mathrm{~mm}$. longi glabri vel glabrati, spicis erectis gracilibus vulgo $8-9 \mathrm{~cm}$. longis et $2.5-3 \mathrm{~mm}$. crassis.

Piper peltatum L. Sp. Pl. 30. 1753. Heckeria peltata Kunth, Linnaea 13: 565. 1839. Pothomorphe peltata Miq. Comm. Phyt. 37. 1840. P. peltata var. hypoleuca Trelease in Standl. Field Mus. Bot. 12: 408.1936 (type from Craig Point, Sibun River, British Honduras, P. H. Gentle 1400). Santa Maria.

Moist or wet, lowland forest or thickets, sometimes in second growth, 600 meters or lower; Alta Verapaz; Izabal; Santa Rosa; Suchitepequez; Retalhuleu; San Marcos. Southern Mexico, southward to Panama; West Indies. 
Plants erect, rather stout, herbaceous throughout or nearly so, generally about 1.5 meters high, sparsely branched, the stems minutely puberulent or almost wholly glabrous, succulent; leaves large, long-petiolate, the petioles broad, longvaginate; leaf blades very thin, ovate-orbicular or almost orbicular, mostly 20-30 $\mathrm{cm}$. long, sometimes broader than long, abruptly acute at the rounded apex, shallowly cordate at the base or rounded, peltate far above the base, sparsely and minutely puberulent or almost glabrous, deep green above, paler and puncticulate beneath, palmate-nerved from the point of insertion, the principal nerve with usually 2 divergent nerves arising on each side above the base; common peduncle shorter than the petiole, 1-7 cm. long, glabrous or sparsely puberulent, bearing 4-10 spikes, these on peduncles 7-12 mm. long; spikes pale green, mostly $8-9 \mathrm{~cm}$. long, $3.5 \mathrm{~mm}$. thick, very obtúse, the bracts puberulent.

Sometimes called "ombligo" in Honduras. In the Botany of Porto Rico and the Virgin Islands, Britton and Wilson treat this and $P$. umbellatum as conspecific, whether on the basis of any authority other than that of the authors we do not know. It is conceivable that $P$. peltatum is only a form of $P$. umbellatum, but this we are inclined to doubt. In Central America it is very rare indeed to find the two growing together. Usually in any one part of the lowlands where there is a suitable habitat one or the other may be found, but almost never both in the same general region. $P$. peltatum is much rarer than $P$. umbellatum. Among the Guatemalan collections, Trelease has indicated two new species under the genus Pothomorphe. One of the specimens consists of very fragmentary material unsuited for description, and both the forms designated as new seem to differ in no respect from $P$. peltatum. This species has been reported from Guatemala as Piper cordillerianum C. DC.

Piper pergamentifolium Trelease \& Standley, sp. nov. Cordoncillo.

Moist or wet, mixed, mountain forest, sometimes in second growth thickets, 600-2,200 meters; so far as known, endemic, but to be expected in southern Mexico; Alta Verapaz; Santa Rosa; Escuintla; Sacatepéquez; Chimaltenango; Sololá; Retalhuleu; Quezaltenango (type from Volcán de Zunil, probably near Santa María de Jesús, A. F. Skutch 876; in Herbarium of Chicago Natural History Museum); San Marcos.

Commonly a shrub of $2-4.5$ meters, glabrous throughout, of ten much branched, the branches slender, with mostly short internodes; petioles slender or stout, commonly 1-1.5 cm. long, vaginate below; leaf blades thin but rather stiff and firm, grayish green when dried, minutely pellucid-punctate, variable in size and somewhat variable in shape, mostly lanceolate or ovate-lanceolate, sometimes rhombic-lanceolate, mostly $11-20 \mathrm{~cm}$. long and $3.5-8.5 \mathrm{~cm}$. wide but sometimes 
larger or smaller, gradually or abruptly acuminate or attenuate-acuminate, equal or nearly so at the base but generally very oblique, one of the sides acute, the other obtuse to shallowly cordate, the two sides of the leaf thus very unequal in breadth and shape, penninerved, the nerves generally about five on each side, very slender, little elevated on either surface and often very inconspicuous, ascending at a wide or narrow angle, the veins very inconspicuous, laxly reticulate; peduncles stout or slender, equaling or often shorter than the petioles, commonly $1 \mathrm{~cm}$. long or less; spikes erect or spreading, rather stout, most of them 4-7 cm. long and about $3 \mathrm{~mm}$. thick, obtuse or subacute at the apex, whitish or pale green; anthers short-exserted.

Frutex ramosus glaber; folia modica in sicco griseo-viridia minute pellucidopunctata vulgo $1-1.5 \mathrm{~cm}$. longe petiolata, plerumque lanceolata vel ovato-lanceolata, sensim vel abrupte acuminata vel attenuato-acuminata, basi vulgo insigniter obliqua subaequalia, uno latere acuta, altero obtusa usque subcordata, penninervia, nervis utroque latere ca. 5 tenerrimis vix elevatis, venis inconspicuis laxe reticulatis; pedunculi petiolos aequantes vel breviores, spicis erectis vel patentibus crassiusculis plerumque 4-7 cm. longis atque $3 \mathrm{~mm}$. crassis.

A very common shrub in the forests of the Pacific foothills and at middle elevations in the mountains. The numerous collections are variable in shape and size of the leaves, but we believe that all or most of them are conspecific, and there is no evident good basis for separating any of the forms as distinct species. Among the sheets that he examined, Trelease designated nine or more additional species, but some of these are clearly conspecific, and the rest of them are probably so.

Piper perlongipedunculum Trelease \& Standley, sp. nov. Cordoncillo.

Dense moist mixed mountain forest, 1,300-1,500 meters; endemic; Quezaltenango (type from lower southern slopes of Volcán de Santa María, along the barranco between Finca Pirineos and Patzulín, Steyermark 33628; in Herbarium of Chicago Natural History Museum; known also from two other collections from Finca Pirineos; also collected below San Martín Chile Verde).

A slender, sparsely branched, erect shrub 1.5-2 meters high, glabrous throughout, the upper internodes rather short; petioles rather stout, mostly 6-7 mm. long or sometimes slightly longer; leaf blades rather thin but firm, drying dark green or grayish green, opaque or usually so, lance-oblong or narrowly ovateoblong, mostly $11-15 \mathrm{~cm}$. long and 4-6 cm. wide, narrowly very long-acuminate, rounded at the base or sometimes subcordate, paler beneath, subequal and symmetric, palmately 5-nerved, the nerves very slender but prominent beneath, the lateral ones usually irregular and more slender than the others, the principal veins divergent at a right angle from the costa and straight or nearly so or the upper ones arcuate-ascending, laxly reticulate; peduncles opposite the leaves, very slender, almost filiform, mostly $1.5-2.5 \mathrm{~cm}$. long, glabrous; spikes very slender, 
pendulous, about $10 \mathrm{~cm}$. long and little more than $2 \mathrm{~mm}$. thick, white, the rachis glabrous or minutely puberulent; bracts glabrous, ciliolate.

Frutex gracilis fere omnino glaber; folia breviter petiolata, petiolo basi tantum vaginante, in sicco non fuscescentia, opaca, lanceolato-oblonga vel anguste ovatooblonga modica, anguste longissime acuminata, basi subaequali late rotundata vel interdum subcordata, palmatim 5-nervia; pedunculi oppositifolii fere filiformes, vulgo $1.5-2.5 \mathrm{~cm}$. longi; spicae graciles vix ultra $2 \mathrm{~mm}$. crassae ca. $10 \mathrm{~cm}$. longae; bracteae glabrae ciliolatae.

A relative of $P$. Amalago L., but apparently fully distinct from that species.

Piper phaeophyllum Trelease \& Standley, sp. nov.

Moist or wet forest or thickets, 1,200 meters or lower; endemic; Petén (Cerro Ceibal); Verapaz (type collected above Tamahú, Standley 70911; in Herbarium of Chicago Natural History Museum).

A shrub 1.5-3 meters high, the branches short-hispidulous, pale, rather slender, with short or elongate internodes; petioles stout, 4-6 $\mathrm{mm}$. long, exalate, dilated at the base, densely puberulent; leaf blades thick and stiff, small, fuscescent when dry, minutely pellucid-punctate or more often punctate, lanceolate or lanceoblong, mostly 7-10 $\mathrm{cm}$. long and $2.5-4 \mathrm{~cm}$. wide, narrowly long-acuminate, unequal and slightly oblique at the base, rounded or obtuse on each side, minutely scabrous above, very rough to the touch, not rugose, somewhat paler beneath, densely strigose on the nerves, scaberulous between them and rough to the touch, penninerved, the nerves usually 3 on each side, arcuate-ascending at an angle of about 45 degrees, the veins mostly very prominent, laxly reticulate; peduncles opposite the leaves, stout, about $6 \mathrm{~mm}$. long, scabrous-puberulent; spikes erectspreading, slender, about $8.5 \mathrm{~cm}$. long, slightly more than $2 \mathrm{~mm}$. thick, obtuse; bracts puberulent; anthers short-exserted; fruit puberulent about the apex.

Rami breviter hispiduli, graciles, internodiis brevibus vel elongatis; petioli crassi 4-6 mm. longi exalati basi dilatati, dense puberuli; lamina parva in sicco fuscescens minute pellucido-punctata, lanceolata vel lanceolato-oblonga, anguste longiacuminata, basi subaequali subobliqua utroque latere rotundata vel obtusa, supra minute scabra tactu aspera, non bullata, subtus paullo pallidior ad nervos dense strigosa inter nervos scaberula, penninervia, nervis utroque latere vulgo 3 arcuato-adscendentibus, venis subtus prominentibus laxe reticulatis; pedunculi oppositifolii $6 \mathrm{~mm}$. longi, spicis gracilibus ca. $8.5 \mathrm{~cm}$. longis $2 \mathrm{~mm}$. vel paullo ultra crassis.

\section{Piper philodendroides Standl. \& Steyerm., sp. nov.}

Known only from the type, Izabal, Cerro San Gil, wet forested slope, 300-900 meters, Steyermark 41928 (in Herbarium of Chicago Natural History Museum).

A stout shrub of 3-4.5 meters, glabrous throughout, the young branches stout and thick, brown, with short internodes; petioles stout, 7-12 cm. long, scarcely vaginate; leaf blades triangular-ovate or broadly oblong-ovate, about $28 \mathrm{~cm}$. long and $13-16 \mathrm{~cm}$. wide, acute or short-acuminate, almost equal at the base but one 
of the sides slightly larger than the other, very shallowly and broadly cordate, somewhat fuscescent when dry, dull, densely and minutely pellucid-punctate, penninerved, the nerves 3-4 on each side, arcuate-ascending at an angle of 45 degrees or more, prominent beneath, the veins prominent, very laxly and openly reticulate; spikes unknown.

Frutex erectus glaber, ramis crassis, internodiis brevibus; petioli crassi 7-12 $\mathrm{cm}$. longi fere omnino nudi; lamina crassiuscula triangulari-ovata vel late oblongoovata magna acuta vel breviter acuminata, basi lata subaequali breviter lateque cordata, lobis basalibus paullo inaequalibus, dense minute pellucido-punctata, penninervia, nervis utroque latere $3-4$ arcuato-adscendentibus subtus prominentibus, venis subtus prominentibus laxe reticulatis; spicae ignotae.

Apparently a well-marked species, the large long-petiolate leaves somewhat suggestive of those of certain species of Philodendron.

Piper pinetorum Standl. \& Steyerm., sp. nov.

Known only from the type, Huehuetenango, in forest of Liquidamber and Pinus Ayacahuite, Cerro Victoria, near Barillas, Sierra de los Cuchumatanes, 1,800-2,000 meters, Steyermark 49712 (in Herbarium of Chicago Natural History Museum).

A shrub 3 meters high, apparently densely branched, glabrous throughout or nearly so, the youngest parts sometimes with a few scattered inconspicuous hairs, the internodes mostly short; petioles stout, about $2 \mathrm{~cm}$. long, winged nearly or quite their full length; leaf blades thick, more or less bullate, slightly blackening or brownish when dry, opaque, oblong or elliptic-oblong, about $11 \mathrm{~cm}$. long and $4 \mathrm{~cm}$. wide, acute or abruptly short-acuminate with an obtuse tip, very unequal at the base, one side 6-7 mm. longer than the other, cordate or subcordate at the base, at least on one side, the other side rounded, dull when dried, the nerves and veins somewhat impressed on the upper surface, the blades penninerved, the nerves usually 3 on each side, ascending at a narrow angle, slightly arcuate, prominent beneath, the veins scarcely elevated, laxly reticulate; peduncles stout, about $1 \mathrm{~cm}$. long; spikes pendent, with alternating rings of white and pale green, very slender, mostly about $16 \mathrm{~cm}$. long and $2 \mathrm{~mm}$. thick; scales very small, ciliate; ovary glabrous.

Frutex trimetralis fere omnino glaber; petioli crassi fere tota longitudine vaginantes; lamina crassa epunctata in sicco fuscescens vel subtus brunnescens plus minusve bullata oblonga vel elliptico-oblonga modica, acuta vel breviter obtuso-acuminata, basi valde inaequalis, saltem uno latere cordata vel subcordata, altero rotundata, pinnatinervia, nervis utroque latere vulgo 3 ; spicae ca. $1 \mathrm{~cm}$. longe pedunculatae graciles pendulae ca. $16 \mathrm{~cm}$. longae et $2 \mathrm{~mm}$. crassae.

\section{Piper planadosense Trelease \& Standley, sp. nov.}

Known only from the type, Zacapa, Sierra de las Minas, cloud forest on summit, vicinity of Finca Planados, 2,500 meters, Steyermark 29994 (in Herbarium of Chicago Natural History Museum).

An erect shrub 4.5 meters high, the young branches rather stout, densely puberulent or hispidulous with spreading hairs, the internodes short; petioles 
stout, $1 \mathrm{~cm}$. long or shorter, densely hispidulous, vaginate only at the base; leaf blades somewhat blackish when dried, dull, thin but firm, densely pellucid-punctate, elliptic or ovate-elliptic, mostly $13-15 \mathrm{~cm}$. long and 6-7 cm. wide, rather abruptly acuminate, conspicuously unequal and oblique at the base, shallowly cordate or subcordate on one side, rounded or obtuse on the other, glabrous above, often brownish beneath, densely strigillose or puberulent on the nerves and veins, between them glabrous or nearly so and finely granular, penninerved, the nerves $3-4$ on each side, very slender, prominent, ascending at an angle of 45 degrees or less, arcuate, the veins prominent, laxly reticulate; peduncles opposite the leaves, stout, about $1 \mathrm{~cm}$. long, puberulent or glabrate; spikes in fruit about $7 \mathrm{~cm}$. long and $5 \mathrm{~mm}$. thick; fruits glabrous or nearly so, almost $2 \mathrm{~mm}$. long, subglobose.

Frutex, ramis crassiusculis dense puberulis vel hispidulis; petioli crassi ca. $1 \mathrm{~cm}$. longi vel breviores hispiduli basi tantum vaginantes; lamina in sicco plus minusve fuscescens dense pellucido-punctata elliptica vel ovato-elliptica modica, subabrupte acuminata, basi manifeste inaequalis et obliqua, uno latere cordata vel subcordata, altero rotundata vel obtusa, supra glabra opaca, subtus ad nervos venasque dense strigillosa vel puberula, penninervia, nervis utroque latere 3-4 angulo angusto arcuato-adscendentibus; pedunculi oppositifolii ca. $1 \mathrm{~cm}$. longi, spicis fructiferis ca. $7 \mathrm{~cm}$. longis atque $5 \mathrm{~mm}$. crassis.

Piper pogonioneuron Trelease \& Standley, sp. nov. Cordoncillo.

Moist or wet thickets or dense mixed forest, chiefly in the mountains, sometimes on white-sand slopes, 2,250 meters or lower; endemic; Alta Verapaz; Izabal; Sacatepéquez; Chimaltenango; Quezaltenango (type from western slopes of Volcán de Zunil, opposite Santa María de Jesús, Steyermark 35174; in Herbarium of Chicago Natural History Museum); San Marcos.

An erect shrub 1.5-3 meters high, the branches rather slender, densely pilose or villous-pilose with rather long, spreading, mostly fulvescent, multicellular hairs, the upper internodes short; petioles mostly 1-2 cm. long, slender or stout, not winged, dilated at the base, villous-pilose; leaf blades rather thin, dull, scarcely fuscescent when dried, generally opaque but with translucent veins, elliptic to ovate-elliptic or oblong-elliptic, mostly $16-22 \mathrm{~cm}$. long and $6.5-10 \mathrm{~cm}$. wide, rather abruptly and narrowly long-acuminate, somewhat unequal and conspicuously oblique at the base, shallowly cordate or rounded on one side, usually obtuse on the other, densely scabrous above and very rough, villous-hirsute along the costa, not or very obscurely rugose, villous-pilose or hirsute beneath on the nerves and veins, scaberulous between them, penninerved, the nerves $3-5$ on each side, ascending at an angle of 45 degrees or more, arcuate, the veins often prominent, laxly reticulate; peduncles opposite the leaves, usually about $1.5 \mathrm{~cm}$. long, scabrous and scabrous-hirtellous; spikes erect or spreading, mostly 7-10 cm. long, $3 \mathrm{~mm}$. thick, obtuse or.subacute; bracts rounded-peltate at the apex, pale, densely pubescent; anthers subexserted; fruits about $1 \mathrm{~mm}$. long, somewhat depressed at the apex, obtusely angulate.

Frutex, ramis dense pilis longiusculis patentibus fulvescentibus multilocularibus pilosis; petioli $1-2 \mathrm{~cm}$. longi exalati basi dilatati villoso-pilosi; lamina majuscula non lucida in sicco vix fuscescens opaca, venis pellucidis, elliptica usque 
ovato-elliptica vel oblongo-elliptica, subabrupte angusteque longiacuminata, basi inaequalis obliqua uno latere cordata vel rotundata, altero obtusa, supra dense scabra et asperrima, non rugosa, ad costam villoso-hirsuta, subtus ad nervos venasque villoso-pilosa vel hirsuta, inter venas scaberula, penninervia, nervis utroque latere 3-5, angulo semirecto vel latiore arcuato-adscendentibus; pedunculi oppositifolii ca. $1.5 \mathrm{~cm}$. longi, spicis plerumque 7-10 cm. longis $3 \mathrm{~mm}$. crassis obtusis vel acutiusculis; bracteae apice rotundo-peltatae dense pubescentes; fructus apice subdepressus obtuse angulatus.

Among the material referred here, some of which was not seen by Trelease, there are twelve sheets that he has indicated as types of new species. One or two of these may have some claims to specific rank but we are inclined to believe that all are conspecific.

Piper pseudoasperifolium C. DC. in DC. Prodr. 16, pt. 1: 318. 1869. P. vestitifolium C. DC. Bot. Gaz. 70: 183. 1920 (type collected near Cajabón, Alta Verapaz, O.F. Cook \& R.F. Griggs 651). P. sibunense Trelease in Standl. Field Mus. Bot. 12: 408. 1936 (type from Gracie Rock, Sibun River, British Honduras, P. H.Gentle 1562). Cordoncillo; Biritac (Cobán, Quecchí); Cuturro (Izabal).

Moist or wet or sometimes rather dry, mixed, mountain or lowland forest, or in thickets, frequently in pine-oak forest, 2,300 meters or lower, most common at middle elevations; Petén; Alta Verapaz; Baja Verapaz; Izabal; Chiquimula; Suchitepequez; Sacatepéquez; Chimaltenango; Quiché; Huehuetenango; Quezaltenango; San Marcos. Southern Mexico, and probably farther southward in Central America.

An erect, rather stout, often much branched shrub, usually 1.5-5 meters high, the branches very densely hispidulous with whitish or yellowish, spreading or often reflexed, harsh hairs, the internodes mostly short; leaves usually grayish when dried, pellucid-punctate or almost opaque, thick, the stout petioles $1.5 \mathrm{~cm}$. long or shorter, vaginate only at the base, densely hispidulous; leaf blades lanceelliptic or ovate-elliptic, mostly $11-22 \mathrm{~cm}$. long and $4-8 \mathrm{~cm}$. wide, rather abruptly acuminate or long-acuminate, conspicuously oblique at the base, rounded or obtuse on each side or sometimes subcordate on one side, penninerved, the nerves usually 3-4 on either side, sometimes as many as 5-6, arising at or below the middle of the blades, very prominent beneath, the blades densely scabrous on the upper surface and very rough to the touch, usually very conspicuously bullate, the veins strongly impressed, at least on the older leaves, densely hispidulous beneath, at least on the nerves and veins, the veins very prominent and closely reticulate; peduncles stout, equaling or shorter than the petioles, densely hispidulous; spikes erect, rather stout, whitish, cream-colored, or pale green, at maturity about $9 \mathrm{~cm}$. long and $4 \mathrm{~mm}$. thick, obtuse; bracts peltate and truncate, densely hispidulous; stamens 4; fruits glabrous or nearly so.

This is a very common shrub in some parts of Guatemala and one of the commonest of all the local species. Trelease designated 
as new species twenty or more plants that we have placed here. Called "Spanish elder" in British Honduras. The plant has been reported from Guatemala as $P$. hirsutum Swartz and $P$. mexicanum C. DC.

Piper psilorhachis C. DC. Ann. Cons. Jard. Bot. Genève 2: 253. 1898 (type supposed to have been collected in Guatemala, Friedrichsthal 1538, the locality unknown). P. colaphitolerans Trelease in Standl. Field Mus. Bot. 17: 231. 1937 (type from Ixlu, Petén, C. L. Lundell 3827). Cucsub (Petén, Maya).

Moist or wet, mixed forest, 1,800 meters or lower, often descending nearly or quite to sea level; Petén; Alta Verapaz; Escuintla; Guatemala; San Marcos. Tabasco; British Honduras.

A slender shrub or small tree, rarely 7.5 meters high, usually much lower, glabrous throughout; leaves on slender petioles $1 \mathrm{~cm}$. long or usually shorter, often blackening when dried, pellucid-punctate, lance-ovate or lance-elliptic, mostly $7-10.5 \mathrm{~cm}$. long and $3-4.5 \mathrm{~cm}$. wide, rather abruptly and narrowly longacuminate, obtuse and only slightly unequal at the base, palmately 5-nerved, slightly paler beneath, the veins prominulous, very laxly reticulate; peduncles about equaling the petioles or somewhat longer; spikes slender, 5-10 cm. long, scarcely $3 \mathrm{~mm}$. thick, the rachis glabrous, the bracts minute, ovate, glabrous; stamens 5-6; fruits oblong, 5-6 $\mathrm{mm}$. long or less at maturity, very minutely puberulent; stigmas 3 , sessile, minute.

The names used in British Honduras are "Spanish elder" and "chucsuc" (Maya).

\section{Piper punctulatum Standl. \& Steyerm., sp. nov.}

Dense, moist or wet, mixed, mountain forest, 1,500-2,600 meters; endemic; Alta Verapaz; El Progreso (type from Sierra de las Minas, between Finca Piamonte and top of Montaña Piamonte, Steyermark 43622; in Herbarium of Chicago Natural History Museum); Zacapa (Sierra de las Minas).

A shrub 1-3 meters high, sometimes herbaceous almost throughout, sparsely branched, erect, the branches with elongate internodes, glabrous or nearly so; petioles rather slender, mostly $3-5 \mathrm{~cm}$. long, winged for almost their whole length, dilated and clasping at the base, glabrous or puberulent, especially above; leaf blades large, thin, usually fuscescent when dry, densely and rather coarsely pellucid-punctate, broadly ovate or rounded-ovate, sometimes rhombic-ovate, mostly $12-23 \mathrm{~cm}$. long and $9.5-16 \mathrm{~cm}$. wide, abruptly short-acute, sometimes rounded and short-cuspidate, shallowly and broadly cordate at the base, the two sides somewhat unequal, deep green and glabrous above, dull when dried, slightly paler beneath, densely blackish-puncticulate, densely puberulent on the nerves and veins and sometimes between them, penninerved, the nerves 3-4 on each side, very slender, prominulous, ascending at an angle of 45 degrees or less, slightly 
arcuate, the veins very slender and openly reticulate; peduncles opposite the leaves, very slender, about $3.5 \mathrm{~cm}$. long, glabrous, or puberulent above; spikes short and stout (only one well-developed one seen), about $7 \mathrm{~cm}$. long and $5 \mathrm{~mm}$. thick, attenuate upward, the bracts pale, densely pubescent; ovaries glabrous.

Frutex erectus sparse ramosus, ramis glabris vel glabratis; petioli $3-5 \mathrm{~cm}$. longi in fere tota longitudine vaginati glabri vel superne puberuli; lamina magna tenuis in sicco fuscescens dense et subgrosse pellucido-punctata, late ovata vel rotundo-ovata interdum rhombeo-ovata, abrupte breviter acuta vel rotundata et breviter cuspidata, basi breviter lateque cordata, lobis basalibus paullo inaequalibus, supra viridis, glabra, subtus paullo pallidior ubique dense fusco-puncticulata, ad nervos venasque et interdum inter venas sat dense puberula, penninervia, nervis utroque latere 3-4 angulo angusto adscendentibus, venis prominulis laxissime reticulatis; pedunculi oppositifolii ca. $3.5 \mathrm{~cm}$. longi glabri vel superne puberuli, spicis crassis ca. $6 \mathrm{~cm}$. longis et $5 \mathrm{~mm}$. basi crassis sursum sensim attenuatis.

We have made about eight collections of this species, most of them in various regions of Alta Verapaz.

\section{Piper retalhuleuense Trelease \& Standley, sp. nov. Corri- miento.}

Moist or rather dry thickets or lowland forest, 325 meters or lower; endemic; Santa Rosa; Retalhuleu (type from the region of Las Delicias, south of Retalhuleu, Standley 88047; in Herbarium of Chicago Natural History Museum).

Plants chiefly herbaceous but often more or less woody about the base, sometimes suberect and 1.5 meters high or less, occasionally scandent, commonly procumbent and rooting at the lower nodes, the branches pale green, rather stout, striate, glabrous or very obscurely puberulent, strongly nodose; petioles $1.5-2.5 \mathrm{~cm}$. long, short-hirsute, vaginate only at the base; leaf blades thin and rather flaccid, green when dried, cordate-orbicular or ovate-orbicular, 4-8 cm. long and 4-8.5 $\mathrm{cm}$. wide, rather abruptly acute or short-acuminate with an obtuse tip, deeply and narrowly cordate at the base, hirtellous above along the nerves, paler beneath, hirtellous on the nerves and veins, palmately 7-nerved, minutely pellucid-punctate, minutely blackish-puncticulate beneath; peduncles opposite the leaves, 7-10 $\mathrm{mm}$. long, short-hispidulous or glabrate; spikes erect, $1.5-3.5 \mathrm{~cm}$. long, $3 \mathrm{~mm}$. thick in fruit; fruits oval-globose, $1.5 \mathrm{~mm}$. long, obscurely puberulent or granular.

Plantae suffruticosae et erectae vel scandentes, saepius fere omnino herbaceae et procumbentes, internodiis saepe valde elongatis, ramis striatis glabris vel obscure puberulis; folia longipetiolata, petiolo breviter hirsuto basi tantum vaginante; lamina cordato-orbicularis vel ovato-orbicularis in sicco viridis subabrupte acuta vel acuminata, acumine obtuso, profunde angusteque basi cordata, supra secus nervos hirtella, subtus ad nervos venasque hirtella, palmatim 7-nervia, pellucidopunctata; pedunculi oppositifolii breviter hispiduli vel glabrati, spicis erectis breves; fructus ovali-globosus obscure puberulus vel granulosus.

\section{Piper santae-clarae Standl. \& Steyerm., sp. nov.}

Known only from the type, Suchitepequez, Volcán de Santa Clara, between Finca El Naranjo and the upper slopes, 1,250-2,600 
meters, Steyermark 46624 (in Herbarium of Chicago Natural History Museum).

A slender branched shrub about a meter high, the branches rather sparsely puberulent or short-pilosulous, the internodes short; petioles short, the longest $5 \mathrm{~mm}$. long, rather stout, puberulent; leaf blades thin, somewhat blackish when dried, minutely pellucid-punctate, lanceolate or oblong-lanceolate, mostly 8-10.5 $\mathrm{cm}$. long and $2-3 \mathrm{~cm}$. wide, very narrowly attenuate-acuminate, strongly unequal at the base, rounded or subcordate on each side, one side much longer decurrent than the other, glabrous above, somewhat paler beneath, minutely hirtellous on the nerves with pale spreading hairs, palmately 3-nerved or obscurely 5-nerved, the veins divergent from the costa at a wide angle, laxly reticulate; peduncles very slender, divaricate and perhaps pendulous, mostly $2.5-3 \mathrm{~cm}$. long, thinly pilosulous or glabrate; spikes small and slender, white, at anthesis $3-3.5 \mathrm{~cm}$. long, $2 \mathrm{~mm}$. thick, obtuse; anthers subexserted; bracts ciliate; ovaries glabrous.

Frutex metralis, ramis gracillimis sparse puberulis vel breviter pilosulis; folia tenuiter membranacea breviter petiolata in sicco fuscescentia minute pellucidopunctata, lanceolata vel oblongo-lanceolata, parva, anguste longeque attenuatoacuminata, basi valde inaequalia, utroque latere rotundata vel subcordata, palmatim 3-nervia vel obscure 5-nervia, supra glabra, subtus at nervos minute hirtella; spicae oppositifolii patentes vel pendulae $3-3.5 \mathrm{~cm}$. longae, pedunculis gracillimis spicis fere aequilongis.

A relative of $P$. Standleyi Trelease, which has normally very much shorter peduncles.

Piper scabrum Swartz, Fl. Ind. Occ. 59. 1797. P. Chanekii Trelease in Standl. Field Mus. Bot. 12: 407. 1936 (type from El Cayo, British Honduras, Mercedes Chanek 10). Cordoncillo.

Moist or wet or sometimes rather dry thickets or forest, often in open forest, sometimes in second growth, 1,900 meters or lower, most common below 1,000 meters; Petén; Alta Verapaz; Izabal; Santa Rosa; Escuintla; Sacatepéquez; Chimaltenango; Suchitepequez; Retalhuleu; Quezaltenango; San Marcos; Huehuetenango; Quiché. Southern Mexico; British Honduras; probably throughout Central America; West Indies; probably also in South America.

An erect, branched, rather stout shrub, commonly 1.5-3 meters high, the young branches densely hispidulous with short, whitish, spreading or somewhat reflexed, harsh hairs, the internodes short or elongate; petioles stout, $1 \mathrm{~cm}$. long or usually shorter, vaginate near the base, hispidulous; leaf blades rather thick and firm, usually drying green or grayish green, rarely blackish, little if at all lustrous, pellucid-punctate, sometimes very obscurely so, green on the upper surface, scabrous and very rough to the touch, not bullate, somewhat paler beneath, inconspicuously scabrous over the whole surface, strigillose or appressed-hispidulous on the nerves and veins, lance-elliptic to broadly ovate-elliptic, mostly $10-20 \mathrm{~cm}$. long and $5-8 \mathrm{~cm}$. wide, abruptly acuminate or cuspidate-a cuminate, very unequal at the base, rounded or obtuse on each side or the shorter side sometimes acute; 
peduncles stout, about equaling the petioles, hispidulous; spikes erect, slender, whitish, cream-colored, or grayish green, obtuse, mostly 8-10 cm. long and about $3.5 \mathrm{~mm}$. thick; bracts densely pubescent; anthers exserted.

This is easily the most common species of Piper found in Guatemala, although perhaps not the widest in range. It is an abundant, often somewhat weedy shrub in many parts of the country, especially on the Pacific slope. We have collected numerous specimens, and they are almost uniform in their characters. Despite this, Trelease has designated among our collections at least seventy new but fortunately unpublished species. It is in this group of the genus that he has in the past indicated and often published the greatest number of species, in Panama, Costa Rica, Honduras, and elsewhere, and the number of such published names that will have to be relegated to synonymy when the genus is carefully monographed probably will reach more than a hundred, when the South American species are considered. In treating the Guatemalan Piper species we have divided this group perhaps too finely, although we have recognized a number of related species that seem to have some claim to specific rank. West Indian material of $P$. scabrum usually has slightly larger leaves than mainland specimens. This species has been reported from Guatemala as P. hispidum Swartz and $P$. hirsutum Swartz.

Piper Schippianum Trelease \& Standley, sp. nov. (P. Schippianum Trelease ex Standl. Field Mus. Bot. 12: 104. 1936, without Latin description).

Known only from the type, British Honduras, wet forest, 19-mile, Stann Creek Railway, 90 meters, W. A. Schipp 316; collected also at Honey Camp; type in Herbarium of Chicago Natural History Museum.

A tree 9 meters high with a trunk $12 \mathrm{~cm}$. in diameter, glabrous throughout, the branches strongly nodose; leaves rather small, thin but firm, epunctate, on slender petioles 5-7 mm. long, narrowly oblong or lance-oblong, mostly 9.5-11.5 $\mathrm{cm}$. long and $3-3.5 \mathrm{~cm}$. wide, abruptly and narrowly long-acuminate, at the base very acute on one side, obtuse on the other, the obtuse side decurrent lower on the petiole than the other side, palmately 3-nerved or obscurely 5-nerved, the 3 principal nerves extending to the apex of the blade, the veins transverse, very slender, closely prominulous-reticulate; spikes very slender, opposite the leaves, on slender glabrous peduncles about $13 \mathrm{~mm}$. long, straight or somewhat flexuous, 7-14 cm. long, 2-3 mm. thick, very densely flowered; immature fruits globoseovoid, $1.5 \mathrm{~mm}$. long, glabrous.

Arbor glabra; folia inter minora firme membranacea epunctata anguste oblonga vel lanceolato-oblonga longe anguste caudato-acuminata, basi inaequali uno latere 
acutissima, altero obtusa, latere obtuso longius decurrente, palmatim 3-nervia vel obscure 5-nervia, venis utrinque prominulis arcte reticulatis; spicae breviter pedunculatae gracillimae foliis longiores; fructus glaber.

Piper sempervirens (Trelease) Lundell, Carnegie Inst. Wash. Publ. 478: 208. 1937. Arctottonia sempervirens Trelease in Standl. Field Mus. Bot. 12: 405. 1936.

Moist or wet, mixed, lowland forest, 300 meters or lower; Petén (type from Uaxactún, H. H. Bartlett 12563); Alta Verapaz (Cerro Chinajá). British Honduras (Chalilla Crossing, El Cayo District); Yucatan Peninsula of Mexico.

A slender shrub or small tree, commonly 1.5-5 meters high, the trunk sometimes $15 \mathrm{~cm}$. in diameter, glabrous throughout; leaves on slender petioles $8 \mathrm{~mm}$. long or short, chartaceous and stiff, usually very lustrous, grayish green when dried, elliptic or oblong-elliptic, mostly 6-9 cm. long and 3-4.5 cm. wide, abruptly long-acuminate, acute and only slightly unequal at the base, epunctate, palmately 3-5-nerved, the inner nerves ending a short distance below the apex, concolorous, the veins prominulous and rather closely reticulate on both surfaces; inflorescences terminal, racemose, $1.5-4 \mathrm{~cm}$. long, on peduncles $14 \mathrm{~mm}$. long or shorter, lax, the pedicels divaricate, about equaling the flowers; fruits ovoid, slightly more than $2 \mathrm{~mm}$. long.

Piper Standleyi Trelease in Standl. Journ. Wash. Acad. Sci. 13: 366. 1923. Cordoncillo.

Wet to rather dry, mixed, mountain forest or thickets, sometimes in rocky places, 1,200-2,400 meters; Guatemala; Chimaltenango; Suchitepequez; Quezaltenango. El Salvador, the type from Voleán de San Salvador.

A very slender, erect, branched shrub 1-2.5 meters high, the branches densely puberulent or hirtellous; petioles very short, $4 \mathrm{~mm}$. long or less, densely hirtellous, vaginate only at the base; leaf blades drying grayish green, very minutely pellucidpunctate or almost wholly opaque, narrowly lanceolate to lance-oblong, mostly $7-10 \mathrm{~cm}$. long and $2-3 \mathrm{~cm}$. wide, occasionally somewhat larger, very narrowly long-attenuate, somewhat oblique and unequal at the base, rounded or very obtuse, usually shallowly and narrowly cordate, the auricles unequal in size, glabrous above or practically so, dull, paler beneath, minutely hirtellous on the nerves, palmately 3-nerved or obscurely 5 -nerved, the veins conspicuous, pale, very openly reticulate; peduncles opposite the leaves, $7-15 \mathrm{~mm}$. long, puberulent; spikes spreading or pendulous, small, mostly $2-3 \mathrm{~cm}$. long, or sometimes $5-7 \mathrm{~cm}$. long, in fruit about $4 \mathrm{~mm}$. thick; bracts very small, densely pubescent on the margins; stigmas 3 , short and thick, sessile; fruits globose, $1.5 \mathrm{~mm}$. long, puberulent above or granular.

The material referred here is somewhat variable and may be separable into two species, except that some specimens are intermediate between the extreme forms that might be considered distinct species. 


\section{Piper stillans Trelease \& Standley, sp. nov.}

Known only from the type, Quiché, Cerro Putul, Zona Reina, 1,200 meters, A.F. Skutch 1822 (in Herbarium of Chicago Natural History Museum).

A slender shrub about a meter high, glabrous throughout; petioles stout, about $3 \mathrm{~mm}$. long, vaginate only at the very base; leaf blades drying green, densely and minutely pellucid-punctate, thin, oblong-elliptic or oblong-ovate, $7.5-10 \mathrm{~cm}$. long, $2.5-4 \mathrm{~cm}$. wide, caudate-acuminate, with a very long and narrow, attenuate, obtuse acumen, rounded to subacute at the base, dull when dried, palmately 3nerved, or 5-nerved but the outer nerves very obscure and irregular, the veins divergent from the costa at almost a right angle, straight or somewhat curved; peduncles opposite the leaves, very slender and almost filiform, $2-2.5 \mathrm{~cm}$. long; spikes small, very slender, probably pendulous, $3-4.5 \mathrm{~cm}$. long, scarcely $2 \mathrm{~mm}$. thick, obtuse; bracts glabrous, ciliate.

Frutex gracilis humilis omnino glaber; folia inter minora breviter petiolata, petiolo $3 \mathrm{~mm}$. tantum longo basi breviter vaginante, in sicco viridia dense minute pellucido-punctata, oblongo-elliptica vel oblongo-ovata, anguste longeque caudatoacuminata, acumine obtuso, basi rotundata usque subacuta, palmatim 3-nervia; pedunculi oppositifolii fere filiformes $2-2.5 \mathrm{~cm}$. longi; spicae gracillimae breves, $3-4.5 \mathrm{~cm}$. tantum longae vix $2 \mathrm{~mm}$. diam. ut videtur pendulae obtusae; bracteae glabrae ciliolatae.

\section{Piper subeburneum Trelease \& Standley, sp. nov.}

Moist or wet, mixed, mountain forest, 900-2,400 meters; endemic; Quezaltenango; San Marcos (type from northwestern slopes of Volcán de Tajumulco, barrancos six miles southwest of Tajumulco, Steyermark 36702 ; in Herbarium of Chicago Natural History Museum).

A glabrous shrub 1.5-2.5 meters high, the branches with short internodes; petioles rather stout, 1-2 cm. long, vaginate only near the base; leaf blades deep green or blackish green when dried, rather thick and firm, dull, minutely pellucidpunctate, lance-oblong or often narrowly so, mostly $13-19 \mathrm{~cm}$. long and 4.5-5.5 or rarely $7 \mathrm{~cm}$. wide, rather abruptly short-acuminate with a subacute tip, subequal but often slightly oblique at the base and rounded or very obtuse, deep green above, the nerves and veins usually prominulous or sometimes not at all elevated, much paler beneath and glaucous or glaucescent, penninerved, the nerves 6-9 on each side, divergent at an angle of 45 degrees or of ten much broader, arcuate, ascending, the veins prominulous or obscure, very laxly reticulate; spikes unknown.

Frutex glaber; folia modica 1-2 $\mathrm{cm}$. longe petiolata, petiolo basi tantum vaginante, lanceolato-oblonga vel anguste lanceolato-oblonga in sicco vix fuscescentia minute pellucido-punctata, subabrupte breviterque acuminata, basi subaequali interdum aliquanto obliqua rotundata vel obtusissima, supra intense viridia, subtus multo pallidiora glauca vel glaucescentia, penninervia, nervis utroque latere 6-9 arcuato-adscendentibus, venis prominulis vel obscuris laxissime reticulatis; spicae ignotae. 
A rather common shrub of the mountains of the Occidente, represented by nine collections. The species is noteworthy, for the lower surface of the leaves has a very pale, glaucous or glaucescent color, which often has a slightly yellowish tinge.

Piper subcitrifolium C. DC. Bot. Gaz. 70: 186. 1920. Cordoncillo.

Wet to rather dry forest and thickets, 1,200 meters or lower; Santa Rosa (type from Cerro Redondo, J. D. Smith 3827); Escuintla; Guatemala; Sacatepéquez; Suchitepequez; Retalhuleu; Quezaltenango; San Marcos. Salvador.

An erect, sparsely branched shrub about 2 meters high, the branches glabrous or merely granular, the internodes often short; petioles short, rather stout, generally less than $1 \mathrm{~cm}$. long, minutely puberulent, vaginate only at the base; leaf blades elliptic or oblong-elliptic, epunctate or inconspicuously pellucid-punctate, with translucent veins, green or somewhat blackish when dried, mostly 11-16 cm. long and $5.5-7.5 \mathrm{~cm}$. wide, abruptly acuminate or long-acuminate, acute or obtuse at the base, glabrous above, usually somewhat lustrous, slightly paler beneath, minutely puberulent or strigillose along the nerves, elsewhere glabrous or nearly so, penninerved, the nerves usually 3 on each side, sometimes as many as 5 , arcuate-ascending, the upper ones arising above the middle of the blade, the veins scarcely prominulous, inconspicuous, laxly reticulate; peduncles stout, usually shorter than the petioles, glabrate; spikes pale green or whitish, mostly 8-10 $\mathrm{cm}$. long and $3 \mathrm{~mm}$. thick, obtuse; bracts truncate-triangular at the apex, hispidulous on the margins; stamens 4 ; stigmas 3 , sessile.

A common plant of the Pacific foothills and plains.

\section{Piper tacananum Trelease \& Standley, sp. nov.}

Moist or wet thickets or dense mixed mountain forest, 1,8002,500 meters; endemic; Sololá (type from Volcán de San Pedro, northern slopes above village of San Pedro, Steyermark 47250; in Herbarium of Chicago Natural History Museum); San Marcos (Río Tacaná above San Antonio).

A slender shrub 1.5-3 meters high, the branches sparsely or densely pilose or villous-pilose with weak spreading hairs; petioles rather stout, $1 \mathrm{~cm}$. long or shorter, vaginate only near the base, sparsely or densely pilose; leaf blades drying dark green or fuscescent, dull or very slightly lustrous, opaque or obscurely pellucidpunctate, oblong-ovate to oblong-lanceolate, mostly 12-16 cm. long and 5-7.5 $\mathrm{cm}$. wide, narrowly very long-acuminate, at the base cordate or shallowly cordate, at least in the lower leaves, or merely subcordate in the upper leaves, sometimes villosulous above at the very base but glabrous elsewhere, somewhat paler beneath or brownish, densely villous-pilosulous beneath over the whole surface or at least on the nerves, palmately 5-nerved, the lateral nerves very irregular and usually evanescent above, the principal veins divaricate from the costa at almost a right angle, straight or slightly arcuate, laxly reticulate; peduncles slender, opposite 
the leaves, densely villous-pilose, $2 \mathrm{~cm}$. long or somewhat longer; spikes white, nutant, very slender, about $9 \mathrm{~cm}$. long and $2 \mathrm{~mm}$. thick; bracts glabrous, ciliate; anthers exserted; fruit glabrous or nearly so.

Frutex gracilis erectus, ramulis sparse denseve pilosis vel villoso-pilosis; folia breviter petiolata, petiolo basi tantum vaginante sparse denseve piloso, in sicco fuscescentia, opaca vel obscure punctata, oblongo-ovata vel oblongo-lanceolata, anguste longissime acuminata, basi subaequali vel inaequali cordata vel breviter cordata, supra fere omnino glabra, subtus saltem ad nervos dense villoso-pilosula, palmatim 5-nervia, venis laxe reticulatis; pedunculi dense villoso-pilosi, spicis nutantibus gracilibus elongatis; bracteae glabrae ciliolatae.

\section{Piper tacticanum Trelease \& Standley, sp. nov.}

Dense, moist or wet, mixed, mountain forest, 1,350-1,650 meters; endemic; Alta Verapaz (type from mountains east of Tactic, on the road to Tamahú, Standley 61197; in Herbarium of Chicago Natural History Museum); Quezaltenango (Finca Pirineos below Santa María de Jesús).

A shrub 1-1.5 meters high, the branches slender, glabrous or sparsely and minutely puberulent, strongly nodose, with short internodes; petioles rather slender, 6-8 mm. long or sometimes as much as $15 \mathrm{~mm}$., minutely and sparsely strigillose or glabrate, not winged; leaf blades small, thin, blackish when dried, minutely pellucid-punctate, lance-ovate, mostly $11-13 \mathrm{~cm}$. long and $4.5-5 \mathrm{~cm}$. wide, rather abruptly and narrowly very long-acuminate, somewhat unequal and oblique at the base, obtuse or sometimes subacute on each side, glabrous above, dull, brownish beneath when dried, minutely strigillose on the nerves and veins and sometimes between them but to the naked eye appearing glabrous, penninerved, the nerves usually 3 on each side, very slender and scarcely elevated, arcuate-ascending, the veins obscure, very laxly reticulate; peduncles opposite the leaves, slender, about $1 \mathrm{~cm}$. long, glabrous; spikes slender, erect-spreading, about $6.5 \mathrm{~cm}$. long and $3 \mathrm{~mm}$. thick, short-mucronate at the apex; bracts densely palepubescent on the margins.

Frutex, ramis gracilibus glabris vel glabratis; folia breviter petiolata, petiolo non alato vulgo $6-8 \mathrm{~mm}$. longo minute sparseque strigilloso vel fere glabro, tenuia in sicco fuscescentia minute pellucido-punctata, lanceolato-ovata, subabrupte anguste longissime acuminata, basi inaequali atque obliqua utroque latere obtusa vel subacuta, supra glabra, subtus in sicco brunnescentia ad nervos venasque et interdum inter venas minute strigillosa, penninervia, nervis utroque latere vulgo 3 arcuato-adscendentibus; pedunculi oppositifolii ca. $1 \mathrm{~cm}$. longi, spicis erectopatentibus gracilibus ca. $6.5 \mathrm{~cm}$. longis atque $3 \mathrm{~mm}$. crassis.

\section{Piper tajumulcoanum Trelease \& Standley, sp. nov.}

Known only from the type, San Marcos, southern slopes of Volcán de Tajumulco, above Finca El Porvenir on Todos Santos Chiquitos, 1,300-1,500 meters, Steyermark 37235 (in Herbarium of Chicago Natural History Museum). 
A very slender shrub 1-1.5 meters high, glabrous throughout or nearly so, the internodes short or elongate; petioles very short, rather stout, $4 \mathrm{~mm}$. long or shorter, sparsely short-hirtellous or glabrous; leaf blades very thin, drying dull green, minutely pellucid-punctate, lanceolate or ovate-lanceolate, $8.5-12.5 \mathrm{~cm}$. long, $2.5-4.5 \mathrm{~cm}$. wide, very narrowly long-attenuate, oblique and conspicuously unequal at the base, shallowly and narrowly cordate, the two auricles broadly rounded, glabrous, paler beneath, palmately 3-nerved or obscurely 5-nerved, the nerves very slender, the veins inconspicuous, divergent from the costa at a wide angle; peduncles opposite the leaves, almost filiform, almost $2 \mathrm{~cm}$. long, glabrous; spikes small, probably pendulous, pale green, about $2 \mathrm{~cm}$. long, in fruit $3 \mathrm{~mm}$. in diameter, the bracts densely hirtellous on the margins; fruit globose, $1.5 \mathrm{~mm}$. long, glabrous or obscurely granular, the style very short and thick.

Frutex gracillimus fere omnino glaber; folia brevissime petiolata tenuiter membranacea in sicco non fuscescentia, petiolo breviter hirtello vel glabrato, minute pellucido-punctata, lanceolata vel ovato-lanceolata, anguste longissime attenuato-acuminata, basi inaequali breviter angusteque cordata, glabra, subtus paullo pallidiora, palmatim 3-nervia vel obscure 5-nervia; pedunculi oppositifolii fere filiformes $2 \mathrm{~cm}$. longi, spicis subaequilongis in statu fructifero $3 \mathrm{~mm}$. diam. obtusis; fructus globosus glaber vel obscure granulosus, stylo brevi.

In general appearance much like $P$. Standleyi Trelease, in which the branches and leaves are abundantly pubescent.

\section{Piper tecutlanum Trelease \& Standley, sp. nov.}

Moist or wet, mixed, mountain forest, sometimes on white-sand slopes, 1,500-2,500 meters; endemic; El Progreso (Sierra de las Minas); Quezaltenango (region below San Martín Chile Verde); San Marcos (Volcán de Tajumulco; type collected between town of Tajumulco and Tecutla, Steyermark 36753; in Herbarium of Chicago Natural History Museum).

A sparsely branched, erect shrub 2.5-4.5 meters high, branches rather slender, densely villous-pilose with soft spreading brownish multicellular hairs; petioles stout, 1-3 cm. long, densely villous-pilose with spreading brownish hairs, not winged; leaf blades thin or rather thick, more or less fuscescent when dry, strongly and closely bullate, at least when mature, densely and minutely pellucid-punctate, broadly elliptic or ovate-elliptic, mostly $13-21 \mathrm{~cm}$. long and 8-14 cm. wide, abruptly acute or acuminate, unequal and somewhat oblique at the base, cordate or subcordate on one or both sides, sometimes merely rounded on both sides, villous-pilosulous above along the costa and nerves, elsewhere glabrous, dull, the nerves and veins much impressed, slightly paler and often brownish beneath, densely pilose on the nerves and veins with long soft spreading hairs, penninerved, the nerves 5-7 on each side, slender, ascending at an angle of about 45 degrees, slightly arcuate or almost straight, the veins very closely reticulate, the surface deeply areolate between the veins; peduncles stout, about $1.5 \mathrm{~cm}$. long, densely villous-pilose, opposite the leaves; spikes in fruit as much as $13 \mathrm{~cm}$. long and $9 \mathrm{~mm}$. thick, pendent, acutish or short-mucronate at the apex; bracts triangular-peltate at the apex, densely sordid-pubescent; fruits glabrous. 
Frutex, ramis dense pilis patentibus brunnescentibus villoso-pilosis; petioli crassi 1-3 cm. longi dense villoso-pilosi; lamina tenuis vel crassiuscula in sicco fuscescens dense minute pellucido-punctata, dense arcte bullata, late elliptica vel ovato-elliptica, magna, abrupte acuta vel acuminata, basi inaequali atque obliqua utroque latere cordata vel subcordata vel interdum altero latere rotundata, supra ad costam nervosque villoso-pilosula, nervis venisque manifeste impressis, subtus ad nervos venasque dense pilosa, penninervia, nervis utroque latere 5-6; pedunculi oppositifolii $1.5 \mathrm{~cm}$. longi, spicis in statu fructifero $13 \mathrm{~cm}$. longis $9 \mathrm{~mm}$. crassis.

Piper telanum Trelease in Standl. Field Mus. Bot. 10: 161. 1931. Cordoncillo.

Moist or wet, mixed, lowland forest, sometimes in Manicaria swamps, 300 meters or lower; Petén (near Chinajá); Alta Verapaz (region of Cubilgüitz); Izabal; Huehuetenango (near Ixcán). Southern Mexico; Honduras (the type from Tela).

Plants herbaceous or frutescent, 1-2.5 meters high, erect, sparsely branched, glabrous throughout; petioles rather stout, about $5 \mathrm{~mm}$. long, somewhat dilated and sheathing at the base; leaf blades narrowly lanceolate or oblong-lanceolate, mostly 13-16 cm. long and $2.5-5.5 \mathrm{~cm}$. wide, attenuate-acuminate, very acute and slightly unequal at the base, finely pellucid-punctate, dull and usually blackish when dried, dark green on the upper surface, somewhat paler and usually brownish beneath, penninerved, the nerves about 6 on each side, arcuate-ascending, the veins laxly reticulate, almost obsolete or at least inconspicuous; spikes opposite the leaves, the peduncles rather stout, $7 \mathrm{~mm}$. long or shorter, the spikes very dense, obtusely pointed at the apex, mostly $12-23 \mathrm{~mm}$. long, $3 \mathrm{~mm}$. thick in anthesis but in fruit as much as $6 \mathrm{~mm}$; bracts densely pubescent on the margins; fruits subglobose, about $2 \mathrm{~mm}$. in diameter, glabrous, granular, abruptly short-rostrate at the apex.

A well-marked species, related to the Costa Rican $P$. candelarianum C. DC., which has uniformly broader leaves and longer flower spikes. It has been reported from Guatemala as $P$. lanceolatum Ruiz \& Pavón.

Piper tuberculatum Jacq. Icon. Pl. Rar. 2: 2. pl. 210. 1786. P. tuberculatum var. obtusifolium C. DC. in Donn. Smith, Bot. Gaz. 19: 8. 1894 (type from Río Ocosito, Quezaltenango, J. D. Smith 2592). Cordoncillo; Cordoncillo negrö.

Moist or wet thickets or forest, often in rather dry, lowland forests or thickets, or in rocky places, 1,000 meters or lower, or perhaps at somewhat higher elevations; Petén; Alta Verapaz; Baja Verapaz; Izabal; Zacapa; Jalapa; Jutiapa; Santa Rosa; Escuintla; Guatemala; Suchitepequez; Retalhuleu; Quezaltenango; San Marcos; Huehuetenango; Quiché. Southern and western Mexico; British Honduras to El Salvador and Panama; South America. 
Usually a shrub of 1.5-3 meters, densely branched, the branches slender, finely and densely puberulent; leaves firm-membranaceous, short-petiolate, oblong or ovate-oblong, mostly $7-14 \mathrm{~cm}$. long and $2.5-7 \mathrm{~cm}$. wide, obtuse or rounded at the apex or sometimes acute, cordate at the base and very unequal, one of the lobes 5-12 $\mathrm{mm}$. longer than the other, the lobes short and broadly rounded,

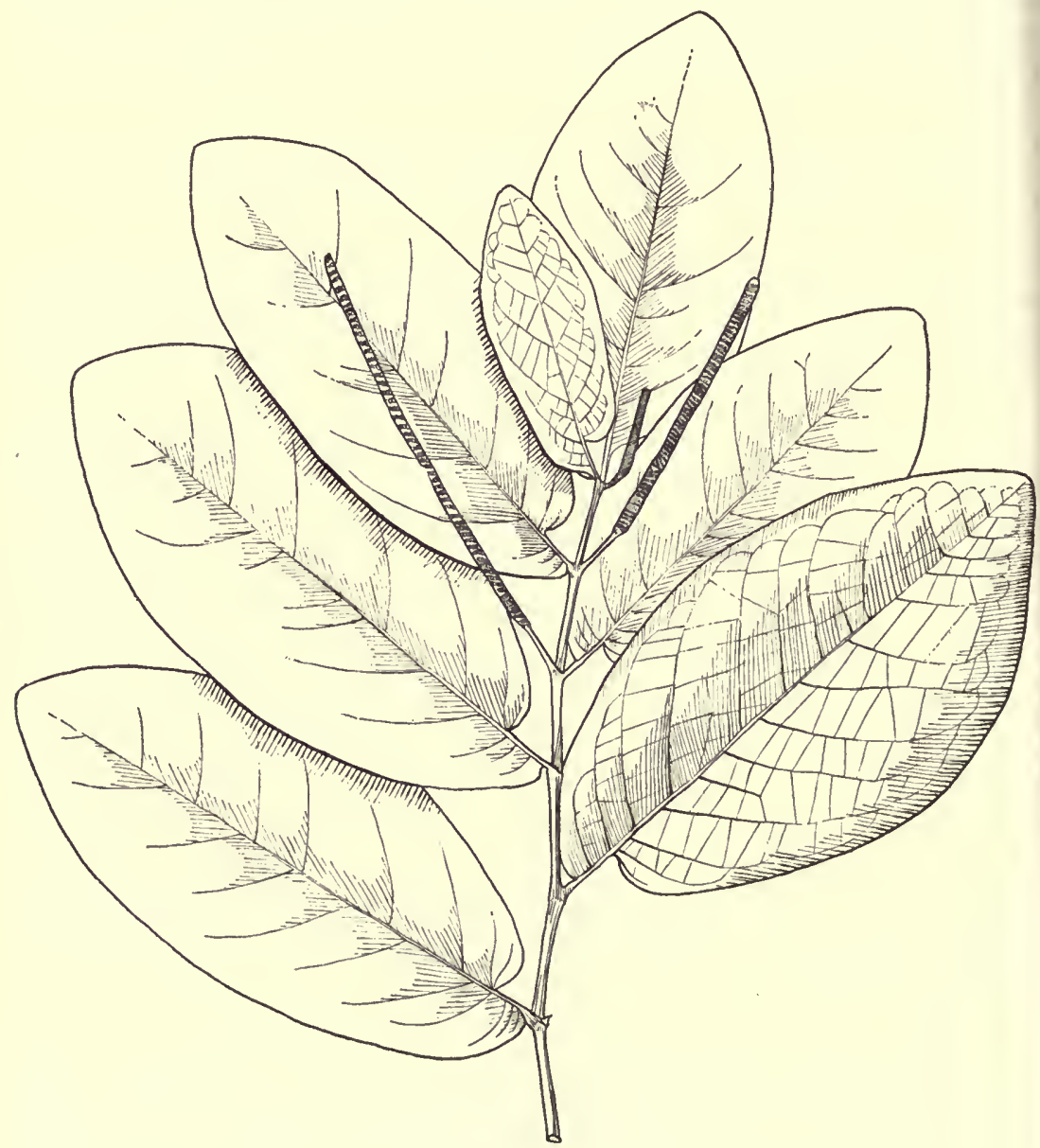

FIG. 45. Piper tuberculatum. Habit of portion of flowering branch; $\times 3 / 5$.

equally penninerved, with about 8 pairs of lateral nerves, deep green and somewhat lustrous above, somewhat paler and densely punctate beneath, glabrous or nearly so on both surfaces; spikes opposite the leaves, short-pedunculate, mostly 4-8 cm. long, $2.5 \mathrm{~mm}$. thick, obtuse, flowers in horizontal verticils. (Fig. 45.)

This is one of the most common and widely distributed of Central American Piper species, and it is also one of those most easily recog- 
nized. While there is nothing particularly distinctive about the leaves, at least nothing that can be described easily, once seen they can not be confused with any other species. The plant is somewhat weedy, thriving in rather dry places, and in some areas, such as the lowland forests toward San José el Puerto, becoming the dominant shrub in thickets and forests. It is a superior hedge plant, and is much cultivated for this purpose in the Pacific bocacosta, especially about dwellings and along the borders of cafetales. The shrubs grow readily from cuttings, and their foliage becomes very dense if they are pruned severely. This pruning is generally done with wide sweeps of a machete. The specific name alludes to the fact that the branchlets often bear tubercle-like lenticels. Called "Spanish elder" in British Honduras.

Piper Tuerckheimii C. DC. ex Donn. Smith, Enum. Pl. Guat. 2: 96. 1891, nomen; in Donn. Smith, Bot. Gaz. 19: 258. 1894.

Moist or wet, dense, mixed forest, 1,150 meters or lower; Alta Verapaz (type from Pansamalá, Türckheim 1038); Izabal. British Honduras; Atlantic lowlands of Honduras.

An erect shrub 1.5 meters high or less, sparsely branched, or the younger plants often sprawling over the ground, the branches slender, strongly nodose, densely sordid-hirtellous, with short or elongate internodes; leaves peltate well above the base, rather thick, usually drooping, on stout hirtellous petioles $4.5 \mathrm{~cm}$. long or shorter, oblong-ovate, mostly $16-25 \mathrm{~cm}$. long and $6.5-10 \mathrm{~cm}$. wide, narrowly very long-acuminate, subcordate or rounded at the base, usually blackening when dried, glabrous above, smooth, the nerves and veins not elevated, villosulous or hirtellous beneath, especially on the nerves and veins, slightly rough to the touch, palmately few-nerved at the base, penninerved above the base with usually 3 nerves on each side, the veins inconspicuous, very openly reticulate; peduncles solitary opposite the leaves, usually much shorter than the petioles, hirtellous; spikes $5 \mathrm{~cm}$. long or shorter, with a naked tail-like tip, the bracts triangularpeltate, hirtellous on the margins; stamens 4; fruit subglobose, hirtellous at the apex.

One of the most distinct species of the genus, easily recognized among Central American ones by its large, conspicuously peltate leaves, abundantly pubescent beneath, at least on the nerves.

Piper umbellatum L. Sp. Pl. 30. 1753. Heckeria umbellata Kunth, Linnaea 13:569. 1839. Pothomorphe umbellata Miq. Comm. Phyt. 36. 1840. Santa María; Jute; Obet, Obbel (Cobán, Quecchí).

Moist or wet forest and thickets, often in second growth, 1,500 meters or lower; Alta Verapaz; Chiquimula; Jalapa; Jutiapa; Escuintla; Guatemala; Sacatepéquez; Chimaltenango; Suchitepe- 
quez; Retalhuleu; Quezaltenango; San Marcos. Southern Mexico; British Honduras to Salvador and Panama; West Indies; South America.

Plants erect, usually 1-1.5 meters high, sparsely branched, herbaceous almost throughout but often somewhat woody below, the young branches densely villouspilose; petioles $20 \mathrm{~cm}$. long or shorter, vaginate for part of their length; leaf blades thin and flaccid, drying green, ovate-orbicular, mostly 20-30 $\mathrm{cm}$. long and of equal or even greater breadth, acute or abruptly short-acute, deeply and usually narrowly cordate at the base, with large rounded basal lobes, green on the upper surface, glabrous to densely villosulous, somewhat paler beneath, sparsely or densely pubescent or villosulous, pellucid-punctate, palmately nerved, with about 13 nerves; spikes pale green or whitish, sometimes cream-colored, mostly $9-15 \mathrm{~cm}$. long and about $4 \mathrm{~mm}$. thick, short-pedunculate, umbellate at the ends of the short axillary peduncles; stamens 2 ; stigmas 3 , sessile, recurved; fruits little more than $0.5 \mathrm{~mm}$. long.

This species and $P$. peltatum as noted under the latter, are much alike, except that one has peltate and the other epeltate leaves. In Guatemala $P$. umbellatum is usually much more densely pubescent than $P$. peltatum, but there is much variation in pubescence among the Guatemalan specimens. Both $P$. umbellatum and $P$. peltatum are noteworthy for the strong odor of the crushed leaves and stems, an odor reminiscent of sarsaparilla and probably arising from the translucent glands that are apparent when the dry leaves are viewed against a strong light. The leaves also have a distinct flavor, and on that account are often used for flavoring meat stews and other dishes. There is a popular belief in some parts of Central America that if the juice of the foliage is rubbed on the skin, it will prevent attacks of redbugs or chiggers, or even of the small ticks. Wisdom records that in the Jocotán (Chiquimula) region, a broth of jutes or snails and Santa María leaves is drunk by nursing women to increase the flow of milk.

Piper uspantanense C. DC. in Donn. Smith, Bot. Gaz. 19: 6. 1894. Cordoncillo.

Moist or wet, mixed, mountain forest, 1,000-1,650 meters; so far as known, endemic; Alta Verapaz; Quiché (type from San Miguel Uspantán, Heyde \& Lux 3827); Quezaltenango; San Marcos.

A rather slender shrub of 1.5-3 meters, the young branches densely hirtellous, the internodes short or elongate; petioles stout, $10 \mathrm{~mm}$. long or shorter, hirtellous, vaginate only at the base; leaf blades thin, usually grayish green when dried, very inconspicuously if at all punctate, elliptic-lanceolate to lanceolate or oblonglanceolate, mostly 14-20 cm. long and 5.5-7.5 cm. wide, narrowly long-acuminate, slightly or strongly unequal at the base, usually acute or subacute on both sides but rarely obtuse, glabrous and smooth above, the nerves scarcely elevated, 
somewhat paler beneath, usually densely and softly pilosulous beneath over the whole surface and on the nerves but sometimes glabrate in age, penninerved, the nerves 3-4 on either side, arising at or below the middle of the blade, arcuateascending, little elevated, the veins inconspicuous but often pale, very laxly reticulate; peduncles rather slender, slightly exceeding the petioles or often shorter, hispidulous; spikes very slender, mucronate at the apex, erect, mostly about 7-8 $\mathrm{cm}$. long and $2 \mathrm{~mm}$. thick; bracts densely hirsutulous on the margins; stamens 4 ; ovary glabrous; stigmas 3 .

\section{Piper vaccinum Standl. \& Steyerm., sp. nov.}

Known only from the type, British Honduras, on hillside, Vaca, El Cayo District, P. H. Gentle 2264 (in Herbarium of Chicago Natural History Museum; duplicates in Herbarium of University of Michigan).

A slender shrub, the branches finely puberulent or in age glabrate, the internodes mostly elongate; leaves on slender petioles 1-1.5 cm. long, thin, green when dried, minutely pellucid-punctate, the petioles puberulent; leaf blades ellipticovate, mostly 9-11 cm. long and $4.5-5.5 \mathrm{~cm}$. wide, rather abruptly and narrowly long-acuminate, obtuse or rounded and slightly oblique at the base, almost glabrous above, puberulent along the nerves, somewhat paler beneath, densely and finely puberulent along the nerves, sparsely and minutely puberulent or glabrate between them, 5-nerved, the veins few, laxly reticulate; peduncles slender, 6-7 $\mathrm{mm}$. long, densely puberulent; spikes very slender, spreading, 5-7.5 cm. long, $2 \mathrm{~mm}$. thick, very densely flowered; bracts densely ciliate.

Frutex gracilis, ramis minute denseque puberulis vel serius glabratis, internodiis plerumque elongatis; folia graciliter petiolata tenuia in sicco viridia dense minute pellucido-punctata, elliptico-ovata, subabrupte angusteque longiacuminata, basi obtusa vel rotundata atque subobliqua, supra fere glabra ad nervos puberula, subtus aliquanto pallidiora ad nervos dense puberula, 5-nervia; pedunculi 6-7 $\mathrm{mm}$. longi dense puberuli, spicis gracilibus ca. 5-7.5 cm. longis $2 \mathrm{~mm}$. crassis, bracteis dense ciliatis.

Piper variabile C. DC. ex Donn. Smith, Enum. Pl. Guat. 2: 66. 1891, nomen; in Donn. Smith, Bot. Gaz. 19: 259. 1894. P. purulhanum C. DC. 70: 169. 1920 (type from Purulhá, Baja Verapaz, Türckheim II.1705). P. middlesexense Trelease ex Standl. Field Mus. Bot. 12: 103. 1936, without Latin description (type from Middlesex, British Honduras, W. A. Schipp 286). Cordoncillo.

Moist or wet thickets or forest, sometimes in rather dry places, 1,600 meters or lower; Petén; Alta Verapaz (type collected near Cobán, Türckheim 434); Baja Verapaz; Izabal; Escuintla; Guatemala; Retalhuleu; Quezaltenango; San Marcos. Veracruz; British Honduras.

An erect shrub or small tree, usually 1-3 meters high, sparsely branched, glabrous throughout or nearly so; petioles rather stout, $1.5-5 \mathrm{~cm}$. long or some- 
times $10 \mathrm{~cm}$. or more, vaginate only at the base; leaf blades epunctate or nearly so, rather thick and firm, usually not at all blackish when dried, broadly ovatecordate to ovate-orbicular, mostly $13-24 \mathrm{~cm}$. long and 7-18 cm. wide, abruptly acute or acuminate, shallowly or deeply cordate at the base, or in the upper leaves truncate or rounded, with broadly rounded basal lobes, usually palmately 7-nerved at the base, the nerves slender but prominent, the costa emitting 1-2 strong nerves on each side slightly above the base of the blade, near the middle, or even higher, the veins barely prominulous, very laxly reticulate, not conspicuous; peduncles opposite the leaves, rather stout, mostly $1-1.5 \mathrm{~cm}$. long; spikes whitish, long and slender, pendent or recurved, commonly $9-18 \mathrm{~cm}$. long, 3-4 mm. thick, very obtuse; bracts glabrous; stamens 3 ; fruits small, glabrous.

The material referred here is somewhat variable, as the specific name might suggest, but there is no obvious basis for dividing it. It is quite possible that the proper name for this plant is $P$. Schiedeanum Steud., based on Mexican plants.

\section{Piper vergelense Trelease \& Standley, sp. nov.}

Dense, wet, mixed, mountain forest, or often on forested plains, 120-1,200 meters; endemic; Santa Rosa; Escuintla; Retalhuleu; San Marcos (type from Finca Vergel, near Rodeo, Standley 68950; in Herbarium of Chicago Natural History Museum).

A slender shrub 1.5-3 meters high, glabrous throughout, the internodes short or often much elongate; leaves medium-sized, membranaceous, drying green, on stout petioles 2-3 mm. long, narrowly oblong or oblong-lanceolate, mostly 8-15 cm. long and $2.5-5 \mathrm{~cm}$. wide, somewhat abruptly long-acuminate, slightly unequal at the base, rounded or obtuse on both sides, palmately 3-nerved, with two very irregular and obscure additional marginal nerves, epunctate, deep green above, paler beneath, the veins prominulous, inconspicuous, very laxly reticulate; young and immature spikes slender, pendent, about $4 \mathrm{~cm}$. long, $2 \mathrm{~mm}$. thick, the peduncles almost filiform, about $1.5 \mathrm{~cm}$. long; bracts large, glabrous.

Frutex gracilis omnino glaber; folia modica membranacea brevissime petiolata anguste oblonga vel oblongo-lanceolata abrupte longiacuminata, basi paullo inaequalia, utrinque obtusa vel rotundata, palmatim 3-nervia, venis prominulis inconspicuis laxissime reticulatis; spicae juveniles gracillimae pendulae, pedunculis fere filiformibus ca. $1.5 \mathrm{~cm}$. longis; bracteae glabrae.

\section{Piper virginicum Trelease \& Standley, sp. nov.}

Known only from the type, Izabal, in forest along creek, between Virginia and Lago de Izabal, base of Montaña del Mico, at or little above sea level, Steyermark 38812 (in Herbarium of Chicago Natural History Museum).

A rather slender shrub 1.5-2.5 meters high, glabrous throughout; petioles stout, $8-15 \mathrm{~mm}$. long, vaginate only at the base; leaf blades thick and stiff, pale green when dried, opaque or nearly so, oblong-lanceolate or ovate-lanceolate, mostly $15-18 \mathrm{~cm}$. long and $5.5-7 \mathrm{~cm}$. wide, narrowly and gradually long-acuminate, 
equal at the base, symmetric or sometimes oblique, rounded, dull or scarcely lustrous, slightly paler beneath, the veins and nerves prominent on both surfaces, the blades penninerved, the nerves usually 6 on each side, ascending at a rather wide angle, strongly arcuate, the veins closely reticulate; spikes (only very young ones seen) on stout peduncles 6-7 mm. long, erect, the longest ones seen $4.5 \mathrm{~mm}$. long and $2 \mathrm{~mm}$. thick, but doubtless much longer when fully developed; bracts pale green, glabrous, minutely ciliate.

Frutex erectus, internodiis superioribus brevibus, omnino glaber; folia 8-15 $\mathrm{mm}$. longe petiolata in sicco pallide viridia subcoriacea rigida subtus pallidiora fere omnino opaca, oblongo-lanceolata vel ovato-lanceolata, magna, sensim longiacuminata, basi aequalia symmetrica vel obliqua rotundata, penninervia, nervis utroque latere vulgo 6 arcuatis, utrinque prominentibus, venis utrinque prominentibus arcte reticulatis.

Piper xanthostachyum C. DC. Anal. Inst. Fís. Geogr. Costa Rica 9: 169. 1897. P. flavirameum C. DC. Bot. Gaz. 70: 181. 1920. P. bryogetum C. DC. op. cit. 175.1920.

Usually on tree trunks in moist or wet, dense, mixed forest, 1,4002,850 meters; Alta Verapaz; Zacapa; Quezaltenango; San Marcos. Chiapas; Costa Rica.

Plants almost always epiphytic, rarely terrestrial and then low shrubs, usually creeping or scandent on tree trunks, glabrous throughout or nearly so, the branches conspicuously nodose, with short or elongate nodes, commonly glabrous but sometimes sparsely hirtellous; stipules often conspicuous on young branches, narrow, as much as $3 \mathrm{~cm}$. long or even longer, caducous; petioles stout, usually very short and often scarcely exceeding the basal lobes of the leaf; leaf blades subcoriaceous, drying greenish or rarely blackish, epunctate or nearly so, lanceoblong or ovate-oblong, mostly 11-24 cm. long and 4.5-10 cm. wide, narrowly long-acuminate, very oblique and unequal at the base, rounded on one side and cordate on the other or more or less cordate on both sides, penninerved, with usually 3 pairs of nerves, or sometimes with as many as 5 nerves on one side, the nerves usually all arising below the middle of the blade, strongly elevated beneath, ascending at a narrow angle, slightly arcuate, the veins rather closely reticulate, the leaves usually lustrous on both surfaces, little paler beneath but sometimes brownish, the veins often very prominent beneath, the nerves frequently conspicuously impressed on the upper surface; peduncles stout, mostly $1-1.5 \mathrm{~cm}$. long, much exceeding the petioles; spikes reddish brown or greenish, mostly 5-9 $\mathrm{cm}$. long, $4 \mathrm{~mm}$. thick or more, very obtuse; bracts hirtellous on the margins; stamens 4 ; stigmas 4 ; ovary glabrous.

The Guatemalan material we place here was referred by Trelease to eleven unpublished species. The species, as here treated, is variable in shape, size, and texture of the leaves, but it is believed that some or most of these differences may be explained on the basis of the stage of their development, the leaves of young sterile plants being thin while those of mature plants are more or less coriaceous. It is, of course, possible that we have erred in uniting 
the three Costa Rican species and combining with them the several Guatemalan forms, but we believe that ultimately at least they will have to be united, unless better characters are found than are now apparent for separating them.

Piper yucatanense C. DC. Linnaea 37: 334. 1871-73.

Moist or wet forest, little above sea level; Petén. Yucatan Peninsula of Mexico; British Honduras.

A slender shrub of 1-3 meters, glabrous throughout; leaves on very short, slender petioles, oblong-ovate, mostly $10-16 \mathrm{~cm}$. long and $3-6 \mathrm{~cm}$. wide, narrowly cuspidate-attenuate, obliquely rounded at the base, rather thin, usually blackening when dried, epunctate, palmately 6-7-nerved, the inner lateral nerves extending to the apex of the blade, very slender, the veins very slender, little elevated, laxly reticulate; inflorescences opposite the leaves, on slender peduncles $10-13 \mathrm{~mm}$. long, the flowers racemose, the racemes lax, 2-3.5 $\mathrm{cm}$. long, the pedicels divaricate, $2-2.5 \mathrm{~mm}$. long; stamens 5 , minute, the anthers globose; fruit glabrous, ovoidoblong, the stigmas $3-5$, minute.

This species is referable to the genus Arctottonia proposed by Trelease, but the transfer of this name has not been made, and need not be. Schipp describes the inflorescences as cream-colored.

Piper yzabalanum C. DC. ex Donn. Smith, Enum. Pl. Guat. 2: 66. 1891, nomen; in Donn. Smith, Bot. Gaz. 19: 7. 1894. Tzakisbá (Huehuetenango).

Moist or wet, mixed, mountain or lowland forest, ascending from sea level to rarely as high as 2,000 meters; Petén; Alta Verapaz; Izabal (type collected at the mouth of Río Polochic, J. D. Smith 1712); El Progreso; Huehuetenango. Veracruz and probably elsewhere in southern Mexico.

A shrub 1-3 meters high, sparsely branched, glabrous throughout; petioles stout, $2.5-4 \mathrm{~cm}$. long, vaginate throughout; leaf blades broadly ovate to oval or elliptic, mostly $18-21 \mathrm{~cm}$. long and $8-12 \mathrm{~cm}$. wide, abruptly acute or shortacuminate, broadly rounded at the base and equal or only slightly asymmetric, most often shallowly and narrowly cordate but often not at all cordate, somewhat lustrous on both surfaces when dried, grayish green or often somewhat blackish, penninerved, with 5-7 nerves on each side, these arcuate, ascending at an angle of 45 degrees or more, slender, prominent beneath, the veins inconspicuous, laxly reticulate, the blades densely and very finely pellucid-punctate; spikes on stout peduncles about $1 \mathrm{~cm}$. long, erect, whitish or greenish white, 4.5-8 cm. long, 4-5 $\mathrm{mm}$. thick, short-mucronate at the apex, the bracts spatulate, triangular and inflexed at the apex, glabrous; stamens 4; fruit glabrous, the stigmas 3.

This species may not be different from $P$. chinantlense Mart. \& Gal. of Oaxaca and other localities in southern Mexico. We refrain from using that name only because we have not seen type material 
of the species. Trelease has indicated in the herbarium two new species from Guatemala which we consider referable to $P$. yzabalanum. In Veracruz this species is known as "cordoncillo" and "acuyo cimarrón."

\section{Piper zacapanum Trelease \& Standley, sp. nov.}

Known only from the type, Zacapa, cloud forest in ravine bordering Quebrada Alejandría, summit of Sierra de las Minas, 2,500 meters, Steyermark 29905 (in Herbarium of Chicago Natural History Museum).

A shrub, the branches stout, tortuous, strongly nodose, with short internodes, densely hispidulous with short, spreading or reflexed, sordid hairs; petioles stout, 4-7 mm. long, densely hispidulous, vaginate only at the base; leaf blades thick and stiff, strongly rugose, grayish when dried, densely pellucid-punctate, oblongelliptic or lance-oblong, mostly 7-10 cm. long and 3-4 cm. wide, acute or acuminate, conspicuously unequal at the base, subcordate on one side, rounded or obtuse on the other, glabrous above or nearly so, sometimes with a few scattered hairs along the costa, smooth to the touch, the veins and nerves strongly impressed, almost concolorous, penninerved, the nerves usually 3 on each side, arcuateascending at an angle of about 45 degrees, elevated and rather stout, the veins prominent and closely reticulate, appressed-hispidulous on the nerves and veins, glabrous or glabrate between them and coarsely granular; spikes unknown.

Frutex ramosus, ramis tortuosis crassiusculis, internodiis brevibus pilis brevibus patentibus vel reflexis dense hispidulis; folia crasse petiolata, petiolo dense hispidulo 4-7 mm. longo, in sicco grisea, dense pellucido-punctata, non lucida, oblongo-elliptica vel lanceolato-oblonga, parva, acuta vel acuminata, basi valde inaequalia, uno latere subcordata, altero obtusa vel rotundata, supra glabra vel glabrata, insigniter bullata, nervis venisque impressis, subtus concoloria ad nervos venasque adpresso-hispidula, penninervia, nervis utroque latere vulgo 3 , venis elevatis arcte reticulatis; spicae ignotae.

\section{CHLORANTHACEAE}

Usually trees, sometimes shrubs or even herbs; leaves opposite, mostly dentate, penninerved, the petioles connected at the base by a transverse line or connate to form a sheath; stipules small, borne on the margins of the sheaths or at the base of the petioles; inflorescences terminal or pseudo-axillary, the flowers spicate or the pistillate variously paniculate or capitate; flowers unisexual, or the staminate and pistillate coherent by their bases and falsely perfect; staminate flower without a perianth, the stamens 1 or 3 , connate to form a 3-lobate mass; filaments very short, the anthers 2-celled, the cells adnate at the base, parallel or divergent, longitudinally dehiscent, the lateral anthers sometimes 1-celled; perianth of the pistillate flower adnate to the ovary, usually minutely 3-dentate at the apex; ovary inferior or naked, 1-celled; stigma sessile, or rarely borne on a short style, truncate, clavate, or short-linear, entire; ovule one, orthotropous, pendulous from the apex of the cell; fruit a small drupe, ovoid or globose, the exocarp fleshy, the endocarp crustaceous or indurate; seed with a membranaceous testa, the endosperm 
abundant, fleshy; embryo minute, remote from the hilum, the cotyledons divaricate or scarcely distinguishable.

A small family of three genera, in tropical America and Asia, the Pacific islands, and New Zealand. A single genus is found in America.

\section{HEDYOSMUM Swartz}

Trees or shrubs, often aromatic, the branches articulate at the nodes and very brittle; leaves usually serrate, the petioles enlarged and connate at the base, forming a sheath, the small stipules borne on the margin of the sheath; inflorescences axillary or pseudoterminal; flowers monoecious or dioecious, each inflorescence unisexual; staminate flowers spicate, ebracteate; anther one, subsessile, linear or oblong, the connective short-appendaged or subpeltate above the cells; pistillate flowers capitate or scattered, the perianth tube adnate to the ovary, the limb very short, 3-dentate; style very short, stigmatose at the apex, or the stigma sessile, obtuse; drupes small, globose or ovoid, the exocarp very juicy.

About twenty species, in tropical America. Three other Central American ones are known in Nicaragua, Costa Rica, and Panama.

Hedyosmum mexicanum Cordemoy, Adansonia 3: 307. 186263. H. Artocarpus Solms in DC. Prodr. 16: pt. 1: 485. 1869. Palo de agua, Oczé (Huehuetenango); Té azteco; Té maya; Té de monte; Mazorco; Onj or Onc (Cobán, Quecchí); Macetero (fide Aguilar); Sandio (Jalapa).

Wet mixed mountain forest, or often in pine forest, 1,200-2,900 meters; Alta Verapaz; Baja Verapaz; Izabal; Zacapa; Jalapa; Guatemala; Chimaltenango; Sololá; Suchitepequez; Quiché; Huehuetenango; Quezaltenango; San Marcos. Southern Mexico; Honduras; Costa Rica.

Very variable in size, often blooming when only a shrub of 2 meters, but more commonly a tree of 8-12 meters or more, with a thick trunk and dense crown; leaves short-petiolate, the sheaths often $2.5 \mathrm{~cm}$. long, funnelform; leaf blades narrowly lanceolate or oblong-lanceolate, mostly $12-20 \mathrm{~cm}$. long and 3-6 cm. wide, acuminate, acute to attenuate at the base, finely or usually coarsely crenateserrate; stipules small, multilaciniate; staminate spikes cylindric and ament-like, $2-8 \mathrm{~cm}$. long, 5-8 mm. thick; pistillate flowers very numerous in a dense, ovoid or subglobose head, the fruiting head $2-3 \mathrm{~cm}$. long and $1.5-2 \mathrm{~cm}$. thick, or in the fresh state larger, very fleshy and juicy, whitish at maturity. (Fig. 46.)

This species has always been called $H$. Artocarpus, H. mexicanum having been placed by Solms (in DC. Prodr. 16, pt. 1: 485. 1869) among the doubtful species, because it was based upon "fragmentary" material. A photograph of the type collection of $H$. mexicanum in the Delessert Herbarium, presumably the one seen by Solms, is 


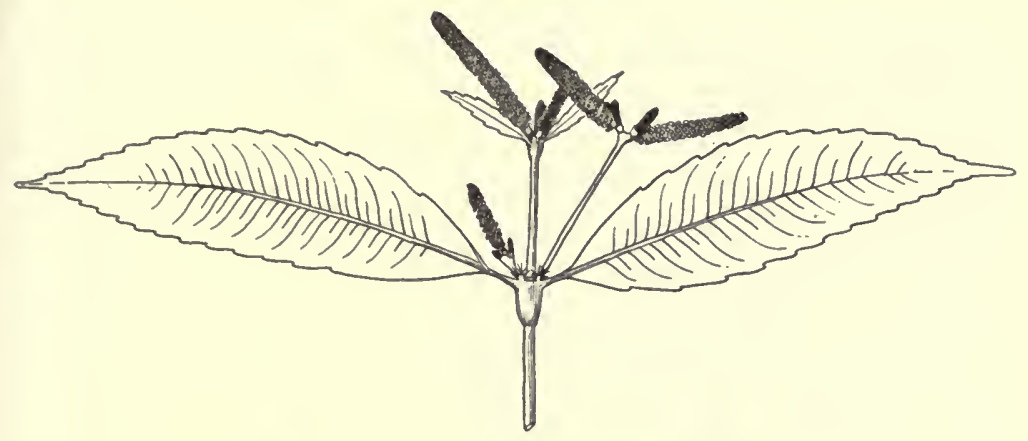

A

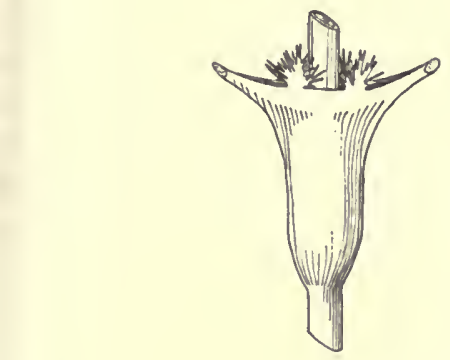

B

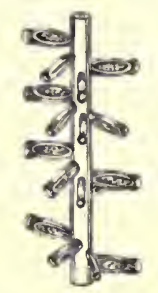

$\mathrm{C}$
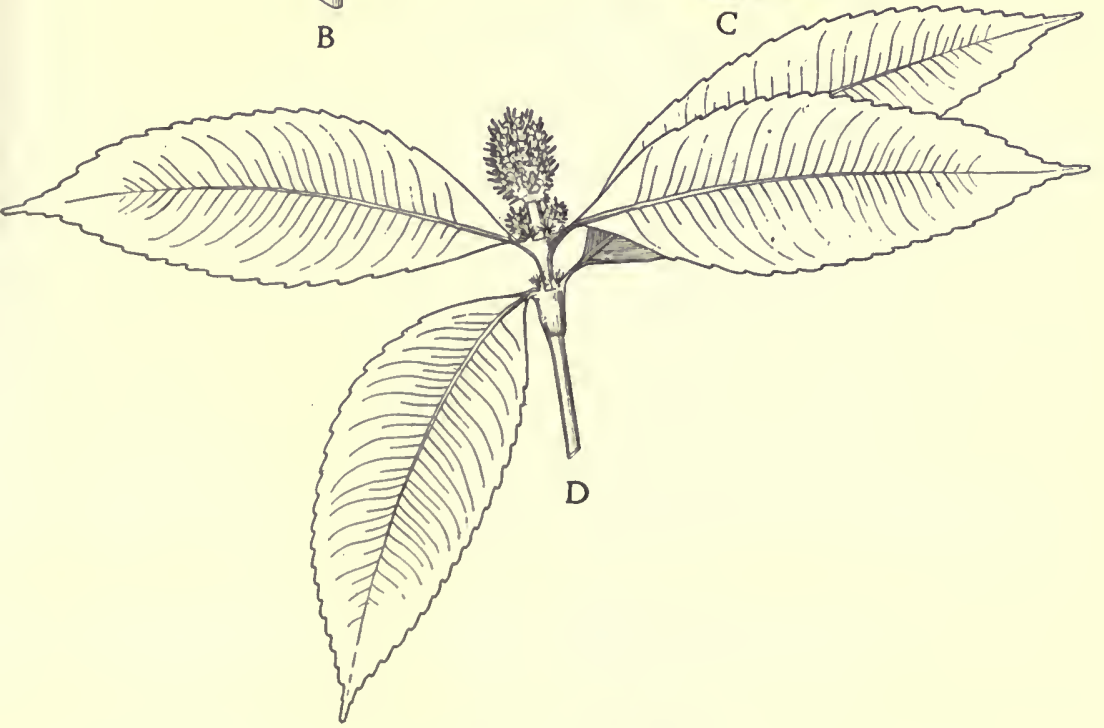

FIG. 46. Hedyosmum mexicanum. A. Habit of staminate branch; $\times 1 / 4$. B. Sheath at base of leaves; $\times 1$. C. Staminate flowers on portion of inflorescence of staminate branch; $\times 2$. D. Habit of pistillate branch; $\times 1 / 4$. 
scarcely to be described as fragmentary, and agrees well with the very numerous sheets of $H$. Artocarpus. Since only one species of Hedyosmum has been found in recent years in Mexico, it is safe to assume that $H$. Artocarpus and $H$. mexicanum are synonymous. In the Cobán region and especially in the mountain forests along the barranco of the Río Samalá in Quezaltenango, this is one of the commonest and most characteristic trees, at times almost dominating the forest. It is strange to find low shrubs sometimes loaded with flowers and fruits, while most of the plants are tall trees. The brittle branches are very easily detached. The leaves, which have a distinctive aromatic odor, turn black as they wither. The fruits at maturity are very succulent, whitish, and edible, with a sweetish flavor. In the Occidente a beverage, a substitute for coffee, is prepared by placing two or three leaves in a cup of hot water. No use, apparently, is made of the wood. It is of interest to note that specimens of this tree were collected in Mexico by Sessé and Mociño 150 years ago, and referred by them, strangely enough, to the genus Pandanus!

\section{LACISTEMACEAE}

Shrubs or small trees; leaves alternate, short-petiolate, penninerved, without stipules; flowers perfect, solitary within the imbricate bracts of a slender amentlike spike, 2-bracteolate, the spikes sessile and often fasciculate in the leaf axils; bractlets inserted at the base of the pedicel, very small, linear-subulate; perianth none or of six or fewer unequal, linear to setaceous or spatulate scales; disk fleshy, explanate and shallowly sinuate-lobate, sometimes concave or cupular, often cleft on one side; stamen one, attached to the disk near its center, the filament slightly complanate or thick; anther of two distinct, usually divaricate-stipitate, ovoid, longitudinally dehiscent cells; ovary superior in the center of the disk, sessile or short-stipitate, 1-celled, with three parietal placentae; stigmas three, erect; ovules 1-2 on each placenta, anatropous, pendulous; fruit capsular, ovoid or subglobose, usually triquetrous, 3-valvate, the valves coriaceous, the placentae medial upon them; seeds by abortion usually one in each capsule, obovoid-oblong, pendulous, the outer coat usually fleshy; embryo straight, the cotyledons broad and foliaceous.

The family consists of a single genus, with about twenty species, all in tropical America. A single species is found in North America.

\section{LACISTEMA Swartz}

Lacistema aggregatum (Berg.) Rusby, Bull. N. Y. Bot. Gard. 4: 447. 1907. Piper aggregatum Berg. Act. Helv. 7: 131. pl. 10. 1777. L. myricoides Swartz, Prodr. Veg. Ind. Occ. 12. 1788. 


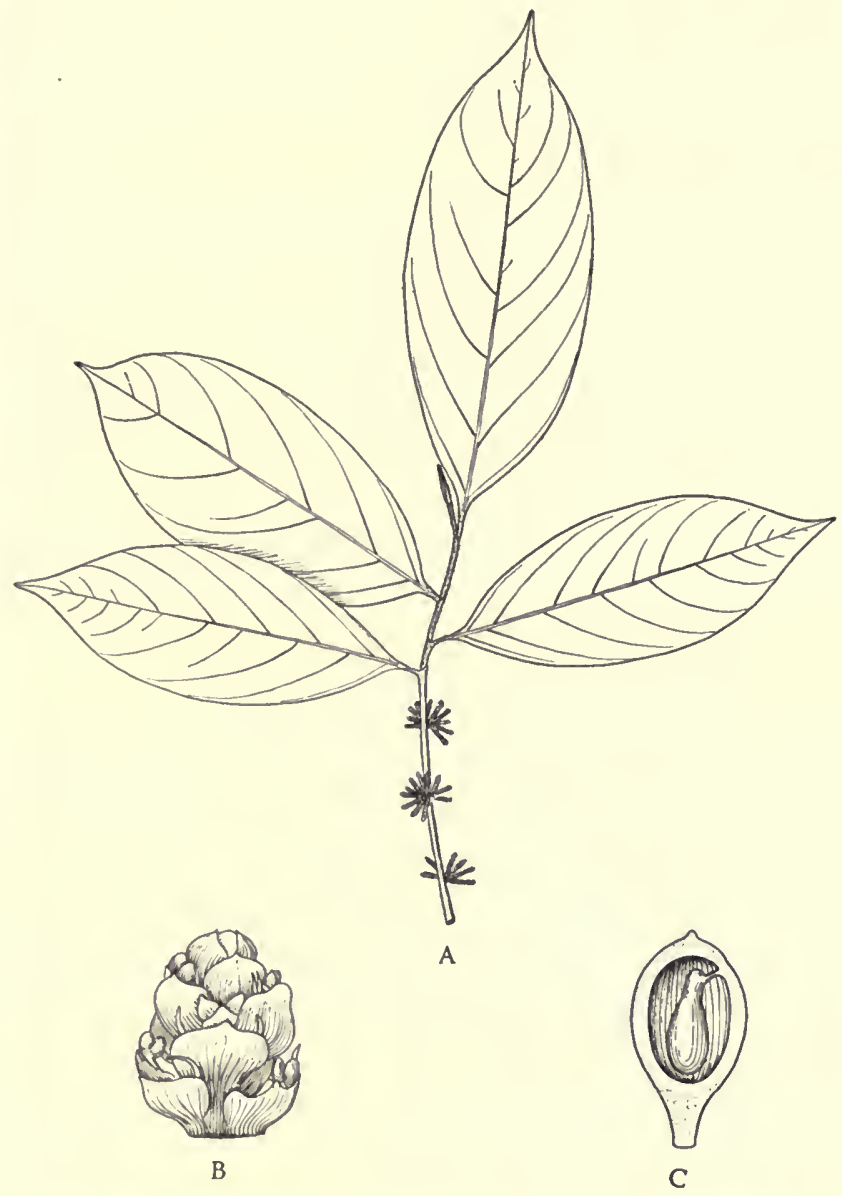

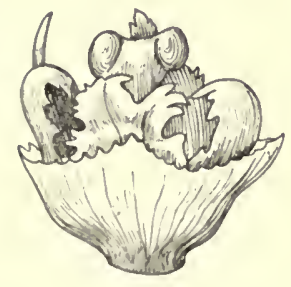

D

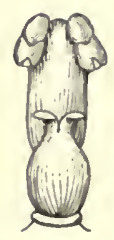

E

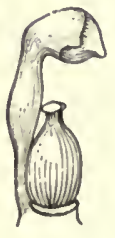

F

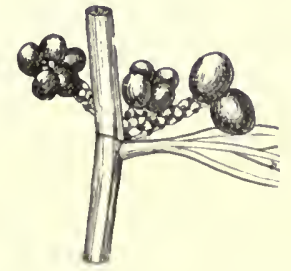

G

FIG. 47. Lacistema aggregatum. A. Habit of portion of branch; $\times 1 / 3$. B. Tip of inflorescence; $\times 8$. C. Longitudinal section through young fruit; $\times 5$. D. Flower with bract and bracteoles; $\times 20$. E. Pistil and stamen; $\times 20$. F. Pistil and stamen from the side; $\times 20$. G. Fruiting branch with fruits; $\times 1$. 
Wet thickets, 300 meters or less; Petén; Alta Verapaz; Izabal; Huehuetenango. Southern Mexico; British Honduras to Panama; West Indies; South America.

A glabrous shrub or tree, sometimes 11 meters high, with a trunk $10-20 \mathrm{~cm}$. in diameter; leaves on short petioles, elliptic or elliptic-oblong, 7-15 cm. long, abruptly acuminate, acute or obtuse at the base, thick-membranaceous, entire; flower spikes about $1 \mathrm{~cm}$. long, sessile and clustered in the leaf axils, shorter than the petioles; capsule ovoid, reddish, 6-7 mm. long:- (Fig. 47.)

The wood is brown, light in weight, tough, and fibrous, somewhat suggestive of willow (Salix). So far as known, no use is made of it in Central America. The tree has no outstanding characters by which it may be recognized easily, unless it be the clusters of small, catkinlike, bracted inflorescences, which are rather distinctive when their appearance is once known. It is called "palo mulato" in British Honduras.

\section{SALICACEAE. Willow Family}

Trees or shrubs with bitter bark; leaves alternate, with stipules, entire or usually serrate; flowers minute, dioecious, in aments, often appearing before the leaves, the individual flowers solitary in the axils of bracts; staminate flowers consisting of 1-many stamens inserted on the receptacle and subtended by a glandlike or cup-shaped disk; anthers 2-celled, the cells longitudinally dehiscent; pistillate aments sometimes raceme-like, the flower consisting of a 1-celled ovary subtended by a minute disk; placentae 2-4, parietal, the ovules usually numerous, anatropous; stigmas 2-4, simple or 2-4-cleft; seeds small or minute, bearing a dense coma of long, soft, silky, usually white hairs; endosperm none, the cotyledons plano-convex.

The family consists of two genera and about 250 species, mostly in the north temperate and arctic zones. Only one genus is native in tropical America.

Disk of the flower cup-like, entire or lobate; leaves broad; aments, at least the

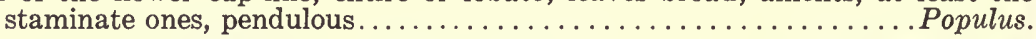
Disk composed of 1-2 glands, these distinct or scarcely connate at the base; leaves linear or lanceolate; aments usually erect......................

\section{POPULUS L.}

Trees, the bud scales usually resinous; petioles often compressed, the blades usually ovate or broader, penninerved and 3-nerved from the base, usually dentate, sometimes lobate; stipules narrow, fugacious; aments lax, the flowers often shortpedicellate; disk fleshy or membranaceous, shortly or broadly cyathiform, often oblique, entire, dentate, or irregularly lobate; stamens 4-30, the filaments filiform; ovary sessile within the disk, with usually 2-3 placentae; style short, the branches as many as the placentae, entire or 2-fid; ovules usually very numerous; capsule 2-3-valvate, small; seeds minute, usually with a long dense white coma of soft hairs. 
About thirty species, natives of the northern hemisphere. Several species are native in Mexico, but none can be expected to extend to Central America.

Populus alba L. Sp. Pl. 1034. 1753. Alamo; Alamo blanco; Coca (Occidente).

Planted commonly in the central and especially the western highlands, in parks and along streets and roads. Native of Europe and Asia, naturalized in some parts of the United States, and perhaps in Mexico.

A large or medium-sized tree with smooth, light gray bark; leaves slenderpetiolate, broadly ovate to suborbicular, $5-10 \mathrm{~cm}$. long, acute, truncate or cordate at the base, glabrate and dark green above, beneath often densely white-tomentose, at least when young, irregularly dentate and often shallowly lobate; staminate aments pendulous, 5-10 cm. long.

While this species may be seen in large numbers in some of the central regions, as about Chimaltenango, it is by far most common, and often a conspicuous feature of the landscape, in the Occidente, about Quezaltenango and San Marcos, where there are many large trees. The finest planting is the long avenue called La Alameda, in the city of Quezaltenango. In passing it may be noted that the word alameda is technically a grove of alamos, i.e. Populus alba, but in vernacular Spanish, at least in Central America, it has come to be applied to any ornamental grove or avenue. The white poplar has been used to some extent by the government of Guatemala for planting along roadsides. In the Occidente the trees are rather untidy in the middle of the winter, half or wholly bare, the leaves gradually shriveling and littering the ground. Pistillate trees of this and other species of Populus are a nuisance as shade trees when the fruits are ripening, for then the "cotton" of the seeds is wafted by the wind in all directions, becoming attached to all sorts of objects, entering dwellings, and even being drawn into one's nose, eyes, and mouth. This nuisance may be avoided by planting only cuttings from staminate trees.

\section{SALIX L. Willow}

Reference: C. Schneider, A conspectus of the Mexican, West Indian, Central and South American species of Salix, Bot. Gaz. 65: 1-41. 1918.

Shrubs or trees with single-scaled buds, the scales with an inner adherent membrane; leaves short-petiolate, mostly linear or lanceolate, persistent or 
deciduous; stipules minute or large and broad, persistent or caducous; bracts of the aments entire; staminate aments dense, erect or spreading, rarely drooping; stamens $1-10$, usually 2 , the filaments distinct or sometimes united; pistillate aments commonly erect or spreading; ovary sessile or short-stipitate, the style short or filiform; stigmas 2, entire or 2-cleft; capsule usually 2-valvate.

About 200 species, almost all in the north temperate and arctic zones, only a few extending to the tropics or to the southern hemisphere. Only the following species are known in Central America.

Leaves densely sericeous, mostly $1.5-3 \mathrm{~cm}$. long; stamens $2 \ldots \ldots \ldots$. taxifolia. Leaves glabrous or sparsely pubescent, mostly more than $3 \mathrm{~cm}$. long.

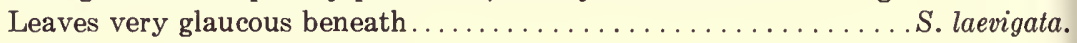
Leaves not glaucous beneath.

Stamens 3-7; native trees; leaves linear or lance-linear. . . . . . . S. chilensis. Stamens 2; introduced cultivated trees or shrubs.

Leaves lanceolate; branches not recurved and pendulous..........S. alba. Leaves lance-linear; branches recurved and pendulous.......S. babylonica.

Salix alba L. Sp. Pl. 1021. 1753.

Collected in cultivation and perhaps naturalized in fence-rows in Quezaltenango, near the city of Quezaltenango and San Mateo, 2,280-2,500 meters. Native of Europe, naturalized in eastern United States and Canada.

A large shrub or a tree with rough gray bark; leaves short-petiolate, lanceolate or oblong-lanceolate, mostly $5-10 \mathrm{~cm}$. long and $8-15 \mathrm{~mm}$. wide, acute or acuminate, narrowed to the base, serrulate, when young often sparsely sericeous but soon glabrate or glabrous, rather pale green beneath but not glaucous in the Guatemalan form; stipules ovate-lanceolate, deciduous; aments on short leafy branches; stamens 2; pistillate aments 3.5-6 cm. long; stigmas almost sessile; capsule shortpedicellate or sessile, ovoid, acute, glabrous.

At the time of collection, it was not noted that the trees were unlike the native willows of Guatemala, and so no special search was made for other trees, which may be of wider distribution in the Occidente. It would be of interest to know how this species, unknown elsewhere in Central America or Mexico, reached Quezaltenango.

\section{Salix babylonica L. Sp. Pl. 1017. 1753. Sauce llorón.}

Not common in Guatemala, but occasionally planted in the central and western highlands, especially about Quezaltenango and in Chimaltenango. Native of Asia.

A medium-sized tree with rough gray bark, the twigs very slender and elongate, drooping; leaves short-petiolate, lance-linear, 8-15 cm. long, 6-12 mm. wide, longacuminate, serrulate, glabrous at maturity, slightly paler beneath but not glaucous; 
aments appearing on short leafy lateral branches; stamens 2 ; style almost obsolete; capsule ovoid, sessile, glabrous.

The finest planting of the weeping willow in Guatemala is along the eastern entrance to Quezaltenango, where there is a double avenue of large and well-grown trees. There are also trees about San Juan Ostuncalco (Quezaltenango) and many handsome ones about Tecpám (Chimaltenango), especially near the Molino Helvetia. Scattered individuals are found in other parts of the highlands.

Salix Bonplandiana HBK. Nov. Gen. \& Sp. 2: 20. pl. 101. 1817. Sauce.

Chiefly in thickets along streams, 1,350-2,800 meters; Alta Verapaz; Baja Verapaz; Jutiapa; Sacatepéquez; Chimaltenango; Sololá; Huehuetenango; Quezaltenango; San Marcos. Arizona and New Mexico; Mexico.

A shrub or small tree, sometimes 12 meters high but usually lower, the trunk sometimes $40 \mathrm{~cm}$. in diameter, the bark brown, irregularly fissured; branchlets slender, red-brown, often somewhat drooping; leaves slender-petiolate, narrowly lanceolate, 5-15 cm. long, mostly $1.5-2.5 \mathrm{~cm}$. wide, serrulate, long-acuminate or attenuate, obtuse or acute at the base, bright green above, very glaucous beneath, glabrous or nearly so; capsule glabrous.

The species is abundant in many places in the Occidente. Worthy of special note in connection with the willows is a large thicket many acres in extent, beside the river at Chiantla (Huehuetenango), where all three of the native Guatemalan species are found together in a very dense growth. Usually in Guatemala the species are found singly. S. Bonplandiana has been much planted in San Marcos along the Carretera Internacional. The shrubs were planted in dense rows, principally for ornament, it is presumed, but perhaps partly to prevent erosion. The soil is poor and the rainfall insufficient, so that the bushes have not thrived, although they have continued to grow slowly. In some parts of San Marcos there are hedges, which are of only fair appearance from an ornamental standpoint. $S$. Bonplandiana has been reported from Guatemala under the name $S$. laevigata Bebb. Dr. Raup has determined all the Guatemalan specimens of $S$. Bonplandiana as $S$. laevigata.

Salix chilensis Molina, Sagg. Storia Nat. Chil. 169. 1782. S. Humboldtiana Willd. Sp. Pl. 4: 657. 1805. S. stipulacea Mart. \& Gal. Bull. Acad. Brux. 10, pt. 1:343. 1843. S. Humboldtiana var. stipulacea C. Schneid. Bot. Gaz. 65: 7. 1918. Sauce; C'os (Poconchí); Saccos (Quiché, Totonicapán, fide Tejada); Chicaj (Huehuetenango, fide Tejada). 


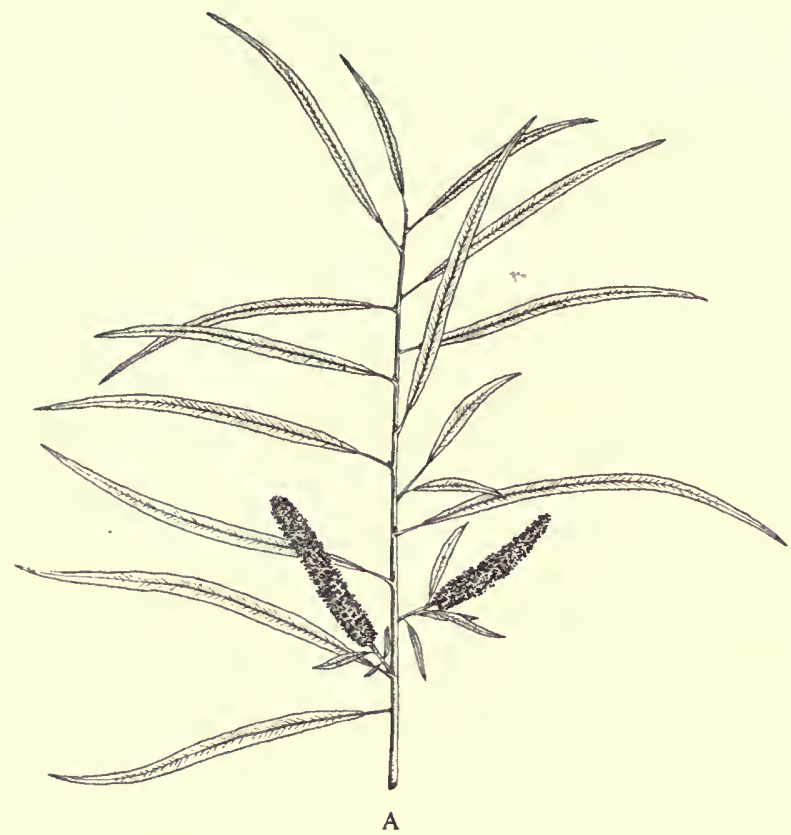

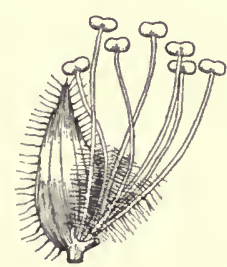

B

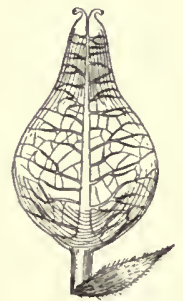

D

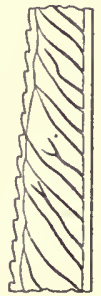

C

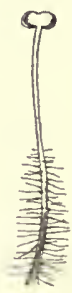

E

FIG. 48. Salix chilensis. A. Habit of portion of staminate branch and leaves of staminate plant; $\times 1 / 3$. B. Staminate flower; $\times 8$. C. Portion of leaf margin; $\times 2$. D. Pistillate flower; $\times 5$. E. Stamen; $\times 9$. 
Along streams or in swamps and marshes, abundant in many regions, ascending from sea level to about 1,900 meters; Petén; Alta Verapaz; Baja Verapaz; Izabal; Zacapa; El Progreso; Jalapa; Jutiapa; Santa Rosa; Escuintla; Guatemala; Sacatepéquez; Retalhuleu; Huehuetenango; Quezaltenango; San Marcos; probably in all the departments, except perhaps Totonicapán. Mexico and British Honduras to Panama, southward to Argentina.

A shrub or usually a medium-sized or rather small tree, sometimes 18 meters high, the branches brown or yellow-brown, slender and often drooping; leaves short-petiolate, linear or lance-linear, 6-15 cm. long, mostly $3-10 \mathrm{~mm}$. wide, long-attenuate, acute at the base, serrulate, bright green, glabrous; capsules short-stipitate, ovoid, glabrous. (Fig. 48.)

According to Schneider, all the Central American material is referable to var. stipulacea, the typical form being South American, but the variety is based upon rather feeble characters. It is of interest that this is probably the only species of Salix in South America, where it has a wide range. A few others have been described, but all probably are mere forms of $S$. chilensis. This willow, closely related to the black willow (S. nigra Marsh.) of the United States and northern Mexico, is very common in many parts of Guatemala and is certainly native in the country. Its range, however, is curious, for few are the native trees that abound in both the hot plains and the cool highlands. S. chilensis is particularly abundant along the Motagua Valley, forming forests in its lower stretches in the banana country, and it is sometimes planted as a shade tree in parks and elsewhere. There is some question as to whether the tree is really native in some regions of southern Central America. In Costa Rica, for instance, it is claimed that all the trees are pistillate, but this is not the case in Guatemala. The bark is light brown with coarse scales, the inner bark medium brown; the sapwood is white, and the heartwood pinkish or dark brown. Little use is made of the wood locally, but the slender flexible tough branches are used in Guatemala for making baskets and wicker furniture. The tree keeps its leaves for all or most of the year and is always green and handsome. The individual trees vary greatly in appearance. When they have plenty of space in which to grow, they have broad and ample crowns; when crowded they grow very tall and narrow, but are not columnar. Worthy of particular note is the columnar form of $S$. chilensis, which in habit is like the Lombardy poplar (Populus italica Moench), i.e. with a tall and massive, pole-like trunk and suberect branches that form a narrow, column-like crown. This species is common in central Mexico, and has been introduced 
into Guatemala, where it is seen only in cultivation, and infrequently. There are numerous trees of this form at Jalapa, about Chichicastenango, in the Cobán region, and doubtless elsewhere. Such a well-marked form should have a name by which to distinguish it, but none seems to have been proposed. Tahuesco, an aldea of Suchitepequez, is said to derive its name from two Nahuatl words, tlalli, "land" or "region," and huexotl, "willow."

Salix taxifolia HBK. Nov. Gen. \& Sp. 2: 18. 1817. S. microphylla Schlecht. \& Cham. Linnaea 6: 354. 1831. S. taxifolia var. microphylla C. Schneid. Bot. Gaz. 65: 24. 1918. Sauce; Ispac blanco (Huehuetenango, fide Skutch).

Thickets along streams, 1,200-2,000 meters; Chiquimula (near Concepción de las Minas); Guatemala; Huehuetenango. Southwestern United States and Mexico.

A shrub or small tree, usually 2-3 meters high; leaves linear or lance-linear, in the Guatemalan form mostly 1-1.5 cm. long, almost sessile, densely silverysericeous on both surfaces, entire or practically so; aments small, oblong, dense, the pistillate ones few-flowered; capsule sessile or nearly so, densely sericeous.

This, the rarest of the Guatemalan species, is local in distribution. It is easy of recognition by its very small, silvery leaves. The Central American specimens are all referable to var. microphylla, which differs but little from the typical form.

\section{MYRICACEAE. Bayberry Family}

Shrubs or small trees, aromatic; leaves alternate, coriaceous, simple, entire or dentate, rarely lobate, resin-dotted, usually without stipules; flowers small, monoecious or dioecious, in oblong or globose aments, the flowers solitary in the axils of bracts; perianth none; staminate flower with 2-16 (usually 4-8) stamens inserted on a receptacle, the filaments short, distinct or slightly united; anthers ovoid, 2-celled, the cells longitudinally dehiscent; pistillate flower of a solitary 1-celled ovary, subtended by $2-8$ bractlets; ovule solitary, orthotropous; style very short, the 2 stigmas linear; fruit a small, oblong or globose drupe or nut, the exocarp often waxy; seed erect, the cotyledons plano-convex.

The family consists of a single genus with the characters of the family.

\section{MYRICA L. Bayberry}

Reference: Auguste Chevalier, Mém. Soc. Sci. Nat. Cherbourg 32: 85-340. 1901.

The genus consists of about forty species, widely distributed in tropical, temperate, and arctic regions. Two other species occur in Costa Rica. 
Leaves acute to long-acuminate, sinuate-dentate or subentire....... cerifera. Leaves mostly obtuse or very obtuse.

Leaves obovate, mostly $2-4 \mathrm{~cm}$. long, entire or sinuate-dentate....M. Pringlei. Leaves oblanceolate-oblong, mostly $5-11 \mathrm{~cm}$. long, conspicuously appressedserrate for almost their whole length................. Lindeniana.

Myrica cerifera L. Sp. Pl. 1024. 1753. M. mexicana Willd. Enum. Pl. 2: 1011. 1809. M. xalapensis HBK. Nov. Gen. \& Sp. 2: 10. 1817. Arrayán; Cera vegetal; Gua-ut (Cobán, Kekchí); Tea-bark, Tea-box (British Honduras).

Common and widely distributed, in a wide variety of habitats, chiefly in pine forest, but often in lowland savannas, coastal thickets, or in bogs, ascending from sea level to about 2,500 meters; Alta Verapaz; Baja Verapaz; Izabal; Zacapa; Chiquimula; Jalapa; Guatemala; Escuintla (Río Guacalate); Sacatepéquez; Chimaltenango; Quezaltenango; Quiché; Huehuetenango. Southeastern United States to Mexico, British Honduras, and Costa Rica; West Indies.

Usually a shrub of 2-4 meters but sometimes in Guatemala as much as 9 meters tall, sparsely or densely branched; leaves short-petiolate, oblong-oblanceolate to linear-oblanceolate, coriaceous, mostly $5-10 \mathrm{~cm}$. long and $1.5-2 \mathrm{~cm}$. wide, usually acute to long-acuminate, rarely obtuse, long-attenuate to the base, subentire or more often sinuate-dentate with only a few remote teeth, at least in leaves of older branches, those of young branches sometimes coarsely serrate, glabrate but often villous-pilose beneath along the costa, densely dotted beneath with golden wax glands; staminate aments sessile, mostly $1 \mathrm{~cm}$. long or less, the pistillate aments larger, laxly flowered, usually with only a few fruits; drupes globose, $3 \mathrm{~mm}$. or less in diameter, covered with a thick coat of white wax. (Fig. 49.)

The Mexican and Central American species of Myrica are difficult of delimitation, so far as the ample material available to us is concerned. The only recent monograph of the American species is that of Chevalier, which is poor so far as these species are concerned, probably because he had little material for their study. The plant or plants of Mexico and Central America generally have been referred to $M$. mexicana, but close comparison of the many specimens of $M$. cerifera, which as usually understood is rather variable, suggests no characters by which $M$. mexicana and $M$. cerifera may be separated. The senior author has previously referred the coastal material from Central America to $M$. cerifera, but when the whole series of material is examined, the differences between the two species are found to be intangible. It is remarkable to find a shrub with such a wide distribution, at least altitudinally, in Central America. The habitats likewise are diverse, and one would not expect a bog plant to be the same species as a plant found in the well-drained pine 

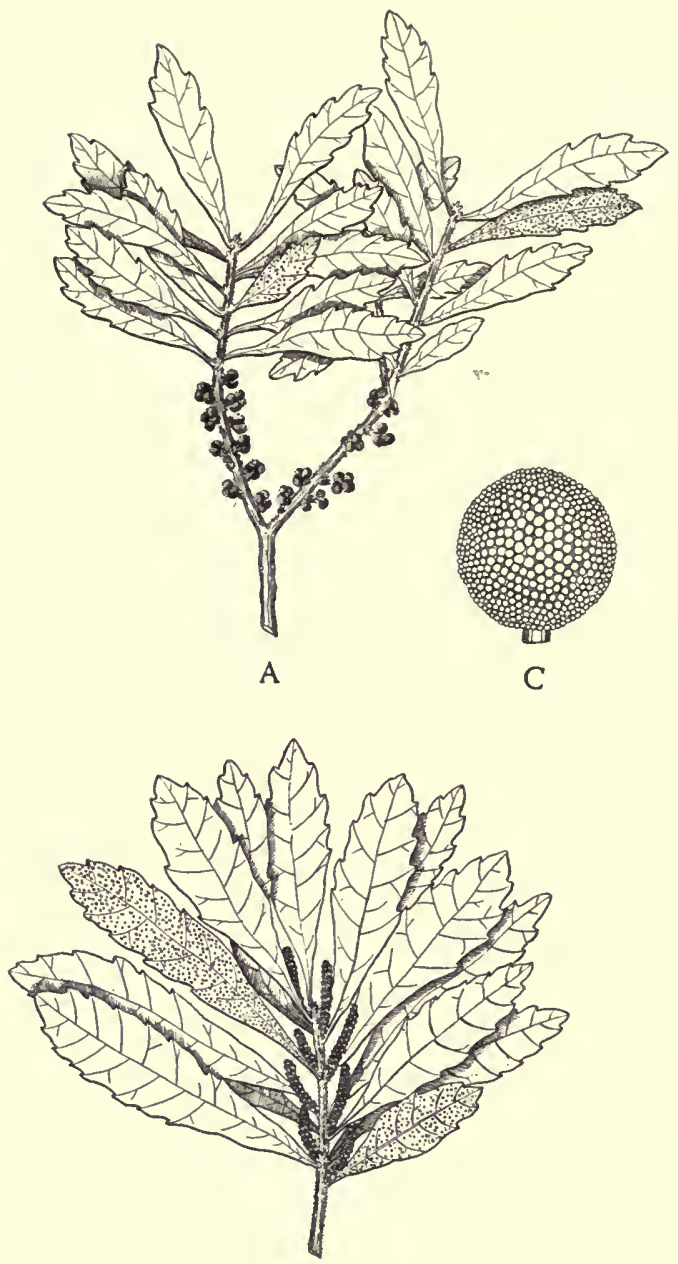

B

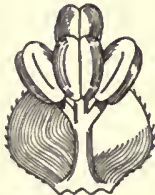

D

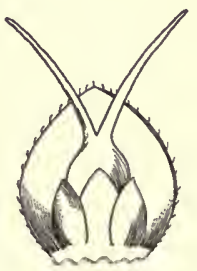

E

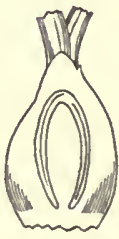

F

Fig. 49. Myrica cerifera. A. Habit of portion of pistillate plant; $\times{ }^{2} / 5$. B. Habit of portion of staminate plant; $\times 2 / 5$. C. Fruit; $\times 8$. D. Staminate flower; $\times 19$. E. Pistillate flower; $\times 18$. F. Vertical section through ovary; $\times 18$. 
forests. In Alta Verapaz the species is found in either habitat, in adjoining areas.

The name "chac olol" is reported for this species from Chiapas by Seler. Large amounts of wax are extracted from the fruits in Guatemala and other parts of Central America, a use of the plant well known also in the United States. The crude wax is greenish, but can be bleached. It is used in Guatemala for making candles that burn with a very pleasing aroma, and are used principally in the churches or on altars in homes. These candles are a common article in the markets, particularly those of Cobán and Quezaltenango, and many thousands of them are burned in the processions of Holy Week in Cobán. The wax is firm and hard and on that account the candles are especially suited to hot climates. A wax sold in the Quezaltenango market as "brea" or "brea de Campeche," for use in candle-making, may be made from Myrica fruits, but this is uncertain. Merchants said only that it was brought in by the Indians. Myrica wax is said to be used commercially in Guatemala for making shoe polish and in Huehuetenango for making soap. Candles similar to the bayberry ones, and prized for the same purposes, often are made in Guatemala from beeswax, but their odor when burning is quite different from that of burning Myrica wax.

Myrica Lindeniana C. DC. in DC. Prodr. 16, pt. 2: 150. 1864. Cera vegetal.

Mostly in moist or wet, mixed forest, 1,600-2,750 meters; Chiquimula; Huehuetenango; San Marcos. Guerrero to Veracruz, Oaxaca, and Chiapas, the type from Chiapas.

A large shrub or a tree, sometimes 12 meters tall, with a trunk $20 \mathrm{~cm}$. in diameter, the tips of the branches usually pilose or puberulent; leaves rather large, short-petiolate, chiefly oblanceolate-oblong, mostly $7-12 \mathrm{~cm}$. long and 2-3.5 cm. wide, commonly obtuse or often acute, cuneate-attenuate to the base, rather closely and evenly serrate almost from base to apex, glabrate, densely yellow-punctate beneath; aments and fruits similar to those of $M$. cerifera.

This plant seems to be reasonably distinct from $M$. cerifera, and recognizable when a considerable number of specimens is available for comparison. In Trees and Shrubs of Mexico it was treated as a synonym of $M$. mexicana, since at that time no authentic material was at hand for comparison. It may be, on the other hand, that it can not be maintained as a distinct species. The serration of the leaves is much more regular and conspicuous than in those of $M$. cerifera. 
Myrica Pringlei Greenm. Proc. Amer. Acad. 41: 236. 1905.

Jalapa, Cerro Alcoba, east of Jalapa, 1,300-1,700 meters, open slopes among oak trees, Steyermark 32585. Hidalgo, Puebla, and Oaxaca.

A densely branched shrub 1-2.5 meters high; leaves small and broad, mostly obovate, $1.5-4 \mathrm{~cm}$. long, $1-1.5 \mathrm{~cm}$. wide, rounded or very obtuse at the apex, entire or remotely and obscurely serrate, glabrous or nearly so, densely gland-dotted beneath; aments and fruits like those of $M$. cerifera.

Known in Guatemala from the single collection cited, growing in a locality far removed from the Mexican stations known for the species. It is quite possible that further collections will show that the plant is a distinct species, or perhaps only an aberrant form of $M$. cerifera.

\section{JUGLANDACEAE. Walnut Family}

References: Wayne E. Manning, The morphology of the flowers of the Juglandaceae: I. The inflorescence, Amer. Journ. Bot. 25: 407-419. 1938; II. The pistillate flowers and fruit, op. cit. 27: 839-852. 1940.

Trees or rarely shrubs; buds naked or scaly, often several superposed; leaves usually deciduous, alternate, rarely opposite or whorled, estipulate, pinnately compound; leaflets entire or serrate, glandular-dotted beneath; flowers monoecious or rarely dioecious, staminate or pistillate flowers or both in elongate drooping or erect catkins or spikes; staminate and pistillate inflorescences sometimes separate, sometimes combined into an androgynous panicle, the central spike wholly or partly pistillate, the lateral elongate or the short branches staminate; separate staminate inflorescence a cluster of 3-8 catkins or a solitary catkin; separate pistillate inflorescence a catkin, a few-flowered spike, or a solitary flower; inflorescences terminal, or lateral on old wood, or the staminate sometimes lateral at the base of new growth; staminate calyx commonly 4-lobed or lacking, the subtending entire or 3-lobed bract and 2 bracteoles usually appearing as part of the perianth; petals none; stamens 3-many; pistillate calyx usually 4-lobed or absent, the subtending 3 -lobed or entire bract and 2 or 3 bracteoles fused only with the pedicel and base of the ovary or with the whole ovary, a ring of minute inner bracteoles very rarely present; ovary inferior, 1-celled above, 2- to 4-celled below, with one erect orthotropous ovule in the center at the top of the primary partial partition; style one with usually 2 stigmatic branches; fruit a nut enclosed in a husk, or a nutlet with 2 or 3 wings; seed solitary, large, 2-4-lobed, without endosperm; cotyledons 4-lobed, oily, at germination remaining in the nut or appearing above ground.

Seven genera are known and about sixty species, in temperate regions of both hemispheres, in the tropics confined to mountain regions. Four genera are represented in America, one of them, Carya, 


\section{the hickory nuts, ranging from southern Canada to Mexico. Only the following genera are found in Central America.}

Leaflets conspicuously lepidote beneath; fruit subtended by a very large, lobate

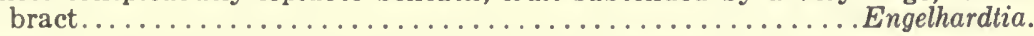

Leaflets not lepidote beneath or sometimes very sparsely and obscurely so when very young; fruit not subtended by a large bract.

Leaves, at least most of them, opposite; staminate inflorescences erect. Alfaroa. Leaves alternate; staminate inflorescences pendulous.............Juglans.

\section{ALFAROA Standl.}

\section{By Wayne E. Manning}

Trees or large shrubs; leaves mostly opposite, pinnate, without a terminal leaflet, the leaflets numerous, mostly alternate but often opposite, membranaceous, serrate or entire, lepidote beneath on the youngest leaves but only remotely so on the older ones; flowers monoecious or partially dioecious, the inflorescence terminal, consisting usually of an androgynous open or spike-like panicle, the main portion pistillate, with $30-50$ flowers, bearing near the base usually $2-4$ lateral short or elongate branches, these staminate, the staminate catkins sometimes forming a separate terminal panicle on different branches or on different trees; bracts of the staminate flowers minute, 3-lobate, beneath the calyx, the 2 bracteoles and 2-4 variable sepals together appearing as an irregular 4-6 lobate calyx, the lobes oblong, obtuse; stamens $6-10$, inserted in a single series around a naked center or rarely around a rudimentary ovary, the filaments almost obsolete; anthers 2-celled, glabrous, dehiscent by longitudinal slits; pistillate flowers subtended by a minute 3-lobate free bract shorter than the ovary; perianth deeply 4-lobate, the lobes oblong-linear, unequal, obtuse, erect, persistent upon the apex of the fruit; style shorter than the perianth lobes, bifurcate, the stigmas subglobose; fruit oval or obovoid, small, the skin ("pericarp" or "exocarp") almost dry, thin, indehiscent, adhering closely to the nut proper ("endocarp"); nut thinwalled, smooth, loculicidally dehiscent at time of germination of the seed, falsely 8-celled in the lower half, 4-celled above the middle, 1-celled at the very apex, the partitions nearly complete, with lamellae projecting from them into the loculus; seeds 8-lobate to the base, each cotyledon 4-lobate.

The genus consists of a single species that has been named for Anastasio Alfaro, a Director of the Museo Nacional de Costa Rica, a distinguished naturalist, and a highly esteemed friend of the senior author of this Flora.

Alfaroa costaricensis Standl. Journ. Wash. Acad. Sci. 17: 78. 1927.

Dense, moist or wet, mixed forest, 1,200-2,100 meters; Suchitepequez; Quezaltenango; Huehuetenango. Mountains of Costa Rica and Panama.

A large shrub or a tree, in Guatemala 6-9 meters high or probably also taller, the crown of rather few, spreading branches, the bark almost smooth, pale brown- 
ish; branchlets and leaf rachis usually densely hirsute with long stiff spreading hairs, sometimes merely hirtellous or in age glabrate; leaves almost all opposite, those of a pair often unequal, or one of the leaves sometimes suppressed; leaflets mostly $10-20$, highly variable, often almost all opposite, oblong to narrowly lanceoblong, mostly $10-18 \mathrm{~cm}$. long and $1.5-4 \mathrm{~cm}$. wide, the lowest leaflets generally reduced, acute to long-acuminate or rarely obtuse, sessile or nearly so, obtuse to truncate at the base and usually very oblique, conspicuously appressed-serrate or almost entire, membranaceous or thicker, glabrous or nearly so along the costa, usually glaucous or glaucescent beneath, usually hirtellous or hirsute along the nerves but sometimes glabrate; flower spikes stout, $3-5 \mathrm{~cm}$. long, short-pedunculate, the rachis densely hirtellous and glandular; staminate flowers $4 \mathrm{~mm}$. broad, the perianth glandular; pistillate flowers green, 5-6 $\mathrm{mm}$. long; ovary sparsely hirtellous and densely covered with golden glands; stigmas red; fruiting spikes $12-18 \mathrm{~cm}$. long or more, each bearing numerous oval or obovoid fruits, about $2.5 \mathrm{~cm}$. long and $2 \mathrm{~cm}$. thick, densely velutinous-hirsute and covered with sessile glands; nut smooth, broadly rounded at base and apex, the wall ("endocarp") less than $1 \mathrm{~mm}$. thick.

The status of the Guatemalan tree referred here is somewhat uncertain because so far only sterile collections have been made. These are rather numerous (about ten), and the tree is plentiful in some regions. Its habitat in Guatemala is somewhat unlike that of the Costa Rican tree, which has been found abundantly in flower and fruit. The tree is particularly plentiful in the mountain forest along the old road between Finca Pirineos and Patzulín, Quezaltenango, and many tall trees are scattered through the forest. Protracted search failed to discover any nuts on the ground, and fallen flowers also were lacking. It is possible that the Guatemalan tree is actually a species of Engelhardtia (distinct from $E$. guatemalensis), but the leaves are so closely like those of Costa Rican Alfaroa that the Guatemalan tree probably belongs at least in that genus. It is to be expected that the Guatemalan tree represents a distinct species, but although the leaves do not agree always in all respects with leaves of Costa Rican material, it has been impossible to suggest any definite character by which two species can be distinguished. Foliage of Costa Rican trees is highly variable in pubescence, serration, and other details.

\section{ENGELHARDTIA Lesch.}

Large trees; leaves large, pinnate, the leaflets numerous, dentate or entire, usually lepidote or resinous-punctate beneath; staminate aments solitary or geminate or sometimes several on a short peduncle, lateral, pendulous; pistillate spikes lateral or terminal, usually elongate and many-flowered, erect or in fruit recurved; staminate perianth concrete with a linear or dilated bract, the margin irregularly 3-6-lobate; stamens $3-15$, biseriate, a linear ovary rudiment generally present; pistillate bracts short-cupular at the base and adnate to the ovary, 3-5- 
lobate, the middle lobe longest; perianth adnate to the ovary, the limb free, short, 4-fid, the lobes subvalvate; style branches $2-4$, stout, papillose-fimbriate; bract in fruit much enlarged, coriaceous, venose, its base embracing the nut and adnate to it; nut small, the endocarp crustaceous or indurate, variously intruded within and forming 2-4 imperfect cells.

About a dozen species, in southeastern Asia and the islands of the southern Pacific; in America three species are known: one in Chiapas (E. mexicana Standl.), another, E. pterocarpa (Oerst.) Standl., in the mountains of Costa Rica, and the following:

Engelhardtia guatemalensis Standl. Field Mus. Bot. 22: 12 . 1940. Palo colorado (Quezaltenango).

Moist or wet, mixed forest, 1,300-2,300 meters; Alta Verapaz (type collected near Tactic, Standley 70477); El Progreso; Guatemala(?); Huehuetenango; Quezaltenango; San Marcos; endemic.

A small to large tree, the branchlets slender, subterete, with numerous elevated lenticels, densely brown-lepidote when young, glabrate in age, sometimes also short-hirsute, especially at the nodes; leaves all or mostly opposite, large, petiolate, the rachis slender, lepidote, sometimes hirtellous; leaflets usually 14-16, narrowly oblong-lanceolate, $9-20 \mathrm{~cm}$. long or more, $2.5-5 \mathrm{~cm}$. wide, narrowly long-attenuate, acute at the base and almost symmetric, sessile or very shortly petiolulate, usually entire, at least in adult leaves, green above, minutely hispidulous along the costa or almost wholly glabrous, pale and often glaucescent beneath, rather densely and minutely appressed-lepidote.

This species is known only from sterile material, but numerous specimens of it are at hand. These specimens exhibit so much variation that it is quite possible that they represent two distinct species. When fruiting material of Engelhardtia and the tree here referred to Alfaroa has been collected in ample quantity, it is possible that some surprising results may be obtained. E. guatemalensis is abundant in Alta Verapaz, especially about Tactic, where it was first observed. The trees may be recognized from a long distance because the young foliage is crimson. In its coloring as well as in the form of the leaves and leaflets the tree closely resembles the dreaded "Amche" (Rhus striata), and the resemblance is so great that the senior author ventured to collect material only after a close inspection of the branches. The leaves are opposite in Engelhardtia and alternate, of course, in the Rhus. In spite of its abundance in this region-one where every plant has a name-no name could be obtained for this conspicuous tree. Neither has it been possible to find flowering or fruiting trees in any part of Guatemala where they grow. The nut in this genus is much like a small hickory nut (Carya), but is subtended by a very large, hand-shaped bract. 


\section{JUGLANS L.}

\section{By Wayne E. Manning}

Trees, rarely shrubby; branchlets with chambered pith; buds scaly; leaves alternate, deciduous; leaflets serrate or entire; flowers monoecious; staminate flowers in sessile, lateral, solitary, though frequently superposed, drooping catkins on last year's twigs; staminate calyx 1-4 lobed, the two subtending bracteoles (each sometimes divided) apparently in the same whorl with the calyx so the perianth appears 6- to 8-lobed in addition to the bract; bract entire; stamens 7-100; pistillate flowers in few- to many-flowered terminal spikes; pistillate calyx usually 4-lobed; the bract, the two bracteoles (the tips of the latter frequently split into several teeth), and the calyx adherent to the ovary in apparently two rings; inner bracteoles present at least in J. nigra; ovary inferior; style branches (stigmas) carinal, the inner surface of each plumose and stigmatic; fruit a nut enclosed in an indehiscent (or in $J$. regia irregularly dehiscent) rather fleshy husk, the latter composed of the ripened involucre and calyx; nut woody, typically rough-ridged or sculptured; a pair of secondary wall cavities present in the outer wall of the nut at each end of the secondary (dorsal) partition or in that location, and traversing the wall of the nut; tertiary wall cavities, between the secondary cavities and the primary partition, frequently present, and at certain levels fusing with the secondary wall cavities; primary wall cavities, at each end of the primary partition, present in a few species; nut finally separating into two valves at germination, the large fleshy cotyledons remaining within the shell.

About twenty species in North, Central and South America and in the Old World from southeastern Europe to eastern Asia. Five or six species of Juglans occur in Mexico.

Leaflets entire or nearly so, 7-9 (rarely to 13); staminate flowers subsessile, the floral receptacle elongate; husk of fruit finally splitting irregularly; nut merely rugose, with a pair of strong longitudinal ridges or lips on each side of the line of dehiscence.................................. regia.

Leaflets serrate, 15-25; staminate flowers clearly stalked, the floral receptacle round; husk not splitting, the nut without lips.

Rachis, fruit, and lower surface of leaflets glabrate; leaflets short-stalked, tapering at base or sometimes subtruncate above the stalk; fruit strongly

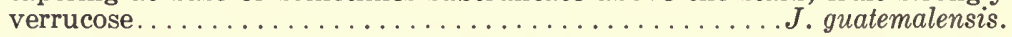

Rachis, fruit, and lower surface of leaflets definitely pubescent; leaflets truncate at base, essentially sessile; fruit not strongly verrucose. . . . .J. Steyermarkii.

Juglans guatemalensis Manning, sp. nov. Nogal.

Mountain sides, river bottoms, along water courses, cafetales, 500-1,500 meters; endemic; Alta Verapaz; Baja Verapaz; Quiché (Finca San Francisco Cotzal, alt. 1,250 meters, December 6, 1934, Alexander F. Skutch 1866; type in Herbarium of Arnold Arboretum; isotype in Herbarium of Chicago Natural History Museum), Huehuetenango; occasionally planted (Guatemala).

A medium-sized or large tree, sometimes 55 meters tall with a trunk 2 meters in diameter, the bark dark and deeply furrowed; twig dark brown, appearing 
glabrate, but minutely glandular-puberulent, the lenticels prominent; leaves alternate, large, chiefly $45-65 \mathrm{~cm}$. long and 30-35 $\mathrm{cm}$. wide, the terminal leaflet usually present; leaflets large, distant, chiefly 17-21, each 14-17 cm. long and 5-6 cm. wide, decidedly stalked, the stalk 2-4 mm. long; leaflets finely to strongly serrate, oblong-elliptic, obliquely truncate or rounded at the base above the stalk, commonly cuneate on the lower side, long-acuminate at apex, the lowest leaflets frequently small; rachis glabrous or glabrate, but with a strong lens appearing densely puberulent with minute stalked glands; upper surface glabrate; lower surface of leaflets glabrate, with only a few stalked glands and a few minute fascicled hairs on midrib and a few on larger lateral nerves, young leaflets with whitish pointed hairs on the smallest veins; very young leaflets drying green, with almost no fascicled hairs beneath; staminate catkins $22-30 \mathrm{~cm}$. long, each bract short-hairy, small, $1 \mathrm{~mm}$. long, obtuse, essentially on the catkin-rachis at the base of the flower-stalk throughout the catkin; flower-stalk well developed, 4-5 $\mathrm{mm}$. long; the bracteole-sepal ring frequently with 8 organs; stamens $61-102$; pistillate flower and immature fruit unknown; mature fruit large, subglobosepyriform, $4.3-4.5 \mathrm{~cm}$. thick and $4.7-4.8 \mathrm{~cm}$. long to probably $5.5 \mathrm{~cm}$. thick and $5.8 \mathrm{~cm}$. long, essentially glabrous, shining greenish-brown, strongly and conspicuously white-punctate-verrucose (warty), with the punctations open and lenticellike, not wrinkled in drying, the husk thick; nut reddish-brown, subglobose, slightly flattened, $3.4-4.5 \mathrm{~cm}$. thick and $3.2-4.2 \mathrm{~cm}$. long, strongly ridged, the ridges broad, flat-topped, interrupted, rather rounded in cross-section, the furrows comparatively shallow except at the depressed base of the nut, where the ridges are sharp and the furrows deep; primary wall cavities well developed usually at all levels, frequently united with tertiary wall cavities, and at the very base of the nut uniting also with secondary wall cavities; secondary wall cavity ridges strongly projecting into the loculus at the one-celled level and at least in one collection at the 2-celled level; secondary septa rather low.

Folia inaequaliter pinnatim foliata; foliolis magnis 17-21 valde $2-4 \mathrm{~mm}$. longe petiolatis oblongo-ellipticis basi oblique truncatis $14-17 \mathrm{~cm}$. longis $5-6 \mathrm{~cm}$. latis, tenuiter vel argute serratis, utrinque glabratis; rhachi glabra vel glabrata sed minute glandulari-puberulenti; foliolis novellis in sicco viridibus glabratis; amentis masculis $22-30 \mathrm{~cm}$. longis, bracteis minutis $1 \mathrm{~mm}$. longis; fructibus subgloboso-pyriformibus $4.7-5.8 \mathrm{~cm}$. longis $4.3-5.5 \mathrm{~cm}$. diam., punctato-verrucosis praecipue glabris lucidis; nuce subglobosa $3.2-4.2 \mathrm{~cm}$. longa $3.4-4.5 \mathrm{~cm}$. diam. valde costata, costis latis planis, sulcis tenuibus.

The collections of Popenoe and of Standley are represented only by nuts, and there is some uncertainty about the identification; the collection of Steyermark has the internal cavities absent at the end of the primary partition in the nut. This may be the species reported by Réné Guérin (as nogal, Juglans nigra), in Catalogue des products presentes par la Republique de Guatemala a l'exposition universelle de Paris, 1900, from Cobán, Alta Verapaz; Cuilapa, Santa Rosa; Chimaltenango, Zacapa, and Chiquimula. He reports the wood of the tree as used for manufacturing fancy furniture; its fruits are edible and the husk of the fruit is used for tanning materials. 
Juglans guatemalensis has been confused with J. pyriformis Liebmann, collected by him near Coscomatepec, Vera Cruz, Mexico; that species has about 24 narrow sessile leaflets which are truncate at base, a glandular pubescent rachis, a rougher husk on the fruit and a slightly more roughly ridged nut. J. guatemalensis resembles most closely the walnuts of central and western Mexico; the cross section of the nut of the type resembles closely that of $J$. peruviana described from "Peru" by Dode. This species may be the one cultivated in El Salvador; a similar collection has been made in Honduras.

\section{Juglans regia L. Sp. Pl. 1415. 1753. Palo de nuez; nogal.}

Huehuetenango (planted) and probably elsewhere cultivated.

Broad-headed tree to $100 \mathrm{feet}$, though in cultivation usually only 40-60 feet tall, with light gray bark, remaining smooth a long time; twigs glabrous; leaflets $5-9$, rarely to 13 , mostly obovate, entire, though on young plants frequently somewhat serrate, essentially glabrous; rachis glabrous; staminate catkins $5-10 \mathrm{~cm}$. long; staminate flowers with elongate receptacles; fruit subglobose, glabrous, green, 4-5 cm. in diameter; nut ovoid to globose, thick to thin-shelled, wrinkled or shallowly pitted externally, with two longitudinal ribs (lips) on each side of line of dehiscence; nut splitting early; septa thin.

Persian or English Walnut, native of southeastern Europe to Himalaya Mountains, the most frequently planted commercial walnut, especially in warmer areas.

The one specimen collected does not seem to be typical $J$. regia and may represent a hybrid between this species and a native one. The specimen is sterile.

\section{Juglans Steyermarkii Manning, sp. nov. Nogal.}

Cañons, between 1,200 and 1,300 meters; endemic; Huehuetenango (Paso del Boqueron, Río Trapichillo, below La Libertad, alt. 1,200-1,300 meters, type collected August 21, 1942, Steyermark 51140, in Herbarium of Chicago Natural History Museum; isotype in W. E. Manning Herbarium).

Tree about 17 meters tall, the bark gray but furrowed; twigs densely glandular pubescent; terminal bud elongate, densely grayish-tomentose; leaf scar only slightly notched; leaves alternate, large, up to $60 \mathrm{~cm}$. long and $30 \mathrm{~cm}$. wide, the terminal leaflet usually absent; leaflets large, distant, mostly $16-18$, each $14-17 \mathrm{~cm}$. long by $5-8 \mathrm{~cm}$. wide, essentially sessile or very short-stalked, ovate or ovatelanceolate, typically finely but rather remotely serrate with the serrations short and turned outward, and with most of the small veins going directly to the serration instead of to the sinus; base of leaflet usually truncate to broadly rounded, the apex acute or abruptly acuminate, the lowest leaflet somewhat reduced; 
rachis conspicuously pubescent with reddish glandular hairs; upper surface of leaflets pubescent with minute glandular hairs, the lower surface pubescent with reddish glandular hairs on larger and smaller veins and especially on the midrib and with solitary or paired whitish pointed hairs on the surface and smaller veins; flowers unknown; nearly mature fruit wrinkled, subglobose-pyriform, truncate at base, $4 \mathrm{~cm}$. diameter and $4.5 \mathrm{~cm}$. high, strongly pubescent with reddish glandular hairs; punctations numerous, drying brown, very inconspicuous; husk not very thick; nut apparently deeply grooved, with rounded ridges, but nut immature; cavities present in the wall at each end of the primary partitions.

Arbor ca. 17-metralis; foliis equaliter pinnatim foliatis; foliolis magnis 16-18 ovatis vel ovato-lanceolatis praecipue sessilibus obtusis vel abrupte acuminatis basi truncatis $14-17 \mathrm{~cm}$. longis $5-8 \mathrm{~cm}$. latis, tenuiter remoteque serratis, subtus pilis prominentibus rubescentibus glandularibus et albidis solitariis vel binis pubescentibus; rhachi dense rubello-glandulari pubescenti; fructibus subglobosopyriformibus, $4 \mathrm{~cm}$. diam., $4.5 \mathrm{~cm}$. longis, dense glandulari-pubescentibus, parce brunneo-punctatis, in sicco corrugatis; nuce subglobosa costata, costis rotundatis tenuibus.

Nuts edible and of value where sufficiently common, but the meat small; wood probably useful, as in all of the black walnut group.

\section{BETULACEAE. Birch Family}

\section{Reference: Hubert Winkler, Pflanzenreich IV. 61: 1-149. 1904.}

Trees or shrubs, the buds with few or numerous scales; leaves alternate, penninerved, mostly serrate or dentate, petiolate; stipules free, commonly deciduous; flowers monoecious, the staminate in aments, the pistillate also in aments or sometimes capitate, terminal or lateral, usually appearing when the trees are leafless; perianth simple, membranaceous, the segments free or united, sometimes absent; stamens 2-12, the filaments free; ovary hypogynous, 2-celled, usually laterally compressed; styles 2, free, filiform; ovules 2, pendulous, anatropous; fruit a nut, usually laterally compressed, often winged, sometimes crowned by the remains of the perianth, often subtended or inclosed in the persistent bracts and bractlets; seed by abortion usually solitary, without endosperm, the testa membranaceous; cotyledons fleshy, smooth, rugose, or ruminate.

Six genera are recognized, chiefly in temperate regions of both hemispheres, some of the genera extending to mountain regions of the tropics. No other genera are represented in Central America. The monograph of Winkler cited above is unsatisfactory so far as tropical American members of the family are concerned.

Pistillate aments cone-like in fruit, with woody bracts; staminate flowers $2-3$ in each bract; no perianth in the pistillate flower............... Alnus.

Pistillate aments not cone-like, the bracts thin; staminate flowers one in each bract; perianth present in the pistillate flower.

Fruit enclosed in a bladder-like closed sac. ................. Ostrya.

Fruit merely subtended by a flat leaf-like 3-lobate bract.......... Carpinus. 
Corylus Avellana L. The European hazel or filbert (Spanish "avellana") is well known for its edible nuts, which are imported into Guatemala in small quantities. A few plants of this species were seen growing in a plantation near Cobán. They were said to have been there for some years but consisted of soft shoots only a few inches high and were said never to grow any taller.

\section{ALNUS Hill. Alder}

References: M. L. Fernald, Proc. Amer. Acad. 40: 24-28. 1904; H. H. Bartlett, Proc. Amer. Acad. 44: 609-612. 1909.

Trees or shrubs; leaves alternate, petiolate, serrate or dentate, penninerved, deciduous; stipules caducous; flowers dioecious; staminate spikes from terminal buds formed the preceding year; pistillate spikes solitary or racemose, arising in the axils of the leaves of the previous year or in the axils of the new leaves; staminate flowers in 3-flowered clusters, these arranged in cylindric, scaly-bracteate spikes; perianth segments 4 or fewer, connate at the base or free; stamens 4 , opposite the perianth segments; anthers ovate, the cells distinct, parallel; pistillate flowers in erect, cylindric or oblong, scaly spikes, without a perianth; ovary 2-celled, the styles short, stigmatose at the apex; ovule one in each cell, pendulous, anatropous; fruit a nutlet, compressed, usually winged, by abortion 1-celled.

About 25 species, in America, central Asia, Algeria, and Europe. No others are known from Central America.

Leaves densely tomentose beneath over almost the whole surface, rarely glabrate

in age. Leaves acute or acuminate, not glandular beneath..... A. ferruginea.

Leaves glabrate beneath, at least in age, the long hairs, if any, confined to the nerves.

Leaf blades all or mostly rounded or very obtuse at the apex..... A. firmifolia. Leaf blades all acute or acuminate.

Leaves with rather dense, yellowish wax glands on the lower surface.

A. jorullensis.
Leaves nearly or quite without wax glands on the lower surface. . A. arguta.

Alnus arguta (Schlecht.) Spach, Ann. Sci. Nat. II. 15: 205. 1841. Betula arguta Schlecht. Linnaea 7: 139. 1832. A. ovalifolia Bartlett, Proc. Amer. Acad. 44: 611. 1909 (type.from San Lucas, Sacatepéquez, J. D. Smith 2188). Aliso; Ilamo; Lemop (Guatemala).

Common in the mountains, often forming almost pure, dense, extensive stands, but more often associated with oaks and often with pines, sometimes in Juniperus forest, 1,350-3,000 meters; Alta Verapaz; El Progreso; Guatemala; Sacatepéquez; Chimaltenango; Sololá; Totonicapán; Quiché; Huehuetenango; Quezaltenango; San Marcos. Southern Mexico; El Salvador.

A tree, sometimes 30 meters high but ordinarily less than half as large, the bark pale, thin, smooth, the branchlets glabrous or nearly so; leaves slender-petio- 


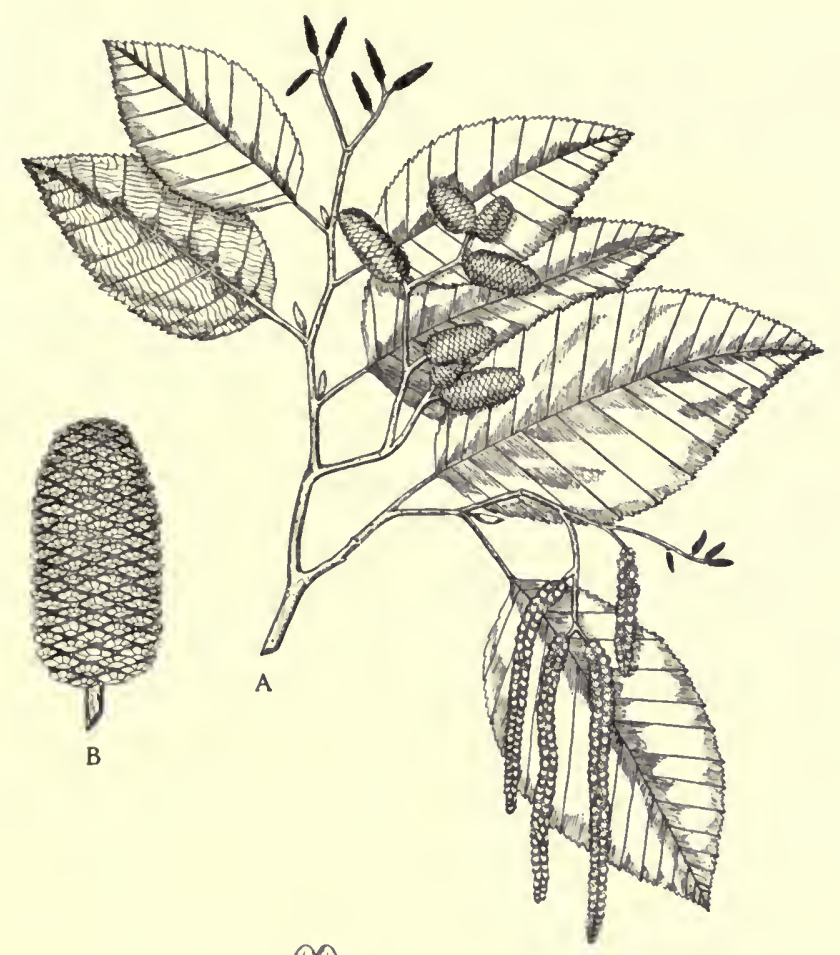

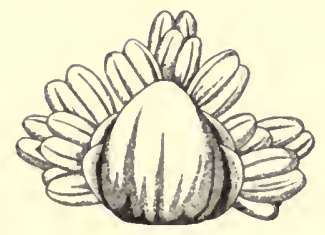

C

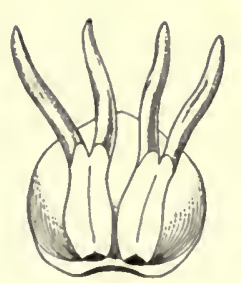

E

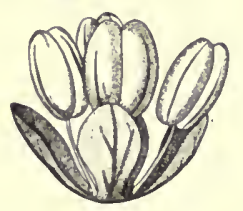

D

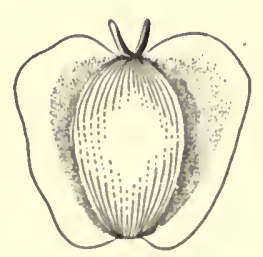

F

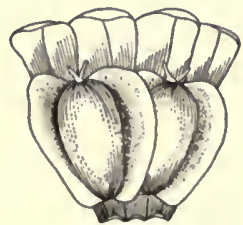

G

FIG. 50. Alnus arguta. A. Habit of portion of fruiting and flowering branch; $\times 1 / 3$. B. Fruiting strobile; $\times 1$. C. Staminate flower with bract; $X 8$. D. Staminate flower; $\times 7$. E. Pistillate flower with bract; $\times 8$. F. Nutlet; $\times 8$. $\mathrm{G}$. Scale of a mature strobile with nutlets in position; $\times 8$. 
late, oblong-ovate to broadly ovate, $3-9 \mathrm{~cm}$. wide, mostly acute or acuminate, obtuse or rounded at the base, duplicate-serrate, often shallowly lobate, glabrous above or nearly so, beneath usually pilose or villous along the nerves, in age usually glabrate, pale or often ferruginous; staminate aments $4-10 \mathrm{~cm}$. long; pistillate strobiles sessile or pedunculate, mostly 2-3 cm. long, sometimes somewhat shorter. (Fig. 50.)

The term "aliso" is the Spanish name for the alder. In geographic names it appears locally in Alisos and Los Alisos, caserios of San Marcos and Huehuetenango, but the name would be appropriate for almost any settlement of the western mountains. Alders are most abundant in the Occidente, and on the inland mountain slopes of San Marcos they form extensive and often pure stands, especially on the white sand slopes typical of that region. The stands are either dense or sparse, and in early morning, seeing the expanses of pure white sand between the trees, one has the impression that snow has fallen during the night, a not unreasonable phenomenon considering the frosty temperatures that commonly prevail. The flora of these Alnus forests is meager and uninteresting. Toward the end of the dry season the trees shed all or most of their leaves, and soon afterward they become covered with pale, bright green, young foliage, a color of vegetation most unusual in Central America, where the prevailing greens are dark and somber. Alders are confined mostly to the drier mountains, and are scarce or quite absent on the slopes facing the Pacific, where there is abundant moisture throughout the year. A few trees do grow below Santa María de Jesús, Quezaltenango, but they do not seem to thrive. Probably the wind carries the winged nutlets down from the abundant stands on the higher slopes of the Volcán de Santa María. On the white sand slopes of San Marcos, alders are perhaps the first trees to establish themselves on abandoned land, or that on which volcanic ash has newly fallen. The trees here bloom in January and February. The bark turns red when cut. It is used to obtain a brown dye much used for cotton and other textiles. The wood seems to be little used except for firewood. Many of the trees on the Volcán de Santa María were bearing "witches' brooms," probably the result of insect attacks.

Alnus ferruginea HBK. Nov. Gen. \& Sp. 2: 21. 1817. A. acuminata var. ferruginea Regel in DC. Prodr. 16. pt. 2: 184. 1864. Lenop (Guatemala); A. guatemalensis Gandoger, Bull. Soc. Bot. France 66: 289. 1920 (type from Cobán, Türckheim probably no. II.1013). Hamam (Cobán, Quecchí). 
Along streams or in wet thickets, often in pine forest, sometimes forming extensive, almost pure stands on mountain slopes, 1,2502,400 meters; Alta Verapaz; Guatemala; Chimaltenango; Quiché; Huehuetenango; Quezaltenango; San Marcos. Probably in Chiapas; Andes of South America.

A small or medium-sized tree, sometimes very large, with thin, dark brown, smooth bark; leaves petiolate, elliptic or broadly ovate, 7-15 $\mathrm{cm}$. long, acute or acuminate, obtuse or rounded at the base, duplicate-serrate, green above and glabrate or puberulent; staminate aments $5-15 \mathrm{~cm}$. long; pistillate strobiles shortpedunculate or subsessile, $1.5-3 \mathrm{~cm}$. long or sometimes slightly larger, 10-14 mm. thick.

This plant is easy of recognition by the abundant pubescence of the leaves, but may prove to be no more than a pubescent variety of the widely distributed $A$. jorullensis. It is particularly plentiful in the mountains of Huehuetenango, where it may be found almost anywhere along streams or on hillsides. It grows in abundance also in the region of Cobán, where it is mostly confined to stream banks, often with Carpinus and Acer.

Alnus firmifolia Fernald, Proc. Amer. Acad. 43: 61. 1907. Aliso; Alis; L'm'ump (Palojunoj, Quezaltenango); Ilamo; Analmat (Volcán de Agua).

Abundant in mixed or coniferous forest on the higher mountains, mostly at 2,500-3,600 meters, rarely at lower elevations (in Huehuetenango as low as 1,900 meters); Guatemala (Volcán de Pacaya); Sacatepéquez (Volcán de Agua); Huehuetenango; Totonicapán; Quezaltenango; San Marcos. Southern Mexico.

A shrub or a tree, sometimes 18 meters high with a trunk almost a meter in diameter, of ten flowering when only a low shrub, especially on the highest mountain slopes, the bark thick and corky, silvery gray, smooth, the branchlets glabrous or often sparsely villous; leaves petiolate, usually thick and subcoriaceous, variable in form, elliptic-oblong to elliptic or oval, mostly $5-10 \mathrm{~cm}$. long, generally obtuse to rounded at the apex but some of the leaves frequently acute or rarely acuminate, obtuse or acute at the base, glabrous and lustrous above, beneath often glaucescent and almost always pale, rarely brownish, at first villous-pilose, at least on the nerves, in age often almost glabrous, the lateral nerves very prominent and conspicuous; staminate aments $3-4 \mathrm{~cm}$. long; pistillate strobiles oval-cylindric, mostly 10-17 mm. long, about $8 \mathrm{~mm}$. thick.

This is one of the most abundant and characteristic trees of the high mountains of central and western Guatemala, where it is practically confined to the uppermost slopes, above those frequented by $A$. arguta and $A$. ferruginea. There is usually an abrupt transition from one species to the other, as one ascends the trails, the change 
in species being easy to recognize because of the difference in color of the trunks. The bark of $A$. firmifolia is unique, suggesting somewhat that of the corky-barked firs (Abies) of the Rocky Mountains. The bark has transverse constrictions, as if it were bound tightly with twine. On the Volcán de Santa María the Indians made no distinction as to the two species so abundantly represented there, yet when the bark difference was pointed out, they recognized it immediately. This is the only Alnus species, apparently, of the higher parts of the Cuchumatanes. Skutch remarks that this and Pinus Montezumae var. rudis are the only common trees in the Cuchumatanes above 3,150 meters, but he overlooked Juniperus Standleyi, which surely is a tree, and abundant. The leaves of $A$. firmifolia, at least on some specimens, are suggestive of those of Crataegus. They usually are devoid of wax glands on the lower surface, but sometimes bear widely scattered, small glands that turn blackish with age. The wood of Alnus is rich in tannin. In Mexico, and quite probably in Guatemala, it is used for tanning leather, to which it imparts a red color. The junior author remembers numerous occasions when his native guides selected alder trees for marking the new trails through the mountain forests. The red marks of the bark cut by their machetes were as effective as red paint. The wood is rather light and soft but firm, straight-grained, rather fine-textured, easy to work, tough and strong, finishes smoothly, is not durable in contact with the ground.

Alnus jorullensis HBK. Nov. Gen. \& Sp. 2: 27. 1817. Aliso.

Moist or wet mixed forest, often associated with oaks, 1,800-3,700 meters; Sacatepéquez; Chimaltenango; Sololá; Quezaltenango; San Marcos; Huehuetenango. Mexico, the type from Volcán de Jorullo; Andes of South America, from Venezuela to Bolivia.

A small or sometimes large tree with thin brown smooth bark, the branchlets usually glabrous; leaves oblong to ovate or oblong-obovate, mostly $7-12 \mathrm{~cm}$. long, acute or acuminate, or a few of the leaves obtuse, acute to rounded at the base, irregularly serrate, green and glabrous above, usually lustrous, pale beneath, more or less pilose at first but in age glabrate, dotted beneath with yellow wax glands, these usually conspicuous and often very dense; staminate aments $3-6 \mathrm{~cm}$. long; strobiles sessile or subsessile, generally about $12 \mathrm{~mm}$. long, sometimes slightly larger.

This species seems to be of only sporadic occurrence, and only a few specimens of it have been collected, in contrast with very numerous collections of the other local species. 


\section{CARPINUS L.}

Large or medium-sized trees; leaves petiolate, serrate, the stipules caducous; staminate flowers in cylindric pendulous aments, bracteate; perianth none; stamens 4-12, inserted on the pilose torus, the filaments bifid; anthers inserted dorsally below the middle, 1-celled, pilose at the apex; pistillate flowers in a large-bracted spike or ament, the flowers solitary within the bract; styles short, the 2 stigmas erect, linear-subulate; nut ovoid, subcompressed, by abortion 1-celled, the pericarp somewhat ligneous; seed solitary, pendulous.

About twenty species, in the northern hemisphere. A single species is found in America.

Carpinus caroliniana Walt. Fl. Carol. 236. 1788.

Ranging from southeastern Canada to central Mexico. Represented in Central America by the following variety:

Carpinus caroliniana var. tropicalis Donn. Smith, Bot. Gaz. 15: 28. 1890. C. tropicalis Lundell, Lloydia 2: 79. 1939. Duraznillo (fide Aguilar).

Usually along streams, in moist or wet forest, 1,300-2,800 meters; Alta Verapaz (type from Chicoyonits, J. D. Smith 1667); Baja Verapaz; Zacapa (Sierra de las Minas); Jalapa; Quiché; Quezaltenango (south slope of Volcán de Santa María); San Marcos; Huehuetenango. Chiapas; Honduras.

A large or medium-sized tree, often 12 meters high or more, with smooth dark bark, the young branchlets densely pilose with ascending or subappressed hairs; leaves membranaceous, on petioles $1 \mathrm{~cm}$. long or less, ovate to ovate-oblong, mostly 5-7 cm. long, acute or acuminate, rounded or subcordate at the base, appressedpilose on the nerves, slightly paler beneath, with 11-15 pairs of conspicuous straight lateral nerves, unequally duplicate-serrate; staminate aments $1.5-2.5 \mathrm{~cm}$. long, 5 $\mathrm{mm}$. thick, the bracts broadly ovate, acute; stamens $6-10$; pistillate inflorescences $7 \mathrm{~cm}$. long or less, the bracts foliaceous, 5-7-costate, trilobate, 2-3 cm. long, the lobes unequal, dentate or subentire; nut ovoid, nerved, pubescent. (Fig. 51.)

Although raised to specific rank by Lundell, this differs but little from the blue beech as it is found in eastern United States, except in its more abundant pubescence. The trunk is more or less fluted, although the fluting seems not to be so conspicuous in Guatemalan trees as in those of eastern United States. So far as known, the wood is not used in Guatemala. In Mexico it is reported to be utilized for firewood and charcoal.

\section{OSTRYA Scopoli. Hop hornbeam}

Trees, pubescent, the leaves short-petiolate, membranaceous, penninerved, plicate along the nerves in vernation; stipules caducous; flowers monoecious, 

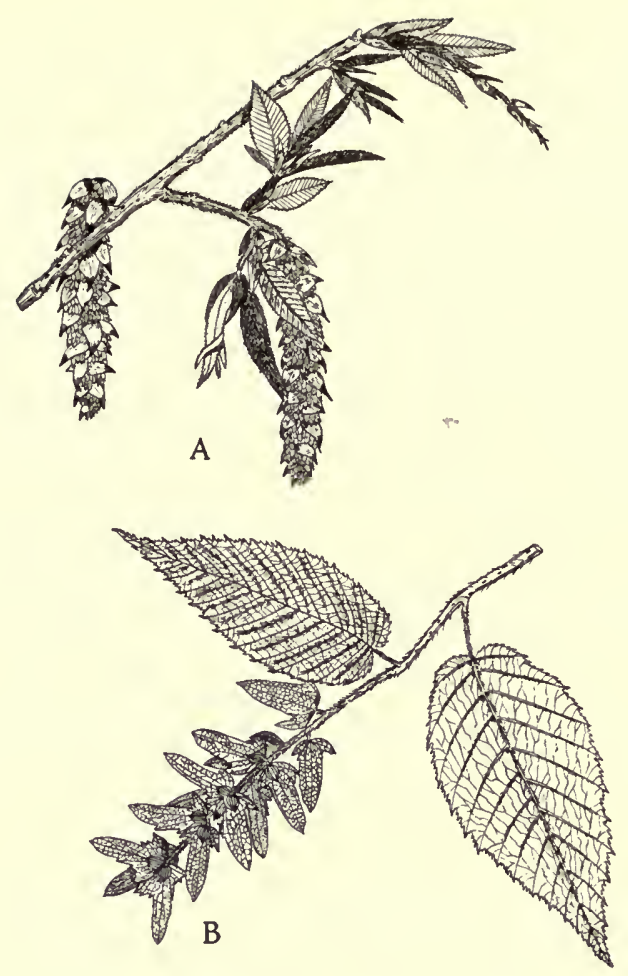

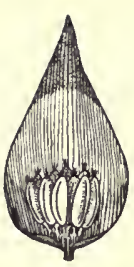

C

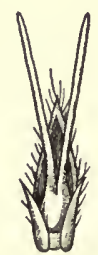

F

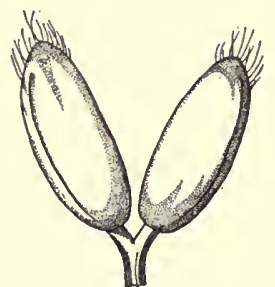

D

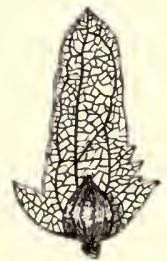

G

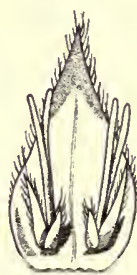

E

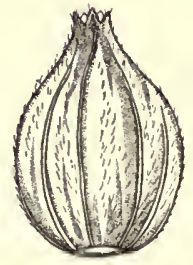

$\mathrm{H}$

FIG. 51. Carpinus caroliniana var. tropicalis. A. Habit of portion of flowering branch; $\times^{2 / 5}$. B. Habit of portion of fruiting branch; $\times^{2 / 5}$. C. Staminate flower with scale; $\times 6$. D. Stamen, $\times 24$. E. Pistillate flower with scale; $\times 6$. F. Pistillate flower with bract; $\times 5$. G. Nut with involucre; $\times 1$. H. Fruit; $\times 8$. 
the staminate in cylindric aments with scale-like bracts; perianth none; stamens $3-14$, inserted on the pilose torus, the filaments slender, bifid at the apex; anthers dorsifixed near the base, pilose at the apex; pistillate flowers disposed in dense spikes, the bracts utricle-like, open at the apex in anthesis, closed in age and accrescent, membranaceous and inflated; ovary 2-celled, the style short, the 2 stigmas erect, linear-subulate; ovules 2 in each cell, pendulous, anatropous; nutlet small, by abortion 1-celled, costate, the pericarp subligneous; seed solitary, pendulous, the cotyledons fleshy, plano-convex, obovate.

Probably three species, in Asia and North America, only one species reaching Central America.

Ostrya virginiana Mill. Dict. ed. 8. 1768.

Widely distributed in eastern North America from southeastern Canada to Florida, and southward into Mexico. Represented in Central America by the following variety:

Ostrya virginiana var. guatemalensis (Winkl.) Macbride, Field Mus. Bot. 4: 193. 1929. O. italica subsp. virginiana var. guatemalensis Winkl. Pflanzenreich IV. 61: 22. 1904. O. guatemalensis Rose, Contr. U. S. Nat. Herb. 8: 292. 1905. Duraznillo (the name most generally used in Guatemala); Aliso blanco; Aliso colorado (Huehuetenango); Mescal; Tatiscoba (Volcán de Agua); Gamuso (Zacapa).

Dry or moist, mountain forests, 1,000-3,000 meters; Baja Verapaz; Zacapa; Chiquimula; Jalapa; Santa Rosa; Guatemala; Sacatepéquez; Chimaltenango; Sololá; Suchitepequez; Quiché; Huehuetenango; Quezaltenango; San Marcos. Southern Mexico; Honduras.

A small to rather large tree, mostly 6-18 meters tall, with thin, light brown bark; leaves thin, short-petiolate, ovate to lance-oblong, mostly $6-10 \mathrm{~cm}$. long, acute to long-acuminate, rounded or subcordate at the base, duplicate-serrate, usually densely soft-pilose beneath and often also on the upper surface; staminate aments slender and elongate, pendent; fruiting aments resembling strobiles of hops (Humulus Lupulus), 5-7 cm. long, the soft enlarged bracts pale green or finally brownish, conspicuously nerved, inflated. (Fig. 52.)

Called "guapaque" in southern Mexico, and "canillo de venado" in Honduras. The wood is very hard, fine-grained, tough, and fairly durable. In some regions it is utilized for railroad ties, tool handles, and fuel. The bark is said to be used in Mexico for tanning and dyeing. The tree is abundant in many parts of the central mountains, where it sometimes forms rather extensive and almost pure stands, as in Guatemala and Sacatepéquez. The foliage is almost exactly like that of Carpinus, but the trunks and bark are somewhat different, 


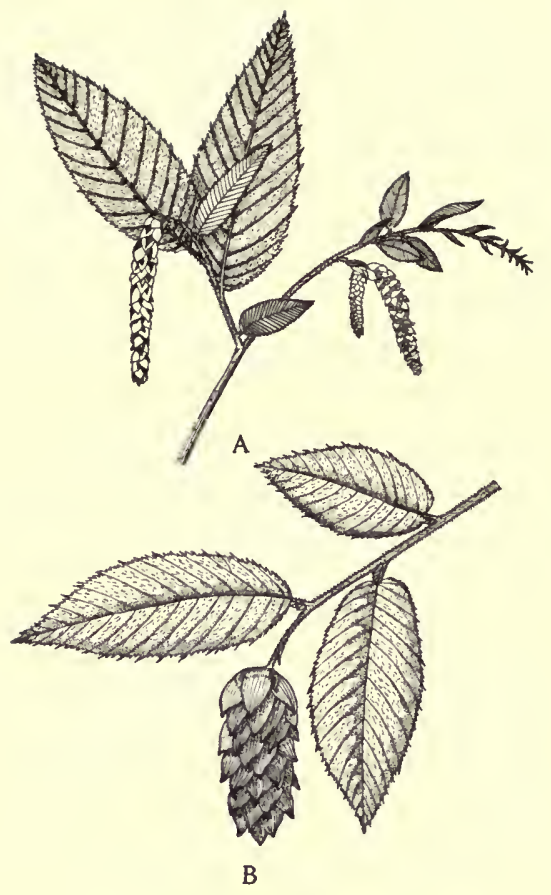

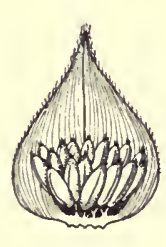

C

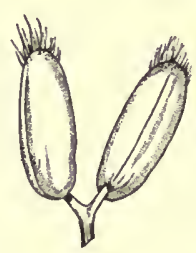

D

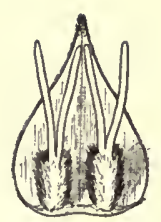

E

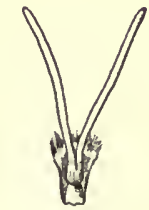

F

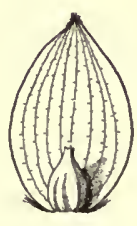

G

FIG. 52. Ostrya virginiana var. guatemalensis. A. Habit of portion of flowering branch; $\times 1 / 3$. B. Habit of portion of fruiting branch; $\times 1 / 3$. C. Staminate flower with scale; $\times 5$. D. Stamen; $\times 20$. E. Pistillate flower with scale; $\times 3$. F. Pistillate flower with bract laid open; $\times 5$. G. Fruit and involucre; $\times 1$. 
and the two genera apparently do not grow together in Guatemala. In fruit it is easy to separate the two trees.

\section{FAGACEAE. Beech Family}

Trees or sometimes shrubs, the buds with imbricate scales; leaves alternate, usually petiolate, persistent or deciduous, penninerved, entire or dentate to deeply pinnatifid; stipules present, generally deciduous; flowers monoecious, usually axillary on young branchlets, the perianth 4-7-lobate; staminate spikes (catkins) slender, usually elongate, pendent, and flexuous, each bract enclosing a single flower; stamens as many or twice as many as the perianth lobes, rarely more numerous, the filaments usually slender; anthers 2-celled, the cells erect, parallel, sessile or short-stipitate at the apex of the filaments, dehiscent by a longitudinal slit; pistillate flowers solitary or in 3's, forming spikes or short clusters, sometimes borne at the base of the pistillate spikes; ovary inferior, 3-celled or rarely 6 -celled at the base, with 3 styles, each cell 2 -ovulate, but all the ovules except one abortive; fruit a nut, solitary or 2-3, partly or wholly enclosed by an involucre or cupule; seed large, without endosperm, the cotyledons thick and carnose.

Six genera, with about 600 species (or perhaps more), widely dispersed in both hemispheres, mostly in temperate and subtropical regions, rarely in truly tropical areas, in the tropics mostly confined to the mountains. Only one genus is native in Central America. To this family belong the chestnut (Castanea; "Castaño;" "castaña"), whose edible nuts doubtless reach Guatemala at times. The European chestnut, Castanea sativa Mill., is in cultivation and fruiting in Costa Rica, and may well be planted in Guatemala, although we have no record of its occurrence there. A few species of the same genus are native in the United States, one of them, $C$. dentata (Marsh.) Borkh., formerly of great importance as a source of lumber and nuts, but now very much depleted because of the attacks of a fungus disease. Also belonging to this family is the beech (Fagus; "haya"), one species of which is native in the eastern half of temperate North America. Another species, Fagus mexicana Martínez, has been described recently from Mexico.

\section{QUERGUS L. Oak}

References: William Trelease, The American oaks, Mem. Nat. Acad. Sci. 20: 1-255. pls. 1-420. 1925. Cornelius H. Muller, The Central American species of Quercus, U. S. Dept. Agr. Misc. Publ. no. 477: 1-92. pls. 1-124. 1942.

Large or medium-sized trees or sometimes shrubs; buds crowded toward the ends of the usually fluted twigs; leaves alternate, almost always distinctly petiolate, entire, dentate, or pinnatifid, persistent or deciduous, the teeth or lobes often aris- 
tate-tipped; stipules associated with the buds rather than the leaves, subulate to ligulate, usually caducous; staminate flowers small, in elongate flexuous pendent catkins, apetalous; calyx of 5 lobes united to form a more or less cupular perianth, this enclosing 5-10 free stamens with short anthers and slender filaments; pistillate flowers borne in a reduced catkin, the stiff woody rachis either short or long and 1-several-flowered, the calyx of 6 sepals adherent to the bases of the styles and fused into a tube; pistil of 3 carpels forming a single 3-celled ovary and 3 free styles, these stigmatic ventrally toward the dilated apex; fruit an acorn (Spanish, bellota), 1-celled and 1-seeded, the 5 other ovules abortive and adherent to the developed seed; seed enclosed in a shell and seated in a cup, this formed of numerous small imbricate scales, the cup enveloping the whole nut or covering only a part of it, or only its base.

The only large genus of the family, the number of species very uncertain because of different treatments by various authors. Rehder estimates the total number of species at "more than 200," while Trelease recognized about 370 from America alone. Muller recognized 46 as occurring in Central America. The majority of these are found in Guatemala, but numerous other species grow southward in Costa Rica and Panama. The oaks of Guatemala and Costa Rica have been collected rather thoroughly, but those of the intervening countries are little known.

The present account of Guatemalan oaks is taken directly from the excellent and recent account by Muller, who has determined the greater part of our collections. We have made rather extensive collections in Guatemala, and as these have been taken from what were assumed to be average and characteristic trees in each region where we have worked, they should be representative of the oak flora as a whole. Most of the species thus far found in the country are represented by a substantial number of collections. Many of our specimens are sterile, probably because they have been taken chiefly during the dry season. At this time of the year it is difficult to find acorns, even old ones on the ground beneath the trees.

As a source of wood and lumber the genus Quercus is one of the most important of all groups of trees. The timber is noted for its strength, durability, and beauty, and is used everywhere for innumerable purposes, ranging from fuel to railroad ties, construction of buildings and ships, interior trim, flooring, and all grades of furniture. The woods of different species vary as to their physical qualities; some of them are very hard and tough, others are lighter in weight, softer, and less tough. Cork of commerce is obtained from the bark of the cork oaks grown for this product in Spain, Portugal, and North Africa. 
In Guatemala oaks and pines are the two most characteristic and important trees. They often are mixed in pine-oak forests, but frequently the oaks form almost pure stands, which formerly must have covered almost unbrokenly the middle elevations of the drier mountains. Even at the present time, when the oak forests have so long been a source of fuel and lumber, there are extensive stands covering great areas of such departments as Guatemala, Quiché, and Huehuetenango. These regions afford the best grazing areas of the mountains. It is an impressive sight to stand on some low elevation near Huehuetenango and observe the oak forests extending in every direction. Most of the trees are rather small, it is true, and often reduced to thicket-forming shrubs, but on all sides, as far as the eye can see, there are oak forests or thickets, extending from the plains up to the highest summits of the great wall of rock that constitutes the westward face of the Cuchumatanes. Few or none of the Guatemalan oaks assume the brilliant colors peculiar to many North American oaks in autumn, but there is a great deal of bright yellow and some dull reds and purples, and the brown coloring of the dead but persistent leaves is characteristic.

Oaks often are found where there are no pine trees, and they frequently occur in mixed forest associations. About Cobán the customary place of the oaks is usurped in places by Liquidambar trees, but not far from Cobán there are extensive stands of oak forest, and the dry mountains of Baja Verapaz probably have the greatest display of large oak trees to be found anywhere in Guatemala. In the dense mixed wet forests of the Pacific slopes of the main chain of volcanoes, oaks occur in great numbers, principally Quercus Skinneri. The drier mountains of Quezaltenango and San Marcos, at middle or rather high altitudes, also afford a great display of oak forest, but this, as about the capital, has been greatly reduced by cultivation and the demands for fuel and lumber.

Oak wood is the favorite fuel everywhere in Guatemala. The wood is carried great distances on men's backs or on animals. It always is sold so cheaply that the woodcutters can earn at best a mere pittance, but firewood is one of the necessities all over Guatemala, and its scarcity imposes great hardship. Oak bark is rich in tannin, and supplies the best of all materials for tanning tough and durable leather. It is much used for this purpose in Guatemala, and it is used there also to furnish a brown dye for textiles. The insect galls found so abundantly and often conspicuously on the trees are particularly rich in tannin, and in many countries have been 
much used for making ink. They doubtless are or have been thus utilized in Guatemala. Because of the tannin present, a decoction of oak leaves or bark often is used as an astringent in domestic medicine, commonly as a mouth wash for alleviating toothache. Ashes of the wood are used commonly for lye in soap-making.

On the Cerro Quemado and elsewhere about Quezaltenango the abundant fallen oak leaves are used commonly for fertilizing the sterile fields of the dry mountain slopes. Large heaps of them are seen rotting about the borders of fields, and in February they are worked into the soil.

The seeds of all the oaks are edible, but in most species they are very bitter. Those of some of the white oaks are relatively sweet and of agreeable flavor. Acorns were an important food among some of the North American Indians. We have no information as to such a use anywhere in Central America, but there can be no doubt that acorns have been eaten in Guatemala, at least in times of famine, such as have occurred in very recent years, when the corn crop fails.

The Pokonchí names for oaks are reported as "pitán" and "zinuh," and the name "tuhs" is reported from Sierra de las Minas. Among Spanish-speaking people of Guatemala the names "encino" and "roble" are applied to the trees, and no distinction is made in the use of these names, nor are the different species, so far as we have observed, given distinctive names. The term "encinaladas" is the one most often applied to oak forests, at least in the central region.

All the Guatemalan oaks are evergreen, as that term is used in the United States, or essentially so. The term is, however, a misleading one. In the wetter forests the trees probably are covered with green leaves at all seasons of the year, the change in foliage taking place gradually. In nearly all the species, however, the new leaves appear in the spring months of the North, and remain on the tree until the following spring, or at least well into the verano. They are dormant but may retain their green coloring, or change gradually to brown. At any rate, when the new buds begin to swell after the first showers, or with the increase in temperature, the old leaves fall rapidly, and the trees often remain for some time quite bare except for catkins. At this time the oak forests in the barrancos of the central mountains have exactly the aspect of northern forests in springtime. They are full of small twittering birds, and many of the shrubs and herbs are in fresh bloom. We have not seen a similar appearance of spring vegetation anywhere else in all Central 
America, although it may be duplicated in the Alnus forests of the white-sand mountains of the Occidente of Guatemala.

Bark rather soft, gray, and scaly; leaves, if dentate, only mucronate-tipped or rounded, never spinose-tipped or aristate-tipped; stigmas abruptly dilated on short styles; fruit annual; scales of the cup usually prominently thickened at the base and loosely appressed at the apex; shell of the acorn glabrous on the inner surface; abortive ovules basal. Subgenus Lepidobalanus. White oaks.

Twigs of the season persistently and densely fulvous-tomentose.

Leaves oblanceolate, tapering to the cuneate or narrowly rounded base, coarsely dentate above the middle; petioles 3-5 mm. long....Q. oocarpa.

Leaves obovate to elliptic-oblanceolate, not tapering below, the base rather broad, cuneate or truncate, subentire or with low teeth; petioles mostly

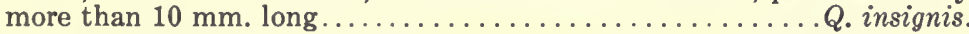

Twigs of the season glabrate or sparsely pubescent or gray-tomentose.

Leaves with a persistent continuous short tomentum beneath, or the lower surface canescent and covered with minute appressed stellate hairs.

Leaf blades cordate at the base, the nerves 11-15 on each side, the lower surface covered with a cream-colored short spreading tomentum.

Q. purulhana.

Leaf blades cuneate to subobtuse at the base, with 6-8 pairs of nerves, appressed-tomentulose beneath............... oleoides.

Leaves glabrate or pubescent beneath, not with a short dense tomentum or with appressed stellate hairs.

Leaves glabrate throughout.

Petioles 1-4 mm. long...................... pilaria.

Petioles $15-40 \mathrm{~mm}$. long..................... corrugata.

Leaves villous or tomentose beneath, or at least with the costa strigose or stellate-tomentose.

Fruit large, the acorns $2.5-3 \mathrm{~cm}$. broad ............. oocarpa.

Fruit small, the acorns usually less than $2 \mathrm{~cm}$. broad at maturity.

Leaves very thick and coriaceous, with conspicuously impressed veins above, evidently reticulate-veined beneath and sparsely tomentose, conspicuously cordate at the base............ pilicaulis.

Leaves relatively thin, the veins not conspicuously impressed above nor evidently reticulate beneath, or, if the leaves are thick and impressed-veined above, then persistently and densely longtomentose beneath, or not cordate at the base.

Leaves with a waxy-glaucous bloom beneath.

Petioles usually 15-25 mm. long; leaves entire or with a few teeth

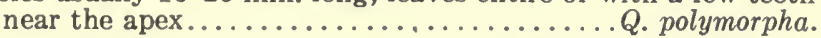

Petioles $7 \mathrm{~mm}$. long or shorter, dentate throughout.Q. peduncularis.

Leaves without a waxy-glaucous bloom beneath, or this obscured by the long lax tomentum.

Leaves thick, impressed-veined on the upper surface, usually laxly long-tomentose beneath............... peduncularis.

Leaves if thick not conspicuously impressed-veined above, glabrate beneath or merely villous or sparsely tomentose, the pubescence not obscuring the surface.

Leaves regularly and usually repandly 10-12-dentate on each side, or merely erose-dentate.

Leaves rather thick and coriaceous, erose-crenate, drying yellowish brown................... segoviensis. 
Leaves thin, usually with regular, rounded or acute teeth, drying green.......... peduncularis var. sublanosa.

Leaves entire or irregularly few-dentate above the middle.

Leaves thick and leathery, glabrate except for the veins, the margins evidently revolute, entire or finely dentate.

Q. pacayana.

Leaves rather thin, glabrate except for the strigose costa and nerves, subentire................. aaata.

Bark rather hard, black, and furrowed but scarcely scaly; leaves, if toothed, aristate-tipped, never with rounded lobes; stigmas gradually (or rarely abruptly) dilated, on long styles; fruit biennial or annual; scales of the cup scarcely thickened at the base and usually tightly appressed at the apex; shell of the acorn tomentose on the inner surface; abortive ovules usually apical. Subgenus Erythrobalanus. Black oaks.

Leaves entire, or the margins sometimes crispate but not at all dentate or aristate.

Leaves rounded or obtuse at the apex, granular-bullate beneath, at first tomentose but becoming glabrate in age.

Leaves granular-bullate beneath, at first tomentose, becoming more or

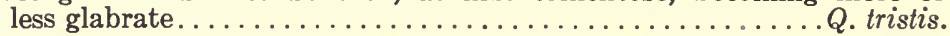

Leaves smooth beneath, not at all bullate, glabrous or at most with tufts

of hairs beneath in the axils of the nerves.......... sapotaefolia.

Leaves acute at the apex and aristate, or acuminate.

Leaf blades low-bullate or granular-bullate beneath.

Leaves glabrate or somewhat pubescent beneath but not persistently and laxly tomentose........................ tristis.

Leaves covered beneath with a persistent lax tomentum.

Twigs covered with a persistent velvety tomentum; leaves waxyglaucous as well as bullate when denuded of pubescence.

$Q$. brachystachys.

Twigs glabrate or furfuraceous but not velvety; leaves not waxyglaucous beneath.

Leaves rather sparsely short-tomentose or merely crisped-villous beneath, at most low-bullate.............. crispipilis.

Leaves rather densely thick-tomentose beneath or finally somewhat glabrate, never sparsely tomentose or short-tomentose, granularbullate..................... crispipilis var. pannosifolia.

Leaf blades smooth beneath, not bullate.

Leaves linear-lanceolate, at least 5 times as long as wide, very longtapering at the apex, the nerves 18-24 pairs, divergent at an angle of $80-85$ degrees from the costa............... flagellifera.

Leaves not linear-lanceolate, less than 5 times as long as wide, the nerves mostly 15 or fewer pairs, usually divergent at a narrower angle.

Fruit biennial.

Leaves acuminate or else narrowly lanceolate.

Petioles 5 or rarely $10 \mathrm{~mm}$. long, the blades entire; acorns $25-30$ $\mathrm{mm}$. long and 22-26 mm. broad........... crispifolia.

Petioles 10 or usually $15-25 \mathrm{~mm}$. long or, if shorter, the blades dentate; acorns $17 \mathrm{~mm}$. long and $14 \mathrm{~mm}$. broad or smaller.

Leaves glabrous beneath except for axillary tufts of hairs, about

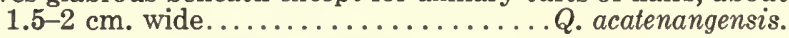
Leaves resinous-puberulent beneath, mostly $3-5 \mathrm{~cm}$. wide.

Q. conspersa.

Leaves neither acuminate nor lanceolate, mostly oblong or ovate, abruptly aristate at the apex, crisped-pubescent or lanate beneath. 
Leaves rather sparsely short-tomentose beneath, smooth or at most low-bullate..................... crispipilis.

Leaves rather densely thick-tomentose beneath or finally glabrate, never sparsely tomentose or short-tomentose, bullate.

Fruit annual.

$Q$. crispipilis var. pannosifolia.

Scales of the cup very loosely appressed.......... Benthami.

Scales of the cup rather closely appressed.

Twigs velutinous-tomentose with short hairs or tardily glabrate.

Q. hondurensis.

Twigs laxly stellate-tomentose with long hairs or almost wholly glabrous.

Leaves long-acuminate............... crispifolia.

Leaves short-acuminate or obtuse.......... borucasana.

Leaves toothed or the margins aristate.

Leaves very large, thin, typically obovate, coarsely dentate or merely longaristate above the middle, the lower surface persistently and densely short-tomentose, but the veins glabrous.............. candicans.

Leaves medium-sized or, if large, not short-tomentose on the lower surface, variously lanate to glabrous.

Leaves persistently, densely, and laxly lanate beneath, or partially glabrate, bullate-granular; fruit biennial.

Twigs coarse, 3-5 mm. thick, persistently velvety-tomentose; leaves waxy-glaucous beneath where denuded of pubescence.

Q. brachystachys.

Twigs 2 or rarely $3 \mathrm{~mm}$. thick, loosely tomentose or glabrate or rather persistently pubescent but not velvety, not waxy-glaucous beneath when denuded ...............Q. crispipilis var. pannosifolia.

Leaves glabrous or loosely tomentose and soon glabrate, or with axillary tufts of hairs, or puberulent beneath, or, if bullate-granular, then the fruit annual, otherwise the fruit either annual or biennial.

Leaves bullate-granular beneath, the veins strongly impressed on the upper surface............................ tristis.

Leaves smooth and not at all bullate beneath, the veins slightly if at all impressed on the upper surface.

Leaves very narrow, elongate, and with tapering tips, finely dentate or merely aristate; petioles 1-3 mm. long....... . flagellifera.

Leaves broad or, if narrow, not as much as 5 times as long as wide and not attenuate-tipped, coarsely dentate or, if merely aristate, then not elongate; petioles much more than $5 \mathrm{~mm}$. long or else the blades coarsely dentate.

Fruit very large, the acorns more than $3 \mathrm{~cm}$. broad; scales of the cup corky-thickened at the base at maturity. Fruit biennial.

Q. Skinneri.

Fruit moderate-sized or small, the acorns usually less than $2 \mathrm{~cm}$. broad; scales of the cup thin and flat or if basally thickened this resulting from swelling of buds in their axils and rarely from their own thickening.

Acorns about $2 \mathrm{~cm}$. broad, almost globose; shell of the acorn $3 \mathrm{~mm}$. thick or more, very hard; scales of the cup corky-thickened at the base at maturity; fruit biennial......... Skinneri.

Acorns less than $2 \mathrm{~cm}$. broad, ovoid or depressed, never subglobose; shell of the acorn $1.5 \mathrm{~mm}$. thick or less; scales of the cup thin or thickened at the base at maturity.

Fruit annual................ anglohondurensis.

Fruit biennial. 
Leaves evidently aristate-tipped at the acute apex, typically yellow-glandular-puberulent beneath, or rarely glabrate except for axillary tufts of hairs; margins of the cup coarsely inrolled.................. conspersa.

Leaves not markedly aristate-tipped at the acute apex, glabrous beneath or with axillary tufts of hairs; margins of the cup not inrolled............. acatenangensis.

Quercus aaata Muller, U. S. Dept. Agr. Misc. Publ. 477: 27. pls. 23-26. 1942.

Moist mixed mountain forest, 1,800-2,200 meters; Jalapa (Volcán Jumay); Guatemala (Volcán de Pacaya, above Las Calderas; type, Standley 58466). Honduras; Costa Rica.

A large tree, sometimes 22 meters high with a trunk 2 meters in diameter, the twigs slender, 1.5-2.5 mm. thick, strigose and stellate-pubescent with appressed pubescence, becoming glabrous and gray or whitish; buds rounded-ovoid to ellipsoid, 3-5 mm. long, glabrous, stramineous; leaves thin but firm, 6-16 $\mathrm{cm}$. long, 2-6 cm. wide, elliptic or oblanceolate to oblong-obovate or rhombic, much or only slightly narrowed toward the apex, the tip narrowly or broadly rounded, attenuate to the very narrowly cuneate to rounded base, subentire or dentate near the apex, the margins plane or slightly revolute, deep green and dull above, glabrous except for the costa, this strigose toward the base, lustrous or dull beneath, strigose or fulvous-tomentose on the costa, otherwise glabrous, the lateral nerves 10-15 pairs, slightly elevated on the upper surface; petioles $2-7 \mathrm{~mm}$. long, usually about $4 \mathrm{~mm}$.; fruits annual, solitary or geminate, pedunculate; cup about $2.5 \mathrm{~cm}$. broad, hemispheric or shallowly cup-shaped, the scales ovate with abruptly contracted oblong tips, these laxly appressed, the scales much thickened and velutinous at the base, the apices brown and strigose; acorn ovoid, $2-2.5 \mathrm{~cm}$. long, scarcely $2 \mathrm{~cm}$. broad, glabrate, one-third to one-half included in the cup.

Called "encino" in Honduras.

Quercus acatenangensis Trelease, Mem. Nat. Acad. Sci. 20: 163. pl. 320. 1924 (type from Guatemala, without definite locality, Warscewicz 47, 48). Q. longifolia Liebm. Dansk. Vid. Selsk. Forh. 185. 1854, not Q. longifolia Raf., 1838 (type same as of $Q$. acatenangensis, which is a renaming of $Q$. longifolia Liebm.). Q. acutifolia var. longifolia A. DC. in DC. Prodr. 16, pt. 2: 67. 1864. Q. xalapensis var. longifolia Wenzig, Jahrb. Bot. Gart. Berlin 3: 210. 1884. Q. Donnell-Smithii Trelease, Mem. Nat. Acad. Sci. 20: 162. pl. 318. 1924 (in part, but not the collection cited as the type, which is Q. sapotaefolia). Q. ambivenulosa Trelease, Journ. Wash. Acad. Sci. 23: 62. 1933 (type from Chichavac, Chimaltenango, A.F. Skutch 14). Encino; Encino sunuj, Sunuj (Sacatepéquez); Masket (Volcán de Santa María); Duraznillo (Zacapa; probably an erroneous name).

Moist or dry, mountain plains and hillsides, in mixed, oak, or pine-oak forest, sometimes associated with Cupressus and Abies, 
often on white-sand hillsides, 1,500-3,300 meters, most common at the higher elevations; Baja Verapaz; Zacapa; Jalapa; Guatemala; Sacatepéquez; Chimaltenango; Sololá; Quiché; Huehuetenango; Totonicapán; Quezaltenango; San Marcos. Chiapas.

A medium-sized or of ten very large tree, sometimes 30 meters high or more with a trunk a meter in diameter, the twigs $1-2 \mathrm{~mm}$. thick, glabrous, or sparsely stellate-pubescent becoming glabrate and reddish brown, with rather inconspicuous lenticels; buds about $3 \mathrm{~mm}$. long, ovoid, acute, sparsely pubescent or glabrate, light brown; leaves rather thick and hard or rarely thin, 3-5 or even $10-15 \mathrm{~cm}$. long, usually $2-3$ but sometimes $1-4.5 \mathrm{~cm}$. wide, typically lanceolate to elliptic or narrowly ovate, acute or acuminate, not conspicuously aristate-tipped, cuneate to rarely attenuate at the base, or in some forms rounded or subcordate, entire or with few obscure teeth toward the apex, in juvenile forms coarsely serrate, the margins minutely cartilaginous-revolute and somewhat crispate, the upper surface more or less lustrous, glabrous or slightly pubescent along the costa, the lower surface less lustrous or dull, glabrous or with rather conspicuous tufts of hairs in the axils of the nerves, the surface not bullate, the lateral nerves 10-14 pairs, more or less elevated on both surfaces; petioles 5-10 or sometimes $20 \mathrm{~mm}$. long, in juvenile forms sometimes very short; staminate catkins $3 \mathrm{~cm}$. long, fulvousvillous or gray-villous, loosely flowered, the anthers oblong, well exserted; pistillate catkins $5-10$ or even $20 \mathrm{~mm}$. long, the glabrous peduncle usually 2-flowered; fruits biennial, solitary or geminate, on a peduncle 5-20 mm. long; cup 10-20 mm. broad, 7-12 mm. high, cup-shaped to turbinate and constricted at the base, the scales triangular to lanceolate or ovate, the apices usually narrowed but rounded, sericeous or glabrate; acorn $10-17 \mathrm{~mm}$. long, $8-14 \mathrm{~mm}$. broad, elliptic to ovoid, sparsely puberulent or glabrate, light brown, one-half or only one-third included in the cup.

This is one of the abundantly and widely distributed oaks of Guatemala, and with a wider variety of habitats than most of the species. It is particularly frequent at the higher elevations in the mountains, and often grows in moist if not wet situations. The species has been reported from Guatemala as Q. nitens Mart. \& Gal.

Quercus anglohondurensis Muller, U. S. Dept. Agr. Misc. Publ. 477: 76. pls. 114, 115. 1942.

Moist or wet, mountain forest, about 800 meters; Petén (Camp 36, British Honduras boundary, W. A. Schipp 1249). British Honduras (type collected in mountain pine ridge, along Río Frío, San Agustín, El Cayo District, C. L. Lundell 6615).

A tree of 15-27 meters, the trunk $45 \mathrm{~cm}$. in diameter, the twigs 1-2.5 mm. thick, laxly fulvous-tomentose at first, soon glabrate and dark reddish brown, becoming gray; buds $2-3 \mathrm{~mm}$. long, ovoid, glabrate, rather dark brown or grayish brown and lustrous; leaves rather thin but firm, 7-10 or even $16 \mathrm{~cm}$. long, 2-3.5 or even $5 \mathrm{~cm}$. wide, lanceolate or elliptic-lanceolate, attenuate-acute, attenuatecuneate at the base or merely cuneate or sometimes rounded, low-dentate or merely 
aristate from the margin, the teeth aristate-tipped, glabrate and lustrous on both surfaces, or stellate-pubescent along the costa, especially beneath in the axils of the nerves, the lateral nerves 10-12 pairs, rather prominent on both surfaces; petioles 5-16 mm. long; pistillate catkins 5-10 $\mathrm{mm}$. long, 1-2-flowered, the peduncles glabrous; fruits annual, solitary or geminate, on a peduncle $4-8 \mathrm{~mm}$. long; cup 13-16 mm. broad, 10-11 mm. high, turbinate or deeply cup-shaped, somewhat constricted at the base, the margin not inrolled, the scales ovate, the narrow apex rounded, closely appressed, minutely fulvous-puberulent or the brown margins glabrate; immature acorn $10-13 \mathrm{~mm}$. long and about as broad, transiently buff-puberulent, probably about half included in the cup at maturity.

This has been reported from the boundary region as $Q$. acutifolia Née, a Mexican species.

Quercus Benthami A. DC. in DC. Prodr. 16, pt. 2: 29. 1864. Q. gemmata Trelease, Mem. Nat. Acad. Sci. 20: 152. pl. 299. 1924 (type from Volcán de San Salvador, El Salvador). Q. undulata Benth. Pl. Hartweg. 81. 1841. not Q. undulata Torr. 1828 (type from Santa María, probably Volcán de Santa María, Quezaltenango, Hartweg $563)$.

Moist or wet, usually mixed, mountain forest, mostly at 1,500 2,700 meters; Jutiapa (Volcán de Suchitán); Chimaltenango; Sololá; Quezaltenango; San Marcos. Chiapas.

A medium-sized or large tree, the twigs $1.5-3 \mathrm{~mm}$. thick, densely velutinoustomentose with short hairs at first, soon glabrate, or sometimes persistently fulvous-pubescent into the second year, dark reddish brown; buds 5-7 mm. long, 2-3 mm. thick, fusiform, light or dark brown, fulvous-tomentose or glabrate; leaves moderately thin but firm and coriaceous, $5-8$ or sometimes $10 \mathrm{~cm}$. long, 2-3 or sometimes $5 \mathrm{~cm}$. wide, acute to attenuate-acuminate but rarely aristate-tipped, cuneate at the base or broadly rounded to narrowly acute, entire, the margins narrowly but distinctly revolute, finely crispate or flat, glabrate on the upper surface and somewhat lustrous, coarsely fulvous-tomentose beneath along the costa and in the axils of the nerves, otherwise glabrate and lustrous, the lateral nerves 10-12 pairs, prominent on both surfaces; petioles 1-2 cm. long; fruits annual, solitary or geminate, subsessile or on a peduncle 3-5 mm. long; cup 20-22 mm. broad, hemispheric, rounded or somewhat constricted at the base, the margins not inrolled, the scales oblong or narrowly ovate, their apices narrowed but truncate or rounded, laxly appressed, finely fulvous-tomentose; acorn depressed-globose or hemispheric, densely fulvous-sericeous or glabrate and light brown, one-half or more included.

Quercus borucasana Trelease, Mem. Nat. Acad. Sci. 20: 161. pl. 315. 1924.

Cloud forest, growing with Abies, 2,500-3,200 meters; Zacapa (Volcán Gemelos, Sierra de las Minas); Huehuetenango (Cerro Cananá, Sierra de los Cuchumatanes). Costa Rica. 
A tree of 9-12 meters or sometimes larger, in Costa Rica as much as 30 meters high, the twigs glabrate and dark reddish brown; buds $1.5-2 \mathrm{~mm}$. long, ovoid or round, obtuse; leaves thick, chartaceous, 3-7 cm. long, 1.25-2.5 cm. broad, elliptic or oblong to narrowly lanceolate, acute and aristate-tipped, base cuneate, entire, the margins slightly thickened but scarcely revolute, lustrous and glabrous above, beneath glabrous or nearly so, the lateral nerves 10-12 pairs; fruits annual, small, solitary or paired on glabrous peduncles 2-5 mm. long; cup 10-15 mm. broad, about 4-5 mm. deep, cup-shaped or more shallow, rounded or slightly constricted at the base, the scales ovate, broadly rounded at the narrowed apex, closely appressed, puberulent to glabrate except at the brown glabrous apex and margins; acorns $10-15 \mathrm{~mm}$. long, 9-13 $\mathrm{mm}$. broad, ovoid to subrotund, fulvous-sericeouspuberulent, light brown where abraded, about one-fifth or less included.

The two Guatemalan specimens had been determined previously by Dr. Muller as atypical Q. eugeniaefolia, but he has recently shown them to be conspecific with Q. borucasana (Madroño 10: 136. 1950).

Quercus brachystachys Benth. Pl. Hartweg. 91. 1842. Roble; Encino; Masket (Quezaltenango); Patán (Volcán de Agua, Sacatepéquez); Col (Huehuetenango).

Moist to dry, mountain forest, often or usually associated with pines and often forming extensive forests, 1,500-2,600 meters; Jalapa; Guatemala (type from Cuesta de Mixco near San Lucas, Hartweg 618); Sacatepéquez; Chimaltenango; Quiché; Huehuetenango; Quezaltenango. Chiapas.

A medium-sized or large tree, the branchlets 3-5 mm. thick, covered with a persistent, gray or brownish, velvety tomentum, reddish brown where denuded; buds $3 \mathrm{~mm}$. long or more, ovoid; leaves very thick and coriaceous, $4-15 \mathrm{~cm}$. long, 2-10 $\mathrm{cm}$. wide, obovate or sometimes oblong or ovate, acuminate to broadly obtuse but aristate-tipped, cordate to truncate at the base, repandly and rather coarsely dentate, the teeth aristate-tipped or reduced to aristae, the margins somewhat revolute, more or less lustrous above, glabrous except on the stellate-tomentose costa and nerves, persistently fulvous-tomentose beneath, the surface where denuded bullate-granular and somewhat waxy-glaucous, the lateral nerves usually 8-10 pairs, strongly impressed on the upper surface, elevated beneath; petioles mostly 12-22 $\mathrm{mm}$. long; staminate catkins about $7 \mathrm{~cm}$. long, tomentose, rather laxly flowered, the anthers glabrous, mucronate, well exserted; pistillate catkins 1-2 or rarely $5 \mathrm{~cm}$. long, $2-4$-flowered or sometimes 10 -flowered, the peduncle tomentose; fruits biennial, medium-sized, solitary, geminate or ternate on a peduncle 1-2 $\mathrm{cm}$. long and $3-4 \mathrm{~mm}$. thick; cup about $15 \mathrm{~mm}$. broad and $10 \mathrm{~mm}$. high, often constricted at the base, the margin not inrolled, the scales ovate, obtuse, thin, closely appressed, puberulent or with glabrate margins; acorn 15-18 $\mathrm{mm}$. long, 10-12 mm. broad, ovoid or narrowly ovoid, glabrous, light brown, about half included.

This probably is the species reported from Guatemala by Hemsley as Q. crassifolia Humb. \& Bonpl., a Mexican species. It is one of the most easily recognized of Guatemalan species because of its large 
and broad, very thick, handsome leaves, covered beneath with a lax or often very dense, soft felt of brownish color. These leaves often form dense heaps under the trees in late winter or early spring. This species is an important and sometimes the principal element of the mountain oak forests of the central and western regions of Guatemala.

Quercus candicans Née, Anal. Cienc. Nat. 3: 277. 1801. Q. calophylla Schlecht. \& Cham. Linnaea 5: 79. 1830. Q. chimaltenangensis f. gemmata Muller, Amer. Midl. Nat. 18: 855. 1937 (type from Nebaj, Quiché, A. F. Skutch 1654).

Rather dry, openly forested mountain slopes or in quebradas or barrancos, about 1,700-2,000 meters; Jalapa; Sololá; Quiché; Huehuetenango. Central and southern Mexico.

A large tree, sometimes 23 meters high with a trunk $45 \mathrm{~cm}$. in diameter; branchlets 4-5 $\mathrm{mm}$. thick, glabrate or rather persistently and shortly stellatetomentose, dark reddish brown or grayish; buds 5-6 mm. long, acute, the scales sometimes ciliate; leaves rather thin but firm and hard, 10-23 cm. long, 4-14 cm. wide, generally obovate, sometimes elliptic-oblong but broadest above the middle, acuminate and aristate-tipped or rarely rounded at the apex, subcordate or truncate at the base, the margins undulate or coarsely dentate, the teeth with aristate tips, usually glabrate above, somewhat lustrous, densely, persistently, and closely bufftomentose beneath with matted stellate hairs, the costa and nerves glabrous, the lateral nerves $8-14$ pairs; petioles $15-20$ or sometimes $40 \mathrm{~mm}$. long; staminate catkins 5-6 cm. long, villous, laxly flowered, the anthers apiculate, somewhat exserted; pistillate catkins $1.5-2 \mathrm{~cm}$. long, 2-3-flowered; fruit biennial, solitary or geminate on a stout peduncle 8-12 mm. long; cup 16-20 mm. broad, 10-12 $\mathrm{mm}$. high, hemispheric or deeper, the margin sometimes inrolled, the scales ovate to lanceolate, thin, closely or rather laxly appressed, rounded at the apex, puberulent; acorn 15-18 mm. long, 11-14 mm. broad, ovoid, at first sericeous-puberulent, becoming glabrate and light brown, about one-third included in the cup.

Quercus conspersa Benth. Pl. Hartweg. 92.1842 (type from mountains of Las Casillas, Hartweg 617; probably in Santa Rosa). Q. acutifolia var. conspersa A. DC. in DC. Prodr. 16, pt. 2: 66. 1864. Q. correpta Trelease, Mem. Nat. Acad. Sci. 20: 153. pl. 300. 1924 (excluding the detached fruit, which is $Q$. sapotaefolia; type from Guatemala, Warscewicz 25, the locality unknown). Q. conspersa f. ovatifolia Trelease, op. cit. 192. pl. 389 (type from Guatemala, Warscewicz 28). Q. conspersa f. caudata Trelease, loc. cit. (type collected between Guatemala and Cobán, F.C.Lehmann 1320). Encino; Roble; Sical (Huehuetenango); Huite (Zacapa); Bans (Huehuetenango). 
Usually in pine-oak or oak forest, on moist or dry mountain hillsides, 1,000-2,700 meters; Baja Verapaz; Zacapa; Jalapa; Santa Rosa; Guatemala; Sacatepéquez; Chimaltenango; Sololá; Quiché; Huehuetenango; Quezaltenango; San Marcos. Southern Mexico; Honduras.

A large or medium-sized tree, the twigs $1.5-2.5$ or rarely $4 \mathrm{~mm}$. in diameter, minutely stellate-pubescent becoming glabrate and reddish brown, with a few inconspicuous lenticels, becoming gray the second season; buds $3-4 \mathrm{~mm}$. long, narrowly ovoid, acute, glabrate or the apex fulvous-tomentose; leaves rather thick and very hard, $6-20 \mathrm{~cm}$. long, $2-10 \mathrm{~cm}$. wide, usually lanceolate and long-acute but varying from oblong to ovate or obovate and attenuate-acute to merely acute, cuneate to unequally rounded or rarely cordate at the base, entire to coarsely dentate, the teeth aristate-tipped or reduced to aristae, antrorse or sometimes widely spreading, the margins rather coarsely cartilaginous but scarcely revolute, the upper surface glabrous and somewhat lustrous, the lower surface glabrate or typically fulvous-puberulent and stellate-barbate in the axils of the nerves, the lateral nerves 9-15 pairs, both the nerves and veins prominent on both surfaces; petioles mostly $8-30 \mathrm{~mm}$. long, puberulent or glabrate; staminate catkins $6-8 \mathrm{~cm}$. long, the rachis densely tomentose or glabrate, rather loosely flowered, the anthers ellipsoid, apiculate, moderately exserted; pistillate catkins $5-20 \mathrm{~mm}$. long, 2-6flowered; fruits biennial, solitary or geminate, on a peduncle $3-10 \mathrm{~mm}$. long; cup $15-18$ or rarely $22 \mathrm{~mm}$. broad, $7-10$ or rarely $13 \mathrm{~mm}$. high, cup-shaped to goblet-shaped, the base rounded or somewhat constricted, the margin coarsely inrolled and sometimes inflated, the scales ovate to triangular, the apices rounded and often much narrowed, rather closely appressed, fulvous-pubescent or in age gray-pubescent or glabrate; acorn about 16 , rarely $20 \mathrm{~mm}$. long, 13 or rarely $20 \mathrm{~mm}$. broad, ovoid to subglobose, rounded at the apex, minutely puberulent, becoming glabrate and light brown, about one-third included in the cup.

This has been reported from Guatemala as Q. Sartorii Liebm., a Mexican species. It is one of the most abundant oaks of Guatemala, especially in Huehuetenango.

Quercus corrugata Hook. Icon. Pl. 5: pls. 403, 404. 1842 (type from Cerro del Tambor, Chimaltenango[?]-Skinner 5). Q. cyclobalanoides Trelease, Proc. Amer. Phil. Soc. 54: 11. pl. 3. 1915 (type from Chiapas). Q. Reevesii Trelease, Mem. Nat. Acad. Sci. 20: 45. pl. 22. 1924 (type from mountains west of Volcán de Santa María, Quezaltenango, E. Reeves). Q. corrugata var. granulifera Trelease, loc. cit. $p l$. 24 (type from Guatemala, without definite locality, Warscewicz 11). Q. corrugata var. ipalensis Trelease, loc. cit. (type from Volcán de Ipala, Chiquimula, around the lake, H. Pittier 1869). Chicharro (San Marcos).

Moist or dry mountain forest, 950-1,700 meters; Chiquimula; Alta Verapaz; Suchitepequez; Retalhuleu; Quezaltenango; San 
Marcos. Chiapas; British Honduras; El Salvador; Honduras; Panama.

A medium-sized or large tree, sometimes 20 meters high or more, the twigs slender or coarse, $1.5-5 \mathrm{~mm}$. thick, glabrous or at first strigose but soon glabrate, brown at first, becoming gray; buds $3 \mathrm{~mm}$. long, round-ovoid, glabrous, grayish brown; leaves thick and rather hard, 5 to usually 15 or even $25 \mathrm{~cm}$. long, 2-5 or as much as $7 \mathrm{~cm}$. wide, lanceolate to oblanceolate or sometimes elliptic to obovate, acute to attenuate-acuminate, with a narrowly rounded or acute tip, cuneate to rounded at the base, coarsely dentate with the teeth directed forward and mucronate, entire toward the base, the margin narrowly revolute or plane, somewhat lustrous and glabrous on both surfaces, the old leaves somewhat bullate-granular above or smooth, the lateral nerves 12-18 pairs, prominulous above; petioles 15-40 $\mathrm{mm}$. long or rarely shorter, glabrous or puberulent; staminate catkins $5-6 \mathrm{~cm}$. long, sparsely villous, laxly flowered, the anthers much exserted; pistillate catkins $5 \mathrm{~mm}$. long, 1-2-flowered; fruits annual, solitary on a peduncle 5-10 $\mathrm{mm}$. long, rather large; cup 3-4 or even $6 \mathrm{~cm}$. broad, shallowly cup-shaped or hemispheric, very thick, the scales broadly ovate with narrowed apices, much thickened basally, appressed, closely tomentose; acorn subglobose to ovoid or oblong, 3-5 cm. in diameter, typically corrugate longitudinally but often smooth, dark brown, sparsely villous at first, soon glabrate, about half included in the cup.

Called "roble" in El Salvador; "encino blanco" (Honduras). Two collections from Huehuetenango are noteworthy in having the leaves stellate-puberulent beneath. These have been determined by Dr. Muller with the remark that they are "atypical but not significantly so."

Quercus crispifolia Trelease, Mem. Nat. Acad. Sci. 20: 147. pl. 286. 1924 (type from Tapachula, Chiapas). Q. amphioxys Trelease, op. cit. 141. pl. 268 (type from Volcán de San Salvador, El Salvador). Q. incrassata Trelease, op. cit. 147. pl. 287 (type collected near Tapachula, Chiapas). Encino; Roble; Roble amarillo.

Moist or wet, mixed, mountain forest, 1,300-2,700 meters; Alta Verapaz; Chiquimula; Jalapa; San Marcos. Chiapas; El Salvador.

A large or medium-sized tree, the twigs 1-3 mm. thick, laxly fulvous-stellatetomentose at first, soon glabrate and grayish or reddish brown, with prominent or inconspicuous lenticels; buds 5-6 $\mathrm{mm}$. long, oblong-fusiform, acute, light brown, glabrous, the scales ciliate; leaves thin but hard and rather coriaceous, 10 to usually $15-20$ or rarely $25 \mathrm{~cm}$. long, 3 or 5 or even $7.5 \mathrm{~cm}$. wide, oblanceolate to linear-lanceolate, acuminate to attenuate or flagellate, inconspicuously aristatetipped, attenuate below, the base cuneate to narrowly rounded or rarely subcordate, entire, the upper surface somewhat lustrous, glabrous or stellate-pubescent at the base of the costa, the lower surface similar, usually somewhat more conspicuously stellate-pubescent along the base of the costa, the lateral nerves 15-20 on each side; petioles 5 to rarely $10 \mathrm{~mm}$. long, dark red at the base, laxly fulvous-tomentose becoming glabrate; fruits biennial(?), the cup unknown; acorn broadly ovoid, 
25-30 mm. long, 22-26 mm. broad, minutely sericeous-puberulent becoming glabrate and brown, included only at the base.

Quercus crispipilis Trelease, Mem. Nat. Acad. Sci. 20: 184. pl. 370. 1924. Q. cerifera Trelease, op. cit. 184. pl. 370. 1924 (type from Chiapas). Q. cinnamomea Trelease, op. cit. 184. pl. 371 (type collected between Quiché and Totonicapán, O.F. Cook 27). Ma-ach (Huehuetenango).

Rather dry plains and hillsides in the mountains, $1,400-2,700$ meters; Chimaltenango; Sololá; Quiché; Huehuetenango (type from Guaxacaná, Seler 2667); Totonicapán; Quezaltenango. Chiapas.

A large or medium-sized tree, the twigs $1.5-3 \mathrm{~mm}$. thick, dark reddish brown, with a sparse or dense, stellate, buff tomentum, the lenticels few, scarcely prominent, the branchlets becoming grayish; buds scarcely $2 \mathrm{~mm}$. long, round-ovoid, glabrous, the scales sometimes ciliate, brown; leaves thin but firm and chartaceous, $3-8$ or even $12 \mathrm{~cm}$. long, 1-3 cm. wide, oblong-elliptic to oblong-lanceolate or rarely oblanceolate, acute or usually rounded at the apex, aristate-tipped, rounded or subcordate at the base, rarely subcuneate, entire, the margins minutely revolute and often undulate-crispate, the upper surface rather dull, glabrous or stellatepubescent about the base of the costa, the lower surface dull or somewhat lustrous, inconspicuously low-bullate or smooth, with a more or less dense, buff, stellate tomentum, tardily glabrate or persistently hairy, the lateral nerves 12-15 or even 20 pairs; fruits biennial, solitary, geminate, or several on a peduncle, $2-7$ or rarely $10 \mathrm{~mm}$. long; cup about $12 \mathrm{~mm}$. broad, $10 \mathrm{~mm}$. high, turbinate, constricted at the base, the margin inrolled, the scales ovate-lanceolate, rounded at the apex, rather closely appressed, grayish-puberulent; acorn about $12 \mathrm{~mm}$. long and $8 \mathrm{~mm}$. broad, glabrous or slightly sericeous, light brown, about one-half or two-thirds included in the cup.

This seems to be one of the common oaks of Huehuetenango, where oaks and pines usually are the dominant trees of the landscape, at least in the drier regions of that department.

Quercus crispipilis var. pannosifolia Muller, U. S. Dept. Agr. Misc. Publ. 477. 79. 1942. Q. brachystachys f. caerulea Trelease, Mem. Nat. Acad. Sci. 20: 130. pl. 240. 1924 (type from barranco below Quezaltenango, Trelease 29). Q. brachystachys f. venulosa Trelease, loc. cit. (type from barranco below Quezaltenango, Trelease 28). Q. Skutchii Trelease, Journ. Wash. Acad. Sci. 23: 61. 1933 (type from Chichavac, Chimaltenango, A. F. Skutch 44). Q. chichavacana Trelease, op. cit. 62 (type from Chichavac, Chimaltenango, Skutch 57). Q. chimaltenangana Trelease, loc. cit. (type from Chichavac, Chimaltenango, Skutch 62). Q. aristigera Trelease, op. cit. 63 (type from Chichavac, Chimaltenango, Skutch 86). Q. chichavacana f. undulata Muller, Amer. Midl. Nat. 18: 852. 1937 (type 
from Chichavac, Chimaltenango, Skutch 689). Q. chichavacana f. sublobata Muller, loc. cit. (type from Chichavac, Skutch 712). Q. chichavacana f. oblanceolata Muller, loc. cit. (type from Chichavac, Skutch 681). Q. pannosifolia Muller, op. cit. 855 (type from Chichavac, Skutch 698). Encino; Masket (Volcán de Santà María, Quezaltenango).

Usually on dry plains or hillsides in oak or pine-oak forest, sometimes with Juniperus, 1,400-2,900 meters; Guatemala; Chimaltenango; Quiché; Huehuetenango; Quezaltenango. Chiapas.

A large or medium-sized tree, similar in most respects to the typical form of the species; leaves thick and firm, 3-10 or even $14 \mathrm{~cm}$. long, $1.5-4$ or even $6 \mathrm{~cm}$. wide, oblong-elliptic to obovate or oblanceolate, rarely lanceolate, usually broadest above the middle, rounded to acute or rarely acuminate at the apex, aristatetipped, cuneate to rounded, truncate, or cordate at the base, entire or coarsely several-dentate or sublobate, the lobes broadly rounded but mucronate, the margins often coarsely crispate, the upper surface somewhat lustrous, sparsely stellatepubescent becoming glabrate or persistently pubescent about the base of the costa, the lower surface dull, densely velutinous-stellate-tomentose with buff or brownish, curled hairs becoming subglabrate or persistently flocculent to velutinous, the surface low-bullate; petioles 4-12 $\mathrm{mm}$. long; fruits solitary or geminate on a glabrous peduncle $3-10 \mathrm{~mm}$. long; cup $12-20 \mathrm{~mm}$. broad, $10-12 \mathrm{~mm}$. high, hemispheric to cup-shaped or turbinate, the scales oblong or ovate, truncate, rather laxly appressed; acorn ovoid to subellipsoid, $15-18 \mathrm{~mm}$. long, 10-14 mm. broad, glabrous, light brown, half or more included in the cup.

Quercus flagellifera Trelease, Mem. Nat. Acad. Sci. 20: 162. pl.319. 1924. Encino.

Moist or wet, usually mixed, mountain forest, 1,250-2,500 meters; endemic, but to be expected in Chiapas; Alta Verapaz (type from Secoyonté, near Finca Sepacuité, O. F. Cook \& R. F. Griggs 607); Chiquimula (Volcán de Quezaltepeque); El Progreso (Sierra de las Minas); Sololá; Suchitepequez; San Marcos (Volcán de Tacaná); Huehuetenango (Sierra de los Cuchumatanes).

A tree of 15-20 meters, the twigs slender, 1-2 mm. thick, stellate-villous at first becoming glabrate and reddish brown; leaves rather thin but becoming coriaceous, mostly $8-16 \mathrm{~cm}$. long and $1.5-2.5 \mathrm{~cm}$. wide, linear-lanceolate to linearoblanceolate, narrowly long-attenuate, often aristate-tipped, gradually attenuate to the cuneate or very narrowly rounded base, entire or rarely with a few aristate teeth toward the apex, the margins rather conspicuously but very narrowly revolute, somewhat lustrous on the upper surface, glabrous or inconspicuously pubescent, especially near the base of the costa, lustrous beneath, glabrous or the costa sometimes sparsely stellate-pubescent, the lateral nerves mostly 18-24 pairs, divergent at a wide angle, plane or prominulous on the upper surface; petiole about $2 \mathrm{~mm}$. long, tardily glabrate; acorns unknown. 
Quercus hondurensis Trelease, Mem. Nat. Acad. Sci. 20: 140. pl. 266. 1924. Q. comayaguana Trelease in Standl. Journ. Arnold Arb. 11: 25. 1930 (type from Honduras). Q. guayabalana Trelease in Standl. Field Mus. Bot. 8: 6. 1930 (type from Honduras).

In pine-oak forest on mountain slopes, 800-1,500 meters; Zacapa (Sierra de las Minas); Huehuetenango (Sierra de los Cuchumatanes). British Honduras (mountain pine ridge, San Agustín); El Salvador; Honduras.

A large or medium-sized tree, the twigs 2-4 mm. thick, persistently velutinoustomentose with a yellow or buff tomentum, becoming dark reddish brown; buds $5 \mathrm{~mm}$. long, broadly fusiform, apparently glabrous; leaves thick and coriaceous, $8-12$ or even $18 \mathrm{~cm}$. long, 3-6 cm. wide, lance-elliptic to oblong or oblanceolate, obtuse to usually acute or acuminate or rarely rounded at the apex, sometimes aristate-tipped, cordate or rounded at the base, entire or slightly undulate and usually crispate, the margins minutely or coarsely revolute, somewhat lustrous on the upper surface, minutely stellate-pubescent at first, soon glabrate, the costa persistently tomentose, the lower surface similar, not bullate, the lateral nerves 8 to usually $10-12$ pairs, slightly impressed above, very prominent beneath; petioles 5-10 mm. long, tomentose like the twigs; staminate catkins $5-10 \mathrm{~cm}$. long, villous, sparsely flowered, the anthers well exserted; fruits annual, solitary or geminate, the peduncle 5-10 mm. long, yellow-tomentose or glabrate; young cups rather small, half-round or constricted at the base, the scales ovate, thin, bufftomentose, the narrowed apices rounded, closely appressed; young acorns sericeous, becoming glabrate and light brown, becoming exserted when half grown.

Called "encino" and "encino de cerro" in Honduras; "roble negro," "roble amarillo," "roble mamilca" (El Salvador).

Quercus insignis Mart. \& Gal. Bull. Acad. Brux. 10, pt. 1: 219. 1843. Q. Schippii Standl. Carnegie Inst. Wash. Publ. 461: 53. 1936 (type from Camp 36, boundary between Petén and British Honduras, W. A. Schipp 1248).

Moist or wet, mountain forest, about 850 meters; Petén. Southern Mexico; British Honduras; Honduras; Costa Rica.

A tree about 30 meters high with a trunk a meter in diameter, the twigs 4-6 mm. thick, densely yellow-tomentose at first, becoming glaucous or gray; buds 10-15 mm. long, ovoid, glabrous; leaves rather thick and hard, large, 10-28 $\mathrm{cm}$. long, 4-10 cm. wide, elliptic to oblong-elliptic or narrowly obovate, acute, with a rounded tip, cuneate to rounded or truncate at the base, subentire to undulate or rarely dentate, the upper surface somewhat lustrous, glabrous, or puberulent along the nerves, the costa tomentose, the lower surface dull, fulvous-villoustomentose or glabrate, the lateral nerves 18-20 pairs, elevated on the upper surface and prominent beneath; petioles $8-25 \mathrm{~mm}$. long, densely fulvous-tomentose; fruits annual, solitary, subsessile, very large at maturity; cup $4-8 \mathrm{~cm}$. broad, saucer-shaped or deeper, often contracted at the base, the scales very coarse, oblong or attenuate, much thickened and very broad at the base, the narrow apices 
laxly appressed or spreading, densely fulvous-tomentose or in age glabrate; acorn 4-7 cm. broad, depressed-hemispheric, longitudinally striate, very thick-shelled, about half included in the cup.

This, like some of the other local species, is noteworthy for its very large acorns, of a size never found in temperate North America.

Quercus oleoides Schlecht. \& Cham. Linnaea 5: 79. 1830. Q. oleoides var. australis Trelease, Mem. Nat. Acad. Sci. 20: 114. pls. 192, 193. 1924. Encino negro; Roblecito.

Moist or dry plains or hillsides, often in lowland pine forest, 300 meters or lower; Petén; Alta Verapaz; Izabal; Zacapa; Chiquimula. Southern Mexico; British Honduras; Honduras; Costa Rica (Guanacaste).

Usually a small tree with a short trunk and a dense, somewhat depressed, spreading crown; branchlets densely and shortly stellate-tomentose, becoming glabrate or persistently puberulent, gray; buds about $2 \mathrm{~mm}$. long, dark reddish brown, glabrate; leaves persistent, thick and stiff, $4-8 \mathrm{~cm}$. long and $2-4 \mathrm{~cm}$. wide, or sometimes $10 \mathrm{~cm}$. long and $6 \mathrm{~cm}$. wide, obovate to oblanceolate or rarely elliptic or rhombic, broadly rounded to acute at the apex, cuneate or subobtuse at the base, entire or sometimes with a few mucronate teeth, especially toward the apex, stellate-puberulent on the upper surface, becoming glabrate or persistently pubescent, somewhat lustrous, densely and minutely stellate-pubescent beneath with an appressed tomentum, the veins often glabrate, the lateral nerves $6-8$ pairs; petioles 4-6 mm. long, or sometimes 2-10 mm.; staminate catkins about $3 \mathrm{~cm}$. long, the rachis puberulent, rather closely flowered, the anthers puberulent, scarcely exserted; pistillate catkins 5-25 mm. long, 1-8-flowered; fruits annual, solitary, geminate, or several on a peduncle 1-6 cm. long; cup turbinate or hemispheric, 10-15 mm. broad, the scales flat or somewhat carinate, not evidently thickened basally except on very young cups, subacute, gray-puberulent; acorn 18-25 mm. long, 13-18 mm. broad, ovoid or ellipsoid, glabrous, light brown, about one-third or sometimes only one-fourth included in the cup.

Called "encino prieto" and "hojaviushi" in Oaxaca; "encino" (Honduras); "roble" (Chiapas). A collection from the Department of Guatemala doubtless was taken from a tree planted in Guatemala, probably in Finca La Aurora. This species is related to the common live oak (Quercus virginiana Mill.) of the Gulf region of the United States. It is a lowland tree in Central America, seldom if ever forming pure stands but occurring as isolated individuals in forests of pine or mixed trees.

Quercus oocarpa Liebm. Dansk. Vid. Selsk. Forth. 184. 1854 (type from Guatemala, Warscewicz 50a, the locality unknown). Q. Warscewiczii Liebm. op. cit. 187 (based on the same collection as Q. oocarpa). Q. Yunckeri Trelease in Yuncker, Field Mus. Bot. 


\section{7: 358. 1938 (type from Honduras). Roble; Encino; Ji (Huehue- tenango).}

Wet to dry, mixed, oak, or pine-oak forest, sometimes in cloud forest but also on open rocky mountain slopes, 800-2,400 meters; Alta Verapaz; Baja Verapaz; Zacapa; Chiquimula; Guatemala; Huehuetenango. Honduras; Costa Rica; Panama.

A medium-sized or large tree, sometimes 25 meters high or more, the twigs rather stout, 3-5 mm. thick, at first densely fulvous-tomentose, becoming glabrate and gray or light brown, with a few scarcely evident lenticels; buds oblong, acute, $4 \mathrm{~mm}$. long, glabrous; leaves thin and papery or rather firm, 10-30 cm. long, 3-14 $\mathrm{cm}$. wide, oblanceolate to obovate or narrowly elliptic, attenuate-acute, narrowly rounded or cuneate at the base, undulately or acutely low-dentate except near the entire base, the upper surface somewhat lustrous, glabrous or glabrate, when young often minutely puberulent, the costa often persistently fulvous-tomentose, the lower surface dull, persistently and sparsely villous, especially on the nerves and veins, the lateral nerves 14-22 pairs; petioles 3-5 mm. long, densely or sparsely fulvous-tomentose; fruits annual, rather large, solitary or geminate on a peduncle 5-18 mm. long; cup 3-4 cm. broad, openly goblet-shaped or cup-shaped, the scales triangular-ovate to oblong, narrowly obtuse, densely short-pubescent, laxly appressed; acorn depressed-subglobose or ellipsoid, $2.5 \mathrm{~cm}$. long, $3 \mathrm{~cm}$. broad, one-half to only one-fourth included in the cup.

This species, and perhaps some of the others also, often bear on their branches great numbers of solid, hard, and heavy galls. These vary greatly in size, some of them being as much as $15 \mathrm{~cm}$. in diameter and at times probably weighing several pounds. A study of the oak galls of Guatemala would be of considerable entomological interest, for there seems to be a great variety in their forms.

Quercus pacayana Muller, U. S. Dept. Agr. Misc. Publ. 477: 30. pl. 30. 1942.

Moist or wet, mixed, mountain forest, 1,800-2,600 meters; endemic; Zacapa (region of Cerro de Monos, Sierra de las Minas); Guatemala (upper slopes of Volcán de Pacaya, above Las Calderas; type, Standley 58467).

A large tree, the twigs $1.5-3 \mathrm{~mm}$. thick, glabrate, pale brown becoming gray; buds rounded-ovoid, $3 \mathrm{~mm}$. long, glabrous, light brown; leaves thick and rigid, 4-8 cm. long, 2-3.5 cm. wide, drying somewhat yellowish, elliptic to usually narrowly obovate, broadly rounded at the apex, subcordate or usually rounded at the base, subentire or crenately low-dentate, especially above the middle, the margins narrowly revolute, dull on the upper surface, glabrous or sparsely strigose on the costa, glabrous beneath except on the strigose and fulvous-tomentose costa, the lateral nerves 10-12 pairs, somewhat impressed on the upper surface; petioles 4-12 mm. long, usually about $6 \mathrm{~mm}$., dark reddish brown; acorns unknown. 
Quercus peduncularis Née, Anal. Cienc. Nat. 3: 270. 1801. Q. callosa Benth. Pl. Hartweg. 91. 1842 (type Hartweg 616; Guatemala, "in montibus Las Casillas, Ingenio de Ayarza, Petaxa, Mixco, etc.”). Q. arachnoidea Trelease, Mem. Nat. Acad. Sci. 20: 59. pl. 55. 1924 (type from Volcán de San Salvador, El Salvador). Q. Barbeyana Trelease, op. cit. 67. pl. 76 (type collected between Ipala and Amatillo, Chiquimula, F. C. Lehmann 1711). Q. barbanthera Trelease, op. cit. 68. pl. 81 (type from "road to Petapa,"' Guatemala, Skinner in 1845). Q. barbanthera var. calva Trelease, loc. cit. (type from Garrucha, Chimaltenango, Heyde \& Lux 3152, in part). Q. peduncularis subsp. callosa A. Camus, Monogr. Quercus 2: 599. 1939. Q. aguana Trelease in Yuncker, Field Mus. Bot. 9: 281. 1940. Encino; Roble; Col (Huehuetenango).

Moist or dry plains and hillsides, often forming almost pure stands of considerable extent, or more often associated with other species to form mixed oak forests, or very often associated with pines, 1,000-3,000 meters; Baja Verapaz; Zacapa; Chiquimula; Jalapa; Jutiapa; Santa Rosa; Escuintla; Guatemala; Sacatepéquez; Chimaltenango; Sololá; Quiché; Huehuetenango; Quezaltenango; San Marcos. Southern Mexico; El Salvador; Honduras.

Usually a medium-sized tree with short trunk and spreading crown, sometimes 18 meters high, of ten only a shrub, the trunk sometimes almost a meter in diameter; twigs $1.5-5 \mathrm{~mm}$. in diameter, brown, with numerous pale lenticels, glabrous or at first usually densely stellate-tomentose; buds $2-5 \mathrm{~mm}$. long, ovoid or lanceolate, obtuse or acute, at first sparsely tomentose, glabrate and reddish brown; leaves thick and coriaceous, $6-16 \mathrm{~cm}$. long and 3-10 cm. wide, usually about $12 \mathrm{~cm}$. long and $7 \mathrm{~cm}$. wide, obovate to oblanceolate or elliptic, broadly rounded to obtuse or abruptly acute at the apex, narrowed to the cordate or rarely rounded or even cuneate base, undulately low-dentate or acutely serrate, subentire only near the base, the upper surface stellate-tomentose becoming glabrate or persistently pubescent along the costa, somewhat lustrous, the lower surface densely or sparsely tomentose, persistently pubescent or glabrate, dull when denuded, the surface depressed-bullate, green or waxy-glaucous, the lateral nerves mostly 10-12 pairs, impressed on the upper surface, very prominent beneath; petioles $3-5 \mathrm{~mm}$. long, dark reddish brown, stellate-pubescent or glabrate; staminate catkins 4-7 cm. long, at length loosely flowered, the rachis yellow-villous, the anthers glabrous, moderately exserted; pistillate catkins 1-5 cm. long, with 2-4 or sometimes more numerous flowers scattered toward the end of the yellow-villous peduncle; fruits annual, solitary or several, subsessile or usually pedunculate; cup 15-18 mm. broad, shallowly saucer-shaped to usually hemispheric, the scales ovate to lanceolate, more or less thickened basally, yellowish-pubescent or grayish-puberulent, the apices thin, appressed, narrowly rounded, glabrate; acorn about $15 \mathrm{~mm}$. long and $12 \mathrm{~mm}$. broad, ovoid, densely pubescent at first, becoming glabrate except about the apex, light to very dark brown, one-third to one-fourth included in the cup. 
Called "roble negro" in El Salvador. This is probably the most widely distributed of all the oaks of Guatemala, if one may judge from our own collections, which are very ample and were taken more or less at random. It is one of the abundant trees of the mountains of Guatemala, Chimaltenango, Quiché, and Huehuetenango, and probably the dominant one in some regions. Naturally it is highly variable, and some of the extreme forms look decidedly different from the mass of material, but there is no reason for supposing that they should be separated specifically or otherwise. The trees are heavily infested with insect galls, as are many of the other Guatemalan oaks. The galls, appearing on the leaves and younger branches, are mostly globose and with a very dense covering of cotton-like, very long and soft, bright red or pink hairs.

Quercus peduncularis var. sublanosa (Trelease) Muller, U. S. Dept. Agr. Misc. Publ. 477; 34. pls. 38, 39. 1942. Q. achoteana Trelease in Yuncker, Field Mus. Bot. 17: 356. 1938 (type from Honduras). Q. achoteana var. sublanosa Trelease, loc. cit. (type from Honduras).

Pine-oak or oak forest in the mountains, in dry or moist situations, 1,100-2,000 meters; Baja Verapaz; Zacapa; Jalapa; Jutiapa; Sacatepéquez; Chimaltenango; Huehuetenango. British Honduras; El Salvador; Honduras; Nicaragua.

A medium-sized or large tree, in most respects similar to the typical form of the species but less variable in leaf shape; leaves rather thin, mostly $10-18 \mathrm{~cm}$. long and 5-10 $\mathrm{cm}$. wide, obovate, broadly rounded to rather abruptly acuminate at the apex, much narrowed to the rounded or cordate base, regularly undulatedentate or serrate with mucronate teeth, the upper surface glabrate or the base of the costa puberulent, the lower surface glabrate or persistently stellate-puberulent or villous, the surface flat-bullate, the lateral nerves $12-16$ pairs; petioles 3-7 $\mathrm{mm}$. long; pistillate catkins 2-4-flowered, the peduncle tomentose or glabrate; fruit usually evidently pedunculate, the cup about $18 \mathrm{~mm}$. broad, hemispheric, the scales lanceolate, thickened basally, puberulent or tomentose; acorn ovoid, about $18 \mathrm{~mm}$. long, glabrous, one-third to one-half included in the cup.

Called "roble" or "roble belloto" in El Salvador.

Quercus pilaria Trelease, Mem. Nat. Acad. Sci. 20: 44. pl. 19. 1924 (type from Tapachula, Chiapas). Q. Yousei Trelease in Yuncker, Field Mus. Bot. 17: 358. 1938 (type from Honduras). Encino; Chicharro (Quezaltenango).

Moist or wet, usually mixed, mountain forest, 500-2,400 meters; Alta Verapaz; Escuintla; Guatemala; Sololá; Suchitepequez; Quezaltenango; San Marcos. Chiapas; Honduras; Costa Rica. 
A medium-sized or large tree, sometimes 25 meters high, the twigs slender, 1-2 mm. thick, sparsely pilose and brown, becoming glabrate and gray, with a few scarcely prominent lenticels; buds subglobose, $3 \mathrm{~mm}$. long, glabrate, the scales ciliate; leaves moderately thick and hard, 6-24 cm. long and 2.5-7 cm. wide, usually about $15 \mathrm{~cm}$. long and $4 \mathrm{~cm}$. wide, lanceolate or oblanceolate, attenuateacute, subcordate to cuneate at the base, coarsely crenate-serrate above the middle, the teeth directed forward, mucronate, somewhat lustrous on both surfaces, the costa and nerves somewhat sericeous at first but soon glabrate, the lateral nerves 12-15 pairs; petioles to rarely $4 \mathrm{~mm}$. long, much thickened at the base, glabrate.

The acorns of this species are not known with certainty, but it is believed that a detached acorn from the vicinity of Cobán, depressed-globose and $4.5 \mathrm{~cm}$. broad, belongs here.

Quercus pilicaulis Trelease, Mem. Nat. Acad. Sci. 20: 67. pl. 77. 1924 (type from Guatemala, the locality unknown, Warscewicz 43). Q. tomentosa var. bullata A. DC. in DC. Prodr. 16, pt. 2: 33. 1864 (type from Guatemala, Warscewicz 15). Q. tomentosa var. abbreviata A. DC. loc. cit. (type from Guatemala, Warscewicz 43). Q. pilicaulis f. macrodonta Trelease, Mem. Nat. Acad. Sci. 20: 68. pl. 78. 1924 (type from Guatemala, Warscewicz 15). Q. pilicaulis $\mathrm{f}$. obovalis Trelease, loc. cit. pl. 79 (type from Guatemala, Warscewicz 18). Q. pilicaulis f. Hurteri Trelease, loc. cit. $p l .80$ (type from Quezaltenango, Trelease 32). Q. pilicaulis f. armata Trelease, loc. cit. $p l .79$ (type from Volcán de Santa María, Quezaltenango, E. W. Nelson 3721). Q. pilicaulis f. concava Muller, Amer. Midl. Nat. 18: 851. 1937 (type from Chichavac, Chimaltenango, A.F. Skutch 685). Q. pilicaulis f. elongata Muller, loc. cit. (type from Chichavac, Skutch 687). Q. pilicaulis f. exserta Muller, op. cit. 852 (type from Chichavac, Skutch 661). Q. peduncularis subsp. pilicaulis A. Camus, Monogr. Quercus 2: 601. pl. 197. 1939. Q. peduncularis subsp. Hurteri A. Camus, op. cit. 603. pl. 197. Encino; Masket (Volcán de Santa María, Quezaltenango).

Dry or moist plains or hillsides in the mountains, in mixed, oak, or pine-oak forest, sometimes on white-sand hillsides, 1,100-2,800 meters; Baja Verapaz; Zacapa; Jutiapa; Guatemala; Sacatepéquez; Chimaltenango; Sololá; Huehuetenango; Quezaltenango; San Marcos. Chiapas.

A large or medium-sized tree, the twigs stout, $2-4 \mathrm{~mm}$. thick, brown or becoming gray, with or without prominent lenticels, at first densely fulvous-tomentose, soon glabrate or rather persistently pubescent; buds $2-3 \mathrm{~mm}$. long, broadly ovoid to rounded, brown, glabrate; leaves very thick and leathery, 5-12 or even $20 \mathrm{~cm}$. long, 2.5-7 or as much as $12 \mathrm{~cm}$. wide, typically obovate to subrotund or almost oblanceolate, usually broadly rounded at the apex, cordate or subcordate at the 
base, subentire to undulate, apiculate-undulate, or with coarse, acute or obtuse teeth, the margins cartilaginous and narrowly revolute, the upper surface at first puberulent, soon glabrate except along the costa and nerves, somewhat lustrous, the lower surface persistently tomentose with a dense or sparse, buff tomentum, the denuded surface rather prominently bullate, the lateral nerves 7-10 pairs; petioles 3-7 $\mathrm{mm}$. long, dark brown, tomentose or glabrate; staminate catkins 6-10 cm. long, fulvous-pilose, loosely flowered, the anthers glabrous, much exserted; pistillate catkins 1-10 cm. long or longer, 2-15-flowered distally or along the stellate-pubescent peduncle; fruits annual, on long or short peduncles, $2-15 \mathrm{~cm}$. long; cup usually about $14 \mathrm{~mm}$. broad, sometimes $20 \mathrm{~mm}$. or only $8 \mathrm{~mm}$., usually hemispheric but sometimes deeply cup-shaped or deeply saucer-shaped, the margin straight or sometimes flaring, the scales narrowly ovate or cuneate, sometimes thickened basally, the apices narrowly rounded, thin, often laxly appressed, densely puberulent or tomentose, buff or the glabrate tips deep red; acorn 15-23 $\mathrm{mm}$. long, 8-15 mm. broad, ovoid to oblong or long-conic, obtuse or acute, light brown, glabrate, one-third to one-fifth included in the cup.

This is a common tree of the mountains, especially in the Occidente. It is particularly abundant on Volcán de Santa María and is apparently the only oak there at middle and high elevations. It ascends there to about 3,450 meters, a higher elevation than is reached commonly in Guatemala by oak trees.

Quercus polymorpha Schlecht. \& Cham. Linnaea 5: 78. 1830 (type from Veracruz). Q. guatimalensis A. DC. in DC. Prodr. 16, pt. 2: 78. 1864 (type from Guatemala, Warscewicz 37, the locality unknown). Q. turbinata Liebm. Dansk. Vid. Selsk. Forh. 186. 1854, not Q. turbinata Blume, 1825 (type, Warscewicz 37). Roble.

Moist or dry slopes, usually in oak forest, 1,000-2,000 meters; Zacapa; Chiquimula; Jalapa; Huehuetenango. Mexico; Honduras.

A small or medium-sized tree, the twigs $2-3 \mathrm{~mm}$. thick, reddish brown, at first laxly buff-tomentose, soon glabrate, with numerous pale lenticels; buds 3-5 $\mathrm{mm}$. long, ovoid or lance-ovoid, acute, reddish brown, glabrate or rather persistently pubescent; leaves rather thick and stiff, $5-15 \mathrm{~cm}$. long, 3-8 cm. wide, oblongelliptic to ovate, lanceolate, or obovate, broadly or narrowly rounded at the apex and often emarginate, rarely acuminate but with a rounded tip, cordate or rounded at the base, entire or crenately coarsely mucronate-dentate above the middle, the upper surface dull or lustrous, glabrate, the lower surface somewhat waxy-glaucous, rather persistently buff-floccose or glabrate, the lateral nerves 10-14 pairs, impressed above, very prominent beneath, the veins also prominent and sharply elevated beneath; petioles 6 to usually $15-25 \mathrm{~mm}$. long, glabrate, reddish brown; staminate catkins $6-8 \mathrm{~cm}$. long, floccose, rather densely flowered, the anthers glabrous, much exserted; pistillate catkins 5-10 mm. long, 1-2-flowered; fruits annual, solitary or geminate on a peduncle $5-30 \mathrm{~mm}$. long; cup about $15 \mathrm{~mm}$. broad, hemispheric, the scales conspicuously thickened basally, acute and appressed at the apex, puberulent; acorn $20-25 \mathrm{~mm}$. long, $12 \mathrm{~mm}$. broad, about one-half included in the cup. 
Quercus purulhana Trelease, Mem. Nat. Acad. Sci. 20: 63. pl. 64. 1924.

Moist or wet, mountain forest; Baja Verapaz (type from Cuesta de Quililhá, near Purulhá, H. Pittier 163; collected also near Rabinal, between Sabinal and Rabinal, and between Santa Rosa and Salamá). British Honduras (Great Southern Pine Ridge).

Twigs moderate or rather coarse, 2-4 mm. thick, reddish brown, at first sparsely villous, becoming glabrous; buds $2 \mathrm{~mm}$. long, ovoid,. pilose or glabrate; leaves moderately thick, 10-20 cm. long, 4-13 cm. wide, obovate to oblong-elliptic, broadly rounded to acute at the apex, subcordate or deeply cordate at the base, obscurely to deeply undulate, with rounded or mucronate teeth, the cartilaginous margins flat or narrowly revolute, somewhat lustrous on the upper surface, at first minutely puberulent, becoming glabrate, densely fulvous-velutinous beneath with short hairs, the nerves glabrate, the surface waxy where denuded, the lateral nerves 11-15 pairs, slightly impressed above, rather prominent beneath; petioles 3-5 $\mathrm{mm}$. long, reddish brown, puberulent or glabrate; staminate catkins about $4 \mathrm{~cm}$. long, laxly flowered, the rachis tomentose; pistillate catkins $2-4 \mathrm{~cm}$. long, 2-4flowered; fruits annual, solitary, geminate, or aggregate, the peduncle $1.5-2.5 \mathrm{~cm}$. long; immature cup $10 \mathrm{~mm}$. broad, apparently becoming deeply cup-shaped, the scales prominently thickened basally, the apices thin, narrow, laxly appressed, densely tomentulose.

This species probably is one of the common oaks in the open forest of pine and oak on the dry mountains of Baja Verapaz. We have done little collecting there and have not collected this species.

Quercus sapotaefolia Liebm. Dansk. Vid. Selsk. Forh. 185. 1854. Q. microcarpa Leibm. op. cit. 184, not Q. microcarpa Lapeyr. 1813 (type from somewhere in Guatemala, Warscewicz 8). Q. elliptica var. microcarpa A. DC. in DC. Prodr. 16, pt. 2: 71. 1864. Q. guatimalensis A. DC. op. cit. 78, in part (Guatemala, Warscewicz 37). Q. parviglans Trelease, Proc. Amer. Phil. Soc. 54: 8. 1915 (new name for Q. microcarpa). Q. parviglans f. polycarpa Trelease, Mem. Nat. Acad. Sci. 20: 152. pl. 299. 1924 (type collected between Salamá and Purulhá, Baja Verapaz, O.F. Cook 291). Q. parviglans f. Tejadana Trelease, loc. cit. (type from Alotepeque, Chiquimula, Tejada 209). Q. apanecana Trelease, op. cit. 152. 1924 (type from El Salvador). Q. correpta Trelease, op. cit. 153. pl. 300, in part (Guatemala, Warscewicz 25). Q. Donnell-Smithii Trelease, op. cit. 162 (El Zapote, Dept. Guatemala, J. D. Smith 1967). Q. siguatepequeana Trelease in Standl. Journ. Arnold Arb. 11: 25. 1930 (type from Honduras). Q. perseaefolia var. achoteana Trelease in Yuncker, loc. cit. (type from Honduras). Roble; Encino; Xaccoy (Baja Verapaz). 
Wet to dry, usually mixed oak-pine forest, 800-2,600 meters; Alta Verapaz; Baja Verapaz; El Progreso; Jalapa; Guatemala; Quiché; Huehuetenango; San Marcos. Chiapas; British Honduras; El Salvador; Honduras; Costa Rica.

A small to large tree, sometimes 30 meters high, or often only a large shrub, the twigs $1.5-2.5 \mathrm{~mm}$. thick, laxly tomentose or stellate-pubescent, becoming glabrate, or persistently floccose, light brown to dark reddish brown, with numerous pale lenticels, becoming grayish; buds $3 \mathrm{~mm}$. long, acute, glabrous, the scales sometimes ciliate, reddish brown; leaves often persistent for several years, thick and coriaceous, $4-8$ or often $12 \mathrm{~cm}$. long, $1-4 \mathrm{~cm}$. wide, oblanceolate to oblong or elliptic-oblong, of ten broadest above the middle, narrowly rounded and aristatetipped to usually broadly or narrowly rounded and not apiculate at the apex, cuneate to usually narrowly rounded at the base, or sometimes broadly rounded or even subcordate, entire, the margins coarsely revolute, sometimes crispate, the upper surface dull or lustrous, glabrous, the lower surface not bullate, somewhat lustrous in age, sometimes waxy-glaucous, usually glabrous, or inconspicuously barbulate in the axils of the nerves, sometimes rather persistently floccose, the lateral nerves 10-18 pairs, slightly or not at all depressed on the upper surface; petioles $2-4$ or even $7 \mathrm{~mm}$. long, stellate-pubescent to glabrate; staminate catkins 5-8 cm. long, rather laxly flowered, sparsely short-villous, the anthers apiculate, well exserted; pistillate catkins 1-3-flowered or rarely 6-8-flowered, subsessile or usually pedunculate, the peduncle $2-20 \mathrm{~mm}$. long; fruits annual, solitary, geminate, or in 3's or more, subsessile or usually pedunculate, the peduncle sometimes $3 \mathrm{~cm}$. long, with scattered fruits; cup small or moderate, $8 \mathrm{~mm}$. broad, cup-shaped, the scales broadly ovate, very thin and tightly appressed, sparsely sericeous or glabrate and light brown and lustrous; acorn about $15 \mathrm{~mm}$. long and $7 \mathrm{~mm}$. broad, ovoid or usually narrowly ellipsoid, finely sericeous or glabrate, light brown, about one-fourth included in the cup.

Sometimes called "encino curtidor" in Honduras; "encino malcote" (El Salvador). This has been reported from Guatemala as Q. nectandraefolia Liebm. and Q. totutlensis A. DC. It is one of the abundant oaks in the oak forests that cover much of the Department of Guatemala, and it is common also in the Cobán region, but the species seems to have a curious, locally restricted distribution in Guatemala. Since its distribution is so wide in the Department of Guatemala, it might well be expected in all the areas where oak forests occur.

Quercus segoviensis Liebm. Dansk. Vid. Selsk. Forh. 186. 1854. Encino.

Moist or dry, mountain forest, with other oaks or in mixed associations, 1,000-2,400 meters; Zacapa; Jalapa; Guatemala; Chimaltenango; Sololá; Huehuetenango; San Marcos. Honduras; Nicaragua.

A medium-sized or large tree, the twigs $1.5-5 \mathrm{~mm}$. thick, stellate-tomentose, becoming glabrate and reddish brown, with numerous prominent pale lenticels; 
buds 4-5 mm. long, ovoid or narrowly conic, acute, reddish brown, glabrate or persistently pubescent about the apex; leaves often drying yellowish brown, 8-15 $\mathrm{cm}$. long, 4-9 cm. wide, broadly obovate to oblanceolate-obovate, broadly rounded at the apex, usually narrowed to the cordate or rarely cuneate base, erose-crenate with mucronate crenations, or entire toward the base, the upper surface dull, glabrate, the lower surface stellate-velutinous, becoming glabrate or somewhat persistently pubescent, the surface low bullate-granular, the lateral nerves 8-11 pairs, prominent on both surfaces; petioles 3-7 $\mathrm{mm}$. long, reddish, glabrate; cup $20 \mathrm{~mm}$. broad, hemispheric, the scales broadly ovate with narrowed obtuse apices, closely appressed, tomentulose; acorn broadly ellipsoid, about $20 \mathrm{~mm}$. long and $17 \mathrm{~mm}$. broad, pale grayish brown, glabrate, scarcely one-third included in the cup.

The pink galls found commonly on the leaves are called "chinchines de encino."

Quercus Skinneri Benth. Gard. Chron. 1841: 16. 1841; Pl. Hartweg. 90. 1842. Q. grandis Liebm. Dansk. Vid. Selsk. Forh. 183. 1854 (type collected in Guatemala by Warscewicz). Q. chiapasensis Trelease, Proc. Amer. Phil. Soc. 54: 9. pl. 2. 1915. Q. salvadorensis Trelease in Standl. Field Mus. Bot. 8: 5. 1930. Q. hemipteroides Muller, Amer. Midl. Nat. 18: 853. 1937 (type from Finca San Francisco, Quiché, A.F. Skutch 1875). Chicharro; Encino.

Usually in moist or wet, mountain forest, or often left in plantations when forest is cleared, frequently seen in cafetales of the Pacific slope, sometimes planted in regions where not native, as about Cobán, 900-2,100 meters; based on Hartweg 615, the localities reported by the collector as Pacific mountain slopes of Acatenango, Medio-monte, and Quezaltenango; Alta Verapaz (probably only in cultivation); Baja Verapaz; Escuintla; Guatemala (perhaps only in cultivation); Sacatepéquez; Chimaltenango; Sololá; Quiché; Quezaltenango; San Marcos. Chiapas; El Salvador; Honduras.

A medium-sized or often very large tree, the twigs $2-4 \mathrm{~mm}$. thick, glabrous or at first fulvous-tomentose and becoming glabrate, dark reddish brown; buds 4-7 mm. long, ovoid, obtuse, sparsely pubescent or glabrate, light brown; leaves thin and membranaceous, 8-12 or even $30 \mathrm{~cm}$. long, 3-6 or even $12 \mathrm{~cm}$. wide, broadly lanceolate or obovate to lanceolate or oblanceolate, attenuate or acuminate, cuneate to subcordate at the base, coarsely or finely dentate with low or attenuate teeth, the teeth long-aristate, or the leaves sometimes entire and the teeth represented by aristae, glabrous on both surfaces or with inconspicuous tufts of hairs beneath in the axils of the nerves, the lateral nerves 10-15 pairs, prominent on both surfaces; petioles $2-5 \mathrm{~cm}$. long, or rarely very short; pistillate catkins $5 \mathrm{~mm}$. long, 1-2-flowered at the apex; fruit biennial, large, solitary on a peduncle about $5 \mathrm{~mm}$. long, very polymorphic at different stages of growth; cup $22-45 \mathrm{~mm}$. broad and 8-20 mm. high at maturity, saucer-shaped to hemispheric, the scales ovate, or narrowed at the apex, corky-thickened basally, the thin apex closely appressed, fulvous-tomentulose or in age glabrate; acorn 18-40 $\mathrm{mm}$. long and broad, sub- 
globose to depressed, short-cylindric, or globose-ovoid, the ends usually truncate or rounded, at first loosely tomentose but soon glabrate, about one-fourth included in the cup, the shell very thick and hard.

This is one of the most easily recognizable of the local species, noteworthy for its very large acorns, much larger than those of any northern oaks. The tree is most abundant in the Pacific bocacosta, where it grows in dense mixed forest, and is the only species of oak found in most parts of that area. It often occurs in great abundance, but seldom is the dominant tree. Many of the trees must reach a height of much more than 35 meters, with a proportionately thick, often very high and clean trunk. The name "chicharro," rather curiously, is given commonly to this species and to no other oak, at least on the Pacific slope, although the common term "encino" sometimes is applied to it. The trees seem to grow more rapidly than other native oaks, and they often are planted about fincas, not only in the coffee plantations of the Pacific bocacosta but about Cobán, where handsome rows of large trees may be seen in some localities. The very large acorns are much used in games by children of the Pacific slope, and the boys often fashion ingenious spinning tops from them.

Quercus tristis Liebm. Dansk. Vid. Selsk. Forh. 174. 1854 (type from Guatemala, Warscewicz 12, the locality unknown). Q. castanea A. DC. in DC. Prodr. 16, pt. 2: 72. 1864, in part, not Née, 1801. Q. castanea var. sublobata A. DC. loc. cit. (type from Guatemala, Warscewicz 10). Q. tristis f. sublobata Trelease, Mem. Amer. Acad. Sci. 20: 171. pl. 343. 1924. Q. tristis f. vulcani Trelease, op. cit. 172. pl. 342 (type from Volcán de Pacaya, Guatemala, Scherzer). Q. tristis f. mixcoensis Trelease, loc. cit. (type collected above Mixco, Guatemala, Trelease 31). Q. Scherzeri Trelease, loc. cit. pl. 343 (type from Honduras). Q. consociata Trelease, loc. cit. pl. 345 (type from Guatemala, Warscewicz 9). Roble; Encino; Encino de la herradura; Machichi (Huehuetenango).

Moist or dry, often rocky plains and hillsides of the mountains, generally in oak or pine-oak forest, 1,000-2,600 meters; Chiquimula; Jalapa; Jutiapa; Guatemala; Sacatepéquez; Chimaltenango; Sololá; Huehuetenango; Quezaltenango; San Marcos. Chiapas; El Salvador.

A large or medium-sized tree, the twigs 1-2.5 mm. in diameter, brown or reddish brown with scarcely evident or rarely prominulous lenticels, sparsely stellate-tomentose at first, soon glabrate or rarely persistently pubescent; buds $4 \mathrm{~mm}$. long, ovoid to conic, acute, pubescent or glabrate, light or dark brown; leaves thin but very hard and coriaceous, $3-6$ or often $12 \mathrm{~cm}$. long, mostly $1-2.5$ but 
sometimes $5 \mathrm{~cm}$. wide, oblong or very narrowly obovate-elliptic, almost always broadest above the middle, acute to broadly rounded at the apex and usually apiculate or aristate-tipped, subcuneate to rounded or usually cordate at the base, subentire to characteristically low-aristate-dentate or coarsely dentate with aristate-tipped teeth, especially toward the apex, the upper surface glabrate or somewhat pubescent about the base of the costa, somewhat lustrous, impressedveined, the lower surface stellate-tomentose becoming glabrate, or somewhat floccose along the costa and nerves, with prominent reticulate venation, the surface prominently bullate-granular, the lateral nerves $10-12$ pairs; petioles $2-5$ or even $15 \mathrm{~mm}$. long, glabrate; staminate catkins 5-6 cm. long, laxly flowered, the rachis shortly stellate-pubescent, the anthers well exserted; pistillate catkins on very short peduncles, 1-2-flowered; fruits annual, subsessile or on a peduncle $5 \mathrm{~mm}$. long, solitary or geminate; cup 10-15 mm. broad, shallowly goblet-shaped or cup-shaped, the scales ovate to triangular, with rounded apices, very closely appressed, puberulent or becoming glabrate and lustrous, light brown; acorn 12-15 mm. long, 10-12 $\mathrm{mm}$. broad, ovoid-rounded, very obtuse, minutely sericeous becoming glabrate, about one-third included in the cup or covered at the base only.

This is one of the most abundant of all the Guatemalan oaks. It forms a high percentage of the oak forests of the central and western highlands.

\section{URTICACEAE. Nettle Family}

Annual or perennial herbs, shrubs, or small trees, often with stinging hairs; leaves simple, alternate, opposite, or verticillate, entire, dentate, or lobate, usually bearing punctiform or linear cystoliths on one or both surfaces; stipules usually present; flowers small, commonly green or whitish, variously arranged, in unisexual or androgynous glomerules, dioecious or monoecious; perianth with 2-5 segments or lobes, sometimes none; stamens as many as the perianth segments and opposite them, the filaments reflexed in bud, with reversed anthers, the filaments porrect in anthesis, the anthers erect; ovary superior or slightly inferior (Pouzolzia), 1-celled; style simple, the stigma filiform or penicillate-capitate; ovule 1, erect or ascending; fruit an achene, sometimes enclosed in the accrescent and fleshy perianth; embryo straight; endosperm none or scant.

About forty genera, in temperate and tropical regions of both hemispheres. One other genus is known from Central America, Gyrotaenia, in Panama.

Leaves opposite or verticillate, those of a pair sometimes very unlike (rarely appearing alternate in species of Pilea). Plants mostly herbaceous.

Plants armed with stinging hairs . ................ Urtica. Plants without stinging hairs.

Pistillate perianth parted, not enclosing the achene............Pilea.

Pistillate perianth shallowly lobate, enclosing the achene.......Boehmeria.

Leaves alternate.

Pistillate flowers subtended by conspicuous green bracts. Leaves mostly entire.

Plants shrubs; pistillate flowers paniculate............. Hemistylis.

Plants small herbs; pistillate flowers glomerate in the leaf axils. 
Stigma filiform, papillose-plumose on one side; staminate flowers short-

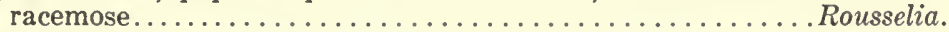

Stigma penicillate, short; staminate flowers in small cymules... Parietaria. Pistillate flowers not subtended by bracts.

Perianth none in the pistillate flowers.

Flowers glomerate in the leaf axils.

Phenax.

Flowers in lax panicles or in long thread-like spikes or racemes.

Perianth present in the pistillate flowers.

Myriocarpa.

Stigma penicillate or very short and in fruit uncinate.

Plants without stinging hairs; leaves white-tomentose beneath.

Plants with stinging hairs; leaves not white-tomentose beneath.

Plants herbaceous; stigma uncinate in fruit............. Fleurya.

Plants shrubs or trees; stigma penicillate-capitate......... Urera.

Stigma linear or filiform, persistent or deciduous.

Plants with stinging hairs; stems succulent, thick...........Laportea.

Plants without stinging hairs; stems not succulent.

Pistillate perianth strongly nerved; achene crustaceous, lustrous; stigma deciduous; leaves often entire.............Pouzolzia.

Pistillate perianth nerveless; achene not crustaceous, dull; stigma persistent; leaves dentate.........................

\section{BOEHMERIA Jacquin}

Small trees, shrubs, or perennial herbs, without stinging hairs; leaves alternate or opposite, petiolate, dentate, 3-nerved, often with punctiform cystoliths; flowers monoecious or dioecious, in small unisexual glomerules, these axillary and sessile or spicate, the spikes often leafy above, or the inflorescence cymose-paniculate; staminate perianth 3-5-parted or 4-lobate, a rudimentary ovary present; pistillate flowers tubular or urceolate, 2-4-dentate; stigma filiform, usually pubescent on one side; achene enclosed in the persistent withering perianth.

About 45 species, widely distributed in tropical and temperate regions. One other species is known from southern Central America.

Flower clusters cymose-paniculate; leaves white-tomentose beneath....B. nivea. Flower clusters sessile in the leaf axils or spicate; leaves not white-tomentose beneath.

Flower clusters sessile in the leaf axils; leaves all alternate.

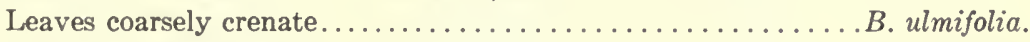

Leaves appressed-serrate or subentire................. Pavonii.

Flower clusters spicate, the spike sometimes leafy at the summit.

Spikes spreading or pendent, leafless; leaves all opposite; a shrub or small

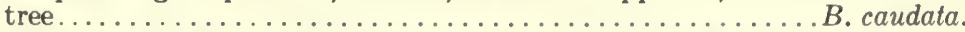

Spikes erect or suberect, leafy at the summit; stem leaves opposite, those of the branches alternate; herb..................... cylindrica.

Boehmeria caudata Swartz, Prodr. Veg. Ind. Occ. 34. 1788. B. guatemalensis Gandoger, Bull. Bot. Soc. France IV. 19: 287. 1919 (type collected in Alta Verapaz, Türckheim). 


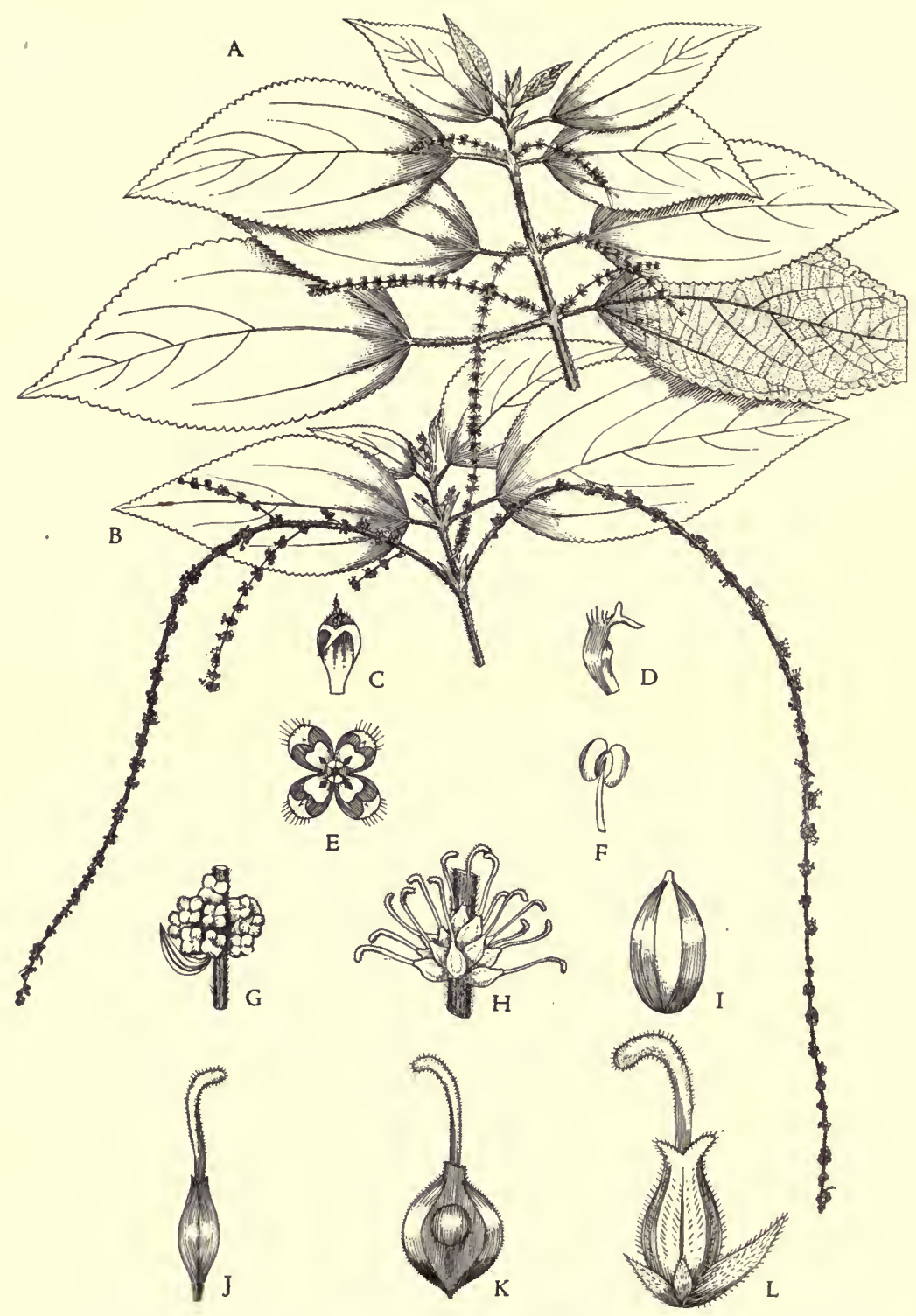

FIG. 53. Boehmeria caudata. A. Habit of upper portion of pistillate plant; $\times 1 / 3$. B. Habit of upper portion of staminate plant; $\times 1 / 3$. C. Staminate petal from within; $\times 13$. D. Staminate petal from side; $\times 13$. E. Staminate flower viewed from above; $\times 7$. F. Stamen; $\times 7$. G. Group of staminate flowers in position; $\times 1$. H. Group of pistillate flowers in position; $\times 3$. I. Seed; $\times 21$. J. Pistil from side; $\times 7$. K. Pistil from the front; $\times 7$. L. Pistillate flower; $\times 7$. 


\section{Alta Verapaz (Senahú, 1,050 meters); San Marcos. Southern} Mexico; Honduras; Costa Rica; West Indies; South America.

A shrub or small tree, sometimes 9 meters high, the young branches densely white-hirsute; leaves long-petiolate, broadly ovate to elliptic, 5-20 cm. long, 3-10 $\mathrm{cm}$. wide, acuminate or long-acuminate, acute to rounded at the base, closely and evenly crenate, hispidulous above and rough to the touch, densely velutinouspilose beneath; spikes very slender, interrupted, leafless, as much as $25 \mathrm{~cm}$. long; fruiting perianth ovate or obovate, its margins thin, membranous. (Fig. 53.)

Boehmeria cylindrica (L.) Swartz, Prodr. Veg. Ind. Occ. 34. 1788. Urtica cylindrica L. Sp. Pl. 984. 1753.

Damp or wet thickets, often in shallow water, 350-1,400 meters; Alta Verapaz. United States and Mexico; Honduras; Costa Rica; Panama; West Indies; South America.

A simple or branched perennial, commonly $50-75 \mathrm{~cm}$. tall, the stems puberulent or almost glabrous, often densely leafy; leaves on long or short petioles, narrowly lanceolate to ovate-lanceolate, mostly $5-11 \mathrm{~cm}$. long, long-acuminate or attenuateacuminate, obtuse or rounded at the base, coarsely dentate, deep green and punctate above, somewhat paler beneath, almost glabrous or sometimes copiously rough-pubescent with short hairs; flower spikes short and about equaling the petioles, or often greatly elongate, naked below but usually leafy toward the apex.

Like most members of the genus, this plant contains a tough fiber.

Boehmeria nivea (L.) Gaud. in Freyc. Voy. Bot. 499. 1826. Urtica nivea L. Sp. Pl. 985. 1753. Ramié; Ramio. Ramie.

Native probably of China, but grown in many remote regions; sometimes planted in central Guatemala, experimentally or as a curiosity.

A coarse herb commonly 1-1.5 meters tall, the young branches hispid; leaves large, thin, long-petiolate, broadly ovate or rounded-ovate, often $15 \mathrm{~cm}$. long and $12 \mathrm{~cm}$. wide, acuminate or caudate-acuminate, broadly cuneate to cordate at the base, very coarsely dentate, thinly hirsute above, green, very rough to the touch, whitish beneath and densely tomentose; inflorescences small or large, often much branched, the flower heads small, globose.

Ramie has been planted in Costa Rica to prevent erosion in gullies. In some parts of the world it is grown extensively for its fiber, and it has been planted in large amounts in California and Louisiana. The fiber is notable for its fineness and strength as well as its endurance. The greatest obstacle to its development in the United States has been the difficulty of devising means of removing the too plentiful resin. If this could be overcome, the fiber would be found highly useful for the manufacture of long-wearing textiles. 
Boehmeria Pavonii Wedd. Ann. Sci. Nat. IV. 1: 202.1854.

Moist or wet thickets along rocky stream banks; El Progreso (Sierra de las Minas, near Finca Piamonte, Steyermark 43749). Peru; Bolivia.

A shrub or small tree, commonly about 2.5 meters high, the branches slender, pilose with short, white, appressed or ascending hairs; leaves alternate, those of adjacent nodes similar but usually very unequal, oblong-lanceolate or ellipticlanceolate, appressed-serrate or subentire, conspicuously 3-nerved, on rather short petioles, attenuate-acuminate, acute or obtuse at the base, flat or slightly rugose, appressed-hispidulous or glabrate above and often lustrous, pale beneath and shortsericeous, the hairs pointing toward the middle of the areolae; larger leaves 4-16 $\mathrm{cm}$. long, the smaller ones 1-3 $\mathrm{cm}$. long and sessile or short-petiolate; flowers dioecious, rarely monoecious, the flowers densely clustered in the leaf axils, the clusters 6-8 $\mathrm{mm}$. in diameter, unisexual, rarely androgynous.

Boehmeria ulmifolia Wedd. Arch. Mus. Paris 9: 347. 1856. $B$. fallax var. ulmifolia Wedd. in DC. Prodr. 16, pt. 1: 198. 1869. Chichicastillo; Chichicaste.

Moist or wet forest or thickets, sometimes in dry thickets, often in second growth, 350-2,800 meters; Petén; Alta Verapaz; El Progreso; Izabal; Chiquimula; Jutiapa; Santa Rosa; Escuintla; Guatemala; Sacatepéquez; Suchitepequez; Retalhuleu; Quezaltenango; San Marcos. Southern Mexico; British Honduras; Honduras; Panama.

Usually a shrub of 1-3 meters, sometimes a tree of 6 meters, the branches very slender, often much elongate, pilose or puberulent to almost glabrous; leaves on short or long petioles, broadly ovate to narrowly oblong-lanceolate, thin, very variable in size, attenuate-acuminate, rounded to subacute at the base and often oblique, coarsely or rather finely crenate or serrate, hispidulous and appressedpilose above, densely short-pilose beneath or often almost glabrous, the alternate leaves unequal, the larger ones 7-15 cm. long and 3-9 $\mathrm{cm}$. wide, the smaller ones much shorter and sometimes very small and stipule-like; flower clusters small, dense, brownish, sessile in the leaf axils or at defoliate nodes; fruiting perianth oblong, narrowed to each end, curved, $1 \mathrm{~mm}$. long, thin-margined, densely pubescent.

Here may belong a Guatemalan record of $B$. ramiflora Jacq. var. cuspidata Wedd., although it is possible that this species does occur in Guatemala. B. ulmifolia is highly variable in respect to leaf form and pubescence.

\section{DEBREGEASIA Gaudichaud}

Shrubs; leaves alternate, petiolate, serrate-crenate, 3-nerved, often gray or whitish beneath; stipules connate; flowers monoecious or dioecious, glomeratecapitate, the pistillate receptacle somewhat fleshy-thickened, the glomerules arising 
in the leaf axils or at defoliate nodes, sessile or in cymes, the bracts scarious; staminate perianth 4-parted, depressed-globose in bud; stamens 4, rarely 3 or 5; pistillate perianth ovoid or obovoid, contracted at the mouth and minutely dentate, in fruit succulent and juicy.

About five species, in tropical Asia and eastern Africa.

Debregeasia longifolia (Burm. f.) Wedd. in DC. Prodr. 16, pt. 1: 235-24. 1869. Urtica longifolia Burm. f. Fl. Ind. 297. 1768.

Abundantly naturalized in some places about Cobán, Alta Verapaz, 1,300 meters, in hedges or wet thickets. Southeastern Asia and Malaysia.

A shrub 1.5-2.5 meters tall, the stout branches hirsute or hispid; leaves longpetiolate, thin, lanceolate or oblong-lanceolate, $10-17 \mathrm{~cm}$. long, acuminate or long-acuminate, rounded or obtuse at the base, rather finely and closely crenateserrate, green above, hispidulous, rough to the touch, closely white-tomentose beneath; flower heads very small, in small lax cymes; fruit heads orange-yellow or red, about $8 \mathrm{~mm}$. in diameter.

The fruits are said to be edible, and it may be on this account that the plant was introduced into the Cobán region. We have no knowledge of its having become naturalized elsewhere in America, and it seems to be scarce in cultivation.

\section{FLEURYA Gaudichaud}

Annuals, somewhat succulent, usually provided with stinging hairs; leaves alternate, petiolate, dentate, 3-nerved, with linear cystoliths; stipules connate; flowers monoecious or dioecious, the glomerules unisexual or androgynous, spicate or paniculate in the leaf axils; staminate perianth 4-5-parted, globose or depressed in bud; stamens 4-5; pistillate perianth of 4 segments, these imbricate, subequal or very unequal; ovary at first straight, soon oblique, the stigma oblique-ovate or linear, finally uncinate-inflexed; achene oblique, compressed, exserted from the perianth.

About eight species in the tropics of both hemispheres. Only one species is found in North America.

Fleurya aestuans (L.) Gaud. in Freyc. Bot. Voy. 497. 1826. Urtica aestuans L. Sp. Pl. ed. 2. 1397. 1763.

Wet thickets or wet or boggy, open ground, at sea level; Izabal. British Honduras; Nicaragua; Costa Rica; Panama. West Indies; tropical South America; Africa.

Plants erect or nearly so, succulent, usually less than a meter tall, the stems densely hirsute or almost glabrous, often very glandular and usually armed with stinging hairs; leaves long-petiolate, broadly ovate, $15 \mathrm{~cm}$. long and $12 \mathrm{~cm}$. wide or usually smaller, acute or acuminate, rounded or subcordate at the base, coarsely 

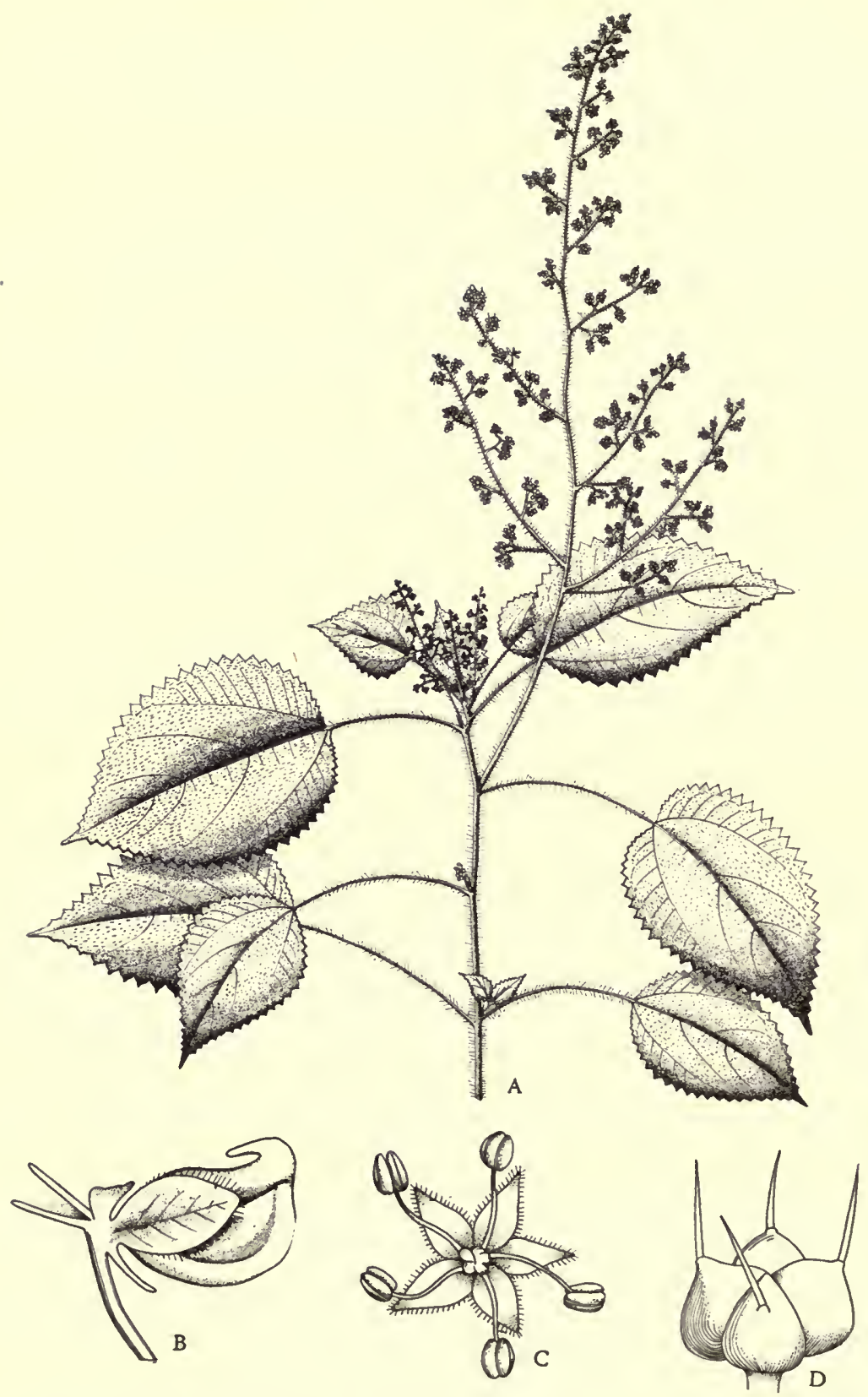

FIG. 54. Fleurya aestuans. A. Habit of upper part of plant; $\times 1 / 3$. B. Fruit with bract; $\times 11$. C. Staminate flower $\times 6$. D. Staminate flower in bud; $\times 6$. 
dentate or crenate, sparsely or rather densely hispid on both surfaces, slightly paler beneath; flowers paniculate, the panicles slender-pedunculate, mostly shorter than the leaves, green, flower clusters mostly androgynous; achene ovate. (Fig. 54.)

The plant stings. It is of only occasional occurrence along the Atlantic coast of Central America, and in many places is absent. Called "nettle," "cow-itch," and "pica" in British Honduras.

\section{HEMISTYLIS Bentham}

Shrubs or small trees; leaves alternate, long-petiolate, 3-nerved, entire or dentate; stipules free; flowers monoecious, the staminate glomerate and spicate, the pistillate geminate and subtended by two foliaceous bracts, the spikes solitary or geminate in the leaf axils; pistillate involucres usually inserted near the base of the spike; staminate perianth 4-parted, subglobose in bud, the segments acute, valvate; stamens 4; pistillate perianth ovoid, contracted and 2-4-dentate at the mouth, compressed in fruit and 2-carinate or 2-winged; stigma filiform, curved, deciduous; achene inclosed in the accrescent perianth, ovoid-conic.

A single species is known in Central America.

Hemistylis odontophylla Wedd. in DC. Prodr. 16, pt. 1: 235-53. 1869.

Damp or wet thickets or forest, 600-900 meters; Santa Rosa. Venezuela and Colombia.

A slender shrub 2-3 meters tall with few long weak branches, these densely or sparsely hispidulous; leaves on long or rather short petioles, apparently deciduous during the dry season, broadly ovate, $20 \mathrm{~cm}$. long and $15 \mathrm{~cm}$. wide or smaller, the upper ones reduced, acuminate or long-acuminate, rounded at the base, rather coarsely dentate, above green, densely puncticulate and hispidulous, slightly rough to the touch, beneath somewhat paler, soft-pilose; inflorescences forming a long narrow dense leafy-bracted panicle $25 \mathrm{~cm}$. long; pistillate flowers subtended by rather large, green, lanceolate to broadly ovate bracts.

This plant presents a rather unusual case of discontinuous distribution. The large panicles, in which the numerous crowded bracts are conspicuous, give it an appearance distinct from any other urticaceous plant of Central America.

\section{LAPORTEA Gaudichaud}

Herbs, shrubs, or small trees, often with stinging hairs; leaves alternate, usually dentate, penninerved or 3-nerved; stipules distinct or connate; flowers monoecious or dioecious, glomerate or cymose and paniculate, the panicles axillary, the flowers and fruits often reflexed; staminate perianth 4-5-parted, depressed in bud, the segments valvate or subimbricate; stamens 4-5; pistillate perianth of four lobes or segments, these equal or very unequal; ovary at first straight, soon oblique, the stigma linear; achene oblique, compressed or slightly ventricose, 
the perianth membranaceous, scarcely accrescent; pericarp membranaceous or fleshy.

About 25 species, in tropical and subtropical regions of both hemispheres, mostly in the Old World. One other Central American species grows in Nicaragua.

Laportea mexicana (Liebm.) Wedd. in DC. Prodr. 16, pt. 1: 84. 1869. Discocarpus mexicanus Liebm. Dansk. Vid. Selsk. Skrivt. V. 2: 309. 1851. Laal (Petén, Maya); Ortïga (Petén).

Wet or moist thickets, 1,200 meters or less; Petén; reported from Guatemala (Río Amatitlán). Southern Mexico; Salvador.

A shrub or small tree 2-5 meters tall, the branches thick, soft, pale, glabrous; leaves clustered at the ends of the branches, long-petiolate, broadly ovate, 5-10 $\mathrm{cm}$. long, 3-6 cm. wide, acute, obtuse or rounded at the base, repand-crenate, green, pilose, abundantly furnished with stinging hairs; flowers dioecious; cymes laxly much branched, the branches retrorse-setulose, longer than the leaves, many-flowered; achenes suborbicular, strongly compressed, green, lustrous, glabrous, the margins narrowly thickened.

In general appearance this is much like the genus Urera, but the fruits are quite different. To judge from the specimens, the shrub must bloom when leafless or when the new leaves are beginning to unfold. Called "chichicaste" and "pan caliente" in Salvador.

\section{MYRIOGARPA Bentham}

Shrubs or small trees, without stinging hairs; leaves alternate, usually large, petiolate, dentate, penninerved and subtrinerved, with cystoliths, these often radiating from the bases or rudiments of the hairs; stipules connate; flowers dioecious or sometimes monoecious, in very long and slender, almost thread-like spikes or racemes, these solitary or fasciculate in the leaf axils or at defoliate nodes, simple or branched, the minute flowers crowded or usually remote along the rachis, the staminate mostly sessile, the pistillate sessile or pedicellate; staminate perianth 4-5-parted, the segments obtuse, imbricate; stamens 4-5; pistillate perianth none; ovary sessile or short-stipitate, compressed; stigma obliquely oblong, villous-papillose, a conspicuous style present; achene ovoid, compressed, the margins often thickened, the pericarp thin-crustaceous.

About seven species, ranging from Mexico to Brazil. One other Central American species is known in Nicaragua.

Pistillate inflorescence paniculate, with short branches; achene long-stipitate, ciliate with very long hairs. Leaves obovate, glabrous........... obovata. Pistillate inflorescence simple or of branched but very long and slender, pendulous racemes; achene sessile or short-stipitate, eciliate or short-ciliate.

Leaves mostly small and less than $5 \mathrm{~cm}$. wide, the cystoliths irregularly distributed over the upper surface................... heterostachya.

Leaves large, mostly 7-15 cm. wide or larger, the cystoliths of the upper surface radiating from the center of the areole. 
Achenes long-ciliate, narrowed to an evident stipe; bractlets divaricate.

$M$. longipes.

Achenes not ciliate, scarcely narrowed at the base; bractlets appressed.

M. yzabalensis.

Myriocarpa heterostachya Donn. Smith, Bot. Gaz. 13: 29. 1888. M. heterospicata Donn. Smith, Bot. Gaz. 12: 133. 1887.

Moist or wet forest, sometimes in thickets on limestone, also in second growth thickets, 1,600 meters or less; Petén; Alta Verapaz (type from Pansamalá, Türckheim 892); Escuintla; Huehuetenango. British Honduras; Nicaragua.

A shrub or a small tree, sometimes 9 meters high but usually much lower; leaves on rather short or sometimes long and slender petioles, lanceolate or lanceovate, sometimes elliptic-lanceolate, mostly 5-15 cm. long and 3-6 cm. wide, acuminate or caudate-acuminate, obtuse at the base, 3-nerved, entire or undulatedentate, strigose beneath on the veins but elsewhere glabrous or nearly so; flowers monoecious, the spikes unisexual, very long and slender, pendent, white, pinkish or dull reddish; staminate spikes few, $7 \mathrm{~cm}$. long or less, once furcate; pistillate spikes up to $20 \mathrm{~cm}$. long, once furcate near the base; achenes elliptic, conspicuously stipitate, sparsely strigillose.

Myriocarpa longipes Liebm. Dansk. Vid. Selsk. Skrivt. V. 2: 306. 1851. M. malacophylla Rob. \& Bartlett, Proc. Amer. Acad. 43: 50. 1907 (type from Gualan, Zacapa, C. C. Deam 361). Chichicaste; Chichicaste manso.

Moist thickets or forest, sometimes in second growth, 200-2,600 meters or less; Alta Verapaz; Petén; Izabal; Zacapa; Sololá; Suchitepequez; Jalapa; Santa Rosa; Chimaltenango; El Quiché; Retalhuleu; Quezaltenango; San Marcos. Southern Mexico; El Salvador; Nicaragua; Costa Rica.

A large shrub or small tree, usually 3-6 meters tall; leaves thin, on long or short petioles, broadly ovate or elliptic to obovate-elliptic, mostly $10-30 \mathrm{~cm}$. long and $8-15 \mathrm{~cm}$. wide, acute or short-acuminate, rounded to broadly cuneate at the base, closely crenate-dentate, of ten rugulose and rough above, rather densely and usually softly pilose or hispidulous beneath; flowers dioecious or rarely monoecious, the spikes long and slender, pendent, once or twice furcate near the base, whitish or pinkish, sometimes pale purplish; achenes elliptic, 1-1.5 mm. long, long-ciliate, narrowed to a short but distinct stipe.

The material is variable in shape and pubescence of the leaves, and it may be that ultimately it can be divided into two or more species. The shrub is easily recognized, with other members of the genus, by its very long and thread-like, whitish spikes that dangle loosely far below the branches, and sometimes attain a great length. In El Salvador this species is often called "chichicaste colorado" 
and "picapica," the latter name referring to the fact that the hairs are sometimes slightly irritant, but not stinging as in Urera.

Myriocarpa obovata Donn. Smith, Bot. Gaz. 46: 117. 1908. M. paniculata Blake, Contr. Gray Herb. 52: 61. 1917 (type from Nicaragua).

Moist or wet thickets or forest, at little above sea level, Petén. British Honduras; Honduras (type from San Pedro Sula); El Salvador; Nicaragua.

A large shrub or small tree, sometimes 12 meters high with a trunk $20 \mathrm{~cm}$. in diameter, the wood soft and pithy, the branches ferruginous, glabrous; leaves petiolate, obovate or oblong-obovate, $16 \mathrm{~cm}$. long and $6 \mathrm{~cm}$. wide or smaller, acute or acuminate, cuneately narrowed to the subobtuse base, 3-nerved, undulatedenticulate or almost entire, glabrous or essentially so; flowers dioecious, the pistillate spikes short, forming lax panicles half as long as the leaves; staminate spikes long and slender, pendulous, furcate; achenes up to $8 \mathrm{~mm}$. long, long-ciliate, long-stipitate.

Myriocarpa yzabalensis (Donn. Smith) Killip, Proc. Biol. Soc. Wash. 40: 29. 1927. M. longipes var. yzabalensis Donn. Smith, Bot. Gaz. 16: 13. 1891 (type from Monte Cachirulo, Izabal, J. D. Smith 1644). Chichicaste; Chichicaste manso.

Wet forest or thickets, in Guatemala at or little above sea level, in other regions sometimes ascending to a greater elevation, frequently in second growth; Alta Verapaz; Izabal; probably also in Petén. British Honduras to Panama.

A coarse shrub or a small tree 2-10 meters high, sparsely branched, the branches green or grayish, the young branches densely hispid; leaves on long or short petioles, lance-oblong to broadly elliptic or rounded-ovate, acute or acuminate, obtuse or rounded at the base, often $30 \mathrm{~cm}$. long and $20 \mathrm{~cm}$. wide, variable in pubescence, glabrate or rough above, often densely hispid beneath with spreading or subappressed hairs; flowers usually dioecious, in very long and slender, white or pinkish, pendulous spikes, these sometimes $40 \mathrm{~cm}$. long, furcate; achenes sessile, scabrous with short white hairs, not ciliate, $1.5 \mathrm{~mm}$. long. (Fig. 55.)

Known in Honduras by the names "chichicastillo" and "tapón." It is reported that in Panama the oropendolas use the thread-like inflorescences for constructing their hanging nests.

\section{PARIETARIA L.}

Annual or perennial herbs, usually diffuse, the pubescence chiefly of uncinate prehensile hairs; leaves alternate, petiolate, entire, 3-nerved or triplinerved, small; stipules none; flowers polygamous, axillary, in dense cymules or fascicles, sessile; outer bracts more or less connate to form an involucre containing 3 or more flowers, sometimes free; perianth deeply 4-lobate, the lobes valvate; stamens 4; ovary 


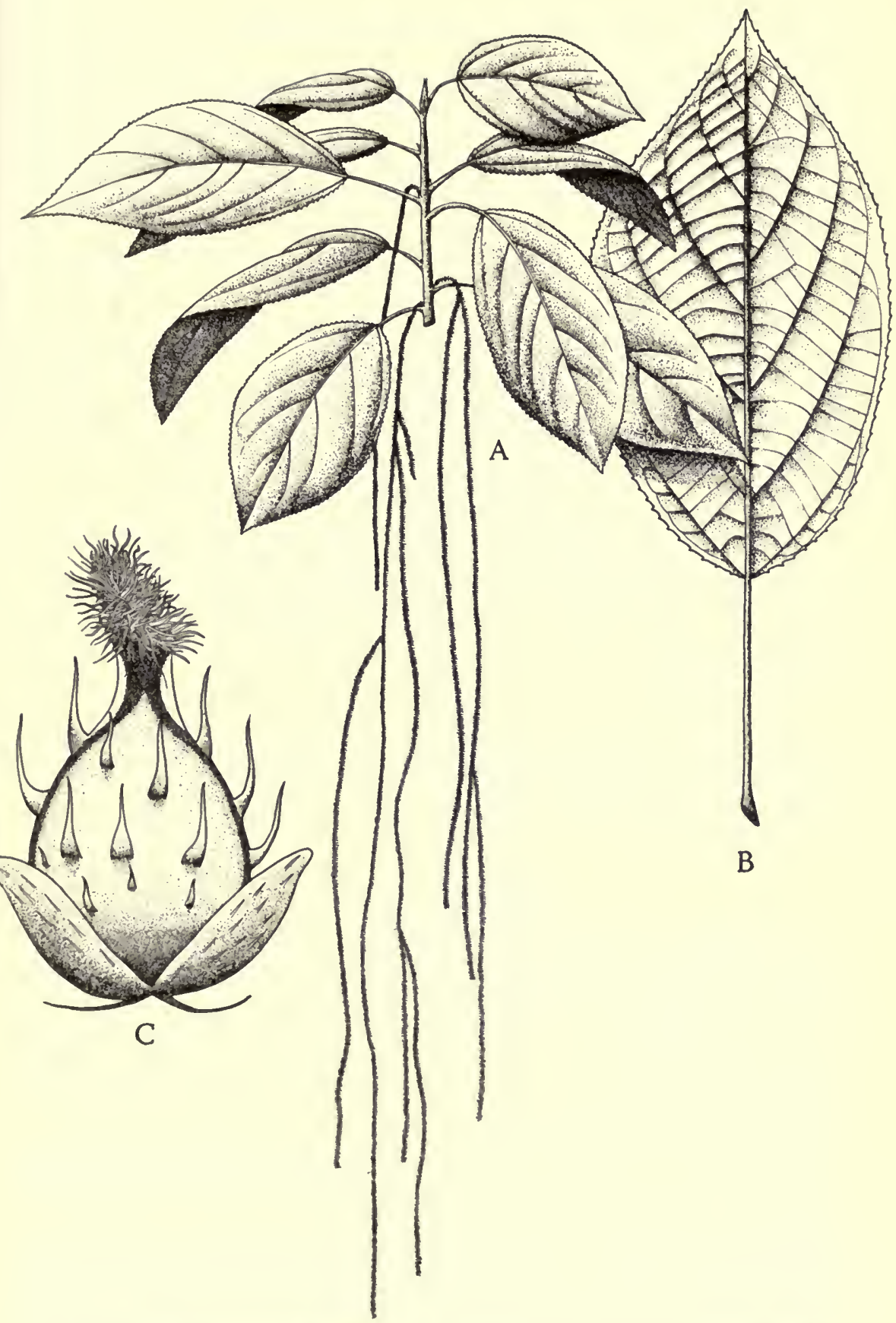

FIG. 55. Myriocarpa yzabalensis. A. Habit of portion of flowering plant; $\times 1 / 4$. B. Leaf; $\times 1 / 2$. C. Seed with bracts; $\times 60$. 
free within the perianth; stigma linear, recurved, penicillate, sessile or borne upon a style; ovule erect from the base of the cell; achene included in the herbaceous perianth, the pericarp thin-crustaceous.

Species about eight, in temperate and tropical regions of both hemispheres. Only one species is known from Central America.

Parietaria debilis Forst. Fl. Ins. Austr. Prodr. 73. 1786. $P$. floridana Nutt. Gen. N. Am. Pl. 1: 208. 1818.

Common in moist shaded places, in forest, frequently in the shade of rocks, often in oak or alder forest, in white sand of the Occidente, sometimes a weed in streets, 1,200-3,700 meters; Alta Verapaz; Guatemala; Sacatepéquez; Chimaltenango; Totonicapán; Huehuetenango; Quezaltenango; San Marcos. Costa Rica; widely dispersed in temperate and tropical regions of both hemispheres.

Plants suberect or diffusely spreading, annual or perennial, fragile and soft, usually much branched, mostly $30 \mathrm{~cm}$. high or less, sparsely or densely soft-pilose almost throughout; leaves on slender and often long petioles, broadly ovate to lance-ovate, mostly 1-3 cm. long, long-acuminate, rounded to subacute at the base, thin, entire, triplinerved, green above, slightly paler beneath, densely whitish-puncticulate above; flowers in axillary cymes, green, the bracts linear or narrowly lanceolate.

A small and inconspicuous weed, sometimes occurring in cultivated ground. It is most plentiful in the mountains of the Occidente, where it often persists throughout the dry season, perhaps because it is not eaten by stock.

\section{PHENAX Weddell}

Mostly shrubs with slender branches, without stinging hairs; leaves alternate, petiolate, crenate or serrate, 3-5-nerved; stipules distinct; flowers monoecious or rarely dioecious, densely glomerate in the leaf axils, the bracts ferruginous, scarious, broad and imbricate; staminate perianth campanulate, 4-lobate above the middle, the lobes broad, valvate or subimbricate, in bud globose or truncate at the apex; stamens normally 4; pistillate perianth none; ovary sessile or short-stipitate, compressed; stigma elongate, persistent; achene more or less compressed, the pericarp thin-crustaceous or submembranaceous.

Ten or more species, all in tropical America, one of them perhaps naturalized in the Old World. In Central America one other species is known, in Costa Rica and Panama.

Leaf blades thin, coarsely crenate, not bullate, usually broadly ovate. P. hirtus. Leaf blades thick, finely and closely crenate.

Leaf blades ovate to lance-oblong, not bullate, glabrate beneath but usually hirtellous on the nerves....................... mexicanus.

Leaf blades broadly ovate, strongly rugose or bullate, densely hirsute beneath. 
Phenax hirtus (Swartz) Wedd. in DC. Prodr. 16, pt. 1: 235-38. 1869. Urtica hirta Swartz, Fl. Ind. Occ. 1: 285. 1797. Chichicastillo.

Moist or wet thickets or forest, sometimes in pine forest, frequently on moist or wet cliffs, common in second growth, $600-2,700$

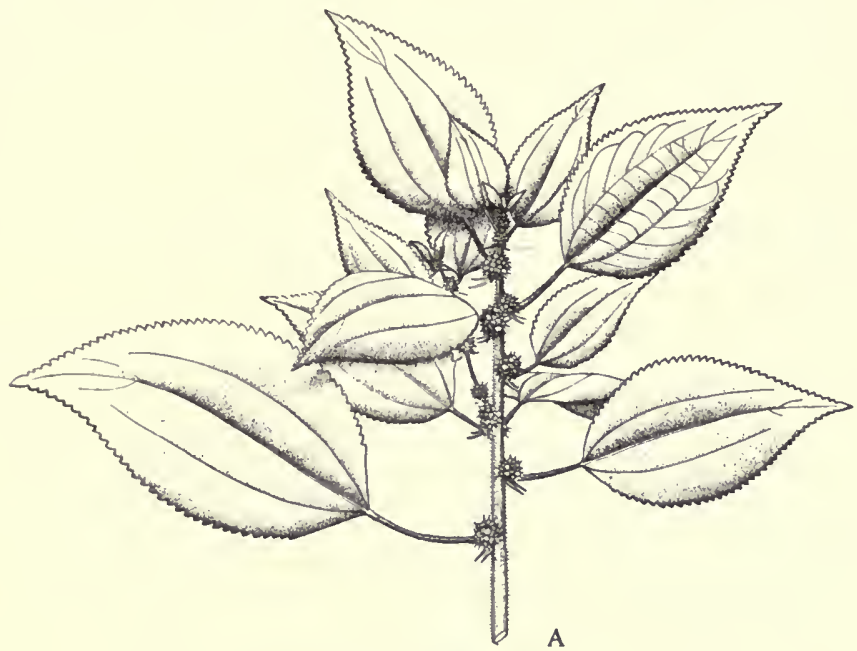

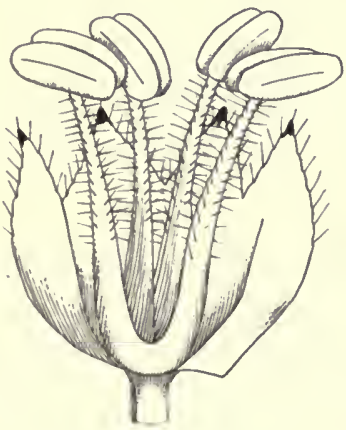

B

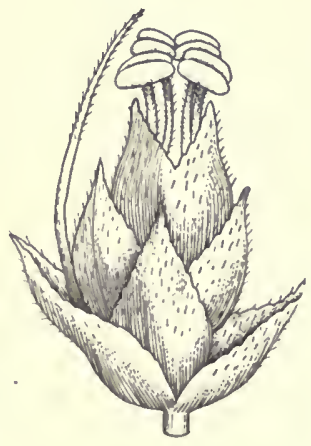

C

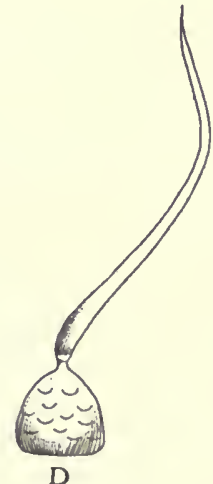

D

FIG. 56. Phenax hirtus. A. Habit of portion of flowering plant; $\times 2 / 3 . \quad B$. Staminate flower opened to show stamens; $\times 12$. C. Group of staminate and pistillate flowers; $\times 8$. D. Pistillate flower; $\times 10$.

meters; Alta Verapaz; El Progreso; Zacapa; Guatemala; Sacatepéquez; Chimaltenango; Sololá; Totonicapán; Quezaltenango; San Marcos. Southern Mexico; Costa Rica and Panama; West Indies; South America.

An herb or shrub 1-2 meters tall, usually erect, the branches slender, ferruginous, more or less hispidulous or short-pilose or almost glabrous; leaves slender- 
petiolate, thin, green, ovate or broadly ovate, $12 \mathrm{~cm}$. long and $6 \mathrm{~cm}$. wide or usually much smaller, acuminate, obtuse or rounded at the base, coarsely crenate, green and minutely punctate above, sometimes also hispidulous, somewhat paler beneath, hirtellous or almost glabrous. (Fig. 56.)

P. hirtus var. minor Wedd. (op. cit. 235-38) is represented by several Guatemalan collections. It is distinguished by having small leaves $1-3.5 \mathrm{~cm}$. long, but there are many intergrading specimens. The leaves are rarely deep purple beneath.

Phenax mexicanus Wedd. Ann. Sci. Nat. IV. Bot. 1: 193. 1854. Mejorana (Cobán, probably an erroneous name); Chilco (Chiquimula).

Wet thickets or forest, often on rocky stream banks, 500-1,700 meters; Alta Verapaz; Chiquimula; Escuintla; Guatemala; Sacatepéquez; Quezaltenango. Southern Mexico; Panama.

A stiff shrub 1-3 meters high, the branches ferruginous, glabrous; leaves on long or short petioles, rather thick, deep green, mostly lance-oblong and 3-7 cm. long, long-acuminate, obtuse or rounded at the base, finely and closely crenate, usually almost glabrous; flower clusters about $7 \mathrm{~mm}$. in diameter, brown.

Phenax rugosus (Poir.) Wedd. in DC. Prodr. 16, pt. 1: 235-38. 1869. Procris rugosa Poir. in Lam. Encycl. 5: 628. 1804.

Moist or wet thickets or forest, often in second growth, 900-2,500 meters; Alta Verapaz; Guatemala; Chimaltenango; Huehuetenango; San Marcos. Southern Mexico; Costa Rica; Panama; Colombia to Ecuador.

A shrub 1-3 meters high, often densely branched, the branches brown, densely pilose; leaves slender-petiolate, broadly ovate, mostly $3-8 \mathrm{~cm}$. long, acute or acuminate, acute to rounded at the base, closely and evenly crenate, bullate above and usually scabrous, rather softly and densely pilose beneath with whitish hairs; flower clusters dense, often $1 \mathrm{~cm}$. in diameter, frequently numerous and crowded, ferruginous; achenes smooth, verrucose on the margin, bearing a persistent style about $2 \mathrm{~mm}$. long.

\section{PILEA Lindley}

Herbs, repent, decumbent, or erect, usually succulent, sometimes suffrutescent at the base, the stems simple or branched; leaves opposite or rarely verticillate, often with conspicuous cystoliths, entire or dentate, those of a node equal or often very unequal and dissimilar; stipules connate; flowers monoecious or dioecious, capitate, spicate, cymose, or paniculate, the inflorescences unisexual or androgynous; staminate perianth commonly 4-parted; pistillate perianth 3-parted, the segments often unequal; stigma sessile, penicillate; achenes compressed, orbicular to ovate. 
Probably 200 species or more, in tropical America, Asia, and Africa. A number of additional species are native in Costa Rica and Panama.

Leaves all entire.

Leaves 1-nerved or nerveless.

Stems succulent, often much thickened below; leaves suborbicular to obovate, longer than wide........................ microphylla.

Stems not succulent, filiform; leaves rounded-deltoid, usually broader than

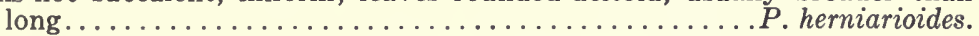

Leaves 3-nerved or triplinerved.

Leaves $0.5-2.5 \mathrm{~cm}$. wide, $2-9 \mathrm{~cm}$. long, thin, usually ciliate, the cystoliths of the upper surface linear or fusiform............... parietaria.

Leaves $1.5-4.5 \mathrm{~cm}$. wide, $8-15 \mathrm{~cm}$. long, thick, glabrous, the cystoliths of the upper surface stellate-punctiform.................. riparia. Leaves, or at least the larger one of each node, dentate.

Leaves in whorls of $4-6 \ldots \ldots \ldots \ldots \ldots \ldots \ldots \ldots \ldots \ldots \ldots \ldots \ldots \ldots$ senarifolia. Leaves opposite.

Leaves penninerved or triplinerved far above the base, or even 1-nerved.

Larger leaf of each pair crenate to the middle with 3 or more crenations on each side, symmetric or nearly so, at the base.

Larger leaves $2-4 \mathrm{~mm}$. wide, subsessile, lanceolate or elliptic.

Larger leaves 6-9 mm. wide, long-petiolate, rhombic.......P. mimema.

Larger leaf of each pair 3-dentate at the apex with only one crenation on each side, asymmetric at the base................ tridentata.

Leaves 3-nerved or triplinerved near the base.

Leaves of a node dissimilar or very unequal, the larger one more than twice as large as the smaller; plants essentially glabrous throughout, rarely sparsely pilosulous above.

Smaller leaf of the pair mostly less than $1.5 \mathrm{~cm}$. long, sometimes up to $2.5 \mathrm{~cm}$. long.

Larger leaf of the pair more than $3 \mathrm{~cm}$. wide......... P. ecbolophylla.

Larger leaf of the pair less than $3 \mathrm{~cm}$. wide......... pansamalana.

Smaller leaf of the pair more than $1.5 \mathrm{~cm}$. long.

Leaves denticulate only in the upper third of the margin.

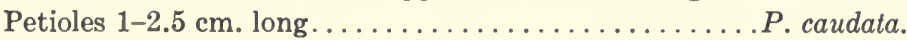

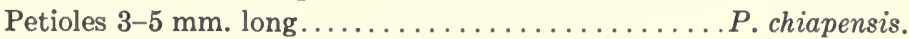

Leaves crenate or serrate almost or quite to the base.

Cystoliths linear; leaves abruptly contracted at the apex and produced into a long linear tip................. Skutchii.

Cystoliths all or mostly punctiform; leaves not abruptly linearcaudate......................... purulensis.

Leaves of a node similar, equal or the larger not more than twice as large as the smaller one; plants glabrous or pubescent.

Stems, leaves, or petioles pubescent, at least with some indument.

Leaf blades orbicular, broadly rounded at the apex.P. nummulariifolia.

Leaf blades narrower than orbicular, obtuse or acute.

Peduncles of the pistillate inflorescences shorter than the petioles. $P$. hyalina.

Peduncles of the pistillate inflorescences longer than the petioles. Stems glabrous; pistillate inflorescence subglobose..P. auriculata. 
Stems pilose or strigillose; pistillate inflorescence paniculate.

$P$. pubescens.

Stems, leaves, and petioles glabrous, leaves slightly pubescent (in $P$. dauciodora).

Leaves very obtuse................... dauciodora.

Leaves acute to attenuate-acuminate.

Cystoliths of the upper leaf surface all punctiform.

Stipules deltoid, obtuse; leaves with thickened margins.

$P$. irrorata.

Stipules lanceolate, acute; leaf margins not thickened. .P. riparia. Cystoliths of the upper leaf surface all linear or fusiform, or fusiform and punctiform intermixed.

Leaves broadly ovate, coarsely crenate.

Pistillate flowers in interrupted spikes or racemose-paniculate.

$P$. gracilipes.

Pistillate flowers in simple crowded cymes.....P. quercifolia.

Leaves narrowly lance-oblong, appressed-serrate.

Leaf blades very obtuse or even rounded at the base.

Leaf blades very acute at the base.

P. Tuerckheimii.

Leaves $2.5-4 \mathrm{~cm}$. wide, elliptic-oblong or elliptic-lanceolate. $P$. quichensis.

Leaves $0.3-0.7 \mathrm{~cm}$. wide, narrowly linear-lanceolate.

P. Killipiana.

Pilea auriculata Liebm. Dansk. Vid. Selsk. Skrivt. V. 2: 299. 1851.

Wet banks or mossy rocks, in forest, often along streams, 1,300 2,700 meters; Zacapa (Sierra de las Minas); El Progreso (Sierra de las Minas); San Marcos. El Salvador; Costa Rica; Panama.

Plants sometimes repent, the branches erect, $30 \mathrm{~cm}$. high or less, slender, glabrous; stipules ovate, $4-5 \mathrm{~mm}$. long, persistent and often conspicuous; leaves slender-petiolate, thin when dried, rounded-rhombic to lance-ovate, $1-5 \mathrm{~cm}$. long, $1-2.5 \mathrm{~cm}$. wide, acute, very coarsely crenate, broadly cuneate at the base, sparsely hirsute, deep green above, paler beneath, with conspicuous, linear and fusiform cystoliths; flowers monoecious; staminate cymes few-flowered, the peduncles $3 \mathrm{~cm}$. long or less, the flowers pedicellate; pistillate spikes globose, the slender peduncles 1-1.5 cm. long, the middle perianth segments auriculate; achenes ovate.

Pilea caudata Killip, Journ. Wash. Acad. Sci. 15: 291. 1925.

Type from Alta Verapaz, Secoyocté, near Finca Sepacuité, O. F. Cook \& R. F. Griggs 609.

Plants glabrous throughout, the stem erect, simple; stipules deltoid, less than $1 \mathrm{~mm}$. long, acute; leaves rather thick, triplinerved, dark green above, paler beneath, with punctiform cystoliths, the larger leaves lance-elliptic, 10-15 cm. long, 2-4 cm. wide, caudate-acuminate, with tips $2-3 \mathrm{~cm}$. long, denticulate in the upper third, the petiole $1-2.5 \mathrm{~cm}$. long; smaller leaves narrowly lance-elliptic, $3 \mathrm{~cm}$. long, $1 \mathrm{~cm}$. wide, acuminate, entire or nearly so; staminate flowers in dense axillary glomerules, globose. 
Pilea chiapensis Killip, Journ. Wash. Acad. Sci. 15: 295. 1925.

Wet mixed forest, 1,500 meters or less; Petén, Camp 32 on the boundary of British Honduras, 630 meters, Schipp S702; Izabal. Type from Chiapas.

Plants succulent, glabrous, the stems simple, said to be sometimes $30 \mathrm{~cm}$. tall; stipules deciduous; leaves of a pair very unequal, the larger ones oblanceolate to narrowly lance-oblong, often somewhat falcate, $7-11 \mathrm{~cm}$. long, $2-2.5 \mathrm{~cm}$. wide, narrowly long-acuminate, narrowed to the oblique base, 3-nerved, remotely and irregularly serrate toward the apex, on petioles $3-5 \mathrm{~mm}$. long; smaller leaves ovate or ovate-lanceolate, mostly $1.5-2.5 \mathrm{~cm}$. long, acute or acuminate, entire or crenateserrulate near the apex, the cystoliths inconspicuous, linear and punctiform on the upper surface; staminate cymes subsessile, dense, 5-7 mm. wide, the perianth globose, $2 \mathrm{~mm}$. wide; pistillate cymes subsessile, $5 \mathrm{~mm}$. long, the flowers sessile; achene ovate, $0.5 \mathrm{~mm}$. long.

Pilea dauciodora (Ruiz \& Pavón) Wedd. Ann. Sci. Nat. III. Bot. 18: 223. 1852. Urtica dauciodora Ruiz \& Pavón ex Wedd. loc. cit. as syn. Parietaria de peña (fide Aguilar).

Usually in wet forest, often in Cupressus and Abies forest, frequently on logs or wet rocks near streams, $1,400-3,500$ meters or less; Alta Verapaz; Izabal; El Progreso; Jalapa; Guatemala(?); Chimaltenango; Huehuetenango; Quezaltenango; San Marcos. West Indies; Colombia to Peru.

Plants repent, glabrous throughout, the branches usually erect, $30 \mathrm{~cm}$. high or less, slender; stipules triangular-ovate; leaves slender-petiolate, rounded-ovate or rhombic-ovate, sometimes $3.5 \mathrm{~cm}$. long and $2.5 \mathrm{~cm}$. wide but mostly much smaller, very obtuse, usually rounded at the base, crenate-serrate, dark green above, paler beneath, furnished on both surfaces with linear and fusiform cystoliths, thin when dried; flowers monoecious or dioecious, the staminate inflorescence capitate, the filiform peduncle $5 \mathrm{~mm}$. long or less; pistillate inflorescence simple or decompound, composed of 2-6 globose clusters about $3 \mathrm{~mm}$. broad and $8-20$-flowered, the perianth segments unequal; achenes ovate, $1 \mathrm{~mm}$. long.

Guatemalan material of this species has been distributed as $P$. rotundata Griseb.

Pilea ecbolophylla Donn. Smith, Bot. Gaz. 19: 10. 1894.

Usually in rocky places, often or usually on limestone, 300-900 meters; endemic; Izabal; Alta Verapaz, the type from Río Dolores, 350 meters, Türckheim 7983, on stream banks.

Plants glabrous, the stems erect from creeping rhizomes, $35 \mathrm{~cm}$. tall or less; larger leaves obovate-elliptic or oblanceolate, 9-12 cm. long, 3-4.5 cm. wide, caudate-acuminate, with a tip $2 \mathrm{~cm}$. long, cuneate at the base, crenate-serrate, or almost wholly entire, on petioles 1-1.5 cm. long; smaller leaves narrowly 
oblong-lanceolate, 7-8 mm. long, 2-3 $\mathrm{mm}$. wide, almost sessile; flowers dioecious, sometimes bright red; pistillate cymes $3-5 \mathrm{~mm}$. long; achenes ovoid, $0.7 \mathrm{~mm}$. long.

Pilea gracilipes Killip, Journ. Wash. Acad. Sci. 15: 294. 1925.

Moist or wet forest, sometimes on mossy rocks, 1,600-2,000 meters; Zacapa (Sierra de las Minas, 2,000 meters, on moist rocks, Steyermark 30017); Huehuetenango (Sierra de los Cuchumatanes). Costa Rica; Panama.

Plants glabrous, often repent, the stems erect, simple, $40 \mathrm{~cm}$. high or less; stipules triangular-ovate, minute, deciduous; leaves long-petiolate, subequal, 1-8 cm. long, 1-2.5 cm. wide, acuminate, rounded or obtuse at the base, thin when dried, crenate-serrate, bright green above, paler beneath, with obscure linear cystoliths on both surfaces; flowers monoecious or dioecious, the staminate and pistillate inflorescences often in the same axil; staminate flowers in globose heads 5-7 mm. broad, the filiform peduncles $2-3.5 \mathrm{~cm}$. long; pistillate flowers in lax glomerules disposed in interrupted spikes, or racemose-paniculate, the very slender peduncles 2-7 $\mathrm{cm}$. long; achenes lance-ovate.

Pilea herniarioides (Swartz) Lindl. Coll. Bot. sub pl. 4. 1821. Urtica herniarioides Swartz, Vet. Akad. Handl. Stockh. 8: 64. 1787. P. deltoidea Liebm. Dansk. Vid. Selsk. Skrivt. V. 2: 298. 1851.

On stream banks, 150 meters, Alta Verapaz (along Río Sebol, Steyermark 45814); reported from Santa Rosa and Guatemala; probably in Peten. Southern Mexico; Nicaragua; Costa Rica; West Indies.

Plants small, essentially annual, creeping or prostrate, the stems $2-10 \mathrm{~cm}$. long, much branched, filiform, scarcely succulent; leaves rounded-deltoid, usually as wide as long or wider, 1-nerved, entire, obtuse, contracted and decurrent to the petiole, $1.5-8 \mathrm{~mm}$. long, 2-9 $\mathrm{mm}$. wide, pilosulous on the upper surface or glabrate; flowers minute, sessile in the leaf axils.

Pilea hyalina Fenzl, Denkschr. Akad. Wiss. Math. Naturw. Wien 1: 4. 1850. P. Lundii Liebm. Dansk. Vid. Selsk. Skrivt. V. 2: 299. 1851. Parietaria.

Moist thickets or forest, frequently a weed in cafetales and other cultivated ground, 250-1,600 meters; Alta Verapaz; Jalapa; Santa Rosa; Guatemala; Sacatepéquez; Retalhuleu; Quiché. Southern Mexico; El Salvador to Panama; tropical South America.

Plants annual, the stems erect, mostly simple, succulent and almost transparent, $40 \mathrm{~cm}$. high or less, glabrous; stipules minute, deciduous; leaves of a pair subequal, the slender petioles $4 \mathrm{~cm}$. long or less, the blades thin, rhombicelliptic or broadly ovate, 1-6 $\mathrm{cm}$. long, 1-3.5 $\mathrm{cm}$. wide, acute, obtuse or broadly cuneate at the base, coarsely serrate, sparsely pilose or villous above, glabrous beneath, with numerous linear cystoliths; flower spikes $2-4$ in the axils of almost 
all the leaves, $2.5 \mathrm{~cm}$. long or less, androgynous, the staminate flowers very few, the pistillate flowers crowded in numerous almost contiguous glomerules; achenes ovate, $0.4 \mathrm{~mm}$. wide.

Pilea irrorata Donn. Smith, Bot. Gaz. 19: 11. 1894.

Wet forest or thickets, usually growing at the edge of streams or on banks kept constantly wet by running water, 1,700 meters or less, usually at 250-700 meters; Izabal; Escuintla; Guatemala; Suchitepequez; Retalhuleu (type from barranco of Río Samalá, 500 meters, J. D. Smith 2751); Quezaltenango; San Marcos; Huehuetenango. Chiapas.

A coarse stout erect simple herb a meter high or less, very fleshy; leaves petiolate, ovate-lanceolate or oblong-elliptic, $10-25 \mathrm{~cm}$. long, 4-10 cm. wide, long-acuminate, usually very narrowly so, acute at the base or long-attenuate, 3-nerved or triplinerved, irregularly and shallowly crenate-serrulate above the middle, densely covered with punctiform cystoliths, paler beneath; flowers monoecious or dioecious; staminate spikes almost sessile, dense, in the axils of the lower leaves, white, the pedicels $4-5 \mathrm{~mm}$. long; pistillate cymes dense and manyflowered, sessile or nearly so in the upper leaf axils.

The plant is a characteristic one of very wet, shaded places along the lower edge of the Pacific bocacosta, and can be found there in almost any very wet ground, often in association with Costus and Heliconia. It is a coarser and stouter plant than other Guatemalan species of Pilea.

\section{Pilea Killipiana Standl. \& Steyerm., sp. nov.}

On rocky banks and wooded slopes, 250-350 meters; Alta Verapaz (type collected along Río Icvolay, north and northwest of Finca Cubilguiitz to Quebrada Diablo, Julian A. Steyermark 44757, in Herbarium of Chicago Natural History Museum; "leaves dark green and shining above, paler green beneath; flowers pinkish-brick."); also collected near Río Icvolay, near Hacienda Yaxcabnal, five miles northwest of Cubilgüitz, Steyermark 44700.

Plants glabrous, erect from a decumbent rooting base, with simple leafy stems; leaves opposite, similar in size and form, dark green and shining above, paler green beneath; leaves narrowly linear-lanceolate, $2.5-6 \mathrm{~cm}$. long, 3-7 mm. wide, obtusely acuminate at apex, cuneate-attenuate at base, decurrent into a petiolate base 2-4 mm. long, finely crenulate in the upper half with 8-9 crenations on each side, triplinerved near the base, the cystoliths fusiform; staminate inflorescences in the axils of the middle and upper leaves, subumbellately flowered, much shorter than the leaves, 4-5 mm. long; pedicels $1.5 \mathrm{~mm}$. long; staminate perianth segments broadly ovate, subacute, $1.5 \mathrm{~mm}$. long, 1-1.2 mm. wide; stamens 4 ; anthers suborbicular, $1 \mathrm{~mm}$. long. 
Herba omnino glabra, caulibus simplicibus erectis e basi decumbente repente 10-23 cm. altis foliosis; foliis crasso-membranaceis supra atroviridibus lucidisque subtus pallidioribus anguste lineari-lanceolatis $2.5-6 \mathrm{~cm}$. longis $3-7 \mathrm{~mm}$. latis obtuse acuminatis basi cuneato-attenuatis in petiolum 2-4 $\mathrm{mm}$. longum decurrentibus, marginibus dimidia parte superiore crenulatis utroque 8-9 dentibus prope basin triplinerviis; inflorescentiis masculis subumbellatis foliis multo brevioribus 4-5 mm. longis; pedicellis $1.5 \mathrm{~mm}$. longis; perianthii masculi segmentis late ovatis subacutis $1.5 \mathrm{~mm}$. longis $1-1.2 \mathrm{~mm}$. latis; staminibus 4 ; antheris suborbicularibus $1 \mathrm{~mm}$. longis.

This species is related to $P$. mexicana Willd., but differs in the shorter stems, and narrower and shorter leaves. It is a pleasure to associate this distinct species with the name of Mr. E. P. Killip, who has carried on detailed studies of the genus and first noted that the material included here represented an undescribed species.

Pilea microphylla (L.) Liebm. Dansk. Vid. Selsk. Skrivt. V. 2: 296. 1851. Parietaria microphylla L. Syst. ed. 10. 1308. 1759. Urtica serpyllacea HBK. Nov. Gen. \& Sp. 2: 37. 1817. Pilea serpyllacea Liebm. Dansk. Vid. Selsk. Skrivt. V. 2: 296. 1851. Pilea microphylla var. longifolia Wedd. in DC. Prodr. 16, pt. 1: 106. 1869. Banixú (Cobán, Quecchí); Parietaria.

Moist or wet, shaded banks, often on old walls of masonry or adobe, or in moist soil about dwellings, frequent among cobblestones of streets, 1,600 meters or less; Alta Verapaz; Izabal; Zacapa; Jalapa; Jutiapa; Santa Rosa; Escuintla; Guatemala; Sacatepéquez; Quiché; Suchitepequez; Retalhuleu; Quezaltenango. Southern Mexico; British Honduras to Panama; West Indies; tropical South America.

Plants essentially annual, erect or more often depressed or prostrate, glabrous, densely branched, the stems usually thick and succulent; leaves oblong to obovate or suborbicular, obtuse, petiolate, those of a pair unequal, the larger ones 2-9 $\mathrm{mm}$. long and 1-5 mm. wide, entire, thick and fleshy, the upper surface striate with conspicuous linear cystoliths; flowers minute, the heads androgynous or unisexual, short-pedunculate or unisexual, sessile, shorter than the leaves, the flowers whitish tinged with red; achenes ovate, $0.5 \mathrm{~mm}$. long.

Called "mariposa" in Honduras and "palma del norte" in El Salvador; the English name used in the Canal Zone is "lace plant." The Maya names of Yucatan are "yomha" or "zizal-xiu." Some forms of the plant with erect or ascending, stout stems are often planted in Guatemalan gardens, and they are grown also as house plants. The plant is particularly characteristic of old walls. The crushed leaves are applied commonly to sores and bruises to heal them. P. microphylla var. longifolia, which has been found in British Honduras, is a form of distinctive appearance with greatly 
elongate stems sometimes $90 \mathrm{~cm}$. tall, the leaves larger and less crowded than in most forms of the species. When more material has been accumulated, it probably will be found worthy of specific rank. Pilea microphylla or some of its forms often are grown in United States hothouses under the name "artillery plant." If the branches of the staminate flowers are jarred, the anthers eject the pollen forcibly in such quantities that it can be seen with the naked eye.

Pilea mimema Standl. \& Steyerm., sp. nov.

Type from rich woods, Cerro Sillab, Senahú, Alta Verapaz, W. R. Hatch \& C. L. Wilson 162, in Herbarium of Chicago Natural History Museum.

Plants glabrous, prostrate, rather sparsely branched, with elongate succulent branches, these densely leafy; leaves distichous, those of a pair very unlike in size and form, with many conspicuous linear cystoliths on both surfaces, deep green above, paler beneath; larger leaves rhombic, $12-16 \mathrm{~mm}$. long, 6-9 $\mathrm{mm}$. wide, obtuse, long-cuneate-attenuate to the base and decurrent into a slender petiole $6 \mathrm{~mm}$. long or less, coarsely crenate in the upper two-thirds with about 4 crenations on each side, triplinerved above the base; smaller leaves sessile, obliquely reniform, entire, broadly rounded at the apex, obliquely cordate at the base, about $8 \mathrm{~mm}$. in greatest diameter; pistillate cymes $5 \mathrm{~mm}$. long or less, few-flowered, inconspicuous, the staminate inflorescences even smaller; achene pale, $1.2 \mathrm{~mm}$. long, oval, broadly rounded at the apex, 1-costate on each side.

Herba subscandens prostrata omnino glabra, caulibus elongatis crassiusculis crebre foliosis; foliis distichis valde inaequalibus, majoribus supra rhaphidosostriolatis, obovato-spathulatis vel rhomboideis obtusis basin versus triplinerviis abrupte cuneatim angustatis in petiolum ad $6 \mathrm{~mm}$. longum decurrentibus 12-16 $\mathrm{mm}$. longis $6-9 \mathrm{~mm}$. latis, supra medium grosse crenatis dentibus utroque latere 4 ; foliis minoribus sessilibus subamplexicaulibus oblique reniformibus late rotundatis basi oblique cordatis, 5-8 mm. longis 5-10 mm. latis; cymis femininis paucifloris ad $5 \mathrm{~mm}$. longis; acheniis ovalibus late rotundatis $1.2 \mathrm{~mm}$. longis utroque latere 1-costata.

This species is noteworthy for the very diverse distichous leaves, the smaller pair sessile, obliquely reniform and entire with an obliquely cordate base, the larger pair cuneately long-petiolate, rhombic and coarsely crenate. It is most closely related to Pilea tridentata Killip, also of Alta Verapaz.

Pilea nummulariifolia (Swartz) Wedd. Ann. Sci. Nat. II. 18: 225. 1851. Urtica nummulariifolia Swartz, Vet. Akad. Handl. Stockh. 8: 63. pl. 1, f. 2. 1787.

Frequently cultivated in Guatemala as a house plant, mostly in hanging baskets. Perhaps native of the West Indies, but cultivated in many tropical regions. 
Plants creeping, the stems villous, often much elongate, slender; stipules rather conspicuous, 1-2.5 mm. long; leaves slender-petiolate, orbicular or nearly so, 6-15 mm. long, 3-nerved, rounded at the apex, villous on both surfaces; cymes small, dense, unisexual or androgynous; staminate flowers pedicellate; pistillate flowers pedicellate or subsessile; achene $0.7 \mathrm{~mm}$. long, rounded-ovate.

Pilea pansamalana Donn. Smith, Bot. Gaz. 19: 10. 1894. La (Huehuetenango).

Dense wet forest, usually epiphytic, 350-2,000 meters, Alta Verapaz; type from Pansamalá, Türckheim 939; Quiché; Huehuetenango. Costa Rica.

Plants usually much branched and long-creeping, forming dense colonies on tree trunks, glabrous; leaves very variable in size and shape, crenate-serrate almost throughout, often very unequally so, triplinerved, the cystoliths punctiform and linear; leaves of a pair very unequal, the larger ones elliptic-lanceolate or lance-oblong, rarely ovate, often $8 \mathrm{~cm}$. long and $2 \mathrm{~cm}$. wide but mostly smaller, obtuse to long-acuminate, acute at the base; smaller leaves obovate to suborbicular, mostly 7-12 mm. long and $10 \mathrm{~mm}$. wide or smaller; flowers monoecious or dioecious; staminate cymes borne on the naked lower portions of the stems, $1 \mathrm{~cm}$. long; pistillate cymes axillary, 3-4 cm. long; achenes oblong.

Noteworthy among Guatemalan species for its epiphytic habit, and apparently never growing upon the ground except by accident. It is found mostly as large creeping colonies of long and interlaced sterile shoots, which exhibit extraordinary diversity in foliage.

Pilea parietaria (L.) Blume, Mus. Bot. Lugd. Bat. 2: 48. 1856. Urtica parietaria L. Sp. Pl. 985. 1753. P. rubiaefolia Blume, op. cit. 49. 1856 (type from Rubelcruz, Alta Verapaz, Guatemala, Türckheim 1270).

Crevices of rocks, 950 meters, Alta Verapaz (Rubelcruz, Türckheim 1270). El Salvador; Costa Rica; Panama; West Indies.

Plants erect, simple or branched, $40 \mathrm{~cm}$. tall or lower, the stems glabrous; petioles glabrous or pilose, $2.5 \mathrm{~cm}$. long or less; leaves of a pair subequal, elliptic to ovate-lanceolate or the lower sometimes broadly ovate, $2-9 \mathrm{~cm}$. long, acute or acuminate, rounded to subacute at the base, entire, glabrous above or sparsely villous, glabrous beneath or pubescent on the nerves, sparsely or densely provided with linear or fusiform cystoliths, the margins usually ciliate; cymes paniculately branched or racemose, 1-4 in an axil, androgynous, the upper ones almost wholly staminate and the lower pistillate, the flowers densely glomerate; achene ovoid.

Pilea pleuroneura Donn. Smith, Bot. Gaz. 19: 12. 1894.

Alta Verapaz, 300-1,140 meters, the type from Pansamalá, Türckheim 754. 
Stems rooting near the base, $30-40 \mathrm{~cm}$. long; leaves of a pair slightly unequal, the larger ones lanceolate, $0.5-2.5 \mathrm{~cm}$. long, $2-4 \mathrm{~mm}$. wide, the upper half crenate with 3-5 crenations on each side, the lower half entire, cuneate, tapering to a petiole 3-4 mm. long; smaller leaves elliptic, 2-12 $\mathrm{mm}$. long, 1-3 $\mathrm{mm}$. wide, obtuse, entire or obsoletely lobulate at the apex, cuneate at the base, sessile, the upper surface with conspicuous linear cystoliths; flowers dioecious; pistillate cymes fasciculate at the ends of slender peduncles.

Pilea pubescens Liebm. Dansk. Vid. Selsk. Skrivt. V. 2: 302. 1851. Paletoria (Huehuetenango).

Moist or wet thickets or forest, sometimes on open banks, 1,700 meters or less; Petén; Alta Verapaz; Chiquimula; Escuintla; Suchitepequez; Retalhuleu; Quezaltenango; San Marcos; Huehuetenango. Southern Mexico; British Honduras to Panama; West Indies; tropical South America.

Plants often repent, the branches erect or ascending, $40 \mathrm{~cm}$. high or less, pubescent; leaves of a pair subequal, long-petiolate, thin when dried, ovate to rounded-ovate, $5 \mathrm{~cm}$. long and $4 \mathrm{~cm}$. wide or smaller, obtuse to caudate-acuminate, subcordate to obtuse at the base, coarsely serrate or crenate, sparsely villous above and bearing minute linear cystoliths, pubescent beneath, especially on the nerves; flowers monoecious, the cymes $5 \mathrm{~cm}$. long or shorter, androgynous or unisexual, the pistillate flowers in numerous glomerules on slender divergent branches, the staminate flowers in few clusters at the base of the branches; achenes minute, ovate.

This species has been reported from Guatemala as P. Chamaedrys Wedd.

Pilea purulensis Donn. Smith, Bot. Gaz. 46: 115. 1908. $P$. pansamalana f. robustior Donn. Smith in Loes. Verh. Bot. Ver. Brandenb. 58: 140. 1917 (type from Yalambohoch, Distr. Nentón, Huehuetenango, Seler 2516).

Wet forest, 1,500-2,500 meters; Alta Verapaz; Baja Verapaz (type from Purulhá, Türckheim II.1707); El Progreso; Huehuetenango. Costa Rica.

Plants glabrous, succulent, the stems simple, $60 \mathrm{~cm}$. high or less; leaves of a pair very unequal, with minute linear cystoliths on the upper surface, paler beneath, the larger leaves oblong-lanceolate, 10-15 cm. long, 4-6 cm. wide, narrowly long-acuminate, obtuse or subacute at the base, the petioles $2.5 \mathrm{~cm}$. long or less; smaller leaves ovate-lanceolate, acuminate, rounded at the base, almost sessile or shortly petiolate; flowers dioecious, the staminate flowers in dense globose heads; pistillate flowers in more lax, short-pedunculate, flat-topped cymes less than $1 \mathrm{~cm}$. broad; achenes ovate, $1 \mathrm{~mm}$. long, slightly curved at the apex.

Pilea quercifolia Killip in Morton, Phytologia 1: 146. 1936.

Wet forest, sometimes on banks in spray of waterfalls, 1,300 3,000 meters; Chimaltenango (type from Chichavac, Skutch 559); 


\section{Huehuetenango; San Marcos (southern slope of Volcán de Taju- mulco); endemic.}

Plants glabrous, often forming loose mats, the branches erect, about $30 \mathrm{~cm}$. high; stipules oblong-lanceolate, 4-5 mm. long, subacute, soon deciduous; leaves of a pair subequal, on petioles 1-3.5 cm. long, ovate or broadly ovate, 4-12 cm. long, 2-5 cm. wide, acute or acuminate, rounded at the base, coarsely crenatedentate, with obscure linear cystoliths on both surfaces; flowers monoecious, the cymes unisexual; staminate cymes on filiform peduncles 2-6.5 cm. long, 10-12flowered, $8-10 \mathrm{~mm}$. broad, the flowers pedicellate; pistillate cymes in the same axils with the staminate on peduncles subequal to or slightly shorter than those of the staminate, $7-8 \mathrm{~mm}$. broad, the 3 perianth segments conspicuously unequal; achenes lance-ovate, $1 \mathrm{~mm}$. long, compressed.

This is very similar to $P$. gracilipes Killip, with which it may eventually have to be merged. The gross dentation of the leaves originally believed by Killip to constitute a noteworthy character in $P$. quercifolia does not prove a reliable one, as later collections of this species show.

Pilea quichensis Donn. Smith, Bot. Gaz. 19: 12. 1894.

Moist or wet forest, often on limestone, 50-2,600 meters; Alta Verapaz; Izabal; El Progreso; Quiché (type from San Miguel Uspantán, Heyde \& Lux 3147); Huehuetenango. Costa Rica.

Plants glabrous, succulent, the stems usually simple, erect, 50-90 cm. tall; leaves of a pair subequal, slender-petiolate, narrowly elliptic-oblong or ellipticlanceolate, $10-15 \mathrm{~cm}$. long, $2.5-4 \mathrm{~cm}$. wide, narrowly attenuate-acuminate, acute at the base, appressed-serrate, the upper surface dark green, covered with minute linear cystoliths, the lower surface paler, with or without cystoliths; flowers monoecious or dioecious; staminate cymes $2 \mathrm{~cm}$. long or less, the perianth segments obtuse; pistillate cymes $3 \mathrm{~cm}$. long or shorter, in the upper leaf axils; achenes ovate, smooth, the margin winged, the beak curved.

Pilea riparia Donn. Smith, Bot. Gaz. 19: 11. 1894. On rocks in streams, or in wet mixed forest, 150-2,300 meters, endemic; Alta Verapaz (type from Pansamalá, Türckheim 1040); Baja Verapaz (Panzal); Huehuetenango (Ixcán).

Plants glabrous, the stems repent or erect, the branches erect, 30-40 cm. high; leaves of a pair very unequal, rarely alternate, entire or obscurely serrulate toward the apex, the margins thickened; larger leaves on petioles $0.5-2.5 \mathrm{~cm}$. long, oblong-elliptic, thick and fleshy, coriaceous when dried, 8-15 cm. long, 2-4 cm. wide, rather abruptly long-acuminate, cuneate at the base, the cystoliths of the upper surface dense, stellulate-punctiform, those of the paler lower surface minute, linear and punctiform, those at the margins of both surfaces fusiform, very conspicuous; staminate cymes $4.5 \mathrm{~cm}$. long or less, dichotomously branched; pistillate cymes short-pedunculate or almost sessile; achene narrowly obovoid, $1 \mathrm{~mm}$. long, smooth. 


\section{Pilea senarifolia Donn. Smith, Bot. Gaz. 19: 12. 1894.}

Epiphytic on tree trunks, 2,400 meters, the type from Chiúl, Quiché, Heyde \& Lux 3145.

Plants glabrous, the stems succulent, $20-30 \mathrm{~cm}$. long, rooting at the base, 6-winged; leaves 4-6-verticillate, obovate-spatulate, 2-9 $\mathrm{mm}$. long, 3-4 mm. wide, attenuate to a petiole 1-2 $\mathrm{mm}$. long, incurved-crenate above the middle, the crenations 3 on each side, the upper surface transverse-striate with fusiform cystoliths, penninerved; flowers monoecious, the cymes unisexual, 2-3 times as long as the petioles, 2-3-flowered; perianth globose in bud, $2 \mathrm{~mm}$. long; segments of the pistillate perianth somewhat unequal.

\section{Pilea Skutchii Killip, sp. nov. Hierba de masamora.}

Moist or wet forest or thickets, sometimes epiphytic but usually terrestrial, 1,300-2,700 meters; Chimaltenango; Sololá; Quezaltenango (type collected on mossy tree trunk in a ravine, Zunil, August 8, 1934, Alexander F. Skutch 974, in United States National Herbarium); San Marcos; endemic.

Plants glabrous, erect, the stems $30-60 \mathrm{~cm}$. high, sometimes purplish, simple or nearly so; leaves of a pair very unequal, thin, slender-petiolate, 3-nerved, coarsely appressed-crenate, deep green above and with many conspicuous large linear cystoliths, paler beneath, the cystoliths obsolete; larger leaves lance-oblong, mostly 8-12 cm. long and $1.5-4.5 \mathrm{~cm}$. wide, attenuate-acuminate and abruptly contracted into a long linear tip up to $3.5 \mathrm{~cm}$. long, narrowed to the obtuse or narrowly rounded base; smaller leaves ovate or elliptic, $3.5 \mathrm{~cm}$. long or less, acuminate or caudate-acuminate; pistillate cymes on long slender peduncles, usually large and lax, many-flowered; achene pale, somewhat compressed, broadly oval, smooth, $1.3 \mathrm{~mm}$. long.

Herba glabra erecta, caulibus $30-60 \mathrm{~cm}$. altis simplicibus; foliis inaequalibus gracillime petiolatis grosse appresse-crenatis supra rhaphidoso-striolatis subtus lineis obsoletis; foliis majoribus lanceolato-oblongis plerumque $8-12 \mathrm{~cm}$. longis $1.5-4.5 \mathrm{~cm}$. latis attenuato-acuminatis apice abrupte angustatis apice ipso lineari angusto ad $3.5 \mathrm{~cm}$. longo basi obtusis vel anguste rotundatis trinerviis; foliis minoribus ovatis vel ellipticis ad $3.5 \mathrm{~cm}$. longis acuminat is vel caudato-acuminatis; cymis femininis multifloris plerumque magnis laxifloris, pedunculis gracilibus $0.7-$ $1.5 \mathrm{~cm}$. longis; acheniis paullo compressis late ovalibus laevibus $1.3 \mathrm{~mm}$. longis.

Pilea tridentata Killip, Journ. Wash. Acad. Sci. 15: 290. 1925.

Known only from the type, collected in forest near Cobán, Alta Verapaz, 1,600 meters, Türckheim II.2011.

Plants glabrous, probably prostrate, $40 \mathrm{~cm}$. long or more, much branched, the stout branches very densely leafy; leaves small, distichous, those of a pair very unlike in size and shape, 1-nerved, with conspicuous fusiform cystoliths on the upper surface, paler beneath; larger leaves oblong-spatulate, 5-8 $\mathrm{mm}$. long, obtuse, with a single small tooth on each side near the apex, cuneate at the base; smaller leaves oval or suborbicular, 3-5 $\mathrm{mm}$. long, rounded at the apex, sessile, entire; 
flowers dioecious; inflorescence cymose, 2-4-flowered, the peduncles $2.5 \mathrm{~mm}$. long or less; achenes narrowly oblong, minutely roughened.

Pilea Tuerckheimii Donn. Smith, Bot. Gaz. 46: 116. 1908.

Wet forest, often among rocks on the borders of streams, 1,150 1,550 meters; endemic; Alta Verapaz (type collected near Cobán, Türckheim II.1835); Huehuetenango (Finca Soledad, southeast of Barillas).

Plants glabrous, the stems radicant at the base, erect, simple or sparsely branched; leaves opposite, subequal, on long slender petioles, lanceolate to ellipticlanceolate, 7-16 cm. long, $6 \mathrm{~cm}$. wide or usually much narrower, elongate-acuminate, mostly rounded or very obtuse at the base, triplinerved, appressed-serrate, the cystoliths conspicuous on the upper surface, linear; flowers dioecious; staminate inflorescences about equaling the petioles or often shorter, several times dichotomous, lax, the flowers pedicellate; pistillate inflorescences similar, many-flowered.

\section{POUZOLZIA Gaudichaud}

Shrubs; leaves alternate, entire or rarely dentate, petiolate, 3-nerved, bearing on the upper surface numerous punctiform cystoliths, stipules free; flowers monoecious, rarely dioecious, in small axillary glomerules; staminate perianth with 4-5 lobes or segments; stamens 3-5; pistillate perianth 2-4-dentate, tubular, usually costate, contracted at the apex; stigma filiform, finally deciduous; ovary included, free from the perianth or coherent with it; achene commonly black or dark brown and lustrous.

Species about forty, in the tropics of both hemispheres. One other, $P$. occidentalis Wedd., has been collected in both Honduras and El Salvador and is to be expected in the Oriente of Guatemala.

Leaves coarsely crenate-serrate................... phenacoides. Leaves entire.

Leaves white-tomentose beneath.................... nivea.

Leaves green beneath and short-pilose, not at all tomentose....... obliqua.

Pouzolzia guatemalana (Blume) Wedd., in spite of its specific name, is not a Guatemalan plant, although it was attributed to Guatemala by Blume. The type was actually from Monte Aguacate, Costa Rica, where it was collected by Friedrichsthal.

\section{Pouzolzia nivea Wats. Proc. Amer. Acad. 22: 453. 1887.}

Brushy rocky slopes or in quebradas, 180-1,000 meters; Zacapa; Chiquimula; Huehuetenango. Mexico.

A usually arching shrub about 2 meters high, the branches ferruginous, hirsutulous; leaves thin, slender-petiolate, ovate or ovate-elliptic, 6-15 cm. long, cuspidately long-acuminate, obtuse or usually rounded at the base, deep green above, 
rough to the touch, short-pilose or glabrate, white-tomentose beneath, usually hirsute along the nerves; staminate perianth 4-dentate, densely pubescent; pistillate perianth truncate at the base, attenuate to the 4-dentate apex, striate, strigillose.

Pouzolzia obliqua Wedd. Arch. Mus. Paris 9: 405. 1856-57. Margarocarpus obliquus Wedd. op. cit. 204. 1856-57.

Wet thickets, sometimes in hilly pine forest, 150 meters or less; Petén; Izabal. Tabasco; Honduras; El Salvador; Costa Rica; Panama; Colombia to Peru.

A shrub 1.5-2.5 meters tall, the branches densely pilose; petioles only 2-7 mm. long; leaf blades ovate to ovate-oblong, 2-7 cm. long, 1-3 cm. wide, acute or acuminate, rounded or subcordate and oblique at the base, densely pilose above, rough to the touch, hirsute and brownish-tomentose beneath; flower clusters small, shorter than the petioles; stipules linear-subulate, brown, persistent and of ten conspicuous.

Pouzolzia phenacoides Killip, Journ. Wash. Acad. Sci. 15: 299. 1925.

Quezaltenango (southeastern slopes of Volcán de Santa María, 1,300 meters, Steyermark 34362, moist thicket); San Marcos (Volcán de Tajumulco, 1,300-1,500 meters). Costa Rica, the type from Escasú.

A slender shrub 1-1.5 meters high, the branches hirsutulous or glabrate; leaves on long slender petioles, ovate or lance-ovate, $6 \mathrm{~cm}$. long and $3 \mathrm{~cm}$. wide or smaller, attenuate-acuminate, obtuse or rounded at the base, thin, green, crenate-dentate, hispidulous or glabrate above, hirsute beneath on the nerves; flowers monoecious, the inflorescences androgynous or unisexual, 1-5-flowered, subsessile or short-pedunculate; staminate perianth 4-lobate; pistillate flowers $2 \mathrm{~mm}$. long, about 12-nerved, finely puberulent; achenes ovoid, $2 \mathrm{~mm}$. long, dark brown, lustrous.

The collection from San Marcos (Steyermark 37503), though sterile, matches the Quetzaltenango sheet identified by Killip.

\section{ROUSSELIA Gaudichaud}

Slender, branched, annual or perennial herbs, diffuse; leaves small, alternate, broad, entire, subtrinerved, the stipules small, free; flowers monoecious, the staminate racemulose in the leaf axils, the pistillate geminate, bibracteate; staminate perianth 4-parted, the segments acute, valvate, the buds globose; stamens 4 ; pistillate perianth ovoid, contracted at the mouth and 2-4-dentate; ovary straight, the stigma filiform, papillose-plumose along one side; achene compressed, ovate, acute, lustrous, enclosed in the accrescent perianth.

The genus consists of two species, one other occurring in Nicaragua and Colombia. 
Rousselia humilis (Swartz) Urban, Symb. Antill. 4: 205. 1905. Urtica humilis Swartz, Vet. Akad. Handl. Stockh. 6: 34. 1785.

Dry arroyos or on ruins, Petén (Uaxactún). Campeche; Yucatan; northern British Honduras.

Plants usually annual, with the habit of Parietaria, the slender stems puberulent, much branched, spreading, 10-30 cm. long; leaves petiolate, broadly ovate to oval, 0.5-4 cm. long, acute to rounded at the apex, rounded to acutish at the base, thinly pilose on both surfaces, densely covered above with punctiform cystoliths; stipules minute; bracts of the pistillate flowers ovate, $3-4 \mathrm{~mm}$. long, entire; achene $1.5 \mathrm{~mm}$. long.

\section{URERA Gaudichaud}

Shrubs or small trees, usually with abundant stinging hairs; leaves alternate, entire, dentate, or lobate, penninerved or 3-5-nerved; stipules free or more or less connate; flowers dioecious or rarely monoecious, the glomerules loosely paniculate, the panicles dichotomously branched, unisexual, mostly solitary at leafless nodes, on long or short peduncles; bracts small or none; staminate perianth 4-5-parted, the segments ovate, slightly imbricate; stamens 4-5; pistillate perianth with 4 lobes or segments, these subequal or the outer ones smaller; ovary straight or oblique; stigma subsessile, usually penicillate-capitate, persistent; achene straight or oblique, compressed or ventricose, surrounded by the fleshy juicy perianth.

Perhaps fifteen species, in tropical America, Africa, and Asia. One other species occurring in Central America (Costa Rica and Panama) is $U$. laciniata Wedd., in which the leaves are deeply lobate.

Achenes more than $2 \mathrm{~mm}$. long; leaves very coarsely dentate; branches armed with stout spine-like hairs having dilated bases; fruit white...U. baccifera.

Achenes less than $2 \mathrm{~mm}$. long; leaves crenate-dentate to subentire; branches without spine-like hairs, the hairs all slender.

Leaves mostly rounded-ovate or ovate-orbicular, usually rather deeply cordate at the base, generally densely and softly pubescent beneath, mostly 10-20 $\mathrm{cm}$. wide or larger; fruit orange-red ................. caracasana.

Leaves rhombic-elliptic to elliptic-oblong, rounded or obtuse at the base, rarely broader and somewhat cordate at the base, often glabrate beneath.

Cystoliths of the upper leaf surface oblong, conspicuously radiating from the center of the areole..............................

Cystoliths of the upper leaf surface punctiform, uniformly scattered over the surface.

Petioles covered with reflexed prickle-like hairs........U. Tuerckheimii. Petioles with spreading or ascending hairs or glabrous.

Leaves glabrous except for a few hairs beneath in the axils of the nerves, bright green when dried...................... Killipiana. Leaves softly pubescent beneath, usually blackish when dried. .U. elata.

Urera alceifolia Gaud. in Freyc. Voy. Bot. 496. 1826. Chichicaste; Chichicaste de montaña. 
Moist or wet mixed forest or thickets, 350-2,700 meters; Alta Verapaz; Zacapa; Escuintla; Sacatepéquez; Suchitepequez; Quezaltenango; San Marcos. Southern Mexico; Honduras; Costa Rica; Panama.

A tall coarse shrub or sometimes a tree of 6 meters with few branches, usually with some stinging hairs, or these often absent; leaves on long or short petioles, mostly oblong-elliptic to ovate-oblong, sometimes $25 \mathrm{~cm}$. long and $12 \mathrm{~cm}$. wide but usually only half as large, acuminate or attenuate-acuminate, narrowly rounded to subacute at the base, 3-nerved, shallowly crenate or dentate or merely undulate, with a few stinging hairs on both surfaces, chiefly along the costa and nerves, otherwise almost glabrous, green above, the cystoliths conspicuous, oblong, short, radiating from the center of the areole, somewhat paler beneath; panicles mostly small and borne on the old wood, $8 \mathrm{~cm}$. long or less, lax and cyme-like, the flowers densely clustered; fruit orange-red, $2-3 \mathrm{~mm}$. in diameter.

This species stings less than most other species of the genus, and often scarcely at all.

Urera baccifera (L.) Gaud. in Freyc. Voy. Bot. 497. 1826. Urtica baccifera L. Sp. Pl. ed. 2. 1398. 1763. U. baccifera var. horrida Wedd. in DC. Prodr. 16, pt. 1: 94. 1869. Chichicaste; Chichicaste blanco; Lah (Petén, Maya).

Common or abundant in wet or dry thickets, often in second growth, mostly in the lowlands at 850 meters or less, but occurring also at higher elevations, where perhaps introduced; much planted in hedges; Petén; Alta Verapaz; Izabal; Zacapa; Chiquimula; Jutiapa; Santa Rosa; Escuintla; Guatemala; Sacatepéquez; Quiché; Suchitepequez; Retalhuleu; San Marcos; Totonicapán. Southern Mexico; British Honduras to Panama; West Indies; tropical South America.

Usually a stout shrub of 2-4 meters but often a small tree of 7 meters, with few thick pale branches, armed throughout with coarse, broad-based, of ten recurved, hollow, stinging, spine-like hairs; leaves rather thick, mostly ovate to roundedovate, often $35 \mathrm{~cm}$. long, acute or acuminate, rounded to shallowly cordate at the base, very coarsely sinuate-dentate, the teeth often almost lobe-like, green above and almost glabrous, the cystoliths punctiform, inconspicuous, often softly pubescent beneath but sometimes glabrate; flowers dioecious, the cymes much branched, axillary or on naked branches, whitish; fruit very juicy, pure white or pinkish, 3-5 $\mathrm{mm}$. long, the achene conspicuously exserted from the calyx.

Maya names of Yucatan are "laal" and "laal tzimin"; called "cow-itch" in British Honduras; "ortiga" (Campeche); "ortiga de caballo" (Yucatan); "chichicaste nigua," "nigua," "nigüilla" (El Salvador). The usual name for the tree in northern Central America is "chichicaste," a term of Nahuatl derivation, that is applied first of all to most stinging or even non-stinging plants of the Urticaceae, 
and has been extended in Guatemala to cover most other stinging plants as well. This term has been introduced into Cuba, where it is altered to "chichicate" and "chichicastre." It appears in many place names of northern Central America, the best known being Chichicastenango in Quiché, Guatemala.

"Chichicaste," especially in the form of Urera baccifera, is one of the best known plants of Guatemala and all Central America, one known and probably physically so, to all Central Americans, for it is one of the most severely stinging plants that exist in America. The large spine-like prickles are hollow and filled with liquid. When one brushes against a branch or a leaf, the prickles penetrate the flesh and cause the most excruciating pain, as sudden as an electric shock, that may last two or three days. The pain gradually disappears, to be followed by numbness in the affected part. It is needless to explain why the shrub makes an effective hedge plant, and for this purpose it is planted throughout the lowlands, and even far up into the mountains, as about Antigua and San Marcos. Horses fear it, and few other large animals will attempt to penetrate such hedges, which are far from being things of beauty. Only in the early part of the rainy season, when the new foliage has developed, are the hedges at all presentable. During the height of the dry season they lose their leaves and are unsightly. Although chichicaste hedges are common in some parts of the highlands, it is probable that the plant is not native there, and the town of Chichicastenango is more likely to have received its name because one or two bushes or hedges grew there than because the plant abounded, which apparently it does not. About Cobán hedges are frequent, but the species was not observed as wild in the region. The thick branches take root quickly when set in the ground. The white fruits have a slight resemblance to nests of the sand fleas or niguas that bury themselves beneath the toe nails, hence the name "nigua" sometimes given to them. Fiber of the branches has been used in the West Indies for making rope and twine.

Urera caracasana (Jacq.) Griseb. Fl. Brit. W. Ind. 154. 1859. Urtica caracasana Jacq. Pl. Hort. Schoenbr. 3: 71. pl. 386. 1798. $U$. caracasana var. tomentosa Wedd. in DC. Prodr. 16, pt. 1: 90. 1869. Chichicaste; chichicaste de hormiga; chichicastón; la (Cobán, Quecchí).

Common in moist or wet thickets or often in dense mixed forest, often abundant in second growth, much planted for hedges, mostly 
at 900-2,900 meters; Petén; Alta Verapaz; El Progreso; Chiquimula; Jalapa; Santa Rosa; Escuintla; Guatemala; Sacatepéquez; Chimaltenango; Sololá; Quiché; Suchitepequez; Retalhuleu; Huehuetenango; Quezaltenango; San Marcos. Southern Mexico; Honduras and El Salvador to Panama; West Indies; tropical South America.

A coarse shrub or small tree, sometimes 10 meters high, with thick pale branches, provided throughout with short, straight, slender, more or less stinging hairs; leaves broadly ovate to orbicular-ovate, often $30 \mathrm{~cm}$. long and broad, shortacuminate to obtuse, cordate at the base, crenate-dentate, green above and often bullate, the cystoliths punctiform, inconspicuous, beneath usually densely velutinous-pilose and of ten pale; flowers dioecious or rarely monoecious, the cymes small or large, lax or dense, mostly on the older branches; pistillate flowers mostly pedicellate, the perianth segments unequal, white-punctate; fruit orange-red, 2-3 $\mathrm{mm}$. in diameter, the achene scarcely or not at all exceeding the juicy perianth.

The Maya name is "laal"; called "ortiga" in Tabasco and in southern Central America. This species is abundant at middle or even rather high elevations, but does not extend far into the tierra caliente. It reaches its best development in rather dense and moist, mixed forest, where the larger trees, a mass of large orange-red fruiting panicles, are handsome and often very conspicuous. It is much planted for hedges but is not nearly so efficient as $U$. baccifera. The hedges are especially common about Antigua. They are trimmed when they get too tall, and then send up long straight simple shoots, whose growth soon restores the hedge to its former height. The plant stings, especially the stiff hairs of the inflorescence, but the pain produced is ephemeral and not nearly so severe as that of $U$. baccifera.

Urera ela ta (Swartz) Griseb. Fl. Brit. W. Ind. 154. 1859. Urtica elata Swartz, Prodr. Veg. Ind. Occ. 37. 1788. Chichicaste blanco; chichicaste; chichicaste de montaña.

Brushy hillsides or moist, often dense forest, 1,800 meters or less; Alta Verapaz; Suchitepequez; Sololá; Huehuetenango; Quezaltenango; San Marcos.

A large shrub or a small tree, sometimes 6 meters high, with rather pale, thick branches, the stinging hairs usually few or absent; leaves large, on long or short petioles, ovate-oblong to broadly ovate, sometimes $25 \mathrm{~cm}$. long, thin, acuminate, rounded or obtuse at the base, sinuate-crenate or undulate-dentate, green and almost glabrous above, the cystoliths punctiform, often velutinous-pilose beneath with short hairs or glabrate; cymes lax or dense, mostly on old wood, sessile or pedunculate; fruit orange-red, $2-3 \mathrm{~mm}$. long.

Urera Killipiana Standl. \& Steyerm., sp. nov. Laté (Huehuetenango). 
Moist or wet, mixed forest of the Occidente, 1,300-2,800 meters; endemic; Huehuetenango; Quezaltenango (type from Volcán de Zunil, Alexander F. Skutch 982, in Herbarium of Chicago Natural History Museum); San Marcos.

A large shrub or a small tree, commonly $3-4.5$ meters high, with stinging hairs only in the inflorescence; leaves slender-petiolate, elliptic or broadly ovate, $22 \mathrm{~cm}$. long and $13 \mathrm{~cm}$. wide or smaller, bright green when dried, acute or short-acuminate, rounded to cuneate-obtuse at the base, 3-nerved, undulate-dentate or undulatecrenate, glabrous or essentially so on both surfaces, the cystoliths of the upper surface minute and punctiform; flowers dioecious, the cymes arising from old wood, pedunculate or almost sessile, dense, the branches puberulent and with few short stinging hairs; fruits scarcely more than $1 \mathrm{~mm}$. long.

Frutex vel arbor 3-4.5-metralis tantum inflorescentiis pilis urentibus; foliis in sicco viridibus gracillime petiolatis ellipticis vel late ovatis $22 \mathrm{~cm}$. longis ad $13 \mathrm{~cm}$. latis acutis vel breve acuminatis basi rotundatis vel cuneato-obtusis trinervatis repando-dentatis vel repando-crenatis, utrinque glabris vel fere glabris, supra minutissime rhaphidoso-punctulatis; floribus dioicis, cymis ex axillis ligni veteris nascentibus pedunculatis vel fere sessilibus densifloris, ramis puberulentibus pilis urentibus paucis; fructibus vix ultra $1 \mathrm{~mm}$. longis.

This species is well-marked by its nearly smooth stems, glabrous leaves, which dry bright green, and the possession of stinging hairs only in the inflorescence.

Urera Tuerckheimii Donn. Smith, Bot. Gaz. 23: 14. 1897. Chichicaste; nigüita.

Moist or wet, mixed forest, 1,500 meters or less; Alta Verapaz, 1,150 meters, Türckheim 1243; type from Pansamalá; also referable here may be material from Izabal, Jutiapa, Chimaltenango, and Sacatepéquez; Huehuetenango (Ixcán, Steyermark 49249; Maxbal, Steyermark 48785). British Honduras.

Branches covered with dense retrorse stinging hairs; leaves 3-nerved, ovatelanceolate, $6.5-7.5 \mathrm{~cm}$. long, $2-2.6 \mathrm{~cm}$. wide, acute, on petioles $10-14 \mathrm{~mm}$. long, dentate, tuberculate above (this presumably meaning with punctiform cystoliths); flowers monoecious, the cymes shorter than the petioles, pedunculate, the flowers pedicellate; staminate flowers globose, $1.5 \mathrm{~mm}$. long; pistillate flowers $0.5 \mathrm{~mm}$. long.

\section{URTICA L. Nettle}

Annual or perennial herbs, provided with stinging hairs, the stems simple or sparsely branched; leaves petiolate, opposite, serrate, dentate, or incised; stipules free or connate; flowers green or greenish, monoecious or dioecious in androgynous or unisexual clusters arranged in elongate spikes, much branched panicles, or subsessile glomerules; staminate perianth 4-parted; pistillate perianth 4-parted, the two outer segments minute, spreading, the two inner ones much larger, erect; 
stigma sessile; achene compressed, ovate or oblong, enclosed in the inner perianth segments.

About 35 species, both hemispheres, chiefly in temperate regions, also in tropical mountains. Two other species are known from southern Central America. The usual Spanish name for plants of the genus is "ortiga," a direct derivative of the Latin urtica. The plants yield a strong fiber that is suitable for making cordage and coarse textiles. It also has been utilized for making paper and there is some reason for believing it might be a profitable source of paper pulp. In Europe the young shoots are sometimes cooked and eaten, and are used in preparing a soup that is said to be very tasty.

Glomerules of flowers forming long slender spikes, these often much interrupted and usually longer than the petioles................... mexicana. Glomerules of flowers in short, dense, mostly subglobose or short-cylindric spikes, these usually shorter than the petioles.

Leaves incised-serrate, more or less obtuse, chiefly $1-5.5 \mathrm{~cm}$. long. . .U. urens. Leaves crenate or dentate, long-acuminate, mostly 6-13 cm. long.

U. nicaraguensis.

Urtica mexicana Liebm. Dansk. Vid. Selsk. Skrivt. V. 2: 291. 1851. Chichicaste; la (Volcán de Santa María). Moist or wet thickets or forest, 1,500-3,600 meters, mostly at higher elevations; Chimaltenango; Quezaltenango; San Marcos. Southern Mexico, the type from Chiantla, Oaxaca.

A coarse herb, sometimes 1.5 meters tall but usually less than 1 meter, simple or sparsely branched, abundantly furnished with long stinging hairs, the stems also puberulent or short-pilose; leaves mostly on long slender petioles, ovate or rounded-ovate, usually $6-13 \mathrm{~cm}$. long, acute to long-acuminate, shallowly or rather deeply cordate at the base, abundantly provided, at least beneath, with long stinging hairs, otherwise almost glabrous, or sometimes copiously pilose with chiefly appressed hairs, very coarsely crenate or dentate; flowers monoecious, the inflorescences androgynous; spike-like, lax, many-flowered, often greatly elongate, the fruiting spikes pendulous; fruiting perianth hispidulous, ovoid.

This has been reported from Guatemala as $U$. chamaedryoides Pursh, a species of the United States and Mexico not known to reach Central America. U. mexicana stings severely.

Urtica nicaraguensis Liebm. Dansk. Vid. Selsk. Skrivt. V. 2: 292. 1851. Chichicaste; chichicaste de chucho.

Moist thickets or fields, 1,600-2,500 meters; Sacatepéquez; Chimaltenango; Quezaltenango. Costa Rica.

An erect herb a meter high or less, the stems mostly simple, hispid with stinging hairs and pilose with short, sometimes reflexed hairs; leaves on long or short petioles, lance-ovate or oblong-lanceolate, mostly 6-13 cm. long, narrowly long- 
acuminate, rounded or obtuse at the base, deep green above, paler beneath, sparsely or rather densely pilosulous, especially beneath, rather closely and evenly crenate or dentate; flower spikes mostly short and oblong, few-flowered, or sometimes more elongate, simple or with a few branches; achenes ovate-oblong, $1 \mathrm{~mm}$. long.

This may not be distinct from $U$. magellanica Poir., a South American species, to which it is referred by H. Ross.

Urtica urens L. Sp. Pl. 984. 1753. Chichicaste; chichicaste de caballo; chichicastillo.

Usually a weed in cultivated ground or waste places, sometimes on dry rocky hillsides, 1,500-3,700 meters; Sacatepéquez; Chimaltenango; Quiché; Quezaltenango. Native of Europe, but widely naturalized in temperate regions of other continents.

An annual, usually $40 \mathrm{~cm}$. tall or less, simple or branched, abundantly provided with stinging hairs; leaves slender-petiolate, elliptic to oval or ovate, 3-5-nerved, small, obtuse at each end, rather deeply incised, thin, bright green, glabrate except for the sparse or dense stinging hairs; flower clusters dense, oblong, mostly much shorter than the petioles, green.

This plant stings severely. It is a noxious weed in gardens and cafetales at many places in the central and western regions.

The drawings in Part III are the work of the following artists: Miss Norma Lockwood, figures 1-6; Mr. George Burian, figures 746; Mr. John Ihle, figures 47-53; Mr. Roy Madsen, figures 54-56. 


\section{INDEX}

Agapanthus, 61

Agave, 104

Aloe, 64

Alfaroa, 353

Allium, 61

Alnus, 360

Alpinia, 192

Amaryllidaceae, 103

Aneilema, 2

Anthericum, 65

Apteria, 223

Asparagus, 68

Beaucarnea, 70

Betulaceae, 359

Boehmeria, 397

Bomarea, 122

Burmannia, 223

Burmanniaceae, 221

Calathea, 208

Callisia, 4

Calochortus, 72

Calydorea, 160

Campelia, 8

Canna, 203

Cannaceae, 203

Carpinus, 365

Casuarina, 227

Casuarinaceae, 227

Chloranthaceae, 337

Cipura, 160

Commelina, 10

Commelinaceae, 1

Costus, 193

Crinum, 124

Curculigo, 126

Curcuma, 197

Debregeasia, 400

Dichorisandra, 18

Dictyostega, 224

Dioscoreaceae, 145

Dracaena, 73

Echeandia, 75

Eichhornia, 44

Elettaria, 198

Eleutherine, 162

Engelhardtia, 354

Eucharis, 128

Fagaceae, 369

Fleurya, 402
Freesia, 163

Furcraea, 129

Gelasine, 163

Gladiolus, 163

Gymnosiphon, 225

Haemodoraceae, 100

Hedychium, 198

Hedyosmum, 338

Heliconia, 178

Hemerocallis, 76

Hemistylis, 403

Heteranthera, 47

Hippeastrum, 134

Hymenocallis, 139

Hypoxis, 135

Iridaceae, 159

Iris, 164

Ischnosiphon, 214

Juglandaceae, 352

Juglans, 356

Juncaceae, 52

Juncus, 53

Kaempferia, 199

Kniphofia, 77

Lacistema, 340

Lacistemaceae, 340

Laportea, 403

Liliaceae, 59

Lilium, 77

Luzula, 58

Maranta, 216

Marantaceae, 207

Milla, 78

Musa, 186

Musaceae, 178

Myrica, 348

Myricaceae, 348

Myriocarpa, 404

Narcissus, 138

Nemastylis, 165

Neomarica, 167

Nothoscordum, 79

Orthrosanthus, 169

Ostrya, 365

Pancratium, 138

Parietaria, 406 
Peperomia, 231

Phaeosphaerion, 19

Phenax, 408

Phormium, 80

Pilea, 410

Piper, 275

Piperaceae, 228

Polianthes, 142

Pontederia, 50

Pontederiaceae, 42

Populus, 342

Pouzolzia, 422

Quercus, 369

Ravenala, 191

Renealmia, 199

Rhoeo, 22

Rigidella, 171

Rousselia, 423

Ruscus, 80

Salicaceae, 342

Salix, 343

Sansevieria, 80

Schoenocaulon, 81

Sisyrinchium, 171

Smilacaceae, 92
Smilacina, 84

Smilax, 92

Strelitzia, 191

Stromanthe, 219

Taetsia, 88

Thalia, 219

Tigridia, 175

Tinantia, 23

Tradescantia, 27

Trimeza, 176

Tripogandra, 32

Tritonia, 177

Urera, 424

Urtica, 428

Urticaceae, 396

Weldenia, 40

Xiphidium, 101

Yucca, 88

Zebrina, 41

Zephyranthes, 143

Zingiber, 202

Zingiberaceae, 191

Zygadenus, 91 



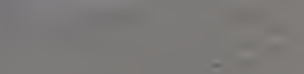

\section{Publication 687}

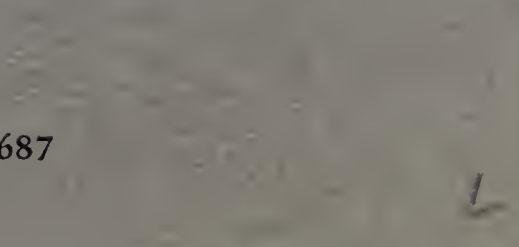









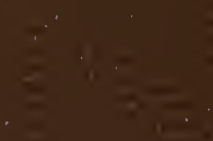
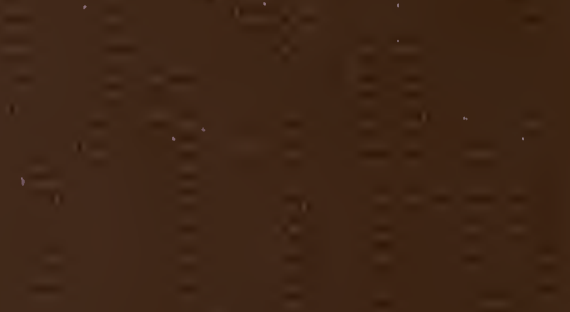

$2+2=0$<smiles></smiles> 